\title{
Explore the physical and chemical properties of 1,2,3-triazole: from fluorescence sensor to ligand in metal catalysis
}

Yanwei Zhang

Follow this and additional works at: https://researchrepository.wvu.edu/etd

\section{Recommended Citation}

Zhang, Yanwei, "Explore the physical and chemical properties of 1,2,3-triazole: from fluorescence sensor to ligand in metal catalysis" (2015). Graduate Theses, Dissertations, and Problem Reports. 7146.

https://researchrepository.wvu.edu/etd/7146

This Dissertation is protected by copyright and/or related rights. It has been brought to you by the The Research Repository @ WVU with permission from the rights-holder(s). You are free to use this Dissertation in any way that is permitted by the copyright and related rights legislation that applies to your use. For other uses you must obtain permission from the rights-holder(s) directly, unless additional rights are indicated by a Creative Commons license in the record and/ or on the work itself. This Dissertation has been accepted for inclusion in WVU Graduate Theses, Dissertations, and Problem Reports collection by an authorized administrator of The Research Repository @ WVU.

For more information, please contact researchrepository@mail.wvu.edu. 


\title{
Explore the physical and chemical properties of 1,2,3-triazole: from fluorescence sensor to ligand in metal catalysis
}

\author{
Yanwei Zhang
}

\author{
Dissertation submitted \\ to the Eberly College of Arts and Sciences \\ at West Virginia University \\ in partial fulfillment of the requirements for the degree of \\ Doctor of Philosophy in \\ Chemistry
}

Björn Söderberg, Ph.D., Chair

Jessica Hoover, Ph.D.

Jeffrey Petersen, Ph.D.

Brian Popp, Ph.D.

Yon Rojanasakul, Ph.D.

C. Eugene Bennett Department of Chemistry

Morgantown, West Virginia

2015

Keywords: Functional 1,2,3-Triazoles, Transition Metal Catalysis, Fluorescence sensor, Ligand

Copyright 2015 Yanwei Zhang 


\title{
Abstract \\ Explore the physical and chemical properties of 1,2,3-triazole: \\ from fluorescence sensor to ligand in metal catalysis \\ Yanwei Zhang
}

\begin{abstract}
1,2,3-Triazole gold (TA-Au) catalysts were developed by Shi's group and employed in several transformations involving propargyl ester rearrangement. Besides the excellent air, moisture and thermal stability introduced through triazole ligands, unique chemoselectivity was observed for these novel $\mathrm{Au}(\mathrm{I})$ complexes. The chemoselectivity allowed the effective activation of the alkyne without affecting the reactivity of the allene ester intermediates. These results led to the investigation of the preparation of allene ester intermediates with TA-Au catalysts under anhydrous conditions. As expected, the desired 3,3-rearrangement products were obtained in excellent yields. Besides the typical ester migrating groups, carbonates and carbamates were also found to be suitable for this transformation, which provided a highly efficient, practical method for the preparation of substituted allenes.
\end{abstract}

Previously research results confirmed TA-Au as a chemoselective catalyst in promoting alkyne activation with high efficiency and improved ligand economy. TA-Au analogues were sequentially revealed as the effective catalysts in promoting allene hydration, giving the enones with excellent yields. Furthermore, the gold-catalyzed intermolecular [2+2] cycloaddition of propargyl esters was achieved with good stereoselectivity. The 'silver-free' condition was critical for this transformation, while only a trace amount of [2+2] products were obtained in the presence of silver under otherwise identical conditions.

Additionally, naphthalene-bridged bis-triazole (NBT) compounds were prepared and characterized for investigation of their photophysical properties. Unlike our previously reported $\mathrm{N}$-2-aryl triazoles (NATs), which gave strong emissions through the planar intramolecular charge transfer mechanism (PICT), this newly developed NBTs adopted a noncoplanar conformation between triazole and naphthalene, achieving fluorescence through twisted intramolecular charge transfer (TICT). 


\section{Acknowledgements}

Firstly, I would wish to express my sincere gratitude to my advisor, Dr. Xiaodong Michael Shi, for his guidance, understanding, patience and most importantly, his encouragement during my graduate studies at West Virginia University. He provided me enough independence to express my own individuality and self-sufficiency. He taught me how to be not only an experimentalist and a chemist but also an independent thinker. Without his support, there is no way for me to finish my Ph.D study.

I would like to give my sincere appreciation to Dr. Björn Söderberg. Thank you for your kindness to accept me in your research group in the past several months. I would like to gratefully thank Dr Brian Popp, and Dr Jessica Hoover in my academic development. All the valuable comments and suggestions I got from them are appreciated and recognized. I would also like to thank Dr. Jeffrey L. Petersen for his help of X-ray crystallographic structure analysis and guidance during my graduate studies. Moreover, I am deeply grateful to the above mentioned and Dr. Yon Rojanasakul for being my Doctoral Research Committee.

I would like to acknowledge my colleagues who l've had the pleasure of working with, Dr. Dawei Wang, Dr. Yijin Su, Dr. Haihui Peng, Dr. Wuming Yan, Dr. Lekn Nath Gautam, Tao Liao, Dr. Qiaoyi Wang, Dr. Xiaohan Ye, Rong Cai, Sraven Kumar, Siddhita Aparaj, Seyedmorteza Hosseyni, Boliang Dong, Stephen Motika, Yumeng Xi and Ying He for all the assistance they have given me in the last five years. I would also like to thank Dr. Novruz Akhmedov for helping me solve the NMR experiment.

Finally, and most importantly, I would like to thank my parents, my husband and my friends. Their support, encouragement, patience and love were the most solid base of my life in the past five years. With everything they gave, I have gained so much energy and courage to overcome the challenge in my Ph.D study.

Financial supports from the C. Eugene Bennett Department of Chemistry at West Virginia University and the National Science Foundation are also gratefully acknowledged. 


\section{TABLE OF CONTENTS}

Explore the physical and chemical properties of 1,2,3-triazole: from fluorescence sensor to ligand in metal catalysis

Abstract

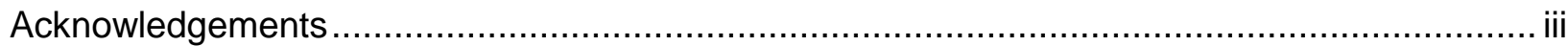

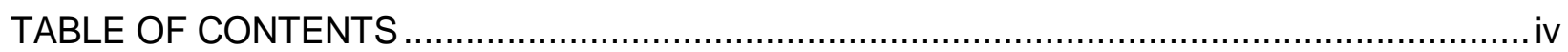

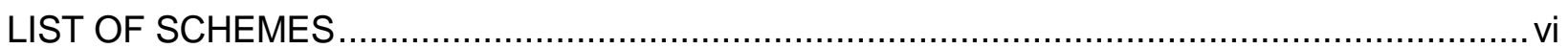

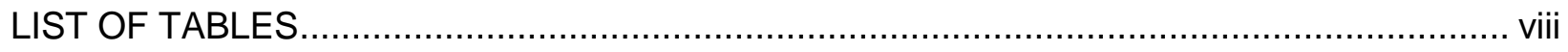

Chapter One: Triazole-Au(I) complex as chemoselective catalyst in promoting propargyl ester

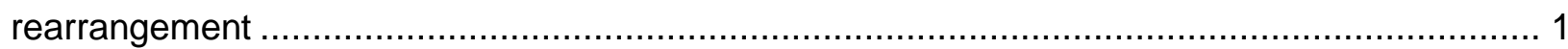

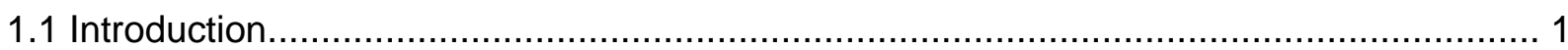

1.1.1 Background of gold catalysis development................................................. 1

1.1.2 The role of different 1,2,3-triazole as counter ligand ' $X$ ' in gold chemistry ................ 5

1.2 Propargyl ester rearrangements promoted by triazole-Au(I) complex as chemoselective

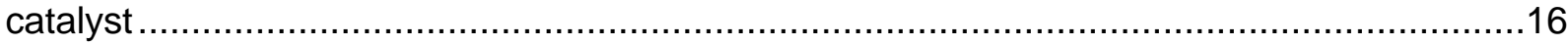

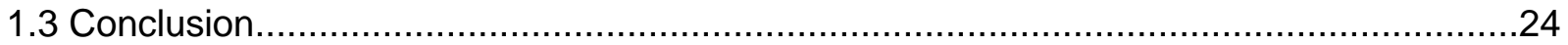

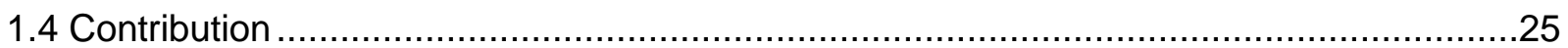

Chapter Two: Further transformations from allene intermediate formed by traizole $\mathrm{Au}(\mathrm{I}) \mathrm{complex}$

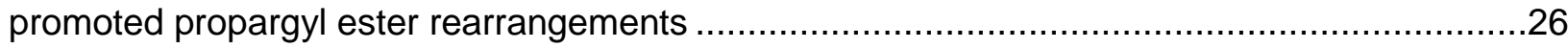

2.1 Triazole-glod promoted, effective synthesis of enones from propargylic esters and

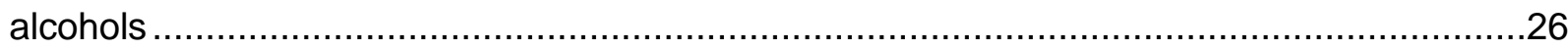

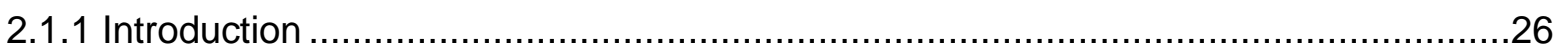

2.1.2 Triazole gold promoted, effective synthesis of enonoes from propargylic esters and alcohols: a catalyst offering chemoselectivity, acidity and ligand economy......................30

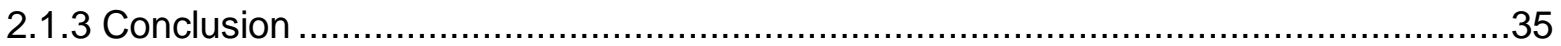

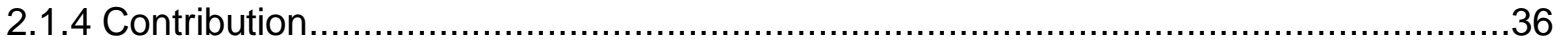

2.2 Ambient intermolecular [2+2] cycloaddition of allene intermediate .............................37

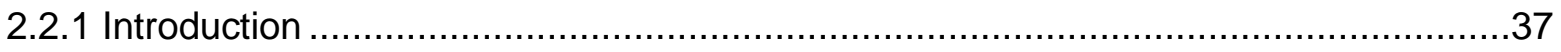

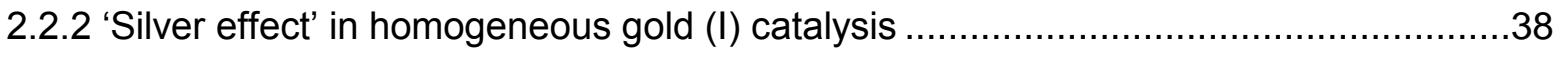

2.2.3 Ambient intermolecular [2+2] cycloaddition: an example of carbophilicity and oxophilicity competition in Au/Ag catalysis .............................................................

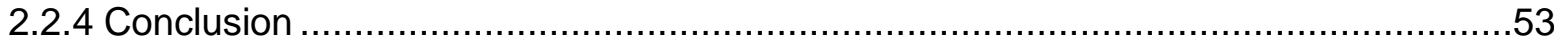

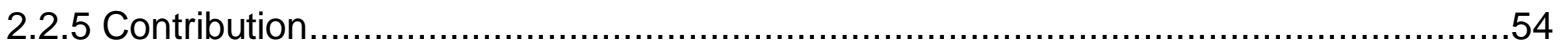


Chapter Three: Synthesis and characterization of bis-N-2-aryl triazole as efficient fluorescence probe .

3.1 Introduction

3.2 Synthesis and characterization of bis-N-2-aryl triazole as efficient fluorescence probe through twisted intramolecular charge transfer mechanism ........................................60

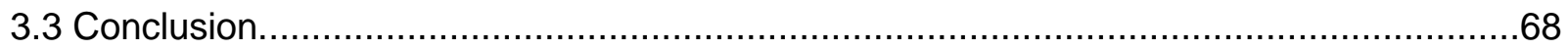

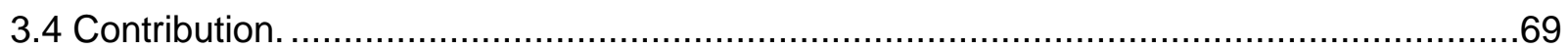

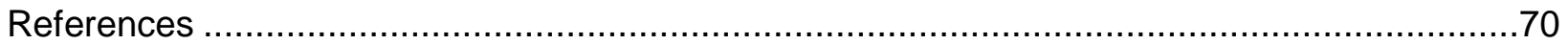

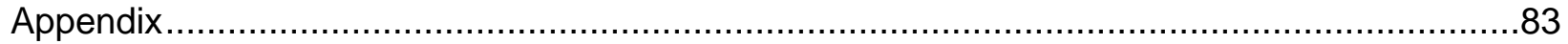

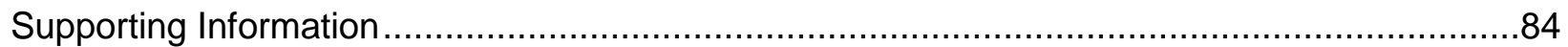

Chapter One: Triazole-Au(I) complex as chemoselective catalyst in promoting propargyl ester

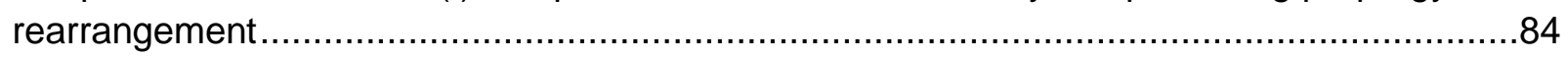

Chapter Two: Further transformations from allene intermediate formed by traizole $\mathrm{Au}(\mathrm{I})$ complex promoted propargyl ester rearrangements.................................................114

2.1 Triazole-glod promoted, effective synthesis of enones from propargylic esters and alcohols 114

2.2 Ambient intermolecular [2+2] cycloaddition of allene intermediate 166 Chapter Three: Synthesis and characterization of bis- $\mathrm{N}-2$-aryl triazole as efficient fluorescence probe. 


\section{LIST OF SCHEMES}

Scheme 1. Representative Samples from Recent Gold Catalysis Chemistry ............................ 2

Scheme 2. Catalytic Cycle for $\mathrm{Au}(\mathrm{I})$ Catalysis for Common Gold Activated Alkyne Reaction...... 3

Scheme 3. IPrAuCl and XPhosAuCl Complexes with Improved Au Cation Stability ................... 5

Scheme 4. One Typical Example of ‘Click Chemistry' .......................................................... 6

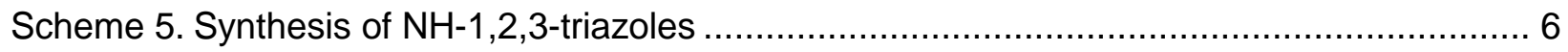

Scheme 6. Thermal Condensation of Nitroalkene and Sodium Azide....................................... 7

Scheme 7. Lewis Base-catalyzed Cascade Condensation to $\mathrm{NH}-1,2,3$-triazole …..................... 7

Scheme 8. Mechanism for Synthesis of 4,5-disubstituted $\mathrm{NH}-1,2,3$-triazoles ............................ 8

Scheme 9. Synthesis to N-2 Alkyl/Aryl Substituted 1,2,3-triaozle .......................................... 9

Scheme 10. Different Post-triazole Functionalization Discovered by Prof. Shi's Group ..............10

Scheme 11. Different 1,2,3-triazole Metal Complexes Obtained by Prof. Shi's Group................11

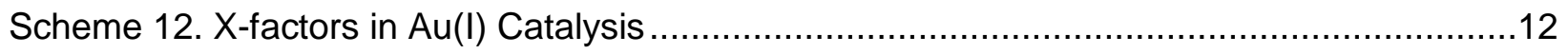

Scheme 13. Examples of Triazole Au(l) Complexes …………......................................13

Scheme 14. A Library of $\mathrm{Au}(\mathrm{I})$ Complexes with Different Primary Liangds and Triazoles ..........14

Scheme 15. The Challenge of the Synthesis of Allenes through Au(I) Activated Alkynes..........17

Scheme 16. X-ray Crystal Structures of Two Different Types of 1,2,3-triazole-Au Complexes ..18

Scheme 17. Synthesis of $\alpha$-lodoenone Compounds from Propargyl Esters.............................19

Scheme 18. Chemoselective Activation of Alkyne over Allene by the TA-Au Catalysts ............20

Scheme 19. NHC: Good Ligand in Gold Catalysis but at High Cost .......................................27

Scheme 20. L-Au+ : Effective Catalysts Activating Both Alkyne and Allene..............................28

Scheme 21. Proposed $\mathrm{S}_{\mathbb{N}} 2^{\prime}$ Addition Mechansim by Nolan ................................................29

Scheme 22. TA-Au Serves as Bronsted Acid in Hydration Transformation..............................30

Scheme 23. Comparison with the Best Results Obtained in the Literature ...............................35 
Scheme 24. Gold-catalyzed Propargyl Ester Activation.

Scheme 25. Different Resting States in the Au(I) Catalysis when Silver Is Presented 39

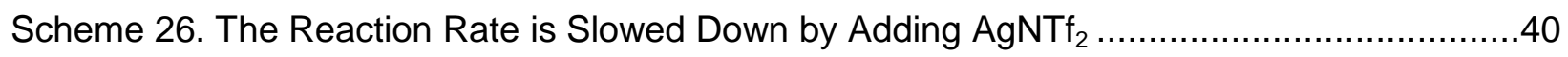

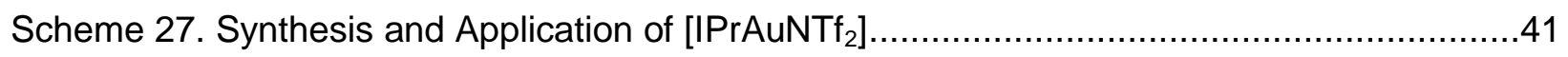

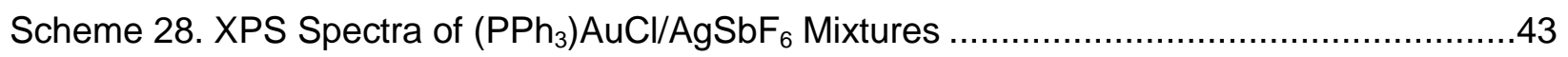

Scheme 29. ${ }^{31} \mathrm{P}$ NMR Spectra of Different $\mathrm{Au}(\mathrm{I})$ Species .........................................4

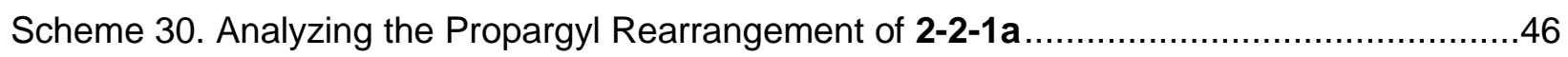

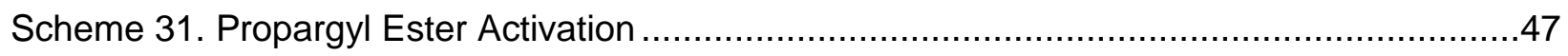

Scheme 32. Investigation on the Role of Au in [2+2] Step..........................................52

Scheme 33. Photoluminscent Spectra of N-2-aryl-1,2,3-triazoles.....................................56

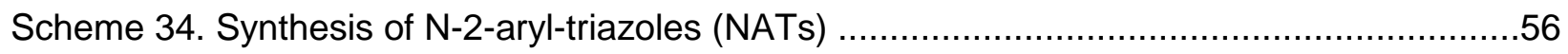

Scheme 35. Fluorescence Emission Behavior of Compounds with Different C-5 Substitution...57

Scheme 36. Substituted Group Effect on the N-2 Position ...........................................57

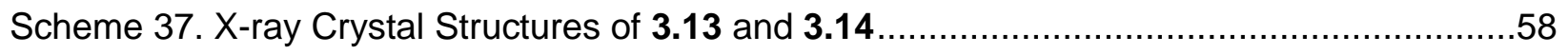

Scheme 38. PICT and TICT in Fluorescence Emission ............................................59

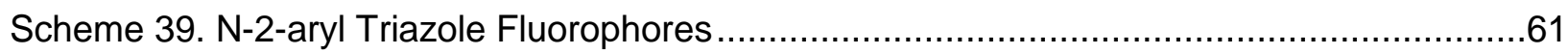

Scheme 40. Fluorescence Emission of NAT with Different Aryl Groups .............................61

Scheme 41. Synthesis of Naphthalene-bridged Bis-triazoles (NBTs) ................................63

Scheme 42. X-ray Crystallography Confirmed the Fromation of Cis-conformer.....................64

Scheme 43. Fluorescence Emission of NBT 3-3 and 3-4a .....................................65

Scheme 44. Fluorescence Emission of NBT 3-5 and 3-4a .......................................68 


\section{LIST OF TABLES}

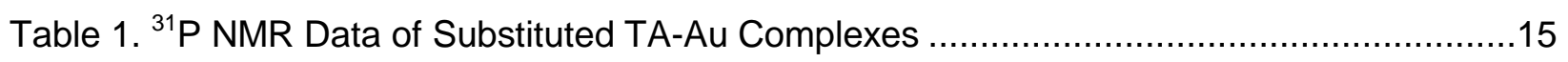

Table 2. The Reaction Substrate Scope ...........................................................................21

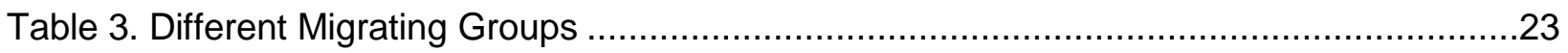

Table 4. TA-Au Catalyzed Propargyl Ester Hydrolysis........................................................32

Table 5. TA-Au Catalyzed Meyer-Schuster Rearrangement...............................................33

Table 6. Silver Effect in Alkyne Hydration.............................................................................41

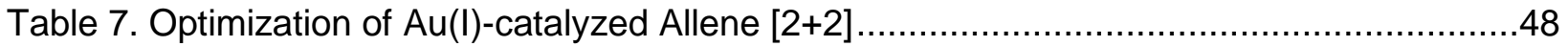

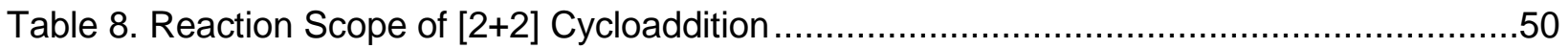

Table 9. Comparison of Optical Properties of Different NBTs................................................65 


\section{Chapter One: Triazole-Au(I) Complex as chemoselective catalyst in promoting propargyl ester rearrangements.}

\subsection{Introduction}

\subsubsection{Background of gold catalysis development}

In the past decade, homogeneous gold catalysis has developed rapidly for activating sp hybridized carbon transformations. ${ }^{1}$ Gold catalysis has been applied in numerous synthetic applications to achieve previously challenging transformations with higher

yield or/and better regioselectivity. ${ }^{2}$ Compared to traditional metal catalysis, gold catalysis presents several advantages:

1) In most reported cases, gold catalyst can act as a strong m-acid towards alkynes/allenes and activate the starting material with high selectivity.

2) The gold catalyst presents highly reactivity while comparing with other transition metals such as $\mathrm{Pd}$, Ru, $\mathrm{Rh}$ or $\mathrm{Cu}(<1 \mathrm{~mol} \%$ loading for gold vs approximately $10 \mathrm{~mol} \%$ loading for others)

3) The mechanism of gold catalysis is flexible based on different reaction patterns (such as ligand, solvent, temp.), leading to diverse products even with the similar starting materials.

Scheme 1 shows several representative examples from the recently developed gold catalysis transformations reported with high yield and low catalyst loading. 
Scheme 1. Representative Samples from Recent Gold Catalysis Chemistry

A<smiles>[R]C#CC1=C([N+](=O)[O-])C=C[R1]C=C1</smiles>

B<smiles></smiles>

14 examples, up to $94 \%$ yield

C
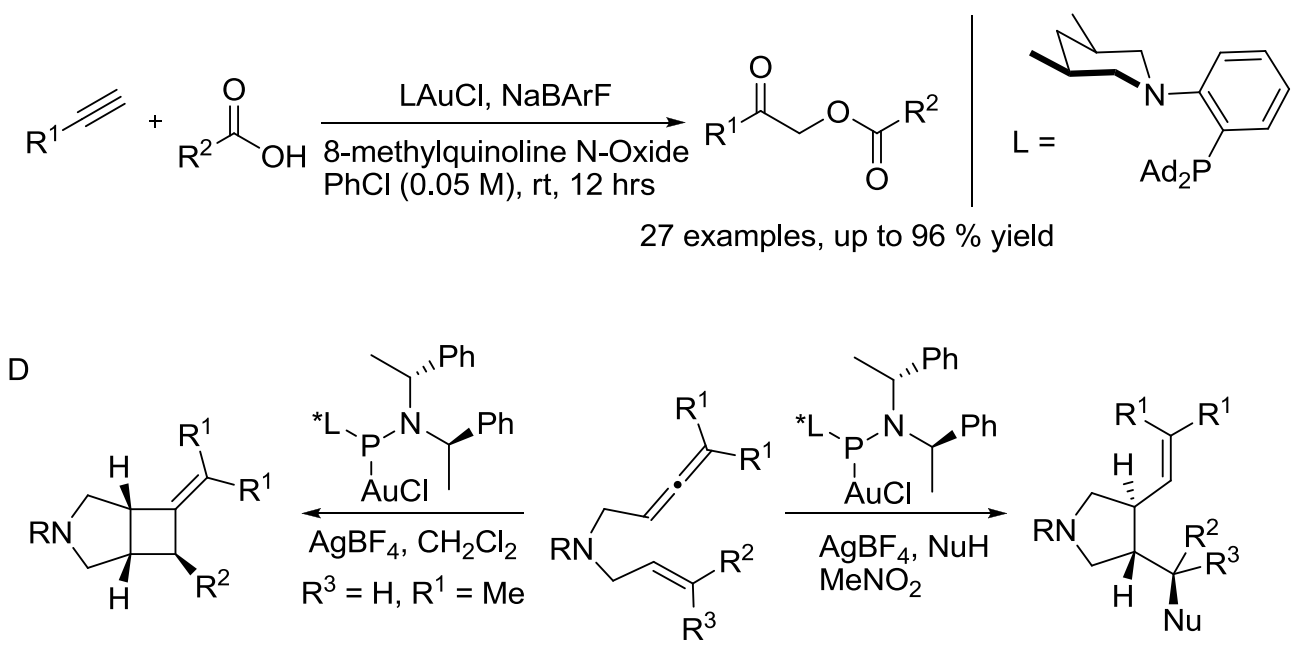

E

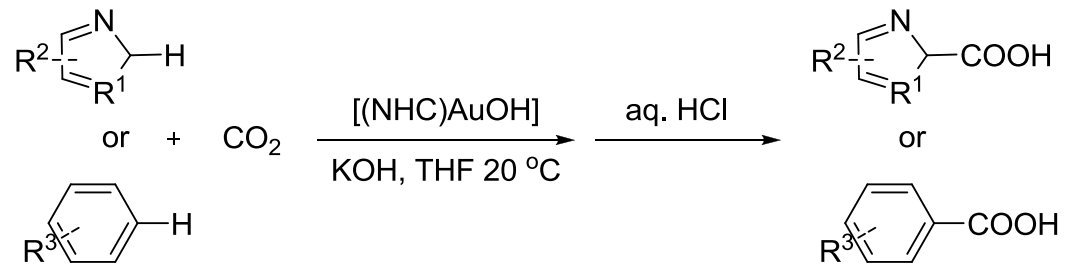

21 examples, up to $96 \%$ yield 
Of the two most common oxidation states, $\mathrm{Au}(\mathrm{I})$ and $\mathrm{Au}(\mathrm{III})$, more studies have been focused on $\mathrm{Au}(\mathrm{I})$ due to easier preparation and better pre-catalyst thermal stability. Most often, $\mathrm{Au}(\mathrm{III})$ is simply considered as common Lewis acid to activate heteroatoms (such as $\mathrm{O}, \mathrm{N}$ ) while $\mathrm{Au}(\mathrm{I})$ can serve as $\pi$-acid for alkyne/allene activation. ${ }^{3,4}$ In the gold catalytic process, one key step to generate the active catalyst complex is to dissociate the $\mathrm{Au}-\mathrm{Cl}$ bond. The most common method adopted is relying on silver salts as $\mathrm{Cl}$ scavenger by forming $\mathrm{AgCl}$ precipitate. As a result, active cationic gold species were afforded with counter anions introduced by the silver salts such as $\mathrm{BF}_{4}^{-}, \mathrm{PF}_{6}^{-}, \mathrm{SbF}_{6}^{-}$, $\mathrm{TfO}^{-}$, and $\mathrm{ClO}_{4}{ }^{-}$. It is accepted by the research community that $\mathrm{Au}(\mathrm{I})$ complexes present two coordination sites with $180^{\circ}$ linear geometry (although some exceptions exist). The actual catalysts involved in alkyne/alkene activation are of the type $[\mathrm{L}-\mathrm{Au}]^{+}$, with the open coordination site on the opposite side of the ligand $(L)$ for substrate binding.

Scheme 2. Catalytic Cycle for $\mathrm{Au}(\mathrm{I})$ Catalysis for Common Gold Activated Alkyne Reaction

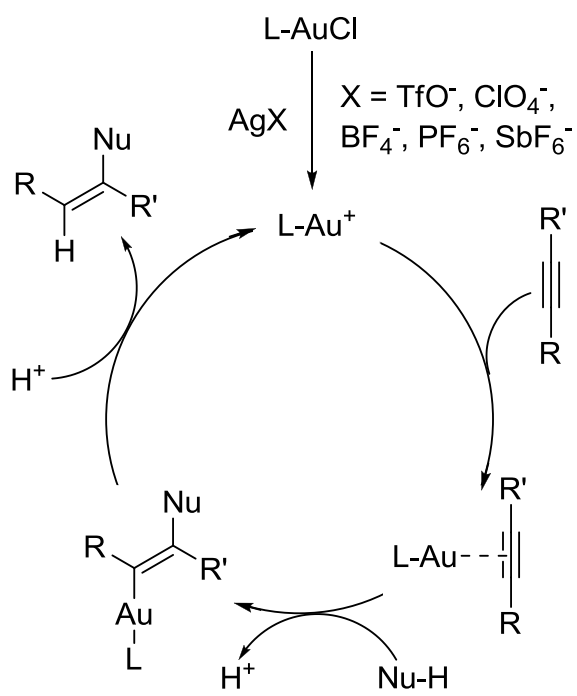


Given the use of an alkyne as a specific reactive substrate, the mechanism of $\mathrm{Nu}-\mathrm{H}$ (such as alcohol, amine) addition across the C-C triple bond via an $\mathrm{Au}(\mathrm{I})$ catalytic cycle is shown in Scheme 2. In this process, the stable L-Au-Cl usually serve as catalyst precursor to generate the active $\mathrm{L}-\mathrm{Au}^{+}$complex in situ with the removal of the bonded $\mathrm{Cl}$ counter anion. This newly opened coordination site will facilitate the substrate (alkyne utilizing the C-C triple bond) binding. After the coordination, the nucleophile attacks the gold activated alkyne complex and forms the corresponding alkene-gold intermediate. The final product is formed by proto deauration and meanwhile, the Au cation was released for the next catalytic cycle.

One major drawback in traditional gold catalysis is the stability of cationic gold complex, since it tends to decompose (formation of $A u(0)$ species) under raised temperature or reductive environment. To improve the stability of gold complex, various research groups are focusing on developing novel ligands to increase the stability of $\mathrm{Au}(\mathrm{I})$ catalyst.

The $\mathrm{NH}$ carbene is one of the most important ligands currently employed in gold catalysis. ${ }^{5}$ The $\mathrm{NH}$ carbene has a unique chemical nature for its lone electron pair and $\pi$-acceptor orbital. On one hand, the lone pair electrons make $\mathrm{NH}$ carbene a good $\sigma$ donor to coordinate towards most transition metals. On the other hand, the $\pi-$ backbonding from a metal d-orbital to the $\pi^{*}$ orbital of $\mathrm{NH}$ carbene, makes the coordination between the metal and $\mathrm{NH}$ carbene even stronger (shorter $\mathrm{C}-\mathrm{M}$ bond) than other heteroatom ligands, and thus the stability of the gold-NH carbene complex is significantly improved. 
Another notable primary ligand in gold catalysis is the phosphine ligand. The bonding between gold and phosphine is typically strong, which can help stabilize the complex. ${ }^{6}$ Additionally, unique spatial conformation of several phosphine ligands can make the complexes more stable. For example, as shown in Scheme 3, in the 3-D structure of XPhosAuCl, the Ar group introduced by XPhos will block one site of the linear L-Au-Cl complex due to the irreplaceable spatial geometry expendation. ${ }^{7}$

Scheme 3. IPrAuCl and XPhosAuCl Complexes with Improved Au Cation Stability

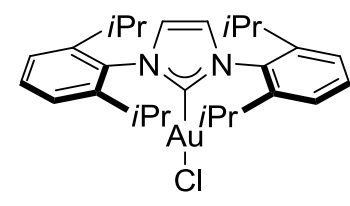

IPrAuCl

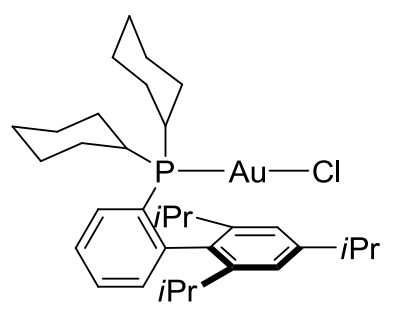

XPhosAuCl

\subsubsection{The role of different 1,2,3-triazole as counter ligand ' $X$-factor' in gold chemistry}

Triazole compounds have been prepared as a unique heterocyclic structure with interesting electronic effect in last century. ${ }^{8}$ In 2001 , 'Click chemistry' was first reported by Professor Sharpless, which facilitated access to various 1,4-disubstituted 1,2,3triazoles with moderate to good yield. ${ }^{9}$ In a 'Click chemistry', the active $\mathrm{Cu}(\mathrm{I})$ catalyst is generated in situ from $\mathrm{Cu}(\mathrm{II})$ salts (such as $\mathrm{CuSO}_{4}$ ), while using sodium ascorbate as the reducing reagent. Additionally, by adding an excess amount of sodium ascorbate, the formation of oxidative homo-coupling products could be successfully avoided in late stage of the reaction (Scheme 4). ${ }^{10,11}$ 
Scheme 4. One Typical Example of 'Click Chemistry'

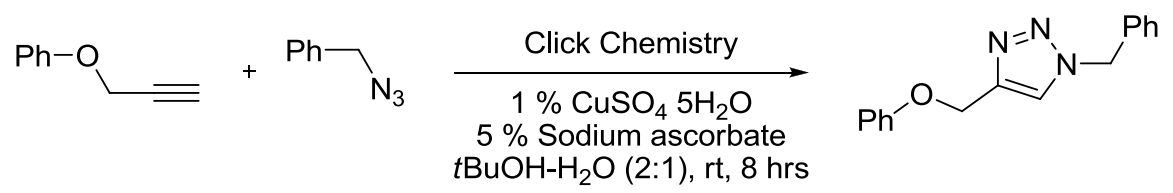

One major drawback of 'Click chemistry' is that unsubstituted triazole ring could not be achieved with $\mathrm{NaN}_{3}$ or $\mathrm{HN}_{3}$ as a coupling partner. To achieve $\mathrm{NH}-1,2,3$ triazole, 'Click chemistry' was modified by using the N-substituted azide with removable functional groups (Scheme 5). ${ }^{12}$ After reaching the 1,4-disubstituted 1,2,3-triazole, $\mathrm{NH}$ 1,2,3-triazole can be synthesized through a simple $\mathrm{N}$-deprotection. This method significantly improved the scope of the 1,2,3-triazole synthesis, whereby postfunctionalization was possible at the free $\mathrm{NH}$ site of 1,2,3-triazole.

Scheme 5. Synthesis of $\mathrm{NH}-1,2,3-$ triazoles

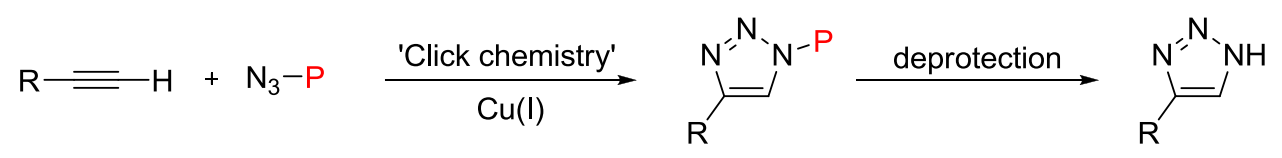

In 2005, another efficient synthesis method towards $\mathrm{NH}-1,2,3$-triazoles is developed by Professor Zard based on the 1,3-dipolar addition between the nitroalkene and sodium azide. $\mathrm{NH}-1,2,3-$ triazoles with different aryl substituents can be achieved with good to excellent yields, only trace amounts of predictable by-products were observed (Scheme 6). ${ }^{13,14}$ 
Scheme 6. Thermal Condensation of Nitroalkene and Sodium Azide

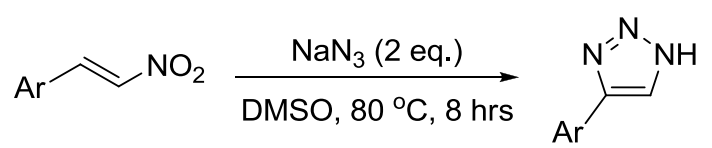

Although the synthesis of 4-mono-substituted 1,2,3-triazole has been reported in various methods, how to reach 4,5-di-substituted 1,2,3-triazoles still remained challenge. In 2008, Professor Shi and co-workers successfully developed the methodology with which to synthesize 4,5-disubstituted $\mathrm{NH}-1,2,3$-triazoles based on a Lewis basecatalyzed cascade condensation (Aza-Henry reaction) using nitroalkene, aldehyde and sodium azide as reaction precursors as shown in scheme $7 .^{15}$ With this method, a series of 4,5-disubstituted $\mathrm{NH}-1,2,3$-triazoles were produced with good to excellent yields.

Scheme 7. Lewis Base-catalyzed Cascade Condensation to $\mathrm{NH}-1,2,3$-triazole

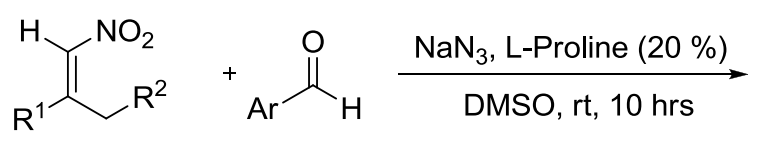<smiles>[R]C=C([R])c1n[nH]nc1N</smiles>

Subsequently, the mechanism of this reaction has been investigated. As described in Scheme 8, initially, the Henry reaction occurred between the nitroalkene and aldehyde, after which, sodium azide addition of the alkene intermediate occurred and formed a new azide intermediate. Follow by the elimination of $\mathrm{NO}_{2}$ anion, the desired triazole was generated as the final product. 
Scheme 8. Mechanism for Synthesis of 4,5-disubstituted $\mathrm{NH}$-1,2,3-triazoles
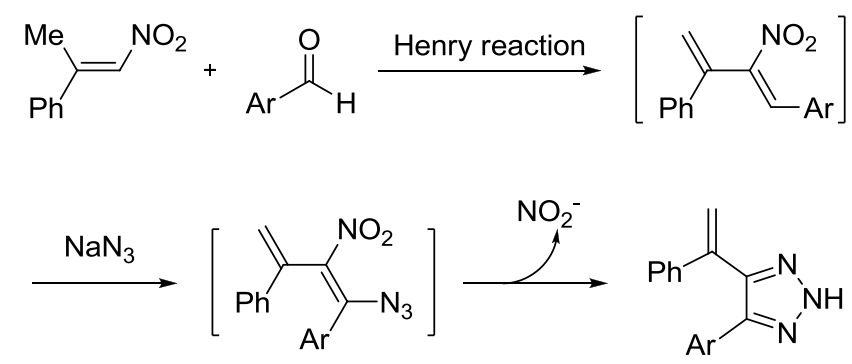

At this stage, Shi's group focused on the development of triazole post functionalization. With the appropriate electrophiles and reaction conditions, Nsubstituted 1,2,3-triazole derivatives could be obtained with $\mathrm{NH}$-triazole as a nucleophile. However, in this type of reaction, the regioselectivity between $\mathrm{N}-1$ and $\mathrm{N}-2$ substitution arose as one major concern. Moreover, the $\mathrm{N}-1$ substitution dominates in most reported results due to its thermodynamic stability. ${ }^{16}$ Shi's group subsequently investigated the selective synthesis towards $\mathrm{N}-2$ substituted 1,2,3-triazole derivatives. With 4,5disubstituted 1,2,3-triazole derivatives, the increased steric hindrance from the two substituents on C-4 and C-5 positions can theoretically block the $\mathrm{N}-1$ nucleophilic sites, which will further lead to the $\mathrm{N}-2$ regioselectivity over $\mathrm{N}-1$ (Scheme 9A). ${ }^{17-18}$ Three different approaches were developed to attain the N-2 aryl substituted derivatives with base or $\mathrm{Cu}(\mathrm{I})$ catalyzed coupling between $\mathrm{NH}-1,2,3$-triaozle and heteroatom substituted aromatic compounds (Scheme 9B). 
Scheme 9. Synthesis to N-2 Alkyl/Aryl Substituted 1,2,3-triaozle

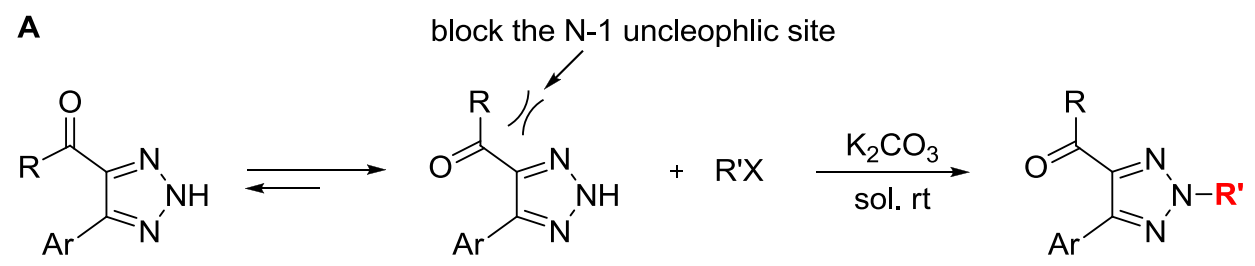

preffered conformation selective $\mathrm{N}-2$ substitution, $70-95 \%$ yield

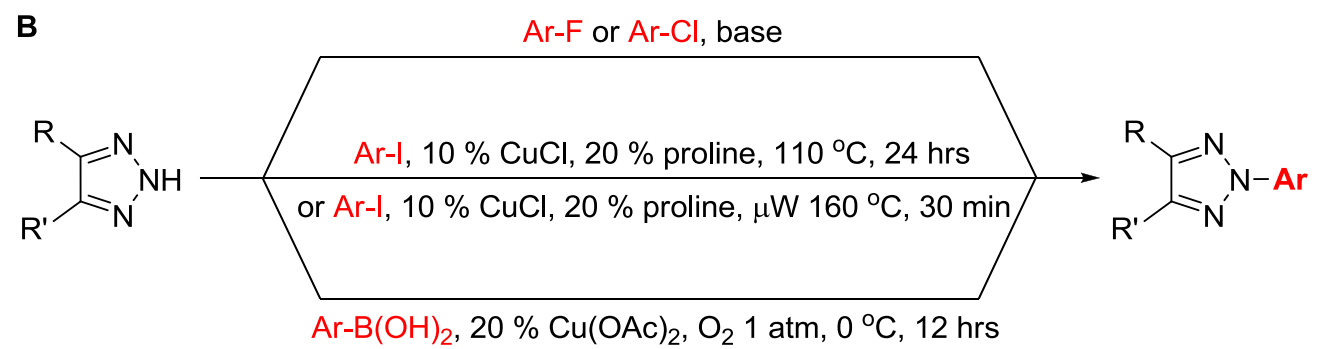

Additionally, our group has developed the post-triazole functionalization to obtain more complicated 1,2,3-triazoles derivatives through alkylation, vinylation, arylation, propargylation and allenation (Scheme 10). 
Scheme 10. Different Post-triazole Functionalization Discovered by Prof. Shi's Group
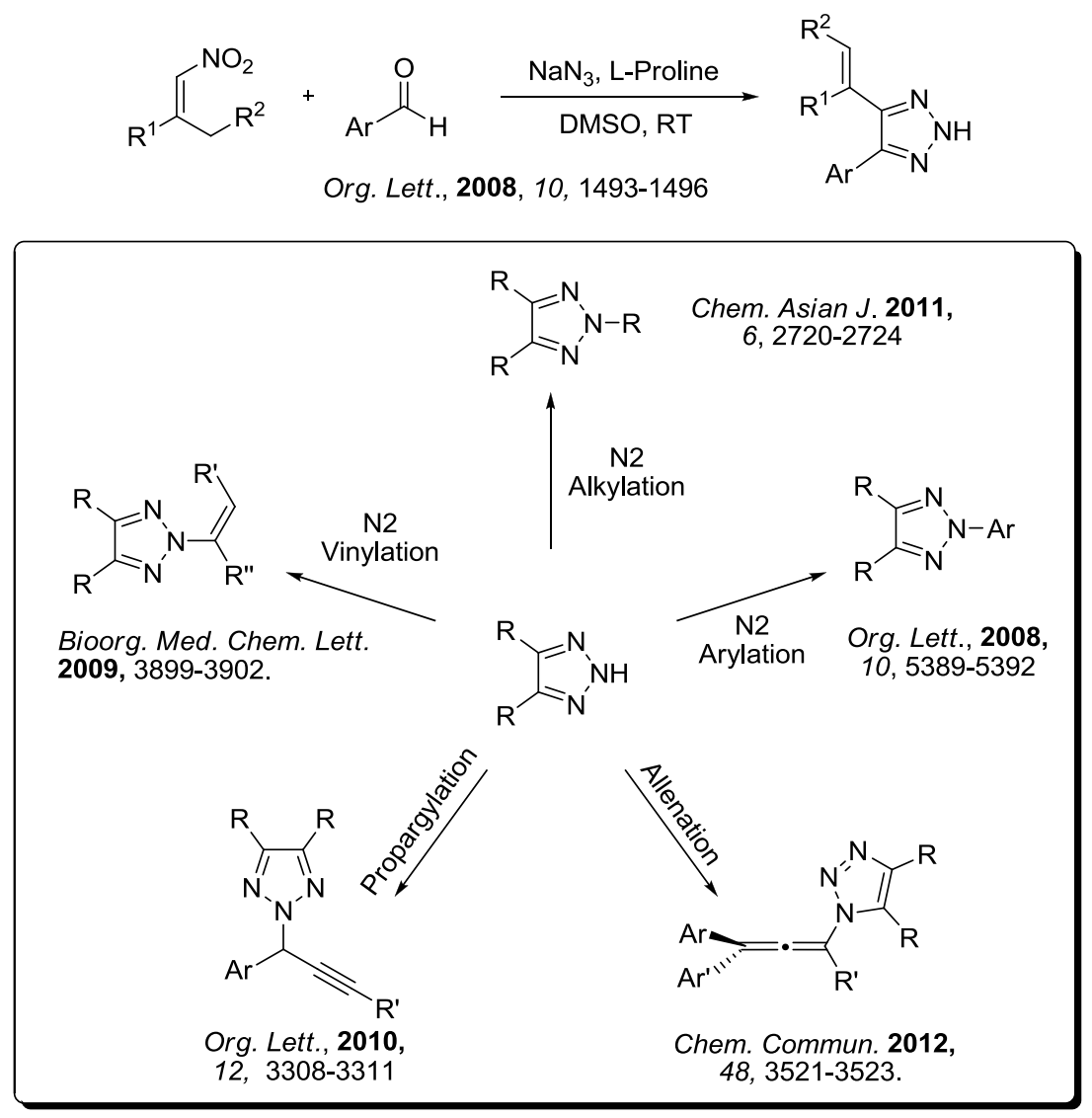

With all well-developed synthetic methodologies, Shi's group decided to investigate the binding of 1,2.3-triazole as ligand with transition metals (such as Rh, B, Au) and examine the reactivities displayed by the novel transition metal complexes (Scheme 11). ${ }^{19-21}$ Despite the fact that all these complexes exhibit interesting reactivities, 1,2,3triazole $\mathrm{Au}(\mathrm{I})$ complexes would be the major focus in this dissertation. 
Scheme 11. Different 1,2,3-triazole Metal Complexes Obtained by Prof. Shi's Group

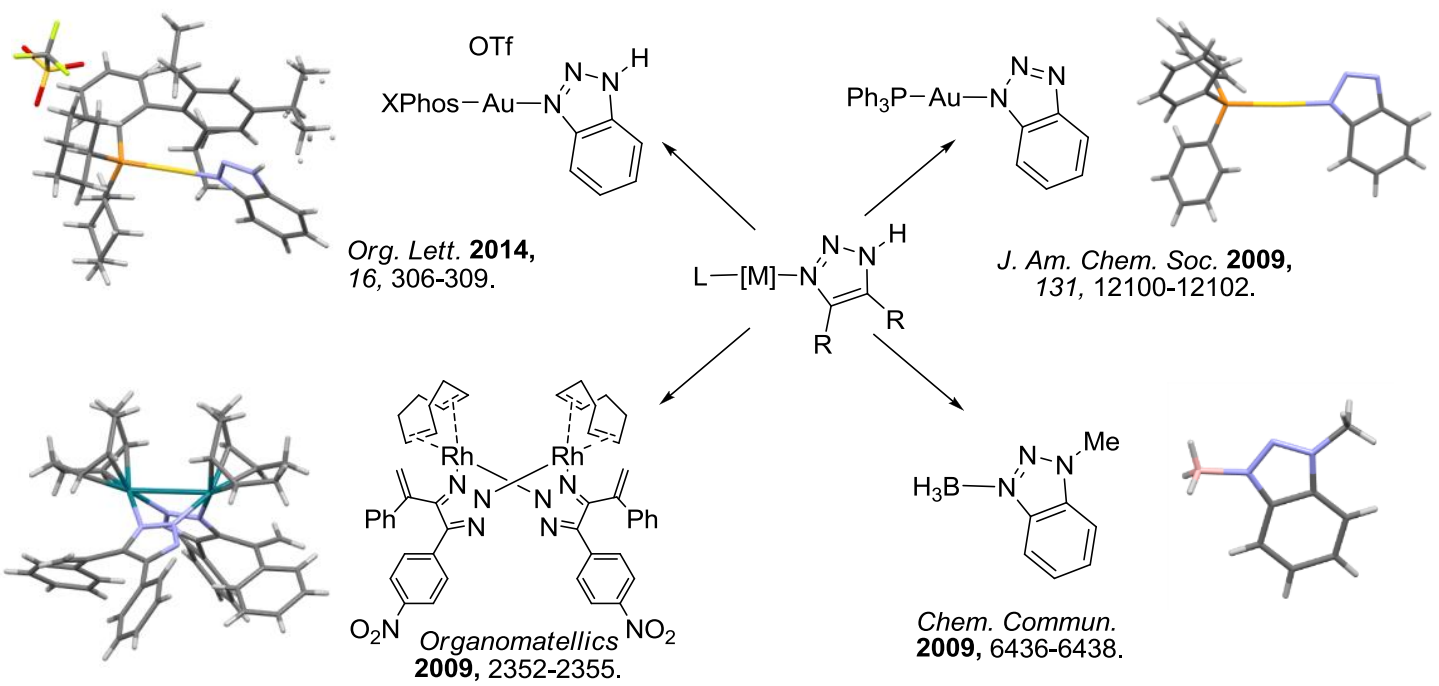

As mentioned, $\mathrm{Au}(\mathrm{I})$ complexes adopt a linear geometry with two coordination sites. One coordination site is occupied by a primary ligand, such as $\mathrm{N}$-heterocyclic carbene or phosphine ligand. Recent research discovered that the second coordination position could be occupied by a weakly bound Lewis donor, such as pyridine, $\mathrm{Tf}_{2} \mathrm{~N}^{-}, \mathrm{OH}^{-}$, or MeCN. These Lewis donor compounds are categorized as ' $X$-factors' (Scheme 12). ${ }^{22}$ More and more recent evidence indicated the significant of these ' $\mathrm{X}$-factors'. Subsequently, Shi's group initiated an effort to evaluate the bonding ability of $1,2,3-$ triazole towards $\mathrm{Au}(\mathrm{I})$ as 'X-factor' and examine the reactivity displayed by the resultant triazole $\mathrm{Au}(\mathrm{I})$ complexes. 
Scheme 12. X-factors in $A u(l)$ Catalysis
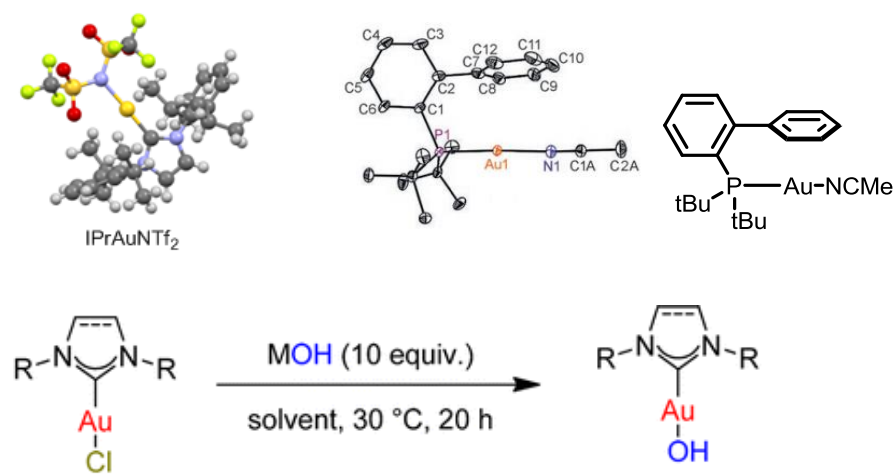

$$
\begin{aligned}
& \mathrm{NHC}=\mathrm{IPr}, \mathrm{SIPr}, \mathrm{IPr}^{\mathrm{Cl}}, \mathrm{IPr}^{\mathrm{Me}}, \mathrm{IPr}^{\star}, \mathrm{IPr}^{\star}{ }^{\mathrm{Tol}}, \text { IMes, SIMes, I'Bu, IAd, ICy, IDD } \\
& \mathrm{M}=\mathrm{K}, \mathrm{Cs}
\end{aligned}
$$

The earliest case of triazole $\mathrm{Au}(\mathrm{I})$ complexes was reported in 1998 by Nomiya et al. They obtained the triazole $\mathrm{Au}(\mathrm{I})$ complexes by using $\mathrm{NaOH}$ in acetone with moderate yield. ${ }^{23}$ Our group prepared the neutral 1,2,3-triazole gold complexes with the analogous strategy. Simply treating the $\mathrm{NH}$-triazoles with $\mathrm{PPh}_{3} \mathrm{AuCl}$ in methanol under basic conditions at room temperature gave the neutral TA-Au 1.3 and 1.4 in >90\% yield. The 'cationic' complex TA-Au 1.3a was prepared either by the reaction between $\mathrm{PPh}_{3} \mathrm{Au}^{+} \mathrm{X}^{-}$(prepared from $\mathrm{PPh}_{3} \mathrm{AuCl}$ and $\mathrm{AgX}$ ) and benzotriazole or from the addition of HOTf to TA-Au 1.3. Both complexes were stable and could be further purified by recrystallization to ensure no extra $\mathrm{Ag}^{+}$or acid remained in the catalysts (Scheme 13). 
Scheme 13. Examples of Triazole Au(l) Complexes

A

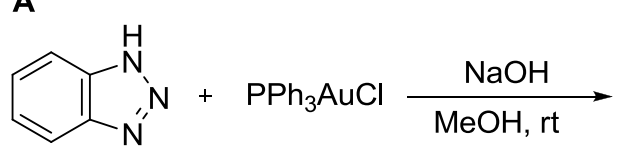<smiles>P[14CH2]n1nnc2ccccc21</smiles>

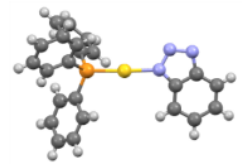

1.3 (quant.)

B

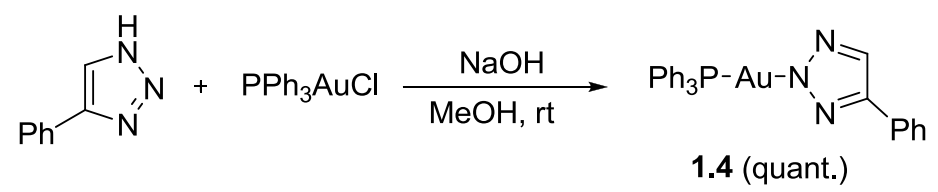

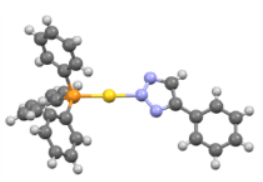

C

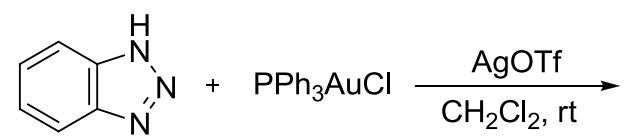

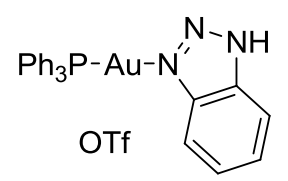

1.3a (quant.)

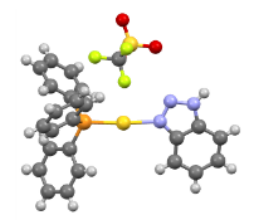

D

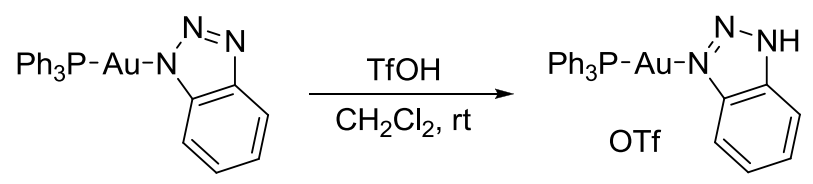

1.3

$1.3 a$

By using the methodologies introduced in Scheme 13, Shi's group synthesized a library of different benzotriazole gold complexes (Scheme 14). 
Scheme 14. A Library of $\mathrm{Au}(\mathrm{I})$ Complexes with Different Primary Ligands and Triazoles

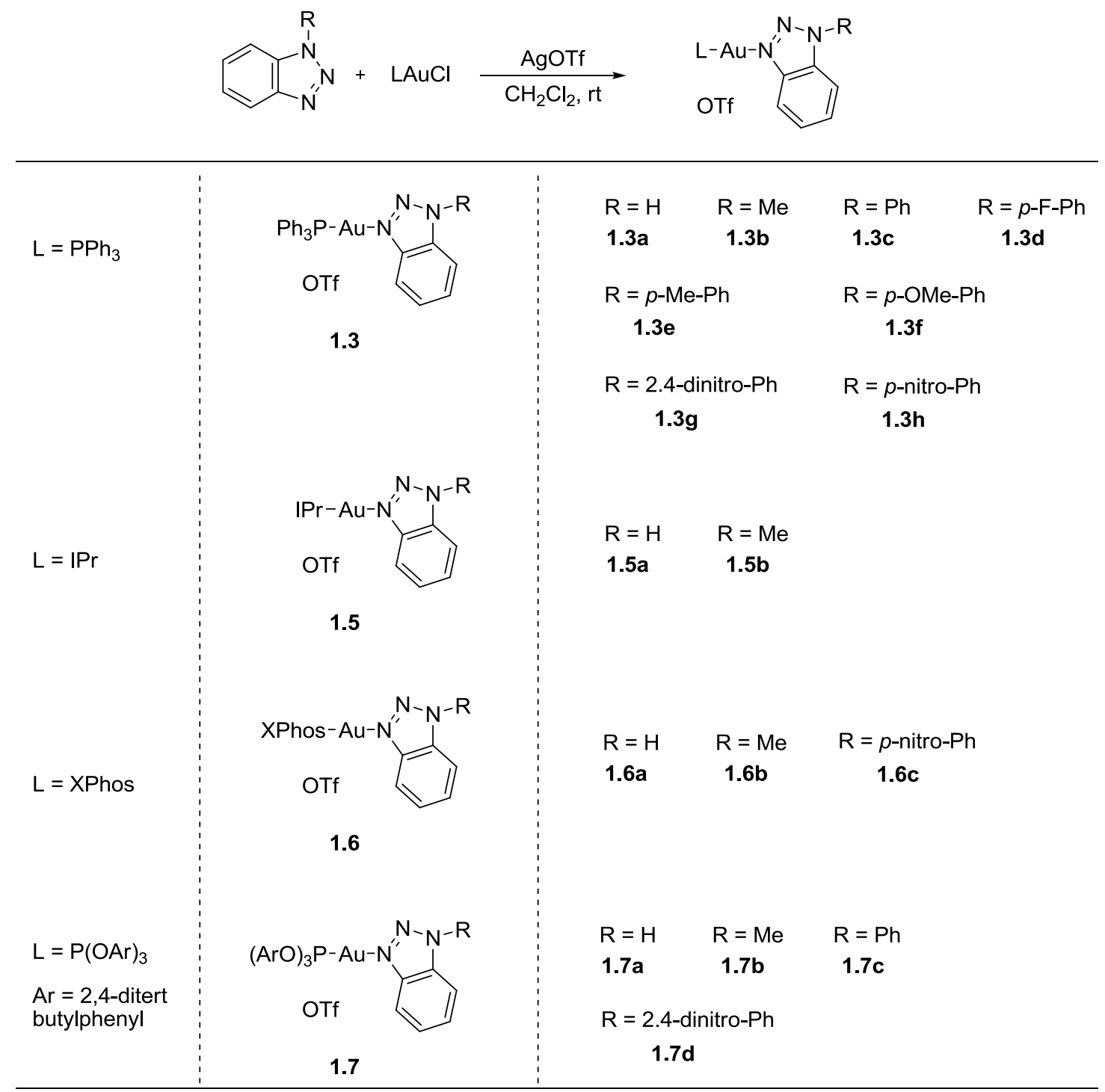

To investigate the electronic structure of gold-benzotriazole complexes, ${ }^{31} \mathrm{P}$ NMR is applied to investigate the chemical shift of triazole gold complexes with different benzotriazoles as 'X-factors'. The ${ }^{31} \mathrm{P}$ NMR chemical shifts of different goldbenzotriazole complexes together with $\mathrm{L}-\mathrm{Au}-\mathrm{Cl}$ and $\mathrm{PPh}_{3} \mathrm{Au}^{+} \mathrm{OTf}$ are listed in the following table (Table 1). 
Table 1. ${ }^{31} \mathrm{P}$ NMR Data of Substituted TA-Au Complexes ${ }^{a}$

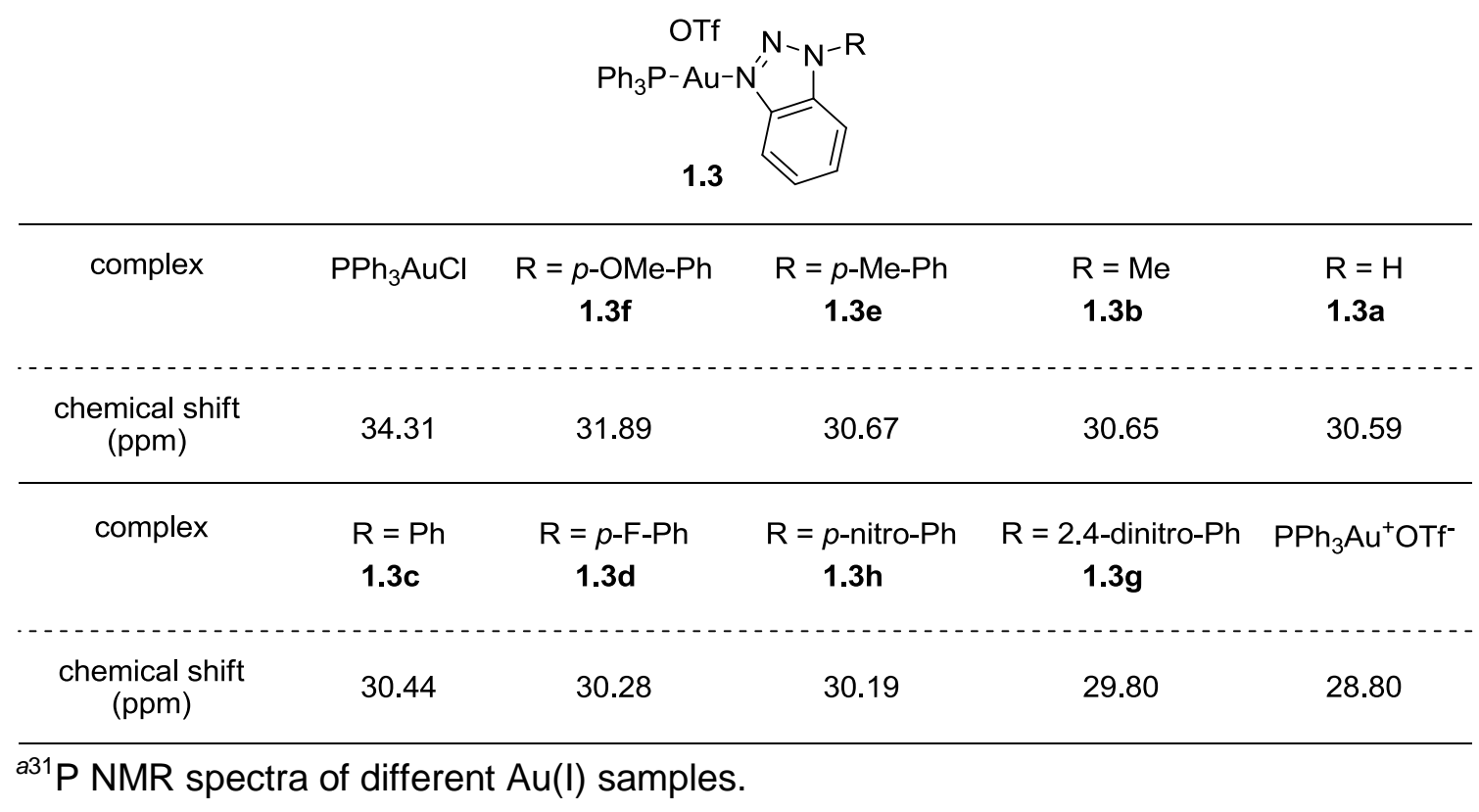

The ${ }^{31} \mathrm{P}$ NMR data in Table 1 clearly showed that with different substituted groups, different chemical shifts of benzotriazole gold compounds were observed. The theoretically most unreactive $\mathrm{Au}(\mathrm{I})$ chloride had the chemical shift of $34.31 \mathrm{ppm}$. And the theoretically most reactive cationic $\mathrm{Au}(\mathrm{I})$ complex $\mathrm{PPh}_{3} \mathrm{Au}^{+} \mathrm{OTf}$ exhibited the lowest ${ }^{31} \mathrm{P}$ chemical shift at $28.80 \mathrm{ppm}$. All triazole gold complexes ${ }^{31} \mathrm{P}$ NMR data lying between these two extreme cases, exhibited a trend which perfectly lined with the electron negativity of different $\mathrm{N}-1$ aromatic substitutions. Complex $1.4 \mathrm{f}$ was the one which contains the most electronic rich R-substituent gave the ${ }^{31} \mathrm{P}$ NMR chemical shift $(\delta$ $31.89 \mathrm{ppm}$ ) closest to $\mathrm{L}-\mathrm{Au}-\mathrm{Cl}$. In contrast, complex $\mathbf{1 . 4 \mathrm { g }}$ with the most electronic deficient R-substituent gave the ${ }^{31} \mathrm{P}$ NMR chemical shift ( $\delta 29.80 \mathrm{ppm}$ ) closest to $\mathrm{PPh}_{3} \mathrm{Au}^{+} \mathrm{OTf}-$. Based on the diverse chemical shift, the reactivity for different gold (I) benzotriazole complexes are tuned with a small range to apply in gold catalysis. 
To better evaluate the reactivity of benzotriazole $A u(I)$ complexes and compare the catalytic performance of benzotriazole $\mathrm{Au}(\mathrm{I})$ complexes with other $\mathrm{Au}(\mathrm{I})$ catalysts, we chose to study the 3,3-rearrangement of propargyl ester to allene promoted by triazole $\mathrm{Au}(\mathrm{I})$ complexes.

\subsection{Propargyl ester rearrangements promoted by triazole $A u(I)$ complex as chemoselective catalyst.}

The propargyl ester rearrangement was considered as one of the most important reaction modes in $\mathrm{Au}(\mathrm{l})$ promoted transformations. ${ }^{24-34}$ Recent experimental and computational mechanistic studies showed that the 3,3-rearrangement to form the

allene ester intermediate as the key step in this transformation (Scheme 15A). ${ }^{35-37}$ Both experimental and theoretical investigations confirmed the reversibility between allene and propargyl ester due to effective activation of both functional groups by the $A u(I)$ catalysts. As a result, it was extremely challenging to obtain the allene intermediates with good yields. 
Scheme 15. The Challenge of The Synthesis of Allenes through Au(I) Activated Alkynes

A. Equilibrium between gold activated alkyne and allene

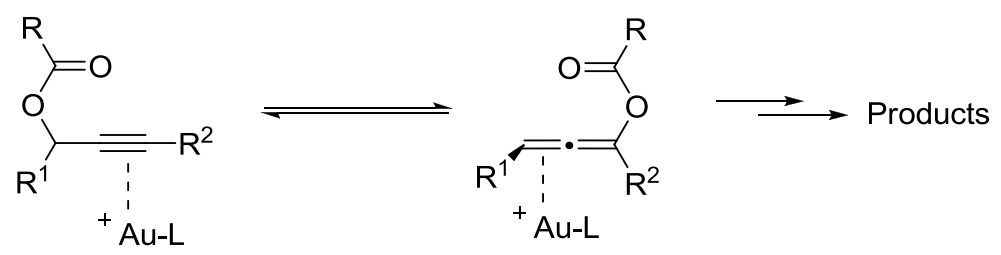

B. Indene synthesis: Quenching of the allene by benzene
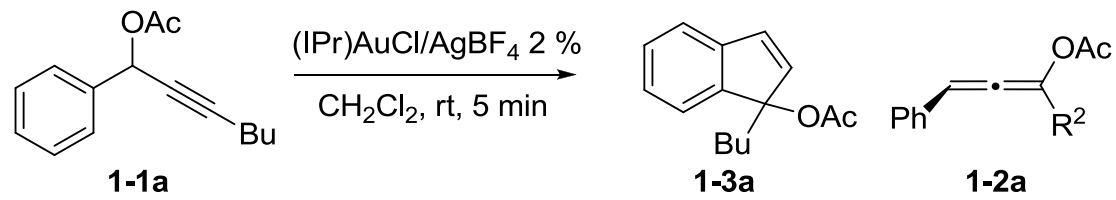

Many strategies have been developed to make the $A u(I)$-activated allene esters react with other proper substrates, forming interesting new products in a cascade fashion. Different types of $A u(l)$ complexes have been applied in the investigation of this reaction, such as $\mathrm{IPrAuCl}_{\mathrm{AgBF}}$. In 2006, Nolan et al developed the synthesis to indene compounds, which is a good example highlighting the importance of the cascade process. ${ }^{38}$ As shown in Scheme 15B, with the $[\mathrm{IPr}-\mathrm{Au}]^{+}$catalyst, only a trace amount of allene was obtained. The major product was derived from the Friedel-Crafts addition of the aromatic ring to the gold activated allene. Therefore, selective activation of the alkyne over the allene was considered as a significant challenge in gold catalysis.

Our group reported the synthesis and characterization of the 1,2,3-triazole coordinated $\mathrm{Au}(\mathrm{I})$ complexes. ${ }^{39-43}$ As revealed by the X-ray crystal structures (Scheme 16), both neutral and anionic triazoles can coordinate with the $A u(I)$ cation, forming stable TA-Au complexes. ${ }^{44}$ 
Scheme 16. X-ray Crystal Structures of Two Different Types of 1,2,3-triazole-Au Complexes

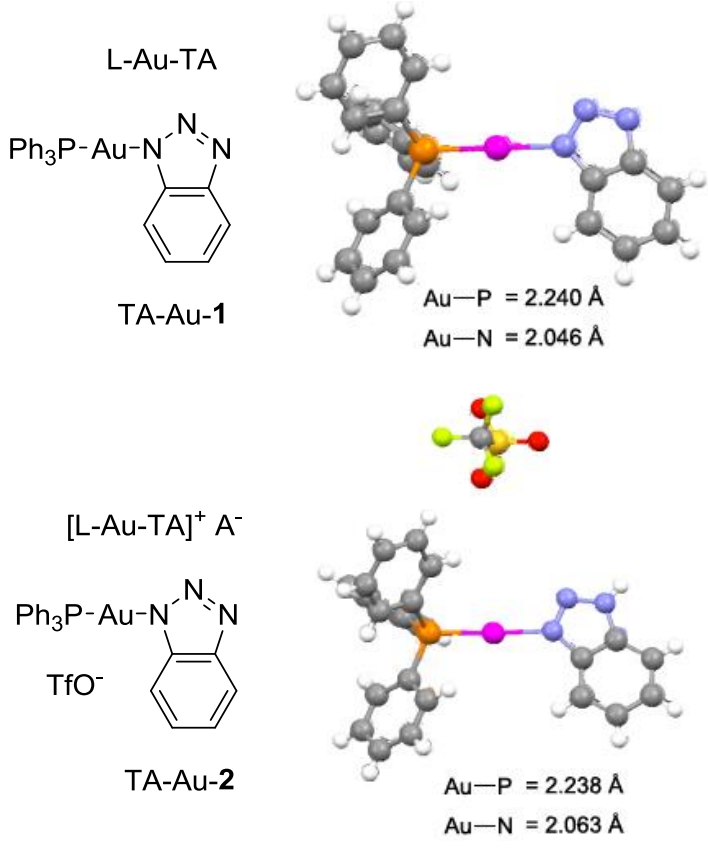

The crystal structures revealed nearly identical Au-P bond distance of $2.24 \AA$ for both the anionic and neutral triazole coordinated $\mathrm{Au}(\mathrm{I})$ complexes. The longer $\mathrm{Au}-\mathrm{N}$ bond in TA-Au-2 implies that the neutral triazole dissociates more easily to release the coordination site for substrate activation. This new class of compounds offers improved thermal stability and substrate stability in the $A u(I)$ promoted hydroamination and Hashimi phenol synthesis ${ }^{45}$ which makes them interesting novel catalysts in the field of gold catalysis. One particular new development of the TA-Au catalysis that attracted our attention was the synthesis of $\alpha$-iodoenone from propargyl esters (Scheme 17). ${ }^{46}$ 
Scheme 17. Synthesis of $\alpha$-lodoenone Compounds from Propargyl Esters

A. Formation of $(E)$ - $\alpha$-haloenone with TA-Au, $(Z)$-isomers with $\mathrm{Au}\left(\mathrm{PPh}_{3}\right) \mathrm{NTf}_{2}$

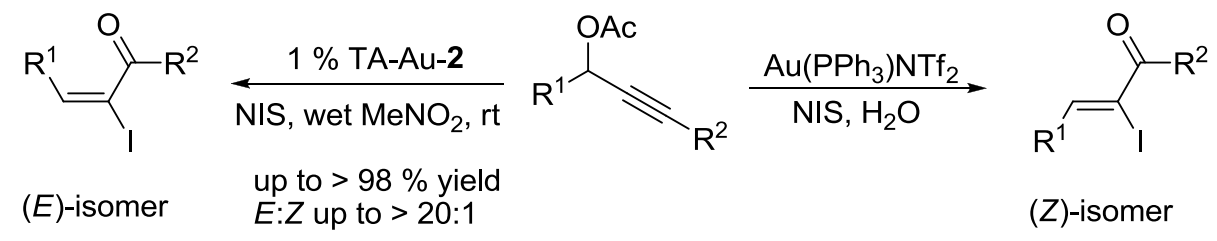

B. Formation of kinetically fovered $(E)$-isomers

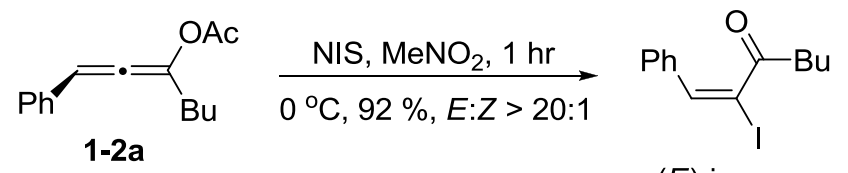

(E)-isomer

As indicated in Scheme 17A, the typical $[\mathrm{L}-\mathrm{Au}]^{+}$catalyst promoted the sequential rearrangement and iodination, giving the thermally, dynamically stable(Z)-isomer. ${ }^{47-49}$ The cationic TA-Au catalyst, on the other hand, produced the kinetically favored $(E)$ isomer. Notably, treating the allene ester with NIS gave the $(E)$-isomer (Scheme 17B). The typical $[\mathrm{L}-\mathrm{Au}]^{+}$catalyst influenced the allene reactivity, probably through gold catalyzed allene activation. The fact that TA-Au gave the dominant $(E)$-isomers strongly suggests that these complexes may be applied as a chemoselective catalyst in alkyne activation over allene.

The reaction of propargyl ester 1-1a with TA-Au catalysts were then investigated as shown in Scheme 18. 
Scheme 18. Chemoselective Activation of Alkyne over Allene by the TA-Au Catalysts

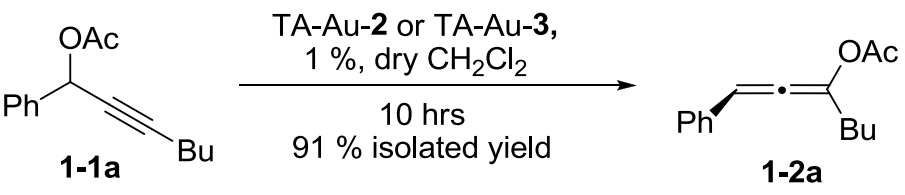

$\begin{array}{ccc:ccc}t & \text { indene 1-3a } & \mathbf{1 - 2 a} & t & \text { indene 1-3a } & \mathbf{1 - 2 a} \\ 10 \mathrm{~min} & 0 & 15 \% & 20 \mathrm{hrs} & 0 & >98 \% \\ 4 \mathrm{hrs} & 0 & 83 \% & 48 \mathrm{hrs} & 0 & >98 \% \\ 8 \mathrm{hrs} & 0 & 95 \% & & & \end{array}$

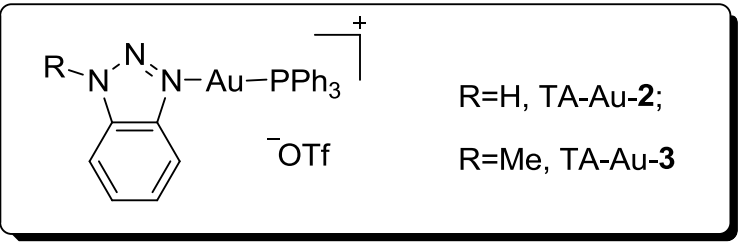

This transformation proceeded smoothly with substrates having both an aromatic group on the propargyl side and an aliphatic group on the alkyne side (entries 1-6) as shown in Table 2. The desired allene products were formed in excellent yields, with $1 \%$ catalyst loading. The electronic density on the aromatic ring did not have a strong impact on the transformation: Both electron donating and electron-withdrawing groups were suitable for the reaction. Again, no indene by-products were observed in any of the tested cases, even with the electron-enriched $p$-OMe substituted alkyne 1-1d. These results highlighted the excellent chemoselective nature of the TA-Au catalyst. 
Table 2. The Reaction Substrate Scope ${ }^{a}$

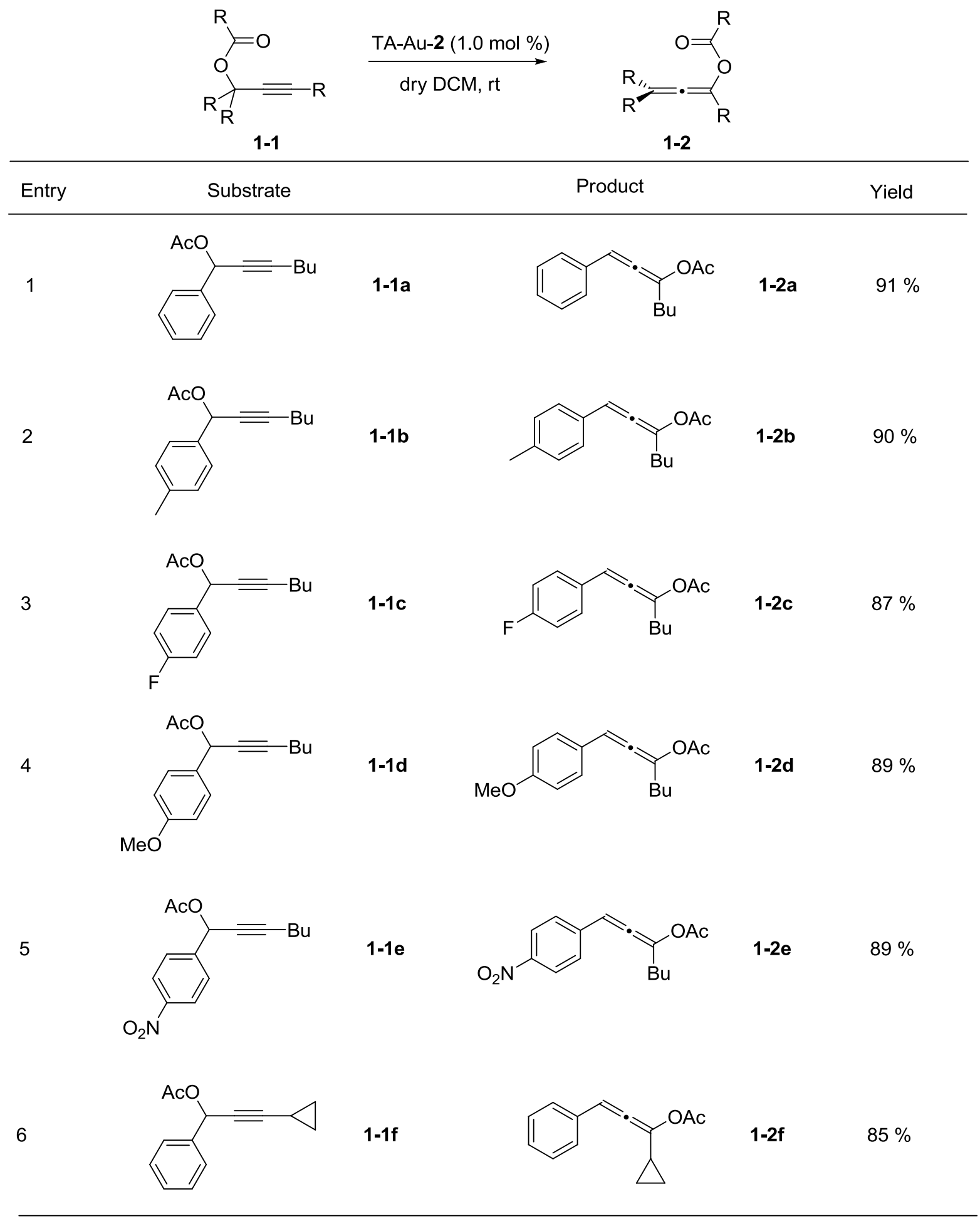


Substrates that did not form the desired allenes ${ }^{b}$

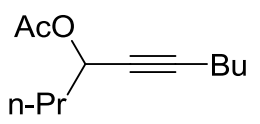

$1-1 g$

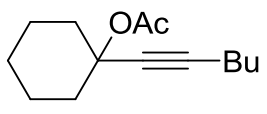

$1-1 h$

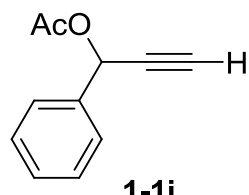

$1-1 \mathrm{i}$

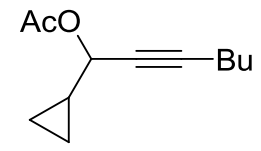

$1-1 j$

${ }^{a}$ General reaction condition: 1-1 $(0.25 \mathrm{mmol})$ and TA-Au-2 $(1.0 \mathrm{~mol} \%)$ in dry DCM $(2.5 \mathrm{~mL})$, the reaction were monitored by TLC (2-10 hrs), rt. ${ }^{b} \mathrm{TA}-\mathrm{Au}-1, \mathrm{TA}-\mathrm{Au}-2$ and TA-Au-3 did not catalyze the reaction under the standard conditions.

The terminal alkyne 1-1i did not give any product when treated in the presence of the TA-Au catalyst, even after an extended reaction time (24 hrs). This was probably caused by the preferred 1,2-rearrangement with the formation of the vinyl-Au intermediate. The aliphatic propargyl ester (1-1g, 1-1h) also did not give any desired allene products although enones from hydrations were produced after a long reaction time (24-48h). The crude NMR of the reaction mixtures did not show an evidence of any allene products. This may be caused by the high reactivity of the corresponding aliphatic allenes under the reaction conditions (activated by TA-Au) and the overall better stability of the propargyl ester compared to the aliphatic substituted allenes (equilibrium favored the starting material). The reaction of cyclopropyl substituted propargyl ester $\mathbf{1 - 1} \mathbf{j}$ with the TA-Au catalyst gave a complex reaction mixture, which suggests possible ring opening and sequential cyclization as reported previously. ${ }^{50}$ Overall, this study suggests that the propargyl ester rearrangement to form allene is highly substrate dependent. This could either be due to the similar reactivity of the alkyne and the allene (giving an equilibrium state favoring the alkyne over the allene) or it could be due to a preferred alternative migration path (2,3-migration versus 3,3migration). In any case, the TA-Au catalyst clearly displayed interesting chemoselectivity. 
To study the feasibility of this migration, we then investigated migrating groups other than esters. The results are summarized in Table 3.

Table 3. Different Migrating Groups ${ }^{a}$

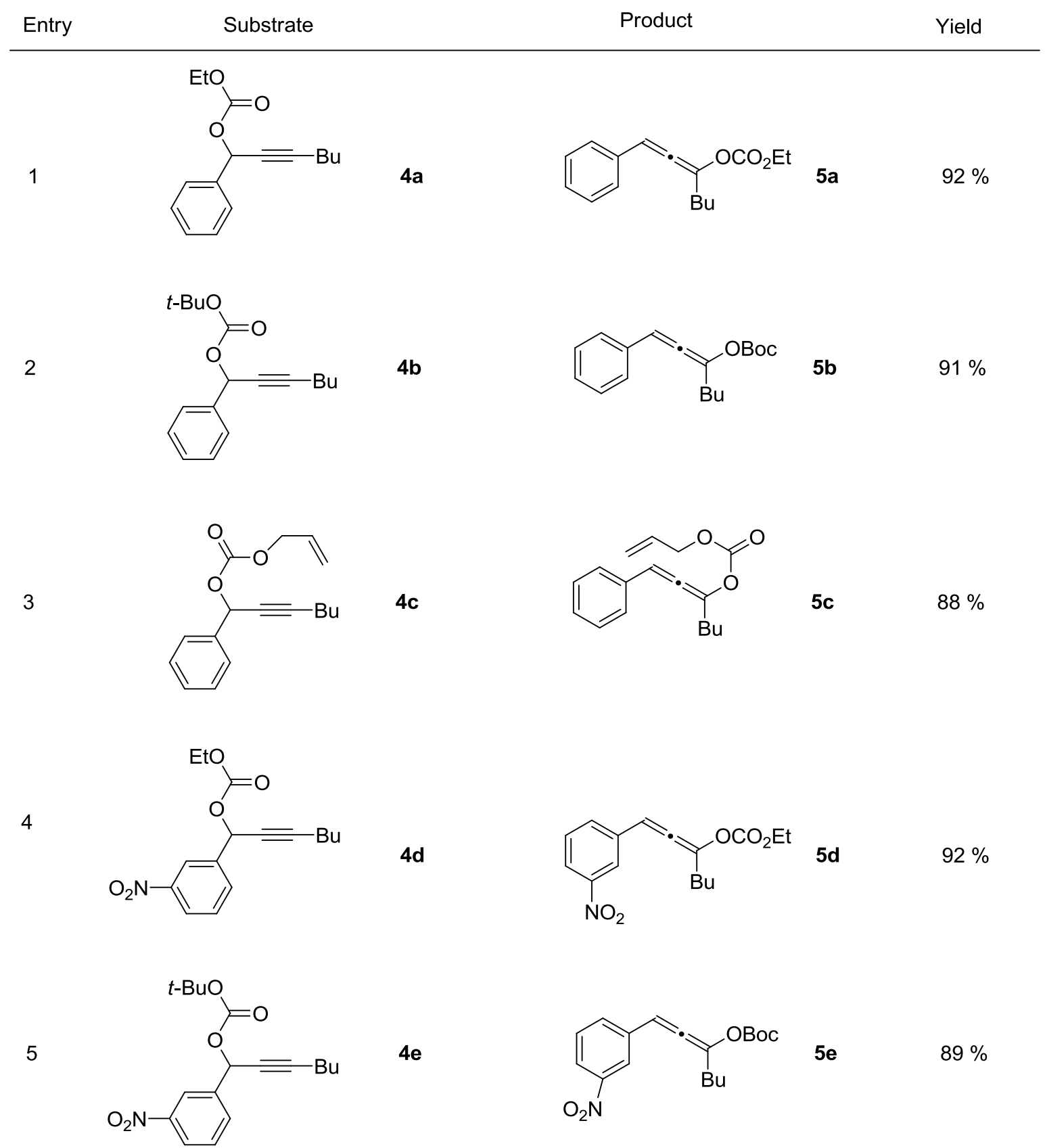


6

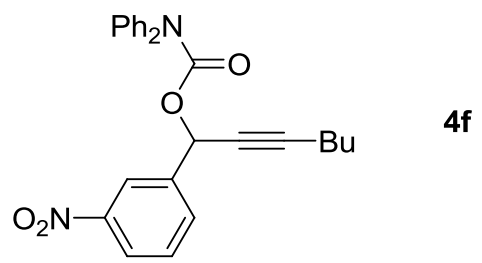

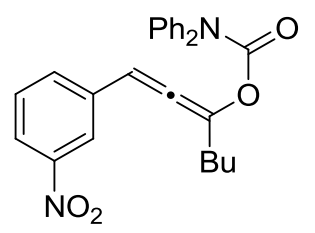

$5 \mathbf{f}$

$85 \%$

${ }^{a}$ General reaction condition: 1-4 $(0.25 \mathrm{mmol})$ and TA-Au-2 $(1.0 \mathrm{~mol} \%)$ in dry DCM $(2.5 \mathrm{~mL})$, the reactions were monitored by TLC (2-10 hrs), rt.

As indicated in Table 3, carbonates (entries 1-5) and carbamate (entry 6) were also suitable for this transformation. Compared to the allene-acetates, the allene-carbonates and allene-carbamate were more stable in water. Notably, although the alkene was considered as a readily reactive functional group in gold catalysis, the substrate 1-4c was suitable for this transformation, giving the desired allene-ene 1-5c in excellent yield.

\subsection{Conclusion}

In this research, we reported the application of triazole-coordinated $\mathrm{Au}(\mathrm{I})$ complexes as the effective catalysts for the promotion of the propargyl ester, carbonate and carbamate 3,3-rearrangement for the synthesis of the corresponding substituted allene derivatives. The chemoselective nature of the TA-Au catalysts was clearly demonstrated, which makes them an interesting class of new catalysts for promoting organic transformations. The application of the allene-carbonates and allenecarbamates as building blocks for development of new synthetic methodologies is currently underway in our group. 


\subsection{Contribution}

Dr. Dawei Wang was the researchers who had first investigated the reaction. Together Dr. Wang and Yanwei Zhang were responsible for the substrate scope evaluation and manuscript completion for successful submission to Beilstein J. Org. Chem.. Detailed X-ray crystallographic data analysis of compound TA-Au-1 and TA-Au2 was done by Prof. Jeffrey L. Petersen, C. Eugene Bennett Department of Chemistry, West Virginia University. 


\section{Chapter Two: Further transformations from allene intermediate formed by triazole-Au(I) Complex promoted propargyl ester rearrangements.}

\subsection{Triazole gold promoted, effective synthesis of enones from propargylic esters and alcohols}

\subsubsection{Introduction}

Among previous reported $A u(I)$ catalysts, none of them exhibits a 'real' chemoseletivity towards alkyne over allene. All the allene intermediates generated from the corresponding 3,3-rearrangement were further activated by the $\mathrm{Au}(\mathrm{I})$ catalysts and transformed to other products. As mentioned above, TA-Au complex could selectively activate alkyne over allene, the isolated allene analogues have been achieved from the $\mathrm{Au}(\mathrm{I})$ activated transformation effectively for the first time. These allene analogues alone could serve as very interesting reaction precursors.

Shi's group successfully synthesized and characterized a library of 1,2,3-triazole gold complexes (TA-Au) as effective catalysts. These complexes exhibit significantly improved thermal and substrate stability. These results opened up a new strategy in tuning gold reactivity through secondary ligand as 'X-factor'. Herein, we report the application of the 1,2,3-triazole-coordinated ${ }^{52} \mathrm{PPh}_{3}-\mathrm{Au}$ catalysts in promoting the propargylic ester rearrangement and sequential hydration to form the enone with high efficiency $(0.2 \%$ catalyst loading, up to $97 \%$ isolated yields), unique reactivity (combining the chemoselectivity and acidity) and improved ligand-economy (utilization 
of the much cheaper triazole and $\mathrm{PPh}_{3}$ ligands as compared with $\mathrm{NHC}$ ligands). In addition, with the significantly improved thermal stability, TA-Au was further applied as the effective catalyst in promoting the propargylic alcohol Meyer-Schuster rearrangement to give the enones ( $0.5 \%$ catalyst loading, up to $98 \%$ yields), which highlighted the advantage of this complex compared with other conventional $\mathrm{L}-\mathrm{Au}^{+}$ catalysts.

As indicated in scheme 19, one advantage of the TA-Au catalyst is the significantly low cost of the ligands. Compared with the NHC ligands, the combination of the $\mathrm{PPh}_{3}$ primary ligand and triazole as $X$ factor, the cost can be only 1,000 th that of a single $\mathrm{NHC}$ primary ligand. Our original intention was to test whether TA-Au could promote transformations that previously required the expensive NHC primary ligands (to improve the ligand economy of the overall reaction). This initiated our investigation on the enone synthesis from the propargylic esters with our TA-Au catalyst.

Scheme 19. NHC: Good Ligand in Gold Catalysis but at High Cost

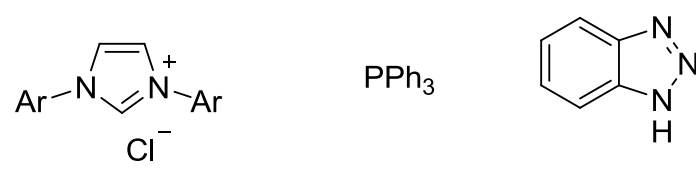

$$
500 \mathrm{mg},>\$ 40 \quad 1 \mathrm{~kg}, \$ 70 \quad 1 \mathrm{~kg}, \$ 70
$$

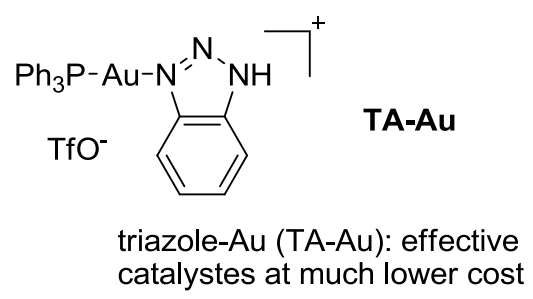


The gold-catalyzed Propargylic ester 3,3-rearrangement is a well-studied transformation. ${ }^{53}$ One application of this process was the synthesis of enones from sequential hydration of the allene-acetate $2-1-2 a$ intermediates. ${ }^{54}$ Although this transformation provided one attractive strategy in preparing enones under mild conditions, it suffered from a limited substrate scope due to the side reactions caused by the gold-promoted allene activation. One side reaction was the intramolecular Friedel-Crafts cyclization of 2-1-2a, giving the indene $2-1-3 a .{ }^{55}$ As a result, a simple $\mathrm{Au}(\mathrm{I})$ catalyst, such as $\mathrm{PPh}_{3} \mathrm{Au}^{+}$, gave poor overall yields of the desired enones $(5 \%$ $\mathrm{Ph}_{3} \mathrm{PAuCl} / \mathrm{AgOTf},<40 \%$ yields) (Scheme 20).

Scheme 20. L-Au+: Effective Catalysts Activating both Alkyne and Allene

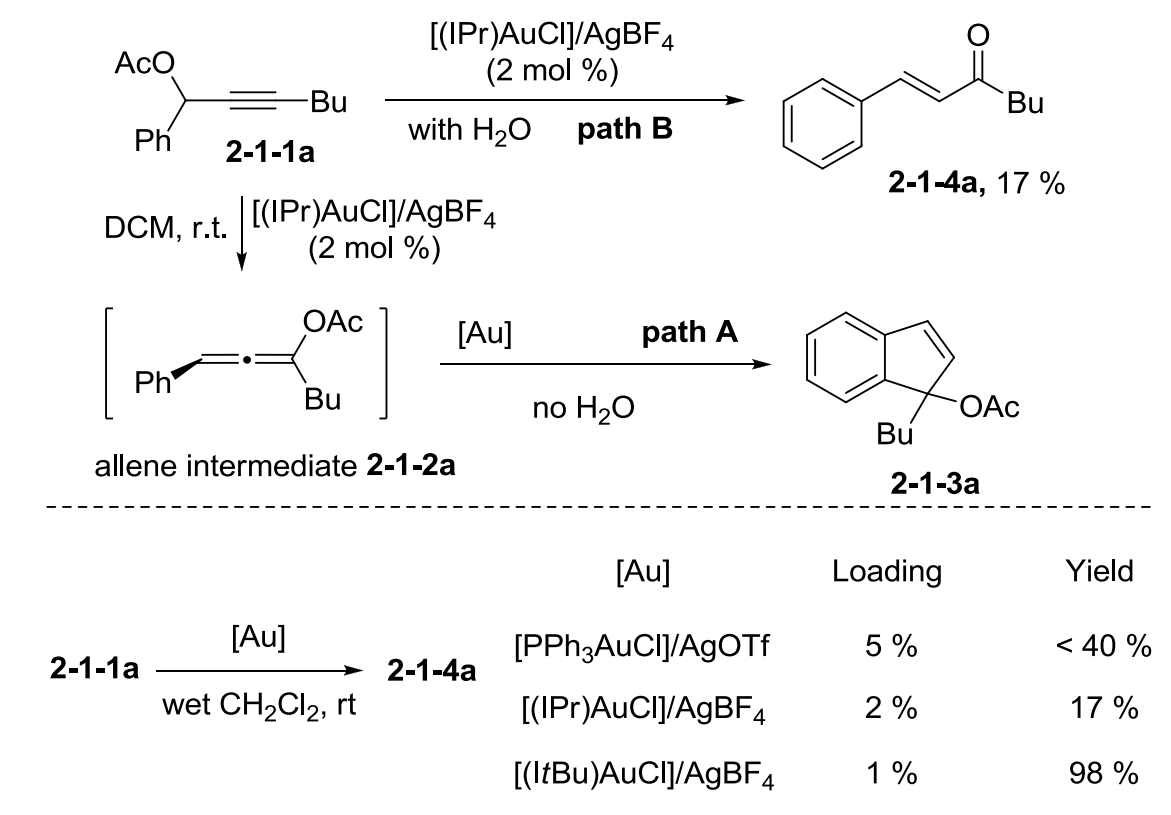

To overcome this problem, Nolan and co-workers investigated different $\mathrm{N}$ heterocyclic carbene ligands. ${ }^{56}$ The more steric hindered $[(I t B u) A u]^{+}$complex was revealed as the optimal catalyst for the formation of enones with high efficiency ( $1 \%$ loading, up to $98 \%$ yields). The authors have performed comprehensive mechanistic 
investigations. ${ }^{54}$ Through both experimental and computational studies, the $\mathrm{S}_{\mathrm{N} 2}$ ' water addition to the gold-activated alkyne was suggested as the mechanism by avoiding the formation of allene (Scheme 21A). This mechanism is further supported by two other experimental observations: (i) no enone formation was observed with the $t$-Busubstituted alkyne 2-1-1b (Scheme 21B), and (ii) treating allene ester 2-1-2a with the NHC-Au catalyst did not give enone 2-1-4a (Scheme 21C).

Scheme 21. Proposed $\mathrm{S}_{\mathrm{N}}$ ' Addition Mechanism by Nolan

A

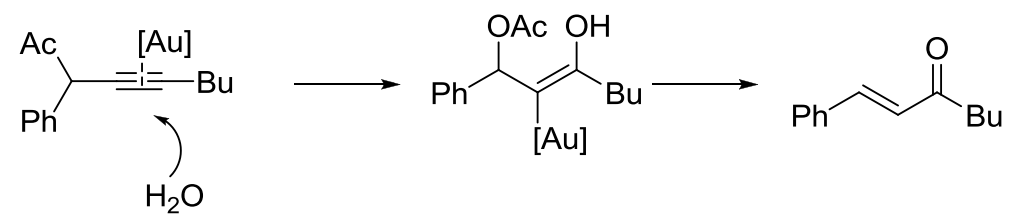

B

conditions

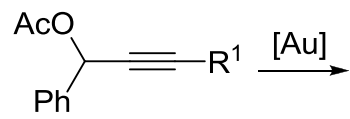<smiles>[R]C(=O)/C=C/c1ccccc1</smiles>

2-1-1a, $R^{1}=B u ;$

2-1-1b, $\mathrm{R}^{1}=t-\mathrm{Bu}$

2-1-4a, $\mathrm{R}^{1}=\mathrm{Bu}$;

2-1-4b, $\mathrm{R}^{1}=t-\mathrm{Bu}$

$2-1-4 a, 98 \%$ yield

2-1-4b, no reaction

C

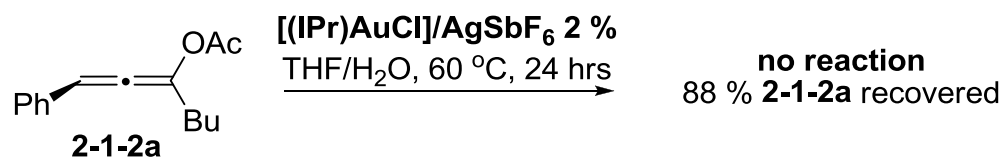




\subsubsection{Triazole gold promoted, effective synthesis of enones from prypargylic esters and alcohols: a catalyst offering chemoselectivity, acidity and ligand economy}

Recently, we reported the synthesis of E-a-iodo-enone from a propargylic ester 3,3rearrangment followed by the iodination of the allene ester. Interestingly, while all other $[\mathrm{L}-\mathrm{Au}]^{+}$catalysts $\left(\right.$such as $[\mathrm{NHC}-\mathrm{Au}]^{+}$and $\left[\mathrm{PPh}_{3}-\mathrm{Au}\right]^{+}$) gave only the thermodynamically stable Z-isomers, the application of TA-Au led to the selective formation of the kinetically favored E-isomers. These results suggested that TA-Au was a chemoselective catalyst, which could effectively promote alkyne activation without interrupting the inherent reactivity of the allene intermediates. ${ }^{46}$

Moreover, as shown in Scheme 22A, although the allene ester $\mathbf{2 - 1 - 2 a}$ is rather stable even at elevated temperatures, treatment of this compound with a catalytic amount of acid could effectively convert the allene to the desired enones with excellent yields. Interestingly, unlike the previously reported NHC-Au complexes (Scheme 21C), TA-Au could effectively catalyze the hydration of $2-1-2 a$ at either room temperature or elevated temperature, giving the desired enone in excellent yields. This was likely caused by the equilibrium shown in Scheme 22B, where a catalytic amount of HOTf was released to serve as the Bronsted acid in promoting the hydration. 
Scheme 22. TA-Au Serves as Bronsted Acid in Hydration Transformation

A

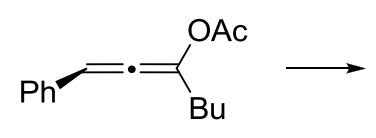

$2-1-2 a$

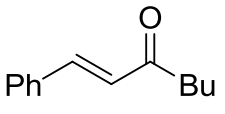

$2-1-4 a$ cat.

conditions

$2-1-4 a$

$\mathrm{MeOH}, 60^{\circ} \mathrm{C}, 10$ hrs n.r.

$5 \% \mathrm{TfOH} \quad \mathrm{MeOH}, 60^{\circ} \mathrm{C}, 6 \mathrm{hrs} \quad 99 \%$

$5 \%$ TA-Au $\mathrm{MeOH}, 60^{\circ} \mathrm{C}, 6 \mathrm{hrs} \quad 98 \%$

B

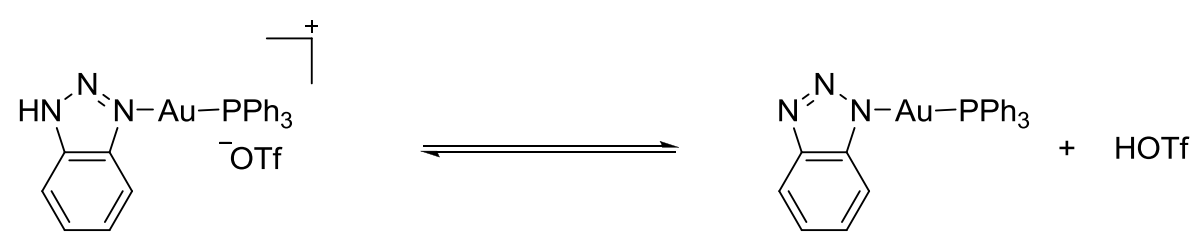

We then postulated that TA-Au might be the effective catalyst in promoting the propargylic ester rearrangement and hydration to give enones. Unlike the previously reported $[(\mathrm{ItBu}) \mathrm{Au}]^{+}$catalyst, TA-Au promoted this reaction through a chemoselective rearrangement followed by an effective hydration with the same pre-catalysts, which therefore provides an alternative to prepare enones compared with the $S_{N} 2$ mechanism by the more expensive $[(1 t \mathrm{Bu}) \mathrm{Au}]^{+}$catalysts.

As expected, with the TA-Au catalyst, enone 2-1-4 was obtained in excellent yields. No indene by-product was observed, which highlighted the chemoselective nature of the TA-Au catalyst.

$\mathrm{TfOH}$ was not a suitable catalyst for this reaction since the 3,3-rearrangement did not occur with only $\mathrm{TfOH}$. Screening of solvents revealed $\mathrm{MeOH}$ as the optimal choice. The reaction worked smoothly at room temperature and gave the enone product in excellent yields over $24 \mathrm{~h}$. Increasing the temperature decreased the reaction time to 3 - 
$6 \mathrm{~h}$. As a result, the enones 2-1-4 were obtained with near quantitative yields (> $99 \%$ NMR yields) at very low catalyst loading (0.2\%).

As shown in Table 4, the reaction tolerated large group substrates, giving the desired enone in excellent yields and good double-bond selectivity (dominant transisomers). The $t$-Bu-substituted alkyne 2-1-2b, which was not suitable with the NHC-Au catalyst due to the $S_{N} 2$ mechanism, proceeded smoothly under these alternative conditions although with slightly decreased Z/E selectivity (2-1-4b). The high efficiency makes TA-Au a very attractive and practical catalyst for this transformation: at least 5 times lower catalyst loading than $\mathrm{NHC}-\mathrm{Au}^{+}$with much less expensive ligands.

Table 4. TA-Au Catalyzed Propargyl Ester Hydrolysis ${ }^{a, b}$
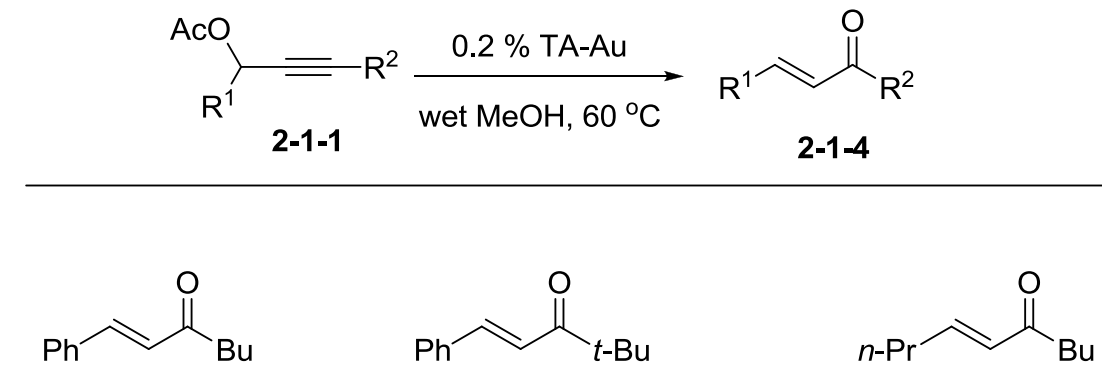

2-1-4a, $92 \%, E / Z=12: 1$

2-1-4b, $93 \%, E / Z=3: 1$

2-1-4c, $92 \%, E / Z>20: 1$
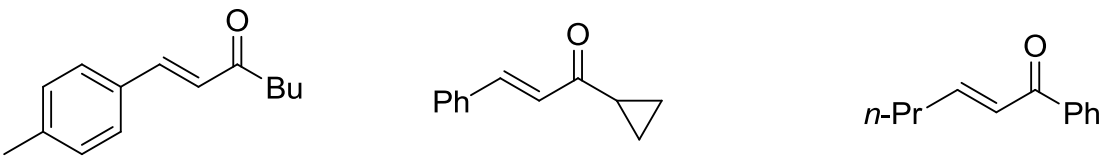

2-1-4d, $91 \%, E / Z>8: 1$

$\mathbf{2 - 1 - 4 e , ~} 83 \%, E / Z=10: 1$

2-1-4f, $89 \%, E / Z>20: 1$<smiles>CC=CC(=O)Br</smiles><smiles>CC(C)CC(=O)/C=C/c1ccc(F)cc1</smiles>

2-1-4g, $85 \%, E / Z>20: 1$

2-1-4h, $95 \%, E / Z>20: 1$<smiles>CC(C)=CC(=O)Br</smiles>

$2-1-4 i, 89 \%$ 


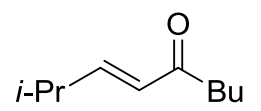

2-1-4j, $93 \%, E / Z>20: 1$

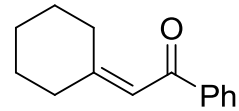

$2-1-4 k, 87 \%$

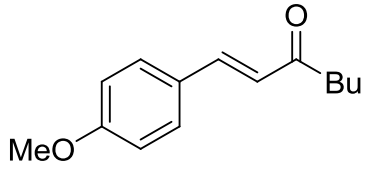

2-1-4I, $97 \%, E / Z>20: 1$

${ }^{a}$ General reaction condition: 2-1-1 (1.0 eq.) and TA-Au (0.2 mol \%) in wet $\mathrm{MeOH}(0.25 \mathrm{M})$, the reaction were monitored by TLC $(3-6 \mathrm{~h}), 60^{\circ} \mathrm{C}$. ${ }^{b}$ Isolated yields; $E / Z$ ratios were determined by ${ }^{1} \mathrm{H}$ NMR.

Heating the $[(\mathrm{IPr}) \mathrm{AuCl}] / \mathrm{AgBF}_{4}$ in wet $\mathrm{MeOH}$ at $60{ }^{\circ} \mathrm{C}$ produced a black solution/participate within $30 \mathrm{~min}$, indicating the rapid decomposition of the catalyst. In contrast TA-Au, on the other hand, showed much improved stability, with no decomposition after more than $6 \mathrm{~h}$ under the same conditions. Considering the good thermal stability of TA-Au, we wondered whether this catalyst could also be used to promote the challenging Meyer-Schuster arrangement of propargylic alcohols 2-1-5 at higher temperature. ${ }^{57}$ Impressively, the desired enone products were formed with excellent yields. The reaction also tolerated a large group of substrates (Table 5).

Table 5. TA-Au Catalyzed Meyer-Schuster Rearrangement ${ }^{a, b}$

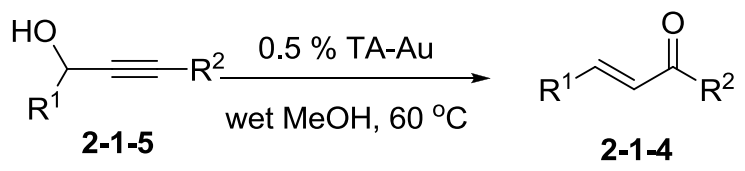<smiles>O=C(/C=C/c1ccccc1)C(=O)c1ccccc1</smiles>

2-1-4a, $89 \%, E / Z=9: 1$<smiles>Cc1ccc(/C=C/C(=O)Br)cc1</smiles>

2-1-4d, $97 \%, E / Z=6: 1$<smiles>CC(C)(C)C(=O)/C=C/c1ccccc1</smiles>

2-1-4b, $90 \%, E / Z=3: 1$<smiles>O=C(/C=C/c1ccccc1)C1CC1</smiles>

2-1-4e, $89 \%, E / Z=11: 1$<smiles>O=C(Br)C=CC=[Po]</smiles>

2-1-4c, $91 \%, E / Z>20: 1$<smiles>O=C(/C=C/[Pb]=P)c1ccccc1</smiles>

2-1-4f, $85 \%, E / Z>20: 1$ 
<smiles>CC=CC(=O)CBr</smiles>

2-1-4g, 94\%, $E / Z>20: 1$<smiles>O=C(Br)/C=C/[PH+]</smiles>

2-1-4j, $96 \%, E / Z>20: 1$<smiles>O=C(/C=C/c1ccccc1)c1ccccc1</smiles>

2-1-4m, $93 \%, E / Z>20: 1$<smiles>Cc1ccc(/C=C/C(=O)c2ccccc2)cc1</smiles>

2-1-4p, $97 \%, E / Z=16: 1$<smiles>COc1ccccc1/C=C/C(=O)CC(C)(C)C</smiles>

2-1-4s, $93 \%, E / Z>20: 1$<smiles>O=C(Br)/C=C/c1ccc(F)cc1</smiles>

2-1-4h, $91 \%, E / Z>20: 1$<smiles>O=C(C=C1CCCCC1)c1ccccc1</smiles>

2-1-4k, $84 \%$<smiles>CC(C)=CC(=O)c1ccccc1</smiles>

$2-1-4 n, 92 \%$<smiles>O=C(Br)/C=C/C1CC1</smiles>

2-1-4q, $92 \%, E / Z>20: 1$<smiles>O=C(Br)C=Cc1ccccc1Cl</smiles>

2-1-4t, $98 \%, E / Z>20: 1$<smiles>CC(C)=CC(=O)C=C(C)C</smiles>

$2-1-4 i, 98 \%$<smiles>COc1ccc(/C=C/C(=O)Cc2ccccc2)cc1</smiles>

2-1-4I, $95 \%, E / Z>20: 1$<smiles>Cc1ccccc1/C=C/C(=O)Br</smiles>

2-1-4o, $94 \%, E / Z=13: 1$<smiles>O=C(C=C1CCCCC1)C=C1CCCCC1</smiles>

$2-1-4 r, 87 \%$<smiles>CC(C)(C)C(=O)/C=C/c1cccc2ccccc12</smiles>

2-1-4u, $88 \%, E / Z>20: 1$

${ }^{a}$ General reaction condition: 2-1-5 (1.0 eq.) and TA-Au (0.5 mol \%) in wet $\mathrm{MeOH}(0.2 \mathrm{M})$, the reaction were monitored by $\operatorname{TLC}(4-12 \mathrm{~h}), 60^{\circ} \mathrm{C}$. ' Isolated yields; $E / Z$ ratios were determined by ${ }^{1} \mathrm{H}$ NMR.

Surprisingly, the bulky tert-butyl-substituted alkyne 2-1-5b was also suitable for this reaction, which suggested the effective water addition to the sterically hindered alkyne at higher temperature. The terminal alkyne propargylic alcohol gave enal in modest yields, which were probably caused by the longer reaction time required for the less favored anti-Markovnikov addition. ${ }^{58-59}$ 
Scheme 23. Comparison with the Best Results Obtained in the Literature

$\begin{array}{ll} & \\ & \end{array}$

Continuous addition of catalysts could improve the overall yields. Nevertheless, the feasibility of this challenging substrate highlighted the strength of the TA-Au catalyst over the $[\mathrm{NHC}-\mathrm{Au}]^{+}$catalyst (Scheme $\mathbf{2 3}$ ) by tolerating the much harsher conditions. ${ }^{60}$

\subsubsection{Conclusion}

In conclusion, we have reported herein the application of triazole-coordinated $\mathrm{Au}(\mathrm{I})$ complex (TA-Au) as an effective catalyst in promoting propargylic ester rearrangement and hydration for the synthesis of substituted enones. The key for the success of the TA-Au catalyst was the combination of its unique chemoselectivity and acidity. Extension of this transformation to the Meyer-Schuster rearrangement by taking advantage of the thermal stability of the TA-Au further improved the atom economy. Compared with the more expensive NHC-Au catalysts, TA-Au promoted the reaction 
through a different mechanism and achieved better performance with lower overall costs.

\subsubsection{Contribution}

Dr. Dawei Wang was the researcher who had first investigated the reaction condition and mechanism investigation. Together, Dr. Wang and Yanwei Zhang were responsible for substrate scope, NMR spectrum, and manuscript completion for successful submission to Advanced Synthesis and Catalysis. 


\subsection{Ambient Intermolecular [2+2] cycloaddition of allene intermediate}

\subsubsection{Introduction}

As mentioned, $\mathrm{Au}(\mathrm{I})$ catalyzed alkyne transformations typically undergo 3,3rearrangement. The allene intermediates can be further activated by the same gold species and converted into various products, such as indenes, enones, and vinyl halides.

Scheme 24. Gold-catalyzed Propargyl Ester Activation

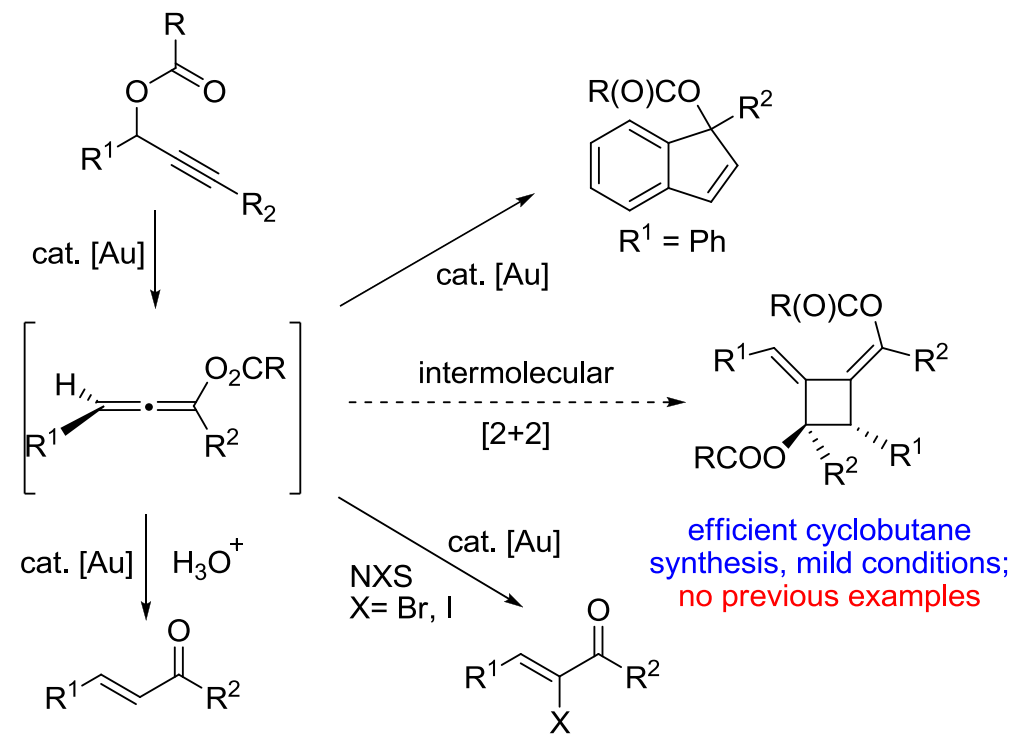

The formation of indene, enones and E- $\alpha$-haloenones has been introduced in chapter 1 and 2.1. One more important application of allene substrate is the intermolecular [2+2] cyclization forming the multiple substituted cyclobutane. In this transformation, TA-Au complexes chemoselectivity was applied in the well-developed process of forming an allene intermediate. The allene intermediate then facilitated the 
[2+2] cyclization process, achieved the cyclobutane under the absolutely 'Silver-free' condition.

\subsection{2 'Silver effect' in homogeneous gold (I) catalysis}

Along with the development of gold catalysis, it is possible to get some traditionally challenging transformation to occur by tuning the reactivity of gold complexes with different primary ligands. However, it still remains one critical issue in gold catalysis, which is referred as 'Silver effect' in the transformations. As indicated above, silver salts are generally adopted to dissociate the $\mathrm{Au}-\mathrm{Cl}$ bond in $\mathrm{L}-\mathrm{Au}-\mathrm{Cl}$ complex by forming $\mathrm{AgCl}$ precipitate. Because these cationic gold complexes slowly decompose over time, they are always freshly prepared right before the reaction setup or generated in situ.

Typically, the resulting $\mathrm{AgCl}$ precipitate can be removed by simply passing the reaction solution mixture through cotton plug or filter paper. ${ }^{61}$ However, recent research indicates that: a) practically, more than necessary silver salt is applied in the reaction mixture, therefore, not all $\mathrm{Ag}^{+}$is converted to $\mathrm{AgCl}$ precipitate. The additional amount of $\mathrm{Ag}^{+}$left in the catalyst system affects the transformation; b) in presence of $\mathrm{Au}^{+}$and $\mathrm{Ag}^{+}$, an unexpected Au-Ag di-metal co-catalysis system is observed in the resting state and leads to diverse reaction patterns.

The first evidence for Au-Ag di-metal co-catalysis was published in 2009. For first time, researchers realized that silver presented a more significant effect in the catalyst system behavior other than just forming $\mathrm{AgCl}$ precipitate (Scheme 25) ${ }^{62}$ 
Scheme 25. Different Resting States in the $A u(I)$ Catalysis when Silver is Presented

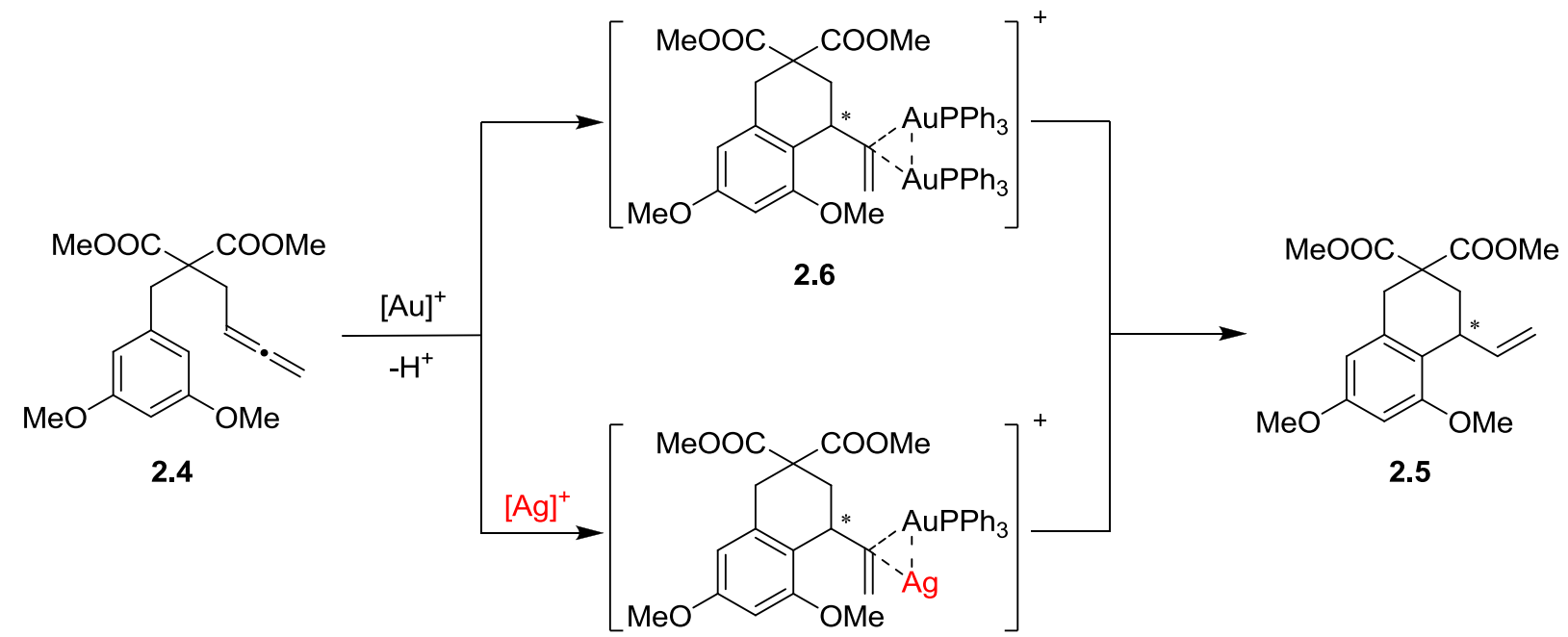

2.7

As shown in Scheme 25, there were two resting states of $A u(I)$ activated FriedelCrafts reaction in this transformation. One (2.6) was established with two $\mathrm{Au}^{+}$atoms, and the other one (2.7) was formed with one $\mathrm{Au}^{+}$and one $\mathrm{Ag}^{+}$. The ratio of these two resting states was differing based on the amount of silver salt introduced in the reaction mixture. Although these two very similar resting states gave the identical product in this specific case, the reaction rates were significantly different. Furthermore, by adding an excess amount of $\mathrm{AgNTf}_{2}$, the reaction was quenched (Scheme 26B). ${ }^{63}$

This case demonstrated that in gold catalysis, $\mathrm{Ag}^{+}$might serve as an important candidate which participated in the catalysis pattern. Subsequently, more and more effort has been devoted to investigating the mechanism of 'silver effect' in gold catalysis. Additionally, to better understand 'silver effect', 'silver free' gold catalyst system is desired as standard in gold catalysis. 
Scheme 26. The Reaction Rate is Slowed Down by Adding AgNTf
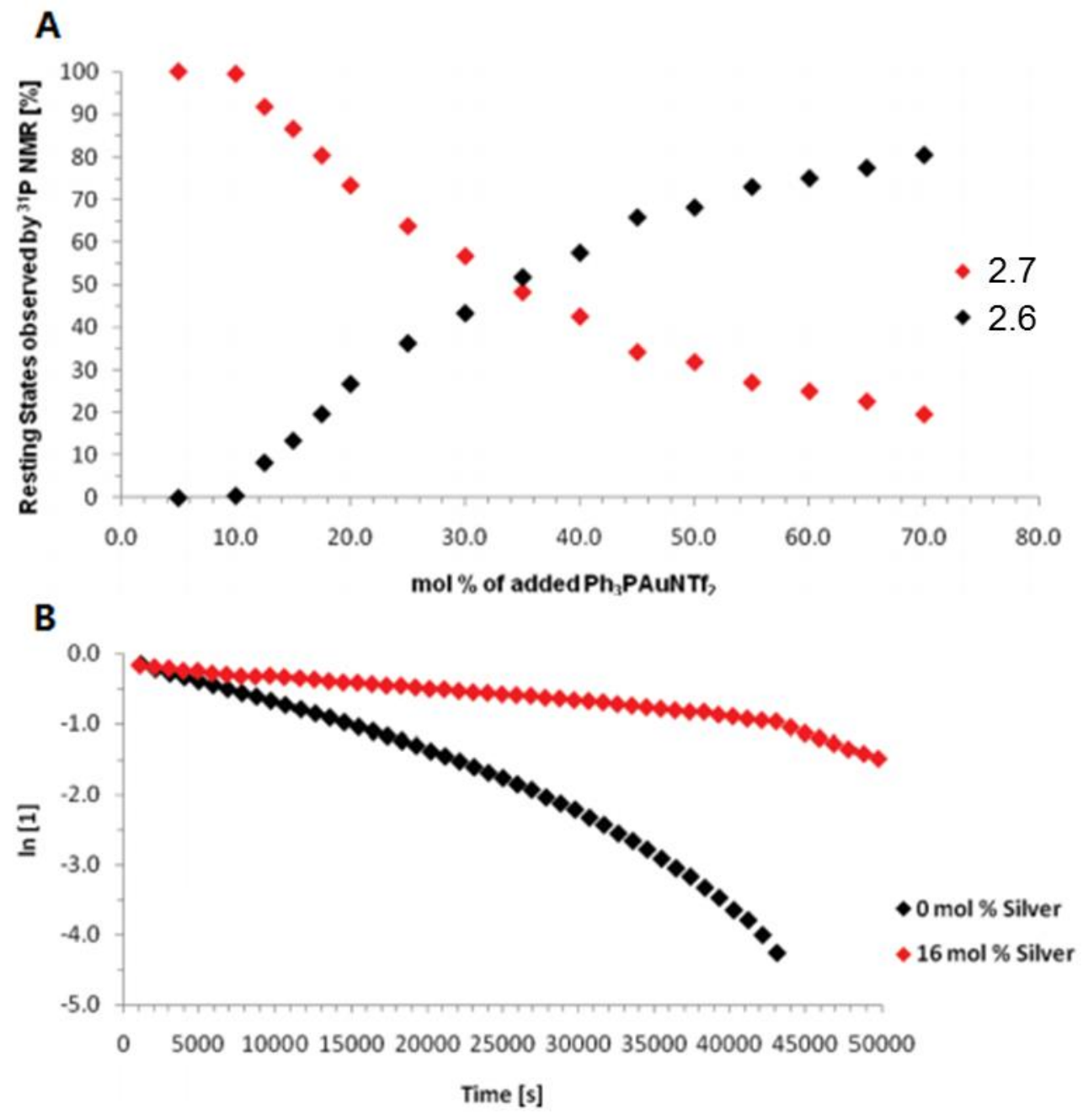

In 2007, the original 'silver free' Au(I) catalyst was developed by Prof. Gagosz et al. The bis(trifluoromethanesulfonyl)imidate moiety $\left(\mathrm{Tf}_{2} \mathrm{~N}^{-}\right)$was applied as the counter ion for $\mathrm{Au}(\mathrm{I})$ complexes (Scheme 27A). It was shown that $\mathrm{AuNTf}_{2}$ is stable enough to perform a recrystallization purification and obtain the 'silver free' gold complexes as a crystal solid. ${ }^{64}$ As mentioned above, the coordination between gold cation and $\mathrm{Tf}_{2} \mathrm{~N}^{-}$is weak and enabled the significant ligand exchange between the $\mathrm{Tf}_{2} \mathrm{~N}^{-}$and reacting substrates without influencing the reactivity of gold catalysts (Scheme 27B). ${ }^{65}$ 
Scheme 27. Synthesis and Application of [IPrAuNTf $\left.{ }_{2}\right]$

A

A

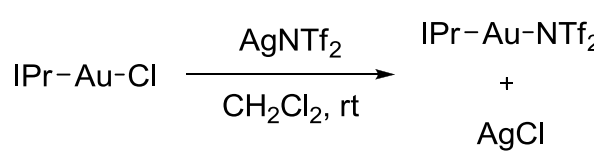

B
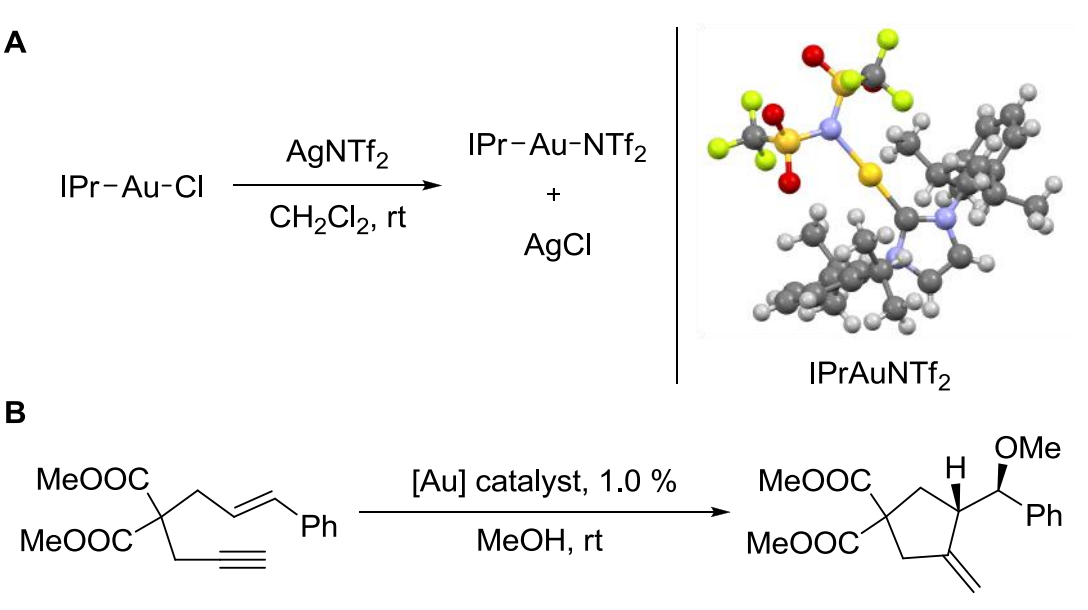

2.8

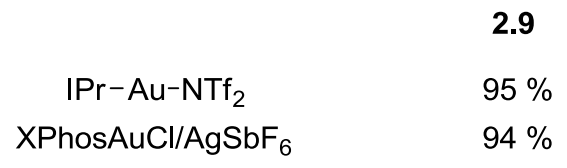

The triazole gold complexes are also able to achieve the 'silver free' crystal by recrystallization due to their moisture and air stability. As a consequence, triazole gold complexes provide us a good 'silver free' model to investigate the 'silver effect' in gold catalysis. To comprehensively understand the function of $\mathrm{Ag}^{+}$in gold catalysis, an alkyne hydration reaction was investigated with both Au-Ag co-catalysts and 'silver free' $A u(I)$ catalysts (such as TA-Au). The consequences of different gold catalysts are summarized in Table 6.

Table 6. Silver Effect in Alkyne Hydration ${ }^{a}$

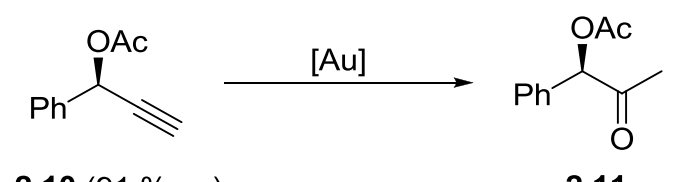

$2.10(91 \%$ ee $)$

2.11

\begin{tabular}{ccccc}
\hline Entry & Catalyst & Conditions & Yield $(\%)^{b}$ & ee (\%) \\
\hline 1 & $1 \%$ TA-Au & $5 \mathrm{hrs}$ & 87 & 90 \\
\hline
\end{tabular}




\begin{tabular}{|c|c|c|c|c|}
\hline 2 & $10 \% \mathrm{AgX}^{c}$ & $12 \mathrm{hrs}$ & 0 & - \\
\hline 3 & $2 \%\left[\mathrm{PPh}_{3} \mathrm{Au}\right]^{+} \mathrm{X}^{-c}$ & $12 \mathrm{hrs}$ & 0 & - \\
\hline 4 & $2 \% \mathrm{PPh}_{3} \mathrm{AuCl} / \mathrm{AgOTf}$ & $12 \mathrm{hrs}$ & 90 & 0 \\
\hline 5 & $2 \% \mathrm{PPh}_{3} \mathrm{AuCl} / \mathrm{AgSbF}_{6}$ & $8 \mathrm{hrs}$ & 97 & 0 \\
\hline 6 & $2 \% \mathrm{PPh}_{3} \mathrm{AuCl} / \mathrm{AgOTf}$ & $5 \mathrm{hrs}\left(\mathrm{N}_{2}\right)$ & 92 & 90 \\
\hline 7 & $2 \%\left[\mathrm{PPh}_{3} \mathrm{Au}\right]^{+} \mathrm{SbF}_{6}^{-}+\mathrm{AgSbF}_{6}$ & $12 \mathrm{hrs}$ & 91 & - \\
\hline
\end{tabular}

${ }^{a}$ General reaction conditions: 2.10 (1.0 equiv) and catalyst in $2.5 \mathrm{~mL}$ of dioxane/water $\left(\mathrm{H}_{2} \mathrm{O}, 3.0\right.$ equiv) at it. Reactions were monitored by TLC. ${ }^{b} \mathrm{NMR}$ yields. ${ }^{\circ} \mathrm{X}^{-}=\mathrm{TfO}^{-}, \mathrm{SbF}_{6}{ }^{-}, \mathrm{BF}_{4}{ }^{-}$.

The results indicated that $\mathrm{Ag}^{+}$by itself did not perform any reactivity towards this transformation (entry 2). Additionally, entry 3 (gravity celite filtration) showed that when using the 'silver free' $\mathrm{Au}^{+}$catalyst, there was no desired product observed no matter what primary ligand was applied. However, when using a mixture of L-Au-Cl and $\mathrm{AgX}$ (entry 4 and 5 , cotton plug or filter paper filtration) as pre-catalyst, the reaction proceeded with high yield under the identical conditions. In addition, a high ee value was observed as reported under $\mathrm{N}_{2}$ protection (entry 6). To confirm the effect of $\mathrm{Ag}^{+}$in this transformation, entry 7 was designed with a mixture of 'silver free' $\left[\left(\mathrm{PPh}_{3}\right) \mathrm{Au}\right]^{+} \mathrm{OTf}^{-}$ and back-addition $\mathrm{AgSbF}_{6}\left(\mathrm{AgSbF}_{6}\right.$ was added to the reaction mixture after the celite filtration). The consistent result was observed as entry 5 , which verified this reaction was actually catalyzed by Au-Ag co-catalysts.

The only difference between entry 3 and entries 4,5 here was the filtration precedure. Entry 3 was using a cotton plug or filter paper to remove the $\mathrm{AgCl}$, while in entry 4 and 5 , celite pipette was used to reach the same target. The gravity filtration through the celite pipette was a quite efficient and reliable process to remove all 
remaining $\mathrm{Ag}^{+}$, which was further confirmed by X-ray photoelectron spectroscopy (XPS) (Scheme 28).

Scheme 28. XPS Spectra of $\left(\mathrm{PPh}_{3}\right) \mathrm{AuCl} / \mathrm{AgSbF}_{6}$ Mixtures

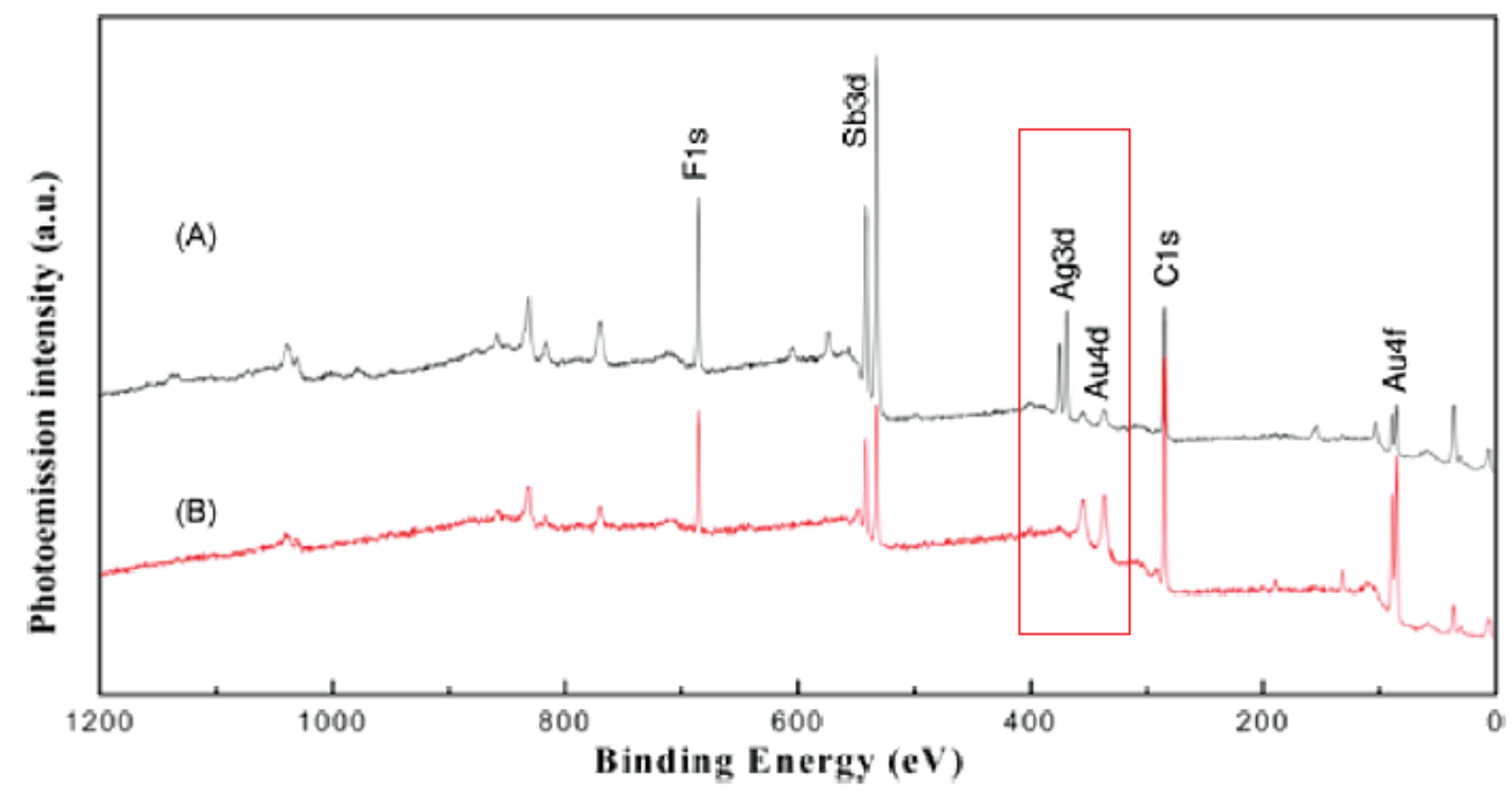

In Scheme 28, both spectra showed the signal of $\mathrm{Au}^{+}$at the binding energy as $\mathrm{Au}$

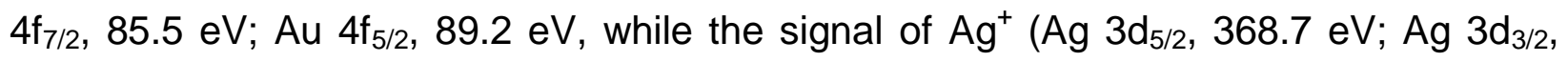
$374.7 \mathrm{eV}$ ) was only observed in spectrum A which regular cotton plug or filter paper was applied in the filtration step. No corresponding $\mathrm{Ag}^{+}$signal was observed which indicated no presence of silver in spectrum B with celite pipette filtration. This result is sufficient to prove that gravity celite filtration procedure is reliable to produce 'silver free' gold catalyst even with excess amount $\mathrm{Ag}^{+}((\mathrm{PPh} 3) \mathrm{AuCl}: \mathrm{AgSbF} 6=1: 1.5)$.

Meanwhile, ${ }^{31} \mathrm{P}$ NMR spectroscopy is applied to inspect the existence of $\mathrm{Ag}^{+}$in $\mathrm{Au}(\mathrm{l})$ complexes (Scheme 29). 
Scheme 29. ${ }^{31} \mathrm{P}$ NMR Spectra of Different Au(I) Species

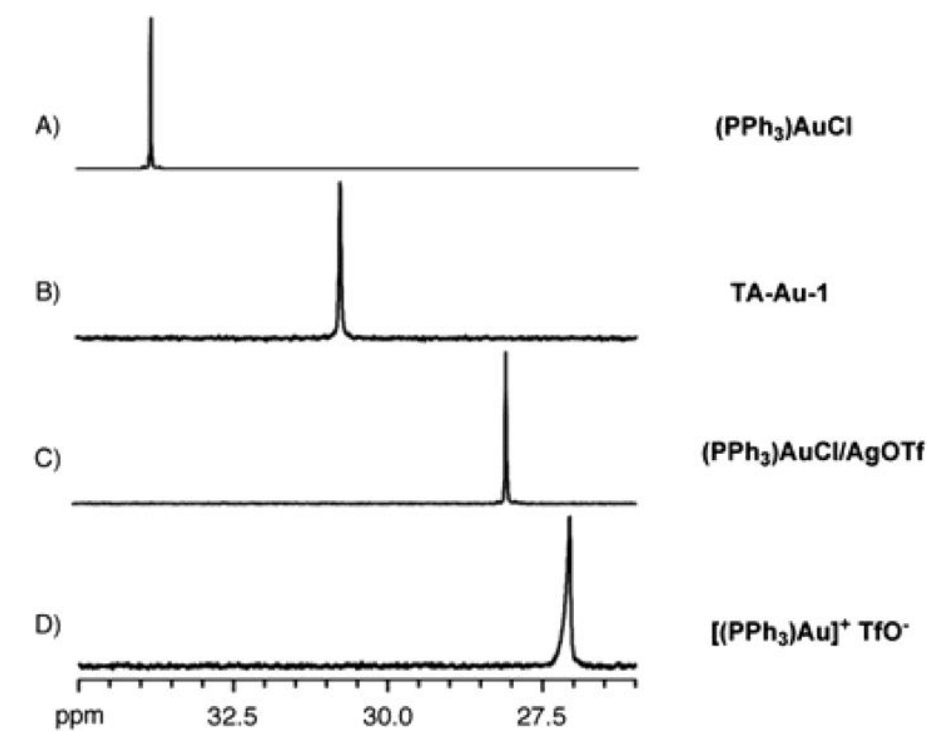

The data in Scheme 29 released the relationship between chemical shift of ${ }^{31} \mathrm{P}$ and the reactivity of $A u(I)$ complexes (more downfield chemical shift, lower reactivity). The unreactive $\left(\mathrm{PPh}_{3}\right) \mathrm{AuCl}$ presented the most downfield chemical shift due to the strong coordination between $\mathrm{Au}$ and $\mathrm{Cl}$. The freshly prepared 'silver free' $\left[\left(\mathrm{PPh}_{3}\right) \mathrm{Au}\right]^{+} \mathrm{TfO}^{-}$ through gravity celite filtration presented the most upfield chemical shift (which is considered as the most reactive catalyst). The $\left(\mathrm{PPh}_{3}\right) \mathrm{AuCl} / \mathrm{AgOTf}$ mixture without any filtration presented a chemical shift between these two mentioned cases. These results indicated that silver here can, to some extent, influence the reactivity of $A u(I)$ complexes.

\subsubsection{Ambient intermolecular [2+2] cycloaddition: an example of carbophilicity and oxophilicity competition in Au/Ag catalysis}

Recently, special gold catalysts have been reported to achieve high yields of allene intermediates, including the triazole gold reported by our group. While this chemistry 
seems well understood, one 'concealed' problem was that most of these transformations generally lack tolerance for the diaryl substituted internal alkynes $\left(R^{1}\right.$, $R^{2}=$ aryl groups). For example, simply treating diphenyl propargyl ester $\mathbf{2 - 2 - 1 a}\left(R^{1}=R^{2}\right.$ $\left.=\mathrm{Ph}, \mathrm{R}=\mathrm{CH}_{3}\right)$ with various $\mathrm{LAuCl} / \mathrm{AgX}\left(\mathrm{L}=\mathrm{PPh}_{3}, \mathrm{IPr}, \mathrm{XPhos} ; \mathrm{X}=\mathrm{TfO}^{-}, \mathrm{Tf}_{2} \mathrm{~N}^{-}, \mathrm{SbF}_{6}^{-}\right.$, $\mathrm{BF}_{4}{ }^{-}$) catalysts gave complex reaction mixtures with little indene or allene obtained. In order to determine the product for diaryl propargyl ester in presence of gold catalysts, we conducted detailed investigations with the diaryl propargyl ester starting material.

We herewith report the different products formed from this diaryl propargyl ester rearrangement and the intermolecular allene $[2+2]$ cycloaddition at ambient temperature. In addition, the 'silver-free' condition is critical in this transformation. In the presence of silver, even a catalytic amount, dimer 2-2-2 was observed over the [2+2] products due to the silver-activated substitution. Considering the extensive efforts from various research groups toward understanding the role of silver in gold catalysis, this work provides another example of silver influence as an oxophilic Lewis acid, which deviates from the gold reaction pathway. ${ }^{66}$

The cationic gold complexes are effective carbophilic $\pi$-acids, which can effectively activate both an alkyne and allene ${ }^{67}$ According to the literature, three types of chemoselective gold catalyst (activate alkyne over allene) have been reported as goldoxo complexes, gold-pyridine/ $\mathrm{Et}_{3} \mathrm{~N}$ complexes, and 1,2,3-triazole gold complexes (TA$\mathrm{Au}) .^{68-70}$ Surprisingly, among all the reported gold-catalyzed propargyl ester rearrangements, diaryl propargyl esters are not viable substrates. In fact, during our investigations of the triazole gold (TA-Au) catalyzed allene synthesis, complex reaction mixtures were observed. In order for us to understand how this particular type of 
substrate reacts, we monitored the reactions of compound $2-2-1 a$ with various gold catalysts (Scheme 30).

Scheme 30. Analyzing the Propargyl Rearrangement of 2-2-1a

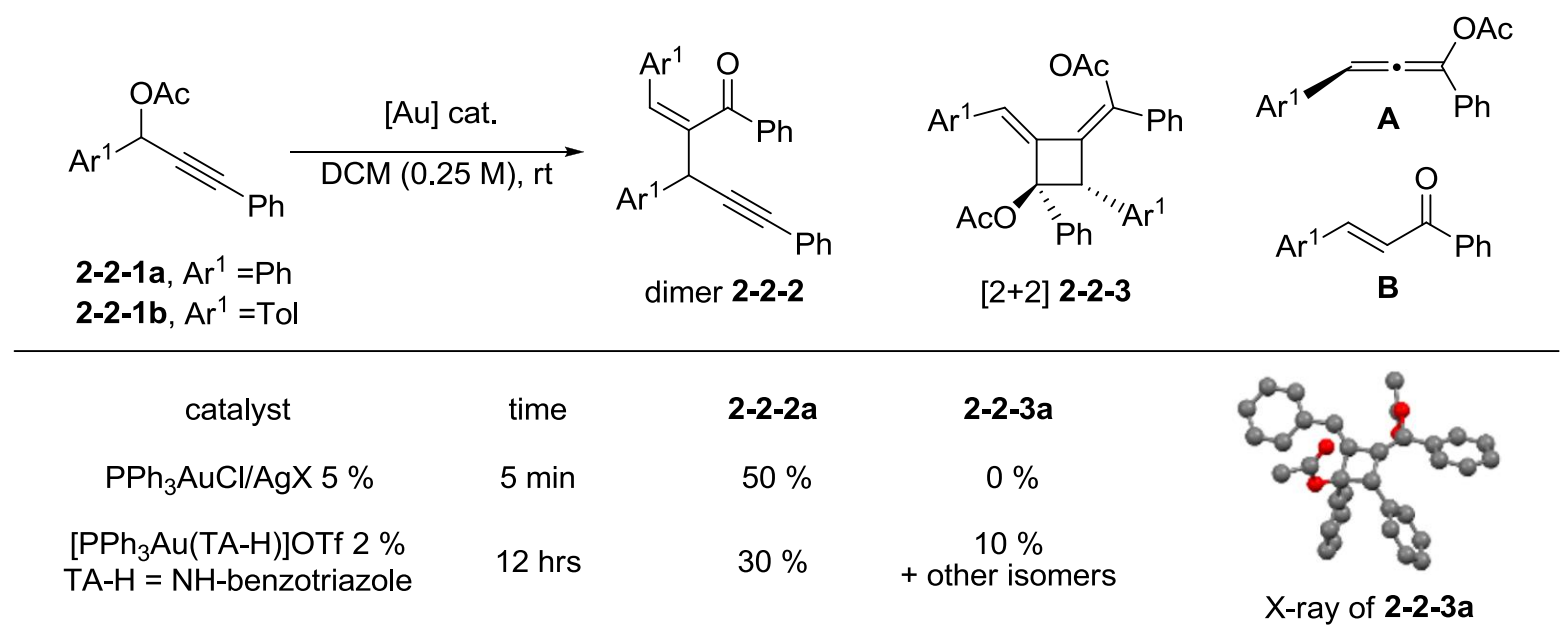

First, the treatment of 2-2-1a with LAuCl/AgX (5 \% loading, $L=\mathrm{PPh}_{3}, \mathrm{IPr}$, XPhos, $\mathrm{X}$ $=\mathrm{OTf}, \mathrm{NTf}_{2}$ or $\mathrm{SbF}_{6}$ ) gave complex reaction mixtures. Through careful examination, dimer 2-2-2a was identified as the major product (50\% yield using anhydrous solvent; see detailed structure analysis in the Supporting Information). With the triazole gold (TA-Au) catalysts, the reaction was much cleaner (less polymerization and decomposition). However, several other products were observed in addition to the dimer 2-2-2a (30\%). Fortunately, the structure of one major product was determined by X-ray crystallography as the [2+2] cycloaddition product 2-2-3a. Other minor products were identified as the stereoisomers generated from the [2+2] cycloaddition.

This result was exciting because it was the first example of an intermolecular allene [2+2] reaction through a propargyl ester rearrangement. Notably, indene was not 
observed in this case. The successful confirmation of the dimer and the $[2+2]$ cycloaddition products greatly enhanced our understanding of this reaction. A proposed reaction mechanism is shown in Scheme 31.

Scheme 31. Propargyl Ester Activation

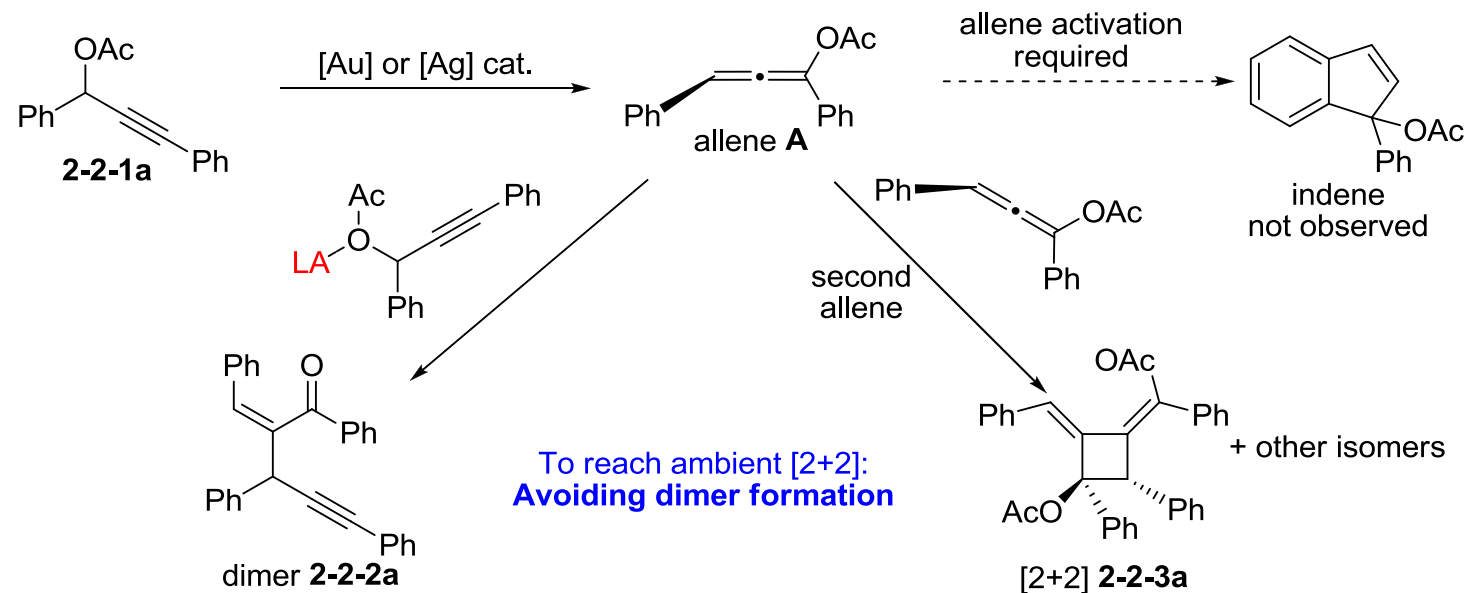

Cyclobutanes are very attractive as building blocks in organic synthesis, and this reaction is conducted under mild conditions (rt) with simple starting materials. Thus the discovery shown above revealed an interesting new approach to access substituted cyclobutanes under mild conditions. As shown in Scheme 31, the allene should be formed prior to either dimerization or cyclization. This was confirmed by monitoring the reaction with NMR: allene $\mathrm{A}$ was the only product formed during the first $2 \mathrm{~h}$ of reaction when treating 2-2-1a with TA-Au catalysts. Efforts to isolate allene $\mathbf{A}$ were unsuccessful due to the poor stability. In order to improve the chemoselectivity ([2+2] over dimer) and stereoselectivity (different cyclobutane isomers), we prepared various propargyl ester derivatives and examined them under the conditions of gold catalysis. The results are summarized in Table 7. 
Table 7. Optimization of $\mathrm{Au}(\mathrm{I})$-catalyzed Allene $[2+2]^{a}$
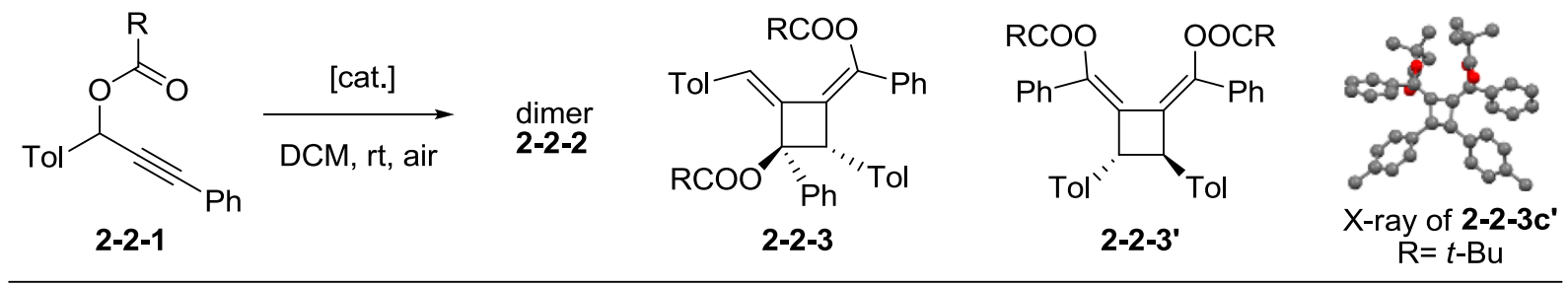

\begin{tabular}{|c|c|c|c|c|c|c|c|c|c|}
\hline \multirow{2}{*}{ entry } & \multirow{2}{*}{ cat. $(\%)$} & \multirow{2}{*}{$\mathrm{R}$} & \multirow{2}{*}{ temp $\left({ }^{\circ} \mathrm{C}\right)$} & \multirow{2}{*}{ time $(\mathrm{h})$} & \multirow{2}{*}{$\operatorname{conv}(\%)^{b}$} & \multicolumn{4}{|c|}{ yield $(\%)^{b}$} \\
\hline & & & & & & $2-2-2$ & $2-2-3$ & $2-2-3^{\prime}$ & other isomer \\
\hline 1 & $\mathrm{PPh}_{3} \mathrm{AuCl} / \mathrm{AgOTf}(5 \%)$ & $\mathrm{CH}_{3}$ & $\mathrm{rt}$ & 1 & 100 & 67 & trace & trace & - \\
\hline $2^{c}$ & {$\left[\mathrm{PPh}_{3} \mathrm{Au}(\mathrm{TA}-\mathrm{H})\right] \mathrm{OTf}(1 \%)$} & $\mathrm{CH}_{3}$ & $\mathrm{rt}$ & 12 & 100 & 43 & 10 & 8 & 35 \\
\hline $3^{d}$ & {$\left[\mathrm{PPh}_{3} \mathrm{Au}(\mathrm{TA}-\mathrm{Me})\right] \mathrm{OTf}(1 \%)$} & $\mathrm{CH}_{3}$ & $\mathrm{rt}$ & 12 & 100 & 12 & 16 & 13 & 50 \\
\hline 4 & {$\left[\mathrm{PPh}_{3} \mathrm{Au}(\mathrm{TA}-\mathrm{Me})\right] \mathrm{OTf}(1 \%)$} & $\mathrm{Ph}$ & $\mathrm{rt}$ & 12 & 100 & 53 & trace & trace & trace \\
\hline 5 & {$\left[\mathrm{PPh}_{3} \mathrm{Au}(\mathrm{TA}-\mathrm{H})\right] \mathrm{OTf}(1 \%)$} & $t-\mathrm{Bu}$ & $\mathrm{rt}$ & 16 & 100 & $<5$ & 68 & 12 & $<5$ \\
\hline 6 & {$\left[\mathrm{PPh}_{3} \mathrm{AuO}\right] \mathrm{OTf}(1 \%)$} & $t-\mathrm{Bu}$ & $\mathrm{rt}$ & 20 & 100 & trace & 69 & 14 & $<5$ \\
\hline 7 & $\begin{array}{l}{\left[\mathrm{PPh}_{3} \mathrm{Au}\left(\mathrm{TA}^{-} \mathrm{H}\right)\right] \mathrm{OTf}(1 \%)} \\
+2 \% \mathrm{AgOTf}\end{array}$ & $t-\mathrm{Bu}$ & $\mathrm{rt}$ & 1 & 100 & 63 & trace & trace & trace \\
\hline 8 & $\operatorname{AgSbF}_{6}(5 \%)$ & $t-\mathrm{Bu}$ & $\mathrm{rt}$ & 16 & 100 & 45 & trace & trace & trace \\
\hline 9 & HOTf (5 \%) & $t-\mathrm{Bu}$ & $\mathrm{rt}$ & 16 & 60 & 0 & 0 & 0 & 0 \\
\hline \multicolumn{2}{|c|}{$10^{e} \mathrm{PtCl}_{2}(5 \%)$} & $t-\mathrm{Bu}$ & 80 & 16 & 100 & 0 & 56 & 14 & $<5$ \\
\hline
\end{tabular}

${ }^{a}$ Reaction conditions: 2-2-1 $(0.2 \mathrm{mmol})$ and catalyst in DCM $(0.8 \mathrm{~mL})$, rt, time. ${ }^{b}$ Determined by ${ }^{1} \mathrm{H}$ NMR using 1,3,5-trimethoxybenzene as internal standard. ${ }^{\circ} \mathrm{TA}-\mathrm{H}=$ benzotriazole. ${ }^{\circ} \mathrm{TA}-\mathrm{Me}=$ $\mathrm{N}$-methyl benzotriazole. ${ }^{e} 15 \%$ yield of $(E)$-1-phenyl-3-( $p$-tolyl)prop-2-en-1-one.

The $\mathrm{PPh}_{3} \mathrm{AuCl} / \mathrm{AgOTf}$ catalysts gave only dimer $\mathbf{2 - 2 - 2}$ with no cycloaddition product 2-2-3 observed (entry 1). The silver-free TA-Au catalyst produced the desired [2+2] products as mixtures of isomers. With the $\mathrm{NH}$-triazole $(\mathrm{TA}-\mathrm{H})$ as the ligand, $43 \%$ dimer was obtained (entry 2). The amount of dimer was decreased when $\mathrm{N}$-methyl triazole (TA-Me) was used (entry 3), probably due to the elimination of an acidic proton on $\mathrm{NH}$ triazole (activating the OAc leaving group). Switching acetate to benzoylate resulted in the exclusive formation of a dimer due to the better propargyl leaving group ( $\mathrm{PhCOO}^{-}$ vs $\mathrm{CH}_{3} \mathrm{COO}^{-}$). Finally, application of pivalate achieved excellent chemoselectivity, giving 
the [2+2] products in good yields ( $>85 \%$ combining all isomers, entry 5 ). Moreover, the bulky pivalate group also gave significantly improved stereoselectivity with only two major cycloaddition products obtained (2-2-3 and 2-2-3') in a 5:1 ratio. The structure of the minor isomer, 2-2-3', was also confirmed by the X-ray crystallography. The silverfree gold oxo catalyst $\left[\left(\mathrm{PPh}_{3} \mathrm{Au}\right)_{3} \mathrm{O}\right] \mathrm{OTf}$ could also promote this reaction effectively (entry 6), though with a slightly lower reaction rate compared with the use of TA-Au.

The silver salt was crucial in this transformation. As shown in entry 7 , the addition of $2 \% \mathrm{AgOTf}$ led to the formation of only dimer $\mathbf{2 - 2 - 2}$ without obtaining any cycloaddition product 2-2-3 obtained. Using a silver catalyst alone (entry 8) gave the same dimer product with a slower reaction rate, likely due to the decreased reactivity of the silver catalyst toward alkyne activation (compared with gold catalyst). Triflate acid did not promote the rearrangement at all, giving only the propargyl ester decomposition over time (entry 9). Finally, the silver-free $\mathrm{PtCl}_{2}$ catalyst gave a similar cycloaddition reaction, albeit at elevated temperature (entry 10). In view of these results, it is clear that the propargyl rearrangement is the initiation step. The reactivity of the three well-known $\pi-$ acids follows the general trend $\mathrm{Au}(\mathrm{I})>\mathrm{AgX}>\mathrm{PtCl}_{2}$ in this transformation. Besides alkyne activation, the silver cation (more oxophilic) can also activate the acetate as a leaving group, giving dimer $\mathbf{2 - 2 - 2}$ as the only product. The silver-free TA-Au catalyst indicated excellent reactivity toward alkyne activation over the undesired oxygen activation, which led to the successful cycloaddition of allene for the first time. The scope of reaction substrate is shown in Table 8. 
Table 8. Reaction Scope of [2+2] Cycloaddition ${ }^{a, b}$
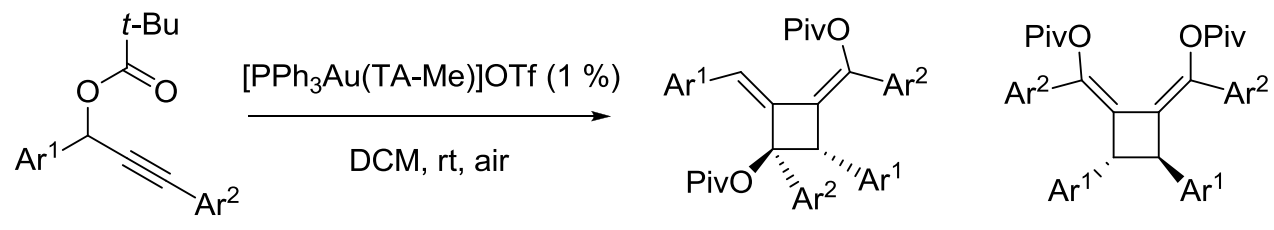

2-2-3

2-2-3'

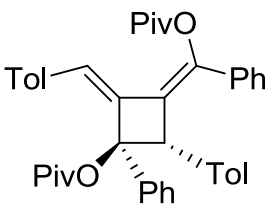

2-2-3c, $68 \%$

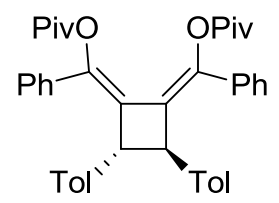

total [2+2], $80 \%$ $3: 3^{\prime}=5.6: 1$

2-2-3c', $12 \%$

$\mathrm{Ar}^{1}$<smiles>CCCCCOC(=C1C(=Cc2ccccc2)[C@@](O[18O])(c2ccccc2)[C@@H]1c1ccccc1)c1ccccc1</smiles>

2-2-3d, $75 \%$;

2-2-3d', $13 \%$<smiles>O/C(=C1C(=C\c2ccc(Cl)cc2)/[C@](O)(c2ccccc2)[C@@H]/1c1ccc(Cl)cc1)c1ccccc1</smiles>

2-2-3g, $80 \%$;

2-2-3g', $17 \%$<smiles>O/C(=C1C(=C/c2cccc(F)c2)\[C@H](c2ccccc2)[C@]\1(O[18OH])c1ccccc1)c1ccccc1</smiles>

2-2-3j, $76 \%$;

2-2-3j', $17 \%$

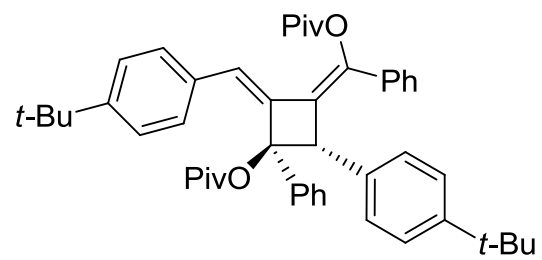

2-2-3e, $65 \%$;

2-2-3e', $19 \%$<smiles>O/C(=C1C(=C\c2ccc(F)cc2)/[C@H](c2ccccc2)[C@]/1(O[18OH])c1ccccc1)c1ccccc1</smiles>

2-2-3h, $76 \%$;

2-2-3h', $19 \%$

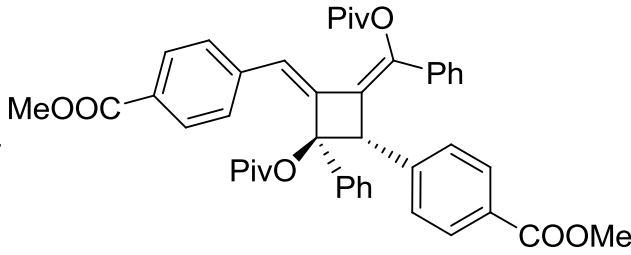

2-2-3k, $71 \%$

2-2-3k', $12 \%$<smiles>O/C(=C1C(=C\c2ccc(Br)cc2)/[C@](O)(c2ccccc2)[C@@H]/1c1ccc(Br)cc1)c1ccccc1</smiles>

2-2-3f, $74 \%$;

2-2-3f', $16 \%$<smiles>COc1ccc(/C=C2C(=C(\O)c3ccccc3)\[C@@H](c3ccc(OC)cc3)[C@@]\2(O[Pb])c2ccccc2)cc1</smiles>

2-2-3i, $68 \%$;

2-2-3i', $12 \%$

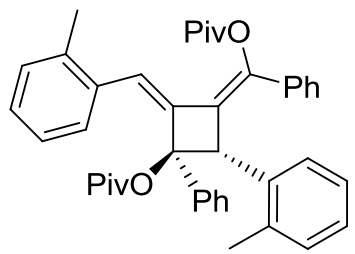

2-2-3I, $73 \%$

2-2-3I', $18 \%$ 


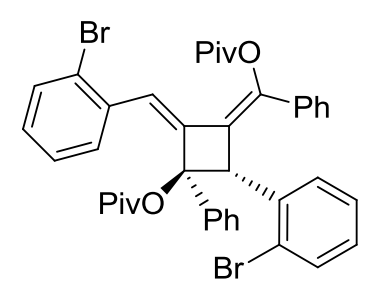

2-2-3m, $63 \%$;

2-2-3m', $18 \%$

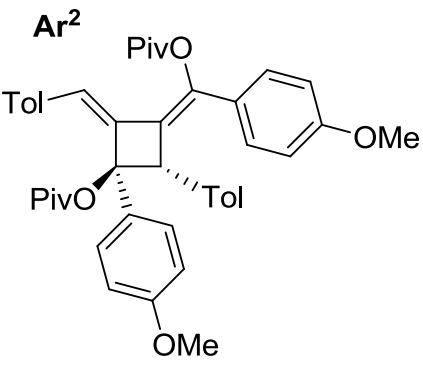

2-2-3p, $68 \%$;

2-2-3p', $10 \%{ }^{c}$

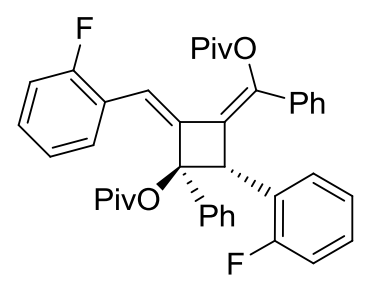

2-2-3n, $74 \%$;

2-2-3n', $18 \%$

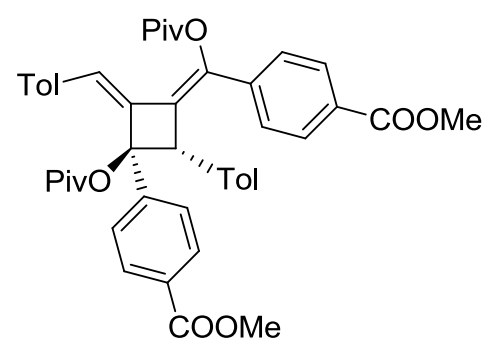

2-2-3p, NR

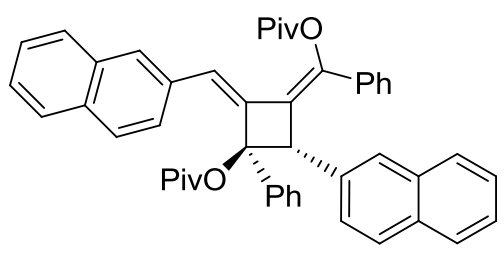

2-2-3o, $43 \%$;

2-2-30, $24 \%$

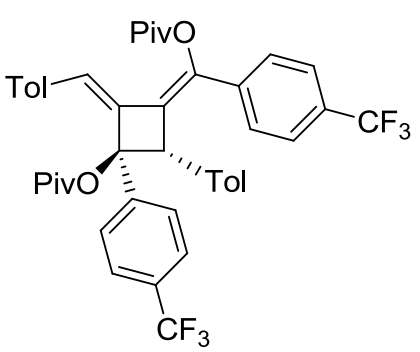

$2-2-3 r, N R$

${ }^{a}$ Reaction conditions: 2-2-1 (0.2 mmol) and [PPh $\left.{ }_{3} \mathrm{Au}(\mathrm{TA}-\mathrm{Me})\right] \mathrm{OTf}$ in DCM $(0.8 \mathrm{~mL}) .{ }^{b}$ Determined by ${ }^{1} \mathrm{H}$ NMR using $1,3,5$-trimethoxybenzene as internal standard. ${ }^{c} 1 \mathrm{~mol} \%$ of $\left[\left(\mathrm{PPh}_{3} \mathrm{Au}\right)_{3} \mathrm{O}\right] \mathrm{OTf}$ was used instead of $\left[\mathrm{PPh}_{3} \mathrm{Au}(\mathrm{TA}-\mathrm{Me})\right] \mathrm{OTf}$.

The reaction tolerates a good substrate scope on the propargyl aryl position (Ar1). Electron-withdrawing groups (2-2-3h, 2-2-3k) were suitable for this reaction, giving the desired cycloaddition products with good yields. The electron-donating group modified substrate (2-2-3i) gave the dimer as one of the major products with TA-Au catalysts, probably due to the improved ability to form a propargyl carbon cation. This problem was resolved by using $\left[\left(\mathrm{PPh}_{3} \mathrm{Au}\right)_{3} \mathrm{O}\right] \mathrm{OTf}$ as the catalyst with a longer reaction time. Steric hindrance was not an issue in this transformation based on the fact that orthosubstituted substrates (2-2-3I-2-2-3n) worked fine under the optimal conditions with the formation of the desired [2+2] cycloaddition products in excellent yields and similar isomer ratios. Poor selectivity was observed with naphthalene-substituted derivative 2- 
2-30 (1.8:1). This result implied the plausibility of $\pi-\pi$ stacking during the $[2+2]$ cycloaddition process.

A greater electronic effect was observed at the alkyne terminal Ar2 position. The electron-donating p-methoxyphenyl substituted alkyne gave the desired cyclobutane 22-3p in excellent yield when $\left[\left(\mathrm{PPh}_{3} \mathrm{Au}\right)_{3} \mathrm{O}\right] \mathrm{OTf}$ was used as the catalyst. However, an electron-withdrawing group reduced the reaction rate for propargyl ester rearrangement due to either the poor reactivity of alkyne toward $\pi$-acid activation (lower electron density) or the unfavored 3,3-migration (over the electronically preferred 1,2rearrangement). Increasing the reaction temperature to $80^{\circ} \mathrm{C}$ (with dichloroethane as the solvent) gave the allenes at low yields (<20\%), along with a significant amount of unidentified side products. These results suggest that the ambient [2+2] cycloaddition is substrate-dependent, which raises the concern whether gold catalysts were involved in the cycloaddition process. To verify the potential role of gold catalysts in the cycloaddition step, we monitored the reaction as shown in Scheme 32.

Scheme 32. Investigation on the Role of $\mathrm{Au}$ in [2+2] Step

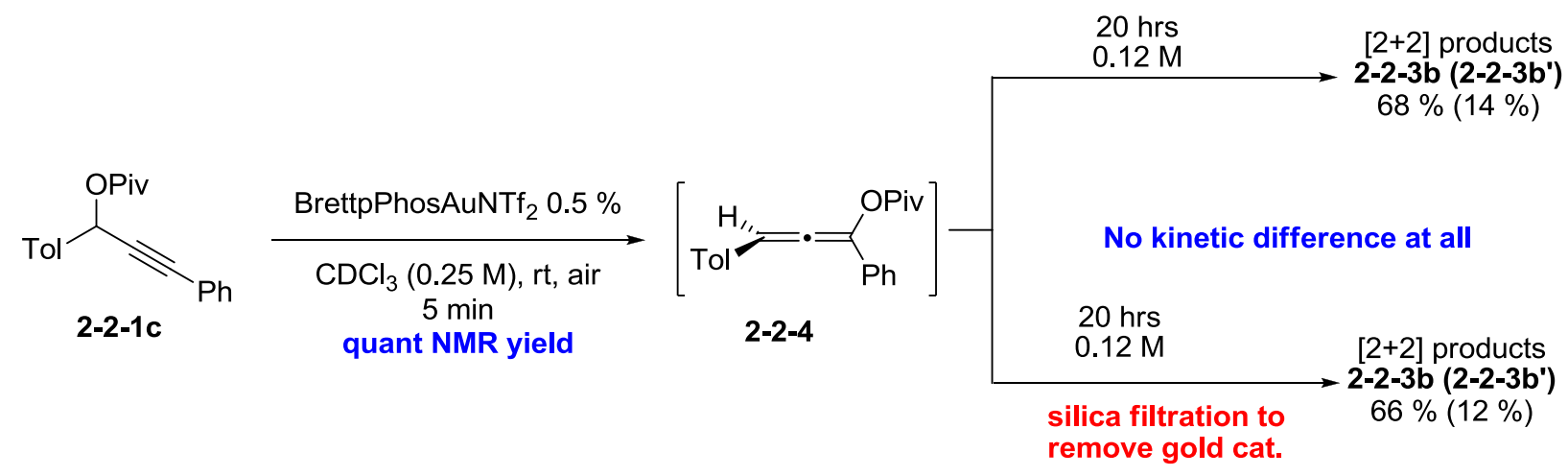


Treating propargyl ester 2-2-1c with silver-free BrettPhosAuNTf $(0.5 \%)$ gave rapid rearrangement (5 min) to allene 2-2-4 in quantitative NMR yield. Because allene 2-2-4 will decompose upon condensation, it is difficult to isolate 2-2-4 in pure form. Thus the reaction mixture was divided into two parts. One part continued to react under the identical conditions (in the presence of the gold catalyst). The other part was filtered through a silica plug so as to completely remove the gold catalyst. The resulting solvent was condensed to ensure a concentration that was identical to that in the case with the gold catalyst. As reviewed by NMR, for both cases, similar reaction rates were observed, which confirmed that the allene [2+2] cycloaddition was a thermal reaction and gold activation was not required. ${ }^{71}$

\subsubsection{Conclusion}

In conclusion, with the silver-free gold catalyst, the selective [2+2] cycloaddition was achieved with high efficiency under mild conditions (ambient temperature, open flask). Although the minor isomers were obtained, the fact that only two isolatable cyclobutane isomers were obtained highlighted the good selectivity and high efficiency of this transformation. The silver-free condition was identified as the crucial factor for the success of this transformation. The strong influence of silver salts (even in catalytic amounts) raised a viable concern for future investigations on gold catalysis, especially when an oxophilic catalyst may be involved. 


\subsubsection{Contribution}

Dr. Yijin Su and Yanwei Zhang were the researchers who had first investigated the reaction kinetic profile. Together Dr Jijin Su, and Yanwei Zhang were responsible for the [2+2] complexes synthesis, NMR spectrum investigation and manuscript completion for successful submission to Organic Letters. The detailed X-ray crystallographic data analysis of compound $\mathbf{2 - 2 - 3 a}$ and $\mathbf{2 - 2 - 3 c}$ ' was done by Prof. Jeffrey L. Petersen, C. Eugene Bennett Department of Chemistry, West Virginia University. 


\section{Chapter Three: Synthesis and characterization of bis- $\mathrm{N}-2-a r y l$ triazole as efficient fluorescence probe}

\subsection{Introduction}

Small organic molecules providing strong fluorescence emission are of great importance to the scientific community. ${ }^{72}$ These molecular fluorophores have been applied into a wide range of research areas, including chemistry, biology and material science. ${ }^{73}$ In 2009, Professor Clement Sanchez and co-workers discovered a novel photoactive crystalline highly porous titanium (IV) dicarboxylate. In the year of 2010, Professor Martin Albrecht and co-workers reported that N-heterocyclic carbene complexes worked not only as catalysts but also components in medicinal, luminescent, and functional material areas. ${ }^{74-76}$

Two notable aspects influence the efficiency of fluorescence: 1) quantum yield, and 2) the wavelengths of excitation and emission.

In 2011, Shi's group reported N-2-aryl-1,2,3-triazoles (NAT) as novel fluorophores with strong emission in the high-energy UV/blue region. ${ }^{77}$ The first interest was initiated by the attractive phenomenon that in the $\mathrm{N}-1$ phenyl triazole 3.1 , basically no emission was observed while the N-2 isomer exhibited a relatively strong fluorescence emission $(\lambda=362 \mathrm{~nm})$ under the identical excitation wavelength $(\lambda=254 \mathrm{~nm})$ (Scheme 33). 
Scheme 33. Photoluminescent Spectra of N-2-aryl-1,2,3-triazoles

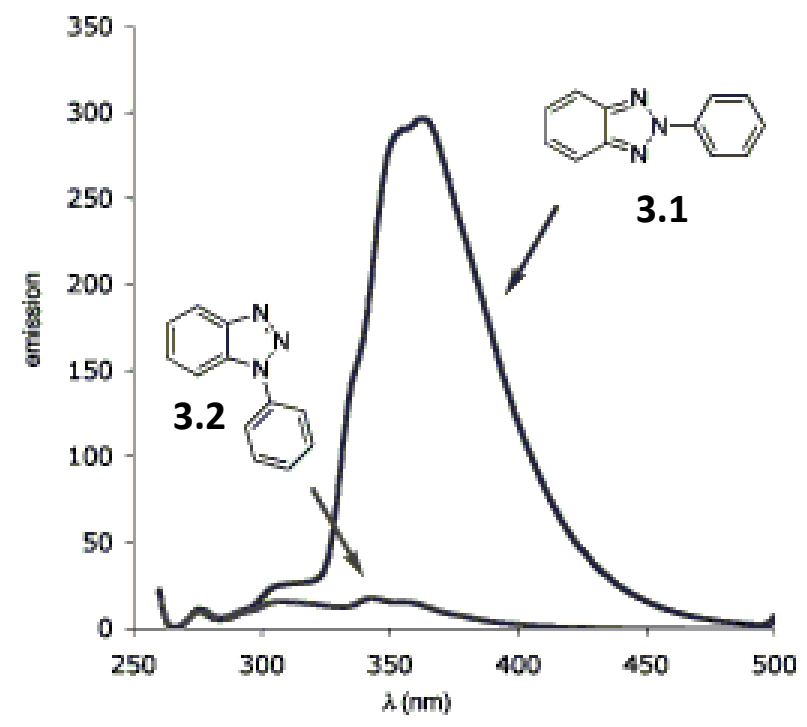

Sample preparation: $1.0 \times 10^{-5} \mathrm{~mol} \mathrm{~L}^{-1}$ in $\mathrm{MeOH}$, excitation at $\lambda=254 \mathrm{~nm}$ with $5 \mathrm{~nm}$ slit, quantum yield of 3.1 $\Phi=0.154$, quantum yield of $3.2 \Phi=0.009$.

Based on this result, it is suggested that, the fluorescence is presumably resulted from the coplanar conformation between the phenyl ring and the benzotriazole in the $\mathrm{N}$ 2-aryl-triazoles (NATs). Therefore, we decided to implement the NATs complexes as effective fluorophores in further fluorescence study based on their fluorescence properties. As a result, a series of new N-2-aryl-triazoles (NATs) were synthesized and characterized (Scheme 34).

Scheme 34. Synthesis of N-2-aryl-triazoles (NATs)

$$
{ }_{\mathrm{R}^{1}}^{\mathrm{R}_{\mathrm{N}}^{2}}=\underset{\mathrm{NH}}{\mathrm{N}}+\mathrm{X}-\mathrm{Ar} \quad \frac{\text { Proline } 20 \%, \mathrm{CuCl} 10 \%}{\mathrm{~K}_{2} \mathrm{CO}_{3}, \mathrm{DMSO}, 85^{\circ} \mathrm{C}}
$$

Three different effects are discussed in this NATs fluorescence investigation. The first investigation is the substituent effect on the C-4 and C-5 positions. Different 
substituted groups were introduced to the C-4 and C-5 positions in the NATs. As discussed previously, the fluorescence emission is possibly resulted from the coplanar structure of the NATs. It was plausible that C-4 and C-5 substitution may influence the fluorescence emission through the conjugation of the entire NAT molecule. Moreover, all of these substrates presented strong emission in the UV/blue-light range with $\lambda_{\max }$ at approximately $350 \mathrm{~nm}$.

Scheme 35. Fluorescence Emission Behavior of Compounds with Different C-5 Substituents

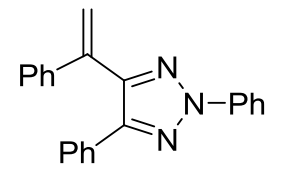

3.3

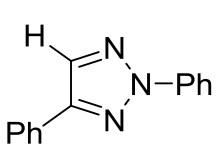

3.4<smiles>c1ccc(Cc2nn(-c3ccccc3)nc2-c2ccccc2)cc1</smiles>

3.5<smiles>CC(c1ccccc1)c1nn(-c2ccccc2)nc1-c1ccccc1</smiles>

3.6

The second investigation was focused on the $\mathrm{N}-2$ position substitution. Because the fluorescence was generated from the coplanar structure, we hypothesized that the variation of substituted group on $\mathrm{N}-2$ position could have a significant influence on fluorescence emission.

Scheme 36. Substituted Group Effect on the N-2 Position

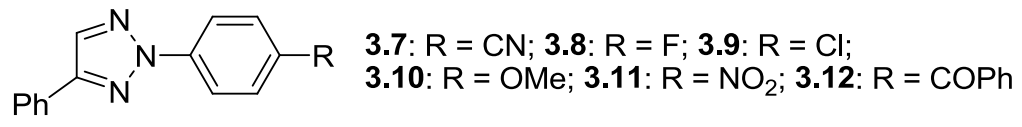<smiles>c1ccc(-c2cnn(-c3ccncc3)n2)cc1</smiles>

3.13<smiles>c1ccc(-c2cnn(-c3ccccn3)n2)cc1</smiles>

3.14

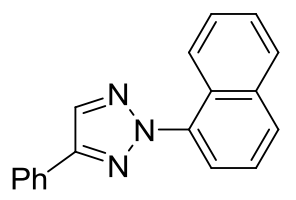

3.15 
Subsequent to synthesis of the above NATs (Scheme 36), the subsequent fluorescence study indicated that most compounds had good fluorescence emission and the overall quantum yield for these NATs is approximately $30 \%$. This result consequently confirmed the application potential of NATs as fluorophores in further research.

Meanwhile, the crystal structures of $\mathbf{3 . 1 3}$ and $\mathbf{3 . 1 4}$ revealed the importance of coplanar structure in the generation of fluorescence. As shown in Scheme 37, due to the electron repulsion between the lone pair elections of the nitrogen atoms on both triazole and pyridine rings, the dihedral angle between the triazole ring and $\mathrm{N}-2$ substituted group in $\mathbf{3 . 1 4}\left(17.9^{\circ}\right)$ was much larger than in $\mathbf{3 . 1 3}\left(5.4^{\circ}\right)$. As a result, the coplanar conjugation of $\mathbf{3 . 1 4}$ was relatively weaker than $\mathbf{3 . 1 3}$. Therefore, $\mathbf{3 . 1 4}$ presented almost no emission but $\mathbf{3 . 1 3}$ presented a relatively strong emission. This result was sufficient to support the hypothesis that the coplanar structure was the key point in the process of generating intense fluorescence emission in the NATs types of compounds.

Scheme 37. X-ray Crystal Structures of 3.13 and 3.14

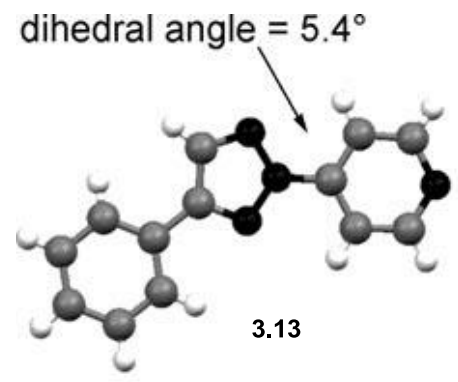

good planar conjugation strong emission $\Phi=0.28$

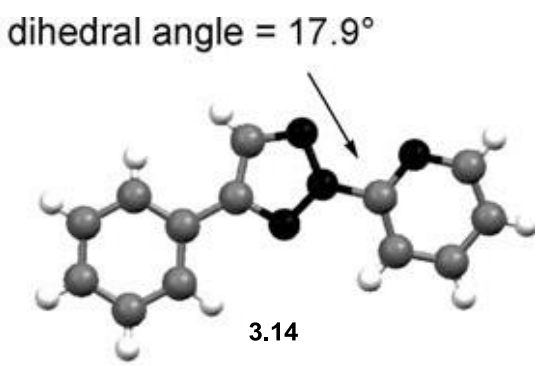

poor conjugation no emission $\Phi=0.15$ 
The last investigation here concerns the substituted groups on $\mathrm{N}-2$ substituted aromatic ring. Based on various electronic effects introduced by substituted groups $(-\mathrm{Cl}$, $-\mathrm{CN},-\mathrm{OMe})$, the fluorescence intensity and the emission wavelength can be tuned to a considerable degree.

From all these above results, the NATs compounds have been demonstrated as a type of potential fluorophore in multiple research areas. Furthermore, we concluded that the strong fluorescence emission of NATs compounds is resulted from the coplanar conjugation between the triazole ring and $\mathrm{N}-2$ substituted aromatic ring.

Given a molecule in the excited state, there are basically two intramolecular charge transfer types: PICT (planar intramolecular charge transfer) and TICT (twisted intramolecular charge transfer). When the D-A (donor-acceptor) type chromophore forms the flat pattern, PICT state will be the major source for generation of fluorescence emission, whereas the twisted pattern will lead to the TICT state. Several typical model molecules have been introduced into the study of the PICT and TICT states. ${ }^{78}$

Scheme 38. PICT and TICT in Fluorescence Emission

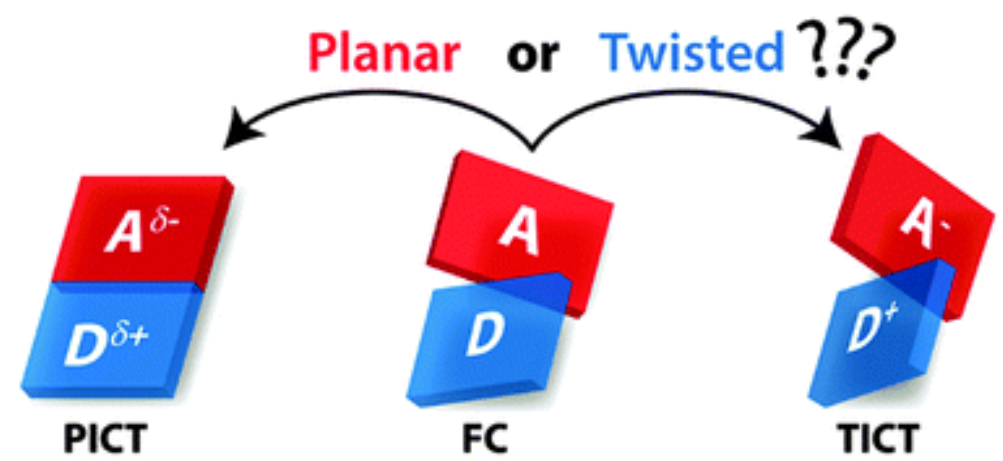

As introduced, the generation of fluorescence emission for the NATs developed by Shi's group is generated by the PICT. However in other reported molecules, the TICT is 
the dominate mechanism for fluorescence emission. When the electron donor (D) /acceptor (A) subgroups form a mutually perpendicular configuration, the TICT excited state will dominate.

\subsection{Synthesis and characterization of naphthalene-bridged bis-N-2-aryl triazoles (NBTs) as efficient fluorescence probe through twisted intramolecular charge transfer mechanism}

To investigate the difference of PICT and TICT, as well as discover a new fluorophore based on TICT mechanism, naphthalene-bridged bis-N-2-aryl triazoles (NBTs) compounds were prepared and applied in the fluorescence study.

As mentioned, the PICT mechanism (observed in N-2 isomers, Scheme 39A) contributed the effective fluorescence emission in NATs compounds. Herein, we reported the design and synthesis of NBT compounds, which gave excellent fluorescence emission, even with a twisted conformation between triazole and N-2 aryl groups (Scheme 39B), suggesting the twisted intramolecular charge transfer (TICT) as the plausible mechanism for the observed strong fluorescence emission. ${ }^{79}$ 
Scheme 39. N-2-aryl Triazole Fluorophores

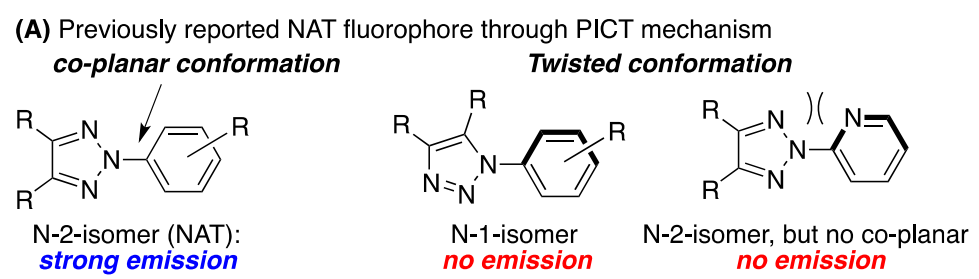

(B) This work: Naphthalene-bridged bis-triazole (NBT) fluorophore

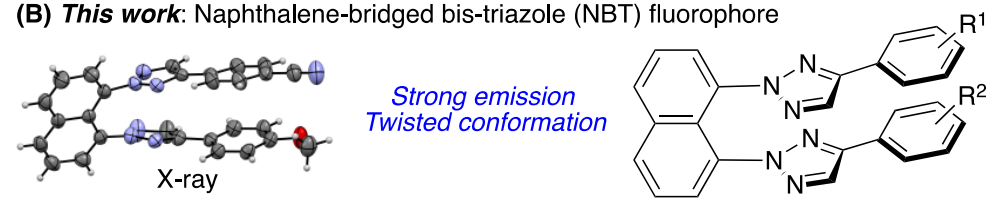

Previously, we reported that N-2-aryl triazole 3.1 gave very strong fluorescence emission while its $\mathrm{N}-1$ isomer $\mathbf{3 . 2}$ gave no emission at all. Two key factors appeared to control the fluorescence emission in these NAT dyes: N-2 substitution and coplanar conformation between the two rings. However, the second assumption was greatly questioned by our recent studies of $\mathrm{N}$-naphthalene triazoles. As shown in Scheme 40, we prepared phenyl triazole 3-1a (N-2 isomer) and 3-1b (N-1 isomer); $\mathrm{N}$-naphthalene triazole 3-1c ( $\mathrm{N}-2$ isomer) and 3-1d ( $\mathrm{N}-1$ isomer). Similar to benzyl triazoles, the $\mathrm{N}-1$ isomer 3-1b and 3-1d gave no fluorescence emission and N-2 isomer 3-1a and 3-1c gave strong emission. However, a closer look of 3-1c suggests that coplanar conformation between naphthalene and triazole ring is highly unlikely due to the steric repulsion. In fact, in our previous research, we found the crystal structure of a similar analog to 3-1c indicated a $49.5^{\circ}$ dihedral angle between the naphthalene ring and triazole ring. ${ }^{80}$ These results initiated our interest in further exploring this new class of fluorescent dyes with the question whether the coplanar conformation is necessary. ${ }^{81}$ 
Scheme 40. Fluorescence Emission of NAT with Different Aryl Groups

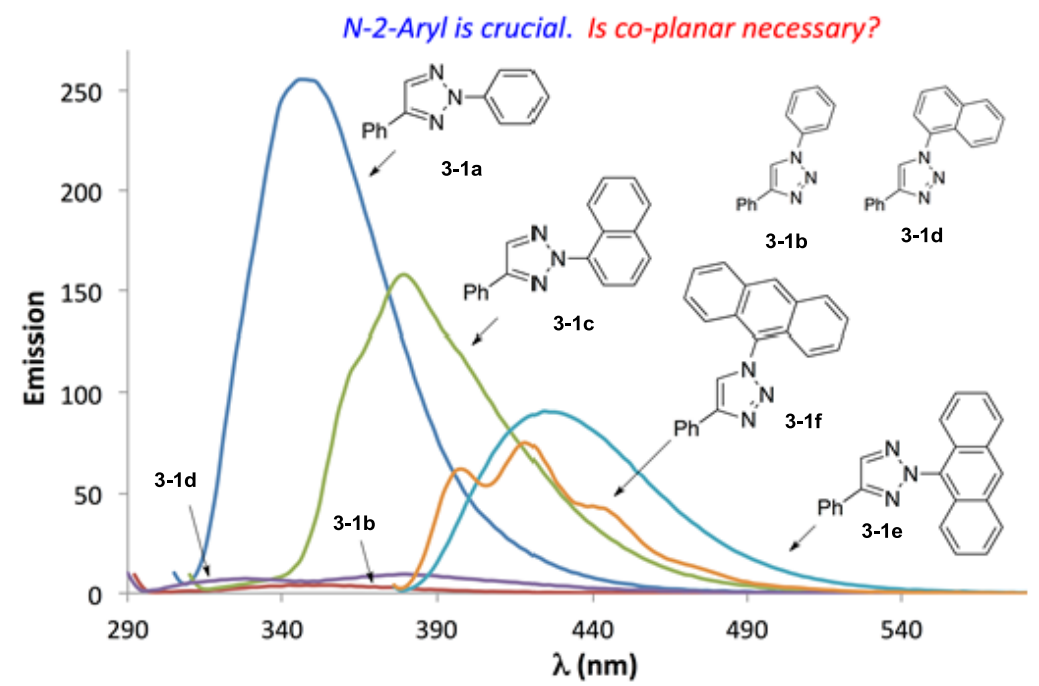

Besides the coplanar intramolecular charge transfer (PICT), another feasible photochemical process associated with this type of extended aromatic ring-i.e., the twisted intramolecular charge transfer (TICT)--was first introduced by Grabowski et al. ${ }^{82}$ One important feature of TICT type of emission is the feasibility of the donor unit in initiating the charge transfer. Numerous nitrogen containing heterocycles have been studied as donors in TICT emitting molecules. ${ }^{83}$ However, to the best of our knowledge 1,2,3-triazoles have not been used as a potential donor in the TICT fluorophores and their photochemical properties remain unknown.

To explore triazole derivatives as potential TICT emitting dyes, we prepared anthracene substituted triazole 3-1e $(\mathrm{N}-2)$ and 3-1f $(\mathrm{N}-1)$. Clearly, the anthracene should provide a large steric repulsion that can prevent the formation of coplanar conformation even in the $\mathrm{N}-2$ isomer 3-1e. Thus the fluorescence emission should be mainly from the twisted state. Interestingly, both $\mathrm{N}-1$ and $\mathrm{N}-2$ isomers gave good 
emission. However, three different emission bands were observed in the $\mathrm{N}-1$ isomer 31f, which was similar to the typical emission of aromatic substituted anthracene. ${ }^{84}$ This result suggested that triazole-anthracene compounds were not good model molecules to evaluate the triazole's influence on TICT emission due to the notable background emission from anthracene. To better evaluate the triazole influence in the twisted systems, we designed the naphthalene-bridged bis-triazole (NBT).

Scheme 41. Synthesis of Naphthalene-bridged Bis-triazoles (NBTs)

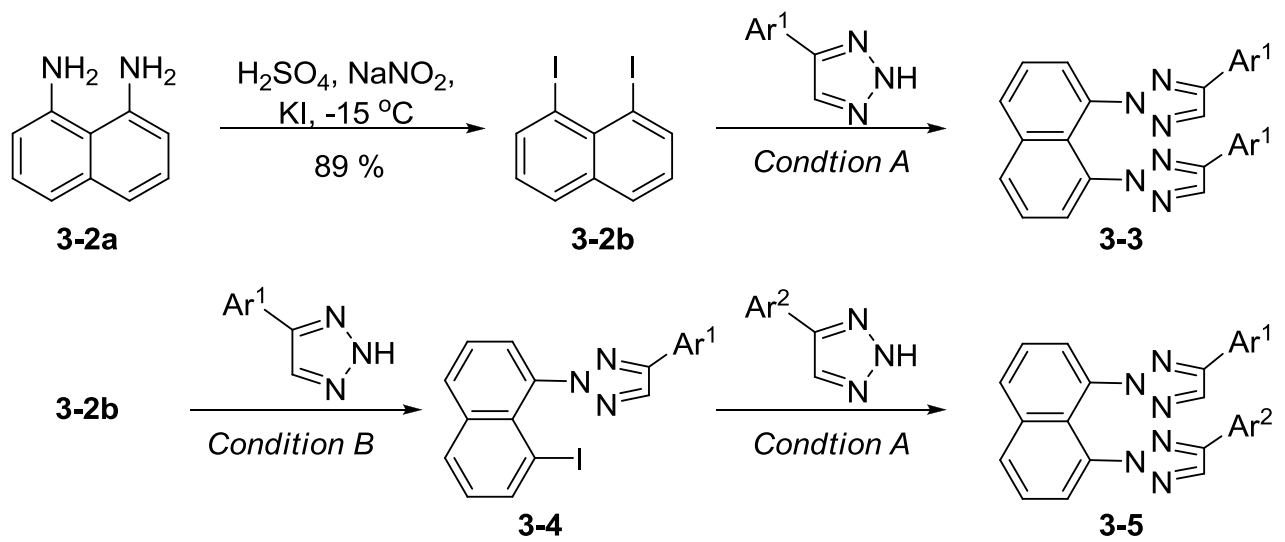

Condition A: $20 \%$ Cul, $40 \%$ Proline, 4.0 eq. $\mathrm{K}_{2} \mathrm{CO}_{3}$, DMSO, $120^{\circ} \mathrm{C}$;

Condition B: $20 \%$ Cul, $40 \%$ Proline, 4.0 eq. $\mathrm{K}_{2} \mathrm{CO}_{3}$, DMSO, $80^{\circ} \mathrm{C}$

As shown in Scheme 41, the bis-triazole can be readily prepared from the copper catalyzed coupling between naphthalene di-iodide $\mathbf{3 - 2} \mathbf{b}$ and $\mathrm{NH}$-triazole. Two different conditions were developed to reach NBT, either in a one-pot fashion (Condition A) or stepwise process (Condition B). With the use of these methods, both symmetrical NBT 3-3 and asymmetrical NBT 3-5 could be easily prepared. Notably, both N-1 and N-2 isomers were observed in all cases. The regioselectivity (ratio between $\mathrm{N}-2$ and $\mathrm{N}-1$ isomers) depends on the substituted groups (Ar), similar to what has been observed previously in triazoles functionalization. ${ }^{85}$ The $\mathrm{N}-1$ and N-2 isomers could be easily 
separated using column chromatography due to the significant polarity difference. Perhaps, the most important question for the synthesis of NBT was how to identify the relative position of the two triazole rings with restricted rotation. Considering the rotation of C-N bonds, theoretically two conformers (cis and trans) could be formed. Interestingly, during our synthesis, only one conformer was observed in nearly all cases, which was later confirmed to be the cis-conformer via X-ray crystallography (Scheme 42).

Scheme 42. X-ray Crystallography Confirmed the Formation of Cis-conformer

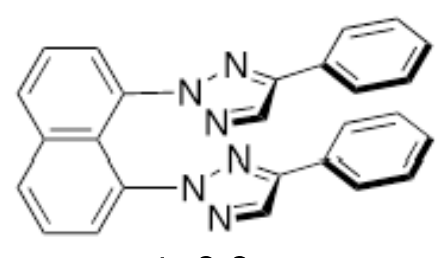

cis-3-3c

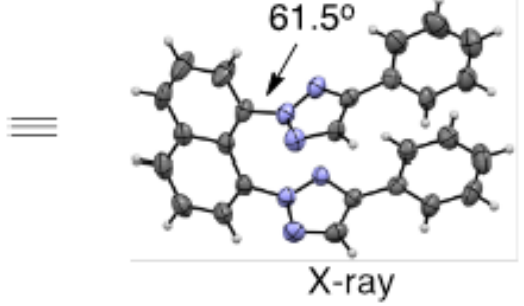

X-ray

As shown in the X-ray crystal structure, the twisted conformation was confirmed between triazole and naphthalene rings with a dihedral angle of $61.5^{\circ}$. The crystal structure of mono-triazole substituted $3-4 a\left(\mathrm{Ar}^{1}=\mathrm{Ph}\right.$, with I on naphthalene ring) was also obtained. Similarly, the dihedral angle observed for 3-4a between these two rings is $62.9^{\circ}$. With all clearly characterized NBTs, their fluorescent properties were measured and shown in Scheme 43. 
Scheme 43. Fluorescence Emission of NBT 3-3 and 3-4a

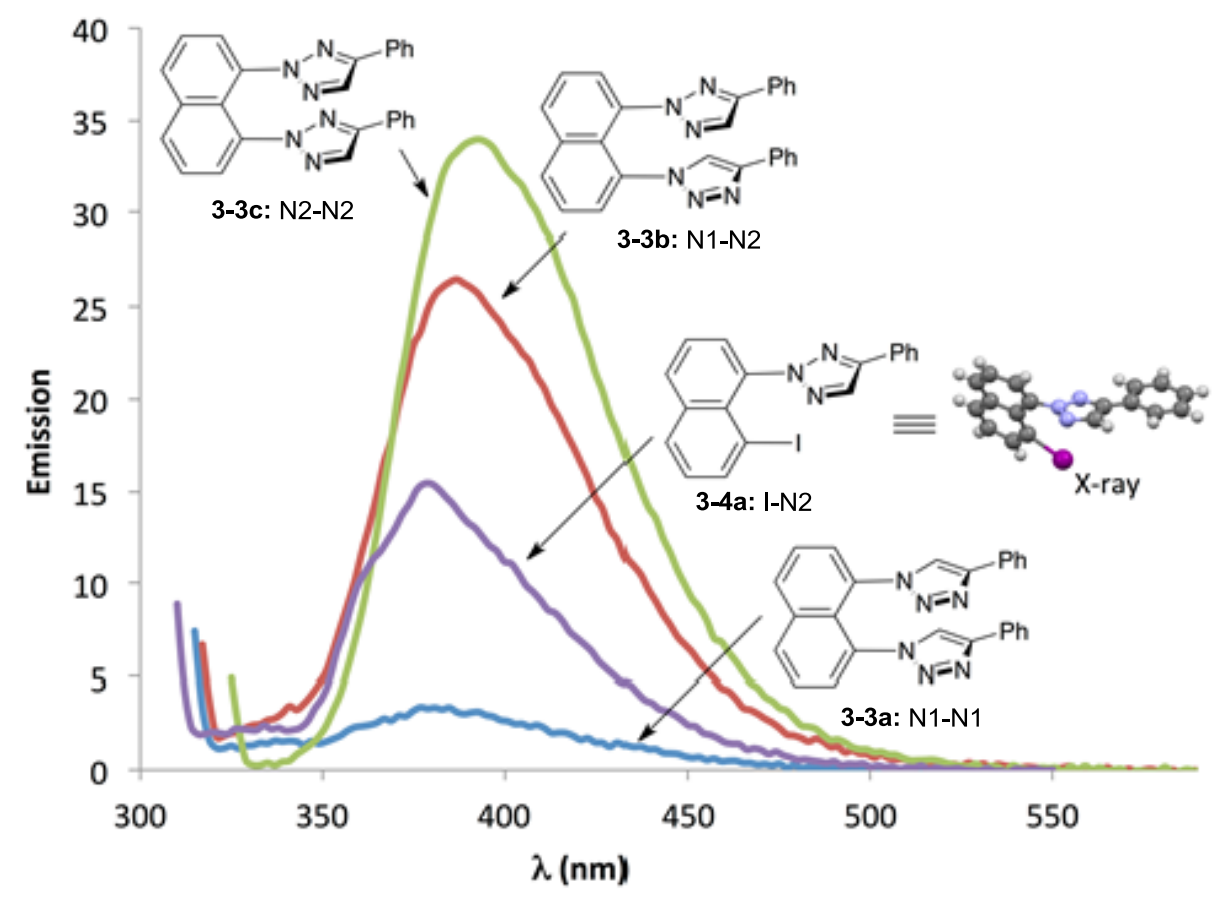

As shown by the solid-state crystal structures, both bis-triazole NBT 3-3 and monotriazole 3-4 adopted a twisted conformation. However, while N-2 isomers generally gave good fluorescence emission, the $\mathrm{N}-1$ isomers gave almost no emission in all cases. The emission intensity of NBT 3-3 followed a clear trend of N2-N2 > N2-N1 > N1-N1 (almost no emission). Due to the rotation strain, it is impossible for NBT 3-3 to adopt a planar conformation even in solution. Thus the observed good fluorescence emission of the $\mathrm{N}-2$ isomers likely represents the photochemical process associated TICT states. The optical properties (emission, excitation and quantum yields) of compounds 3-3 and 3-4 were determined and summarized in Table 9. 
Table 9. Comparison of Optical Properties of Different NBTs ${ }^{a}$

\begin{tabular}{|c|c|c|c|c|c|}
\hline & $\mathrm{R}^{1} / \mathrm{R}^{2}$ & excitation & emission & $\Phi$ & Stokes shift \\
\hline \multicolumn{6}{|c|}{ NAT } \\
\hline $3-1 a$ & - & 298 & 347 & 0.34 & 49 \\
\hline $3-4 a$ & N2-TA-I & 300 & 378 & 0.20 & 78 \\
\hline \multicolumn{6}{|c|}{ NBT } \\
\hline 3-3a & $\mathrm{R}^{1}=\mathrm{R}^{2}=\mathrm{H}(\mathrm{N} 1-\mathrm{N} 1)$ & - & - & $<0.01$ & - \\
\hline $3-3 b$ & $\mathrm{R}^{1}=\mathrm{R}^{2}=\mathrm{H}(\mathrm{N} 1-\mathrm{N} 2)$ & 307 & 384 & 0.13 & 77 \\
\hline $3-3 c$ & $\mathrm{R}^{1}=\mathrm{R}^{2}=\mathrm{H}(\mathrm{N} 2-\mathrm{N} 2)$ & 315 & 393 & 0.24 & 78 \\
\hline $3-5 a$ & $\mathrm{R}^{1}=\mathrm{R}^{2}=\mathrm{Cl}$ & 305 & 393 & 0.26 & 88 \\
\hline $3-5 b$ & $\mathrm{R}^{1}=\mathrm{R}^{2}=\mathrm{OMe}$ & 315 & 403 & 0.29 & 88 \\
\hline $3-5 c$ & $\mathrm{R}^{1}=\mathrm{R}^{2}=\mathrm{COOMe}$ & 300 & 396 & 0.41 & 96 \\
\hline $3-5 d$ & $\mathrm{R}^{1}=\mathrm{R}^{2}=\mathrm{CN}$ & 302 & 403 & 0.47 & 101 \\
\hline $3-5 e$ & $\mathrm{R}^{1}=\mathrm{OMe}, \mathrm{R}^{2}=\mathrm{CN}$ & 300 & 408 & 0.39 & 108 \\
\hline
\end{tabular}

aSample information: $1.0 \times 10^{-6} \mathrm{~mol} / \mathrm{L}$ in dichloromethane; Quantum yields $(\Phi)$ were determined based on $1.0 \times 10^{-6} \mathrm{~mol} / \mathrm{L} 9,10$-diphenylanthracene in cyclohexane $(\Phi=0.9)$; Calculated photo emission integration from the original spectra. All fluorescence data are measured under identical conditions.

While these N-2 isomers of NBTs were identified as a new class of fluorophores, one interesting feature offered by the naphthalene-bridge was the potential for $\pi-\pi$ stacking between the two triazoles. ${ }^{86}$ As revealed by the structural analysis of $\mathbf{3 - 3} \mathbf{c}$, the two triazoles in NBT are nearly parallel, with the distance just slightly longer than the sum of the van der Waals radii. Thus, it is reasonable to expect that the substituted groups on the triazole phenyl ring may provide various electronic effects that will influence the 
overall optical properties ${ }^{87}$ In order to explore the substituted group influence, a series of symmetrical and asymmetrical NBT 3-5 were prepared with various substituents on the triazole phenyl rings. Their photochemical properties were evaluated (Table 9), and the fluorescence spectra of some representative NBTs are shown in Scheme 44.

Among all the tested NBTs, the N-2 substitution is crucial for effective emission. Compared with previous planar NAT 3-1a, the new twisted NBT fluorophores gave more red shift emissions approximately $400 \mathrm{~nm}$ (blue light). Interestingly, although the two triazole rings are nearly parallel, changing the substituent groups on phenyl rings did not influence the overall emission of the NBT. For example, with either EDG (3-5b) or EWG (3-5c and 3-5d) substituted NBT; there were few changes on the emission and excitation wavelengths. Furthermore, substrate 3-5e with EDG and EWG incorporated on different rings also gave similar emission, which strongly suggested that minimal $\pi-\pi$ interactions occurred between the two rings. Notably, the substitute groups did help to improve the quantum yields (up to $47 \%$ ) through the introduction of extended conjugations. ${ }^{88}$ Overall, in comparison with NAT, this new NBT system gave significantly higher fluorescence efficiency, which implied great potential for future applications. 
Scheme 44. Fluorescence Emission of NBT 3-5 and 3-4a

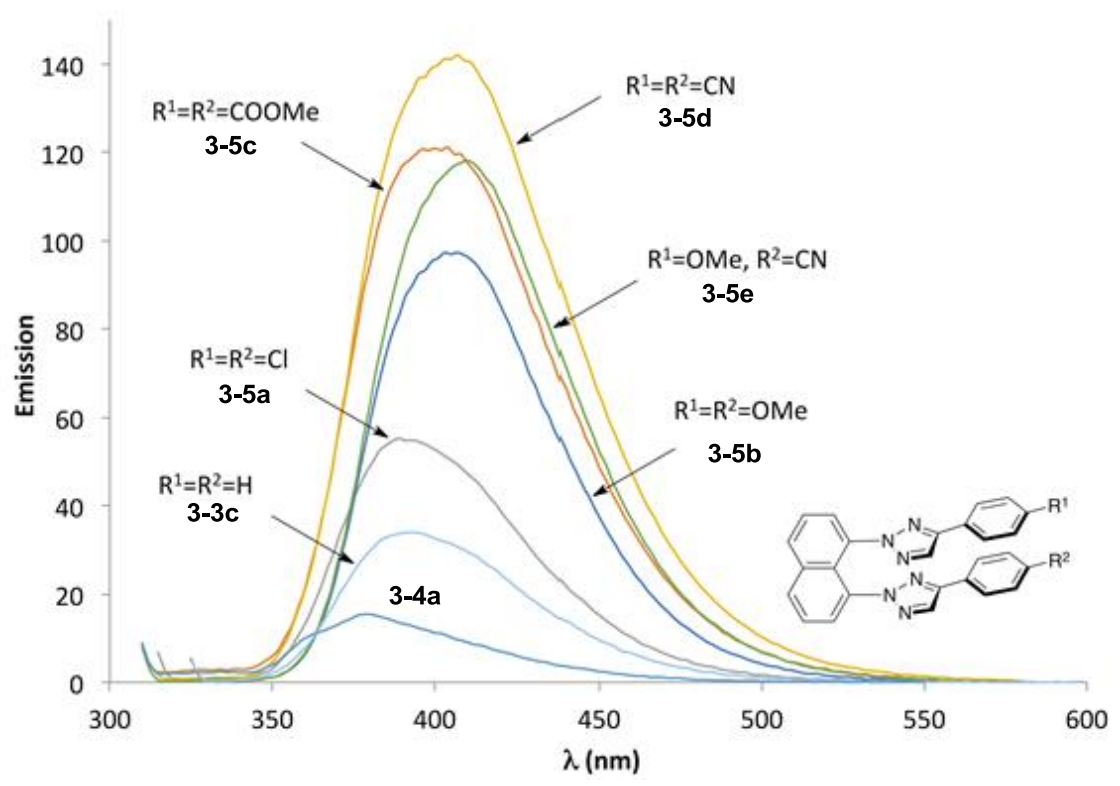

\subsection{Conclusion}

In conclusion, we herewith report a new type of triazole based fluorescence-active compounds: naphthalene-bridged bis-triazole (NBT). Practical syntheses have been developed and regio-isomers of compounds were characterized by X-ray crystallography. The fluorescence studies reveal that in this twisted system, the N-2 substitution is crucial for effective fluorescence emission. Comparing with previously reported NAT system, this new NBT gave higher fluorescence efficiency and larger Stokes shifts, which warrants the potential as new molecule probes for chemical and biological applications. 


\subsection{Contribution}

Yanwei Zhang was the researcher who had first investigated the reaction condition and fluorescence property. Together, Yanwei Zhang and Xiaohan Ye were responsible for substrate scope, NMR spectrum, fluorescence data and manuscript completion for successful submission to Journal of Organic Chemistry. The detailed X-ray crystallographic data analysis of compound 3-3c was done by Prof. Jeffrey L. Petersen, C. Eugene Bennett Department of Chemistry, West Virginia University. 


\section{References}

1 (a) A. S. K. Hashmi; F. D. Toste, Modern Gold Catalyzed Synthesis, Wiley-VCH, Weinheim, 2012; (b) A. S. K. Hashmi; M. Rudolph, Chem. Soc. Rev. 2012, 41, 2448;

(c) D. J. Gorin, B. D. Sherry; F. D. Toste, Chem. Rev. 2008, 108, 3351; (d) A. Arcadi, Chem. Rev. 2008, 108, 3266; (e) E. Jimenez-Nunez; A. M. Echavarren, Chem. Rev. 2008, 108, 3326; ( f) A. S. K. Hashmi, Chem. Rev. 2007, 107, 3180; (g) A. Furstner and P. W. Davies, Angew. Chem., Int. Ed. 2007, 46, 3410; (h) L. Zhang, J. Sunand S. A. Kozmin, Adv. Synth. Catal. 2006, 348, 2271; (i) A. S. K. Hashmi; G. J. Hutchings, Angew. Chem. Int. Ed. 2006, 45, 7896.

2 (a) Nösel, P.; dos Santos Comprido, L. N.; Lauterbach, T.; Rudolph, M.; Rominger, F.; Hashmi, A. S. K. J. Am. Chem. Soc. 2013, 135, 15662; (b) Ji, K.; Zhao, Y.; Zhang, L. Angew. Chem. Int. Ed. 2013, 52, 6508; (c) González, A. Z.; Benitez, D.; Tkatchouk, E.; Goddard, W. A.; Toste, F. D. J. Am. Chem. Soc. 2011, 133, 5500; (d) Boogaerts, I. I. F.; Nolan, S. P. J. Am. Chem. Soc. 2010, 132, 8858.

3 (a) A. S. K. Hashmi, J. P. Weyrauch, M. Rudolph; E. Kurpejovic, Angew. Chem. Int. Ed. 2004, 43, 6545; (b) A. S. K. Hashmi, M. Rudolph, J. P. Weyrauch, M. Wolfle, W. Frey; J. W. Bats, Angew. Chem. Int. Ed. 2005, 44, 2798; (c) N. Debono, M. Iglesias; F. Sanchez, Adv. Synth. Catal. 2007, 349, 2470; (d) A. S. K. Hashmi, M. Rudolph, H. U. Siehl, M. Tanaka, J. W. Bats; W. Frey, Chem. Eur. J. 2008, 14, 3703; (e) N. D. Shapiro, Y. Shi, F. D. Toste, J. Am. Chem. Soc. 2009, 131, 11654; (f) Y. Zhang, B. Feng; C. Zhu, Org. Biomol. Chem. 2012, 10, 9137; (g) J. A. O’Neill, G. M. Rosair, A. L. Lee, Catal. Sci. Technol. 2012, 2, 1818. 
4 (a) A. S. K. Hashmi; F. D. Toste, Modern Gold Catalyzed Synthesis, Wiley-VCH, Weinheim, 2012; (b) A. S. K. Hashmi; M. Rudolph, Chem. Soc. Rev. 2012, 41, 2448; (c) D. J. Gorin, B. D. Sherry; F. D. Toste, Chem. Rev. 2008, 108, 3351; (d) A. Arcadi, Chem. Rev. 2008, 108, 3266; (e) E. Jimenez-Nunez; A. M. Echavarren, Chem. Rev. 2008, 108, 3326; ( f) A. S. K. Hashmi, Chem. Rev. 2007, 107, 3180; (g) A. Furstner; P. W. Davies, Angew. Chem. Int. Ed. 2007, 46, 3410; (h) L. Zhang, J. Sun; S. A. Kozmin, Adv. Synth. Catal. 2006, 348, 2271; (i) A. S. K. Hashmi; G. J. Hutchings, Angew. Chem. Int. Ed. 2006, 45, 7896.

5 (a) Gaillard, S.; Cazin, C. S. J.; Nolan, S. P. Acc. Chem. Res. 2011, 45, 778; (b) Nolan, S. P. Acc. Chem. Res. 2010, 44, 91; (c) Marion, N.; Nolan, S. P. Chem. Soc. Rev. 2008, 37, 1776; (d) Marion, N.; Carlqvist, P.; Gealageas, R.; de Frémont, P.; Maseras, F.; Nolan, S. P. Chem. Eur. J. 2007, 13, 6437.

6 Schwerdtfeger P.; Hermann H. L.; Schmidbaur H. Inorg. Chem., 2003, 42, 1334.

7 (a) Mauger, C. C.; Mignani, G. A. Aldrichimica Acta. 2006, 39, 17; (b) Schlummer, B.; Scholz, U. Adv. Synth. Catal. 2004, 346, 1599.

(a) Chabre, Y. M.; Roy, R. Curr. Top. Med. Chem. 2008, 8, 1237;. (b) Colombo, M.; Peretto, I. Drug Discovery Today 2008, 13, 677; (c) Hanselmann, R.; Job, G. E.; Johnson, G.; Lou, R. L.; Martynow, J. G.; Reeve, M. M. Org. Process Res. Dev. 2010, 14, 152; (d) Moumne, R.; Larue, V.; Seijo, B.; Lecourt, T.; Micouin, L.; Tisne, C. Org. Biomol. Chem. 2010, 8, 1154-1159; (e) Li, H. M.; Cheng, F. O.; Duft, A. M.; Adronov, A. J. Am. Chem. Soc. 2005, 127, 14518; (f) Rozkiewicz, D. I.; Janczewski, D.; Verboom, W.; Ravoo, B. J.; Reinhoudt, D. N. Angew. Chem., Int. Ed. 2006, 45, 5292; (g) Wyszogrodzka, M.; Haag, R. Chem. Eur. J. 2008, 14, 9202; (h) Gadzikwa, 
T.; Farha, O. K.; Malliakas, C. D.; Kanatzidis, M. G.; Hupp, J. T.; Nguyen, S. T. J. Am. Chem. Soc. 2009, 131, 13613; (i) Golas, P. L.; Matyjaszewski, K. Chem. Soc. Rev. 2010, 39, 1338; (j) Hahn, M. E.; Muir, T. W. Trends Biochem. Sci. 2005, 30, 26; (k) Heal, W. P.; Wickramasinghe, S. R.; Leatherbarrow, R. J.; Tate, E. W. Org. Biomol. Chem. 2008, 6, 2308; (I) Ahsanullah, J.; Schmieder, P.; Kuhne, R.; Rademann, J. Angew. Chem., Int. Ed. 2009, 48, 5042; (m) Schneider, G. Nat. Rev. Drug Discovery 2010, 9, 273.

9 (a) Rostovtsev, V. V.; Green, L. G.; Fokin, V. V.; Sharpless, K. B. Angew. Chem., Int. Ed. 2002, 41, 2596; (b) Kolb, H. C.; Finn, M. G.; Sharpless, K. B. Angew. Chem., Int. Ed. 2001, 40, 2004; (c) Moses, J. E.; Moorhouse, A. D. Chem. Soc. Rev. 2007, 36, 1249. (d) Wu, P.; Fokin, V. V. Aldrichim. Acta. 2007, 40, 7.

10 (a) Wang, D.; Zhang, Y.; Harris, A.; Gautam, L. N. S.; Shi, X. Adv. Syn. Catal. 2011, 353, 2584;. (b) Wang, D.; Zhang, Y.; Cai, R.; Shi, X.; Beilstein J. Org. Chem. 2011, 7, 1014;. (c) Wang, D.; Gautam, L. N. S.; Bollinger, C.; Harris, A.; Li, M.; Shi, X. Org. Lett. 2011, 13, 2618; (d) Duan, H.; Sengupta, S.; Petersen, J. L.; Akhmedov, N.; Shi, X. J. Am. Chem. Soc. 2009, 131, 12100; (e) Duan, H.; Yan, W.; Sengupta, S.; Shi, X. Bioorg. Med. Chem. Lett. 2009, 3899.

11 (a) Aucagne, V.; Hanni, K. D.; Leigh, D. A.; Lusby, P. J.; Walker," D. B. J. Am. Chem. Soc. 2006, 128, 2186; (b) Suijkerbuijk, B. M. J. M.; Aerts, B. N. H.; Dijkstra, H. P.; Lutz, M.; Spek, A. L.; van Koten, G.; Gebbink, R. J. M. K. Dalton. Trans. 2007, 1273; (c) Maeda, C.; Yamaguchi, S.; Ikeda, C.; Shinokubo, H.; Osuka, A.Org. Lett. 2008, 10, 549; (d) Mullen, K. M.; Gunter, M. J. J. Org. Chem. 2008, 73, 3336; (e) Detz, R. J.; Heras, S. A.; de Gelder, R.; van Leeuwen, P. W. N. M.; Hiemstra, H.; Reek, J. N. 
H.; van Maarseveen, J. H. Org. Lett. 2006, 8, 3227; (f) Monkowius, U.; Ritter, S.; König, B.; Zabel, M.; Yersin, H. Eur. J. Inorg. Chem. 2007, 4597; (g) Fukuzawa, S.; Oki, H.; Hosaka, M.; Sugasawa, J.; Kikuchi, S. Org. Lett. 2007, 9, 5557; (h) Richardson, C.; Fitchett, C. M.; Keene, F. R.; Steel, P. J. Dalton Trans. 2008, 2534; (i) Schweinfurth, D.; Hardcastle, K. I.; Bunz, U. H. F. Chem. Commun. 2008, 2203; (j) Maisonial, A.; Serafin, P.; Traïkia, M.; Debiton, E.; Thery, V.; Aitken, D. J.; Lemoine, P.; Bernard, V.; Gautier, A. Eur. J. Inorg. Chem. 2008, 298.

Loren, Jon C.; Krasinski, Antoni; Fokin, Valery V.; Sharpless, K. Barry Synlett, 18, 2005, 2847.

Zefirov, N.S.; Chapovskaya, N.K.; Kolesnikov, V. V. Chem. Commoun. 1971, 1001.

Yan, W.; Liao, T.; Tuguldur, O.; Zhong, C.; Petersen, J. L.; Shi, X. Chem. Asian. J. $2011,6,2720$.

18 (a) Chen, Y.; Liu, Y.; Petersen, J. L.; Shi, X. Chem. Commun. 2008, 3254; (b) Liu, Y.; Yan, W.; Chen, Y.; Petersen, J. L.; Shi, X. Org. Lett. 2008, 10, 5389.

Duan, H.; Sengupta, S.; Petersen, J. L.; Shi, X. Organometallics 2009, 28, 2352. Liao, W.; Chen, Y.; Liu, Y.; Duan, H.; Petersen, J. L.; Shi, X. Chem. Commun. 2009, 6436.

21 (a) Duan, H.; Sengupta, S.; Petersen, J. L.; Akhmedov, N. G.; Shi, X. J. Am. Chem. Soc. 2009, 131, 12100; (b) Xi, Y.; Wang, D.; Ye, X.; Akhmedov, N. G.; Petersen, J. L.; Shi, X. Org. Lett. 2013, 16, 306. 
22 (a) Herrero-Gómez, E.; Nieto-Oberhuber, C.; López, S.; Benet-Buchholz, J.;

Echavarren, A. M. Angew. Chem. Int. Ed. 2006, 45, 5455. (b) Patrick, S. R.; Gómez-

Suárez, A.; Slawin, A. M. Z.; Nolan, S. P. Organometallics 2013, 33, 421.

${ }^{23}$ Nomiya, K.; Noguchi, R.; Ohsawa, K.; Tsuda, K. J. Chem. Soc., Dalton Trans. 1998, 4101.

${ }^{24}$ Zhang, L. J. Am. Chem. Soc. 2005, 127, 16804-16805.

25 Zhang, L.; Wang, S. J. Am. Chem. Soc. 2006, 128, 1442-1443.

${ }^{26}$ Buzas, A.; Istrate, F.; Gagosz, F. Org. Lett. 2006, 8, 1957-1959.

${ }^{27}$ Wang, S.; Zhang, L. Org. Lett. 2006, 8, 4585-4587.

${ }^{28}$ Wang, S.; Zhang, L. J. Am. Chem. Soc. 2006, 128, 8414-8415.

${ }^{29}$ Buzas, A.; Gagosz, F. J. Am. Chem. Soc. 2006, 128, 12614-12615.

30 Wang, S.; Zhang, L. J. Am. Chem. Soc. 2006, 128, 14274-14275.

${ }^{31}$ Marion, N.; Nolan, S. P. Angew. Chem., Int. Ed. 2007, 46, 2750-2752.

${ }^{32}$ Marco-Contelles, J.; Soriano, E. Chem.-Eur. J. 2007, 13, 1350-1357.

33 Barluenga, J.; Riesgo, L.; Vicente, R.; Lopéz, L. A.; Tomás, M. J. Am. Chem. Soc. 2007, 129, 7772-7773.

34 Shi, F.-Q.; Li, X.; Xia, Y.; Zhang, L.; Yu, Z.-X. J. Am. Chem. Soc. 2007, 129, 1550315512.

35 Saucy, R.; Marbet, R.; Lindlar, H.; Isler, O. Helv. Chim. Acta 1959, 42, 1945-1955.

36 Cherbuliez, E.; Moll, H.; Baehler, B. R.; Rabinowitz, J. Helv. Chim. Acta 1967, 50, $1154-1158$.

37 Wang, D.; Gautam, L. N. S.; Bollinger, C.; Harris, A.; Li, M.; Shi, X. Org. Lett. 2011, 13, 2618-2621. 
Marion, N.; Díez-González, S.; de Fremont, P.; Noble, A. R.;Nolan, S. P. Angew. Chem., Int. Ed. 2006, 45, 3647-3650.

Sengupta, S.; Duan, H.; Lu, W.; Petersen, J. L.; Shi, X. Org. Lett. 2008, 10, 14931496.

40 Chen, Y.; Liu, Y.; Petersen, J. L.; Shi, X. Chem. Commun. 2008, 3254-3256.

41 Liu, Y.; Yan, W.; Chen, Y.; Petersen, J. L.; Shi, X. Org. Lett. 2008, 10, 5389-5392.

42

Duan, H.; Yan, W.; Sengupta, S.; Shi, X. Bioorg. Med. Chem. Lett. 2009, 19, 3899_ 3902.

43 Yan, W.; Wang, Q.; Chen, Y.; Petersen, J. L.; Shi, X. Org. Lett. 2010, 12, 3308-3311.

44 Duan, H.; Sengupta, S.; Petersen, J. L.; Akhmedov, N. G.; Shi, X. J. Am. Chem. Soc. 2009, 131, 12100-12102.

45 Chen, Y.; Yan, W.; Akhmedov, N. G.; Shi, X. Org. Lett. 2010, 12, 344-347.

46 Wang, D.; Ye, X.; Shi, X. Org. Lett. 2010, 12, 2088-2091.

${ }^{47}$ Yu, M.; Zhang, G.; Zhang, L. Org. Lett. 2007, 9, 2147-2150.

48 Ye, L.; Zhang, L. Org. Lett. 2009, 11, 3646-3649.

49 Yu, M.; Zhang, G.; Zhang, L. Tetrahedron 2009, 65, 1846-1855.

50 Mauleón, P.; Krinsky, J. L.; Toste, F. D. J. Am. Chem. Soc. 2009, 131,4513-4520.

51 (a) Diez-Gonzalez, S.; Marion, N.; Nolan, S. P. Chem. Rev. 2009, 109, 3612-3676;

(b) Fremont, P.; Marion, N.; Nolan, S. P. Coord. Chem. Rev. 2009, 253, 862-892; (c) Marion, N.; Nolan, S. P. Acc. Chem. Res. 2008, 41, 1440-1449; (d) Marion, N.; Nolan, S. P. Chem. Soc. Rev. 2008, 37, 1776-1782; (e) Diez-Gonzalez, S.; Nolan, S. P. Acc. Chem. Res. 2008, 41, 349-358. 
${ }^{52}$ For Au-catalyzed Meyer-Schuster rearrangements, see: (a) Georgy, M.; Boucard, V.; Campagne, J.-M. J. Am. Chem. Soc. 2005, 127, 14180-14181. (b) Engel, D.; Dudley, G. B. Org. Lett. 2006, 8, 4027-4029. (c) Yu, M.; Li, G.; Wang, S.; Zhang, L.; Adv. Synth. Catal. 2007, 349, 871- 875. (d) Ramon, R. S.; Marion, N.; Nolan, S. P. Tetrahedron 2009, 65, 1767-1773. (e) Ye, L.; Zhang, L. Org. Lett. 2009, 11, 36463649. (f) Gaillard, S.; Bosson, J.; Ramon, R. S.; Nun, P.; Slawin, A. M. Z.; Nolan, S. P. Chem. Eur. J. 2010, 16, 13729-13740. (g) Zanoni, G.; D’Alfonso, A.; Porta, A.; Feliciani, L.; Nolan, S. P.; Vidari, G. Tetrahedron 2010, 66, 7472-7478. (h) Merlini, V.; Gaillard, S.; Porta, A.; Zanoni, G.; Vidari, G.; Nolan, S. P. Tetrahedron Lett. 2011, 52, 1124-1127. (i) Pennell, M. N.; Unthank, M. G.; Turner, P.; Sheppard, T. D. J. Org. Chem. 2011, 76, 1479-1482.

${ }^{53}$ For selected examples of 1,3-shifts, see: (a) Zhang, L. J. Am. Chem. Soc. 2005, 127, 16804-16805. (b) Zhang, L; Wang, S. J. Am. Chem. Soc. 2006, 128, 1442-1443. (c) Buzas, A.; Istrate, F.; Gagosz, F. Org. Lett. 2006, 8, 1957-1959. (d) Wang, S.; Zhang, L. Org. Lett. 2006, 8, 4585-4587. (e) Wang, S.; Zhang, L. J. Am. Chem. Soc. 2006, 128, 8414-8415. (f) Buzas, A.; Gagosz, F. J. Am. Chem. Soc. 2006, 128, $12614-$ 12615. (g) Wang, S.; Zhang, L. J. Am. Chem. Soc. 2006, 128, 14274-14275. (h) Marion, N.; Nolan, S. P. Angew. Chem. 2007, 119, 2806-2809; Angew. Chem. Int. Ed. 2007, 46, 2750-2752. (i) Marco-Contelles, J.; Soriano, E. Chem. Eur. J. 2007, 13, 1350-1357. (j) Barluenga, J.; Riesgo, L.; Vicente, R.; Lopez, L.; Tomas, M. J. Am. Chem. Soc. 2007, 129, 7772-7773. (k) Shi, F.-Q.; Li, X.; Xia, Y; . Zhang, L.; Yu, Z.-X. J. Am. Chem. Soc. 2007, 129, 15503-15512. 
Marion, N.; Carlqvist, P.; Gealageas, R.; Fremont, P.; Maseras, F.; Nolan, S. P. Chem. Eur. J. 2007, 13, 6437-6451.

${ }^{55}$ Marion, N.; Diez-Gonzalez, S.; Fremont, P.; Noble, A. R.; Nolan, S. P. Angew. Chem. 2006, 118, 3729; Angew. Chem. Int. Ed. 2006, 45, 3647- 3650.

56 Ramon, R. S.; Gaillard, S.; Slawin, A. M. Z.; Porta, A.; D’Alfonso, A.; Zanoni, G.; Nolan, S. P. Organometallics 2010, 29, 3665-3668.

57 Significant TA-Au catalyst decomposition was observed while treating with 4 a over time (after $30 \mathrm{~h}$ ) even at room temperature.

58 It is known that the gold cations decompose faster in the presence of terminal alkynes. The 31P NMR investigation of $A u(I)$ decomposition in terminal alkyne has been reported.

${ }^{59}$ Reaction of a terminal propargylic alcohol gave poor yields due to the undesired antiMarkovnikov addition.

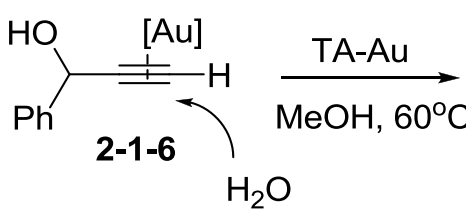<smiles>[Z10]/C=C/C=O</smiles>
$\begin{array}{ccc}\text { TA-Au 2\% } & 12 \mathrm{~h} & 29 \% \\ & & \\ & & \\ \text { TA-Au 0.5\% } & 4 \mathrm{~h} & \\ \text { x 5 times } & \text { x } 5 \text { times } & 62 \%\end{array}$

60 The allene ester from the TA-Au propargylic ester 2-1-1 catalyzed 3,3-rearrangment has been recently isolated, which confirmed the suggested rearrangement-hydration mechanism. See: Wang, D.; Gautam, L. N. S.; Bollinger, C.; Harris, A.; Li, M.; Shi, X. Org. Lett. 2011, 13, 2618-2621.

61 For recent reviews, see: (a) A. S. K. Hashmi, Angew. Chem. Int. Ed. 2010, 49, 5232; (b) L. Liu, G. B. Hammond, Chem. Soc. Rev. 2012, 41, 3129; (c) R. E. M. Brooner, R. A. Widenhoefer, Angew. Chem. Int. Ed. 2013, 52, 11714. 
62 (a) Weber, D.; Gagné, M. R. Org. Lett. 2009, 11, 4962; (b) Weber, D.; Tarselli, M. A.; Gagné, M. R. Angew. Chem. Int. Ed. 2009, 48, 5733.

Wang, D.; Cai, R.; Sharma, S.; Jirak, J.; Thummanapelli, S. K.; Akhmedov, N. G.; Zhang, H.; Liu, X.; Petersen, J. L.; Shi, X. J. Am. Chem. Soc. 2012, 134, 9012.

64 de Frémont, P.; Scott, N. M.; Stevens, E. D.; Nolan, S. P. Organometallics 2005, 24, 2411.

65 Nieto-Oberhuber, C.; Muñoz, M. P.; López, S.; Jiménez-Núñez, E.; Nevado, C.; Herrero-Gómez, E.; Raducan, M.; Echavarren, A. M. Chem. Eur. J. 2006, 12, 1677. 66 (a)Weber, D.; Gagne, M. R. Org. Lett. 2009, 11, 4962. (b) Weber, S. G.; Rominger, F.; Straub, B. F. Eur. J. Inorg. Chem. 2012, 2863. (c) Zhu, Y.; Day, C. S.; Zhang, L.; Hauser, K. J.; Jones, A. C. Chem. Eur. J. 2013, 19, 12264. (d) Homs, A.; Escofet, I.; Echavarren, A. M. Org. Lett. 2013, 15, 5782 and references cited therein.

${ }^{67}$ (a) Rudolph, M.; Hashmi, A. S. K. Chem. Soc. Rev. 2012, 41, 2448. (b) Gorin, D. J.; Sherry, B. D.; Toste, F. D. Chem. Rev. 2008, 108, 3351. (c) Jiménez-Núñez, E.; Echavarren, A. M. Chem. Rev. 2008, 108, 3326. (d) Arcadi, A. Chem. Rev. 2008, 108, 3266. (e) Widenhoefer, R. A. Chem. Eur. J. 2008, 14, 5382.

${ }^{68}$ Sherry, B. D.; Toste, F. D. J. Am. Chem. Soc. 2004, 126, 15978.

69 Nun, P.; Gaillard, S.; Slawin, A. M. Z.; Nolan, S. P. Chem. Commun. 2010, 46, 9113. ${ }^{70}$ (a) Wang, D.; Ye, X.; Shi, X. Org. Lett. 2010, 12, 2088. (b) Wang, D.; Gautam, L. N.; Bollinger, C.; Harris, A.; Li, M.; Shi, X. Org. Lett. 2011, 13, 2618. (c) Wang, Q.; Aparaj, S.; Akhmedov, N. G.; Petersen, J. L.; Shi, X. Org. Lett. 2012, 14, 1334. (d) Xi, Y.; Wang, Q.; Su, Y.; Li, M.; Shi, X. Chem. Commun. 2014, 50, 2158. (e) Xi, Y.; Dong, B.; Shi, X. Beilstein J. Org. Chem. 2013, 9, 2537. (f) Xi, Y.; Wang, D.; Ye, X.; Akhmedov, 
N. G.; Petersen, J. L.; Shi, X. Org. Lett. 2014, 16, 306. (g) Xi, Y.; Dong, B.; McClain, E. J.; Wang, Q.; Gregg, T. L. Akhmedov, N. G.; Petersen, J. L.; Shi, X. Angew. Chem., Int. Ed. 2014, 53, 4657-4461. (h) Wang, Q.; Motika, S. E.; Akhmedov, N. G.; Petersen, J. L.; Shi, X. Angew. Chem., Int. Ed. 2014, 53, 5418-5422.

71 Thermal [2 + 2] cycloaddition of allene: (a) Skraba, S. L.; Johnson, R. P. J. Org. Chem. 2012, 77, 11096. (b) Tejedor, D.; Méndez-Abt, G.; González-Platas, J.; Ramírez, M. A.; García-Tellado, F. Chem. Commun. 2009, 2368. (c) Christl, M.; Groetsch, S.; Günther, K. Angew. Chem., Int. Ed. 2000, 39, 3261. (d) Alcaide, B.; Almendros,P.; Aragoncillo, C. Chem. Soc. Rev. 2010, 39, 783.

${ }^{72}$ For selected examples, see: a) Saha S.; Stoddart J. F. Chem. Soc. Rev. 2007, 36, 77. b) Sakai N.; Sisson A. L.; Burgi T.; Matile S. J. Am. Chem. Soc. 2007, 129, 15758. c) Díaz D. D.; Cid J. J.; Vazquez P.; Torres T. Chem. Eur. J. 2008, 14, 9261. d) Armstrong N. R.; Veneman P. A.; Ratcliff E.; Placencia D.; Brumbach M. Acc. Chem. Res. 2009, 42, 1748. e) Singhal K.; Kalkan A. K. J. Am. Chem. Soc. 2010, 132, 429.

${ }^{73}$ For selected examples, see: a) Zhang J.; Campbell R. E.; Ting A. Y.; Tsien R. Y. Nat. Rev. Mol. Cell Biol. 2002, 3, 906. b) Calzaferri G.; Pauchard M.; Maas H.; Huber S.; Khatyr A.; Schaafsma T. J. Mater. Chem. 2002, 12, 1. c) Giepmans B. N. G.; Adams S. R.; Ellisman M. H.; Tsien R. Y. Science 2006, 312, 217; Cheon J.; Lee J. H.; Acc. Chem. Res. 2008, 41, 1630. d) Domaille D. W.; Que E. L.; Chang C. J. Nat. Chem. Biol. 2008, 4, 168.

${ }^{74}$ For selected recent examples, see: (a) Medintz, I. L.; Uyeda, H. T.; Goldman, E. R.; Mattoussi, H. Nat. Mater. 2005, 4, 435 - 446; (b) Johnsson, N.; Johnsson, K. ACS 
Chem. Biol. 2007, 2, 31 - 38; (c) Low, P. S. W.; Henne, A.; Doorneweerd, D. D. Acc. Chem. Res. 2008, 41, 120 - 129; (d) Takaoka, Y.; Sakamoto, T.; Tsukiji, S.; Narazaki, M.; Matsuda, T.; Tochio, H.; Shirakawa, M.; Hamachi, I. Nat. Chem. 2009, 1, 557 - 561; (e) Jayagopal, A.; Halfpenny, K. C.; Perez, J. W.; Wright, D. W. J. Am. Chem. Soc. 2010, 132, 9789 - 9796; (f) Yang, Y.; Seidlits, S. K.; Adams, M. M.; Lynch, V. M.; Schmidt, C. E.; Anslyn, E. V.; Shear, J. B. J. Am. Chem. Soc. 2010, 132, 13114- 13116.

75 For selected recent examp les, see: (a) Sohn, Y. S.; Goodey, A.; Anslyn, E. V.; McDevitt, J. T.; Shear, J. B.; Neikirk, D. P. Biosens. Bioelectron. 2005, 21, 303 -312; (b) Khong, S. H.; Sivaramakrishnan, S.; Png, R. Q.; Wong, L. Y.; Chia, P. J.; Chua, L. L.; Ho, P. K. H. Adv. Funct. Mater. 2007, 17, 2490 -2499; (c) Tian, E. T.; Wang, J. X.; Zheng, Y. M.; Song, Y. L.; Jiang, L.; Zhu, D. B. J. Mater. Chem. 2008, 18, 1116 1122; (d) Ensafi, A. A.; Far, A. K.; Meghdadi, S. J. Hazard. Mater. 2009, 35 , 10691075; (e) Zhao, Y. S.; Zhan, P.; Kim, J.; Sun, C.; Huang, J. X. ACS Nano 2010, 4, 1630-1636; (f) Sparano, B. A.; Koide, K. J. Am. Chem. Soc. 2007, 129, 4785 4794.

(a) Yan, D. C.; Mohsseni-Ala, J.; Auner, N.; Bolte, M.; Bats, J. W. Chem . Eur. J. 2007, 13, 7204 - 7214; (b) Zhang, X. Y.; Matsuo, Y.; Naka- mura, E. Org. Lett. 2008, 10, 4145 - 4147; (c) Dan-Hardi, M.; Serre, C.; Frot, T.; Rozes, L.; Maurin, G.; Sanchez, C.; Ferey, G. J. Am. Chem. Soc. 2009, 131, 10857-10859; (d) Wahab, M. A.; Hussain, H.; He, C. Lang-muir 2009, 25, 4743 - 4750; (e) Mercs, L.; Albrecht, M.; Chem. Soc. Rev. 2010, 39, $1903-1912$. 
77 Yan W.; Wang Q.; Lin Q.; Li M.; Petersen J. L.; Shi X. Chem. Eur. J. 2011, 17, 5011.

78 Zhong, C. Phys. Chem. Chem. Phys., 2015, 17, 9248-9257

79 a) Rettig W. Angew. Chem. Int. Ed. 1986, 25, 971. b) Rettig W. Appl. Phys. B 1988, $45,145$.

${ }^{80}$ Liu Y.; Yan W.; Chen Y.; Petersen J. L.; Shi X. Org. Lett. 2008, 10, 5389.

${ }^{81}$ (a) Tonzola C. J.; Kulkarni A. P.; Gifford A. P.; Kaminsky W.; Jenekhe S. A. Adv. Funct. Mater. 2007, 17, 863.(b) Tong Q. X.; Lai S. L.; Chan M. Y.; Zhou Y. C.; Kwong H. L.; Lee C. S.; Lee S. T. Chem. Mater. 2008, 20, 6310. (c) Park Y.; Lee J. H.; Jung D. H.; Liu S. H.; Lin Y. H.; Chen L. Y.; Wu C. C.; Park J. J. Mater. Chem. 2010, 20, 5930. (d) Gómez R.; Veldman D.; Langeveld B. M. W.; Segura J. L.; Janssen R. A. J. J. Mater. Chem. 2007, 17, 427.

82 (a) Grabowski Z. R.; Rotkiewicz K.; Rubaszewska W.; Kirkorkaminska E. Acta. Phys. Pol. A. 1978, 54, 767. (b) Grabowski Z. R.; Rotkiewicz K.; Siemiarczuk A. J. Lumin. 1979, 18-9, 420. (c) Grabowski Z. R.; Rotkiewicz K.; Siemiarczuk A.; Cowley D. J.; Baumann W. Nouv. J. Chim. 1979, 3, 443. (d) Grabowski Z. R.; Dobkowski J. Pure Appl. Chem. 1983, 55, 245.

${ }^{83}$ Selected examples see: (a) Dash N.; Chipem F. A. S.; Swaminathan R.; Krishnamoorthy G.; Chem. Phys. Lett. 2008, 460, 119. (b) Mishra A.; Sahu S.; Dash N.; Behera S. K.; Krishnamoorthy G. J. Phys. Chem. B 2013, 117, 9469. (c) Xia J.; Zhou M.; Sun S.; Wang G.; Song P.; Ge M. Dyes Pigm. 2014, 103, 71.

${ }^{84}$ (a) Ishikawa J.; Sakamoto H.; Nakao S.; Wada H. J. Org. Chem. 1999, 64, 1913. (b) Thapaliya E. R.; Captain B.; Raymo F. M. J. Org. Chem. 2014, 79, 3973. 
85 (a) Sengupta S.; Duan H.; Lu W.; Petersen J. L.; Shi X. Org. Lett. 2008, 10, 1493. (b) Chen Y.; Liu Y.; Petersen J. L.; Shi X. Chem. Commun. 2008, 3254. (c) Duan H.; Yan W.; Sengupta S.; Shi X. Bioorg. Med. Chem. Lett., 2009, 19, 3899. (d) Yan W.; Wang Q.; Chen Y.; Petersen J. L.; Shi X. Org. Lett. 2010, 12, 3308.

${ }^{86}$ (a) Fun H. K.; Quah C. K.; Vijesh A. M.; Malladi S.; Isloor A. M. Acta Cryst. 2009, 66, 29. (b) Karimov Z.; Abdugafurov I.; Talipov S.; Tashkhodjaev B. Acta Cryst. 2010, 66, O1674. (c) Shan G. G.; Li H. B.; Zhu D. X.; Su Z. M.; Liao Y. J. Mater. Chem. 2012, 22, 12736.

87 (a) Goodpaster J. V.; Harrison J. F.; McGuffin V. L. J. Phys. Chem. A. 2002, 106, 10645. (b) Focsaneanu K.S.; Scaiano J. C. Photochem. Photobiol. Sci. 2005, 4, 817. 88 Brouwer A. M. Pure Appl. Chem. 2011, 83, 2213. 


\section{Appendix}

Publications during Ph.D. work at West Virginia University:

1). Zhang, Y.; Ye, X.; Petersen, J. L.; Li, M.; Shi, X. J. Org. Chem. 2015, 80. 3664-3669.

2). Ye, X.; Zhang, Y.; He, Y.; Shi, X. Tetrahedron Letters 2015 submitted.

3). Su, Y.; Zhang, Y.; Akhmedov, N. G.; Petersen, J. L.; Shi, X. Org. Lett. 2014, 16, 2478-2481.

4). Senty, T. R.; Yalamanchi, M.; Zhang, Y.; Cushing, S. K.; Seehra, M. S.; Shi, X.; Bristow, A. D. J. Appl. Phys. 2014,115, 163107.

5). Wang, D.; Zhang, Y.; Cai, R.; Shi, X. Beilstein J. Org. Chem. 2011, 7, 1014-1020. [special issue on gold catalysis]

6). Wang, D.; Zhang, Y.; Harris, A.; Gautam, L. N. S.; Shi, X. Adv. Syn. Cat. 2011, 353, 2584-2588. 


\title{
Supporting Information
}

\author{
Chapter One: Triazole-Au(I) complex as chemoselective catalyst in promoting \\ propargyl ester rearrangements.
}

\section{General methods and materials}

All of the reactions dealing with air and/or moisture-sensitive react were carried out under an atmosphere of nitrogen using oven/flame-dried glassware and standard syringe/septa techniques. Unless otherwise noted, all commercial reagents and solvents were obtained from a commercial provider and used without further purification. ${ }^{1} \mathrm{H}$ NMR and ${ }^{13} \mathrm{C}$ NMR spectra were recorded on Varian $600 \mathrm{MHz}$ spectrometers. Chemical shifts were reported relative to internal tetramethylsilane $(\delta 0.00 \mathrm{ppm})$ or $\mathrm{CDCl}_{3}(\delta 7.26 \mathrm{ppm})$ for ${ }^{1} \mathrm{H}$ NMR and $\mathrm{CDCl}_{3}(\delta 77.0 \mathrm{ppm})$ for ${ }^{13} \mathrm{C}$ NMR. Flash column chromatography was performed on 230-430 mesh silica gel. Analytical thin layer chromatography was performed with precoated glass baked plates $(250 \mu)$ and visualized by fluorescence and by charring after treatment with potassium permanganate stain. HRMS were recorded on LTQ-FTUHRA spectrometer.

Substrates 1-1, 1-5 were synthesized according to the literatures as below:

1. Hashmi, A. S. K.; Rudolph, M. Chem. Soc. Rev. 2008, 37, 1766-1775.

2. Gorin, D. J.; Sherry, B. D.; Toste, F. D. Chem. Rev. 2008, 108,

3. Arcadi, A. Chem. Rev. 2008, 108, 3266-3325. 
Representative procedure for the preparation of allene 1-2a
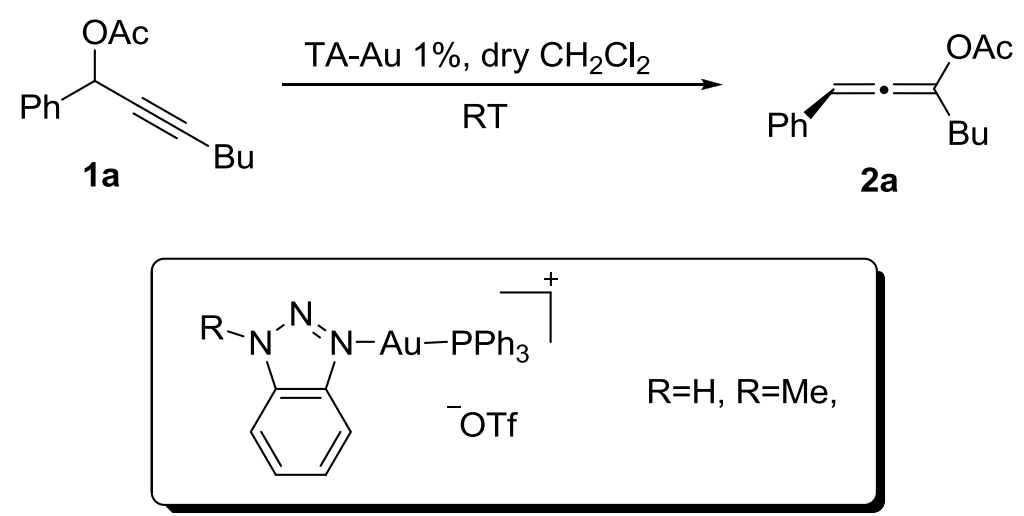

To a solution of 1-1a (58 mg, $0.25 \mathrm{mmol})$ in dry $\mathrm{CH} 2 \mathrm{Cl} 2(2.5 \mathrm{~mL}, 0.1 \mathrm{M})$, was added $\mathrm{Au}(\mathrm{I})$ catalyst $(1.9 \mathrm{mg}, 0.0025 \mathrm{~mol}, 1.0 \mathrm{~mol} \%)$ at RT. The reaction mixture was stirred at RT and monitored by TLC. After the reaction was completed (2-10 h), the solvent was removed under reduced pressure and the residue was purified by flash chromatography on silica gel (ethyl acetate/hexane $=1: 20, \mathrm{v} / \mathrm{v})$ to give $1-2 \mathrm{a}(91 \%$ yield) as colorless oil.

\section{Compounds characterization}<smiles>CC(=O)OC(=C=Cc1ccccc1)Cc1ccccc1</smiles>

1-Phenylhepta-1,2-dien-3-yl acetate (1-2a): $91 \%$ yield, ${ }^{1} \mathrm{H}$ NMR $\left(600 \mathrm{MHz}, \mathrm{CDCl}_{3}\right): \delta$ 7.43-7.44 (m, 2H), 7.32-7.35 (m, 2H), 7.25-7.27 (m, 1H), $6.59(\mathrm{t}, J=3.0 \mathrm{~Hz}, 1 \mathrm{H})$, 2.33$2.37(\mathrm{~m}, 2 \mathrm{H}), 2.15(\mathrm{~s}, 3 \mathrm{H}), 1.46-1.51(\mathrm{~m}, 2 \mathrm{H}), 1.38-1.43(\mathrm{~m}, 2 \mathrm{H}), 0.90(\mathrm{t}, J=7.2 \mathrm{~Hz}, 3 \mathrm{H})$; ${ }^{13} \mathrm{C}$ NMR $\left(150 \mathrm{MHz}, \mathrm{CDCl}_{3}\right): \delta 196.7,168.6,133.9,129.2,128.6,127.9,127.0,104.5$, $31.5,28.3,22.1,21.0,13.8$.<smiles>CC(=O)OC(Br)=C=Cc1ccc(C)cc1</smiles>

1-p-Tolylhepta-1,2-dien-3-yl acetate (1-2b): $90 \%$ yield, ${ }^{1} \mathrm{H}$ NMR $\left(600 \mathrm{MHz}, \mathrm{CDCl}_{3}\right): \delta$ $7.32(\mathrm{~d}, J=8.4 \mathrm{~Hz}, 2 \mathrm{H}), 7.13(\mathrm{~d}, J=7.8 \mathrm{~Hz}, 2 \mathrm{H}), 6.56(\mathrm{t}, J=3.0 \mathrm{~Hz}, 1 \mathrm{H}), 2.31-2.35(\mathrm{~m}$, $2 \mathrm{H}), 2.33(\mathrm{~s}, 3 \mathrm{H}), 2.13(\mathrm{~s}, 3 \mathrm{H}), 1.45-1.48(\mathrm{~m}, 2 \mathrm{H}), 1.34-1.40(\mathrm{~m}, 2 \mathrm{H}), 0.89(\mathrm{t}, J=7.2 \mathrm{~Hz}$, $3 \mathrm{H}) ;{ }^{13} \mathrm{C}$ NMR $\left(150 \mathrm{MHz}, \mathrm{CDCl}_{3}\right): \delta 196.1,168.6,137.9,131.0,129.3,127.7,126.7$, 104.4, 31.5, 28.3, 22.1, 21.2, 21.0, 13.8.<smiles>C=CC(=CCc1ccc(F)cc1)OC(C)=O</smiles>

1-(4-Fluorophenyl)hepta-1,2-dien-3-yl acetate (1-2c): $87 \%$ yield, ${ }^{1} \mathrm{H}$ NMR $(600 \mathrm{MHz}$, $\left.\mathrm{CDCl}_{3}\right): \delta$ 7.39-7.41 (m, 2H), 7.00-7.03 (m, 2H), $6.55(\mathrm{t}, \mathrm{J}=3.0 \mathrm{~Hz}, 1 \mathrm{H}), 2.31-2.35(\mathrm{~m}$, $2 \mathrm{H}), 2.15(\mathrm{~s}, 3 \mathrm{H}), 1.44-1.49(\mathrm{~m}, 2 \mathrm{H}), 1.36-1.41(\mathrm{~m}, 2 \mathrm{H}), 0.90(\mathrm{t}, J=7.2 \mathrm{~Hz}, 3 \mathrm{H}) .{ }^{13} \mathrm{C}$ $\operatorname{NMR}\left(150 \mathrm{MHz}, \mathrm{CDCl}_{3}\right): \delta 196.4,168.6,161.8(\mathrm{~d}, J=246.5 \mathrm{~Hz}), 130.0(\mathrm{~d}, J=3.2 \mathrm{~Hz})$, 
$129.4(\mathrm{~d}, J=8.3 \mathrm{~Hz}), 126.9,115.5(\mathrm{~d}, J=21.9 \mathrm{~Hz}), 103.4(\mathrm{~d}, J=2.7 \mathrm{~Hz}), 31.5,28.3$, $22.1,21.0,13.8$.<smiles>COc1ccc(C=C(Br)C(C)=O)cc1</smiles>

1-(4-Methoxyphenyl)hepta-1,2-dien-3-yl acetate (1-2d): 89\% yield, ${ }^{1} \mathrm{H}$ NMR $(600 \mathrm{MHz}$, $\left.\mathrm{CDCl}_{3}\right): \delta 7.36(\mathrm{~d}, J=8.4 \mathrm{~Hz}, 2 \mathrm{H}), 6.87(\mathrm{~d}, J=9.0 \mathrm{~Hz}, 2 \mathrm{H}), 6.54(\mathrm{t}, J=3.0 \mathrm{~Hz}, 1 \mathrm{H}), 3.81$ (s, 3H), 2.28-2.34 (m, 2H), $2.14(\mathrm{~s}, 3 \mathrm{H}), 1.44-1.47(\mathrm{~m}, 2 \mathrm{H}), 1.35-1.39(\mathrm{~m}, 2 \mathrm{H}), 0.90(\mathrm{t}, J$ $=7.2 \mathrm{~Hz}, 3 \mathrm{H}) .{ }^{13} \mathrm{C}$ NMR $\left(150 \mathrm{MHz}, \mathrm{CDCl}_{3}\right): \delta 195.3,168.8,159.6,129.0,126.6,126.4$, $114.2,104.0,55.3,31.6,28.4,22.1,21.1,13.8$.<smiles>CC(=O)OC(Br)=CC=Cc1ccc([N+](=O)[O-])cc1</smiles>

1-(4-Nitrophenyl)hepta-1,2-dien-3-yl acetate (1-2e): 89\% yield, ${ }^{1} \mathrm{H}$ NMR $(600 \mathrm{MHz}$, $\left.\mathrm{CDCl}_{3}\right): \delta 8.18-8.20(\mathrm{~m}, 2 \mathrm{H}), 7.56-7.58(\mathrm{~m}, 2 \mathrm{H}), 6.63(\mathrm{t}, \mathrm{J}=3.0 \mathrm{~Hz}, 1 \mathrm{H}), 2.34-2.37(\mathrm{~m}$, $2 \mathrm{H}), 2.17(\mathrm{~s}, 3 \mathrm{H}), 1.45-1.55(\mathrm{~m}, 2 \mathrm{H}), 1.37-1.41(\mathrm{~m}, 2 \mathrm{H}), 0.91(\mathrm{t}, J=7.2 \mathrm{~Hz}, 3 \mathrm{H}) \cdot{ }^{13} \mathrm{C}$ $\operatorname{NMR}\left(150 \mathrm{MHz}, \mathrm{CDCl}_{3}\right): \delta 200.2,168.2,147.2,140.9,128.3,127.5,124.0,102.6,31.4$, 28.2, 22.1, 22.0, 13.8. HRMS Calculated for [C15H17NO4+Na]+: 298.1050, Found: 298.1050 .<smiles>CC(=O)OC(=Cc1ccccc1)C1CC1</smiles>

1-Cyclopropyl-3-phenylpropa-1,2-dienyl acetate (1-2f): 85\% yield, ${ }^{1} \mathrm{H}$ NMR $(600 \mathrm{MHz}$, $\left.\mathrm{CDCl}_{3}\right): \delta$ 7.39-7.40 (m, 2H), 7.31-7.33 $(\mathrm{m}, 2 \mathrm{H}), 7.23-7.24(\mathrm{~m}, 1 \mathrm{H}), 6.59(\mathrm{~d}, J=2.4 \mathrm{~Hz}$, $1 \mathrm{H}), 2.16(\mathrm{~s}, 3 \mathrm{H}), 1.55-1.59(\mathrm{~m}, 1 \mathrm{H}), 0.77-0.80(\mathrm{~m}, 2 \mathrm{H}), 0.59-0.65(\mathrm{~m}, 2 \mathrm{H}) .{ }^{13} \mathrm{C} N M R$ $\left(150 \mathrm{MHz}, \mathrm{CDCl}_{3}\right): \delta 196.4,168.6,133.7,128.7,128.1,127.8,105.1,93.0,20.9,11.9$, 6.4, 5.9. HRMS Calculated for [C14H14O2+H]+: 215.1066, Found: 215.1059.<smiles>CCOC(=O)OC(Br)=Cc1ccccc1</smiles>

Ethyl 1-phenylhepta-1,2-dien-3-yl carbonate (1-5a): 92\% yield, ${ }^{1} \mathrm{H}$ NMR $(600 \mathrm{MHz}$, $\left.\mathrm{CDCl}_{3}\right)$ : $\delta$ 7.42-7.43 (m, 2H), 7.32-7.35 (m, 2H), 7.24-7.27 (m, 1H), $6.65(\mathrm{t}, J=3.0 \mathrm{~Hz}$, $1 \mathrm{H}), 4.24(\mathrm{q}, J=7.2 \mathrm{~Hz}, 2 \mathrm{H}), 2.37-2.41(\mathrm{~m}, 2 \mathrm{H}), 1.47-1.51(\mathrm{~m}, 2 \mathrm{H}), 1.37-1.41(\mathrm{~m}, 2 \mathrm{H})$, $1.32(\mathrm{t}, J=7.2 \mathrm{~Hz}, 3 \mathrm{H}), 0.89(\mathrm{t}, J=7.2 \mathrm{~Hz}, 3 \mathrm{H}) ;{ }^{13} \mathrm{C} \mathrm{NMR}\left(150 \mathrm{MHz}, \mathrm{CDCl}_{3}\right): \delta 196.4$, $153.1,133.7,128.7,128.3,128.1,127.9,105.7,64.5,31.3,28.2,22.1,14.2,13.8$. HRMS Calculated for [C16H20O3+Na]+: 283.1305, Found: 283.1305.<smiles>CC(C)OC(=O)OC(Br)=CCc1ccccc1</smiles> 
t-Butyl 1-phenylhepta-1,2-dien-3-yl carbonate (1-5b): $91 \%$ yield, ${ }^{1} \mathrm{H}$ NMR $(600 \mathrm{MHz}$, $\left.\mathrm{CDCl}_{3}\right): \delta$ 7.41-7.42 (m, 2H), 7.31-7.34 (m, 2H), 7.23-7.26 (m, 1H), $6.63(\mathrm{t}, J=3.0 \mathrm{~Hz}$, $1 \mathrm{H}), 2.35-2.39(\mathrm{~m}, 2 \mathrm{H}), 1.50(\mathrm{~s}, 9 \mathrm{H}), 1.46-1.48(\mathrm{~m}, 2 \mathrm{H}), 1.37-1.41(\mathrm{~m}, 2 \mathrm{H}), 0.89(\mathrm{t}, J=$ $7.5 \mathrm{~Hz}, 3 \mathrm{H}) .{ }^{13} \mathrm{C}$ NMR $\left(150 \mathrm{MHz}, \mathrm{CDCl}_{3}\right): \delta 196.7,151.2,134.0,128.6,128.1,128.0$, 127.8, 105.2, 82.9, 31.4, 28.3, 27.9, 22.1, 13.8. HRMS Calculated for [C18H24O3+Na]+: 311.1618, Found: 311.1604.<smiles>C=CCOC(=O)OC(Br)=Cc1ccccc1</smiles>

Allyl 1-phenylhepta-1,2-dien-3-yl carbonate (1-5c): 88\% yield, ${ }^{1} \mathrm{H}$ NMR $(600 \mathrm{MHz}$, $\left.\mathrm{CDCl}_{3}\right): \delta 7.41(\mathrm{~d}, J=7.8 \mathrm{~Hz}, 2 \mathrm{H}), 7.33(\mathrm{t}, J=7.5 \mathrm{~Hz}, 2 \mathrm{H}), 7.24-7.27(\mathrm{~m}, 1 \mathrm{H}), 6.65(\mathrm{~s}$, 1H), 5.91-5.97 (m, 1H), $5.35(\mathrm{~d}, J=17.4 \mathrm{~Hz}, 1 \mathrm{H}), 5.26(\mathrm{~d}, J=10.2 \mathrm{~Hz}, 1 \mathrm{H}), 4.65(\mathrm{~d}, J=$ $6.0 \mathrm{~Hz}, 2 \mathrm{H}), 2.30-2.34(\mathrm{~m}, 2 \mathrm{H}), 1.47-1.53(\mathrm{~m}, 2 \mathrm{H}), 1.36-1.43(\mathrm{~m}, 2 \mathrm{H}), 0.89(\mathrm{t}, J=6.9 \mathrm{~Hz}$, $3 \mathrm{H}) .{ }^{13} \mathrm{C}$ NMR $\left(150 \mathrm{MHz}, \mathrm{CDCl}_{3}\right): \delta 196.3,152.9,133.7,131.3,128.7,128.4,128.1$, 127.9, 119.2, 105.8, 68.9, 31.3, 28.2, 22.1, 13.8. HRMS Calculated for [C17H20O3+Na]+: 295.1305, Found: 295.1306.<smiles>CCOC(Br)=Cc1cccc([N+](=O)[O-])c1</smiles>

Ethyl 1-(3-nitrophenyl)hepta-1,2-dien-3-yl carbonate (1-5d): 92\% yield, ${ }^{1} \mathrm{H}$ NMR $(600$ $\left.\mathrm{MHz}, \mathrm{CDCl}_{3}\right): \delta 8.25-8.26(\mathrm{~m}, 1 \mathrm{H}), 8.09-8.12(\mathrm{~m}, 1 \mathrm{H}), 7.77-7.78(\mathrm{~m}, 1 \mathrm{H}), 7.51(\mathrm{t}, J=8.1$ $\mathrm{Hz}, 1 \mathrm{H}), 6.70(\mathrm{t}, J=3.0 \mathrm{~Hz}, 1 \mathrm{H}), 4.24(\mathrm{q}, J=7.4 \mathrm{~Hz}, 1 \mathrm{H}), 2.39-2.43(\mathrm{~m}, 2 \mathrm{H}), 1.48-1.56$ $(\mathrm{m}, 2 \mathrm{H}), 1.39-1.44(\mathrm{~m}, 2 \mathrm{H}), 1.33(\mathrm{t}, J=8.1 \mathrm{~Hz}, 3 \mathrm{H}), 0.91(\mathrm{t}, J=7.2 \mathrm{~Hz}, 3 \mathrm{H}) .{ }^{13} \mathrm{C}$ NMR $\left(150 \mathrm{MHz}, \mathrm{CDCl}_{3}\right): \delta 198.3,152.7,148.7,135.9,133.4,129.5,129.2,122.7,122.5$, 103.6, 64.8, 31.3, 28.1, 22.1, 14.2, 13.7. HRMS Calculated for [C16H19NO5+Na]+: 328.1155, Found: 328.1142.<smiles>CC(Br)(Br)Oc1cccc(C=C(Br)[N+](=O)[O-])c1</smiles>

t-Butyl 1-(3-nitrophenyl)hepta-1,2-dien-3-yl carbonate (1-5e): $89 \%$ yield, ${ }^{1} \mathrm{H}$ NMR $\left(600 \mathrm{MHz}, \mathrm{CDCl}_{3}\right): \delta 8.23-8.24(\mathrm{~m}, 1 \mathrm{H}), 8.09-8.11(\mathrm{~m}, 1 \mathrm{H}), 7.77(\mathrm{dt}, J=7.8 \mathrm{~Hz}, 1.2 \mathrm{~Hz}$, $1 \mathrm{H}), 7.50(\mathrm{t}, J=8.1 \mathrm{~Hz}, 1 \mathrm{H}), 6.68(\mathrm{t}, J=3.0 \mathrm{~Hz}, 1 \mathrm{H}), 2.37-2.41(\mathrm{~m}, 2 \mathrm{H}), 1.51(\mathrm{~s}, 9 \mathrm{H})$, 1.47- $1.50(\mathrm{~m}, 2 \mathrm{H}), 1.38-1.42(\mathrm{~m}, 2 \mathrm{H}), 0.90(\mathrm{t}, J=7.2 \mathrm{~Hz}, 3 \mathrm{H}) .{ }^{13} \mathrm{C}$ NMR $(150 \mathrm{MHz}$, $\left.\mathrm{CDCl}_{3}\right): \delta 198.6,150.8,148.7,136.2,133.4,129.5,128.9,122.5,122.4,103.2,83.4$, 31.4, 28.2, 27.7, 22.1, 13.8. HRMS Calculated for [C18H23NO5+Na]+: 356.1468, Found: 356.1454 . 


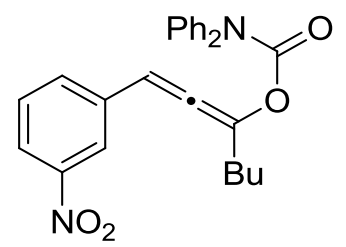

1-(3-Nitrophenyl)hepta-1,2-dien-3-yl diphenylcarbamate (1-5f): $85 \%$ yield, ${ }^{1} \mathrm{H}$ NMR $\left(600 \mathrm{MHz}, \mathrm{CDCl}_{3}\right): \delta 8.22(\mathrm{t}, J=2.1 \mathrm{~Hz}, 1 \mathrm{H}), 8.07(\mathrm{dq}, J=8.4 \mathrm{~Hz}, 1.0 \mathrm{~Hz}, 1 \mathrm{H}), 7.77$ (dt, $J=7.8 \mathrm{~Hz}, 1.2 \mathrm{~Hz}, 1 \mathrm{H}), 7.48(\mathrm{t}, J=7.8 \mathrm{~Hz}, 1 \mathrm{H}), 7.34(\mathrm{t}, J=7.8 \mathrm{~Hz}, 4 \mathrm{H}), 7.21-7.28(\mathrm{~m}$, $6 \mathrm{H}), 6.65(\mathrm{t}, J=3.0 \mathrm{~Hz}, 1 \mathrm{H}), 2.30-2.34(\mathrm{~m}, 2 \mathrm{H}), 1.31-1.41(\mathrm{~m}, 4 \mathrm{H}), 0.85(\mathrm{t}, J=7.2 \mathrm{~Hz}$, $3 \mathrm{H}) .{ }^{13} \mathrm{C}$ NMR $\left(150 \mathrm{MHz}, \mathrm{CDCl}_{3}\right): \delta 198.7,152.0,148.6,142.2,136.4,133.5,129.5$, $128.9,128.3,126.8,126.4,122.4,122.3,102.8,31.6,28.1,21.9,13.7$. HRMS Calculated for [C26H24N2O4+Na]+: 451.1628, Found: 451.1610 
III. NMR spectra 


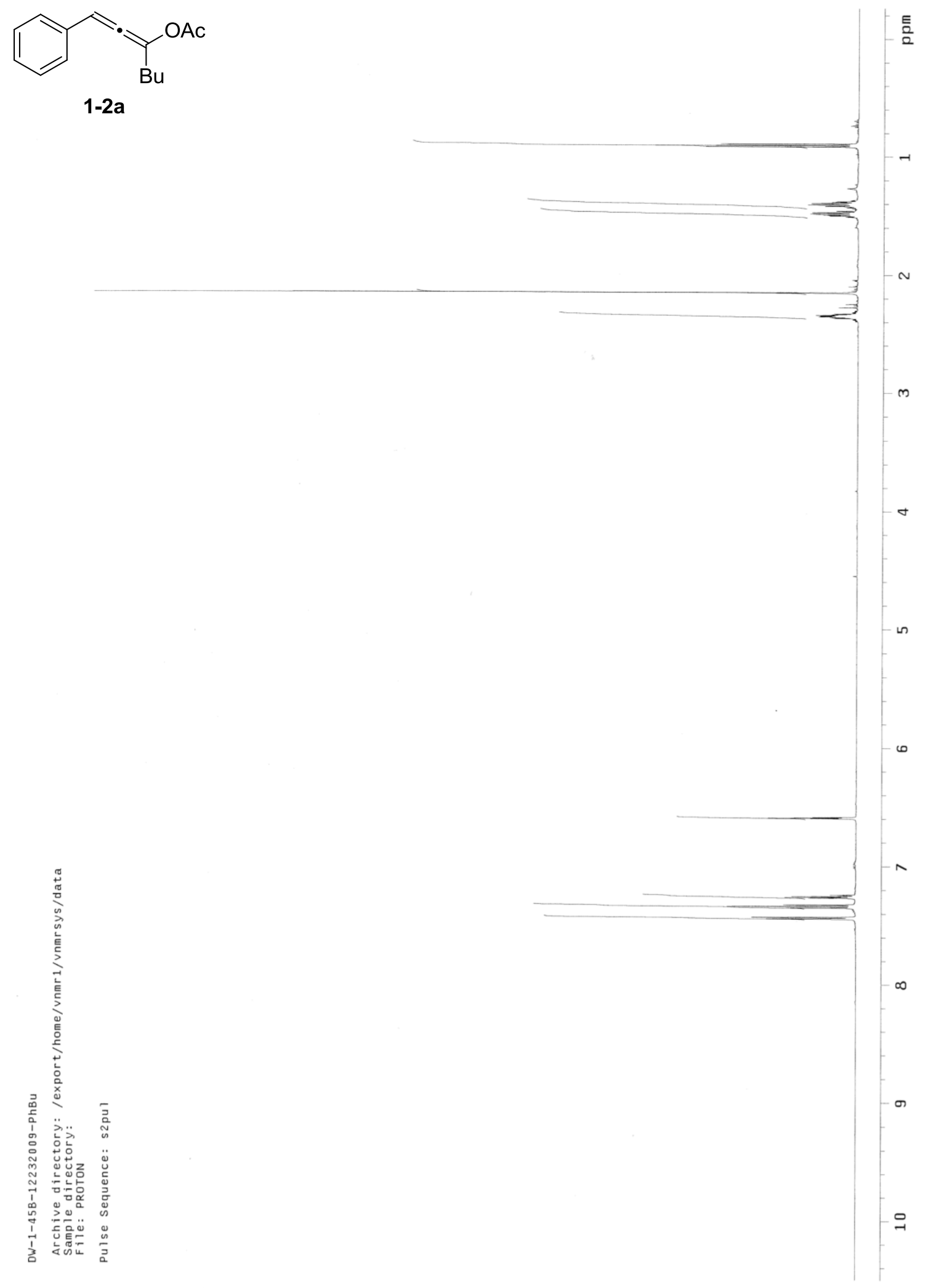



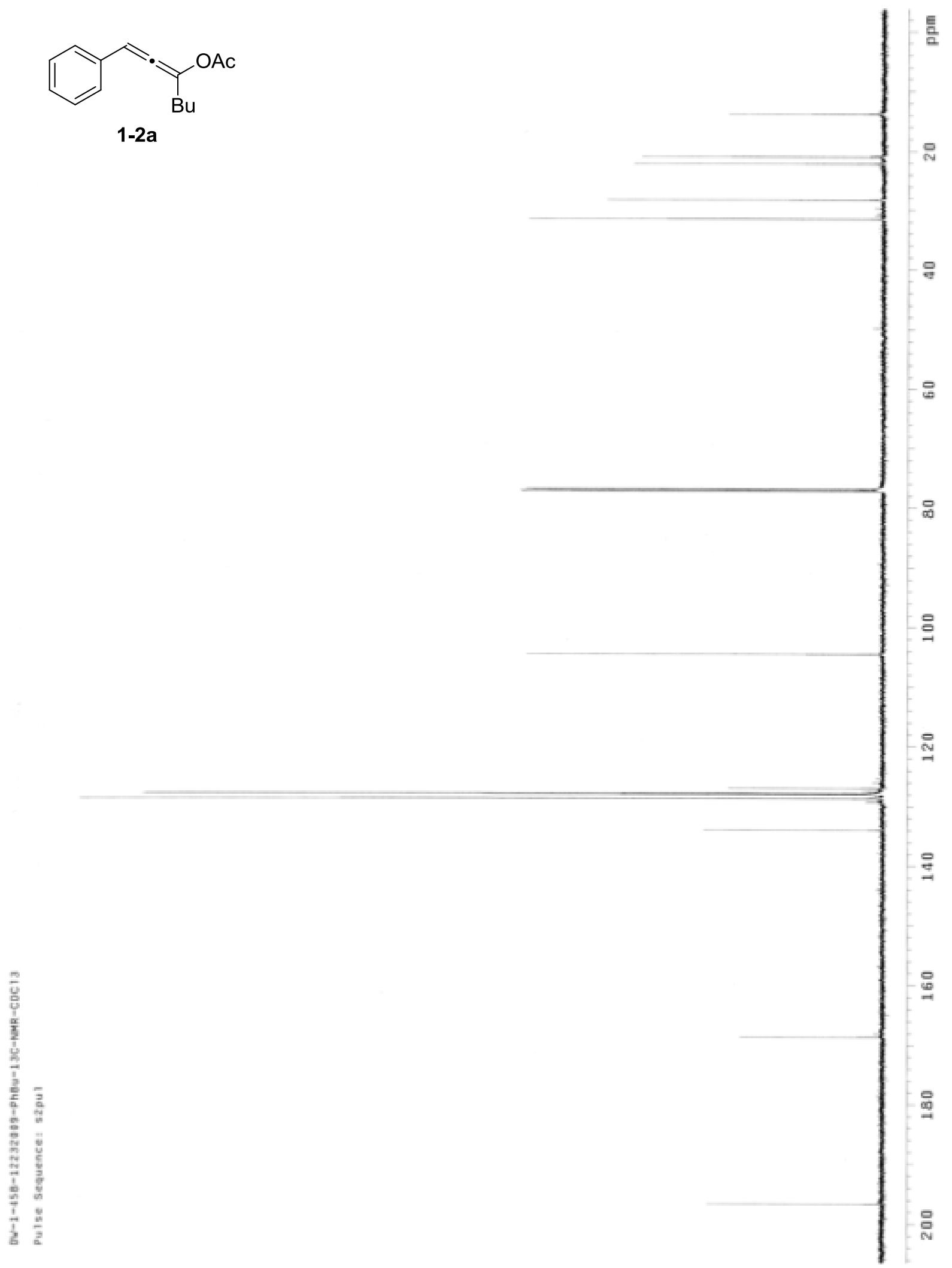


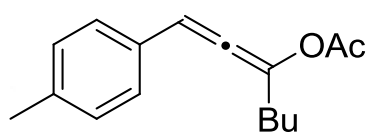

1-2b
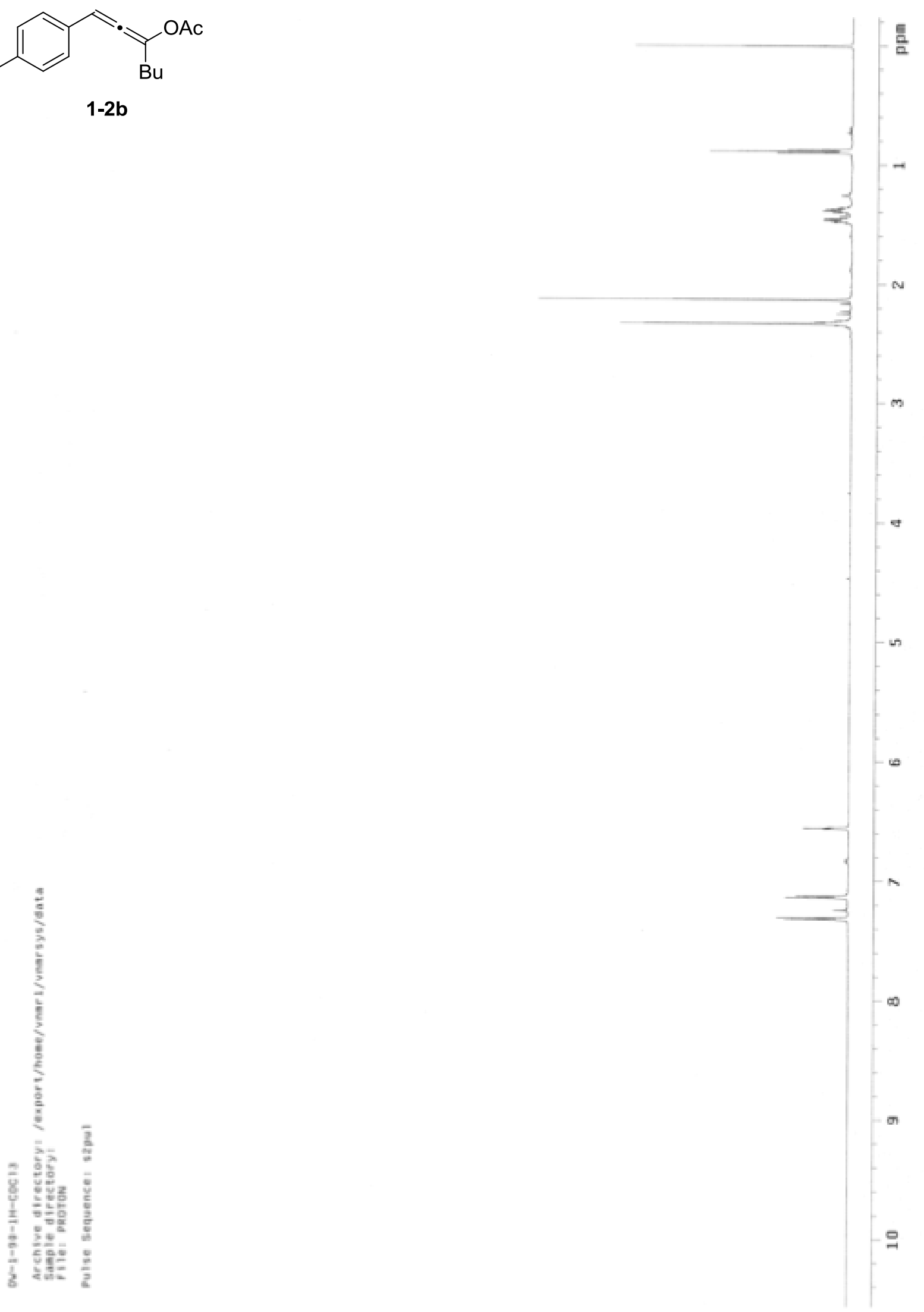


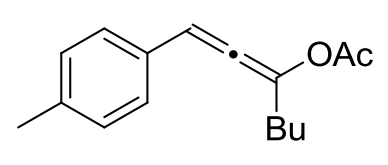

1-2b

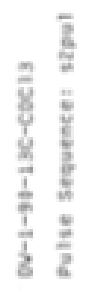

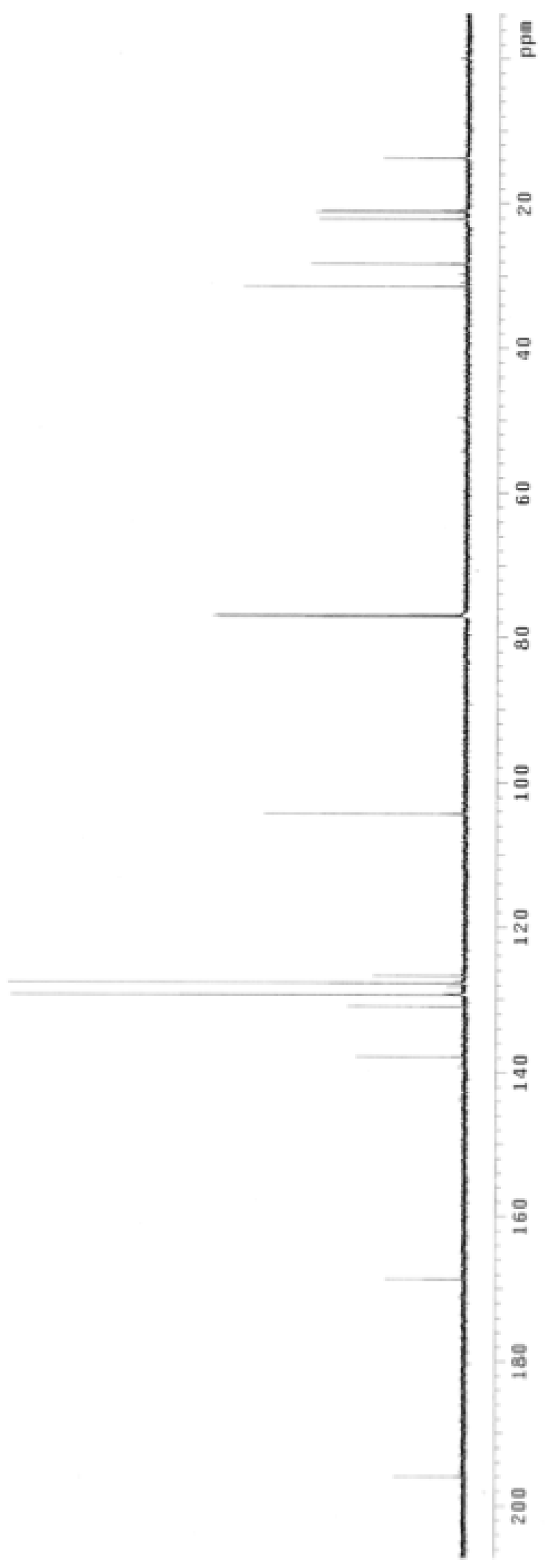



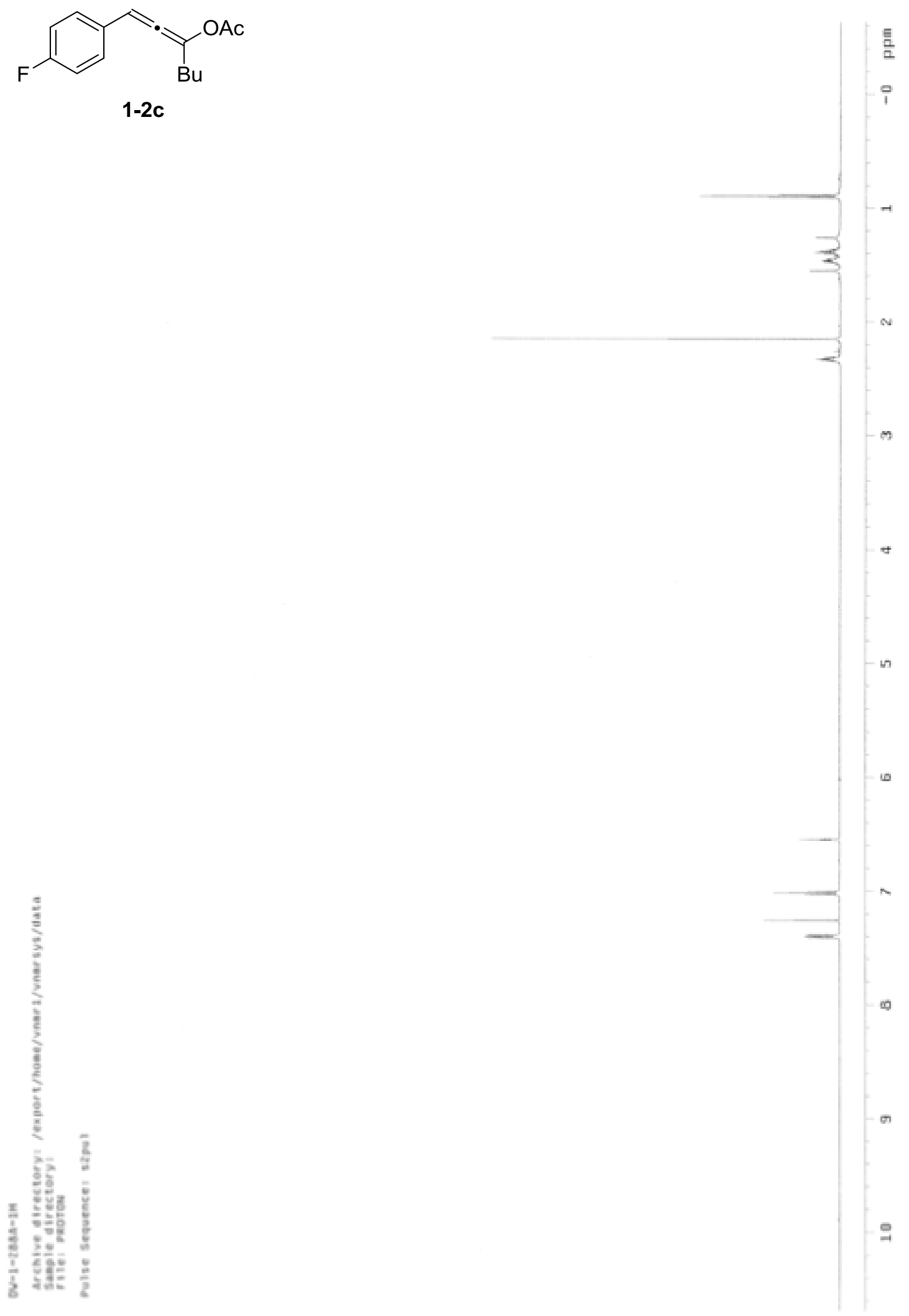

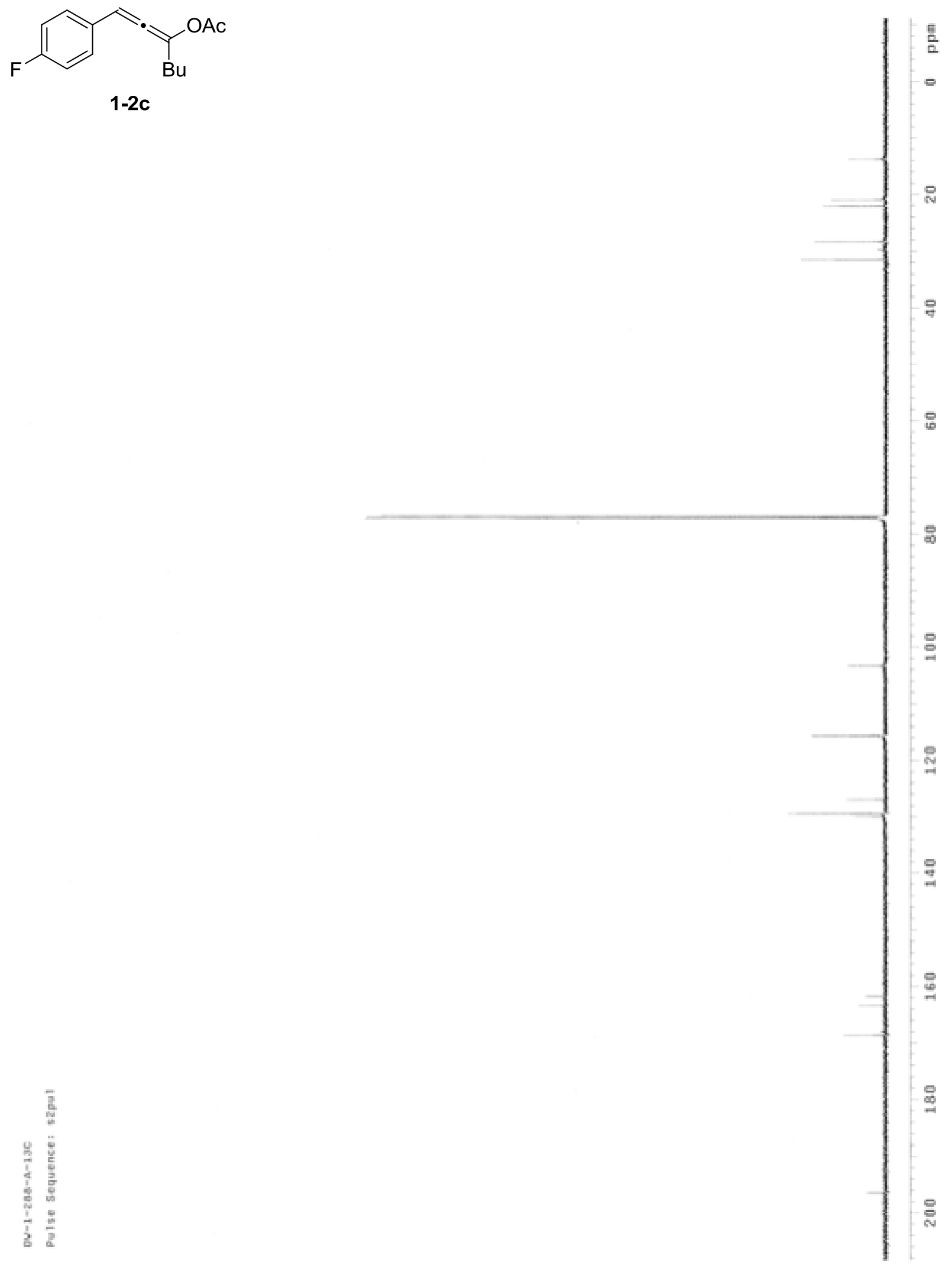

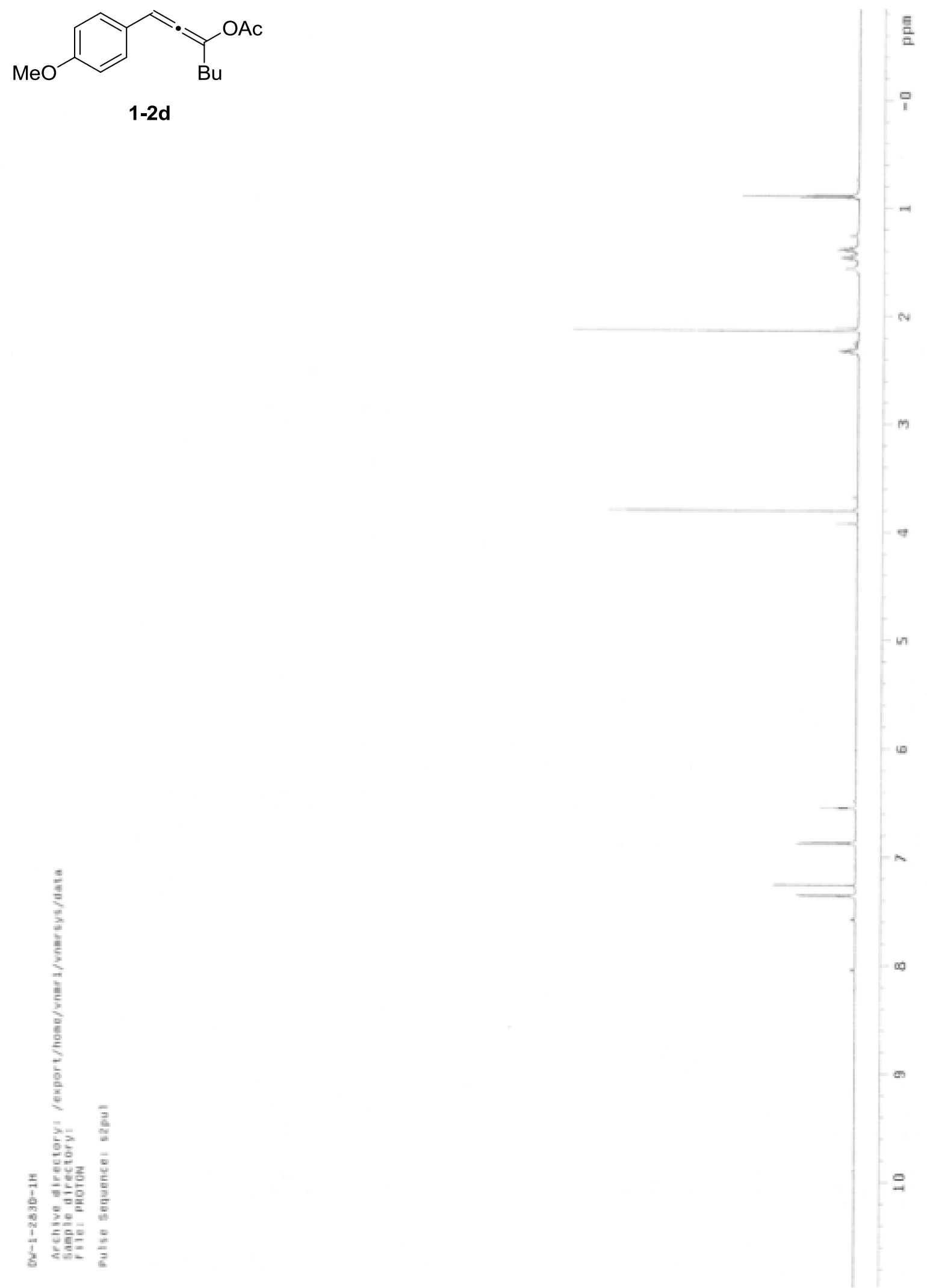

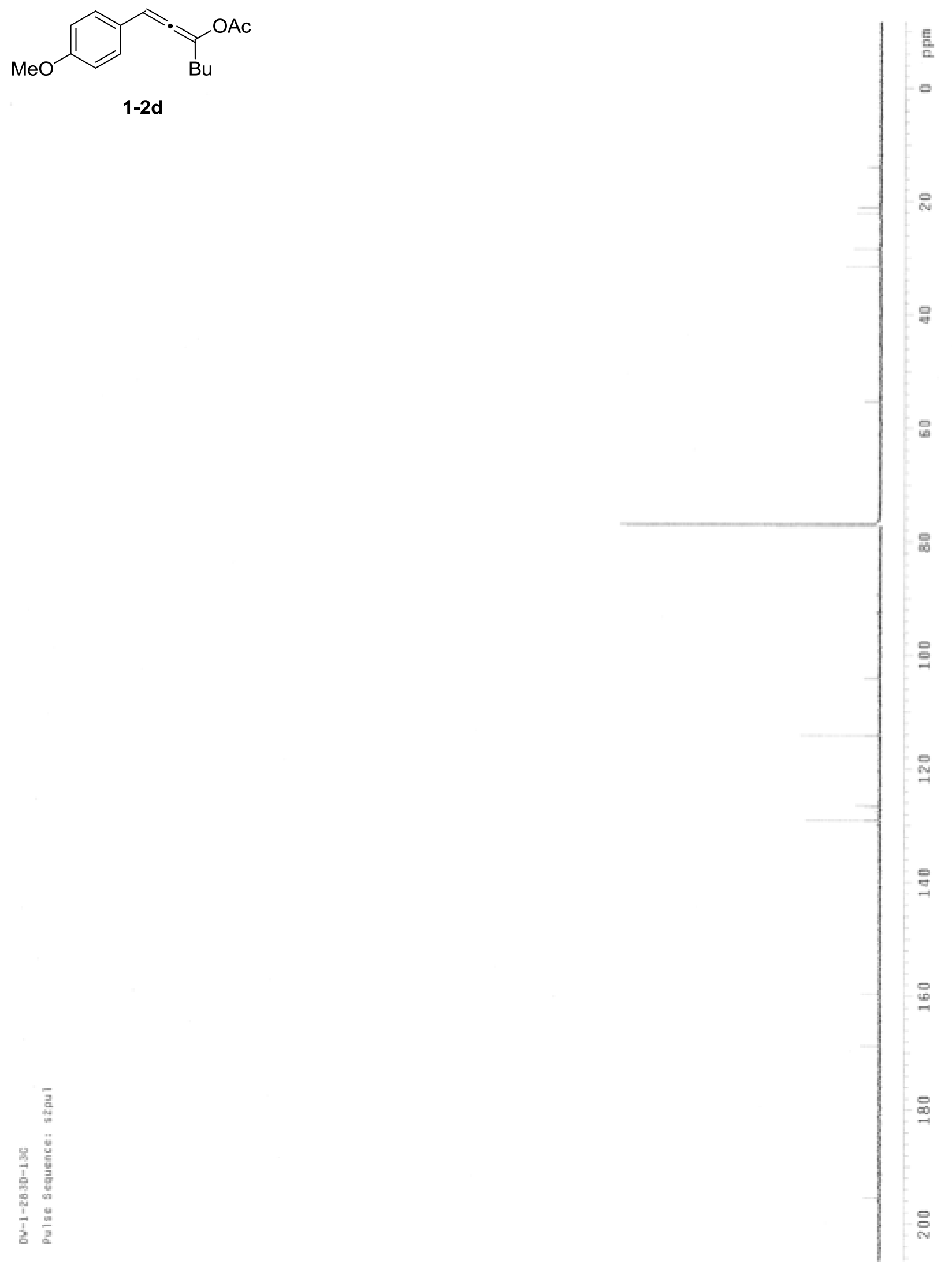


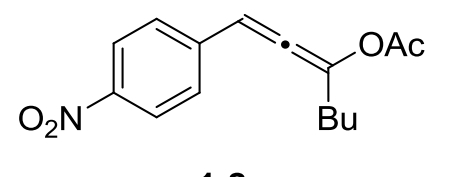

1-2e
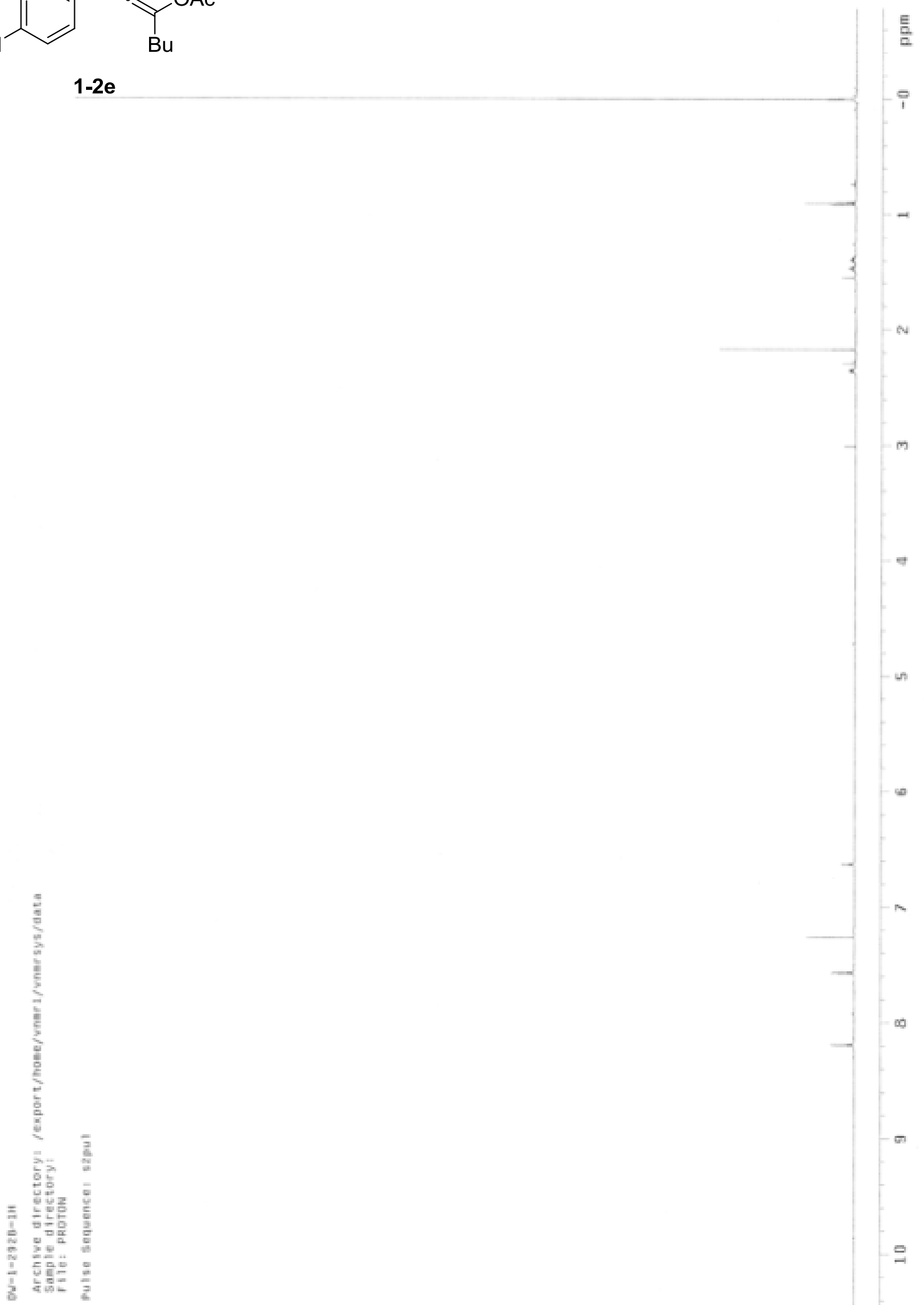

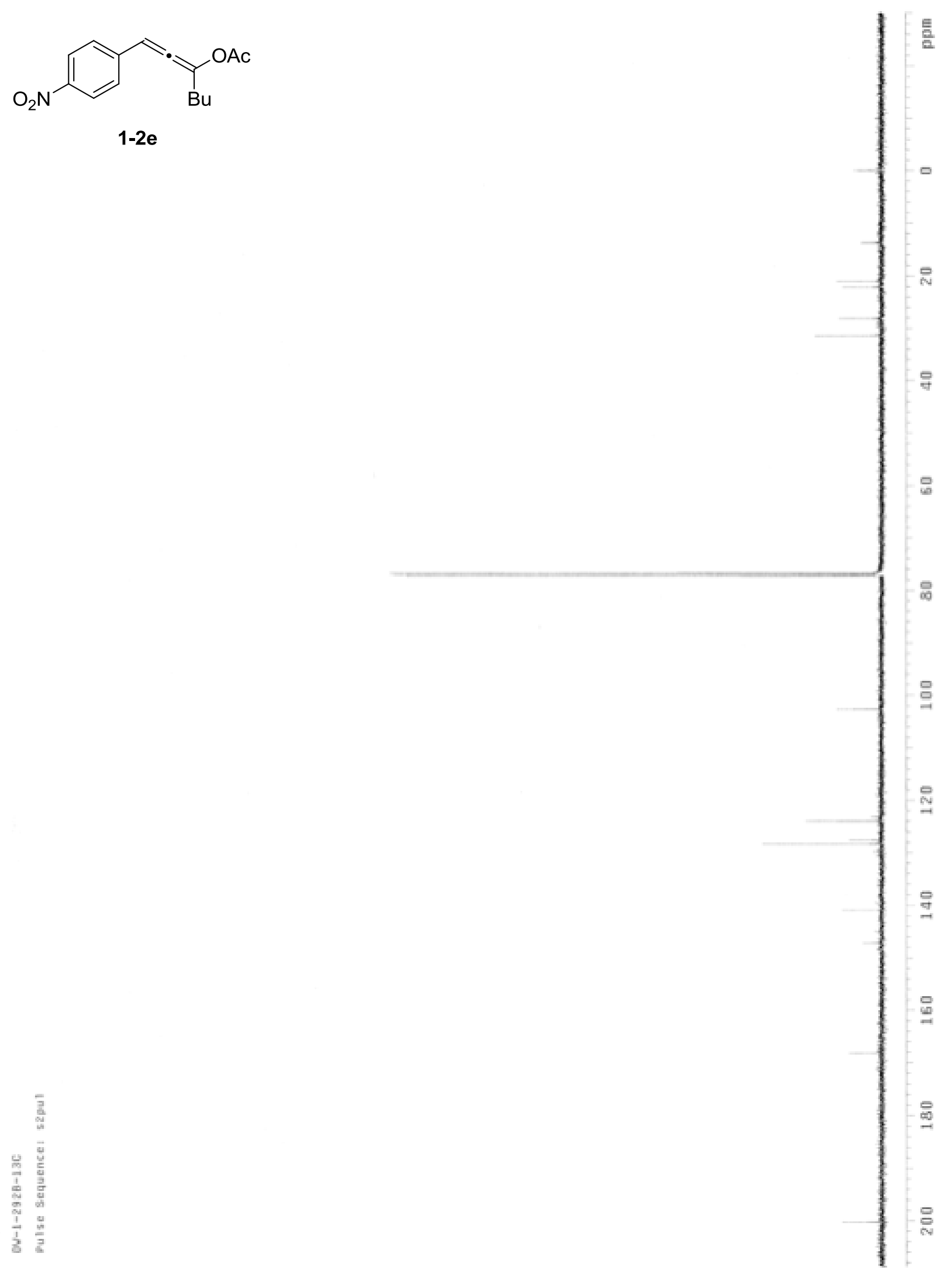


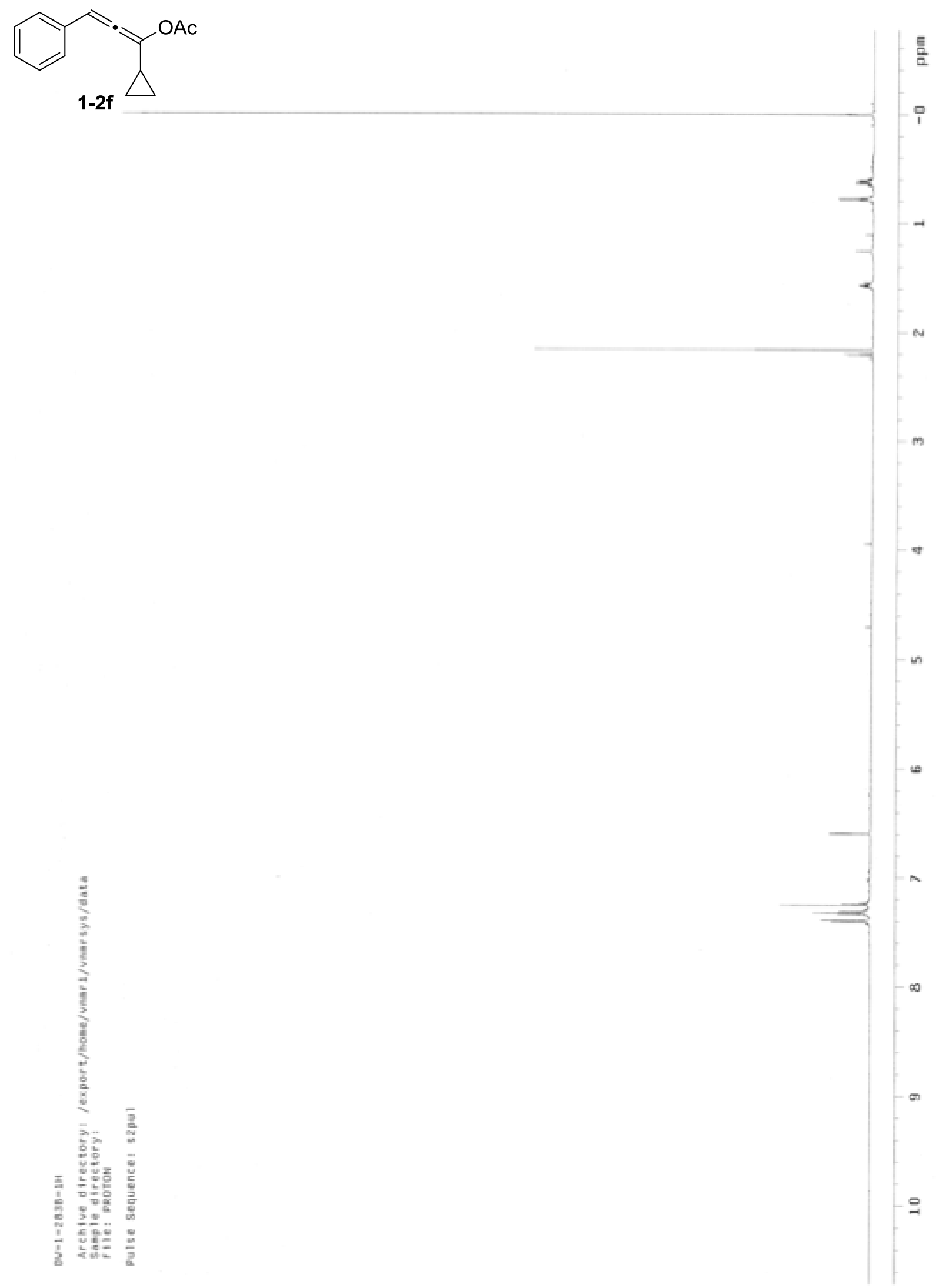



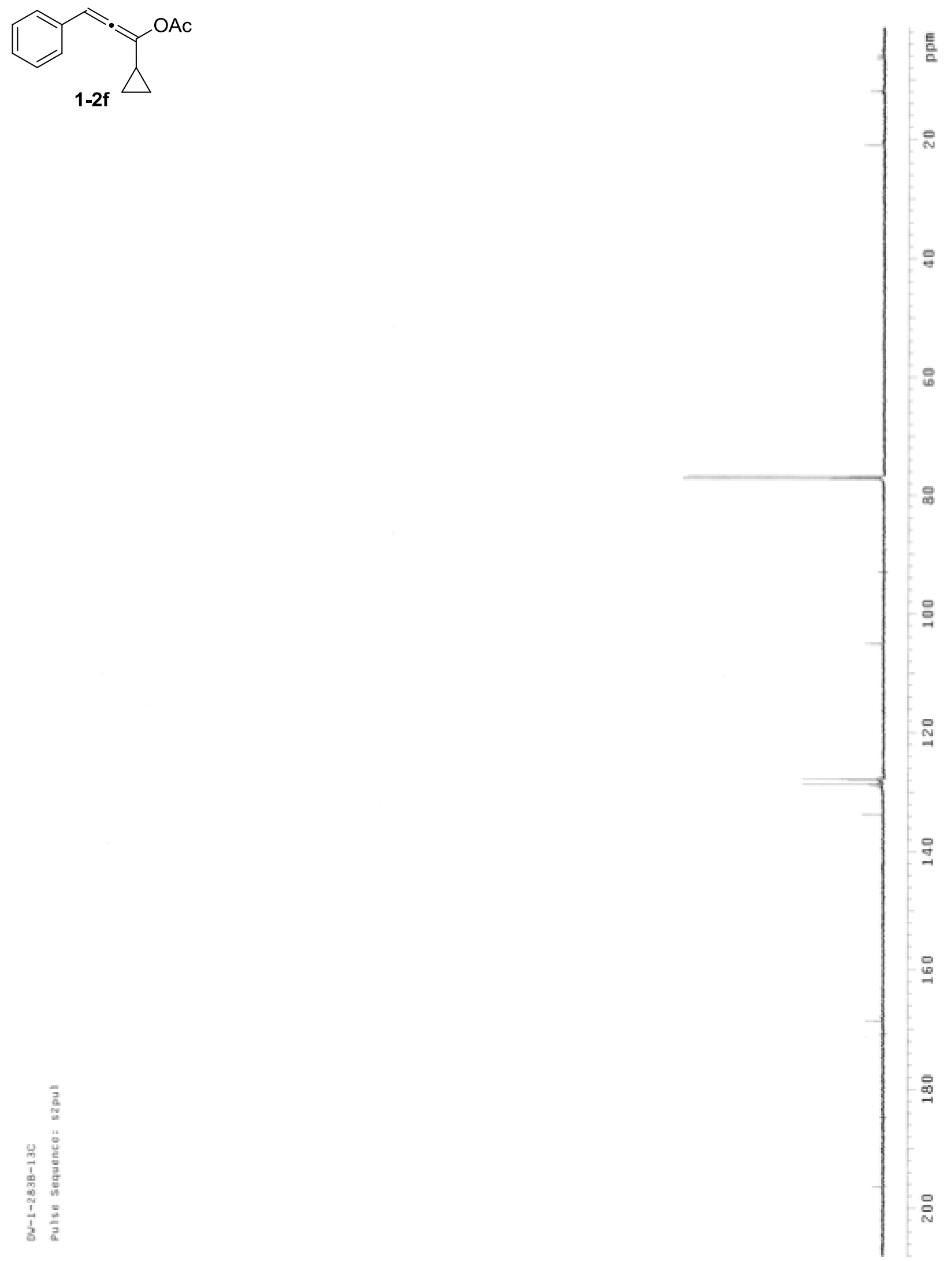


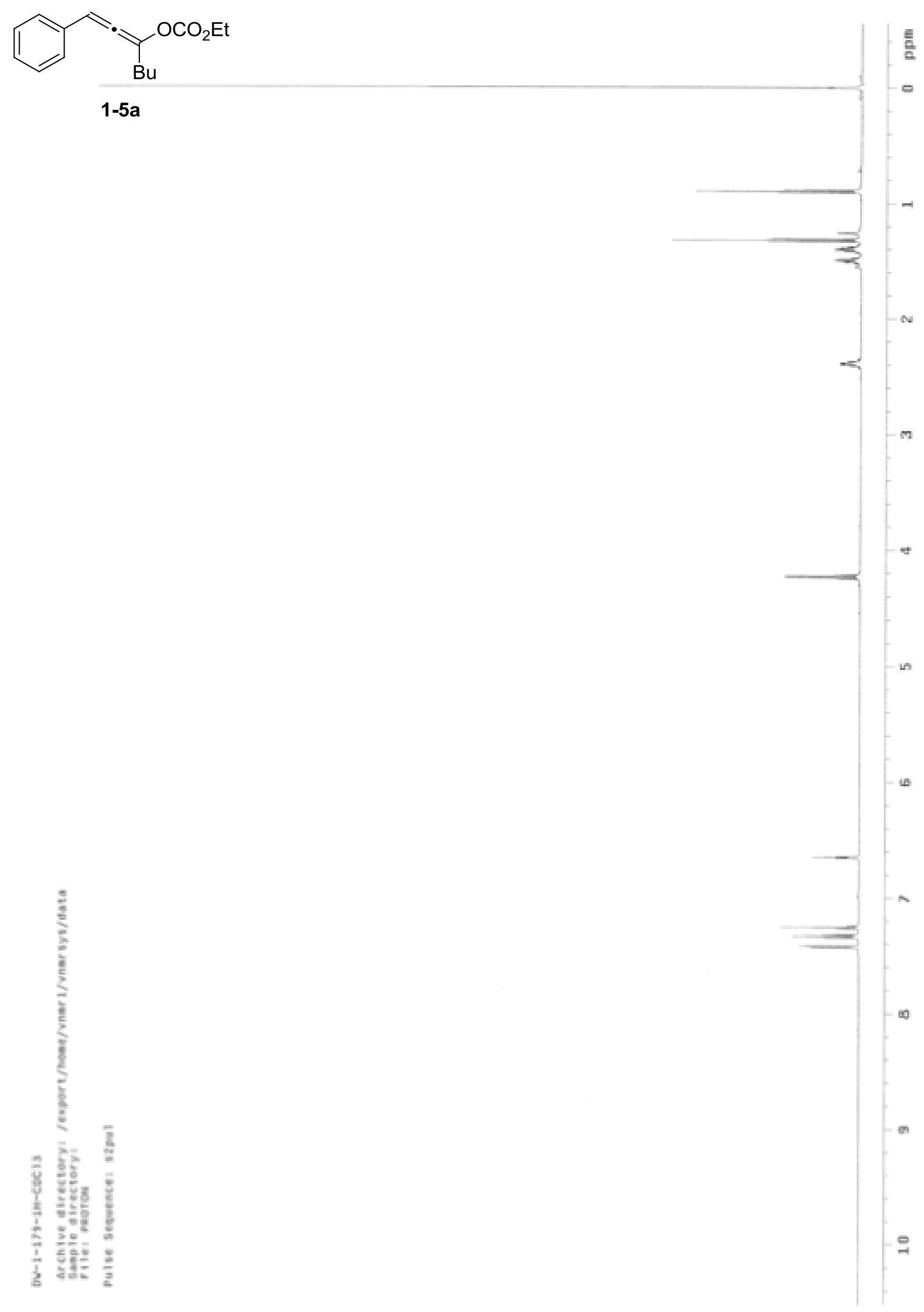



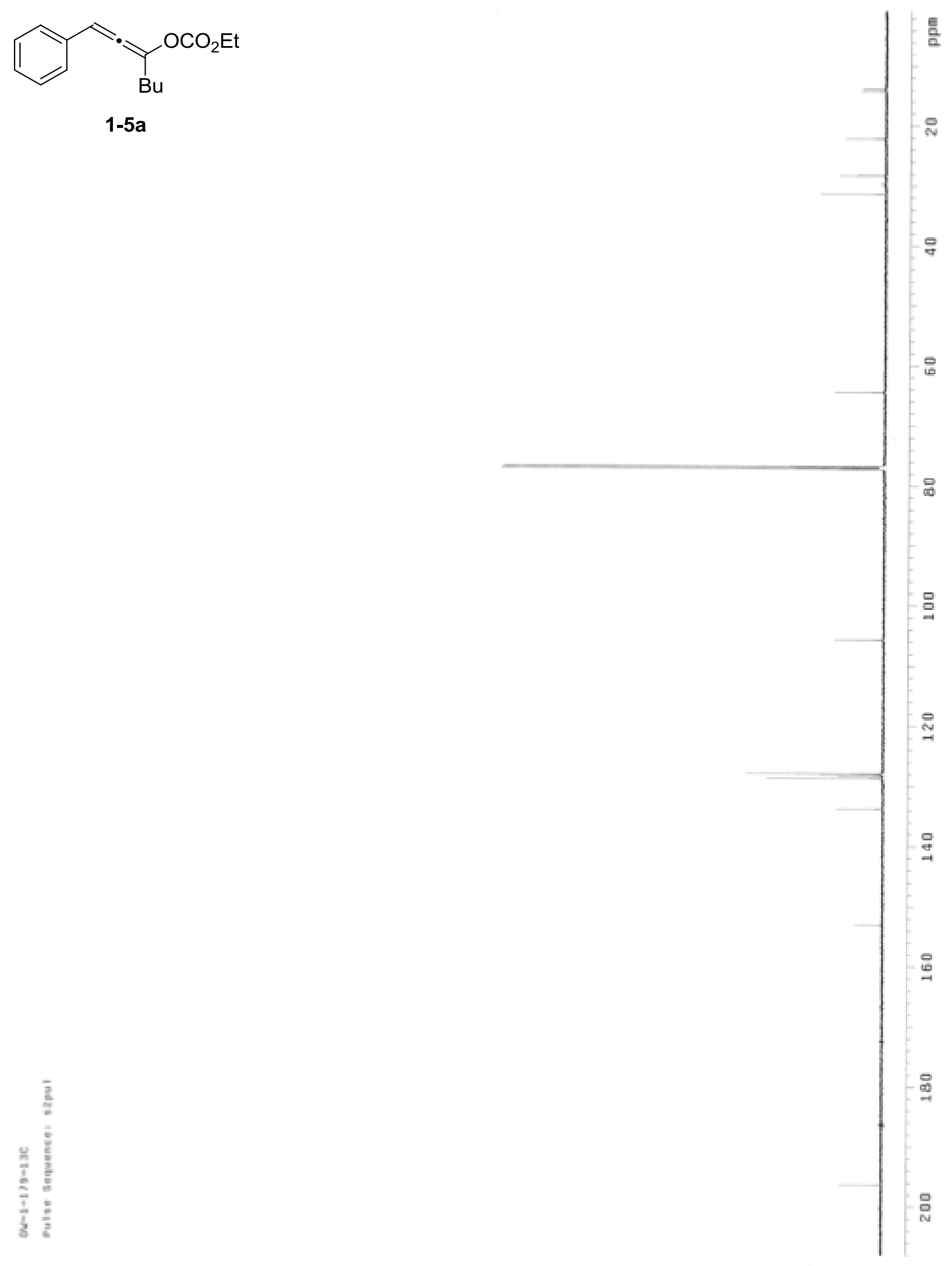

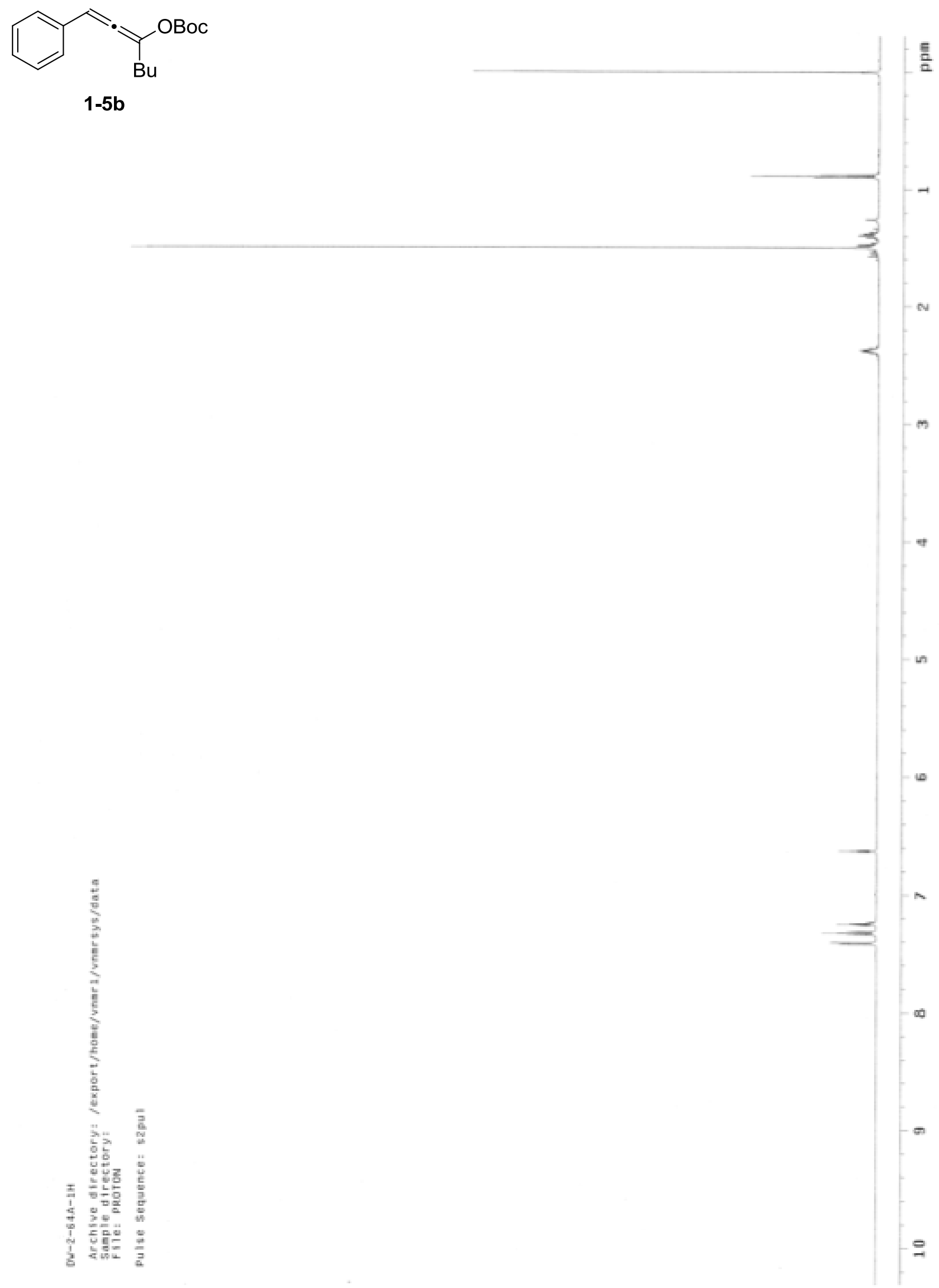

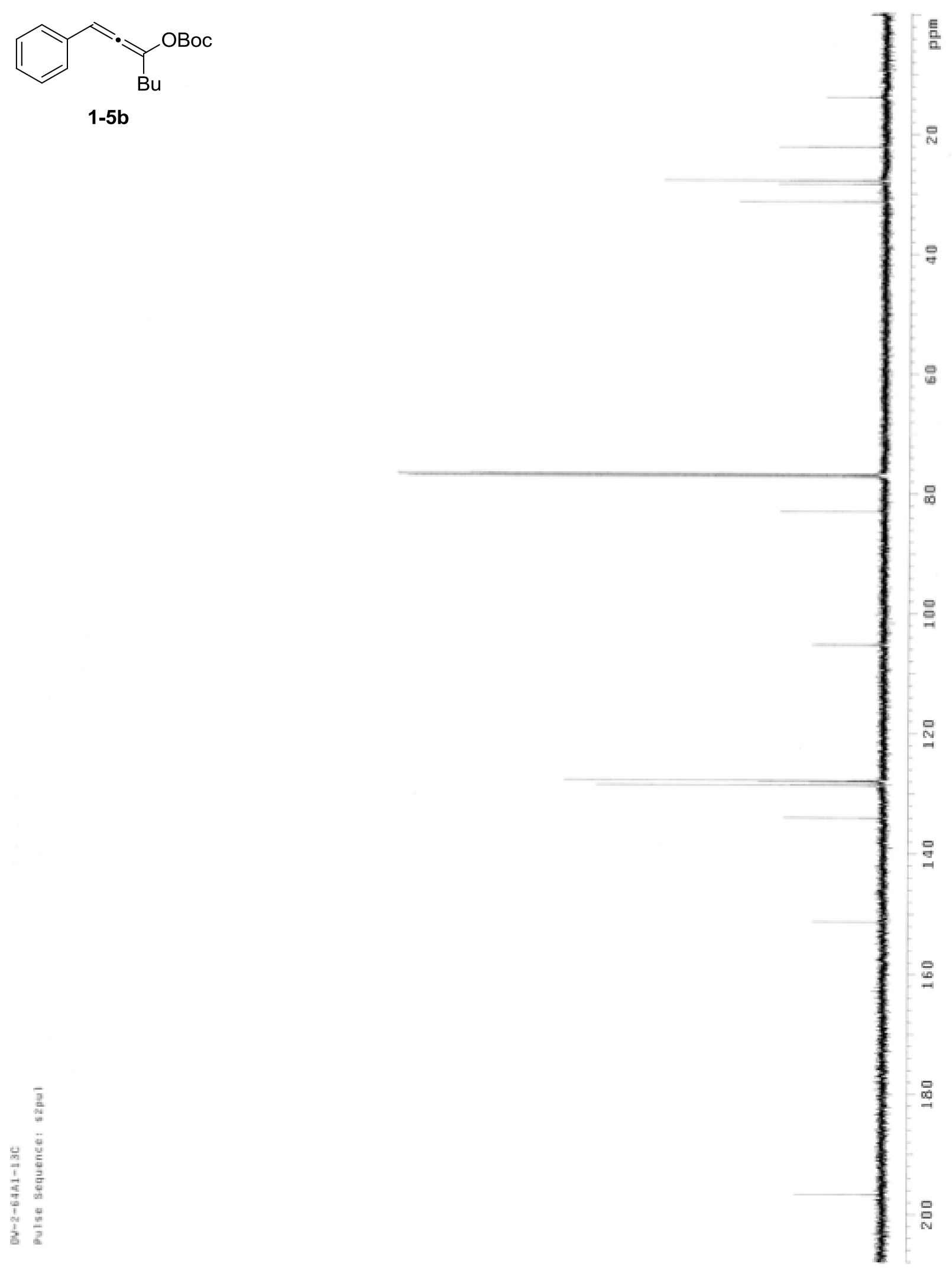

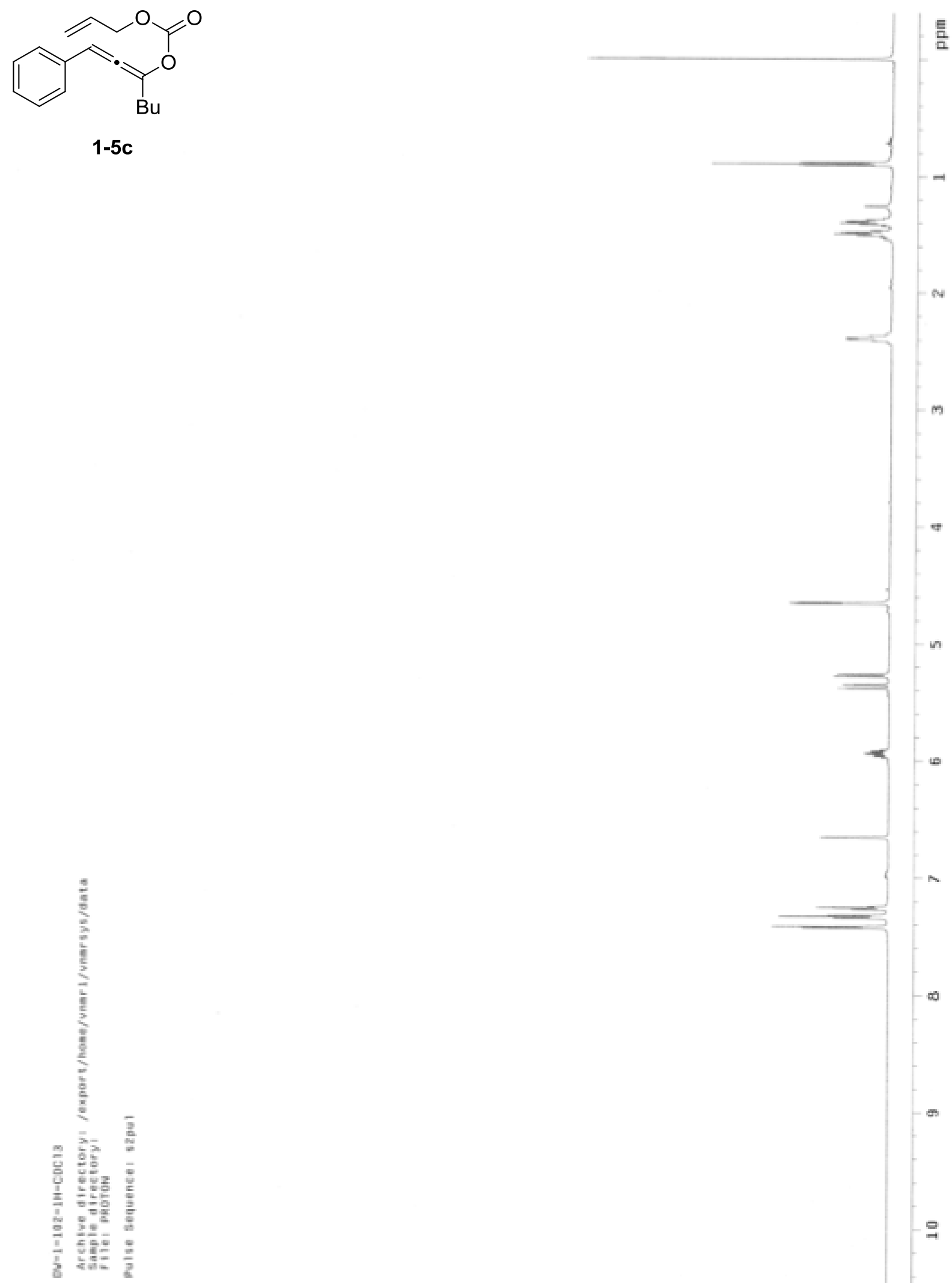

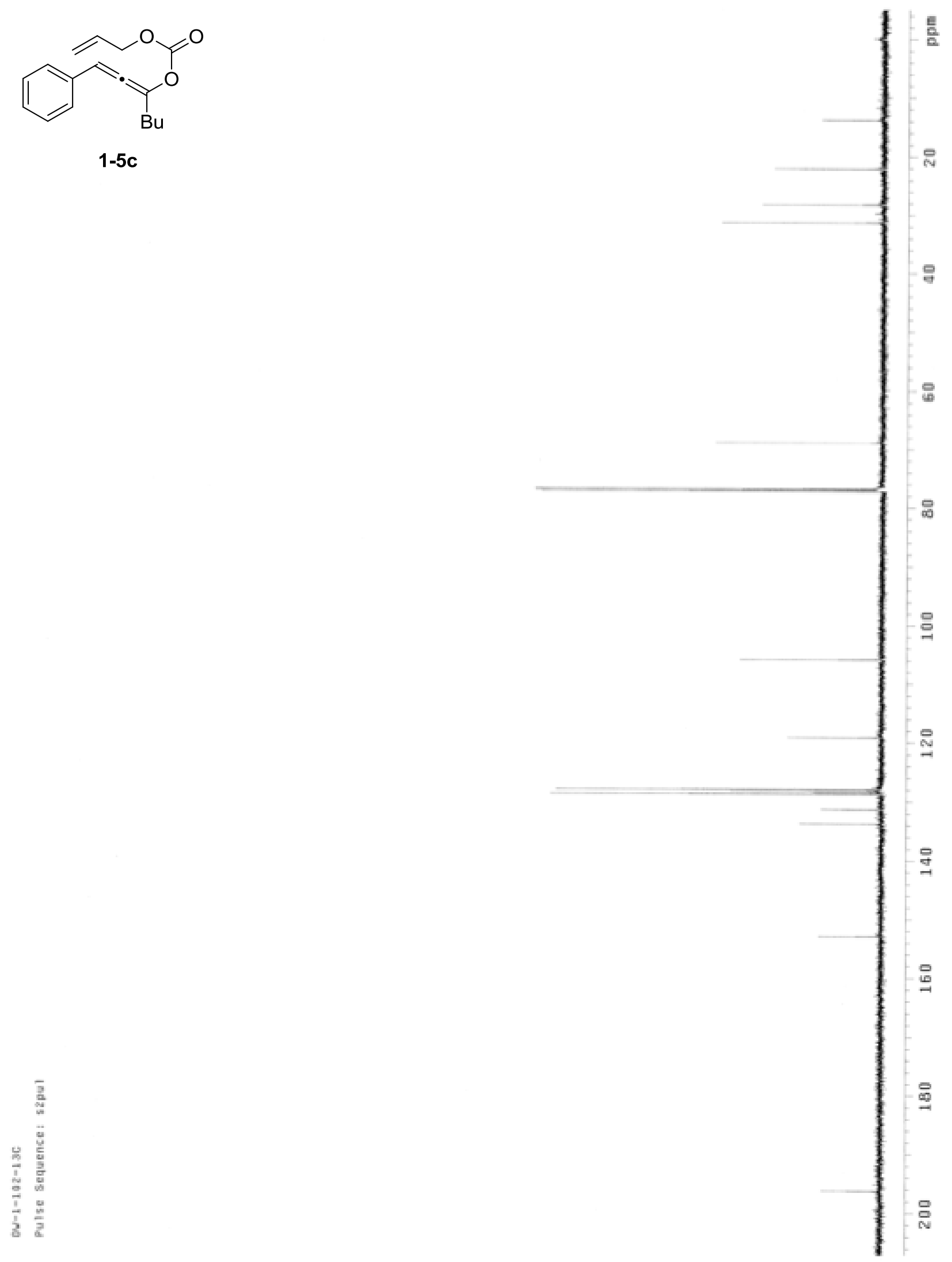


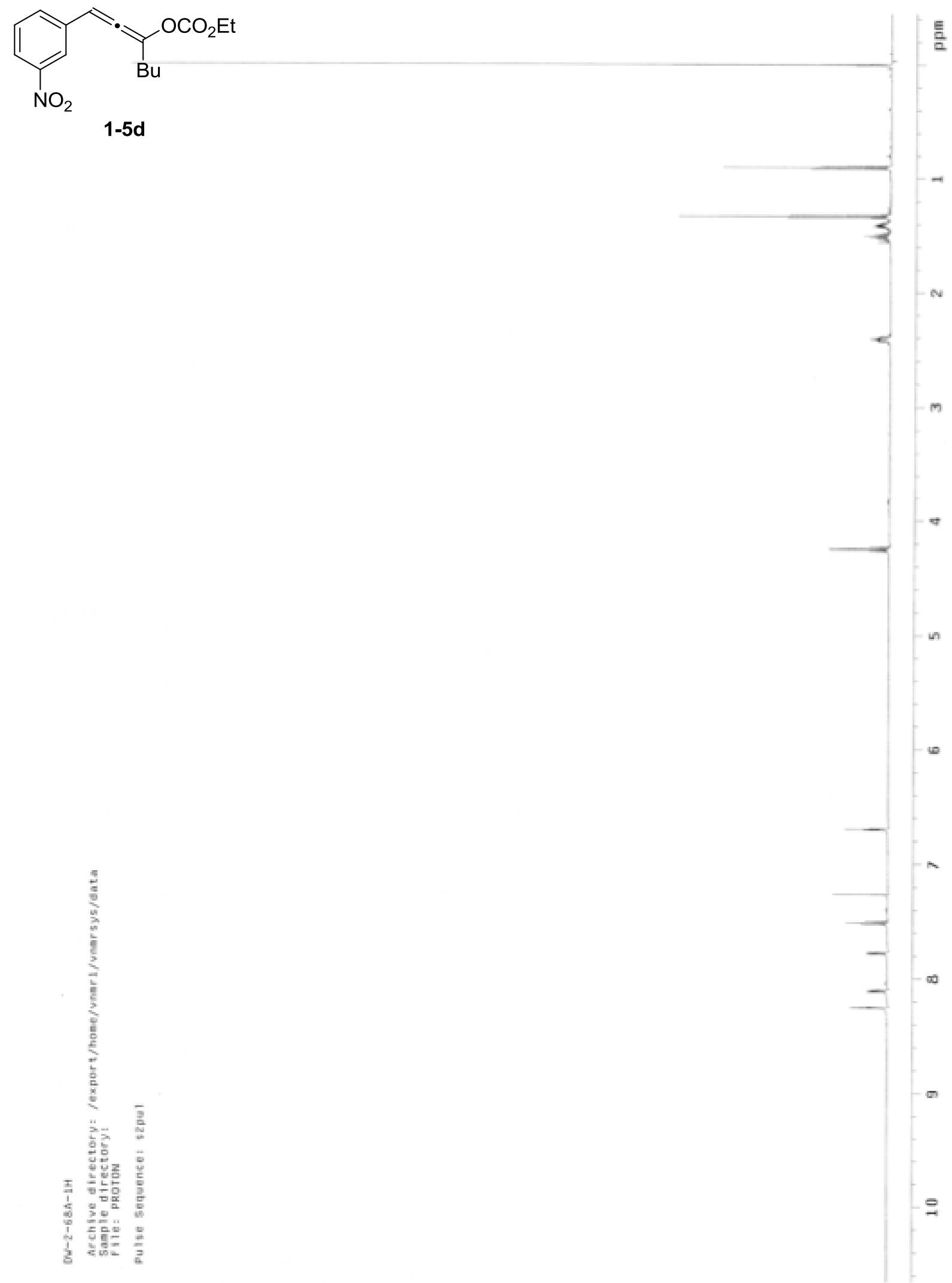



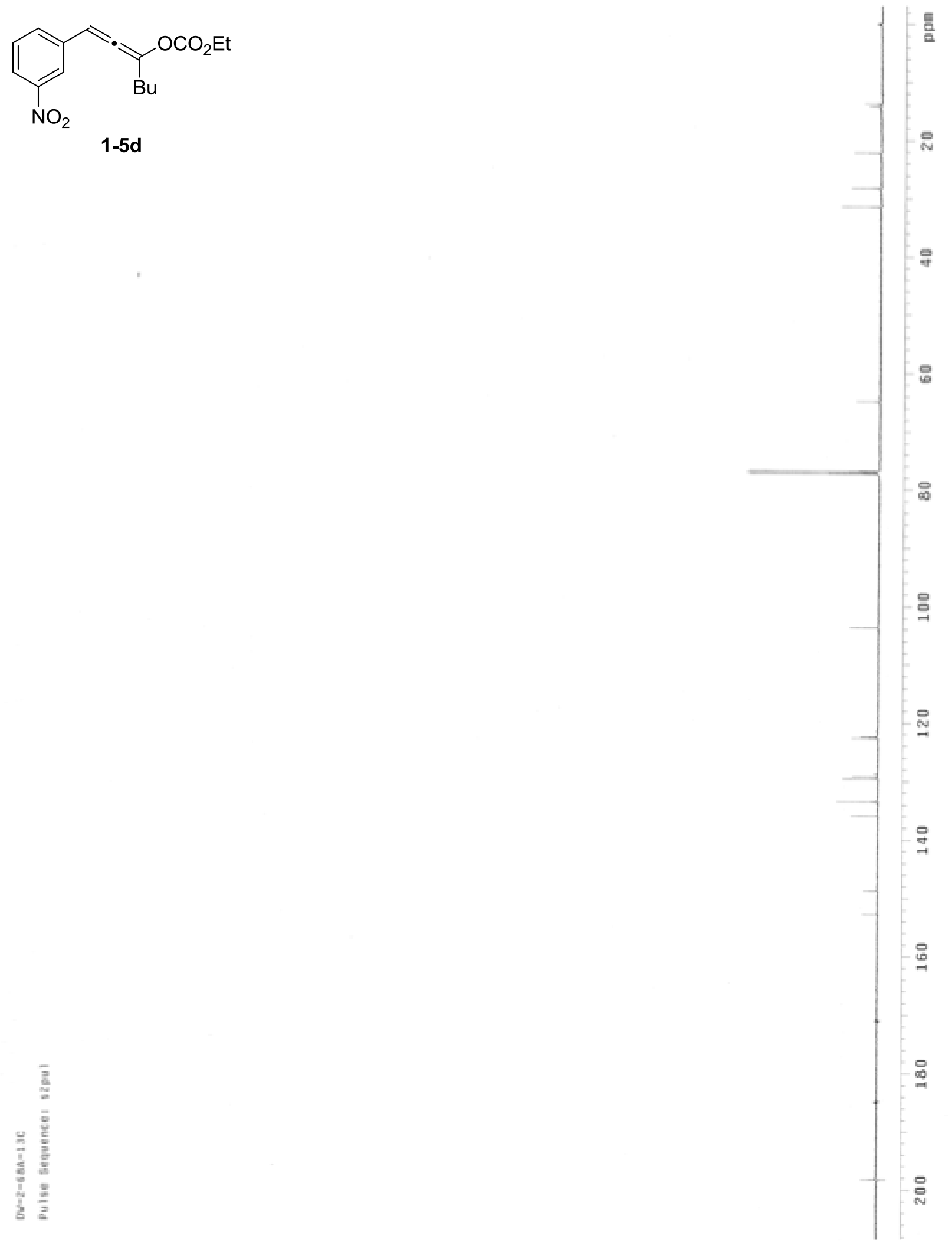

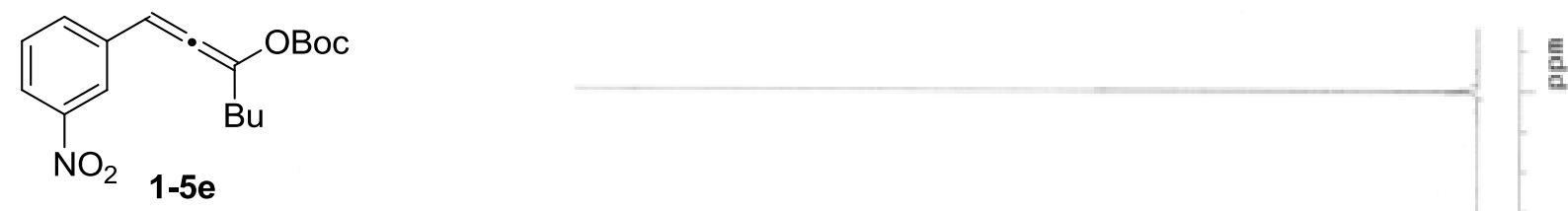

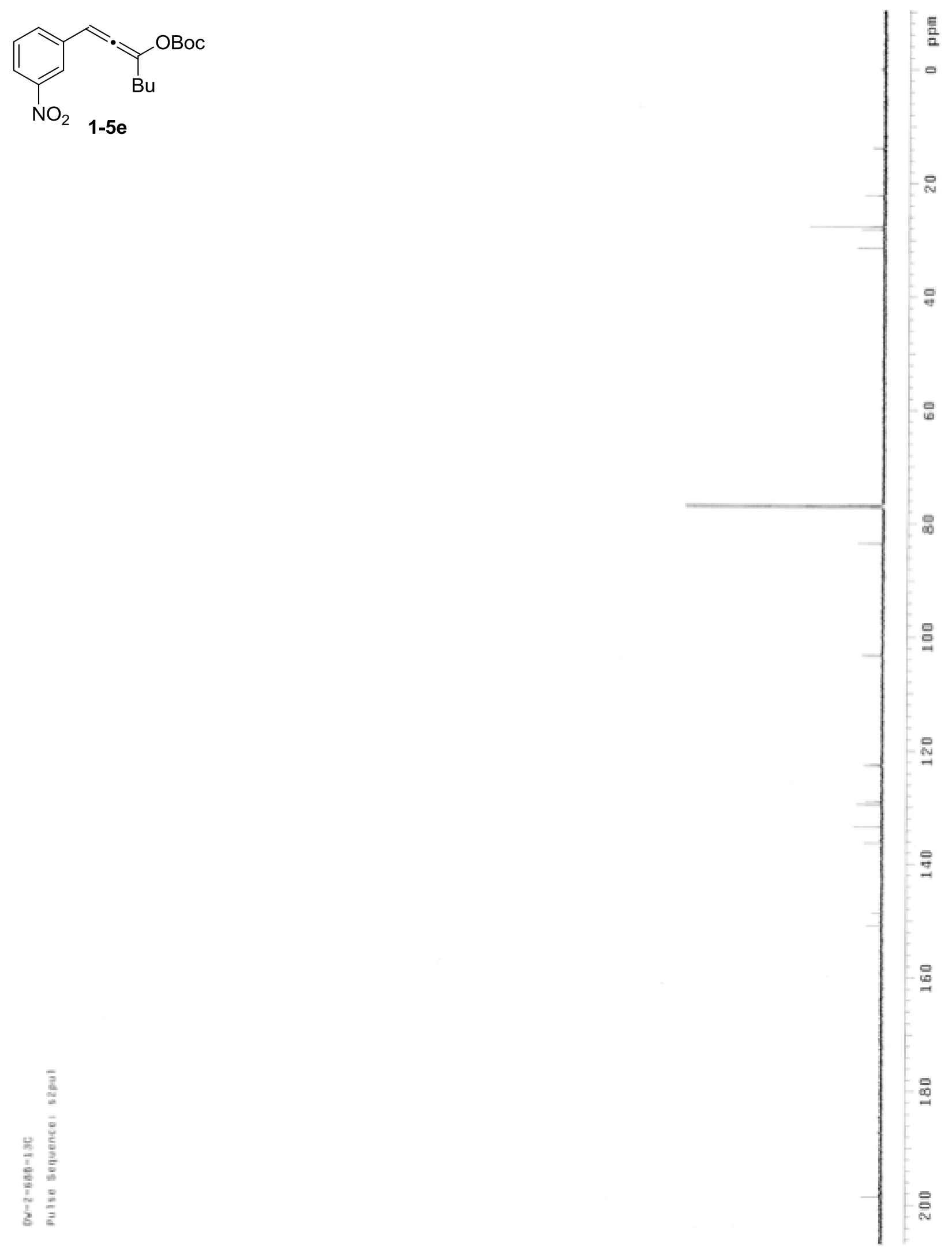


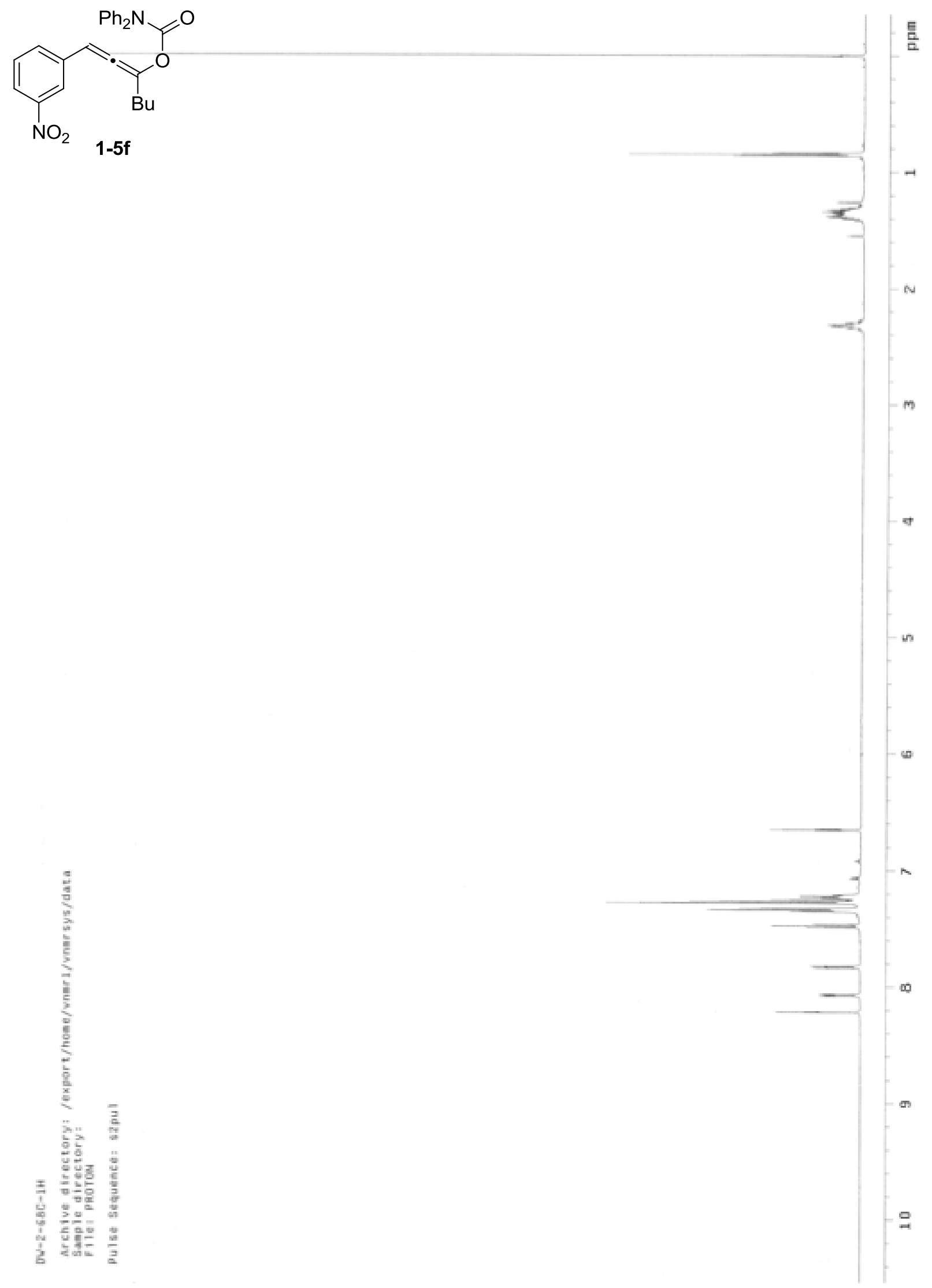



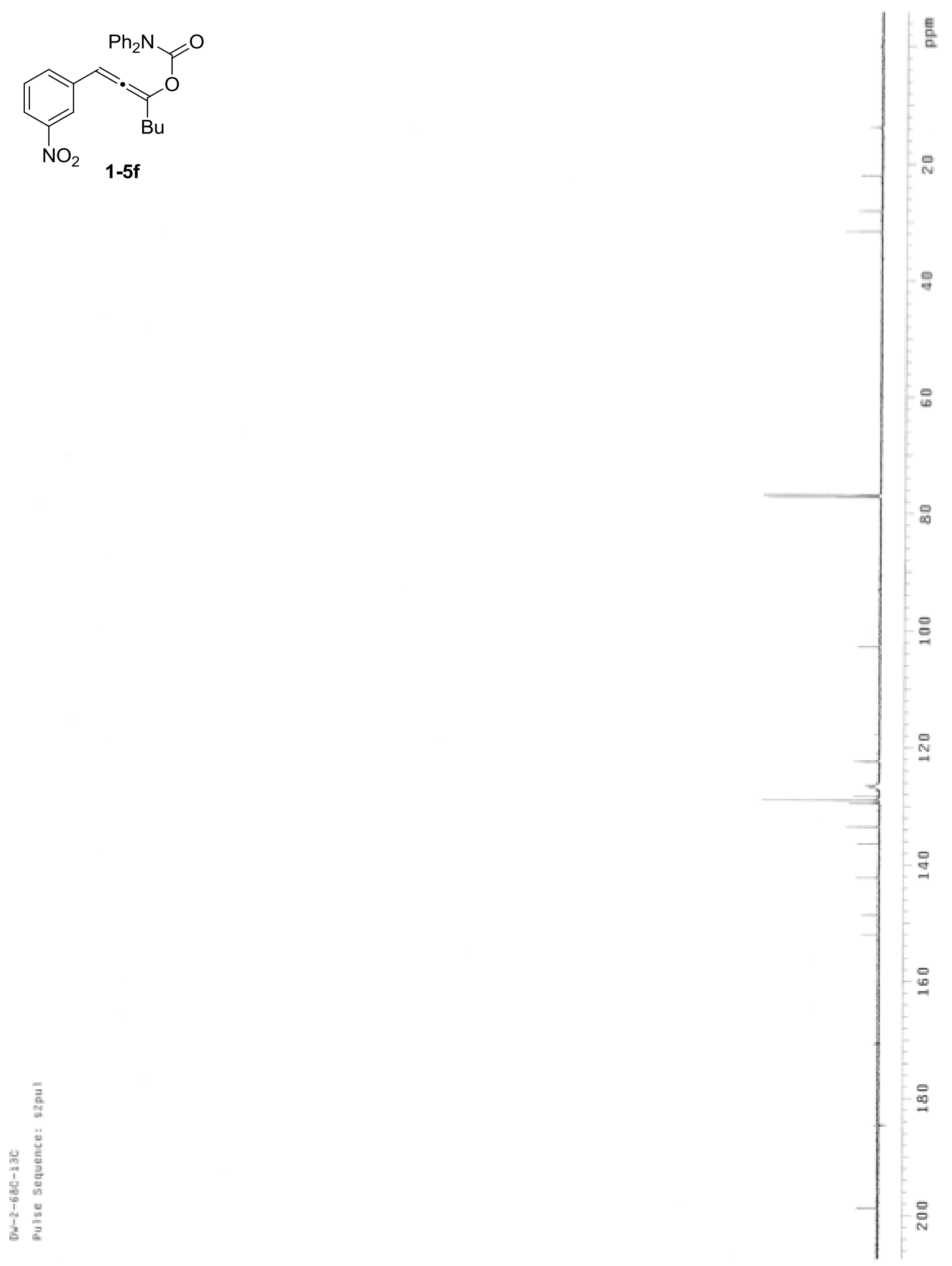
Chapter Two: Further transformations from allene intermediate formed by

Triazole-Au(I) complex as promoting propargyl ester rearrangements.

2.1 Triazole gold promoted, effective synthesis of enonoes from prypargylic esters and alcohols

\section{General methods and materials}

All of the reactions dealing with air and/or moisture-sensitive reactions were carried out under an atmosphere of nitrogen using oven/flame-dried glassware and standard syringe/septa techniques. Unless otherwise noted, all commercial reagents and solvents were obtained from the commercial provider and used without further purification. ${ }^{1} \mathrm{H}$ NMR and ${ }^{13} \mathrm{C}$ NMR spectra were recorded on Varian $600 \mathrm{MHz}$ spectrometers. Chemical shifts were reported relative to internal tetramethylsilane $(\delta$ $0.00 \mathrm{ppm}$ ) or $\mathrm{CDCl}_{3}(\delta 7.26 \mathrm{ppm})$ for ${ }^{1} \mathrm{H} \mathrm{NMR}$ and $\mathrm{CDCl}_{3}(\delta 77.0 \mathrm{ppm})$ for ${ }^{13} \mathrm{C} \mathrm{NMR}$. Flash column chromatography was performed on 230-430 mesh silica gel. Analytical thin layer chromatography was performed with precoated glass baked plates $(250 \mu)$ and visualized by fluorescence and by charring after treatment with potassium permanganate stain. HRMS were recorded on LTQ-FTUHRA spectrometer.

Substrates 2-1-1 and 2-1-5 were synthesized according to the literature as below:

1. M. Yu, G. Zhang, L. Zhang, Org. Lett. 2007, 9, 2147-2150.

2. N. Marion, P. Carlqvist, R. Gealageas, P. Fremont, F. Maseras, S. P. Nolan, Chem. Eur. J. 2007, 13, 6437-6451.

Representative procedure for the preparation of $\alpha, \beta$-unsatured ketone 2-1-4a

To a solution of 2-1-1a (288 mg, $1.25 \mathrm{mmol})$ in wet $\mathrm{MeOH}\left(5 \mathrm{~mL}, 0.25 \mathrm{M}, \mathrm{MeOH}: \mathrm{H}_{2} \mathrm{O}=\right.$ $100: 1)$, was added $\mathrm{Au}(\mathrm{I})$ catalyst ( $1.8 \mathrm{mg}, 0.0025 \mathrm{~mol}, 0.2 \mathrm{~mol} \%)$ at $60{ }^{\circ} \mathrm{C}$. The reaction mixture was stirred at $60^{\circ} \mathrm{C}$ and monitored by TLC. After the reaction was completed (4 h), the solvent was removed under reduced pressure and the residue was purified by flash chromatography on silica gel (ethyl acetate/hexane $=1: 20, \mathrm{~V} / \mathrm{V}$ ) to give 2-1-4a (92\% yield) as colorless oil.

Representative procedure for the preparation of $\alpha, \beta$-unsatured ketone 2-1-4a from 2-1-5a

To a solution of 2-1-5a (94 mg, $0.5 \mathrm{mmol})$ in wet $\mathrm{MeOH}\left(2.5 \mathrm{~mL}, \mathrm{MeOH}: \mathrm{H}_{2} \mathrm{O}=100: 1\right)$, was added $\mathrm{Au}(\mathrm{l})$ catalyst $(1.8 \mathrm{mg}, 0.0025 \mathrm{~mol}, 0.5 \mathrm{~mol} \%)$ at $60{ }^{\circ} \mathrm{C}$. The reaction mixture 
was stirred at $60{ }^{\circ} \mathrm{C}$ and monitored by TLC. After the reaction was completed ( $\left.3 \mathrm{~h}\right)$, the solvent was removed under reduced pressure and the residue was purified by flash chromatography on silica gel (ethyl acetate/hexane $=1: 20, \mathrm{~V} / \mathrm{V})$ to give $\mathbf{2 - 1 - 4 a}(89 \%$ yield) as colorless oil.

\section{Compounds characterization}<smiles>O=C(Br)/C=C/c1ccccc1</smiles>

(E)-1-phenylhept-1-en-3-one (E-2-1-4a): (Known compound, See: N. Marion, P. Carlqvist,. Gealageas, P. Fremont, F. Maseras, S. P. Nolan, Chem. Eur. J. 2007, 13, 6437-6451) ${ }^{1} \mathrm{H}$ NMR $\left(600 \mathrm{MHz}, \mathrm{CDCl}_{3}\right): \delta 7.53-7.56(\mathrm{~m}, 3 \mathrm{H}), 7.38-7.40(\mathrm{~m}, 3 \mathrm{H}), 6.73(\mathrm{t}$, $J=16.2 \mathrm{~Hz}, 1 \mathrm{H}$ ), $2.66(\mathrm{t}, J=7.5 \mathrm{~Hz}, 2 \mathrm{H}$ ), 1.66 (quintet, $J=7.5 \mathrm{~Hz}, 2 \mathrm{H}$ ), 1.37 (sextet, $J=$ $7.4 \mathrm{~Hz}, 2 \mathrm{H}$ ), 0.94 (t, $J=7.5 \mathrm{~Hz}, 3 \mathrm{H}) ;{ }^{13} \mathrm{C}$ NMR $\left(150 \mathrm{MHz}, \mathrm{CDCl}_{3}\right): \delta 200.8,142.5,134.8$, 130.6, 129.1, 128.4, 126.5, 40.9, 26.7, 22.7, 14.1.<smiles>CC(C)(C)C(=O)/C=C/c1ccccc1</smiles>

(E)-4,4-dimethyl-1-phenylpent-1-en-3-one (E-2-1-4b): (Known compound, See: R. S. Ramon, S. Gaillard, A. M. Z. Slawin, A. Porta, A. D'Alfonso, G. Zanoni, S. P. Nolan, Organometallics 2010, 29, 3665-3668) ${ }^{1} \mathrm{H}$ NMR $(600 \mathrm{MHz}, \mathrm{CDCl} 3)$ : $\delta 7.69(\mathrm{~d}, J=16.2$ $\mathrm{Hz}, 1 \mathrm{H}, E), 7.56-7.58(\mathrm{~m}, 2 \mathrm{H}, E), 7.53-7.54(\mathrm{~m}, 2 \mathrm{H}, Z), 7.37-7.40(\mathrm{~m}, 3 \mathrm{H}, E), 7.29-7.33$ $(\mathrm{m}, 3 \mathrm{H}, Z), 7.13(\mathrm{~d}, J=15.6 \mathrm{~Hz}, 1 \mathrm{H}, E), 6.78(\mathrm{~d}, J=13.0 \mathrm{~Hz}, 1 \mathrm{H}, Z), 6.45(\mathrm{~d}, J=13.0$ $\mathrm{Hz}, 1 \mathrm{H}, Z), 1.23$ (s, 9H, E), 1.20 (s, 9H, Z). ${ }^{13} \mathrm{C}$ NMR (150 MHz, CDCl $)$ : $\delta ~ 204.2,142.9$, $140.1,134.9,130.2,129.5,128.8,128.3,128.1,124.3,120.8,43.2,26.3,26.2(Z+E)$.<smiles>O=C(Br)/C=C/C=[PH2]</smiles>

(E)-dec-6-en-5-one (E-2-1-4c): (Known compound, See: M. N. Pennell, M. G. Unthank, P. Turner, T. D. Sheppard, J. Org. Chem. 2011, 76, 1479-1482) ${ }^{1} \mathrm{H}$ NMR $(600 \mathrm{MHz}$, $\left.\mathrm{CDCl}_{3}\right): \delta 6.82(\mathrm{dt}, J=16.2,6.6 \mathrm{~Hz}, 1 \mathrm{H}), 6.10(\mathrm{dt}, J=15.6,3.6 \mathrm{~Hz}, 1 \mathrm{H}), 2.53(\mathrm{t}, J=7.8$ $\mathrm{Hz}, 2 \mathrm{H}$ ), 2.20 (qd, $J=7.2,1.2 \mathrm{~Hz}, 2 \mathrm{H}$ ), 1.60 (quintet, $J=7.7 \mathrm{~Hz}, 2 \mathrm{H}$ ), 1.50 (sextet, $J=$ $7.4 \mathrm{~Hz}, 2 \mathrm{H}$ ), 1.34 (sextet, $J=7.4 \mathrm{~Hz}, 2 \mathrm{H}$ ), 0.95 (t, $J=7.2 \mathrm{~Hz}, 3 \mathrm{H}$ ), 0.92 (t, $J=7.2 \mathrm{~Hz}$, $3 \mathrm{H}) ;{ }^{13} \mathrm{C}$ NMR $\left(150 \mathrm{MHz}, \mathrm{CDCl}_{3}\right): \delta 200.9,146.9,130.5,39.8,34.4,26.4,22.4,21.3$, 13.8, 13.6 . 
<smiles>Cc1ccc(/C=C/C(=O)CC(C)(C)C)cc1</smiles>

(E)-1-p-tolylhept-1-en-3-one (E-2-1-4d): (Known compound, See: N. Marion, P. Carlqvist, R. Gealageas, P. Fremont, F. Maseras, S. P. Nolan, Chem. Eur. J. 2007, 13, 6437-6451) ${ }^{1} \mathrm{H}$ NMR (600 MHz, CDCl $): \delta 7.51$ (d, J=16.2, Hz, 1H), 7.43 (d, J = $7.8 \mathrm{~Hz}$, 2H), $7.19(\mathrm{~d}, J=8.4 \mathrm{~Hz}, 2 \mathrm{H}), 6.71(\mathrm{~d}, J=15.6 \mathrm{~Hz}, 1 \mathrm{H}), 2.64(\mathrm{t}, J=7.5 \mathrm{~Hz}, 2 \mathrm{H}), 2.37$ (s, $3 \mathrm{H}$ ), 1.66 (quintet, $J=7.7 \mathrm{~Hz}, 2 \mathrm{H}$ ), 1.37 (sextet, $J=7.4 \mathrm{~Hz}, 2 \mathrm{H}$ ), 0.92 (t, $J=7.5 \mathrm{~Hz}, 3 \mathrm{H}$ ); ${ }^{13} \mathrm{C}$ NMR (150 MHz, CDCl $):$ ס. 200.6, 142.3, 140.8, 131.8, 129.6, 128.2, 125.3, 40.5, 26.5, 22.4, 21.4, 13.8 .<smiles>O=C(/C=C/c1ccccc1)C1CC1</smiles>

(E)-1-cyclopropyl-3-phenylprop-2-en-1-one (E-2-1-4e): (Known compound, See: G. V. Kryshtal, G. M. Zhdankina, S. G. Zlotin, Eur. J. Org. Chem. 2005, 13, 2822-2827) ${ }^{1} \mathrm{H}$ NMR (600 MHz, CDCl $)$ : $\delta 7.63(\mathrm{~d}, J=16.2 \mathrm{~Hz}, 1 \mathrm{H}), \delta$ 7.55-7.57 (m, 2H), 7.38-7.40 (m, $3 \mathrm{H}), 6.86(\mathrm{~d}, J=16.2 \mathrm{~Hz}, 1 \mathrm{H}), 2.22-2.27(\mathrm{~m}, 1 \mathrm{H}), 1.15-1.17(\mathrm{~m}, 2 \mathrm{H}), 0.95-0.99(\mathrm{~m}, 2 \mathrm{H})$; ${ }^{13} \mathrm{C}$ NMR (150 MHz, $\left.\mathrm{CDCl}_{3}\right): \delta 199.9,141.9,134.6,130.2,128.8,128.2,126.4,19.6$, 11.3.<smiles>O=C(/C=C\c1ccccc1)C1CC1</smiles>

(Z)-1-cyclopropyl-3-phenylprop-2-en-1-one (Z-2-1-4e): (Known compound, See: Kryshtal, G. M. Zhdankina, S. G. Zlotin, Eur. J. Org. Chem. 2005, 13, 2822-2827) ${ }^{1} \mathrm{H}$ NMR (600 MHz, CDCl $)$ : $\delta$ 7.49-7.51 (m, 2H), 7.32-7.35 (m, 3H), 6.93 (d, J = $12.6 \mathrm{~Hz}$, $1 \mathrm{H}), 6.24(\mathrm{~d}, J=12.6 \mathrm{~Hz}, 1 \mathrm{H}), 1.88-1.92(\mathrm{~m}, 1 \mathrm{H}), 1.10-1.13(\mathrm{~m}, 2 \mathrm{H}), 0.81-0.83(\mathrm{~m}, 2 \mathrm{H})$; ${ }^{13} \mathrm{C}$ NMR (150 MHz, $\left.\mathrm{CDCl}_{3}\right): \delta 203.7,139.3,135.4,129.6,129.5,128.9,128.1,22.1$, 12.5 .<smiles>O=C(/C=C/[P][In])c1ccccc1</smiles>

(E)-1-phenylhex-2-en-1-one (E-2-1-4f): (Known compound, See: N. Marion, $P$. Carlqvist, R. Gealageas, P. Fremont, F. Maseras, S. P. Nolan, Chem. Eur. J. 2007, 13,

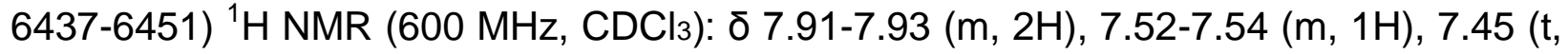
$J=7.5 \mathrm{~Hz}, 2 \mathrm{H}), 7.05(\mathrm{dt}, J=15.6,7.8 \mathrm{~Hz}, 1 \mathrm{H}), 6.86(\mathrm{dt}, J=15.0,1.5 \mathrm{~Hz}, 1 \mathrm{H}), 2.28(\mathrm{~m}$, $2 \mathrm{H}$ ), 1.54 (sextet, $J=7.3 \mathrm{~Hz}, 2 \mathrm{H}), 0.97(\mathrm{t}, J=7.2 \mathrm{~Hz}, 3 \mathrm{H}) ;{ }^{13} \mathrm{C} \mathrm{NMR}\left(150 \mathrm{MHz}, \mathrm{CDCl}_{3}\right)$ : $\delta 190.8,149.6,137.9,132.4,128.4,128.3,125.9,34.7,21.3,13.6$. 
<smiles>CC=CC(=O)Br</smiles>

(E)-oct-2-en-4-one (E-2-1-4g): (Known compound, See: A. R. Katritzky, D. C. Oniciu, I. Ghiviriga, F. Soti, J. Org. Chem. 1998, 63, 2110-2115) ${ }^{1} \mathrm{H}$ NMR $\left(600 \mathrm{MHz}, \mathrm{CDCl}_{3}\right): \delta$ 6.85 (dq, $J=16.2,6.8 \mathrm{~Hz}, 1 \mathrm{H}$ ), 6.11 (dq, $J=15.6,1.6 \mathrm{~Hz}, 1 \mathrm{H}$ ), $2.52(\mathrm{t}, J=7.5 \mathrm{~Hz}, 2 \mathrm{H}$ ), 1.90 (dd, $J=6.6,1.8 \mathrm{~Hz}, 3 \mathrm{H}$ ), 1.59 (quintet, $J=7.5 \mathrm{~Hz}, 2 \mathrm{H}$ ), 1.33 (sextet, $J=7.6 \mathrm{~Hz}$, 2H), $0.91(\mathrm{t}, J=7.2 \mathrm{~Hz}, 3 \mathrm{H}) ;{ }^{13} \mathrm{C}$ NMR $\left(150 \mathrm{MHz}, \mathrm{CDCl}_{3}\right): \delta 200.7,142.2,131.9,39.8$, $26.4,22.4,18.2,13.8$.<smiles>O=C(Br)/C=C/c1ccc(F)cc1</smiles>

(E)-1-(4-fluorophenyl)hept-1-en-3-one (E-2-1-4h): (Known compound, See: N. Marion, P. Carlqvist, R. Gealageas, P. Fremont, F. Maseras, S. P. Nolan, Chem. Eur. J. 2007, 13, 6437-6451) ${ }^{1} \mathrm{H}$ NMR $\left(600 \mathrm{MHz}, \mathrm{CDCl}_{3}\right): \delta$ 7.50-7.54 (m, 3H), $7.08(\mathrm{t}, J=8.4 \mathrm{~Hz}, 2 \mathrm{H})$, $6.66(\mathrm{~d}, J=16.2 \mathrm{~Hz}, 1 \mathrm{H}$ ), $2.65(\mathrm{t}, J=7.5 \mathrm{~Hz}, 2 \mathrm{H}$ ), 1.66 (quintet, $J=7.4 \mathrm{~Hz}, 2 \mathrm{H}$ ), 1.38 (sextet, $J=7.5 \mathrm{~Hz}, 2 \mathrm{H}), 0.94(\mathrm{t}, J=7.5 \mathrm{~Hz}, 3 \mathrm{H}) ;{ }^{13} \mathrm{C} \mathrm{NMR}\left(150 \mathrm{MHz}, \mathrm{CDCl}_{3}\right): \delta 200.3$, $163.0(\mathrm{~d}, J=249.8 \mathrm{~Hz}$ ), 140.8, $130.8(\mathrm{~d}, J=1.8 \mathrm{~Hz}), 130.0(\mathrm{~d}, J=8.3 \mathrm{~Hz}), 125.9,116.0$ (d, $J=21.8 \mathrm{~Hz}), 40.7,26.4,22.3,13.8$.<smiles>CC(C)=CC(=O)Br</smiles>

2-methyloct-2-en-4-one (2-1-4i): (Known compound, See: M. Yu, G. Li, S. Wang, L. Zhang, Adv. Synth. Catal. 2007, 349, 871-875) ${ }^{1} \mathrm{H}$ NMR $\left(600 \mathrm{MHz}, \mathrm{CDCl}_{3}\right): \delta 6.06-6.08$ (m, 1H), 2.40 (t, $J=7.5 \mathrm{~Hz}, 2 \mathrm{H}), 2.14(\mathrm{~d}, J=1.2 \mathrm{~Hz}, 3 \mathrm{H}), 1.88(\mathrm{~d}, J=1.2 \mathrm{~Hz}, 3 \mathrm{H}), 1.57$ (quintet, $J=7.5 \mathrm{~Hz}, 2 \mathrm{H}$ ), 1.32 (sextet, $J=7.4 \mathrm{~Hz}, 2 \mathrm{H}$ ), 0.91 (t, $J=7.2 \mathrm{~Hz}, 3 \mathrm{H}$ ); ${ }^{13} \mathrm{C}$ NMR (150 MHz, CDCl3): $\delta$ 201.2, 154.5, 123.8, 43.9, 27.5, 26.4, 22.4, 20.6, 13.8.<smiles>O=C(Br)/C=C/[PH+]=[In]</smiles>

(E)-2-methylnon-3-en-5-one (E-2-1-4j): (Known compound, See: M. Yu, G. Li, S. Wang, L. Zhang, Adv. Synth. Catal. 2007, 349, 871-875) ${ }^{1} \mathrm{H}$ NMR $\left(600 \mathrm{MHz}, \mathrm{CDCl}_{3}\right): \delta$ $6.78(\mathrm{dd}, J=16.2,6.6 \mathrm{~Hz}, 1 \mathrm{H}), 6.03(\mathrm{dd}, J=16.2,1.8 \mathrm{~Hz}, 1 \mathrm{H}), 2.53(\mathrm{t}, J=7.5 \mathrm{~Hz}, 2 \mathrm{H})$, 2.41-2.48 (m, 1H), 1.59 (quintet, $J=7.4 \mathrm{~Hz}, 2 \mathrm{H}$ ), 1.32 (sextet, $J=7.4 \mathrm{~Hz}, 2 \mathrm{H}), 1.07$ (d, $J$ $=6.6 \mathrm{~Hz}, 6 \mathrm{H}), 0.91(\mathrm{t}, J=7.2 \mathrm{~Hz}, 3 \mathrm{H}) ;{ }^{13} \mathrm{C} \mathrm{NMR}\left(150 \mathrm{MHz}, \mathrm{CDCl}_{3}\right): \delta 201.2,153.1$, $127.5,39.8,31.0,26.4,22.4,21.3,13.8$. 
<smiles>O=C(C=C1CCCCC1)c1ccccc1</smiles>

2-cyclohexylidene-1-phenylethanone (2-1-4k): (Known compound, See: B. Lu, C. Li, L. Zhang, J. Am. Chem. Soc. 2005, 127, 14180-14181) ${ }^{1} \mathrm{H}$ NMR (600 MHz, CDCl $)^{2}: \delta$ 7.93-7.95 (m, 2H), 7.51-7.54 (m, 1H), 7.43-7.46 (m, 2H), 6.60-6.61 (m, 1H), 2.76-2.78 $(\mathrm{m}, 2 \mathrm{H}), 2.31(\mathrm{td}, J=6.3,0.6 \mathrm{~Hz}, 2 \mathrm{H}), 1.71-1.75(\mathrm{~m}, 2 \mathrm{H}), 1.62-1.66(\mathrm{~m}, 4 \mathrm{H}) ;{ }^{13} \mathrm{C}$ NMR $\left(150 \mathrm{MHz}_{\mathrm{CDCl}}\right): \delta 192.3,162.7,139.3,132.3,128.4,128.3,118.7,38.4,30.6,28.9$, 28.0, 26.3.<smiles>COc1ccc(/C=C/C(=O)CC(C)(C)C)cc1</smiles>

(E)-1-(4-methoxyphenyl)hept-1-en-3-one (E-2-1-4I): (Known compound, See: N. Marion, P. Carlqvist, R. Gealageas, P. Fremont, F. Maseras, S. P. Nolan, Chem. Eur. J. 2007, 13, 6437-6451) ${ }^{1} \mathrm{H}$ NMR (600 MHz, CDCl3): $\delta 7.51$ (d, J=15.6 Hz, 1H), 7.49 (d, J $=8.4 \mathrm{~Hz}, 2 \mathrm{H}), 6.90(\mathrm{~d}, J=8.4 \mathrm{~Hz}, 2 \mathrm{H}), 6.63(\mathrm{~d}, J=16.2 \mathrm{~Hz}, 1 \mathrm{H}), 3.83(\mathrm{~s}, 3 \mathrm{H}), 2.63(\mathrm{t}, J$ $=7.5 \mathrm{~Hz}, 2 \mathrm{H}$ ), 1.66 (quintet, $J=7.5 \mathrm{~Hz}, 2 \mathrm{H}$ ), 1.38 (sextet, $J=7.4 \mathrm{~Hz}, 2 \mathrm{H}$ ), 0.94 (t, $J=$ $7.2 \mathrm{~Hz}, 3 \mathrm{H}) ;{ }^{13} \mathrm{C}$ NMR (150 MHz, CDCl 3 ): $\delta 200.6,161.5,142.0,129.9,127.2,124.1$, 114.3, 55.3, 40.5, 26.6, 22.4, 13.9 .<smiles>O=C(/C=C/c1ccccc1)c1ccccc1</smiles>

(E)-chalcone (E-2-1-4m): (Known compound, See: N. Marion, P. Carlqvist, R. Gealageas, P. Fremont, F. Maseras, S. P. Nolan, Chem. Eur. J. 2007, 13, 6437-6451) ${ }^{1} \mathrm{H}$ NMR $\left(600 \mathrm{MHz}, \mathrm{CDCl}_{3}\right)$ : $\delta$ 8.00-8.02 (m, 2H), $7.80(\mathrm{~d}, J=15.6 \mathrm{~Hz}, 1 \mathrm{H}), 7.62-7.63(\mathrm{~m}$, 2H), 7.55-7.58 (m, 1H), $7.52(\mathrm{~d}, J=15.6 \mathrm{~Hz}, 1 \mathrm{H}), 7.49(\mathrm{t}, J=7.5 \mathrm{~Hz}, 2 \mathrm{H}), 7.38-7.41$ (m, $3 \mathrm{H}) ;{ }^{13} \mathrm{C}$ NMR $\left(150 \mathrm{MHz}, \mathrm{CDCl}_{3}\right): \delta 190.4,144.7,138.2,134.8,132.7,130.5,128.9$, 128.6, 128.4, 128.4, 122.1 .<smiles>CC(C)=CC(=O)c1ccccc1</smiles>

3-methyl-1-phenylbut-2-en-1-one (2-1-4n): (Known compound, See: P. N. Chatterjee,

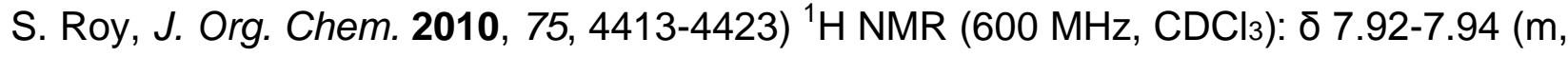
$2 \mathrm{H}), 7.50-7.53(\mathrm{~m}, 1 \mathrm{H}), 7.42-7.45(\mathrm{~m}, 2 \mathrm{H}), 6.74-6.75(\mathrm{~m}, 1 \mathrm{H}), 2.21(\mathrm{~d}, J=1.2 \mathrm{~Hz}, 3 \mathrm{H})$, $2.01(\mathrm{~d}, J=1.2 \mathrm{~Hz}, 3 \mathrm{H}) ;{ }^{13} \mathrm{C} \operatorname{NMR}\left(150 \mathrm{MHz}, \mathrm{CDCl}_{3}\right): \delta 191.8,156.6,139.2,132.2$, 128.4, 128.1, 121.1, 27.9, 21.1. 
<smiles>Cc1ccccc1/C=C/C(=O)CC(C)(C)C</smiles>

(E)-1-o-tolylhept-1-en-3-one (E-2-1-40): (Known compound, See: N. Marion, P. Carlqvist, R. Gealageas, P. Fremont, F. Maseras, S. P. Nolan, Chem. Eur. J. 2007, 13, 6437-6451) ${ }^{1} \mathrm{H}$ NMR (600 MHz, CDCl $): \delta 7.85$ (d, J = 16.2 Hz, 1H), 7.56 (d, J = $7.8 \mathrm{~Hz}$, $1 \mathrm{H}), 7.25$ (t, J=7.2 Hz, 1H), 7.20 (t, J=7.5 Hz, 2H), 6.66 (d, J=16.2 Hz, 1H), 2.65 (t, J $=7.2 \mathrm{~Hz}, 2 \mathrm{H}$ ), $2.43(\mathrm{~s}, 3 \mathrm{H}$ ), 1.67 (quintet, $J=7.5 \mathrm{~Hz}, 2 \mathrm{H}$ ), 1.39 (sextet, $J=7.4 \mathrm{~Hz}, 2 \mathrm{H}$ ), 0.95 (t, $J=7.2 \mathrm{~Hz}, 3 \mathrm{H}) ;{ }^{13} \mathrm{C}$ NMR $\left(150 \mathrm{MHz}, \mathrm{CDCl}_{3}\right): \delta 200.4,139.6,137.8,133.5$, $130.7,129.9,127.1,126.3,126.2,40.9,26.4,22.4,19.6,13.8$.<smiles>Cc1ccc(/C=C/C(=O)c2ccccc2)cc1</smiles>

(E)-1-phenyl-3-p-tolylprop-2-en-1-one (E-2-1-4p): (Known compound, See: Y. Zhang, Y.-L. Shao, H.-S. Xu, W. Wang, J. Org. Chem. 2011, 76, 1472-1474) ${ }^{1} \mathrm{H}$ NMR $(600 \mathrm{MHz}$, $\left.\mathrm{CDCl}_{3}\right)$ : $\delta$ 8.00-8.01 (m, 2H), $7.79(\mathrm{~d}, J=15.6 \mathrm{~Hz}, 1 \mathrm{H}), 7.53-7.57(\mathrm{~m}, 3 \mathrm{H}), 7.47-7.50(\mathrm{~m}$, $3 \mathrm{H}), 7.22(\mathrm{~d}, J=7.8 \mathrm{~Hz}, 2 \mathrm{H}), 2.38(\mathrm{~s}, 3 \mathrm{H}) ;{ }^{13} \mathrm{C}$ NMR (150 MHz, CDCl $): \delta$ 190.6, 144.9, 141.0, 138.4, 132.6, 132.2, 129.7, 128.5, 128.4, 121.1, 21.5.<smiles>O=C(Br)C=CC1CC1</smiles>

(E)-1-cyclopropylhept-1-en-3-one (E-2-1-4q): (Known compound, See: M. N. Pennell, M. G. Unthank, P. Turner, T. D. Sheppard, J. Org. Chem. 2011, 76, 1479-1482) ${ }^{1} \mathrm{H}$ $\operatorname{NMR}\left(600 \mathrm{MHz}, \mathrm{CDCl}_{3}\right): \delta 6.31(\mathrm{dd}, J=15.6 \mathrm{~Hz}, 9.6 \mathrm{~Hz}, 1 \mathrm{H}), 6.21(\mathrm{~d}, J=15.6 \mathrm{~Hz}, 1 \mathrm{H})$, $2.48(\mathrm{t}, J=7.5 \mathrm{~Hz}, 2 \mathrm{H}), 1.53-1.61(\mathrm{~m}, 3 \mathrm{H}), 1.34$ (sextet, $J=7.4 \mathrm{~Hz}, 2 \mathrm{H}), 0.95-0.99(\mathrm{~m}$, $2 \mathrm{H}), 0.91$ (t, $J=7.5 \mathrm{~Hz}, 3 \mathrm{H}), 0.64-0.66(\mathrm{~m}, 2 \mathrm{H}) ;{ }^{13} \mathrm{C} \mathrm{NMR}(150 \mathrm{MHz}, \mathrm{CDCl}): \delta 199.8$, $152.0,127.2,40.0,26.5,22.4,14.5,13.8,8.8$.<smiles>CC(C)CC(=O)C=C1CCCCC1</smiles>

1-cyclohexylidenehexan-2-one (2-1-4r): (Known compound, See: M. Yu, G. Li, S. Wang, L. Zhang, Adv. Synth. Catal. 2007, 349, 871-875) ${ }^{1} \mathrm{H}$ NMR (600 MHz, CDCl 3$): \delta$ $5.97(\mathrm{~s}, 1 \mathrm{H}), 2.79(\mathrm{t}, J=5.4 \mathrm{~Hz}, 2 \mathrm{H}), 2.40(\mathrm{t}, J=7.2 \mathrm{~Hz}, 2 \mathrm{H}), 2.16(\mathrm{t}, J=6.3 \mathrm{~Hz}, 2 \mathrm{H})$, 1.54-1.69 (m, 8H), 1.32 (sextet, $J=7.4 \mathrm{~Hz}, 2 \mathrm{H}), 0.91$ (t, $J=7.5 \mathrm{~Hz}, 3 \mathrm{H}) ;{ }^{13} \mathrm{C}$ NMR $(150$ $\left.\mathrm{MHz}_{2} \mathrm{CDCl}_{3}\right)$ : $\delta 202.1,161.4,121.0,44.2,38.1,29.9,28.8,27.9,26.4,26.3,22.4,13.9$. 
<smiles>COc1ccccc1/C=C/C(=O)Br</smiles>

(E)-1-(2-methoxyphenyl)hept-1-en-3-one (E-2-1-4s): ${ }^{1} \mathrm{H}$ NMR (600 MHz, CDCl$): \delta$ $7.91(\mathrm{~d}, J=16.8 \mathrm{~Hz}, 1 \mathrm{H}), 7.53(\mathrm{~d}, J=7.8 \mathrm{~Hz}, 1 \mathrm{H}), 7.35(\mathrm{t}, J=8.1 \mathrm{~Hz}, 1 \mathrm{H}), 6.96(\mathrm{t}, J=$ $7.5 \mathrm{~Hz}, 1 \mathrm{H}), 6.91(\mathrm{~d}, J=8.4 \mathrm{~Hz}, 1 \mathrm{H}), 6.78(\mathrm{~d}, J=16.2 \mathrm{~Hz}, 1 \mathrm{H}), 3.89(\mathrm{~s}, 3 \mathrm{H}), 2.67(\mathrm{t}, J=$ $7.5 \mathrm{~Hz}, 2 \mathrm{H}$ ), 1.66 (quintet, $J=7.5 \mathrm{~Hz}, 2 \mathrm{H}$ ), 1.38 (sextet, $J=7.4 \mathrm{~Hz}, 2 \mathrm{H}$ ), 0.94 (t, $J=7.5$ $\mathrm{Hz}, 3 \mathrm{H}) ;{ }^{13} \mathrm{C} \mathrm{NMR}\left(150 \mathrm{MHz}, \mathrm{CDCl}_{3}\right): \delta 201.2,158.3,137.5,131.5,128.3,126.9,123.5$, 120.7, 111.1, 55.4, 40.1, 26.6, 22.4, 13.9.<smiles>O=C(Br)/C=C/c1ccccc1Cl</smiles>

(E)-1-(2-chloro-5-nitrophenyl)hept-1-en-3-one (E-2-1-4t): ${ }^{1} \mathrm{H}$ NMR $\left(600 \mathrm{MHz}, \mathrm{CDCl}_{3}\right)$ : $\delta 8.04(\mathrm{~d}, J=1.8 \mathrm{~Hz}, 1 \mathrm{H}), 7.67(\mathrm{dd}, J=7.8 \mathrm{~Hz}, 1.8 \mathrm{~Hz}, 1 \mathrm{H}), 7.58(\mathrm{~d}, J=8.4 \mathrm{~Hz}, 1 \mathrm{H})$, $7.50(\mathrm{~d}, J=16.2 \mathrm{~Hz}, 1 \mathrm{H}), 6.80(\mathrm{~d}, J=15.6 \mathrm{~Hz}, 1 \mathrm{H}), 2.67(\mathrm{t}, J=7.5 \mathrm{~Hz}, 2 \mathrm{H}), 1.67$ (quintet, $J=7.5 \mathrm{~Hz}, 2 \mathrm{H}$ ), 1.38 (sextet, $J=7.4 \mathrm{~Hz}, 2 \mathrm{H}$ ), 0.95 (t, $J=7.2 \mathrm{~Hz}, 3 \mathrm{H}$ ); ${ }^{13} \mathrm{C}$ NMR

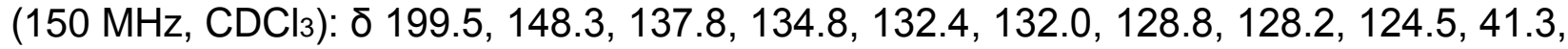
26.1, 22.3, 13.8; HRMS Calculated for $\left[\mathrm{C}_{13} \mathrm{H}_{14} \mathrm{ClNO} 3+\mathrm{Na}\right]_{+}: 290.05599$, Found: 290.05585.<smiles>O=C(Br)/C=C/c1cccc2ccccc12</smiles>

(E)-1-(naphthalen-4-yl)hept-1-en-3-one (E-2-1-4u): (Known compound, See: R. S. Ramón, N. Marion, S. P. Nolan, Tetrahedron, 2009, 65, 1767-1773) ${ }^{1} \mathrm{H}$ NMR $(600$ MHz, $\left.\mathrm{CDCl}_{3}\right): \delta 8.40(\mathrm{~d}, J=16.2 \mathrm{~Hz}, 1 \mathrm{H}), 8.17(\mathrm{~d}, J=8.4 \mathrm{~Hz}, 1 \mathrm{H}), 7.88(\mathrm{t}, J=9.0 \mathrm{~Hz}, 2 \mathrm{H})$, $7.76(\mathrm{~d}, J=7.2 \mathrm{~Hz}, 1 \mathrm{H}), 7.57(\mathrm{t}, J=7.5 \mathrm{~Hz}, 1 \mathrm{H}), 7.52(\mathrm{t}, J=7.5 \mathrm{~Hz}, 1 \mathrm{H}), 7.48(\mathrm{t}, J=7.8$ $\mathrm{Hz}, 1 \mathrm{H}$ ), 6.83 (d, $J=16.2 \mathrm{~Hz}, 1 \mathrm{H}), 2.73$ (t, $J=7.5 \mathrm{~Hz}, 2 \mathrm{H}$ ), 1.72 (quintet, $J=7.5 \mathrm{~Hz}, 2 \mathrm{H}$ ), 1.42 (sextet, $J=7.4 \mathrm{~Hz}, 2 \mathrm{H}), 0.97(\mathrm{t}, J=7.5 \mathrm{~Hz}, 3 \mathrm{H}) ;{ }^{13} \mathrm{C} \mathrm{NMR}\left(150 \mathrm{MHz}, \mathrm{CDCl}_{3}\right): \delta$ 200.4, 139.1, 133.7, 132.0, 131.6, 130.6, 128.8, 128.7, 126.8, 126.2, 125.4, 125.0, 123.3, 41.1, 26.5, 22.5, 13.9 . 
III. NMR spectra 


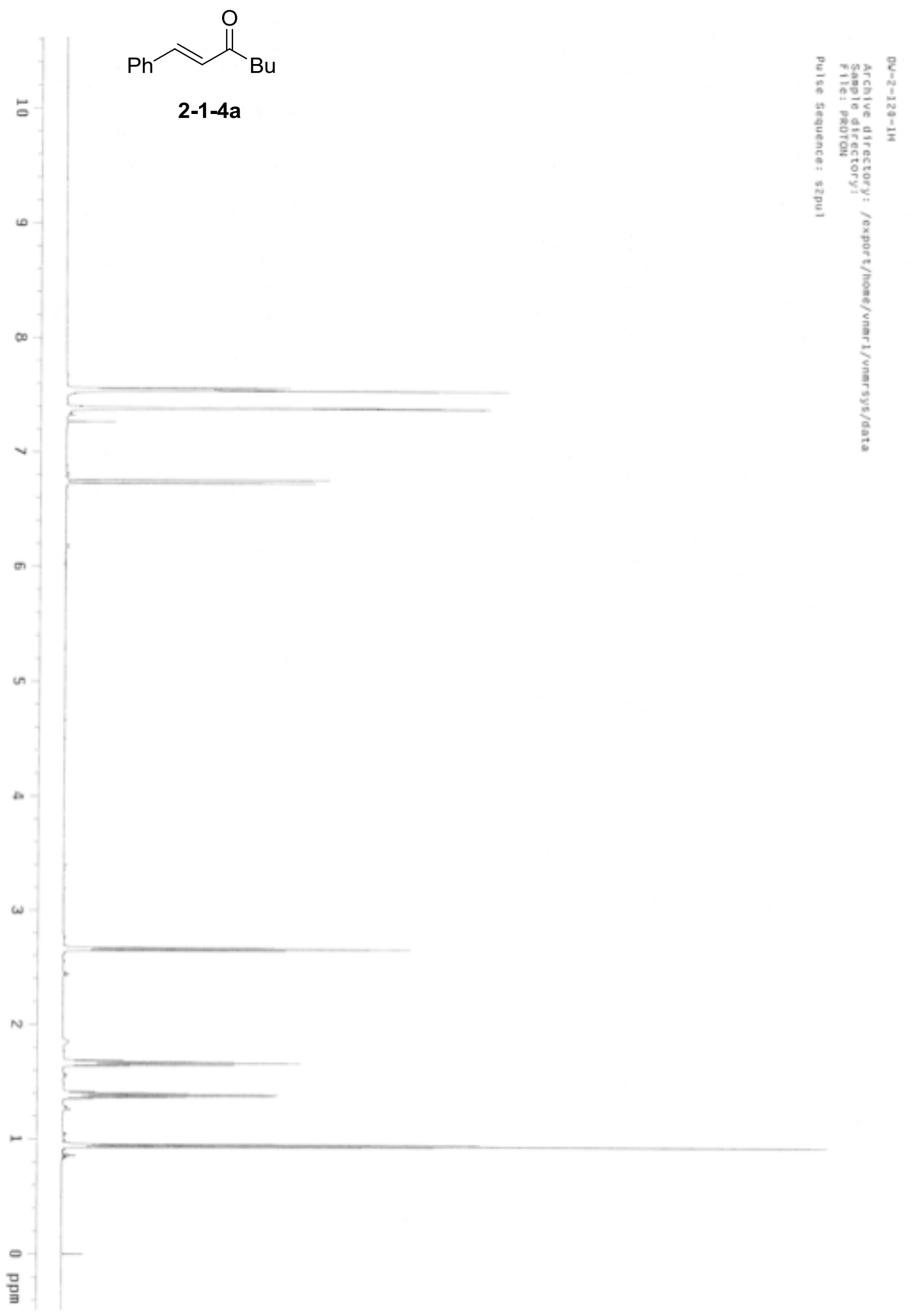



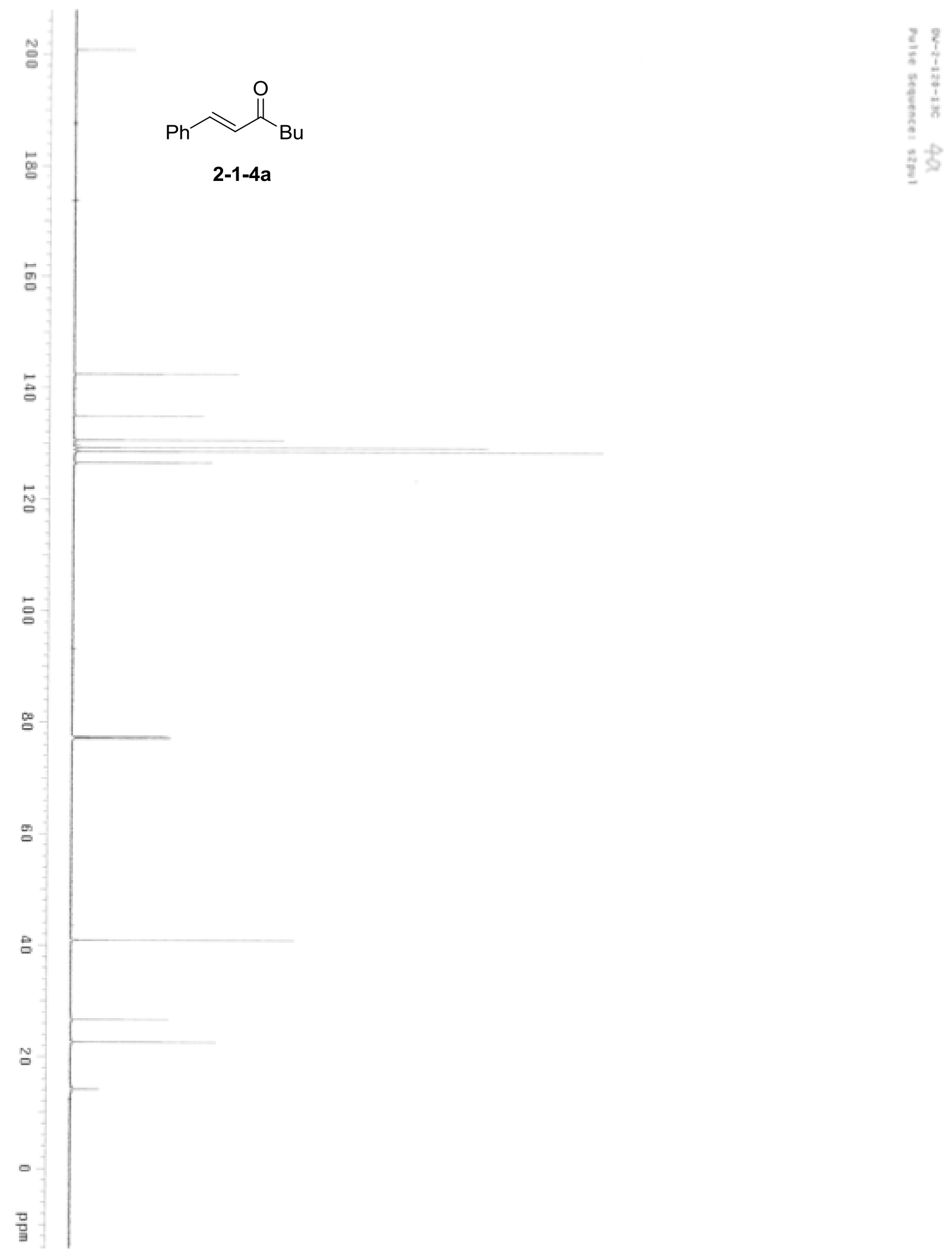

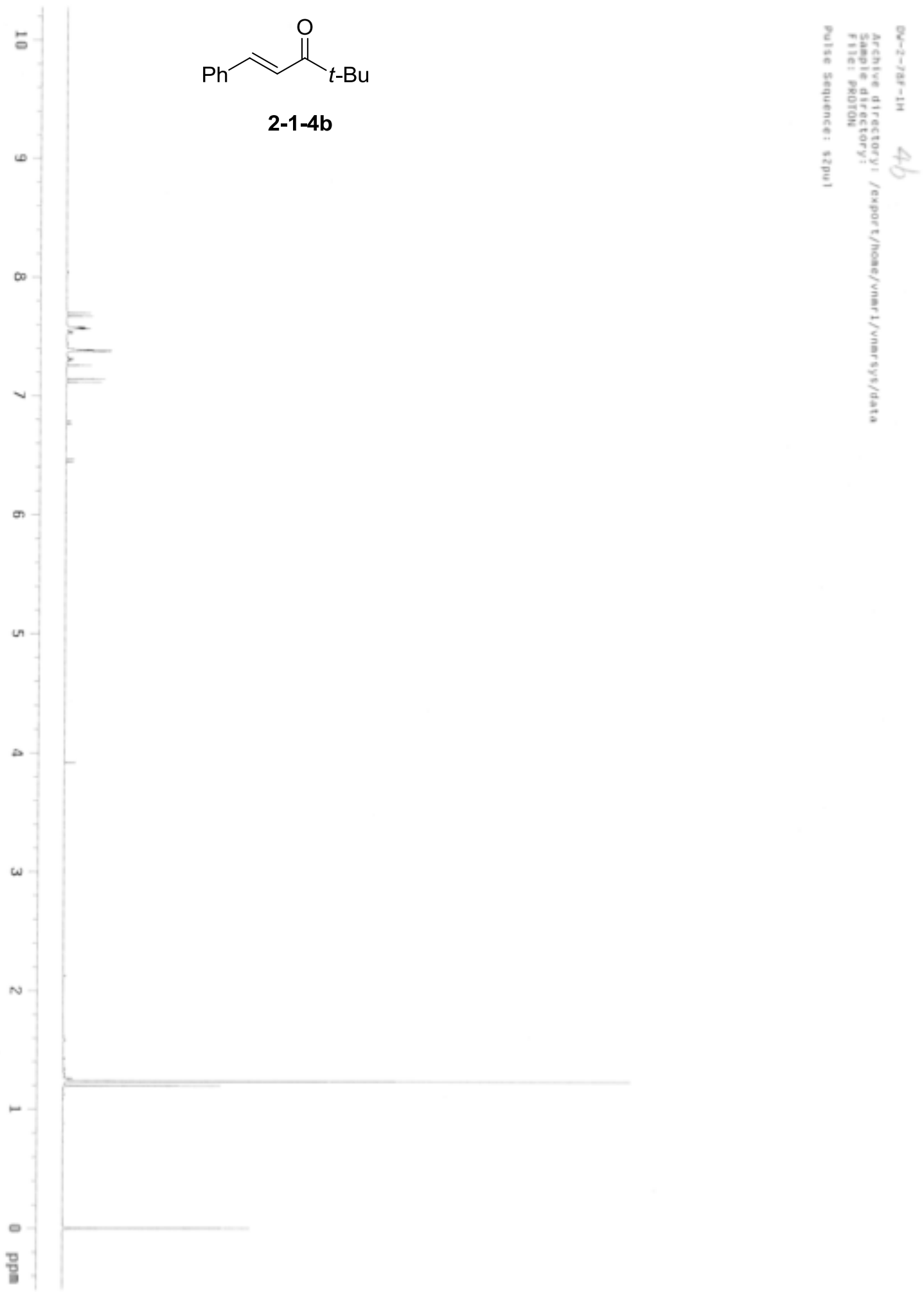

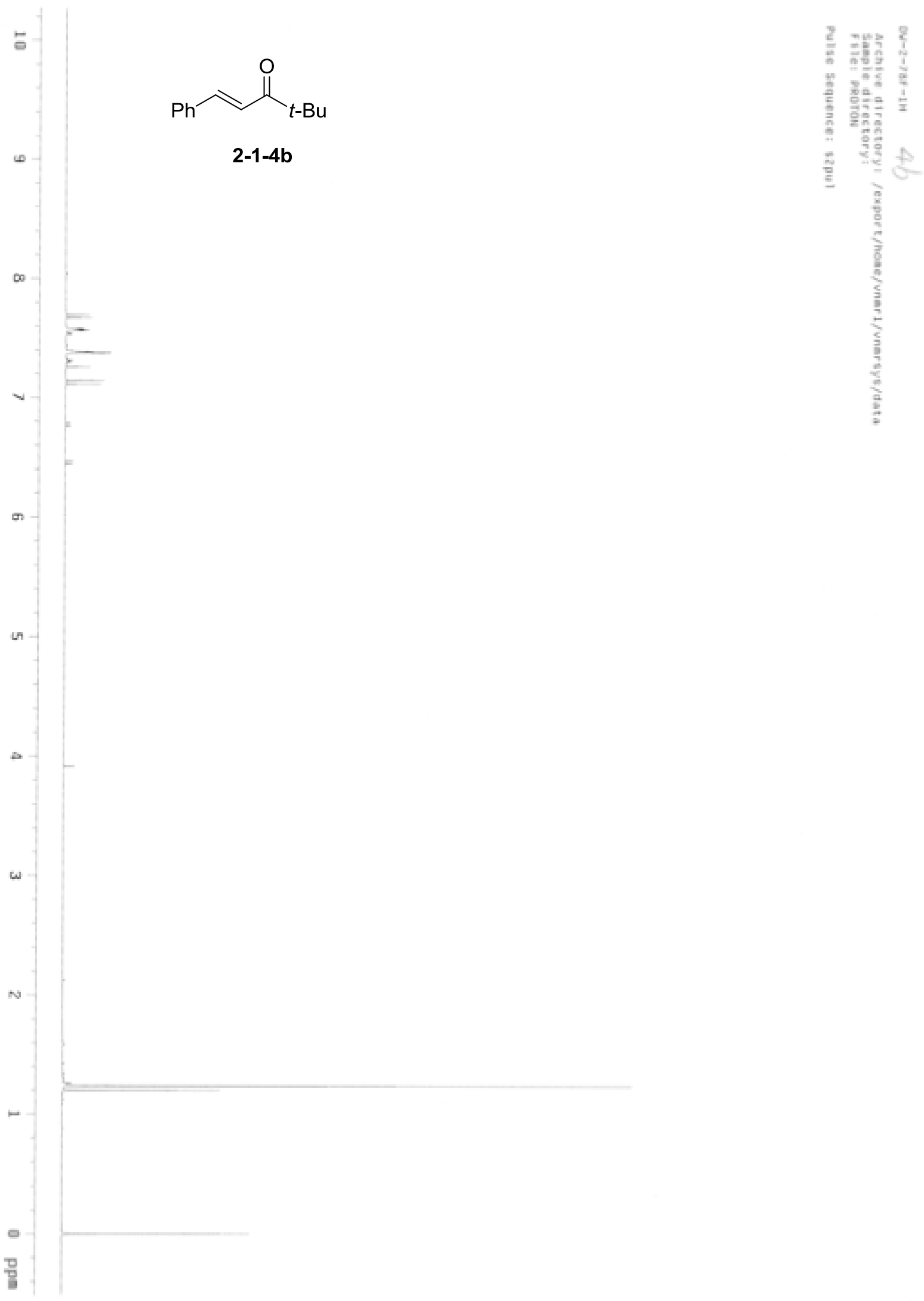

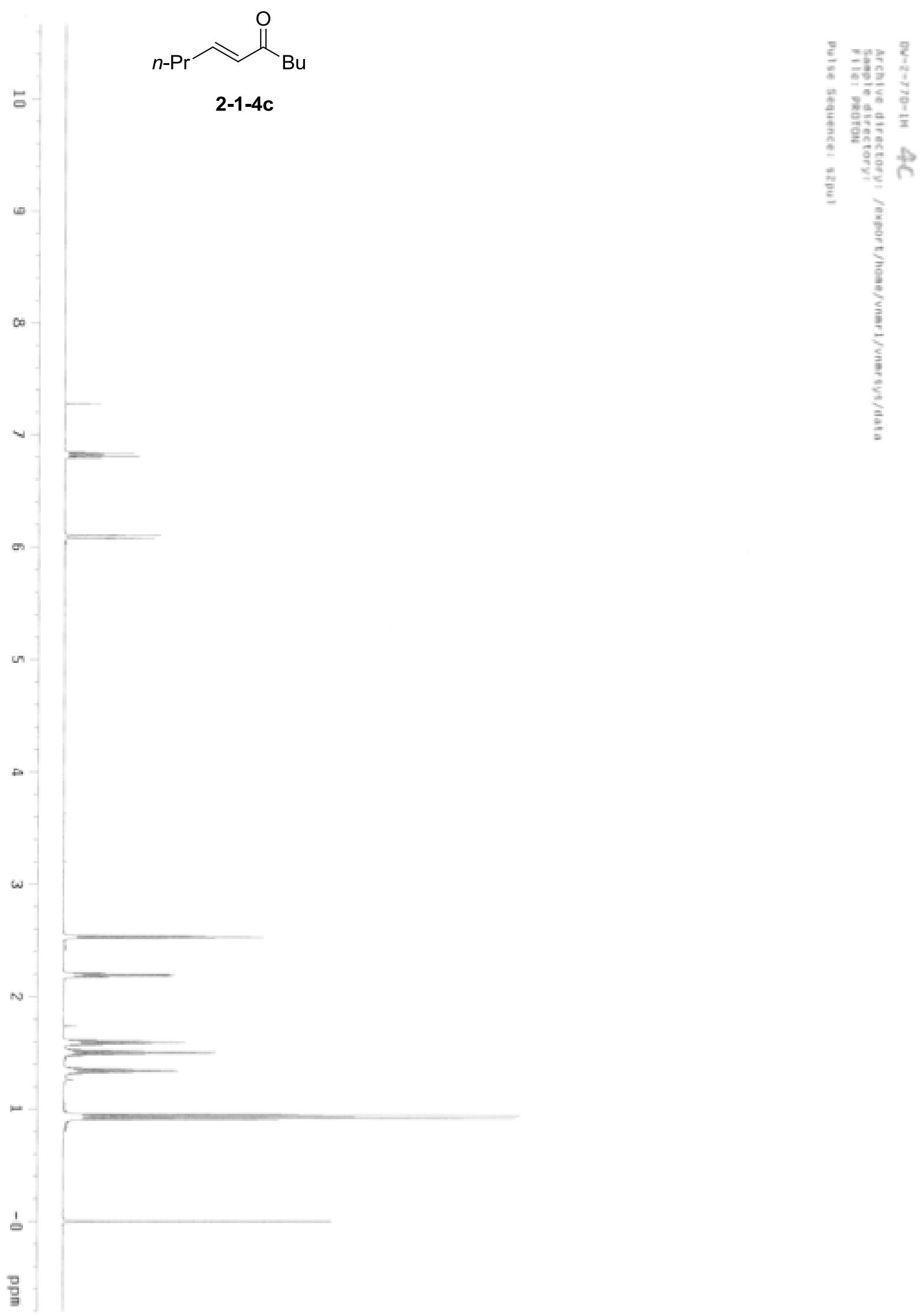


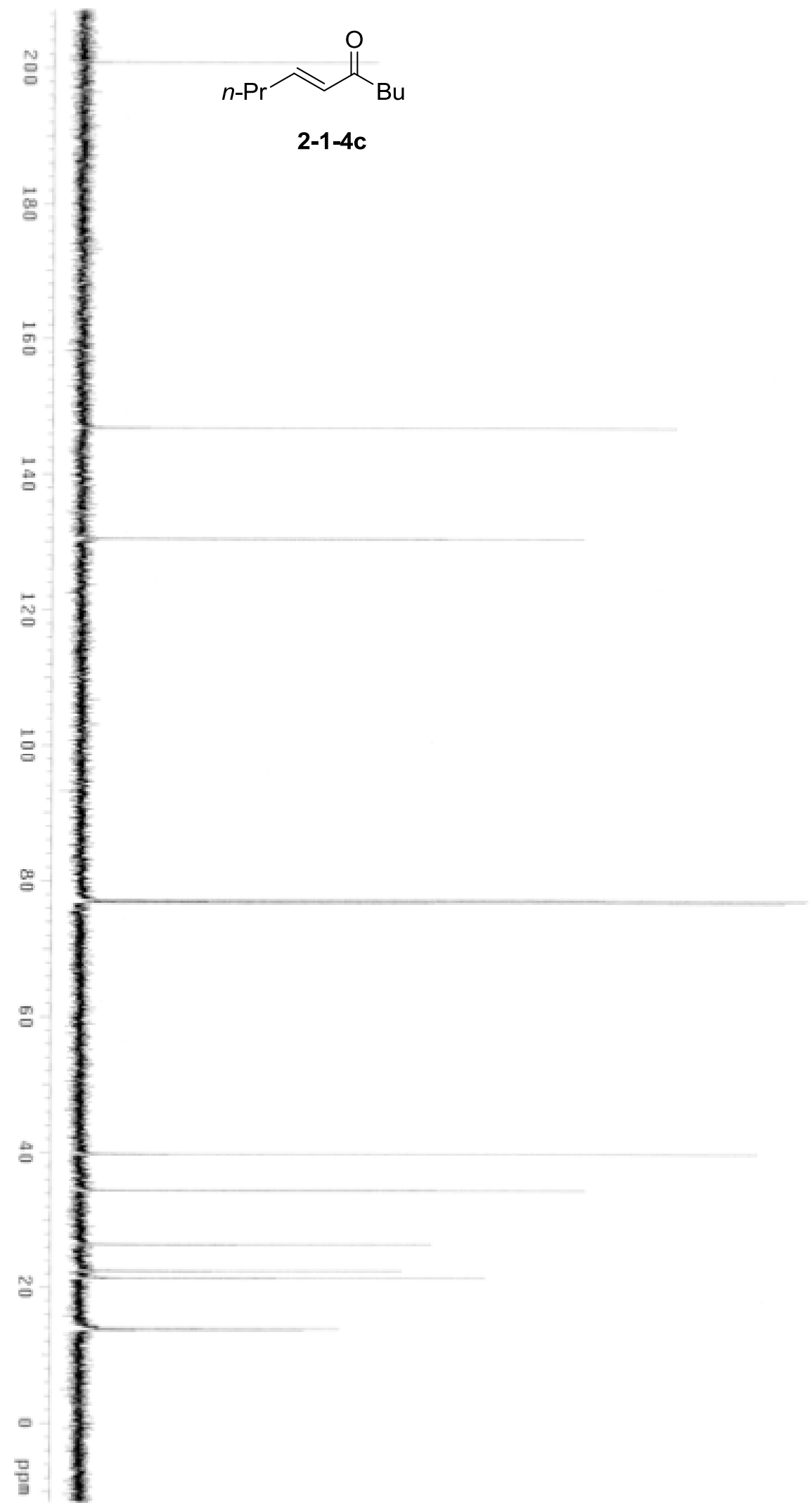



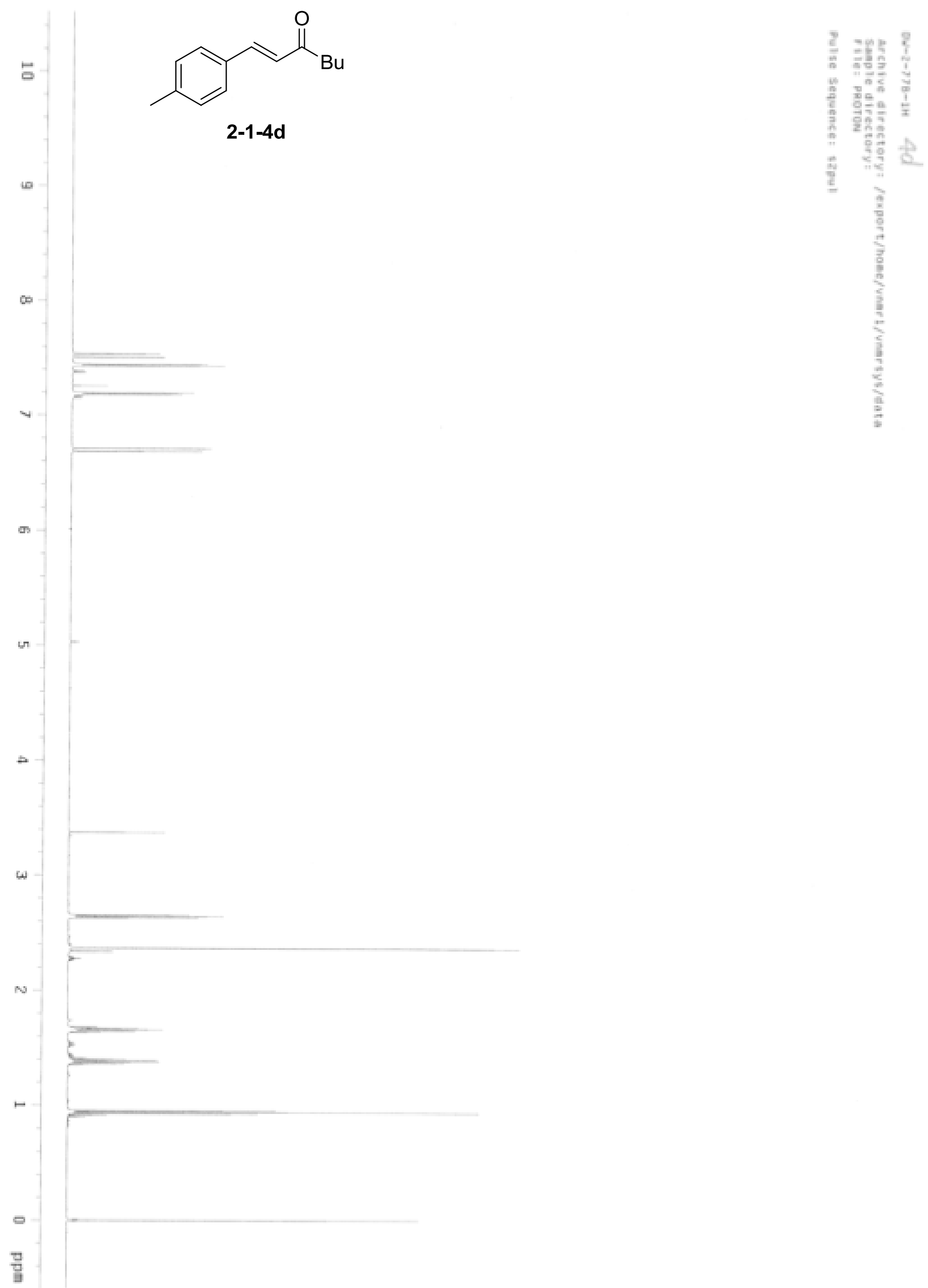


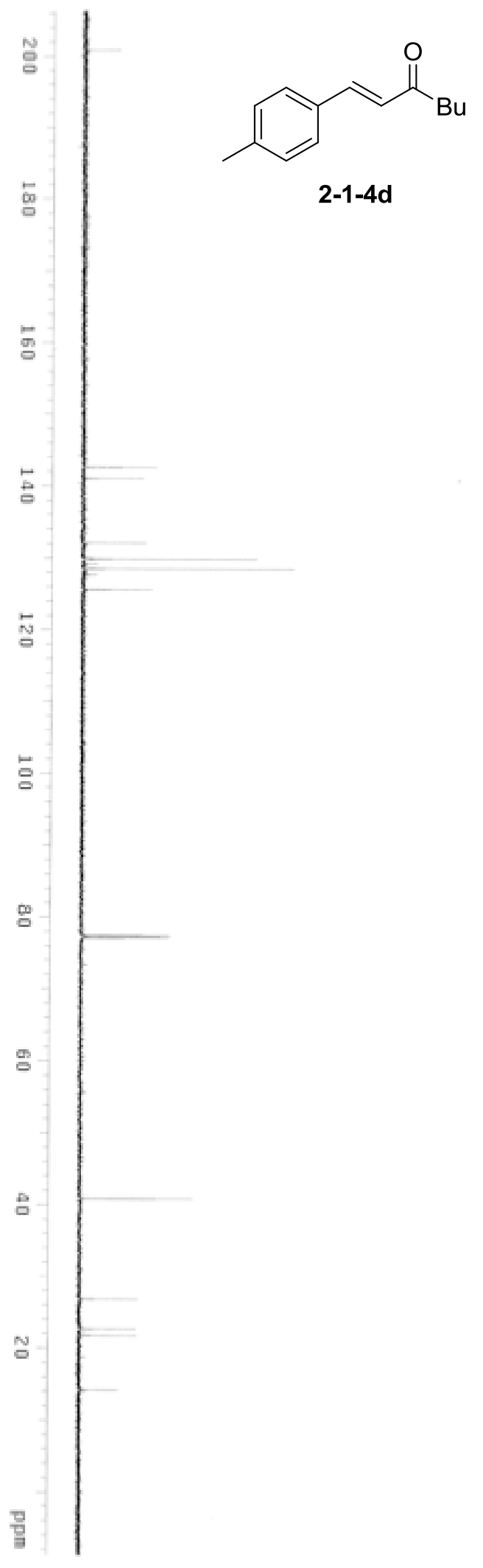

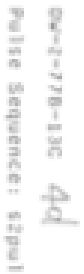



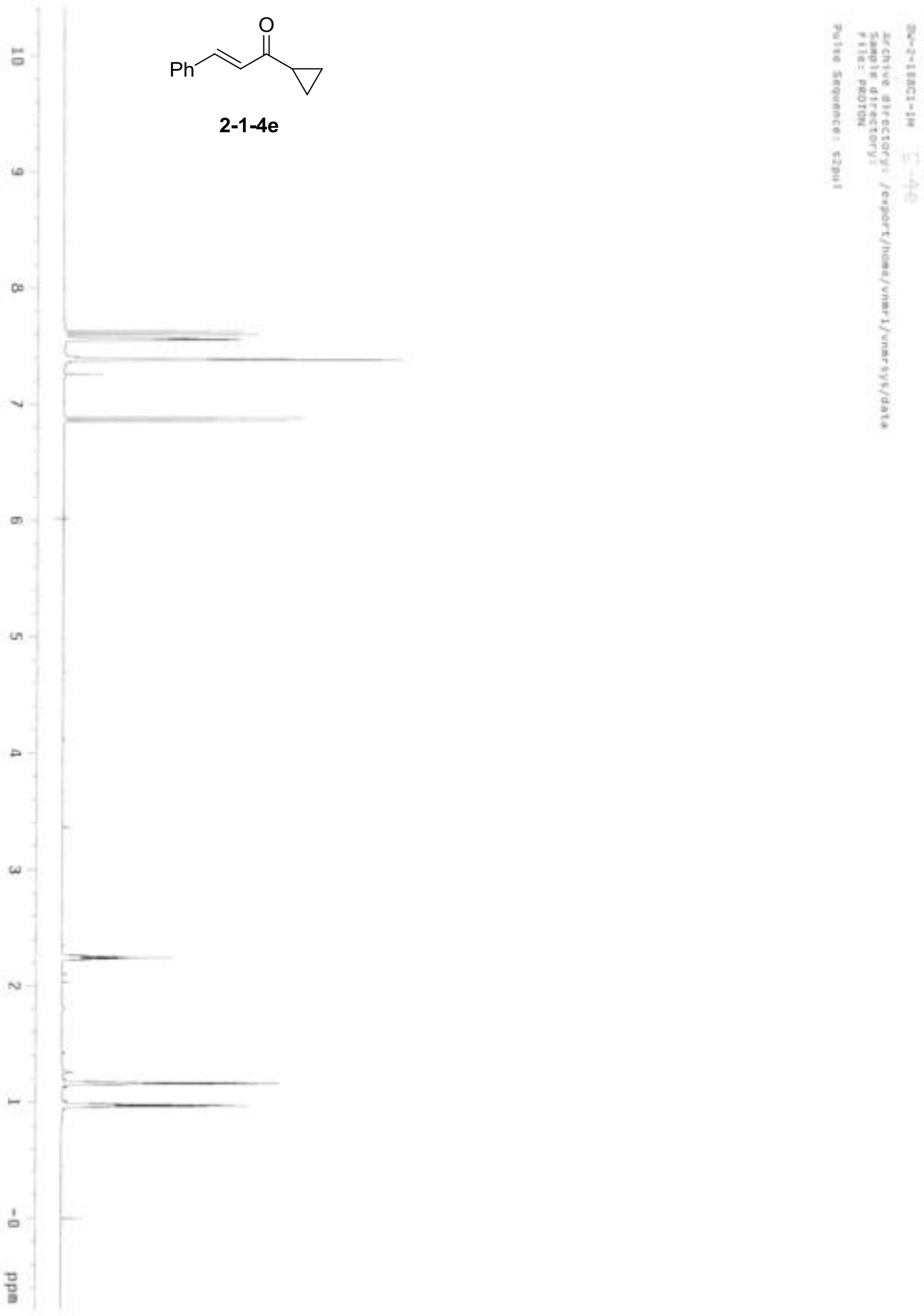


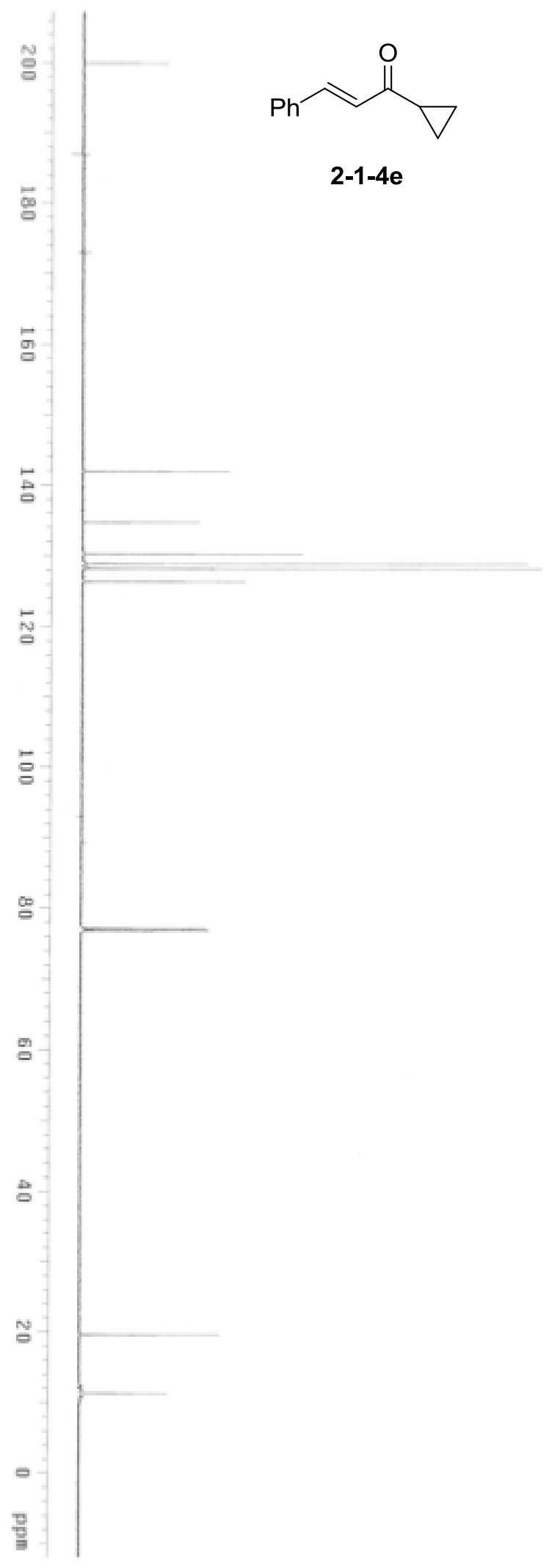

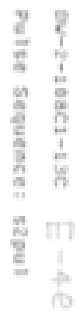



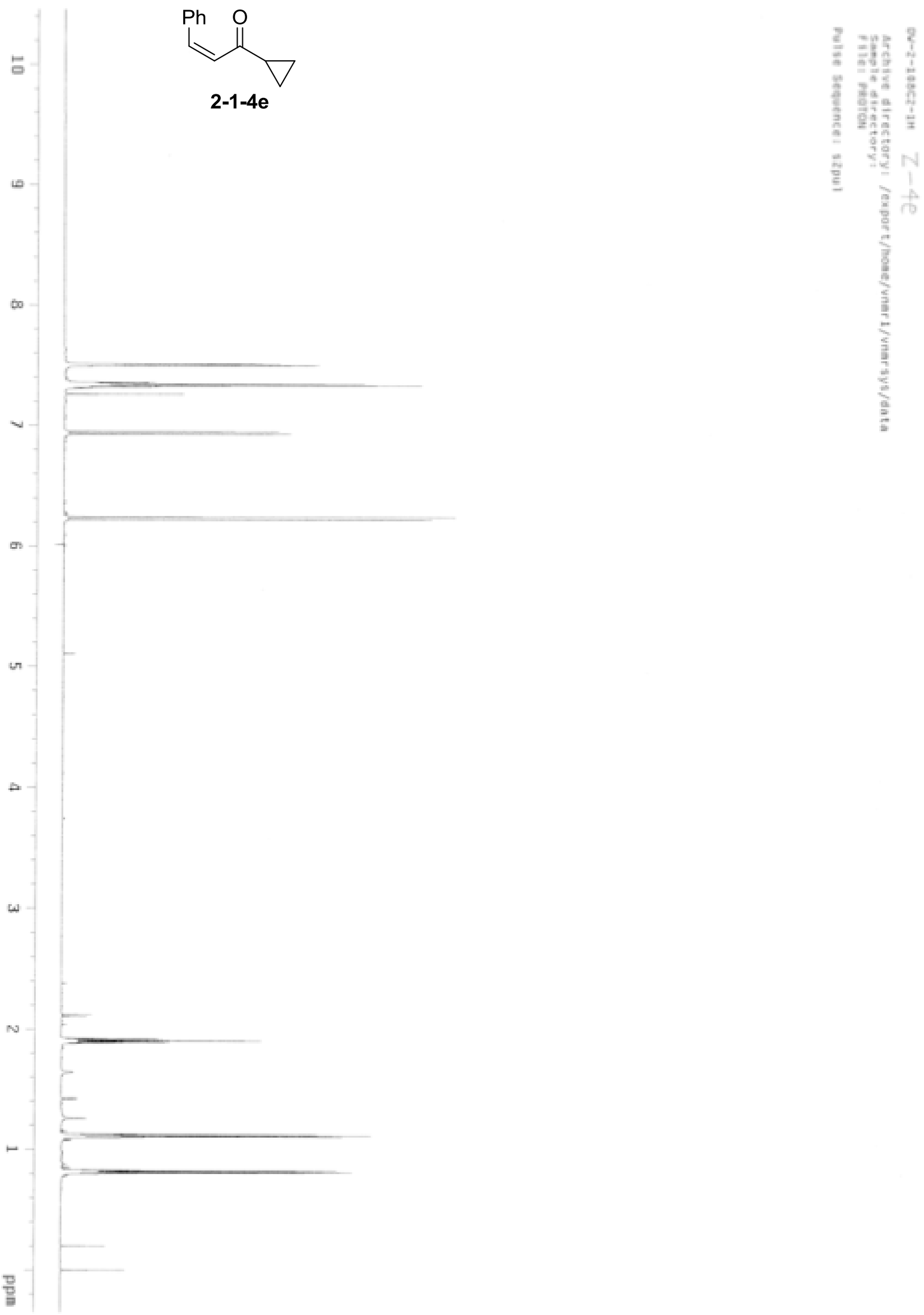

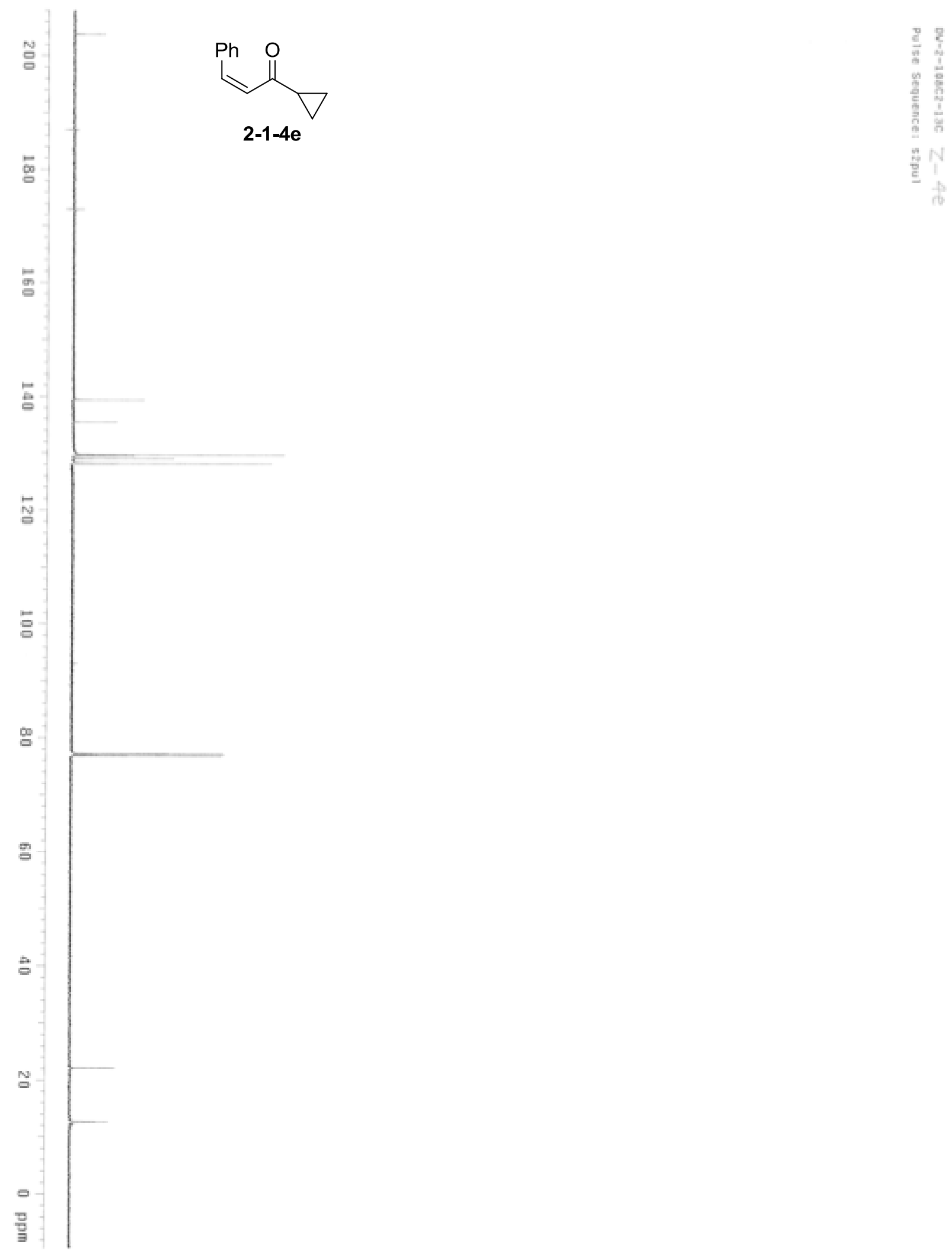

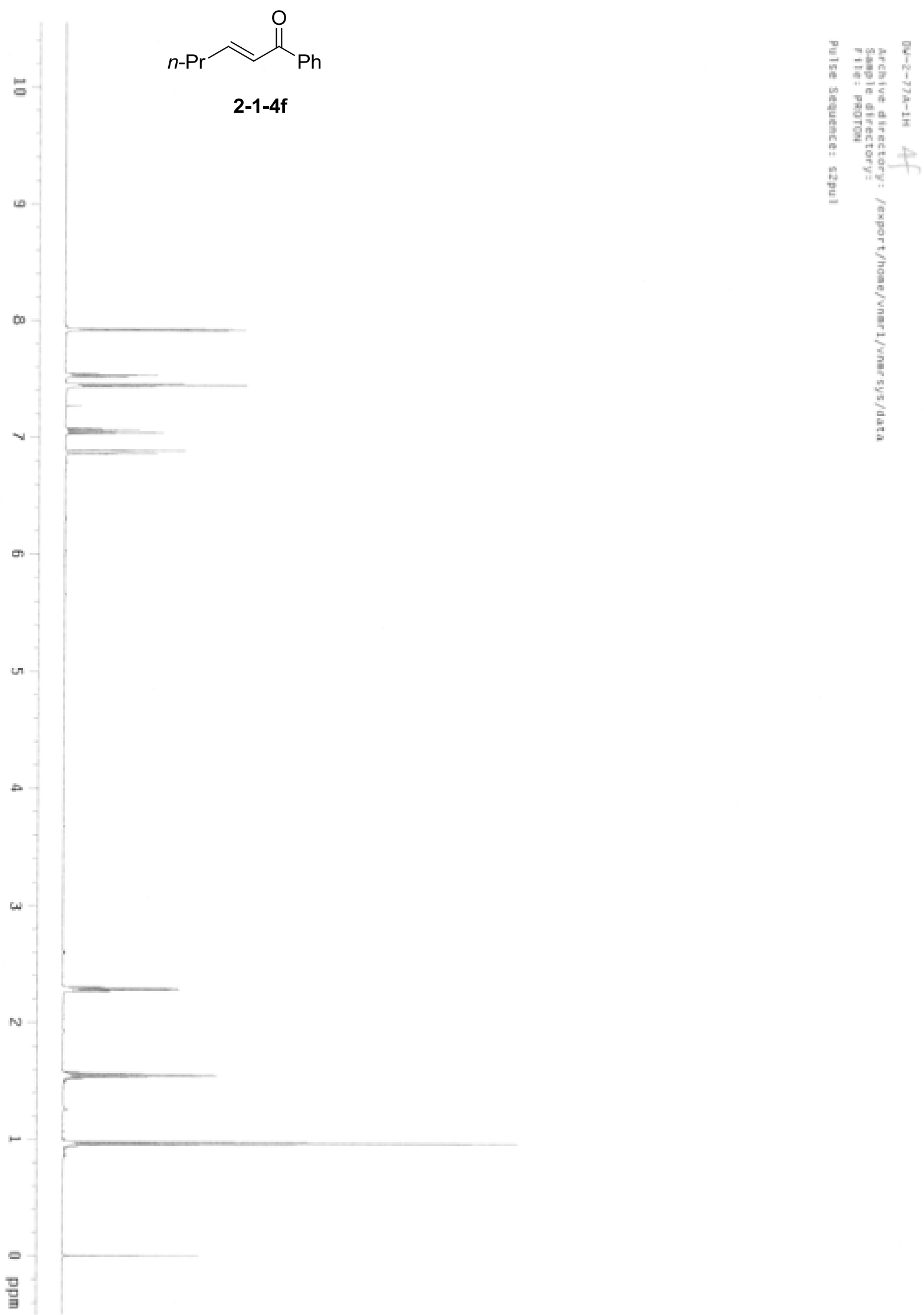

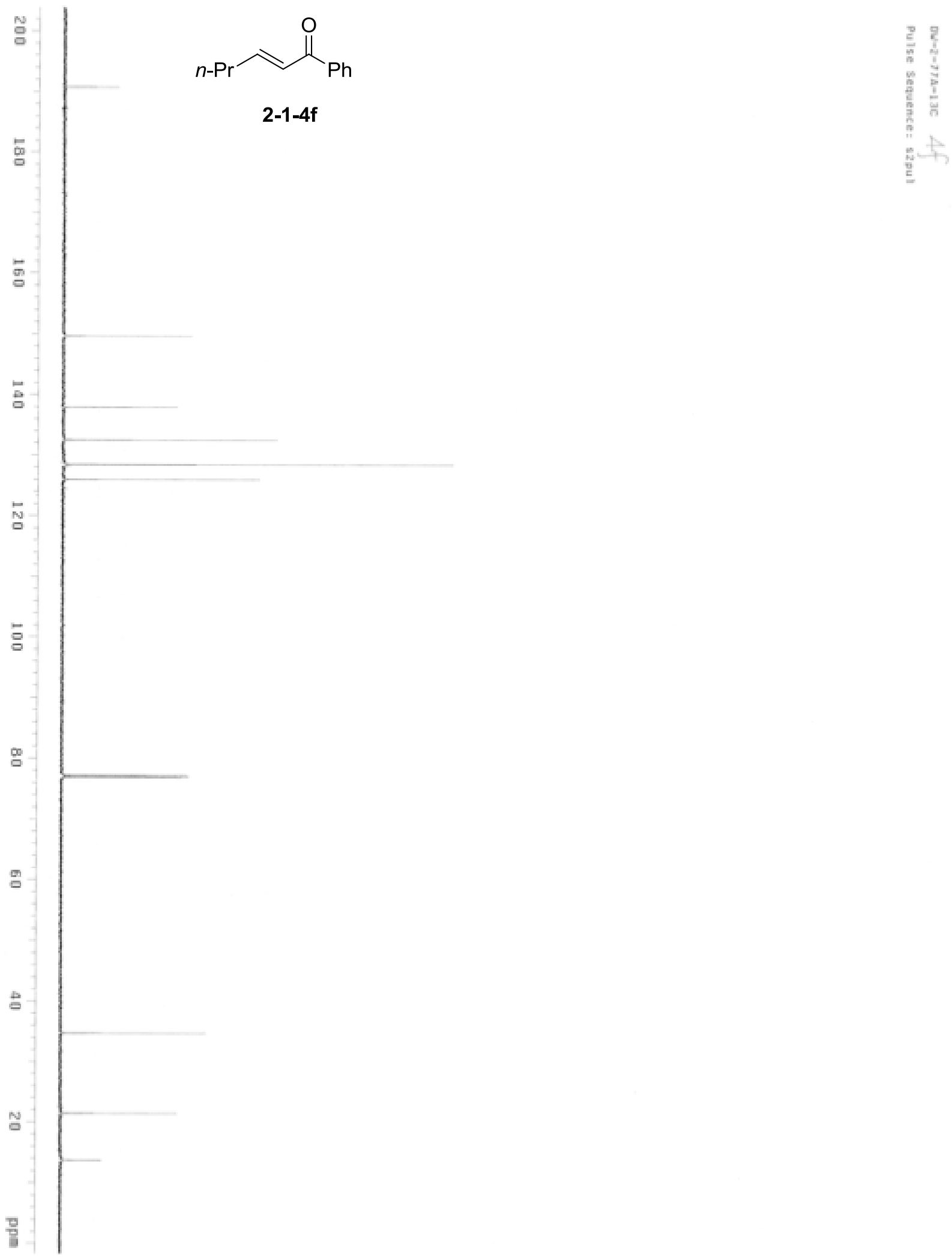

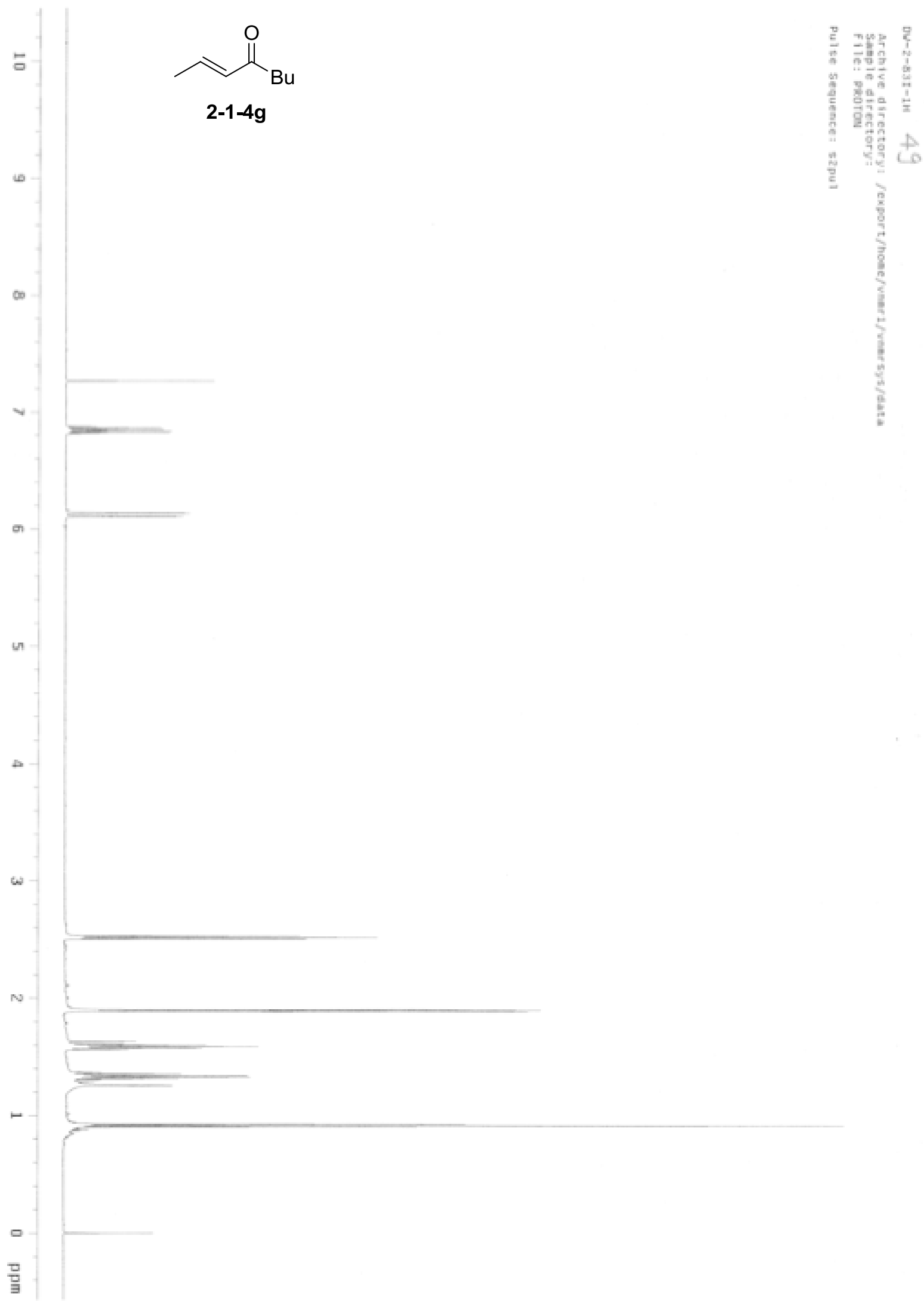


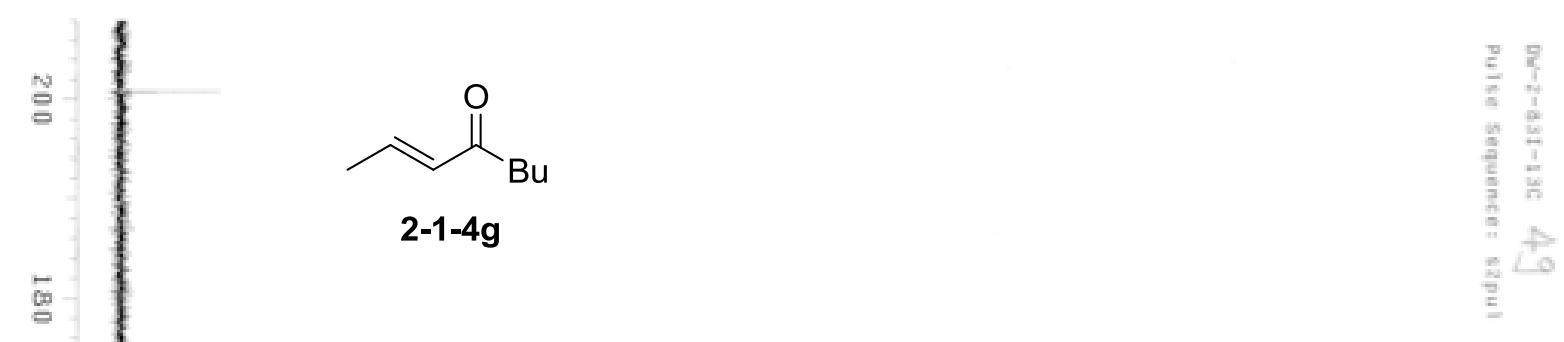

$\stackrel{\infty}{\circ}$

a

$\stackrel{5}{\circ}$

흠

g

i

.

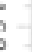

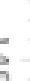

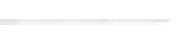

1

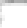




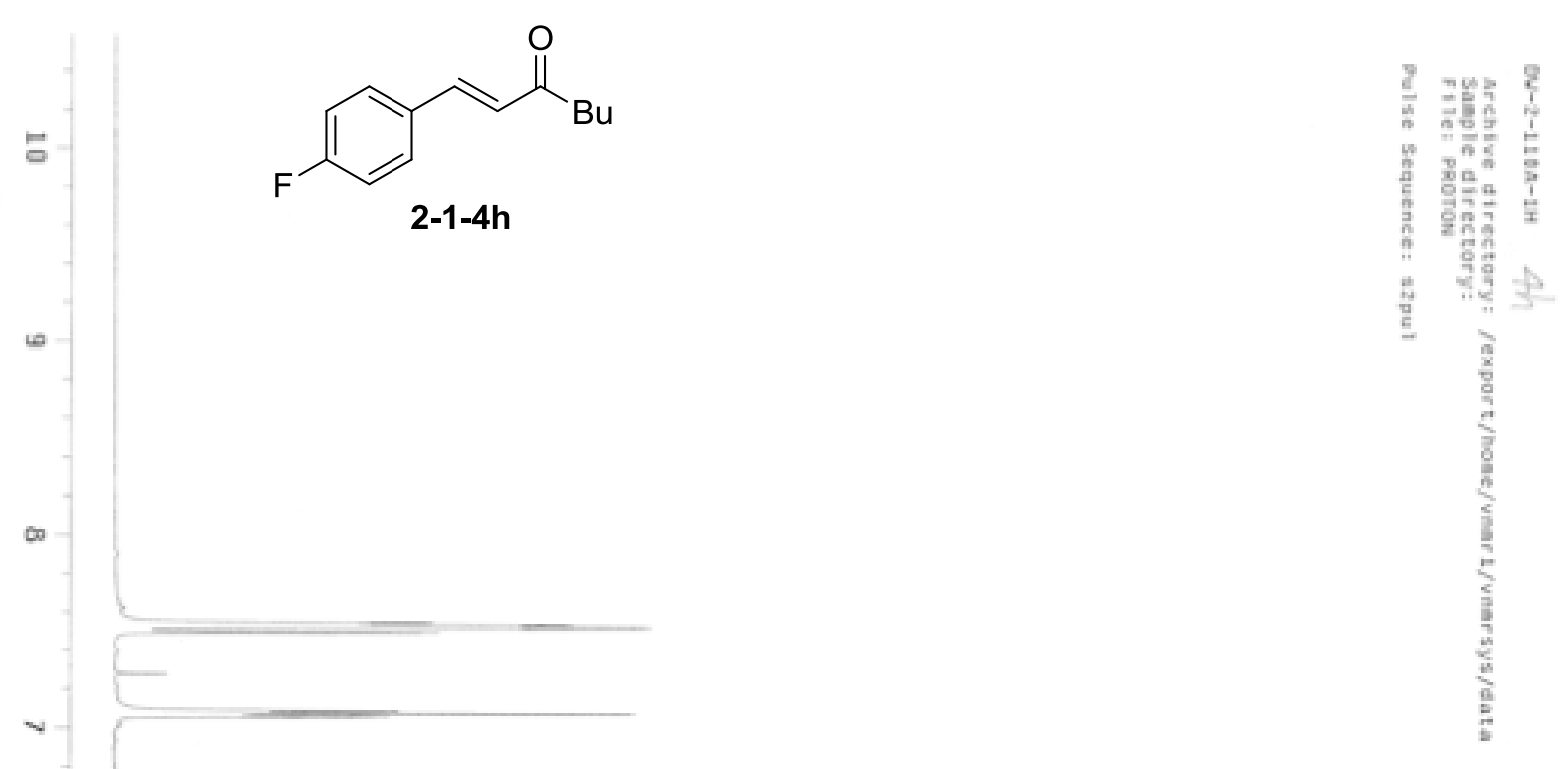

o

v

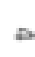

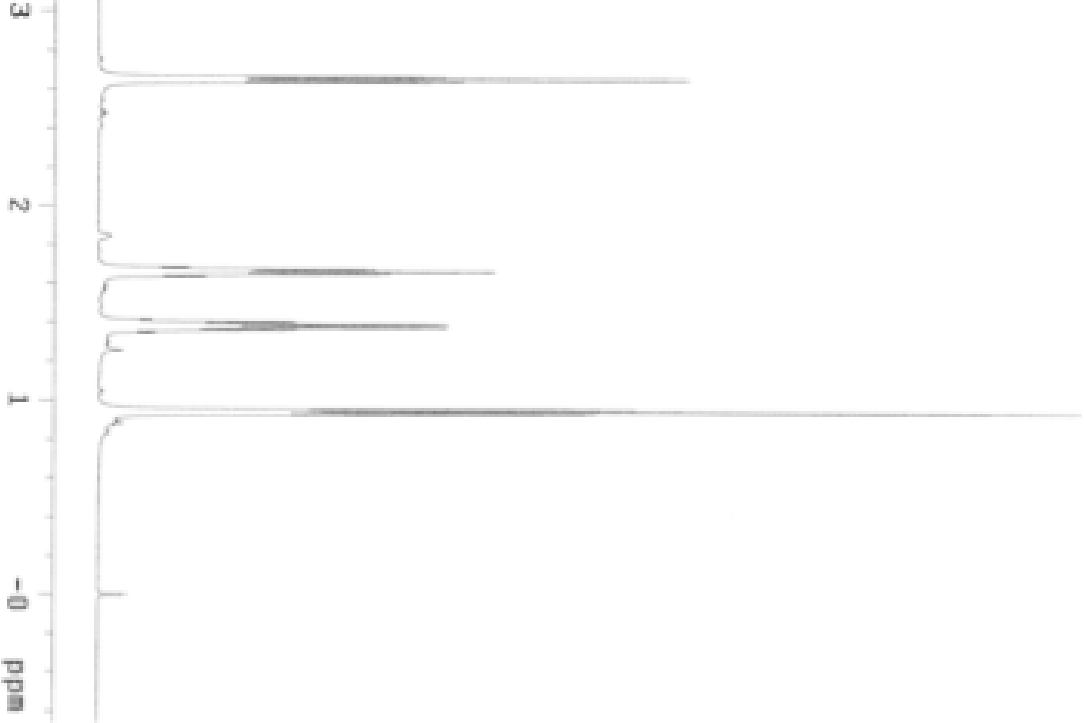




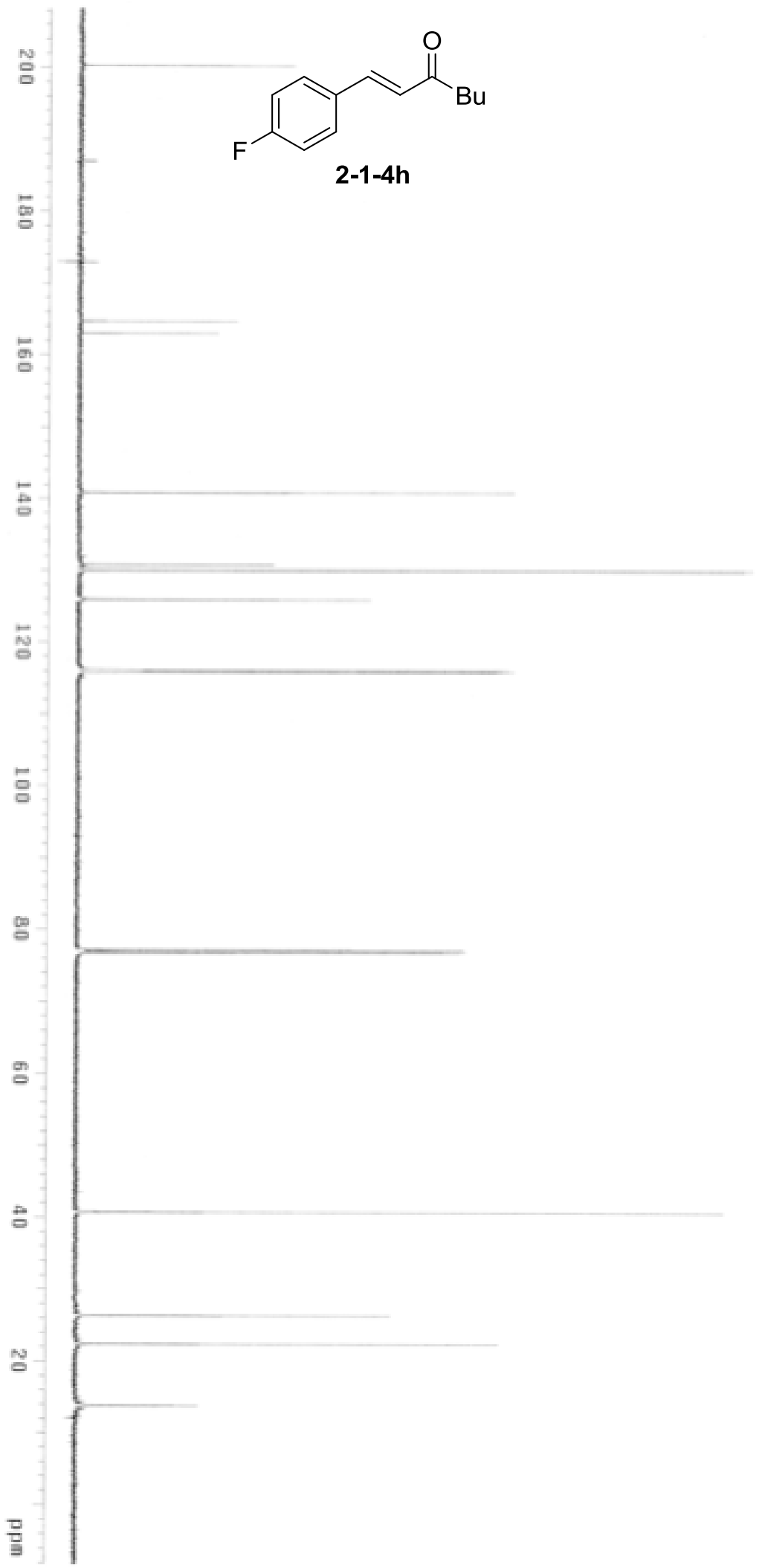



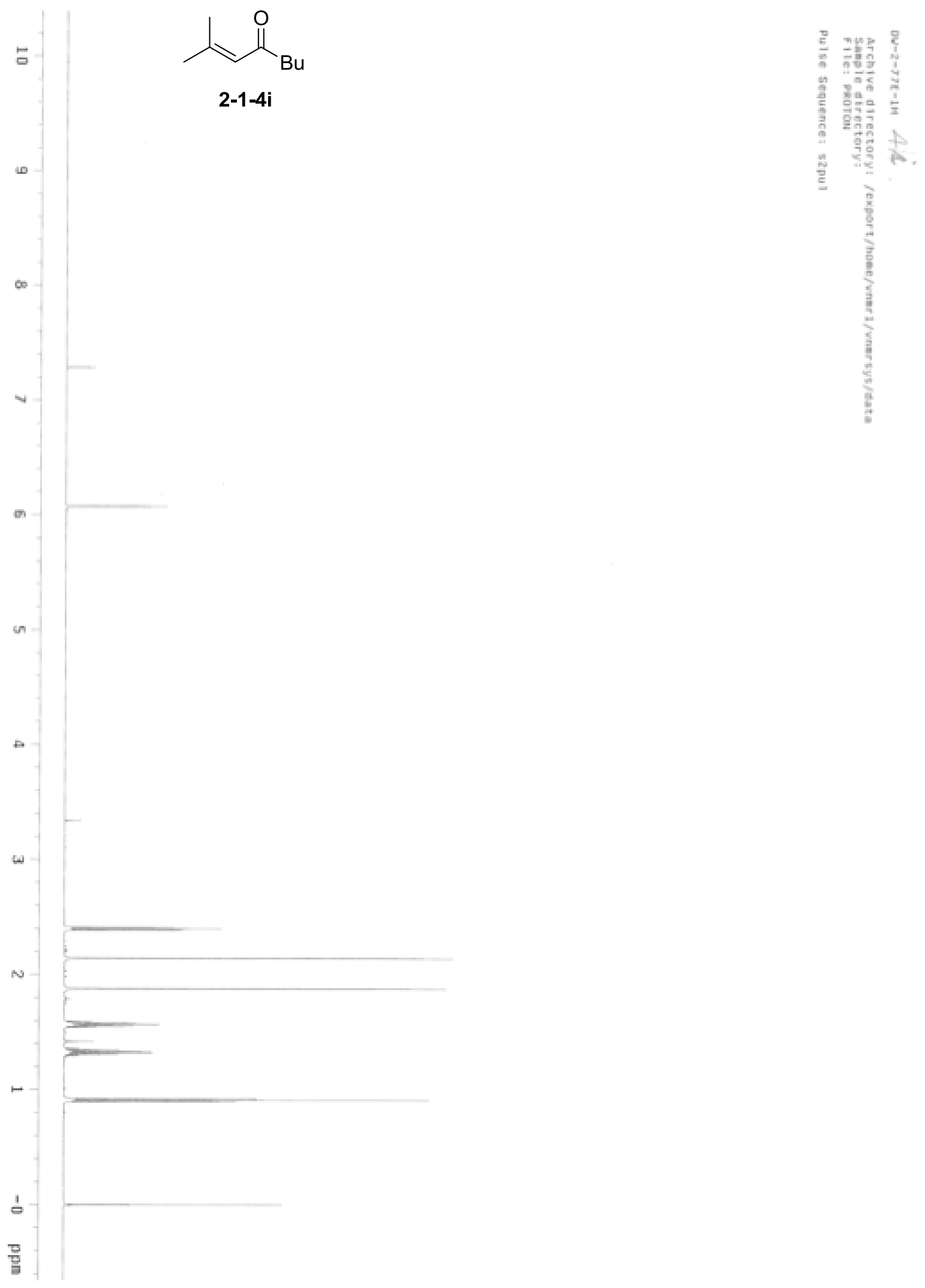


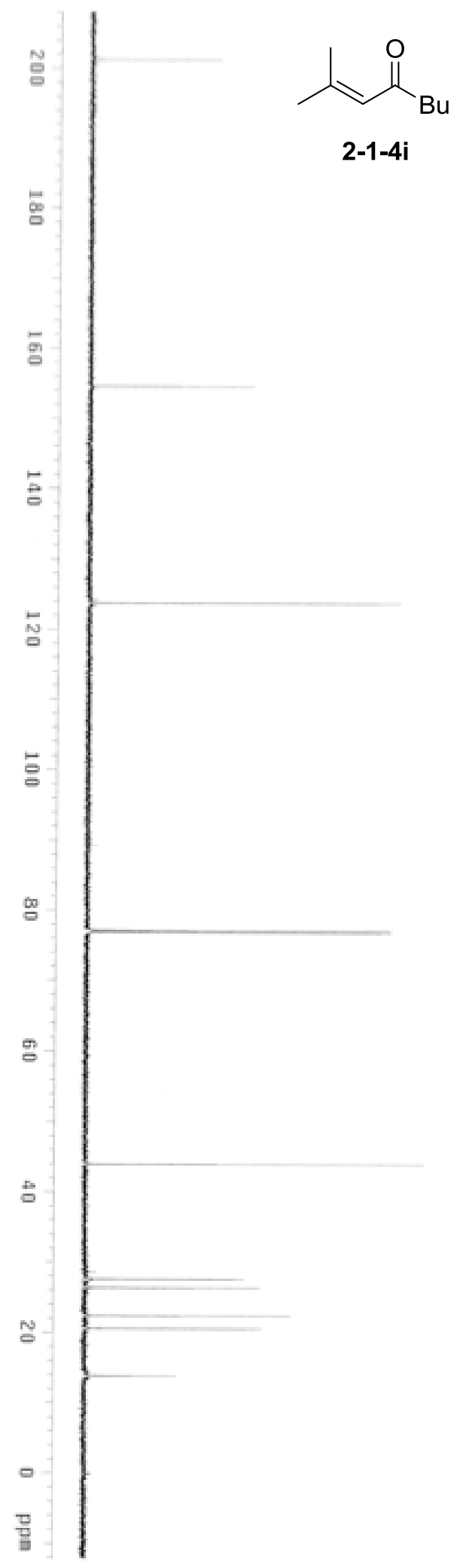

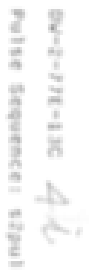




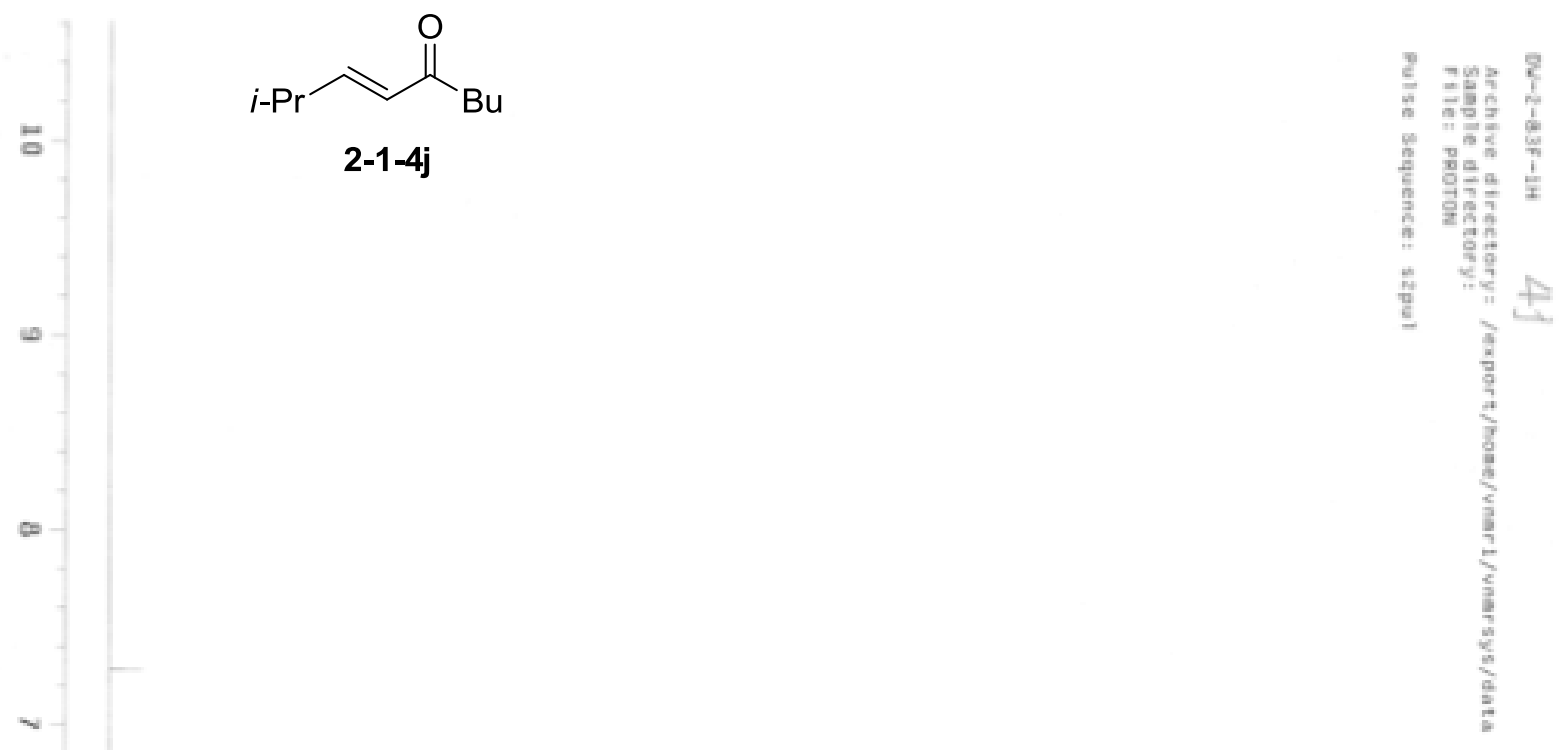




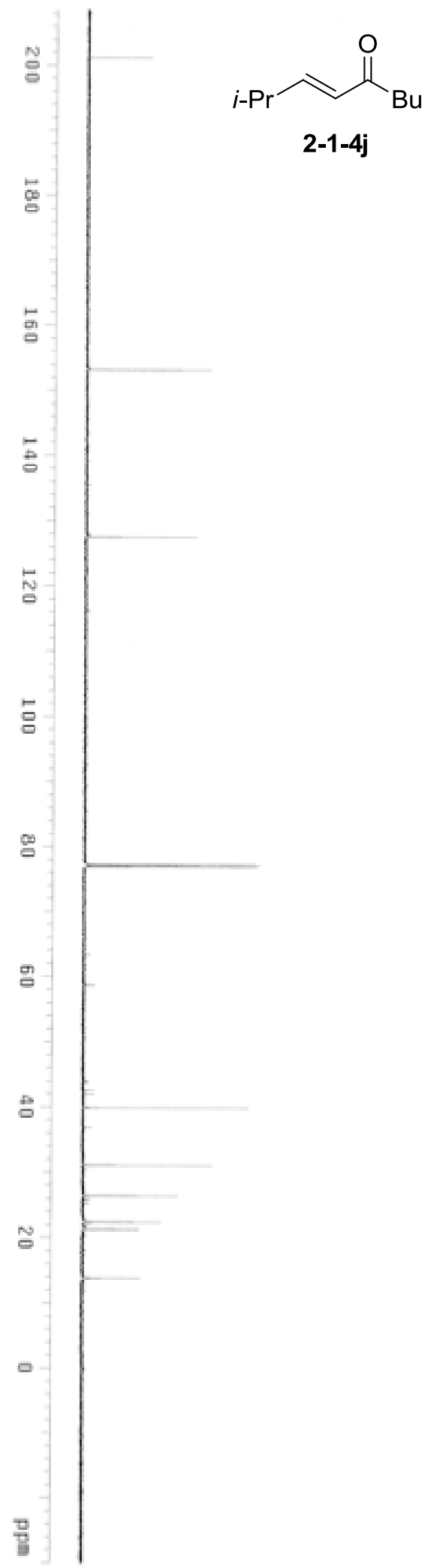



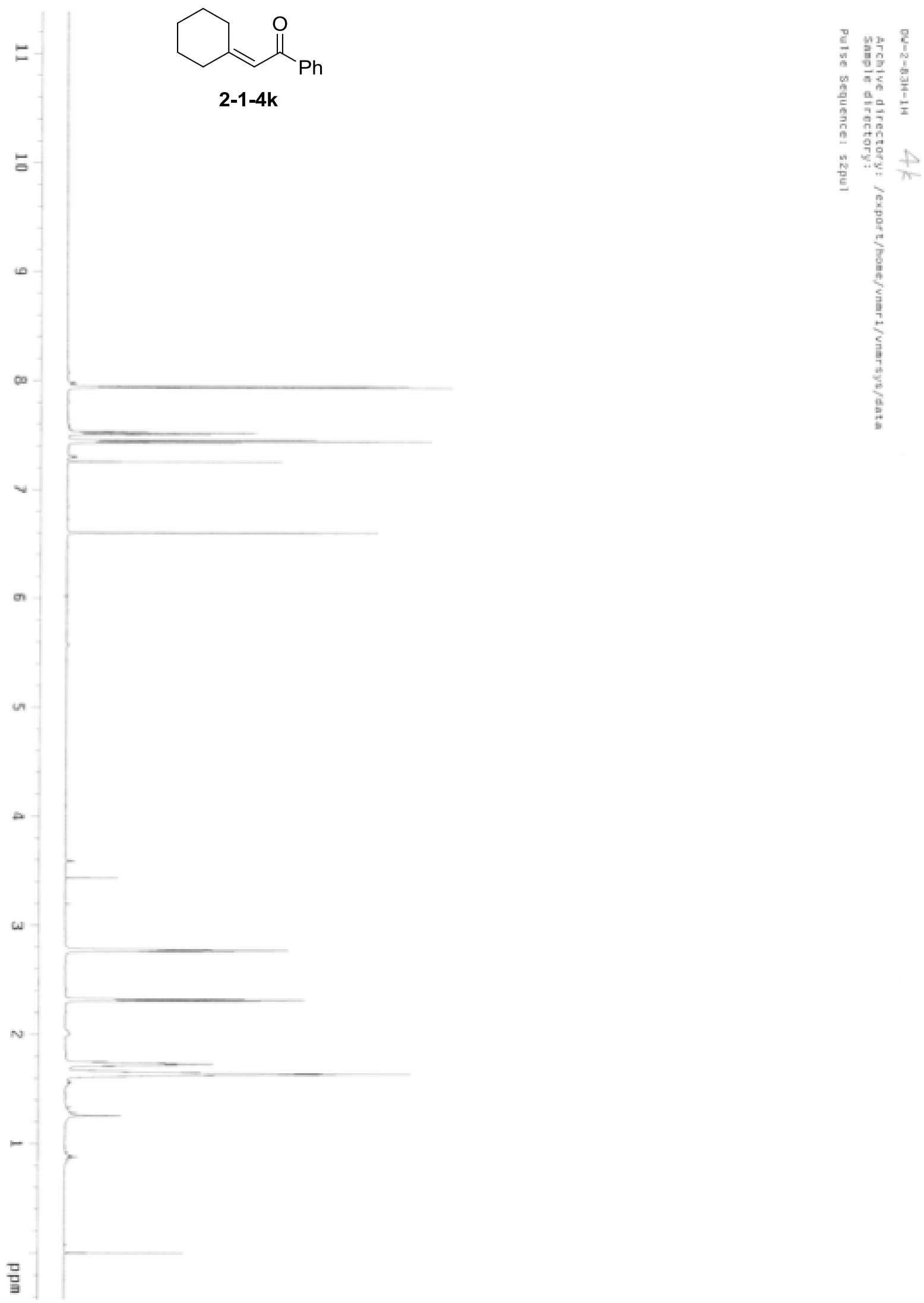

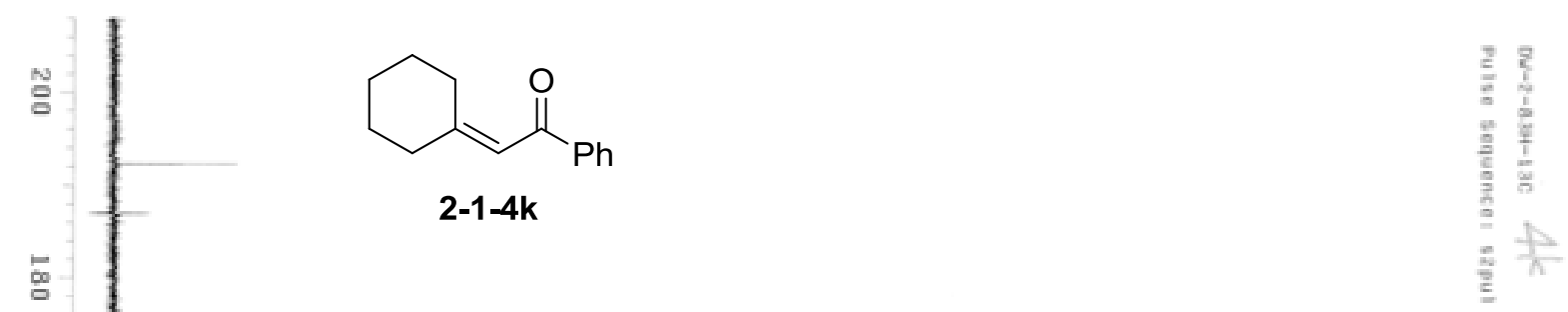

ฌ

g

อ

a

:

음

5

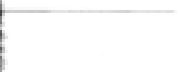

6

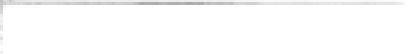

.

3

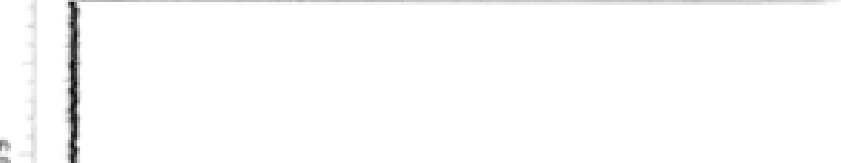

음 

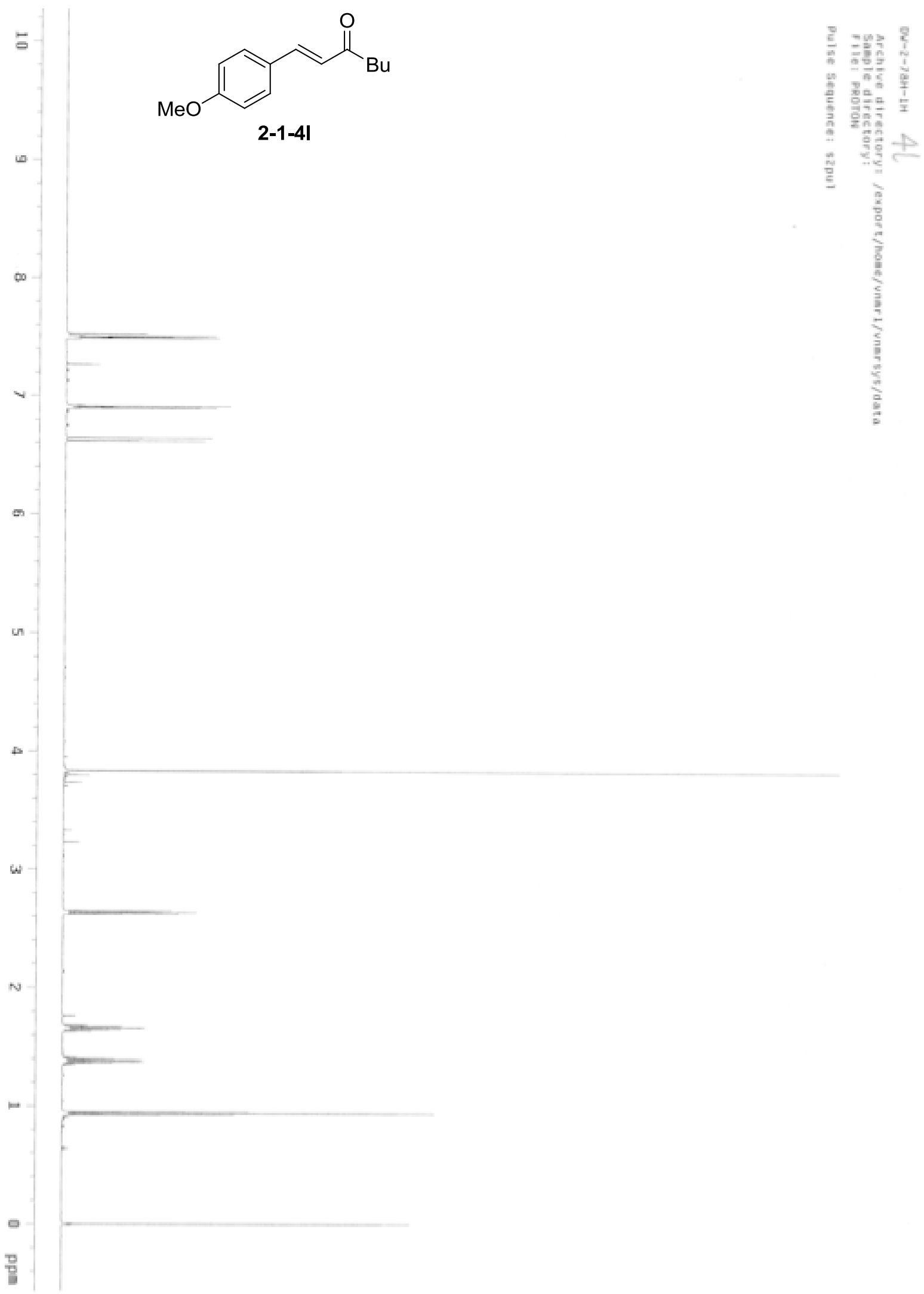

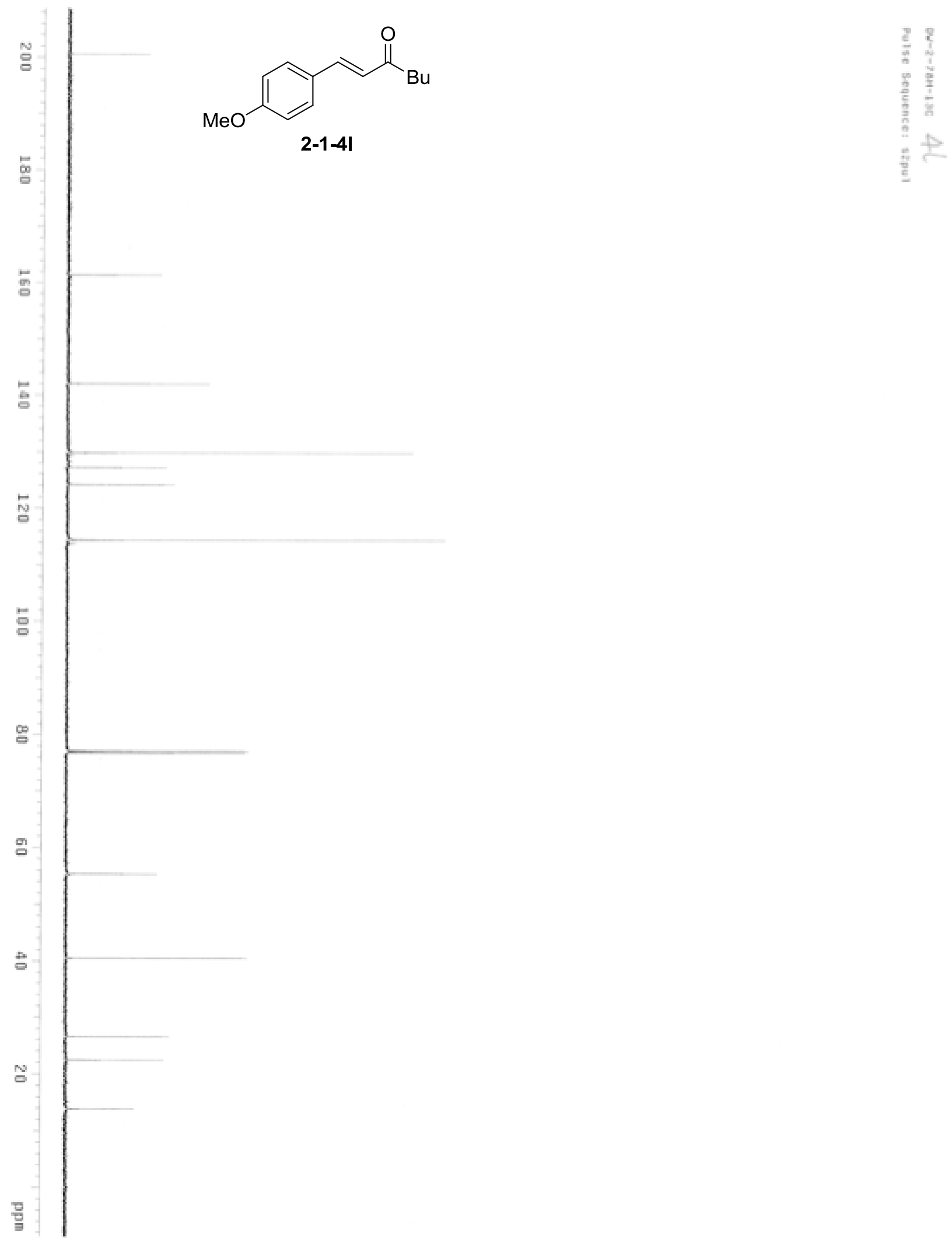


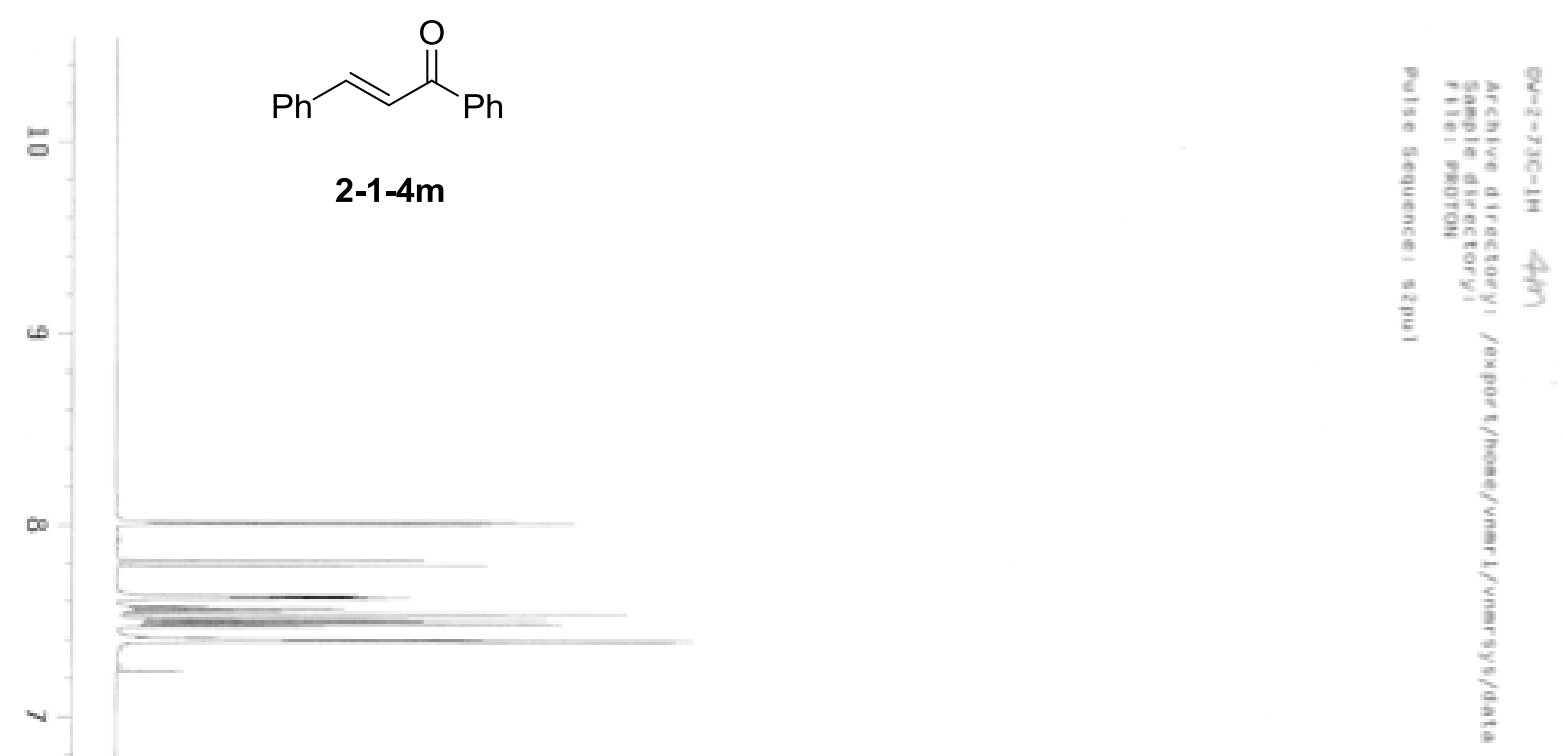

.

क

un

$\omega$

$N$

อ

름 


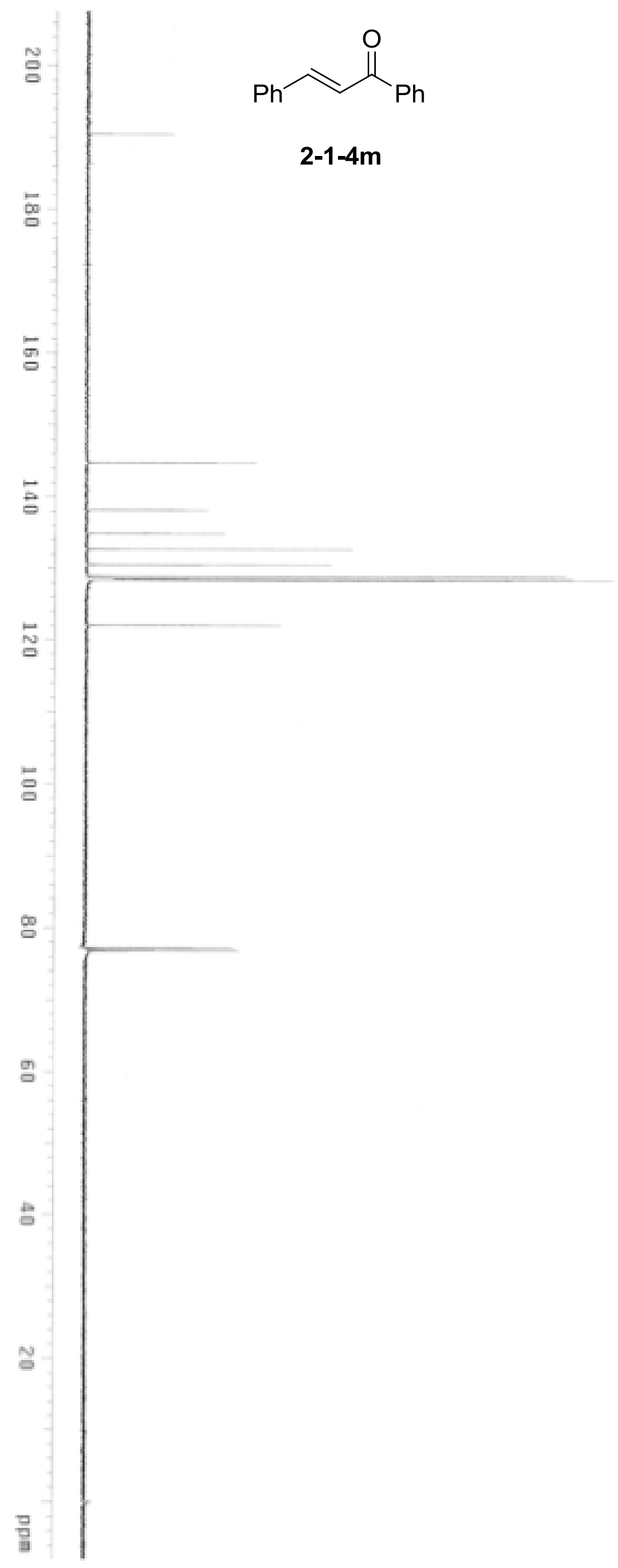

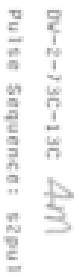



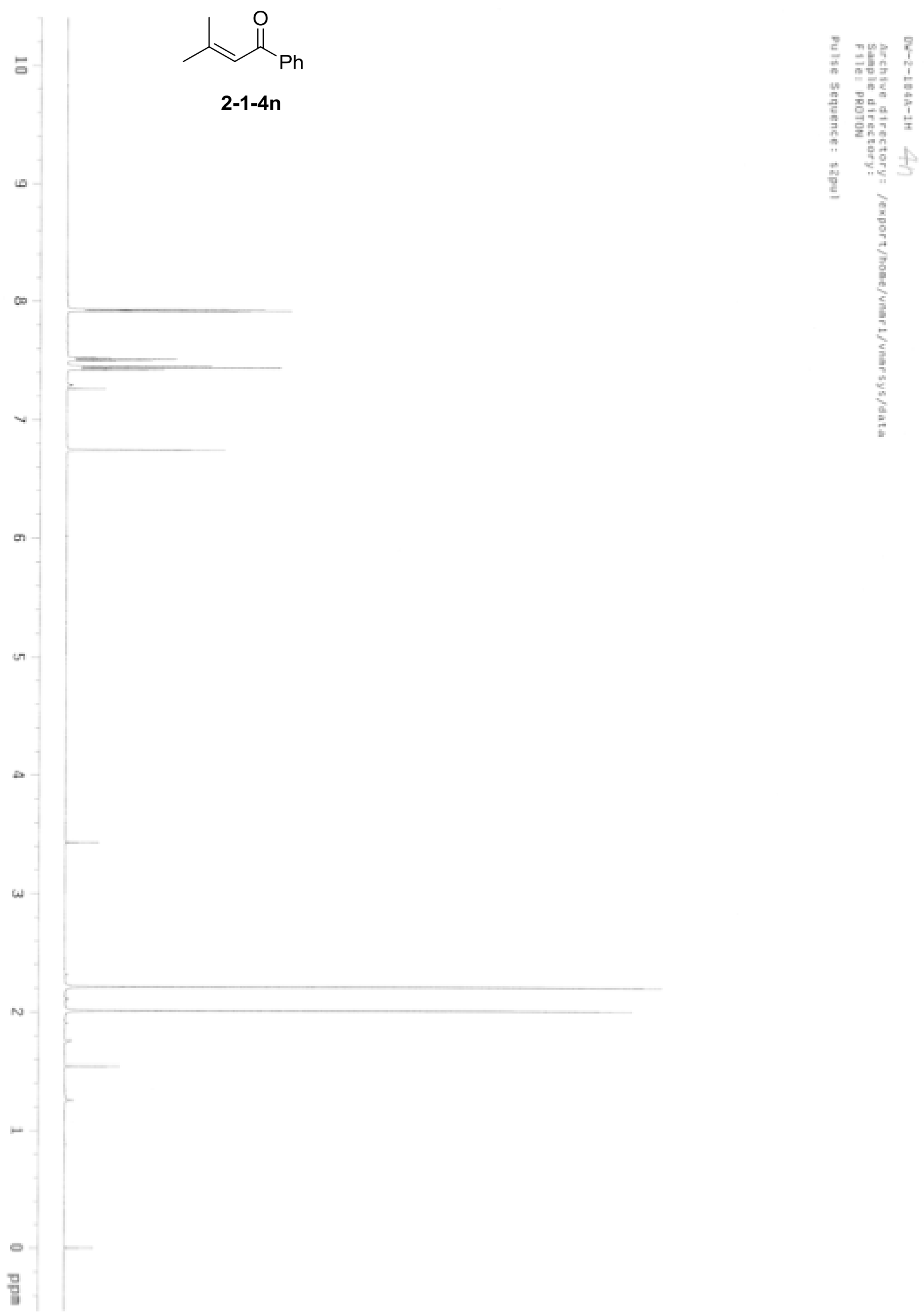


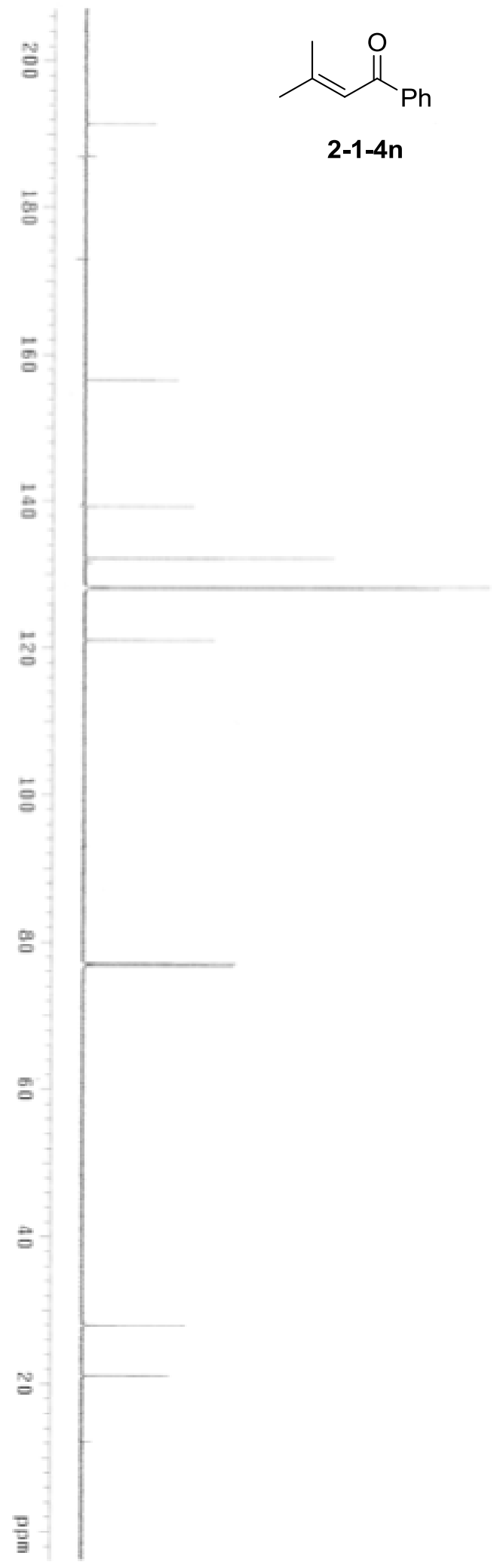

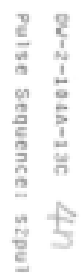



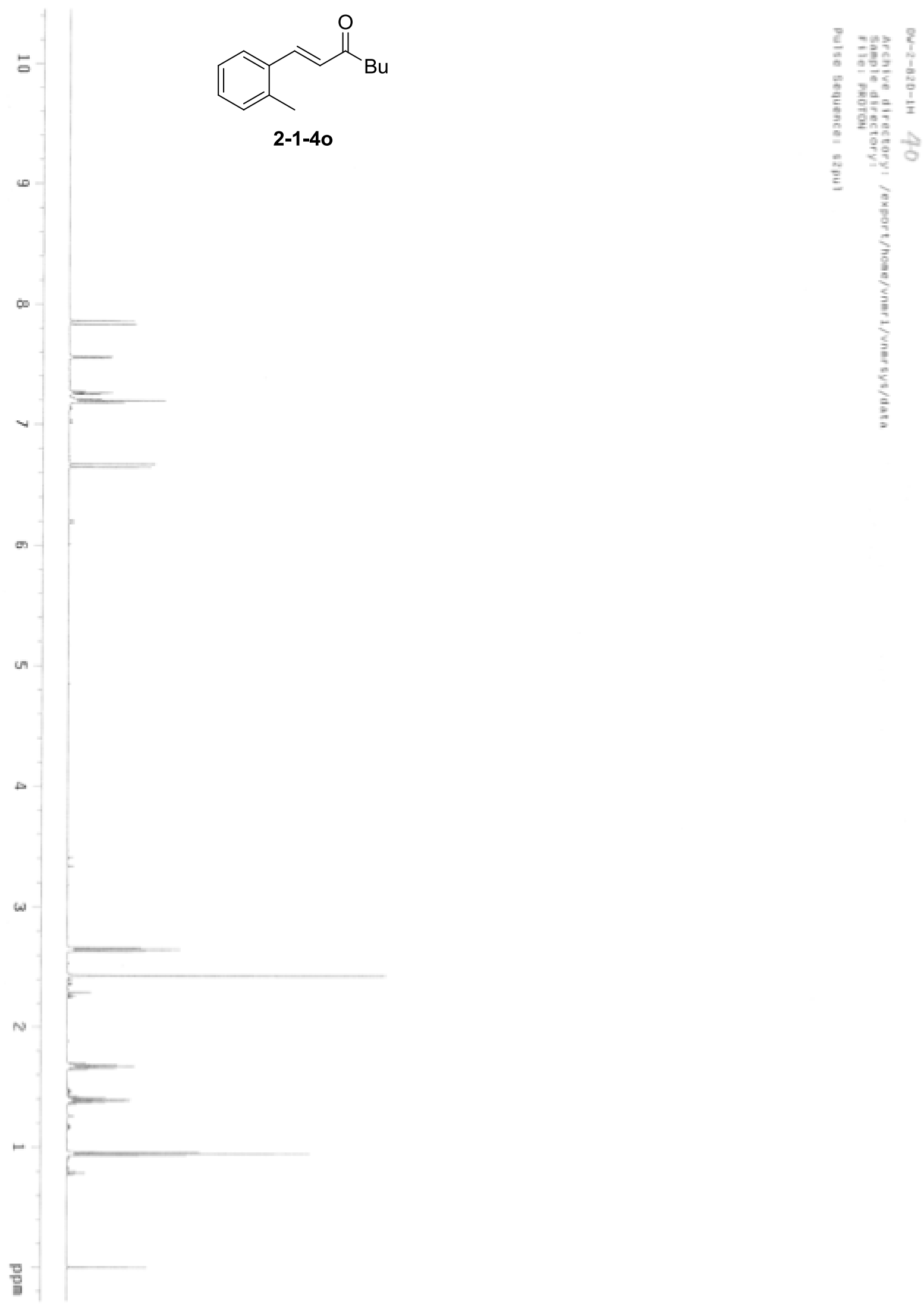


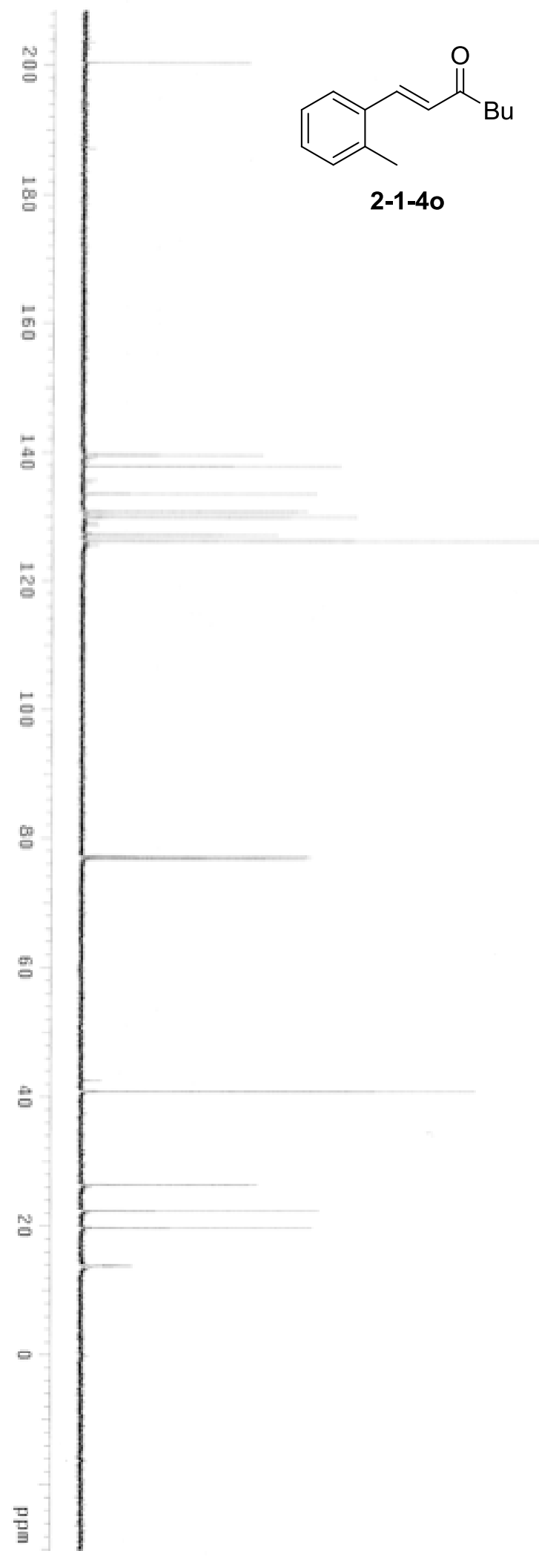




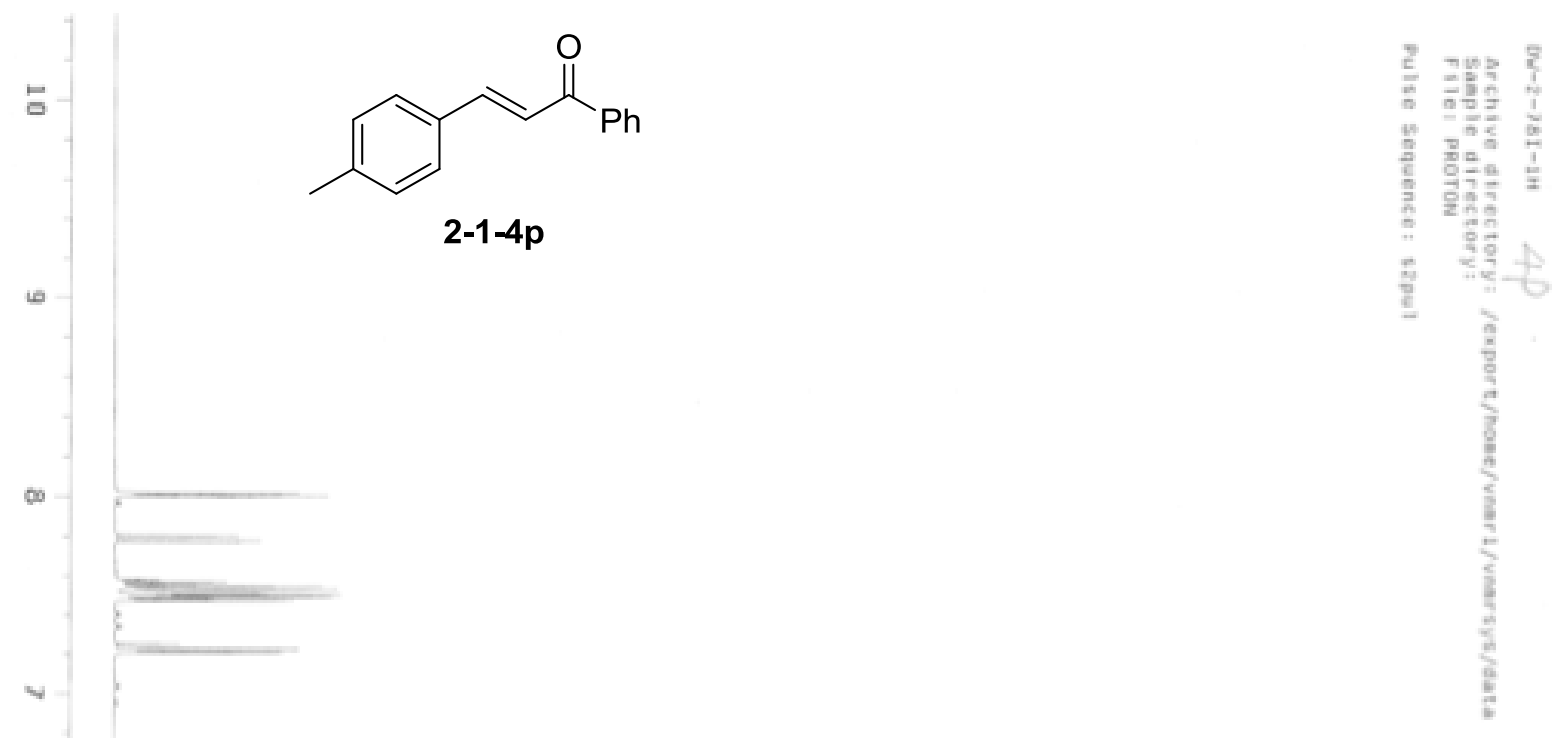

$\omega$

u

뭄 

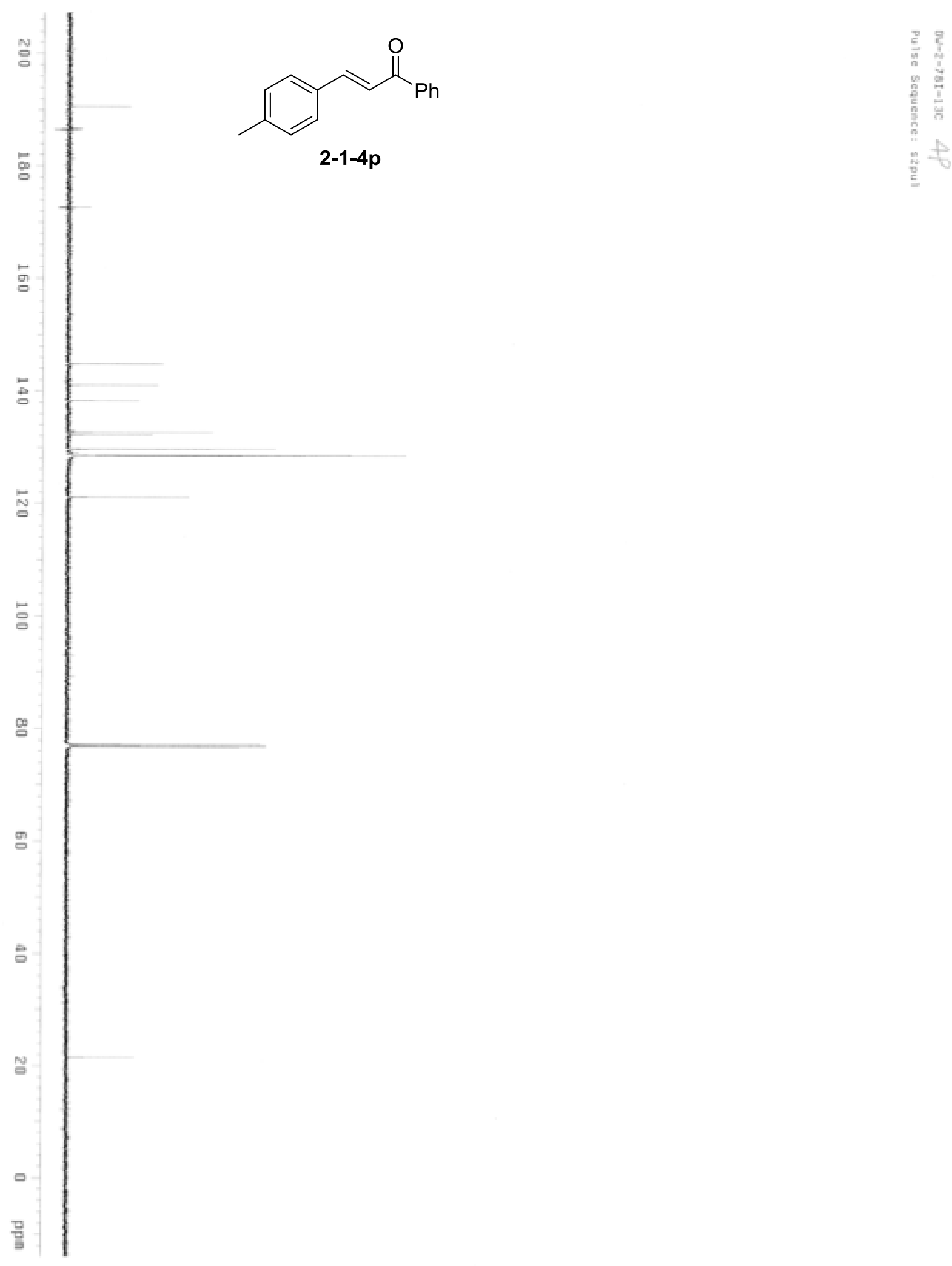

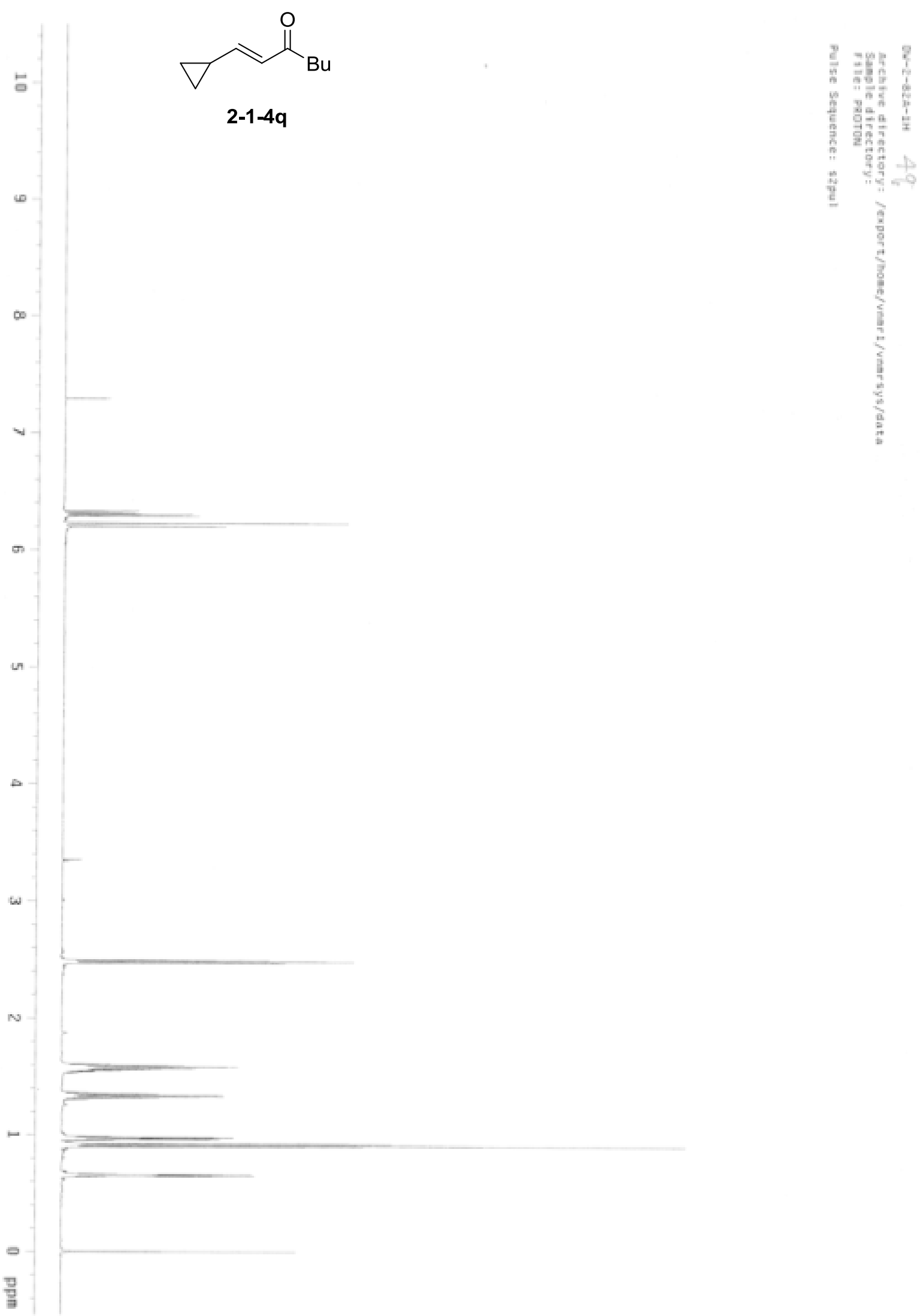

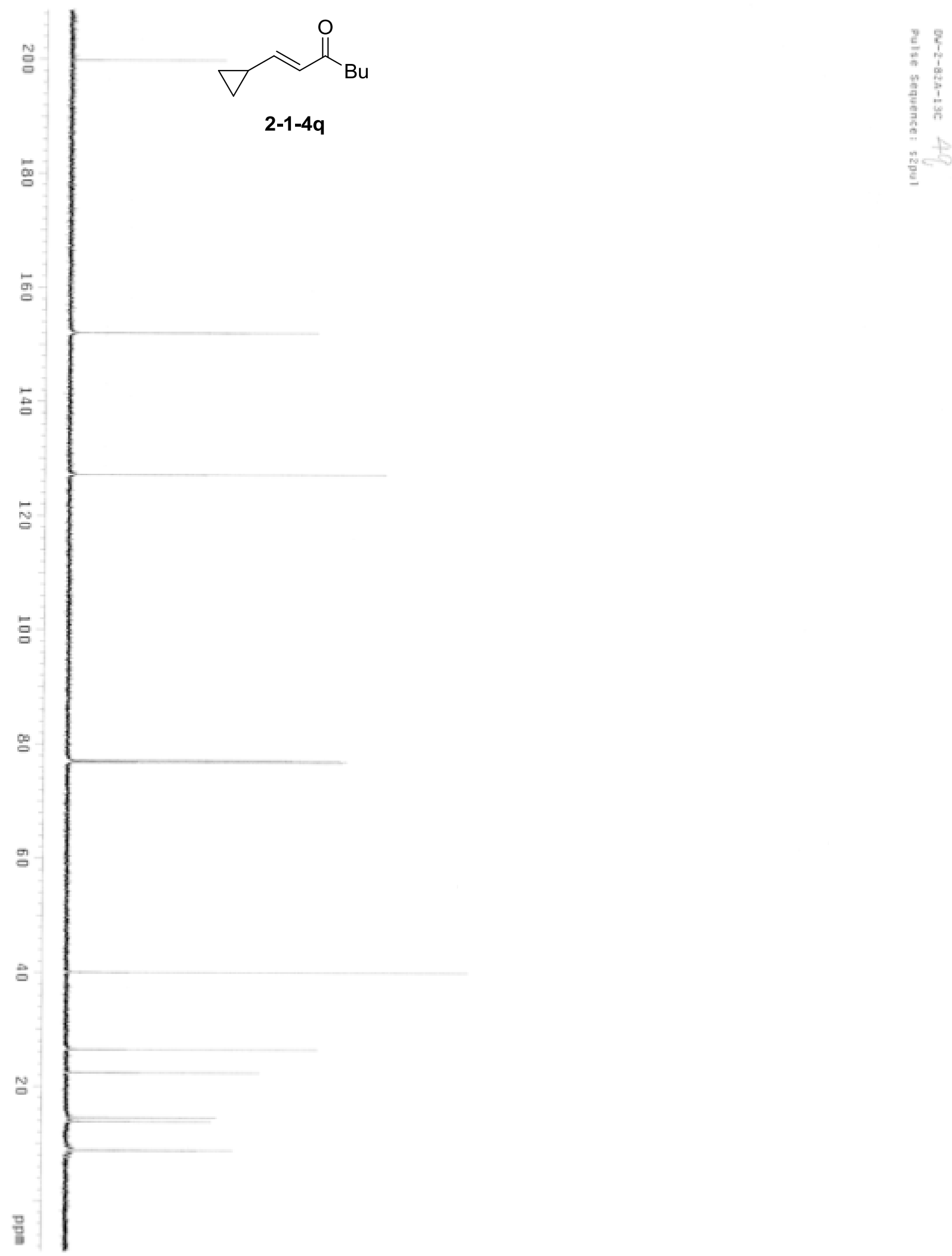

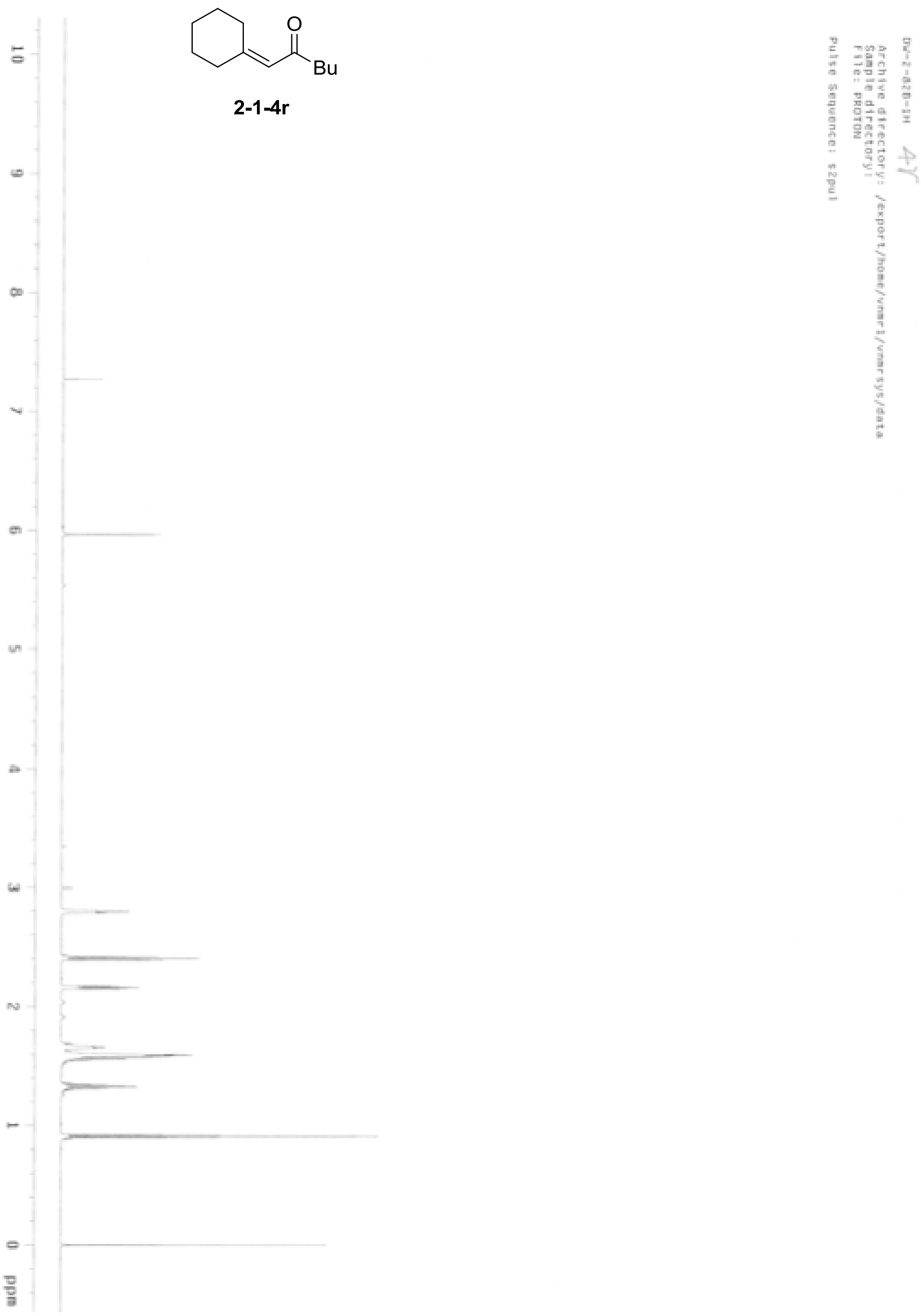


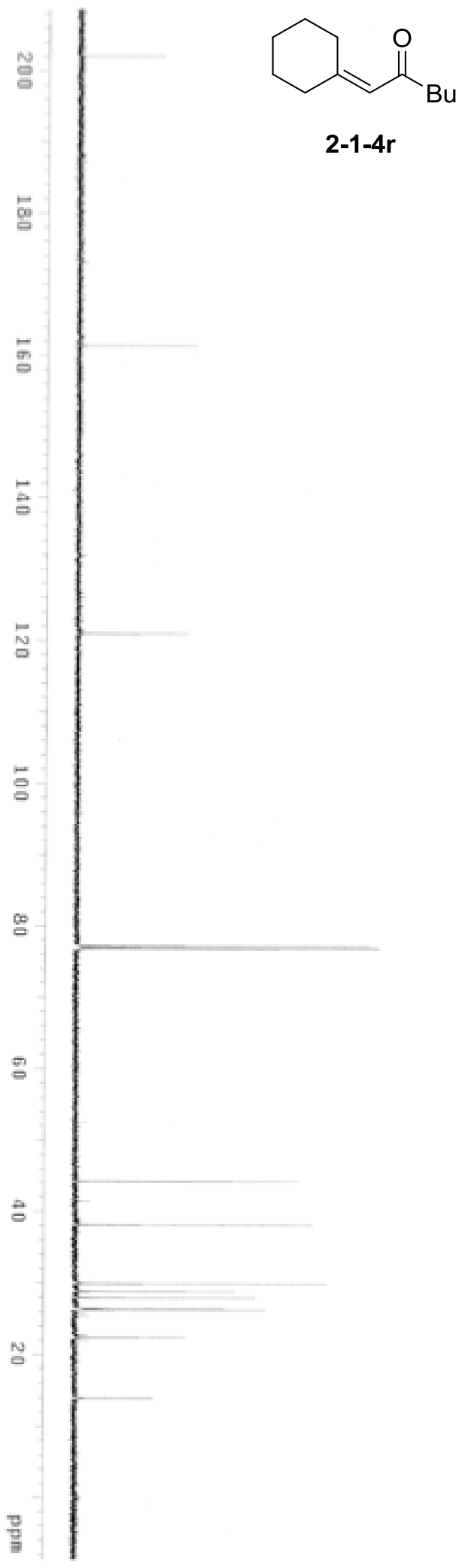




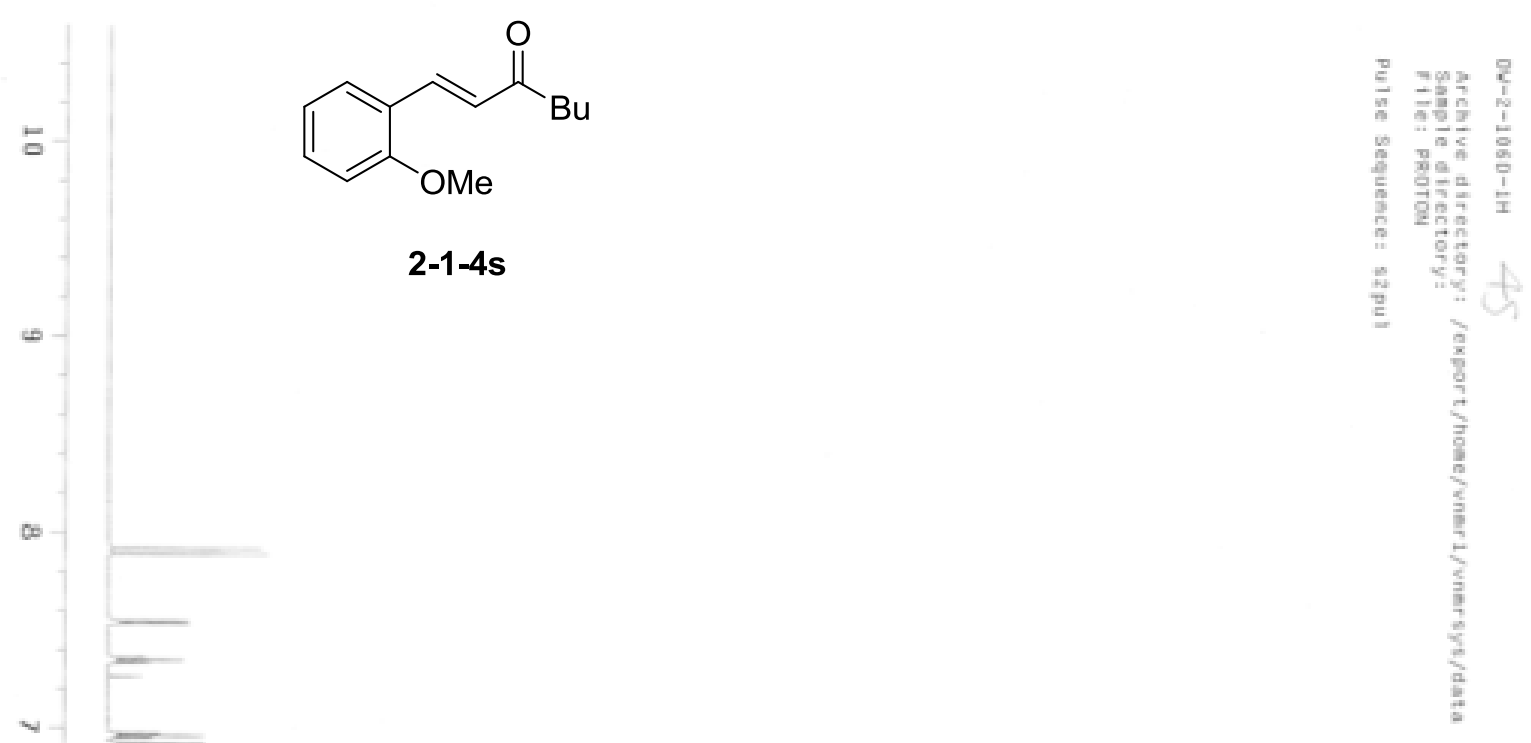

a.

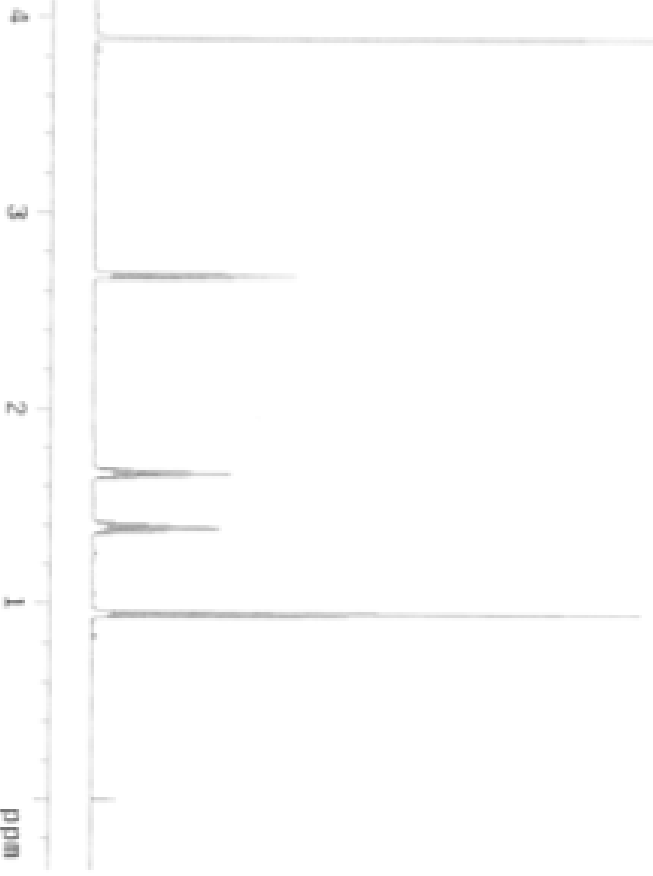




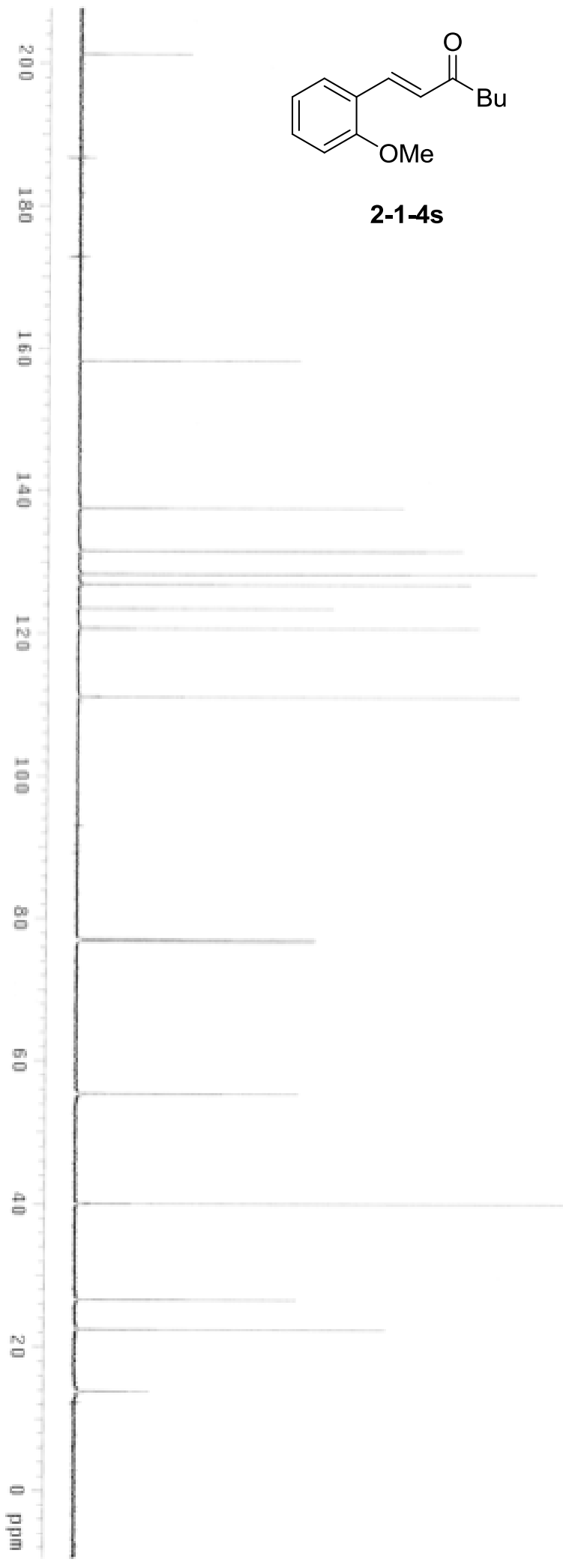




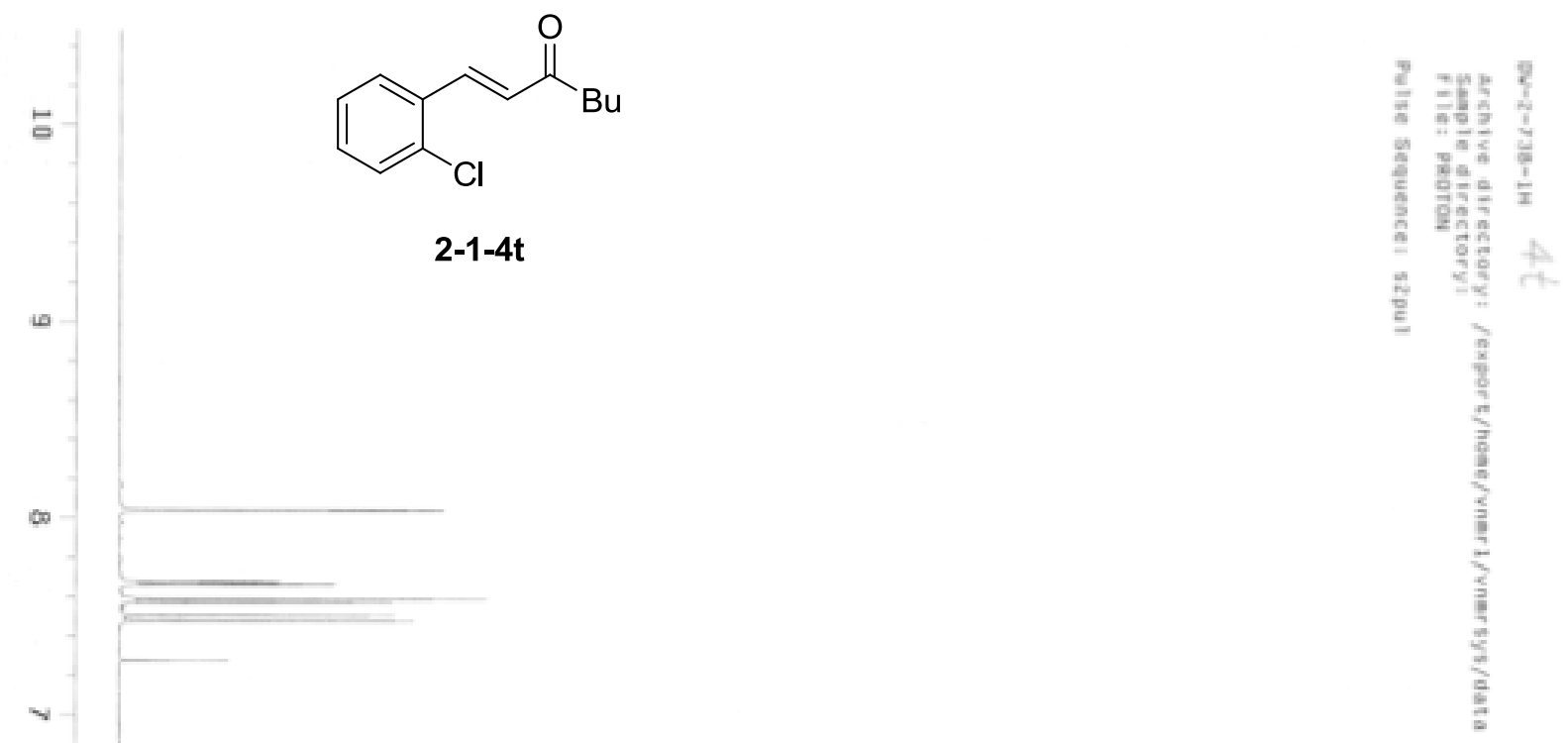

뭅

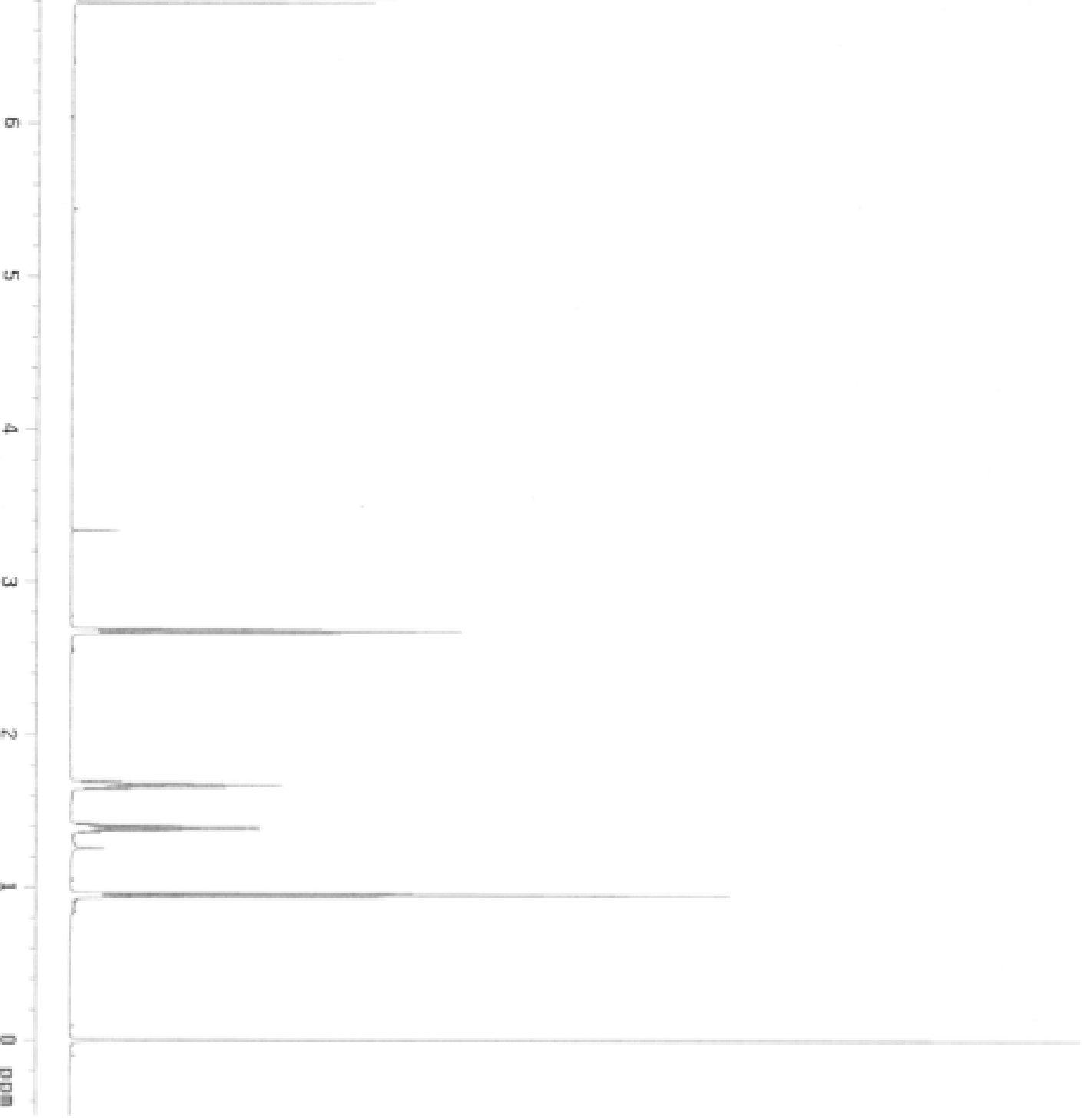




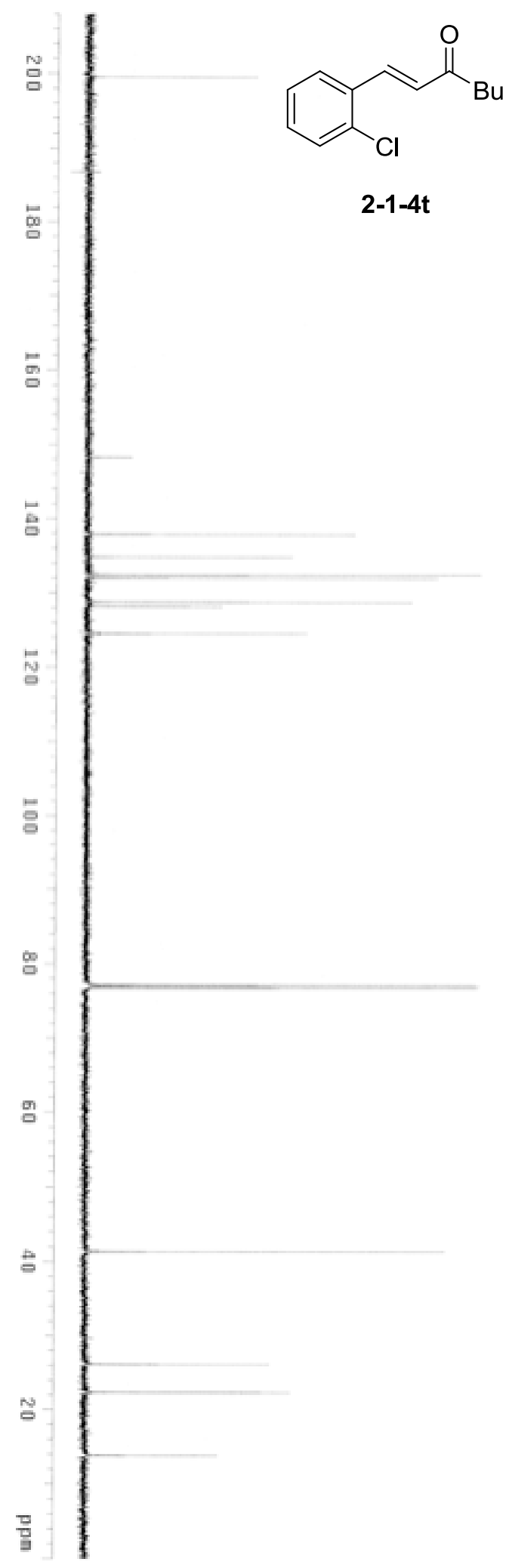

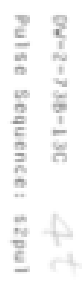




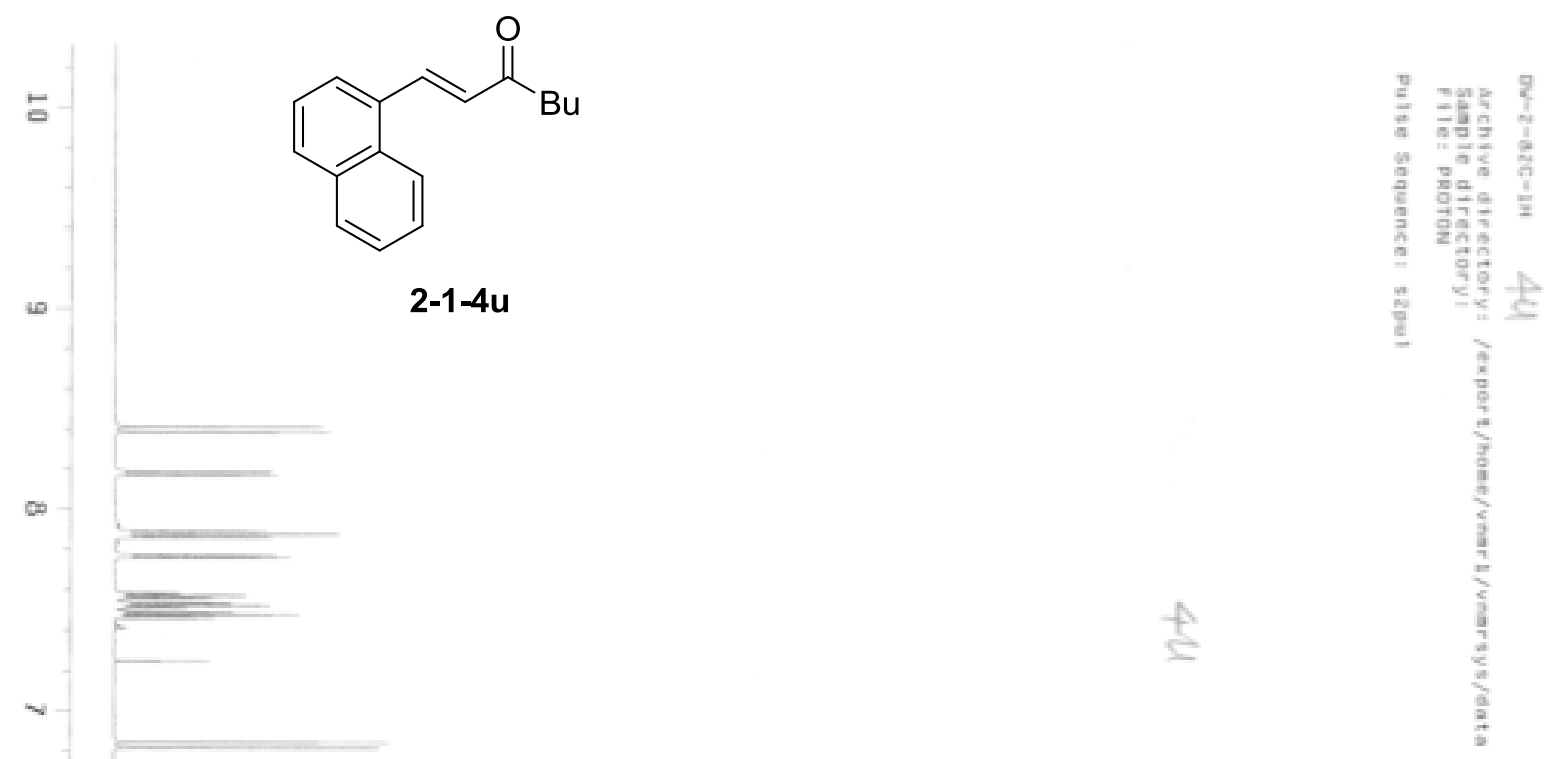

б

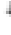




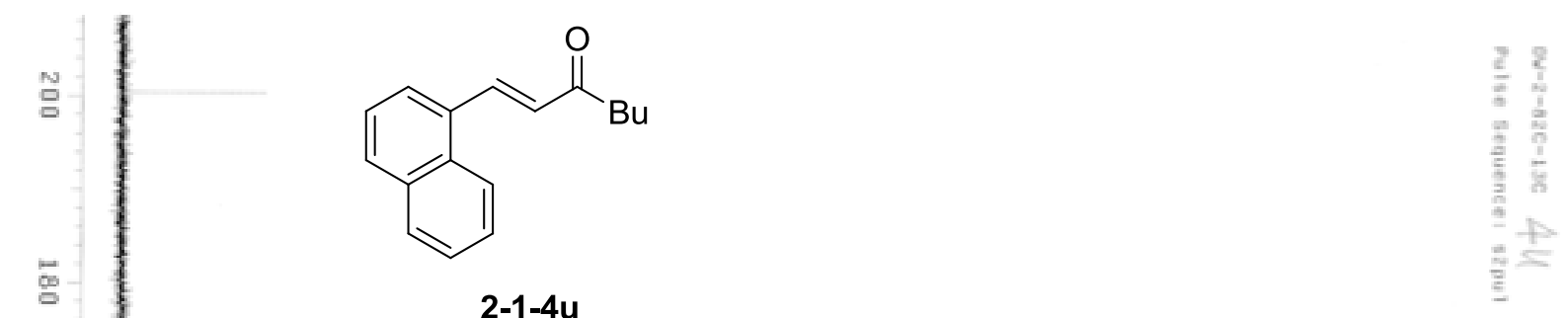

뭉

b

吅

몸

g

옹

ํํㅇ

$2-1-4 u$
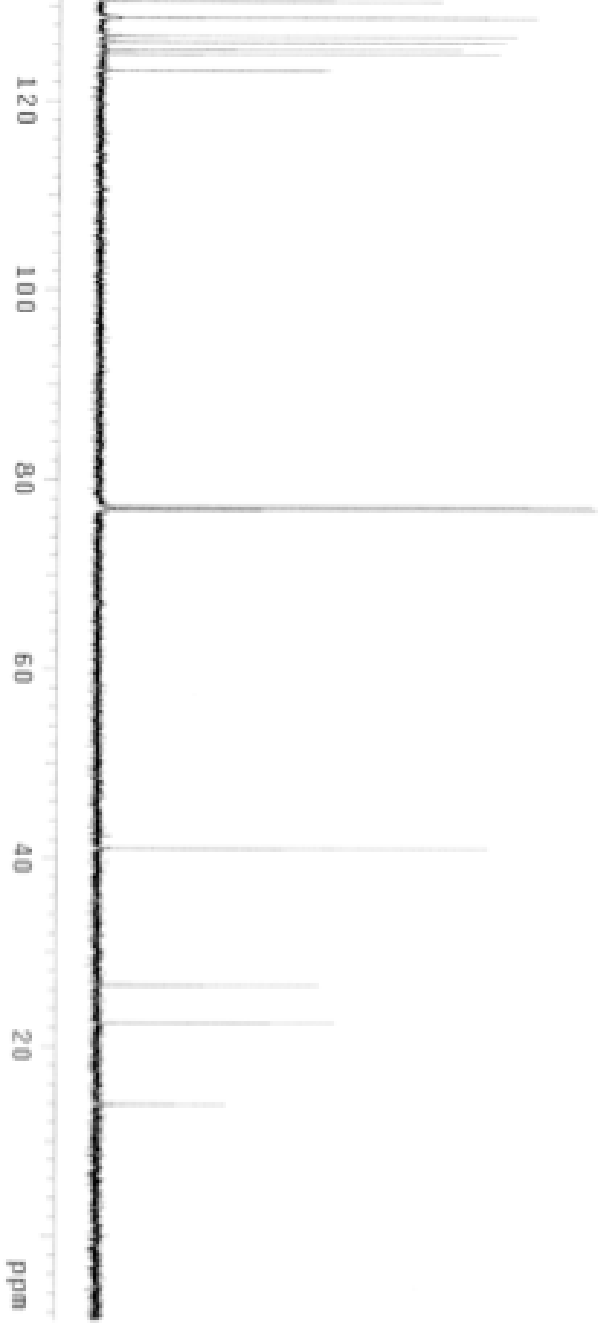


\subsection{Ambient intermolecular [2+2] cycloaddition of allene intermediate}

\section{General methods and materials}

All of the reactions dealing with air and/or moisture-sensitive reactions were carried out under an atmosphere of nitrogen using oven/flame-dried glassware. Unless otherwise noted, all commercial reagents were obtained from the commercial provider and used without further purification. Anhydrous solvents were used after general distillation strategies ( $\mathrm{Na}$ for THF and $\mathrm{CaH}_{2}$ for $\mathrm{DCM}$ ). All gold complexes were synthesized from $\mathrm{HAuCl}_{4}$, which was purchased from Strem. XPhos was purchased from Acros and used as received (stored at $4 \circ \mathrm{C}$ and handled in glovebox). ${ }^{1} \mathrm{H}$ NMR, and ${ }^{13} \mathrm{C}$ NMR spectra were recorded on Varian $600 \mathrm{MHz}$ and Agilent $400 \mathrm{MHz}$ spectrometers. Chemical shifts were reported relative to internal tetramethylsilane $(\delta 0.00 \mathrm{ppm})$ or $\mathrm{CDCl}_{3}(\delta 7.26 \mathrm{ppm})$ for ${ }^{1} \mathrm{H}$ and $\mathrm{CDCl}_{3}(\delta 77.0 \mathrm{ppm})$ for ${ }^{13} \mathrm{C}$. Flash column chromatography was performed on 230-430 mesh silica gel. HRMS were recorded on LTQ-FTUHRA spectrometer.

\section{General procedure of propargyl ester}

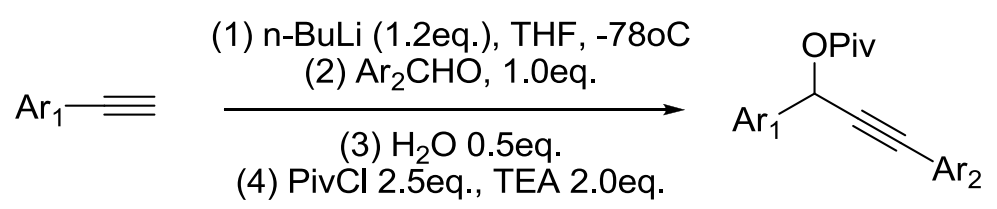

Reaction conditions: To a solution of alkyne (12 mmol) in anhydrous THF (50 mL) at $78{ }^{\circ} \mathrm{C}$ under $\mathrm{N}_{2}$ was added $n$-BuLi $(2.5 \mathrm{M}$ solution in hexanes, $5.0 \mathrm{~mL}, 12.5 \mathrm{mmol})$. The reaction was stirred at this temperature for $20 \mathrm{~min}$ then aldehyde $(10 \mathrm{mmol})$ was added to the mixture and was allowed to warm to room temperature gradually and stirred for an additional hour (TLC monitored untill the aldehyde was consumed completely). 10 Mins after addition of 0.5 eq. of $\mathrm{H}_{2} \mathrm{O}, \mathrm{PivCl}(25 \mathrm{mmol}$ ) and TEA (20 eq.) were added at room temperature and stirred for $6 \mathrm{~h}$. The mixture was extracted with EtOAc $(3 \times 20 \mathrm{~mL})$, and the combined organic phases were washed with water and brine, dried with anhydrous $\mathrm{MgSO}_{4}$, and filtered. The filtrate was concentrated, and the residue was purified through silica gel flash column chromatography (hexanes/ethyl acetate $=20 / 1$ ) to yield the desired pivalate ester $(70 \%-90 \%)$. 


\section{Compounds characterization}<smiles>Cc1ccc(C(C#Cc2ccccc2)O[Na])cc1</smiles>

3-phenyl-1-(p-tolyl)prop-2-yn-1-yl pivalate (2-2-1c). Pale yellow solid; $1 \mathrm{H}-\mathrm{NMR}\left(\mathrm{CDCl}_{3}, 400 \mathrm{MHz}\right.$, ppm) $\delta=7.47-7.44(\mathrm{~m}, 4 \mathrm{H}), 7.32-7.27(\mathrm{~m}, 3 \mathrm{H}), 7.19(\mathrm{~d}, J=8.0 \mathrm{~Hz}, 2 \mathrm{H}), 6.64(\mathrm{~s}, 1 \mathrm{H}), 2.36(\mathrm{~s}, 3 \mathrm{H})$, $1.23(\mathrm{~s}, 9 \mathrm{H}) ;{ }_{13} \mathrm{C}-\mathrm{NMR}\left(\mathrm{CDCl}_{3}, 100 \mathrm{MHz}, \mathrm{ppm}\right) \delta=177.22,138.51,134.59,131.86,129.25,128.60$, 128.21, 127.39, 122.35, 86.53, 86.0, 65.71, 38.76, 26.99, 21.19; HRMS calcd for $\mathrm{C}_{21} \mathrm{H}_{22} \mathrm{O}_{2} \mathrm{Na}$ $[\mathrm{M}+\mathrm{Na}]_{+}:$329.1512, found 329.1512 .<smiles>C#CC(O[Na])c1ccccc1</smiles>

1,3-diphenylprop-2-yn-1-yl pivalate (2-2-1d). Pale yellow solid; ${ }^{1} \mathrm{H}-\mathrm{NMR}\left(\mathrm{CDCl}_{3}, 400 \mathrm{MHz}, \mathrm{ppm}\right) \delta$ $=7.58-7.56(\mathrm{~m}, 2 \mathrm{H}), 7.48-7.45(\mathrm{~m}, 2 \mathrm{H}), 7.42-7.34(\mathrm{~m}, 3 \mathrm{H}), 7.33-7.24(\mathrm{~m}, 3 \mathrm{H}), 6.68(\mathrm{~s}, 1 \mathrm{H}), 1.24(\mathrm{~s}$, $9 \mathrm{H}) ;{ }_{13} \mathrm{C}-\mathrm{NMR}\left(\mathrm{CDCl}_{3}, 100 \mathrm{MHz}, \mathrm{ppm}\right) \delta=177.20,137.49,131.88,128.68,128.65,128.58,128.24$, 127.38, 122.27, 86.72, 85.81, 65.80, 38.79, 26.99; HRMS calcd for $\mathrm{C}_{20} \mathrm{H}_{20} \mathrm{O}_{2} \mathrm{Na}[\mathrm{M}+\mathrm{Na}]_{+}: 315.1356$, found 315.1356 .<smiles>CC(C)(C)c1ccc(C(C#Cc2ccccc2)O[Na])cc1</smiles>

1-(4-(tert-butyl)phenyl)-3-phenylprop-2-yn-1-yl pivalate (2-2-1e). Pale yellow solid; ${ }^{1} \mathrm{H}-\mathrm{NMR}$ $\left(\mathrm{CDCl}_{3}, 400 \mathrm{MHz}, \mathrm{ppm}\right) \delta=7.51-7.45(\mathrm{~m}, 4 \mathrm{H}), 7.42-7.39(\mathrm{~m}, 2 \mathrm{H}), 7.33-7.28(\mathrm{~m}, 3 \mathrm{H}), 6.65(\mathrm{~s}, 1 \mathrm{H})$, $1.33(\mathrm{~s}, 9 \mathrm{H}), 1.24(\mathrm{~s}, 9 \mathrm{H}) ;{ }_{13} \mathrm{C}-\mathrm{NMR}\left(\mathrm{CDCl}_{3}, 100 \mathrm{MHz}, \mathrm{ppm}\right) \delta=177.29,151.65,134.44,131.89$, 128.61, 128.22, 127.11, 125.53, 122.40, 86.50, 86.06, 65.63, 38.82, 31.30, 27.03; HRMS calcd for $\mathrm{C}_{24} \mathrm{H}_{28} \mathrm{O}_{2} \mathrm{Na}[\mathrm{M}+\mathrm{Na}]_{+}: 371.1982$, found 371.1982 .<smiles>N#CC(O[Na])c1ccc(Br)cc1</smiles>

1-(4-bromophenyl)-3-phenylprop-2-yn-1-yl pivalate (2-2-1f). Pale yellow solid; ${ }^{1} \mathrm{H}-\mathrm{NMR}\left(\mathrm{CDCl}_{3}\right.$, $400 \mathrm{MHz}, \mathrm{ppm}) \delta=7.54-7.51(\mathrm{~m}, 2 \mathrm{H}), 7.47-7.43(\mathrm{~m}, 4 \mathrm{H}), 7.34-7.31(\mathrm{~m}, 3 \mathrm{H}), 6.62(\mathrm{~s}, 1 \mathrm{H}), 1.23(\mathrm{~s}$, $9 \mathrm{H}) ;{ }^{13} \mathrm{C}-\mathrm{NMR}\left(\mathrm{CDCl}_{3}, 100 \mathrm{MHz}, \mathrm{ppm}\right) \delta=177.11,136.62,131.89,131.78,129.14,128.86,128.30$, 122.82, 122.01, 87.09, 85.22, 65.19, 38.79, 26.97; HRMS calcd for $\mathrm{C}_{20} \mathrm{H}_{19} \mathrm{BrO}_{2} \mathrm{Na}[\mathrm{M}+\mathrm{Na}]_{+}$: 393.0461, found 393.0461 . 
<smiles>O=C(C#Cc1ccccc1)OCc1ccc(Cl)cc1</smiles>

1-(4-chlorophenyl)-3-phenylprop-2-yn-1-yl pivalate (2-2-1g). Pale yellow solid; ${ }^{1} \mathrm{H}-\mathrm{NMR}\left(\mathrm{CDCl}_{3}\right.$, 400MHz, ppm) $\delta=7.53-7.49(\mathrm{~m}, 2 \mathrm{H}), 7.47-7.44(\mathrm{~m}, 2 \mathrm{H}), 7.38-7.35(\mathrm{~m}, 2 \mathrm{H}), 7.33-7.30(\mathrm{~m}, 3 \mathrm{H}), 6.63$ $(\mathrm{s}, 1 \mathrm{H}), 1.23(\mathrm{~s}, 9 \mathrm{H}) ;{ }^{13} \mathrm{C}-\mathrm{NMR}\left(\mathrm{CDCl}_{3}, 100 \mathrm{MHz}, \mathrm{ppm}\right) \delta=177.13,147.0,136.10,134.63,131.90$, 128.85, 128.83, 128.30, 122.04, 87.07, 85.30, 65.15, 38.80, 26.97; HRMS calcd for $\mathrm{C}_{20} \mathrm{H}_{19} \mathrm{ClO}_{2} \mathrm{Na}$ $[\mathrm{M}+\mathrm{Na}]_{+}:$349.0966, found 349.0967.<smiles>N#CC(C#Cc1ccccc1)c1ccc(F)cc1</smiles>

1-(4-fluorophenyl)-3-phenylprop-2-yn-1-yl pivalate (2-2-1h). Pale yellow solid; ${ }^{1} \mathrm{H}-\mathrm{NMR}(\mathrm{CDCl} 3$, 400MHz, ppm) $\delta=7.58-7.53(\mathrm{~m}, 2 \mathrm{H}), 7.48-7.45(\mathrm{~m}, 2 \mathrm{H}), 7.34-7.30(\mathrm{~m}, 3 \mathrm{H}), 7.10-7.05(\mathrm{~m}, 2 \mathrm{H}), 6.65$ $(\mathrm{s}, 1 \mathrm{H}), 1.23(\mathrm{~s}, 9 \mathrm{H}) ;{ }^{13} \mathrm{C}-\mathrm{NMR}\left(\mathrm{CDCl}_{3}, 100 \mathrm{MHz}, \mathrm{ppm}\right) \delta=177.15,162.85(\mathrm{~d}, J=236.7 \mathrm{~Hz}), 133.44$ (d, $J=3.8 \mathrm{~Hz}$ ), 131.87, 129.37 (d, $J=8.4 \mathrm{~Hz}$ ), 128.80, 128.28, 122.10, 115.53 (d, $J=21.3 \mathrm{~Hz}$ ), 86.94, 85.54, 65.17, 38.77, 26.96; HRMS calcd for $\mathrm{C}_{20} \mathrm{H}_{19} \mathrm{FO}_{2} \mathrm{Na}[\mathrm{M}+\mathrm{Na}]_{+}:$333.1261, found 333.1262 .<smiles>COc1ccc(C(C#Cc2ccccc2)O[Na])cc1</smiles>

1-(4-methoxyphenyl)-3-phenylprop-2-yn-1-yl pivalate (2-2-1i). Pale yellow solid; ${ }^{1} \mathrm{H}-\mathrm{NMR}$ (CDCl 3 , $400 \mathrm{MHz}, \mathrm{ppm}) \delta=7.52-7.49(\mathrm{~m}, 2 \mathrm{H}), 7.48-7.45(\mathrm{~m}, 2 \mathrm{H}), 7.33-7.30(\mathrm{~m}, 3 \mathrm{H}), 6.93-6.90(\mathrm{~m}, 2 \mathrm{H}), 6.63$ $(\mathrm{s}, 1 \mathrm{H}), 3.82(\mathrm{~s}, 3 \mathrm{H}), 1.22(\mathrm{~s}, 9 \mathrm{H}) ;{ }^{13} \mathrm{C}-\mathrm{NMR}\left(\mathrm{CDCl}_{3}, 100 \mathrm{MHz}, \mathrm{ppm}\right) \delta=177.29,159.87,131.86$, 129.72, 128.97, 128.62, 128.23, 122.35, 113.91, 86.52, 86.05, 65.57, 55.28, 38.77, 26.99; HRMS calcd for $\mathrm{C}_{21} \mathrm{H}_{22} \mathrm{O}_{3} \mathrm{Na}[\mathrm{M}+\mathrm{Na}]_{+}: 345.1461$, found 345.1461 .<smiles>O=POC(C#Cc1ccccc1)c1cccc(F)c1</smiles>

1-(3-fluorophenyl)-3-phenylprop-2-yn-1-yl pivalate (2-2-1j). Pale yellow solid; ${ }^{1} \mathrm{H}-\mathrm{NMR}\left(\mathrm{CDCl}_{3}\right.$, $400 \mathrm{MHz}, \mathrm{ppm}) \delta=7.48-7.45(\mathrm{~m}, 2 \mathrm{H}), 7.39-7.28(\mathrm{~m}, 6 \mathrm{H}), 7.07-7.03(\mathrm{~m}, 1 \mathrm{H}), 6.66(\mathrm{~s}, 1 \mathrm{H}), 1.25(\mathrm{~s}$, $9 \mathrm{H}) ;{ }^{13} \mathrm{C}-\mathrm{NMR}\left(\mathrm{CDCl}_{3}, 100 \mathrm{MHz}, \mathrm{ppm}\right) \delta=177.07,162.80(\mathrm{~d}, J=245.9 \mathrm{~Hz}), 139.92(\mathrm{~d}, J=6.8 \mathrm{~Hz})$, 131.90, 130.15 (d, $J=8.3 \mathrm{~Hz}), 128.86,128.29,122.98(\mathrm{~d}, J=3.0 \mathrm{~Hz}), 122.00,115.63(\mathrm{~d}, J=21.2$ $\mathrm{Hz}), 114.37(\mathrm{~d}, J=22.8 \mathrm{~Hz}), 87.05,85.15,65.06(\mathrm{~d}, J=2.2 \mathrm{~Hz}), 38.81,26.98$; HRMS calcd for $\mathrm{C}_{20} \mathrm{H}_{19} \mathrm{FO}_{2} \mathrm{Na}[\mathrm{M}+\mathrm{Na}]_{+}:$333.1261, found 333.1262. 
<smiles>COC(C#Cc1ccccc1)c1ccc(C(=O)O[Na])cc1</smiles>

methyl 4-(3-phenyl-1-(pivaloyloxy)prop-2-yn-1-yl)benzoate (2-2-1k). Pale yellow solid; ${ }^{1} \mathrm{H}-\mathrm{NMR}$ $\left(\mathrm{CDCl}_{3}, 400 \mathrm{MHz}, \mathrm{ppm}\right) \delta=8.09-8.06(\mathrm{~m}, 2 \mathrm{H}), 7.66-7.62(\mathrm{~m}, 2 \mathrm{H}), 7.48-7.45(\mathrm{~m}, 2 \mathrm{H})$, 7.35-7.29 (m, $3 \mathrm{H}), 6.71(\mathrm{~s}, 1 \mathrm{H}), 3.92(\mathrm{~s}, 3 \mathrm{H}), 1.25(\mathrm{~s}, 9 \mathrm{H}) ;{ }^{13} \mathrm{C}-\mathrm{NMR}\left(\mathrm{CDCl}_{3}, 100 \mathrm{MHz}, \mathrm{ppm}\right) \delta=177.05,166.61$, 142.28, 131.89, 130.39, 129.94, 128.88, 128.28, 127.25, 121.96, 87.29, 85.08, 65.26, 52.17, 38.81, 26.96; HRMS calcd for $\mathrm{C}_{20} \mathrm{H}_{20} \mathrm{O}_{2} \mathrm{Na}[\mathrm{M}+\mathrm{Na}]_{+}: 373.1410$, found 373.1411 .<smiles>Cc1ccccc1C(C#Cc1ccccc1)O[Na]</smiles>

1-(2-methylphenyl)-3-phenylprop-2-yn-1-yl pivalate (2-2-1I). Pale yellow solid; ${ }^{1} \mathrm{H}-\mathrm{NMR}$ (CDCl3, $400 \mathrm{MHz}, \mathrm{ppm}) \delta=7.66-7.63(\mathrm{~m}, 1 \mathrm{H}), 7.45-7.42(\mathrm{~m}, 2 \mathrm{H}), 7.31-7.28(\mathrm{~m}, 3 \mathrm{H}), 7.27-7.24(\mathrm{~m}, 2 \mathrm{H}), 7.22-$ $7.19(\mathrm{~m}, 1 \mathrm{H}), 6.75(\mathrm{~s}, 1 \mathrm{H}), 2.48(\mathrm{~s}, 3 \mathrm{H}) 1.24(\mathrm{~s}, 9 \mathrm{H}) ;{ }^{13} \mathrm{C}-\mathrm{NMR}\left(\mathrm{CDCl}_{3}, 100 \mathrm{MHz}, \mathrm{ppm}\right) \delta=177.08$, 136.27, 135.46, 131.83, 130.77, 128.68, 128.59, 128.21, 127.83, 126.14, 122.37, 86.52, 85.64, 64.20, 38.87, 27.04, 19.07; HRMS calcd for $\mathrm{C}_{21} \mathrm{H}_{22} \mathrm{O}_{2} \mathrm{Na}[\mathrm{M}+\mathrm{Na}]_{+}: 329.1512$, found 329.1513.<smiles>O=POC(C#Cc1ccccc1)c1ccccc1Br</smiles>

1-(2-bromophenyl)-3-phenylprop-2-yn-1-yl pivalate (2-2-1m). Pale yellow solid; ${ }^{1} \mathrm{H}-\mathrm{NMR}\left(\mathrm{CDCl}_{3}\right.$, $400 \mathrm{MHz}, \mathrm{ppm}) \delta=7.84-7.81(\mathrm{~m}, 1 \mathrm{H}), 7.60-7.57(\mathrm{~m}, 1 \mathrm{H}), 7.48-7.45(\mathrm{~m}, 2 \mathrm{H}), 7.40-7.35(\mathrm{~m}, 1 \mathrm{H})$, 7.33$7.28(\mathrm{~m}, 3 \mathrm{H}), 7.25-7.19(\mathrm{~m}, 1 \mathrm{H}), 6.88(\mathrm{~s}, 1 \mathrm{H}), 1.25(\mathrm{~s}, 9 \mathrm{H}) ;{ }^{13} \mathrm{C}-\mathrm{NMR}\left(\mathrm{CDCl}_{3}, 100 \mathrm{MHz}, \mathrm{ppm}\right) \delta=$ $176.73,136.56,133.09,131.90,130.23,129.47,128.75,128.22,127.65,123.28,122.13,87.09$, 84.83, 65.55, 38.84, 27.05; HRMS calcd for $\mathrm{C}_{20} \mathrm{H}_{19} \mathrm{BrO}_{2} \mathrm{Na}[\mathrm{M}+\mathrm{Na}]_{+}: 393.0461$, found 393.0462 .<smiles>Fc1ccccc1C(C#Cc1ccccc1)O[Na]</smiles>

1-(2-fluorophenyl)-3-phenylprop-2-yn-1-yl pivalate (2-2-1n). Pale yellow solid; ${ }^{1} \mathrm{H}-\mathrm{NMR}\left(\mathrm{CDCl}_{3}\right.$, $400 \mathrm{MHz}, \mathrm{ppm}) \delta=7.60-7.71(\mathrm{~m}, 1 \mathrm{H}), 7.49-7.46(\mathrm{~m}, 2 \mathrm{H}), 7.37-7.28(\mathrm{~m}, 4 \mathrm{H}), 7.22-7.18(\mathrm{~m}, 1 \mathrm{H})$, 7.11$6.90(\mathrm{~m}, 1 \mathrm{H}), 6.90(\mathrm{~s}, 1 \mathrm{H}), 1.24(\mathrm{~s}, 9 \mathrm{H}) ;{ }^{13} \mathrm{C}-\mathrm{NMR}\left(\mathrm{CDCl}_{3}, 100 \mathrm{MHz}, \mathrm{ppm}\right) \delta=176.85,160.21(\mathrm{~d}, J=$ $249 \mathrm{~Hz}$ ), 131.92, 130.60 (d, $J=8.4 \mathrm{~Hz}), 129.27$ (d, $J=3.8 \mathrm{~Hz}), 128.77,128.24,124.78,124.22(\mathrm{~d}, J$ $=3.8 \mathrm{~Hz}$ ), 122.12, $115.66(\mathrm{~d}, J=20.5 \mathrm{~Hz}), 86.86,84.67,60.32(\mathrm{~d}, J=5.3 \mathrm{~Hz}), 38.78,26.97$; HRMS calcd for $\mathrm{C}_{20} \mathrm{H}_{19} \mathrm{FO}_{2} \mathrm{Na}[\mathrm{M}+\mathrm{Na}]_{+}: 333.1261$, found 333.1262 . 
<smiles>CCOC(C#Cc1ccccc1)c1ccc2ccccc2c1</smiles>

1-(naphthalen-2-yl)-3-phenylprop-2-yn-1-yl pivalate (2-2-10). Pale yellow solid; ${ }^{1} \mathrm{H}-\mathrm{NMR}\left(\mathrm{CDCl}_{3}\right.$, $400 \mathrm{MHz}, \mathrm{ppm}) \delta=8.04(\mathrm{~s}, 1 \mathrm{H}), 8.04-7.81(\mathrm{~m}, 3 \mathrm{H}), 7.68-7.65(\mathrm{~m}, 1 \mathrm{H}), 7.51-7.45(\mathrm{~m}, 4 \mathrm{H}), 7.32-7.27$ $(\mathrm{m}, 3 \mathrm{H}), 6.85(\mathrm{~s}, 1 \mathrm{H}), 1.25(\mathrm{~s}, 9 \mathrm{H}) ;{ }^{13} \mathrm{C}-\mathrm{NMR}\left(\mathrm{CDCl}_{3}, 100 \mathrm{MHz}, \mathrm{ppm}\right) \delta=177.17,134.80,133.33$, 133.03, 131.87, 128.70, 128.55, 128.25, 128.24, 127.65, 126.76, 126.50, 126.32, 124.93, 122.23, 87.03, 85.81, 66.01, 38.81, 26.99; HRMS calcd for $\mathrm{C}_{24} \mathrm{H}_{22} \mathrm{O}_{2} \mathrm{Na}[\mathrm{M}+\mathrm{Na}]_{+}: 365.1512$, found 365.1512.<smiles>COc1ccc(C#CC(O[Na])c2ccc(C)cc2)cc1</smiles>

3-(4-methoxyphenyl)-1-(p-tolyl)prop-2-yn-1-yl pivalate (2-2-1p). Pale yellow solid; ${ }^{1} \mathrm{H}-\mathrm{NMR}$ $\left(\mathrm{CDCl}_{3}, 400 \mathrm{MHz}, \mathrm{ppm}\right) \delta=7.46-7.44(\mathrm{~m}, 2 \mathrm{H}), 7.42-7.37(\mathrm{~m}, 2 \mathrm{H}), 7.20-7.18(\mathrm{~m}, 2 \mathrm{H}), 6.85-6.80(\mathrm{~m}$, $2 \mathrm{H}), 6.62(\mathrm{~s}, 1 \mathrm{H}), 3.80(\mathrm{~s}, 3 \mathrm{H}), 2.36(\mathrm{~s}, 3 \mathrm{H}), 1.22(\mathrm{~s}, 9 \mathrm{H}) ;{ }^{13} \mathrm{C}-\mathrm{NMR}\left(\mathrm{CDCl}_{3}, 100 \mathrm{MHz}, \mathrm{ppm}\right) \delta=$ 177.28, 159.86, 138.43, 134.83, 133.38, 129.22, 127.38, 114.45, 113.84, 86.53, 84.66, 65.86, 55.26, 38.77, 27.00, 21.20; HRMS calcd for $\mathrm{C}_{22} \mathrm{H}_{24} \mathrm{O}_{3} \mathrm{Na}[\mathrm{M}+\mathrm{Na}]_{+}: 359.1618$, found 359.1618.<smiles>COC(=O)c1ccc(C#CC(O[Na])c2ccc(C)cc2)cc1</smiles>

methyl 4-(3-(pivaloyloxy)-3-(p-tolyl)prop-1-yn-1-yl)benzoate (2-2-1q). Pale yellow solid; ${ }^{1} \mathrm{H}-\mathrm{NMR}$ $\left(\mathrm{CDCl}_{3}, 400 \mathrm{MHz}, \mathrm{ppm}\right) \delta=7.98(\mathrm{~d}, J=8.0 \mathrm{~Hz}, 2 \mathrm{H}), 7.51(\mathrm{~d}, J=8.0 \mathrm{~Hz}, 2 \mathrm{H}), 7.45(\mathrm{~d}, J=8.0 \mathrm{~Hz}, 2$ $\mathrm{H}), 7.21(\mathrm{~d}, J=8.0 \mathrm{~Hz}, 2 \mathrm{H}), 6.63(\mathrm{~s}, 1 \mathrm{H}), 3.91(\mathrm{~s}, 3 \mathrm{H}), 2.37(\mathrm{~s}, 3 \mathrm{H}), 1.23(\mathrm{~s}, 9 \mathrm{H}) ;{ }^{13} \mathrm{C}-\mathrm{NMR}\left(\mathrm{CDCl}_{3}\right.$, $100 \mathrm{MHz}$, ppm) $\delta=177.17,166.41,138.72,134.20,131.77,129.91,129.38,129.34,127.36,126.99$, 88.98, 85.65, 65.58, 52.21, 38.78, 26.98, 21.20; HRMS calcd for $\mathrm{C}_{23} \mathrm{H}_{24} \mathrm{O}_{4} \mathrm{Na}[\mathrm{M}+\mathrm{Na}]_{+}:$387.1567, found 387.1567 .<smiles>Cc1ccc(C(C#Cc2ccc(C(F)(F)F)cc2)O[Na])cc1</smiles>

1-(p-tolyl)-3-(4-(trifluoromethyl)phenyl)prop-2-yn-1-yl pivalate (2-2-1r). Pale yellow solid; ${ }^{1} \mathrm{H}$ $\operatorname{NMR}\left(\mathrm{CDCl}_{3}, 400 \mathrm{MHz}, \mathrm{ppm}\right) \delta=7.56(\mathrm{~s}, 4 \mathrm{H}), 7.45(\mathrm{~d}, J=8.0 \mathrm{~Hz}, 2 \mathrm{H}), 7.21(\mathrm{~d}, J=8.0 \mathrm{~Hz}, 2 \mathrm{H}), 6.63$ $(\mathrm{s}, 1 \mathrm{H}), 2.37(\mathrm{~s}, 3 \mathrm{H}), 1.24(\mathrm{~s}, 9 \mathrm{H})$; contaminant: ${ }^{1} \mathrm{H}-\mathrm{NMR}\left(\mathrm{CDCl}_{3}, 400 \mathrm{MHz}, \mathrm{ppm}\right) \delta=7.68(\mathrm{~d}, J=8.4$ $\mathrm{Hz}, 2 \mathrm{H}), 7.64(\mathrm{~d}, J=8.4 \mathrm{~Hz}, 2 \mathrm{H}), 1.29$ (s, 9H); HRMS calcd for $\mathrm{C}_{22} \mathrm{H}_{21} \mathrm{~F}_{3} \mathrm{O}_{2} \mathrm{Na}[\mathrm{M}+\mathrm{Na}]_{+}: 397.1386$, found 397.1388 . 


\section{General procedure of [2+2] cycloaddition}

Reaction conditions: To a solution of 2-2-1c $(61.2 \mathrm{mg}, 0.20 \mathrm{mmol})$ in dry $\mathrm{CH}_{2} \mathrm{Cl}_{2}(0.8 \mathrm{~mL}, 0.25$ $\mathrm{M})$, was added [PPh $3 \mathrm{Au}(\mathrm{TA}-\mathrm{Me})] \mathrm{OTf}(1.5 \mathrm{mg}, 0.002 \mathrm{~mol}, 1.0 \mathrm{~mol} \%)$ at $\mathrm{RT}$. The reaction mixture was stirred at room temperature. After the reaction was completed $(20 \mathrm{~h}), 0.1 \mathrm{mmol}$ of $1,3,5-$ trimethoxybenzene $(16.8 \mathrm{mg})$ was added into the reaction mixture, and the solvent was removed under reduced pressure and the crude $1 \mathrm{H}$ NMR give the crude yield: $66 \%$ of 2-2-3c, and $13 \%$ of 22-3c'. Purification of 2-2-3c and 2-2-3c': After silica column (Ethyl Acetate / Hexane $=1 / 10$ ), crude

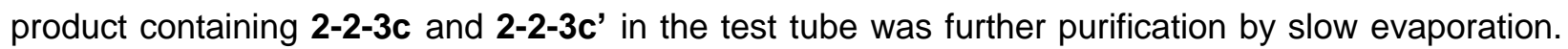
Pure 2-2-3c was obtained in the bottom of test tube and was washed with hexane. The pure 2-2-3c' was obtained by prepared TLC of the residue in the test tube.

\section{Compounds characterization}<smiles>Cc1ccc(C=C(C(=O)c2ccccc2)C(C#Cc2ccccc2)c2ccccc2)cc1</smiles>

(Z)-2-(4-methylbenzylidene)-1,5-diphenyl-3-(p-tolyl)pent-4-yn-1-one (2-2-2b). Yellow liquid; ${ }^{1} \mathrm{H}-$ NMR $\left(\mathrm{CDCl}_{3}, 400 \mathrm{MHz}, \mathrm{ppm}\right) \delta=7.73(\mathrm{~d}, J=8.0 \mathrm{~Hz}, 2 \mathrm{H}), 7.37(\mathrm{~d}, J=8.0 \mathrm{~Hz}, 2 \mathrm{H}), 7.33-7.24(\mathrm{~m}, 6 \mathrm{H})$, 7.23-7.15 (m, 2H), 7.11-7.07 (m, 3H), $6.99(\mathrm{~d}, J=8.0 \mathrm{~Hz}, 2 \mathrm{H}), 6.84(\mathrm{~d}, J=8.0 \mathrm{~Hz}, 2 \mathrm{H}), 5.19(\mathrm{~s}, 1 \mathrm{H})$, $2.28(\mathrm{~s}, 3 \mathrm{H}), 2.12(\mathrm{~s}, 3 \mathrm{H}) ;{ }^{13} \mathrm{C}-\mathrm{NMR}\left(\mathrm{CDCl}_{3}, 100 \mathrm{MHz}, \mathrm{ppm}\right) \delta=199.55,139.50,137.66,136.93$, $136.50,135.45,132.80,132.45,131.55,131.39,129.47,129.28,128.83,128.73,128.30,128.12$, $128.05,127.98,123.20,88.46,86.53,43.24,21.06,21.04$

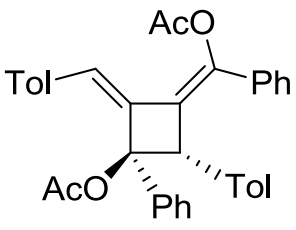

(2Z,3Z)-2-(4-methylbenzylidene)-1-phenyl-3-(phenyl(pivaloyloxy)methylene)-4-(p-tolyl) cyclobutyl pivalate (2-2-3b). Colorless Solid; ${ }^{1} \mathrm{H}-\mathrm{NMR}\left(\mathrm{CDCl}_{3}, 600 \mathrm{MHz}, \mathrm{ppm}\right) \delta=7.20-7.18$ (m, $2 \mathrm{H}), 7.17(\mathrm{~d}, J=9.6 \mathrm{~Hz}, 2 \mathrm{H}), 7.14-7.12(\mathrm{~m}, 2 \mathrm{H}), 7.10(\mathrm{~s}, 1 \mathrm{H}), 7.03-6.99(\mathrm{~m}, 6 \mathrm{H}), 6.96(\mathrm{~d}, J=9.6 \mathrm{~Hz}$, 2H), 6.68 (d, J = 7.2 Hz, 2H), 6.57 (d, J = 7.2 Hz, 2H), $5.71(\mathrm{~s}, 1 \mathrm{H}), 2.48(\mathrm{~s}, 3 \mathrm{H}), 2.25(\mathrm{~s}, 3 \mathrm{H}), 2.03$ (s, $3 \mathrm{H}), 2.02$ (s, 3H); ${ }^{13} \mathrm{C}-\mathrm{NMR}\left(\mathrm{CDCl}_{3}, 125 \mathrm{MHz}, \mathrm{ppm}\right) \delta=169.57,169.06,141.52,138.07,137.85$, $136.20,135.53,133.40,132.17,131.83,129.32$, 129.21, 129.03, 127.85, 127.70, 127.58, 127.50, $127.41,127.07,126.76,126.39,90.65,57.37,21.68,21.22,20.91$;

2-2-3b and 2-2-3b': 2-2-1b (61.2 $\mathrm{mg}, 0.20 \mathrm{mmol})$ was used, and the NMR show that: $66 \%$ yield of 2-2-3b [ ${ }^{1} \mathrm{H}-\mathrm{NMR}\left(\mathrm{CDCl}_{3}, 400 \mathrm{MHz}, \mathrm{ppm}\right) \delta=6.66(\mathrm{~d}, J=8.0 \mathrm{~Hz}, 2 \mathrm{H}), 6.53(\mathrm{~d}, J=8.0 \mathrm{~Hz}, 2 \mathrm{H}), 5.67$ 
(s, 1H), $2.22(\mathrm{~s}, 3 \mathrm{H}), 2.15(\mathrm{~s}, 3 \mathrm{H}), 1.52(\mathrm{~s}, 9 \mathrm{H}), 1.17(\mathrm{~s}, 9 \mathrm{H})$ ], and $13 \%$ yield of 2-2-3b' ['H-NMR $\left.\left(\mathrm{CDCl}_{3}, 400 \mathrm{MHz}, \mathrm{ppm}\right) \delta=4.34(\mathrm{~s}, 1 \mathrm{H}), 2.15(\mathrm{~s}, 3 \mathrm{H}), 1.42(\mathrm{~s}, 9 \mathrm{H})\right]$.

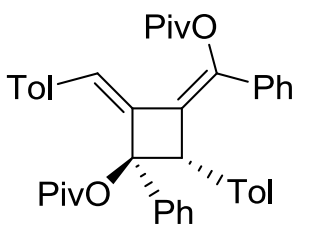

(2Z,3Z)-2-(4-methylbenzylidene)-1-phenyl-3-(phenyl(pivaloyloxy)methylene)-4-(p-tolyl)cyc

lobutyl pivalate (2-2-3c). Colorless Solid; ${ }^{1} \mathrm{H}-\mathrm{NMR}\left(\mathrm{CDCl}_{3}, 400 \mathrm{MHz}, \mathrm{ppm}\right) \delta=7.24-7.21(\mathrm{~m}, 2 \mathrm{H})$, 7.15-7.10 (m, 5H), 7.04-6.97 (m, 6H), $6.93(\mathrm{~d}, J=8.4 \mathrm{~Hz}, 2 \mathrm{H}), 6.65(\mathrm{~d}, J=7.6 \mathrm{~Hz}, 2 \mathrm{H}), 6.53(\mathrm{~d}, J=$ $7.6 \mathrm{~Hz}, 2 \mathrm{H}), 5.66(\mathrm{~s}, 1 \mathrm{H}), 2.23(\mathrm{~s}, 3 \mathrm{H}), 2.01(\mathrm{~s}, 3 \mathrm{H}), 1.52(\mathrm{~s}, 9 \mathrm{H}), 1.17(\mathrm{~s}, 9 \mathrm{H}) ;{ }^{13} \mathrm{C}-\mathrm{NMR}(\mathrm{CDCl}, 100$ $\mathrm{MHz}, \mathrm{ppm}) \delta=176.99,176.27,141.57,138.23,137.65,136.68,135.34,133.99,132.23,131.94$, 129.37, 129.19, 128.97, 127.74, 127.73, 127.61, 127.58, 127.49, 127.33, 126.71, 126.68, 126.46, 90.12, 57.26, 39.53, 27.66, 27.27, 21.20, 21.19, 20.92; HRMS calcd for $\mathrm{C}_{42} \mathrm{H}_{44} \mathrm{O} 4 \mathrm{Na}[\mathrm{M}+\mathrm{Na}]_{+}:$ 635.3132 , found 635.3134 .

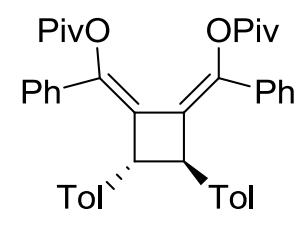

\section{(1Z,1'Z)-(3,4-di-p-tolylcyclobutane-1,2-diylidene)bis(phenylmethanylylidene)bis}

(2,2-dimethylpropanoate) (2-2-3c'). Colorless solid; ${ }^{1} \mathrm{H}-\mathrm{NMR}\left(\mathrm{CDCl}_{3}, 400 \mathrm{MHz}, \mathrm{ppm}\right) \delta=7.16(\mathrm{~d}, \mathrm{~J}$ $=5.2 \mathrm{~Hz}, 4 \mathrm{H}), 7.01(\mathrm{~s}, 10 \mathrm{H}), 6.85(\mathrm{~d}, J=5.2 \mathrm{~Hz}, 4 \mathrm{H}), 4.33(\mathrm{~s}, 2 \mathrm{H}), 2.16(\mathrm{~s}, 6 \mathrm{H}), 1.42(\mathrm{~s}, 18 \mathrm{H}) ;{ }^{13} \mathrm{C}-$ $\mathrm{NMR}\left(\mathrm{CDCl}_{3}, 100 \mathrm{MHz}, \mathrm{ppm}\right) \delta=177.56,140.17,135.88,135.63,133.05,132.15,128.65,128.26$, 127.87, 127.54, 126.70, 59.47, 39.42, 27.39, 21.03; HRMS calcd for $\mathrm{C}_{42} \mathrm{H}_{44} \mathrm{O} 4 \mathrm{Na}[\mathrm{M}+\mathrm{Na}]_{+}: 635.3132$, found 635.3134 .

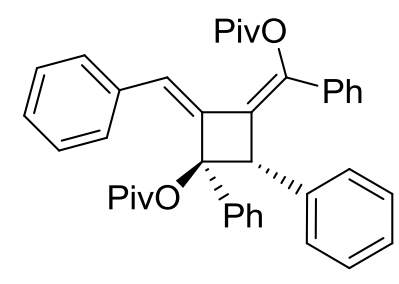

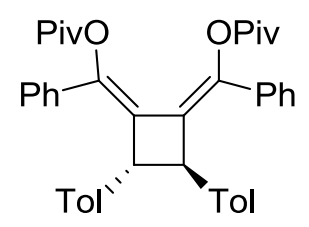

2-2-3d and 2-2-3d': 2-2-1d (58.5 mg, $0.20 \mathrm{mmol})$ was used, and the NMR show that: $79 \%$ yield of 2-2-3d [ ${ }^{1} \mathrm{H}-\mathrm{NMR}\left(\mathrm{CDCl}_{3}, 400 \mathrm{MHz}, \mathrm{ppm}\right) \delta=6.79-6.74(\mathrm{~m}, 5 \mathrm{H}), 5.73(\mathrm{~s}, 1 \mathrm{H}), 1.53(\mathrm{~s}, 9 \mathrm{H}), 1.15(\mathrm{~s}$, 
$9 \mathrm{H})$ ], and $13 \%$ yield of 2-2-3d' [ ${ }^{1} \mathrm{H}-\mathrm{NMR}\left(\mathrm{CDCl}_{3}, 400 \mathrm{MHz}, \mathrm{ppm}\right) \delta=4.42(\mathrm{~s}, 1 \mathrm{H}), 1.43(\mathrm{~s}, 9 \mathrm{H})$ ]. HRMS calcd for $\mathrm{C}_{40} \mathrm{H}_{40} \mathrm{O}_{4} \mathrm{H}[\mathrm{M}+\mathrm{H}]_{+}: 585.2999$, found 585.3002 .

2-2-3e and 2-2-3e': 2-2-1e (34.8 mg, $0.10 \mathrm{mmol}$ ) was used, and the NMR show that: $65 \%$ yield of 22-3e [ ${ }^{1} \mathrm{H}-\mathrm{NMR}\left(\mathrm{CDCl}_{3}, 400 \mathrm{MHz}, \mathrm{ppm}\right) \delta=6.71(\mathrm{~d}, J=8.0 \mathrm{~Hz}, 2 \mathrm{H}), 6.62(\mathrm{~d}, J=8.0 \mathrm{~Hz}, 2 \mathrm{H}), 5.67$ (s, $1 \mathrm{H}), 1.51(\mathrm{~s}, 9 \mathrm{H}), 1.21(\mathrm{~s}, 9 \mathrm{H}), 1.10(\mathrm{~s}, 9 \mathrm{H}), 1.04(\mathrm{~s}, 9 \mathrm{H})]$, and $19 \%$ yield of 2-2-3e' [ ${ }^{1} \mathrm{H}-\mathrm{NMR}\left(\mathrm{CDCl}_{3}\right.$, $400 \mathrm{MHz}, \mathrm{ppm}) \delta=4.40(\mathrm{~s}, 1 \mathrm{H}), 1.42(\mathrm{~s}, 9 \mathrm{H}), 1.16(\mathrm{~s}, 9 \mathrm{H})]$.

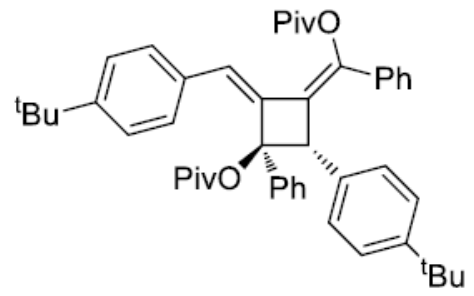

\section{2-(4-(tert-butyl)benzylidene)-4-(4-(tert-butyl)phenyl)-1-phenyl-3-(phenyl(pivaloyloxy)methy}

lene)cyclobutyl pivalate (2-2-3e). Colorless solid; ${ }^{1} \mathrm{H}-\mathrm{NMR}\left(\mathrm{CDCl}_{3}, 400 \mathrm{MHz}, \mathrm{ppm}\right) \delta=7.23-7.14$ $(\mathrm{m}, 8 \mathrm{H}), 7.12-7.09(\mathrm{~m}, 2 \mathrm{H}), 7.04-6.95(\mathrm{~m}, 8 \mathrm{H}), 6.71(\mathrm{~d}, J=8.4 \mathrm{~Hz}, 2 \mathrm{H}), 6.61(\mathrm{~d}, J=8.4 \mathrm{~Hz}, 2 \mathrm{H}), 5.66$ $(\mathrm{s}, 1 \mathrm{H}), 1.51(\mathrm{~s}, 9 \mathrm{H}), 1.21(\mathrm{~s}, 9 \mathrm{H}), 1.10(\mathrm{~s}, 9 \mathrm{H}), 1.04(\mathrm{~s}, 9 \mathrm{H}) ;{ }^{13} \mathrm{C}-\mathrm{NMR}\left(\mathrm{CDCl}_{3}, 150 \mathrm{MHz}, \mathrm{ppm}\right) \delta=$ 177.0, 176.3, 150.7, 141.6, 137.0, 133.9, 132.3, 131.9, 129.1, 128.9, 127.7, 127.6, 127.5, 127.4, 127.2, 126.7, 126.4, 125.2, 123.8, 110.0, 90.2, 57.2, 39.5, 34.5, 34.0, 31.3, 31.1, 31.1, 29.7, 27.6, 27.4, 27.2; HRMS calcd for $\mathrm{C}_{48} \mathrm{H}_{56} \mathrm{O}_{4} \mathrm{H}[\mathrm{M}+\mathrm{H}]_{+}: 697.4251$, found 697.4252 .

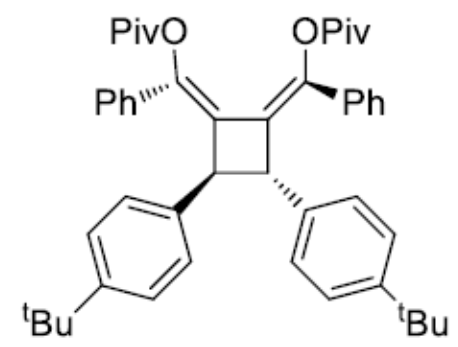

(1Z,1'Z)-(3,4-bis(4-(tert-butyl)phenyl)cyclobutane-1,2-diylidene)bis(phenylmethanylylidene)

bis(2,2-dimethylpropanoate) (2-2-3e'). Colorless solid; ${ }^{1} \mathrm{H}-\mathrm{NMR}\left(\mathrm{CDCl}_{3}, 400 \mathrm{MHz}, \mathrm{ppm}\right) \delta=7.21$ (d, $J=8.4 \mathrm{~Hz}, 2 \mathrm{H}), 7.03(\mathrm{~d}, J=8.4 \mathrm{~Hz}, 2 \mathrm{H}), 6.96(\mathrm{~s}, 5 \mathrm{H}), 4.40(\mathrm{~s}, 1 \mathrm{H}), 1.42(\mathrm{~s}, 9 \mathrm{H}), 1.16(\mathrm{~s}, 9 \mathrm{~h}) ;{ }^{13} \mathrm{C}-$ NMR $\left(\mathrm{CDCl}_{3}, 150 \mathrm{MHz}, \mathrm{ppm}\right) \delta=177.6,149.2,135.3,133.0,132.9,128.3,127.7,127.4,126.7$, 125.2, 124.7, 58.7, 39.4, 34.2, 31.9, 31.3, 31.1, 29.7, 27.6, 27.4; HRMS calcd for $\mathrm{C}_{48} \mathrm{H}_{56} \mathrm{O}_{4} \mathrm{H}[\mathrm{M}+\mathrm{H}]_{+}$: 697.4251 , found 697.4254 .

2-2-3f and 2-2-3f': 2-2-1f (74.0 mg, $0.20 \mathrm{mmol})$ was used, and the NMR show that: $74 \%$ yield of 22-3f [1 $1 \mathrm{H}-\mathrm{NMR}\left(\mathrm{CDCl}_{3}, 400 \mathrm{MHz}, \mathrm{ppm}\right) \delta=6.86(\mathrm{~d}, J=8.0 \mathrm{~Hz}, 2 \mathrm{H}), 6.66(\mathrm{~d}, J=8.0 \mathrm{~Hz}, 2 \mathrm{H}), 5.66(\mathrm{~s}$, $1 \mathrm{H}), 1.51(\mathrm{~s}, 9 \mathrm{H}), 1.17(\mathrm{~s}, 9 \mathrm{H})$ ], and $16 \%$ yield of 2-2-3f' [1 $1 \mathrm{H}-\mathrm{NMR}\left(\mathrm{CDCl}_{3}, 400 \mathrm{MHz}, \mathrm{ppm}\right) \delta=4.32$ $(\mathrm{s}, 1 \mathrm{H}), 1.42(\mathrm{~s}, 9 \mathrm{H})]$. 


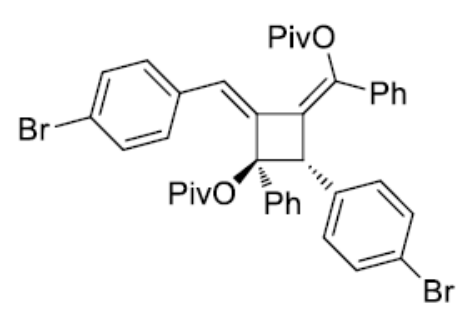

2-(4-bromobenzylidene)-4-(4-bromophenyl)-1-phenyl-3-(phenyl(pivaloyloxy)methylene)cycl

obutyl pivalate (2-2-3f). Colorless solid; ${ }^{1} \mathrm{H}-\mathrm{NMR}\left(\mathrm{CDCl}_{3}, 400 \mathrm{MHz}, \mathrm{ppm}\right) \delta=7.24(\mathrm{~s}, 1 \mathrm{H}), 7.21-7.17$ $(\mathrm{m}, 2 \mathrm{H}), 7.11-7.01(\mathrm{~m}, 11 \mathrm{H}), 6.86(\mathrm{~d}, J=8.0 \mathrm{~Hz}, 2 \mathrm{H}), 6.66(\mathrm{~d}, J=8.0 \mathrm{~Hz}), 5.65(\mathrm{~s}, 1 \mathrm{H}), 1.51(\mathrm{~s}, 9 \mathrm{H})$, 1.17 (s, 9H); ${ }^{13} \mathrm{C}-\mathrm{NMR}\left(\mathrm{CDCl}_{3}, 150 \mathrm{MHz}, \mathrm{ppm}\right) \delta=177.1,176.2,143.4,142.6,139.8,135.9,134.1$, 133.7, 133.6, 132.9, 132.2, 131.4, 131.0, 130.7, 130.2, 129.8, 128.7, 128.5, 128.4, 128.0, 127.9, 127.8, 127.3, 126.5, 125.6, 125.5, 121.9, 120.2, 89.7, 56.9, 39.6, 39.5, 27.6, 27.2; HRMS calcd for $\mathrm{C}_{40} \mathrm{H}_{38} \mathrm{Br}_{2} \mathrm{O}_{4} \mathrm{H}[\mathrm{M}+\mathrm{H}]_{+}:$741.1210, found 741.1211.

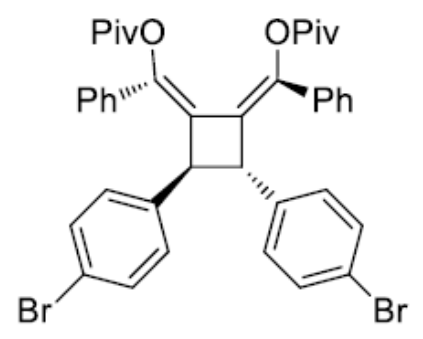

(1Z,1'Z)-(3,4-bis(4-bromophenyl)cyclobutane-1,2-diylidene)bis(phenylmethanylylidene)

bis(2,2-dimethylpropanoate) (2-2-3f'). Colorless solid; ${ }^{1} \mathrm{H}-\mathrm{NMR}\left(\mathrm{CDCl}_{3}, 400 \mathrm{MHz}, \mathrm{ppm}\right): \delta=7.18$ $7.11(\mathrm{~m}, 4 \mathrm{H}), 7.07-6.96(\mathrm{~m}, 5 \mathrm{H}), 4.31(\mathrm{~s}, 1 \mathrm{H}), 1.42(9 \mathrm{H}) ;{ }^{13} \mathrm{C}-\mathrm{NMR}\left(\mathrm{CDCl}_{3}, 150 \mathrm{MHz}, \mathrm{ppm}\right) \delta=177.7$, $140.5,137.1$, 132.7, 131.2, 130.9, 130.1, 128.5, 127.8, 126.8, 120.6, 59.1, 39.5, 27.4; HRMS calcd for $\mathrm{C}_{40} \mathrm{H}_{38} \mathrm{Br}_{2} \mathrm{O}_{4} \mathrm{H}[\mathrm{M}+\mathrm{H}]_{+}:$741.1210, found 741.1213 .

2-2-3g and 2-2-3g': 2-2-1g (32.6 mg, $0.10 \mathrm{mmol})$ was used, and the NMR show that: $80 \%$ yield of 2-2-3g [1 $\left.1 \mathrm{H}-\mathrm{NMR}\left(\mathrm{CDCl}_{3}, 400 \mathrm{MHz}, \mathrm{ppm}\right) \delta=6.72(\mathrm{~s}, 4 \mathrm{H}), 5.67(\mathrm{~s}, 1 \mathrm{H}), 1.51(\mathrm{~s}, 9 \mathrm{H}), 1.17(\mathrm{~s}, 9 \mathrm{H})\right]$, and $17 \%$ yield of 2-2-3g' [1 $\left.\mathrm{H}-\mathrm{NMR}\left(\mathrm{CDCl}_{3}, 400 \mathrm{MHz}, \mathrm{ppm}\right) \delta=4.33(\mathrm{~s}, 1 \mathrm{H}), 1.42(\mathrm{~s}, 9 \mathrm{H})\right]$.<smiles>[O-][P+]([O-])(c1ccccc1)C1C(=C(\O)c2ccccc2)/C(=C\c2ccc(Cl)cc2)[C@@H]1c1ccc(Cl)cc1</smiles>

\section{2-(4-chlorobenzylidene)-4-(4-chlorophenyl)-1-phenyl-3-(phenyl(pivaloyloxy)methylene)cycl}

obutyl pivalate (2-2-3g). Colorless solid; ${ }^{1} \mathrm{H}-\mathrm{NMR}\left(\mathrm{CDCl}_{3}, 400 \mathrm{MHz}, \mathrm{ppm}\right) \delta=7.21-7.15(\mathrm{~m}, 4 \mathrm{H})$, 7.12-7.06 (m, 8H), 7.03-7.01 (m, 3H), $6.71(\mathrm{~s}, 4 \mathrm{H}), 5.66(\mathrm{~s}, 1 \mathrm{H}), 1.51(\mathrm{~s}, 9 \mathrm{H}), 1.17(\mathrm{~s}, 9 \mathrm{H}) ;{ }^{13} \mathrm{C}-\mathrm{NMR}$ $\left(\mathrm{CDCl}_{3}, 150 \mathrm{MHz}, \mathrm{ppm}\right) \delta=177.1,176.2,143.3,142.5,139.7,136.0,133.6,133.5,133.3,132.9$, 
$131.9,130.6,130.4,129.7,129.6,129.3,128.7,128.5,128.4,128.3,128.2,128.0,127.9,127.7$, 127.3, 127.2, 126.8, 126.5, 125.5, 122.5, 89.8, 56.9, 39.6, 39.5, 27.6, 27.3; HRMS calcd for $\mathrm{C}_{40} \mathrm{H}_{38} \mathrm{Cl}_{2} \mathrm{O}_{4} \mathrm{H}[\mathrm{M}+\mathrm{H}]_{+}: 653.2220$, found 653.2222 .

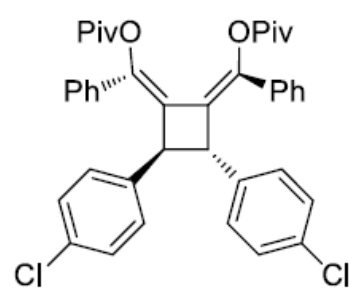

\section{2-(4-chlorobenzylidene)-4-(4-chlorophenyl)-1-phenyl-3-(phenyl(pivaloyloxy)methylene)cycl}

obutyl pivalate (2-2-3g'). Colorless solid; ${ }^{1} \mathrm{H}-\mathrm{NMR}\left(\mathrm{CDCl}_{3}, 400 \mathrm{MHz}, \mathrm{ppm}\right) \delta=7.20$ (d, $\mathrm{J}=8.4 \mathrm{~Hz}$, $2 \mathrm{H}), 7.05-6.95(\mathrm{~m}, 7 \mathrm{H}), 4.33(\mathrm{~s}, 1 \mathrm{H}), 1.42(\mathrm{~s}, 9 \mathrm{H})$; HRMS calcd for $\mathrm{C}_{40} \mathrm{H}_{38} \mathrm{Cl}_{2} \mathrm{O}{ }_{4} \mathrm{H}[\mathrm{M}+\mathrm{H}]_{+}: 653.2220$, found 653.2223 .

2-2-3h and 2-2-3h': 2-2-1h $(62.0 \mathrm{mg}, 0.20 \mathrm{mmol})$ was used, and the NMR show that: $76 \%$ yield of 2-2-3h [1 $\mathrm{H}-\mathrm{NMR}\left(\mathrm{CDCl}_{3}, 400 \mathrm{MHz}, \mathrm{ppm}\right) \delta=6.43(\mathrm{t}, J=8.8 \mathrm{~Hz}, 2 \mathrm{H}), 5.68(\mathrm{~s}, 1 \mathrm{H}), 1.52(\mathrm{~s}, 9 \mathrm{H}), 1.16$ $(\mathrm{s}, 9 \mathrm{H})]$, and $19 \%$ yield of 2-2-3h' [ $\left.{ }^{1} \mathrm{H}-\mathrm{NMR}\left(\mathrm{CDCl}_{3}, 400 \mathrm{MHz}, \mathrm{ppm}\right) \delta=4.35(\mathrm{~s}, 1 \mathrm{H}), 1.42(\mathrm{~s}, 9 \mathrm{H})\right]$.<smiles>O/C(=C1C(=C\c2ccc(F)cc2)/[C@@H](c2ccccc2)[C@]/1(O)c1ccccc1)c1ccccc1</smiles>

\section{2-(4-fluorobenzylidene)-4-(4-fluorophenyl)-1-phenyl-3-(phenyl(pivaloyloxy)methylene)cycl}

obutyl pivalate (2-2-3h). Colorless solid; ${ }^{1} \mathrm{H}-\mathrm{NMR}\left(\mathrm{CDCl}_{3}, 400 \mathrm{MHz}, \mathrm{ppm}\right) \delta=7.24-7.19(\mathrm{~m}, 4 \mathrm{H})$, 7.12-7.05 (m, 6H), 7.02-7.00 (m, 3H), 6.85-6.80 (m, 2H), 6.77-6.73 (m, 2H), $6.41(\mathrm{t}, J=8.8 \mathrm{~Hz}, 2 \mathrm{H})$, $5.68(\mathrm{~s}, 1 \mathrm{H}), 1.52(\mathrm{~s}, 9 \mathrm{H}), 1.16(\mathrm{~s}, 9 \mathrm{H}) ;{ }^{13} \mathrm{C}-\mathrm{NMR}\left(\mathrm{CDCl}_{3}, 150 \mathrm{MHz}, \mathrm{ppm}\right) \delta=177.1,176.3,163.0$, 162.0, 161.4, 160.4, 142.1, 138.5, 136.3, 133.7, 131.1, 131.1, 131.0, 130.9, 130.8, 130.8, 128.2, 128.0, 127.8, 127.6, 127.4, 126.5, 126.2, 125.6, 115.4, 115.3, 114.0, 113.9, 110.0, 90.0, 56.7, 39.5, 30.0, 27.6, 27.2; $\mathrm{HRMS}$ calcd for $\mathrm{C}_{40} \mathrm{H}_{38} \mathrm{~F}_{2} \mathrm{O}_{4} \mathrm{H}[\mathrm{M}+\mathrm{Na}]_{+}:$621.2811, found 621.2814.

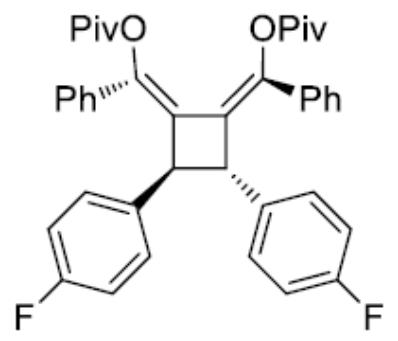




\section{3,4-bis(4-fluorophenyl)cyclobutane-1,2-diylidene)bis(phenylmethanylylidene)}

bis(2,2-dimethylpropanoate (2-2-3h'). Colorless solid; ${ }^{1} \mathrm{H}-\mathrm{NMR}\left(\mathrm{CDCl}_{3}, 400 \mathrm{MHz}, \mathrm{ppm}\right) \delta=7.24-$ $7.20(\mathrm{~m}, 2 \mathrm{H}), 7.05-6.95(\mathrm{~m}, 5 \mathrm{H}), 6.72-6.69(\mathrm{~m}, 2 \mathrm{H}), 4.34(\mathrm{~s}, 1 \mathrm{H}), 1.42(\mathrm{~s}, 9 \mathrm{H}) ;{ }^{13} \mathrm{C}-\mathrm{NMR}(\mathrm{CDCl}, 150$ $\mathrm{MHz}, \mathrm{ppm}) \delta=177.8,162.4,160.8,140.3,133.8,132.7,131.7,130.0,129.9,128.3,127.6,126.8$, 114.9, 114.7, 59.0, 39.5, 27.4; HRMS calcd for $\mathrm{C}_{40} \mathrm{H}_{38} \mathrm{~F}_{2} \mathrm{O}_{4} \mathrm{H}[\mathrm{M}+\mathrm{H}]_{+}:$643.2632, found 643.2630.

2-2-3i and 2-2-3i': 2-2-1i $(64.4 \mathrm{mg}, 0.20 \mathrm{mmol}),\left[\left(\mathrm{PPh}_{3} \mathrm{Au}\right){ }_{3} \mathrm{O}\right] \mathrm{OTf}_{2} 1 \mathrm{~mol} \%$ was used instead of [PPh $\left.{ }_{3} \mathrm{Au}(\mathrm{TA}-\mathrm{Me}) \mathrm{OTf}\right] 1 \mathrm{~mol} \%$, and the NMR show that: $68 \%$ yield of 2-2-3i [ ${ }^{1} \mathrm{H}-\mathrm{NMR}\left(\mathrm{CDCl}_{3}\right.$, $400 \mathrm{MHz}, \mathrm{ppm}) \delta=6.71(\mathrm{~d}, J=8.4 \mathrm{~Hz}, 2 \mathrm{H}), 6.67(\mathrm{~d}, J=9.6 \mathrm{~Hz}, 2 \mathrm{H}), 6.29(\mathrm{~d}, J=8.4 \mathrm{~Hz}, 2 \mathrm{H}), 5.64(\mathrm{~s}$, $1 \mathrm{H}), 3.72(\mathrm{~s}, 3 \mathrm{H}), 3.54(\mathrm{~s}, 3 \mathrm{H}), 1.52(\mathrm{~s}, 9 \mathrm{H}), 1.17(\mathrm{~s}, 9 \mathrm{H})$ ], and $12 \%$ yield of $\mathbf{2 - 2 - 3 \mathbf { i } ^ { \prime }}\left[{ }^{1} \mathrm{H}-\mathrm{NMR}\left(\mathrm{CDCl}_{3}\right.\right.$, $400 \mathrm{MHz}, \mathrm{ppm}) \delta=6.58(\mathrm{~d}, J=8.8 \mathrm{~Hz}, 2 \mathrm{H}), 4.31(\mathrm{~s}, 1 \mathrm{H}), 3.64(\mathrm{~s}, 3 \mathrm{H}), 1.42(\mathrm{~s}, 9 \mathrm{H})]$.

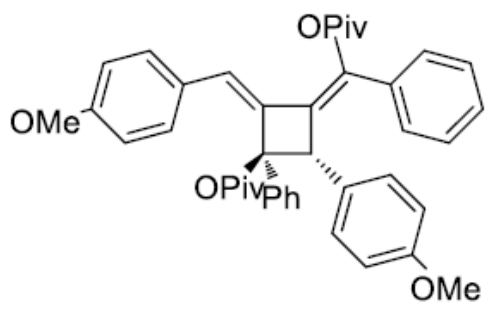

\section{(2Z,3Z)-2-(4-methoxybenzylidene)-4-(4-methoxyphenyl)-1-phenyl-3-(phenyl(pivaloyloxy)m}

\section{ethylene)cyclobutyl pivalate (2-2-3i).}

Colorless Solid; ${ }^{1} \mathrm{H}-\mathrm{NMR}\left(\mathrm{CDCl}_{3}, 400 \mathrm{MHz}, \mathrm{ppm}\right) \delta=7.24-7.18(\mathrm{~m}, 4 \mathrm{H}), 7.12-7.09(\mathrm{~m}, 3 \mathrm{H})$, 7.07-6.97 $(\mathrm{m}, 6 \mathrm{H}), 6.71(\mathrm{~d}, J=8.4 \mathrm{~Hz}, 2 \mathrm{H}), 6.67(\mathrm{~d}, J=9.6 \mathrm{~Hz}, 2 \mathrm{H}), 6.29(\mathrm{~d}, J=8.4 \mathrm{~Hz}, 2 \mathrm{H}), 5.64(\mathrm{~s}, 1 \mathrm{H}), 3.72$ $(\mathrm{s}, 3 \mathrm{H}), 3.54(\mathrm{~s}, 3 \mathrm{H}), 1.52(\mathrm{~s}, 9 \mathrm{H}), 1.17(\mathrm{~s}, 9 \mathrm{H}) ;{ }^{13} \mathrm{C}-\mathrm{NMR}\left(\mathrm{CDCl}_{3}, 100 \mathrm{MHz}, \mathrm{ppm}\right) \delta=177.09,176.36$, 159.23, 157.73, 141.21, 136.72, 136.70, 133.94, 130.90, 130.42, 127.91, 127.73, 127.71, 127.62, $127.51,127.45,127.42,127.08,126.44,126.40,113.76,112.49,90.34,56.93,55.22,55.19,54.92$, 54.90, 39.51, 27.67, 27.30; HRMS calcd for $\mathrm{C}_{42} \mathrm{H}_{44} \mathrm{O}_{6} \mathrm{Na}[\mathrm{M}+\mathrm{Na}]_{+}: 667.3030$, found 667.3031.

2-2-3j and 2-2-3j': 2-2-1j $(62.0 \mathrm{mg}, 0.20 \mathrm{mmol})$, and the NMR show that: $76 \%$ yield of $\mathbf{2 - 2}-\mathbf{3 j} \mathbf{~}^{1} \mathrm{H}-$ $\operatorname{NMR}\left(\mathrm{CDCl}_{3}, 400 \mathrm{MHz}, \mathrm{ppm}\right) \delta=6.58(\mathrm{~d}, J=7.6 \mathrm{~Hz}, 1 \mathrm{H}), 6.50-6.43(\mathrm{~m}, 2 \mathrm{H}), 5.69(\mathrm{~s}, 1 \mathrm{H}), 1.52(\mathrm{~s}$, $9 \mathrm{H}), 1.18(\mathrm{~s}, 9 \mathrm{H})]$, and $17 \%$ yield of 2-2-3j' [ ${ }^{1} \mathrm{H}-\mathrm{NMR}\left(\mathrm{CDCl}_{3}, 400 \mathrm{MHz}, \mathrm{ppm}\right) \delta=4.39(\mathrm{~s}, 1 \mathrm{H}), 1.43$ $(\mathrm{s}, 9 \mathrm{H})]$.HRMS calcd for $\mathrm{C}_{40} \mathrm{H}_{38} \mathrm{~F}_{2} \mathrm{O}_{4} \mathrm{Na}[\mathrm{M}+\mathrm{Na}]_{+}:$643.2630, found 643.2633.

2-2-3k and 2-2-3k': 2-2-1k (70.0 mg, $0.20 \mathrm{mmol})$, and the NMR show that: $71 \%$ yield of $\mathbf{2}-\mathbf{2}-\mathbf{3 k}\left[{ }^{1} \mathrm{H}\right.$ $\operatorname{NMR}\left(\mathrm{CDCl}_{3}, 400 \mathrm{MHz}, \mathrm{ppm}\right) \delta=6.86(\mathrm{~d}, J=7.6 \mathrm{~Hz}, 2 \mathrm{H}), 5.78(\mathrm{~s}, 1 \mathrm{H}), 3.84(\mathrm{~s}, 3 \mathrm{H}), 3.75(\mathrm{~s}, 3 \mathrm{H})$, $1.54(\mathrm{~s}, 9 \mathrm{H}), 1.17(\mathrm{~s}, 9 \mathrm{H})]$, and $11 \%$ yield of 2-2-3k' [ ${ }^{1} \mathrm{H}-\mathrm{NMR}\left(\mathrm{CDCl}_{3}, 400 \mathrm{MHz}, \mathrm{ppm}\right) \delta=4.48(\mathrm{~s}$, $1 \mathrm{H}), 3.82(\mathrm{~s}, 3 \mathrm{H}), 1.44(\mathrm{~s}, 9 \mathrm{H})]$. HRMS calcd for $\mathrm{C}_{44} \mathrm{H}_{44} \mathrm{O}_{8} \mathrm{H}[\mathrm{M}+\mathrm{H}]_{+}:$701.3109, found 701.3111.

2-2-3l and 2-2-3l': 2-2-1l $(61.2 \mathrm{mg}, 0.20 \mathrm{mmol})$, and the NMR show that: 73 \% yield of 2-2-3k [ ${ }^{1} \mathrm{H}$ $\operatorname{NMR}\left(\mathrm{CDCl}_{3}, 400 \mathrm{MHz}, \mathrm{ppm}\right) \delta=6.64(\mathrm{t}, J=7.6 \mathrm{~Hz}, 1 \mathrm{H}), 6.55(\mathrm{~d}, J=7.6 \mathrm{~Hz}, 1 \mathrm{H}), 6.31$ (d, $J=7.6 \mathrm{~Hz}$, 
$1 \mathrm{H}), 6.14(\mathrm{~s}, 1 \mathrm{H}), 2.39(\mathrm{~s}, 3 \mathrm{H}), 2.31(\mathrm{~s}, 3 \mathrm{H}), 1.49(\mathrm{~s}, 9 \mathrm{H}), 0.92(\mathrm{~s}, 9 \mathrm{H})]$, and $18 \%$ yield of 2-2-3k' [ [ $\mathrm{H}$ $\left.\operatorname{NMR}\left(\mathrm{CDCl}_{3}, 400 \mathrm{MHz}, \mathrm{ppm}\right) \delta=4.72(\mathrm{~s}, 1 \mathrm{H}), 1.90(\mathrm{~s}, 3 \mathrm{H}), 1.45(\mathrm{~s}, 9 \mathrm{H})\right]$.<smiles>Cc1ccccc1/C=C1C(=C(/OC#N)c2ccccc2)/[C@@H](c2ccccc2C)C/1([N+](=O)[O-])[N+](=O)[O-]</smiles>

(2Z,3Z)-2-(2-methylbenzylidene)-1-phenyl-3-(phenyl(pivaloyloxy)methylene)-4-(o-tolyl)cycl

obutyl pivalate (2-2-3I). Colorless solid; note: $12 \%$ of $\mathbf{3} \mathbf{k}^{\prime}$ is contained in the $\mathbf{3 k}$, so the ${ }^{13} \mathrm{C}$ NMR can not be characterized. ${ }^{1} \mathrm{H}-\mathrm{NMR}\left(\mathrm{CDCl}_{3}, 400 \mathrm{MHz}, \mathrm{ppm}\right) \delta=7.33-7.31(\mathrm{~m}, 2 \mathrm{H}), 7.12-6.98(\mathrm{~m}, 12 \mathrm{H})$, 6.82-6.74 (m, 2H), $6.64(\mathrm{t}, J=7.6 \mathrm{~Hz}, 1 \mathrm{H}), 6.55(\mathrm{~d}, J=7.6 \mathrm{~Hz}, 1 \mathrm{H}), 6.31(\mathrm{~d}, J=7.6 \mathrm{~Hz}, 1 \mathrm{H}), 6.14(\mathrm{~s}$, $1 \mathrm{H}), 2.39(\mathrm{~s}, 3 \mathrm{H}), 2.31(\mathrm{~s}, 3 \mathrm{H}), 1.49(\mathrm{~s}, 9 \mathrm{H}), 0.92(\mathrm{~s}, 9 \mathrm{H})$; HRMS calcd for $\mathrm{C}_{42} \mathrm{H}_{44} \mathrm{O}_{4} \mathrm{Na}[\mathrm{M}+\mathrm{Na}]_{+}$: 635.3132 , found 635.3133 .

2-2-3m and 2-2-3m': 2-2-1m (74.0 mg, $0.20 \mathrm{mmol})$, and the NMR show that: $63 \%$ yield of $\mathbf{2 - 2 - 3 m}$ [ ${ }^{1} \mathrm{H}-\mathrm{NMR}\left(\mathrm{CDCl}_{3}, 400 \mathrm{MHz}, \mathrm{ppm}\right) \delta=6.62-6.56(\mathrm{~m}, 2 \mathrm{H}), 6.44(\mathrm{~s}, 1 \mathrm{H}), 6.41-6.36(\mathrm{~m}, 1 \mathrm{H}), 1.52(\mathrm{~s}, 9 \mathrm{H})$, $1.00(\mathrm{~s}, 9 \mathrm{H})$ ], and $18 \%$ yield of 2-2-3m' [ ${ }^{1} \mathrm{H}-\mathrm{NMR}\left(\mathrm{CDCl}_{3}, 400 \mathrm{MHz}, \mathrm{ppm}\right) \delta=6.80\left(\mathrm{dt}, \mathrm{J}_{1}=2.0 \mathrm{~Hz}, \mathrm{~J}_{2}\right.$ $=8.0 \mathrm{~Hz}, 1 \mathrm{H}), 5.13(\mathrm{~s}, 1 \mathrm{H}), 1.45(\mathrm{~s}, 9 \mathrm{H})]$.

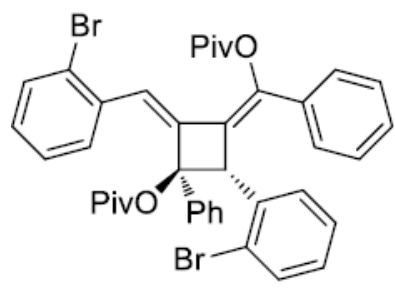

(2Z,3Z)-2-(2-bromobenzylidene)-4-(2-bromophenyl)-1-phenyl-3-(phenyl(pivaloyloxy)methy

lene)cyclobutyl pivalate (2-2-3m). ${ }^{1} \mathrm{H}-\mathrm{NMR}\left(\mathrm{CDCl}_{3}, 400 \mathrm{MHz}, \mathrm{ppm}\right) \delta=7.52(\mathrm{~d}, J=1.2 \mathrm{~Hz}, 1 \mathrm{H})$, $7.50(\mathrm{~s}, 1 \mathrm{H}), 7.50-7.37(\mathrm{~m}, 2 \mathrm{H}), 7.23-7.19(\mathrm{~m}, 2 \mathrm{H}), 7.18-7.08(\mathrm{~m}, 4 \mathrm{H}), 7.05-7.00(\mathrm{~m}, 4 \mathrm{H}), 6.96-6.86$ $(\mathrm{m}, 2 \mathrm{H}), 6.62-6.56(\mathrm{~m}, 2 \mathrm{H}), 6.44(\mathrm{~s}, 1 \mathrm{H}), 6.41-6.36(\mathrm{~m}, 1 \mathrm{H}), 1.52(\mathrm{~s}, 9 \mathrm{H}), 1.00(\mathrm{~s}, 9 \mathrm{H}) ;{ }^{13} \mathrm{C}-\mathrm{NMR}$ $\left(\mathrm{CDCl}_{3}, 100 \mathrm{MHz}, \mathrm{ppm}\right) \delta=176.71,176.37,142.20,141.12,137.96,134.64,134.38,133.71,132.82$, 131.64, 131.17, 130.03, 128.80, 128.27, 127.95, 127.66, 127.62, 127.57, 126.94, 126.80, 126.66, $125.88,125.43,124.90,124.68,124.57,89.50,55.52,39.40,39.31,27.59,27.27$; HRMS calcd for $\mathrm{C}_{40} \mathrm{H}_{38} \mathrm{Br}_{2} \mathrm{O} 4 \mathrm{Na}[\mathrm{M}+\mathrm{Na}]_{+}:$763.1029, found 763.1028 .

2-2-3n and 2-2-3n': 2-2-1n (62.0 mg, $0.20 \mathrm{mmol})$, and the NMR show that: $74 \%$ yield of $\mathbf{2 - 2 - 3 n}\left[{ }^{1} \mathrm{H}\right.$ $\operatorname{NMR}\left(\mathrm{CDCl}_{3}, 400 \mathrm{MHz}, \mathrm{ppm}\right) \delta=6.52(\mathrm{t}, J=8.0 \mathrm{~Hz}, 1 \mathrm{H}), 6.25(\mathrm{t}, J=8.0 \mathrm{~Hz}, 1 \mathrm{H}), 6.14(\mathrm{~s}, 1 \mathrm{H}), 1.53$ $(\mathrm{s}, 9 \mathrm{H}), 1.20(\mathrm{~s}, 9 \mathrm{H})]$, and $18 \%$ yield of 2-2-3n' [ ${ }^{1} \mathrm{H}-\mathrm{NMR}\left(\mathrm{CDCl}_{3}, 400 \mathrm{MHz}, \mathrm{ppm}\right) \delta=4.97(\mathrm{~s}, 1 \mathrm{H})$, $1.43(\mathrm{~s}, 9 \mathrm{H})]$. 


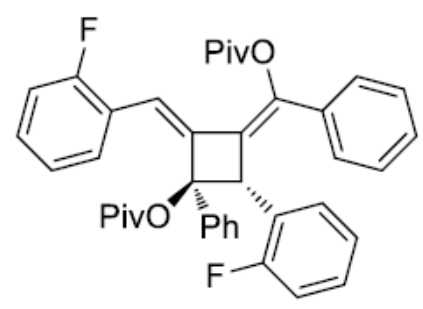

(2Z,3Z)-2-(2-fluorobenzylidene)-4-(2-fluorophenyl)-1-phenyl-3-(phenyl(pivaloyloxy)methyle

ne)cyclobutyl pivalate (2-2-3n). ${ }^{1} \mathrm{H}-\mathrm{NMR}\left(\mathrm{CDCl}_{3}, 400 \mathrm{MHz}, \mathrm{ppm}\right) \delta=7.25-7.23(\mathrm{~m}, 2 \mathrm{H}), 7.15-7.00$ $(\mathrm{m}, 11 \mathrm{H}), 6.94(\mathrm{~d}, J=10.8 \mathrm{~Hz}, 1 \mathrm{H}), 6.83-6.78(\mathrm{~m}, 1 \mathrm{H}), 6.71(\mathrm{~d}, J=8.0 \mathrm{~Hz}, 1 \mathrm{H}), 6.69-6.57(\mathrm{~m}, 1 \mathrm{H})$, 6.51-6.43 (m, 2H), $5.68(\mathrm{~s}, 1 \mathrm{H}), 1.52(\mathrm{~s}, 9 \mathrm{H}), 1.17(\mathrm{~s}, 9 \mathrm{H}) ;{ }^{13} \mathrm{C}-\mathrm{NMR}\left(\mathrm{CDCl}_{3}, 100 \mathrm{MHz}, \mathrm{ppm}\right) \delta=$ $177.08,176.08,163.79,161.35,160.72,142.92,140.49,137.55,137.47,136.93,135.92,133.72$, $129.69,129.61,128.50,128.42,128.38,127.94,127.89,127.74,127.71,127.26,126.76,126.56$, 125.56, 125.53, 125.32, 125.22, 125.20, 125.09, 125.06, 116.17, 115.95, 115.63, 115.41, 114.66, 114.45, 113.15, 112.94, 89.63, 57.01, 56.99, 39.59, 27.59, 27.20; HRMS calcd for $\mathrm{C}_{40} \mathrm{H}_{38} \mathrm{~F}_{2} \mathrm{O}_{4} \mathrm{Na}$ $[\mathrm{M}+\mathrm{Na}]_{+}: 643.2630$, found 643.2631 .

2-2-3o and 2-2-3o': 2-2-10 (68.4 mg, $0.20 \mathrm{mmol}$ ), and the NMR show that: $43 \%$ yield of $\mathbf{2 - 2}-\mathbf{3 0}\left[{ }^{1} \mathrm{H}^{-}\right.$ $\left.\operatorname{NMR}\left(\mathrm{CDCl}_{3}, 400 \mathrm{MHz}, \mathrm{ppm}\right) \delta=65.92(\mathrm{~s}, 1 \mathrm{H}), 1.58(\mathrm{~s}, 9 \mathrm{H}), 1.15(\mathrm{~s}, 9 \mathrm{H})\right]$, and $24 \%$ yield of 2-2-3o' $\left[{ }^{1} \mathrm{H}-\mathrm{NMR}\left(\mathrm{CDCl}_{3}, 400 \mathrm{MHz}, \mathrm{ppm}\right) \delta=5.13(\mathrm{~s}, 1 \mathrm{H}), 1.11(\mathrm{~s}, 9 \mathrm{H})\right]$.

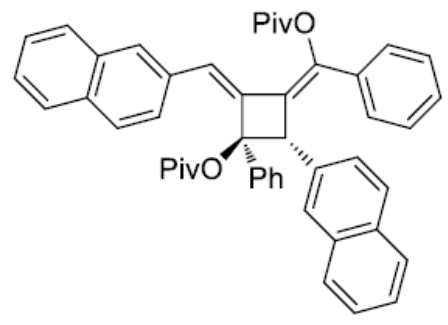

\section{(3Z,4Z)-2-(naphthalen-2-yl)-4-(naphthalen-2-ylmethylene)-1-phenyl-3-(phenyl(pivaloyloxy)}

methylene)cyclobutyl pivalate (2-2-3o). ${ }^{1} \mathrm{H}-\mathrm{NMR}\left(\mathrm{CDCl}_{3}, 400 \mathrm{MHz}, \mathrm{ppm}\right) \delta=7.70(\mathrm{~s}, 1 \mathrm{H}), 7.68$ $7.65(\mathrm{~m}, 1 \mathrm{H}), 7.56-7.48(\mathrm{~m}, 5 \mathrm{H}), 7.43-7.31(\mathrm{~m}, 5 \mathrm{H}), 7.27-7.25(\mathrm{~m}, 1 \mathrm{H}), 7.21-7.17(\mathrm{~m}, 2 \mathrm{H})$, 7.15-7.12 $(\mathrm{m}, 1 \mathrm{H}), 6.98-6.85(\mathrm{~m}, 7 \mathrm{H}), 5.92(\mathrm{~s}, 1 \mathrm{H}), 1.58(\mathrm{~s}, 9 \mathrm{H}), 1.15(\mathrm{~s}, 9 \mathrm{H}) ;{ }^{13} \mathrm{C}-\mathrm{NMR}\left(\mathrm{CDCl}_{3}, 100 \mathrm{MHz}, \mathrm{ppm}\right)$ $\delta=177.13,176.32,142.43,139.83,136.54,133.90,133.21,133.04,132.70,132.66,132.61,131.98$, $129.00,128.65,128.21,128.03,127.72,127.64,127.61,127.57,127.42,127.26,127.14,126.88$, 126.86, 126.51, 126.48, 126.39, 126.20, 126.09, 125.05, 124.99, 90.09, 57.68, 39.61, 29.69, 27.72, 27.27; HRMS calcd for $\mathrm{C}_{48} \mathrm{H}_{44} \mathrm{O}{ }_{4} \mathrm{Na}[\mathrm{M}+\mathrm{Na}]_{+}: 685.3312$, found 685.3314.

2-2-3p and 2-2-3p': 2-2-1p (67.2 $\mathrm{mg}, 0.20 \mathrm{mmol}$ ), and the NMR show that: $66 \%$ yield of 2-2-3p [ ${ }^{1} \mathrm{H}$ $\operatorname{NMR}\left(\mathrm{CDCl}_{3}, 400 \mathrm{MHz}, \mathrm{ppm}\right) \delta=5.58(\mathrm{~s}, 1 \mathrm{H}), 3.65(\mathrm{~s}, 3 \mathrm{H}), 3.63(\mathrm{~s}, 3 \mathrm{H}), 2.23(\mathrm{~s}, 3 \mathrm{H}), 2.04(\mathrm{~s}, 3 \mathrm{H})$, $1.51(\mathrm{~s}, 9 \mathrm{H}), 1.15(\mathrm{~s}, 9 \mathrm{H})]$, and $10 \%$ yield of 2-2-3p' [ [ ${ }^{1} \mathrm{H}-\mathrm{NMR}\left(\mathrm{CDCl}_{3}, 400 \mathrm{MHz}, \mathrm{ppm}\right) \delta=4.29(\mathrm{~s}$, $1 \mathrm{H}), 3.65(\mathrm{~s}, 3 \mathrm{H}), 2.18(\mathrm{~s}, 3 \mathrm{H}), 1.41(\mathrm{~s}, 9 \mathrm{H})]$. 


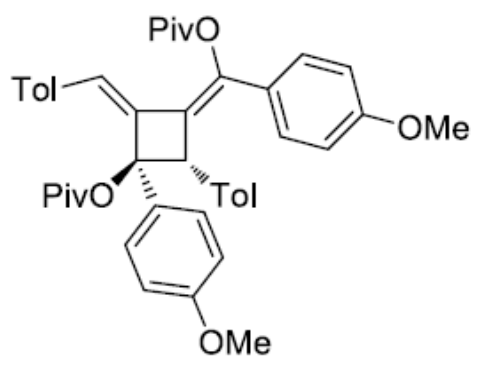

\section{(4-methoxyphenyl)(3-(4-methoxyphenyl)-2-(4-methylbenzylidene)-3-(pivaloyloxy)-4-(p-toly}

I)cyclobutylidene)methyl pivalate (2-2-3p). ${ }^{1} \mathrm{H}-\mathrm{NMR}\left(\mathrm{CDCl}_{3}, 400 \mathrm{MHz}, \mathrm{ppm}\right) \delta=7.16-7.12(\mathrm{~m}, 4 \mathrm{H})$, $7.06(\mathrm{~s}, 1 \mathrm{H}), 7.04(\mathrm{~d}, J=5.6 \mathrm{~Hz}, 2 \mathrm{H}), 6.93(\mathrm{~d}, J=5.6 \mathrm{~Hz}), 6.57(\mathrm{~d}, J=6.4 \mathrm{~Hz}, 2 \mathrm{H}), 6.52(\mathrm{~d}, J=6.4 \mathrm{~Hz}$, $2 \mathrm{H}), 5.57(\mathrm{~s}, 1 \mathrm{H}), 3.66(\mathrm{~s}, 3 \mathrm{H}), 3.65(\mathrm{~s}, 3 \mathrm{H}), 2.24(\mathrm{~s}, 3 \mathrm{H}), 2.05(\mathrm{~s}, 3 \mathrm{H}), 1.51(\mathrm{~s}, 9 \mathrm{H}), 1.15(\mathrm{~s}, 9 \mathrm{H}){ }^{; 13} \mathrm{C}-$ NMR $\left(\mathrm{CDCl}_{3}, 100 \mathrm{MHz}, \mathrm{ppm}\right) \delta=177.0,176.4,159.3,159.1,158.7,141.5,138.7,137.4,135.3$, $132.4,132.3,130.8,129.7,129.3,129.2,129.1,129.0,128.9,128.8,128.2,128.0,127.9,127.8$, $127.1,126.6,125.8,124.9,113.8,113.1,113.0,110.0,90.0,57.1,55.1,39.5,39.4,27.7$, 27.4;HRMS calcd for $\mathrm{C}_{44} \mathrm{H}_{48} \mathrm{O} 6 \mathrm{Na}[\mathrm{M}+\mathrm{H}]_{+}: 673.3524$, found 673.3527 .

2-2-3q and 2-2-3q': 2-2-1q (72.8 $\mathrm{mg}, 0.20 \mathrm{mmol})$, and the NMR show that no reaction occur.

2-2-3r and 2-2-3r': 2-2-1r (90 $\mathrm{mg}, 0.20 \mathrm{mmol})$, and the NMR show that no reaction occur.

\section{Possible role of gold in allene [2+2] step}

Reaction conditions: To a solution of 2-2-1c $(61.2 \mathrm{mg}, 0.20 \mathrm{mmol})$ in dry, base-washed $\mathrm{CDCl}_{3}$ $(0.8 \mathrm{~mL}, 0.25 \mathrm{M})$, was added XphosAuNTf 2 (2.0 mg, $0.002 \mathrm{~mol}, 1.0 \mathrm{~mol} \%)$ at RT. The reaction mixture was monitored by ${ }^{1} \mathrm{H}$ NMR. After 2-2-1c was transformed into allene 2-2-4 completely (around 5 mins), around half of reaction mixture went through the short silica gel column to remove the XphosAuNTf 2 immediately, and another 3 portions of dry, based washed $\mathrm{CDCl}_{3}$ to washed the column, and the major part of solvent was removed in vacuo (make the concentration around 0.12M). ${ }_{1} \mathrm{H}$ NMR show that the 2+2 cycloaddition of allene 2-2-4 was consumed completely in 20 hours with or without XphosAuNTf (the same concentration, 0.12M). 


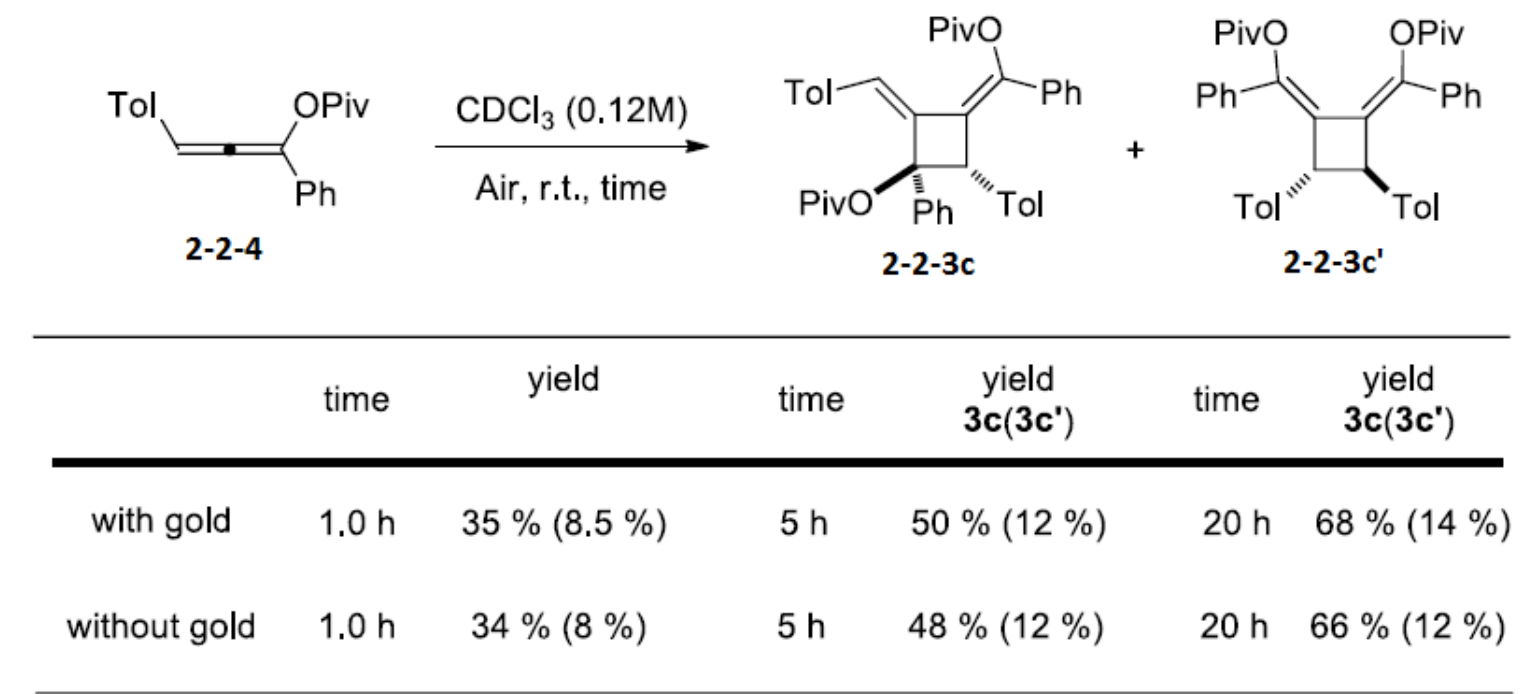<smiles></smiles>

1-phenyl-3-(p-tolyl)propa-1,2-dien-1-yl pivalate (2-2-4). ${ }^{1} \mathrm{H}-\mathrm{NMR}\left(\mathrm{CDCl}_{3}, 400 \mathrm{MHz}, \mathrm{ppm}\right) \delta=7.43$ $7.39(\mathrm{~m}, 4 \mathrm{H}), 7.33(\mathrm{t}, J=7.6 \mathrm{~Hz}, 2 \mathrm{H}), 7.28-7.24(\mathrm{~m}, 1 \mathrm{H}), 7.16(\mathrm{~d}, J=8.0 \mathrm{~Hz}, 2 \mathrm{H}), 6.96(\mathrm{~s}, 1 \mathrm{H}), 2.35$ (s, 3H), $1.37(\mathrm{~s}, 9 \mathrm{H})$. 
VI. NMR spectra 


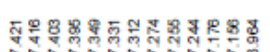

U.W.
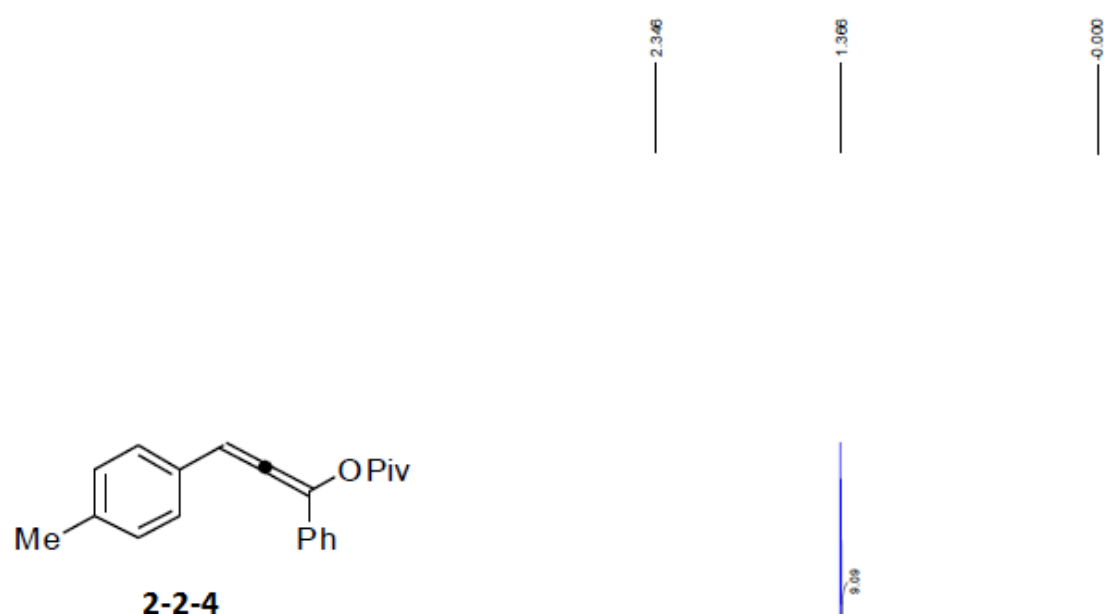

2-2-4

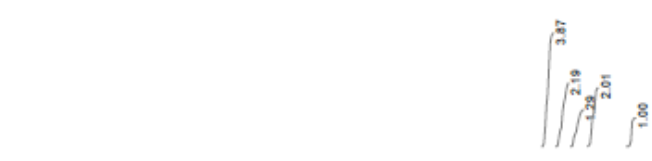

Shal 


\section{Crude NMR Spectrum}

[1,3,5-trimethoxybenzene $(0.1 \mathrm{mmol})$ was used as internal standard] 


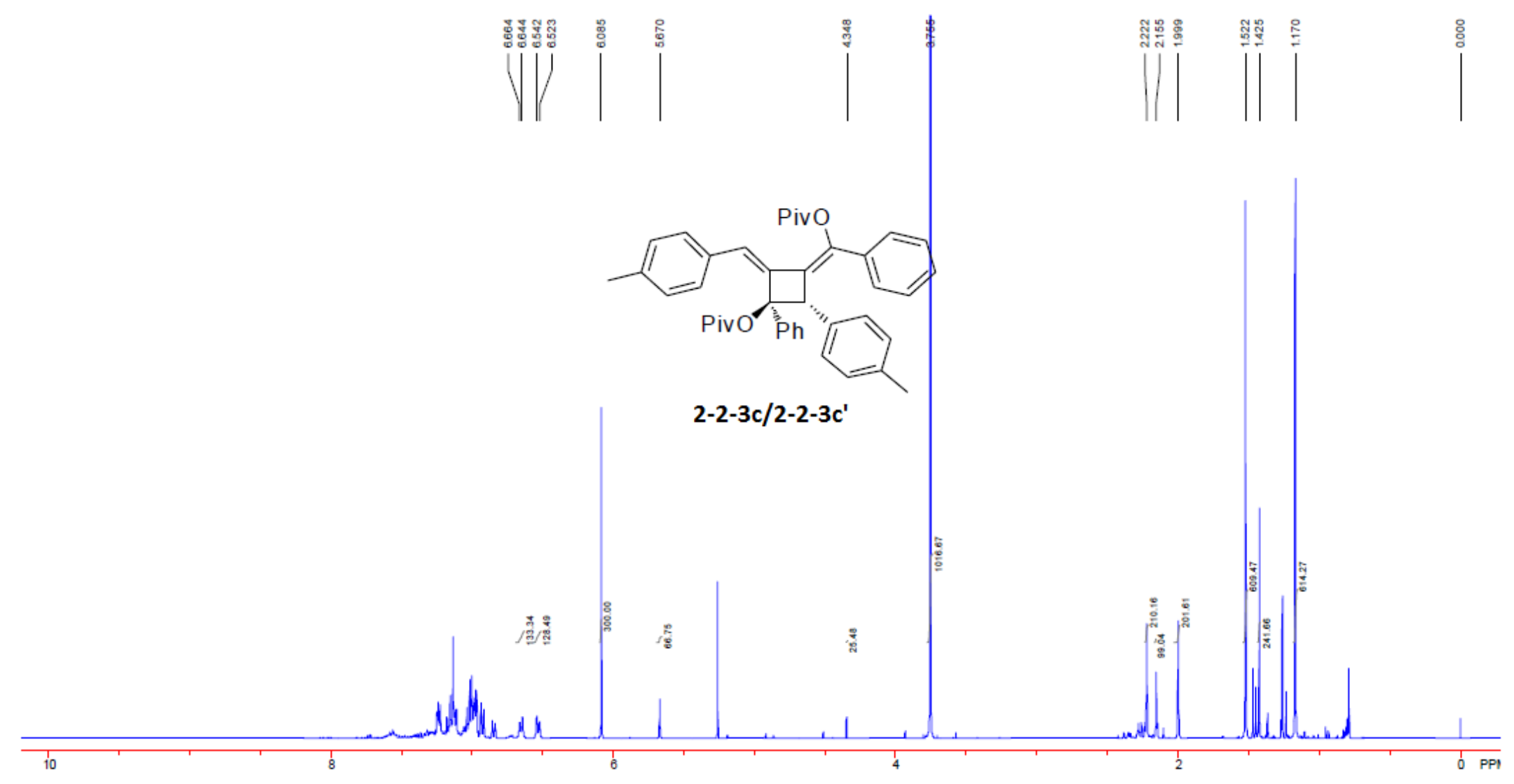




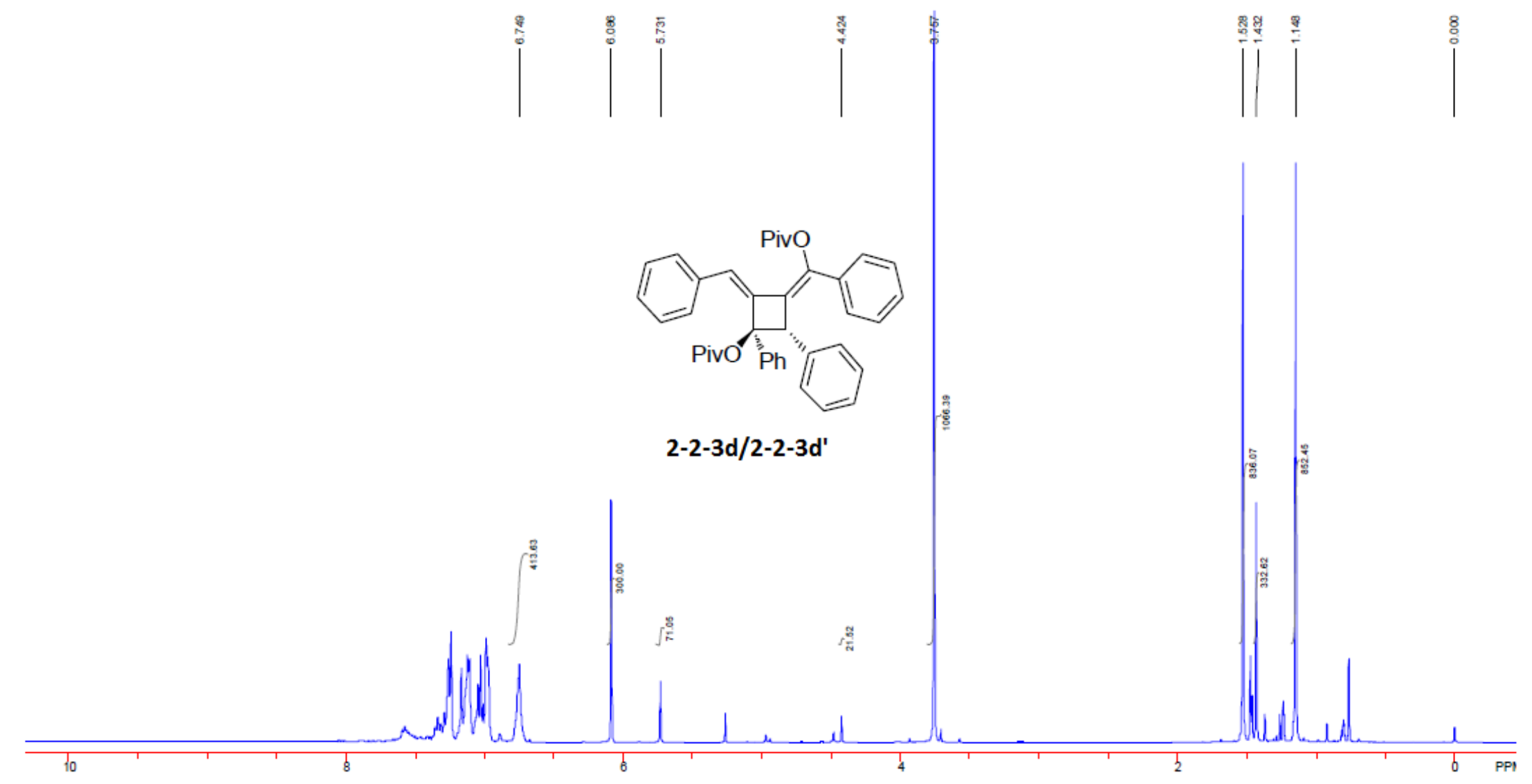




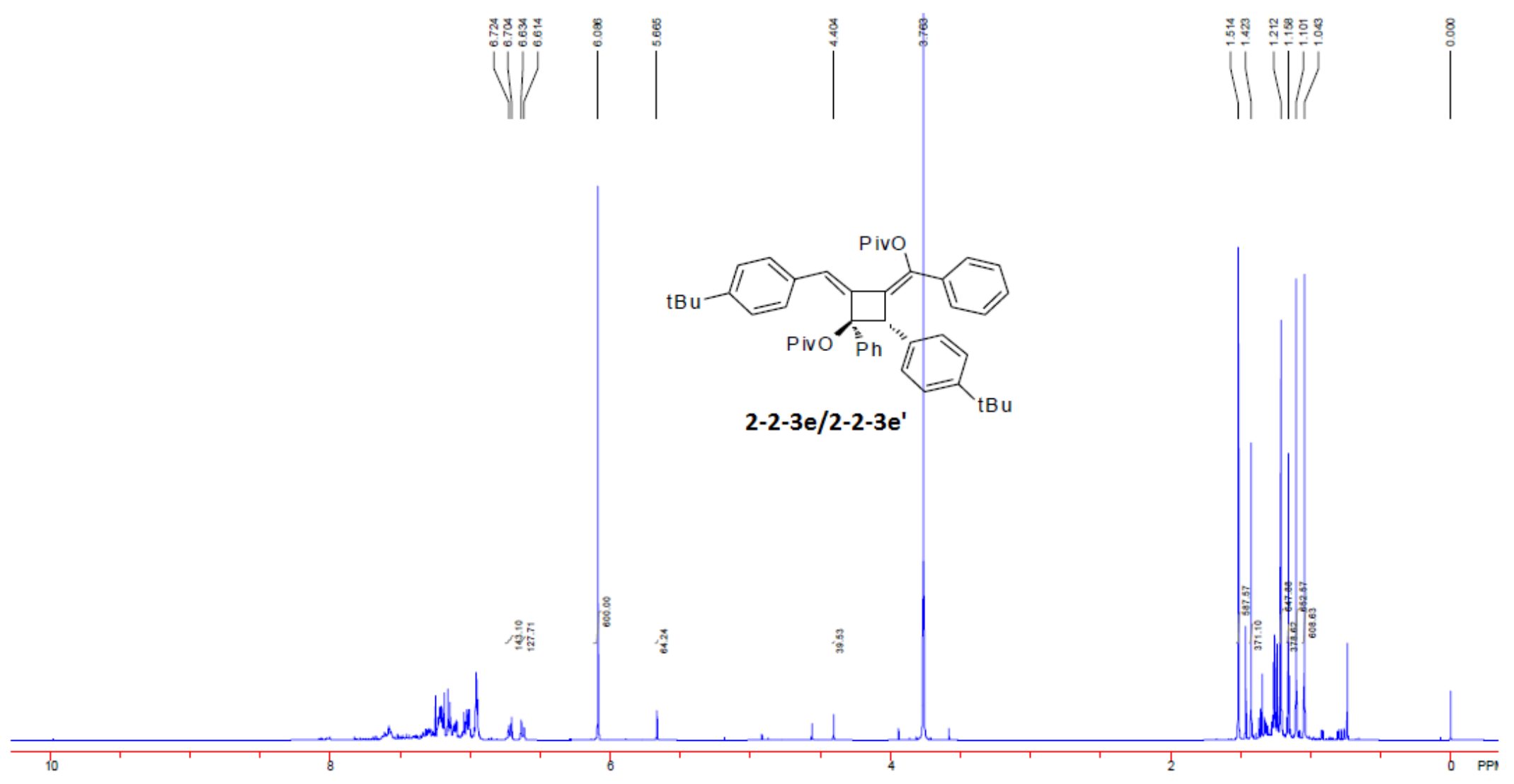




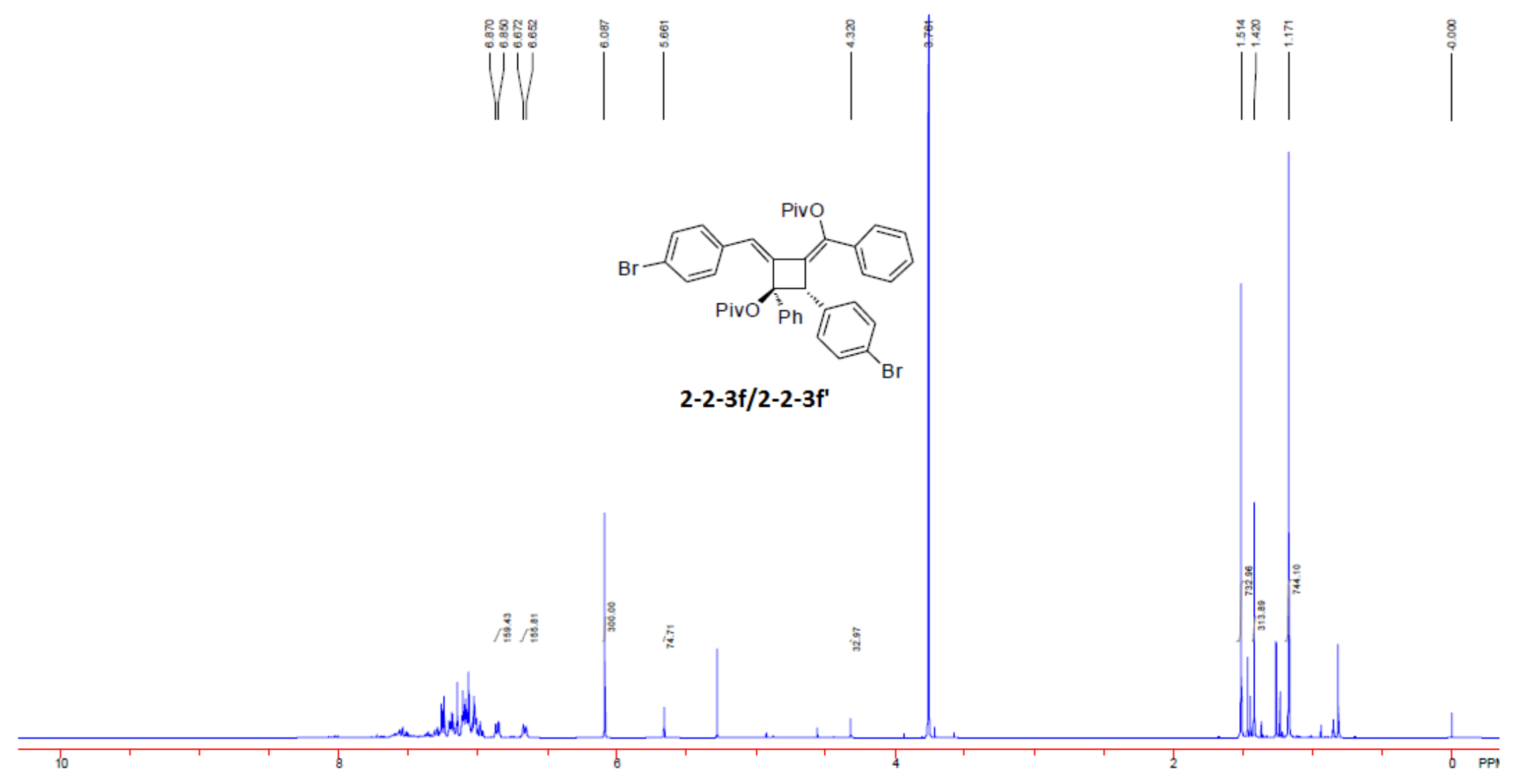




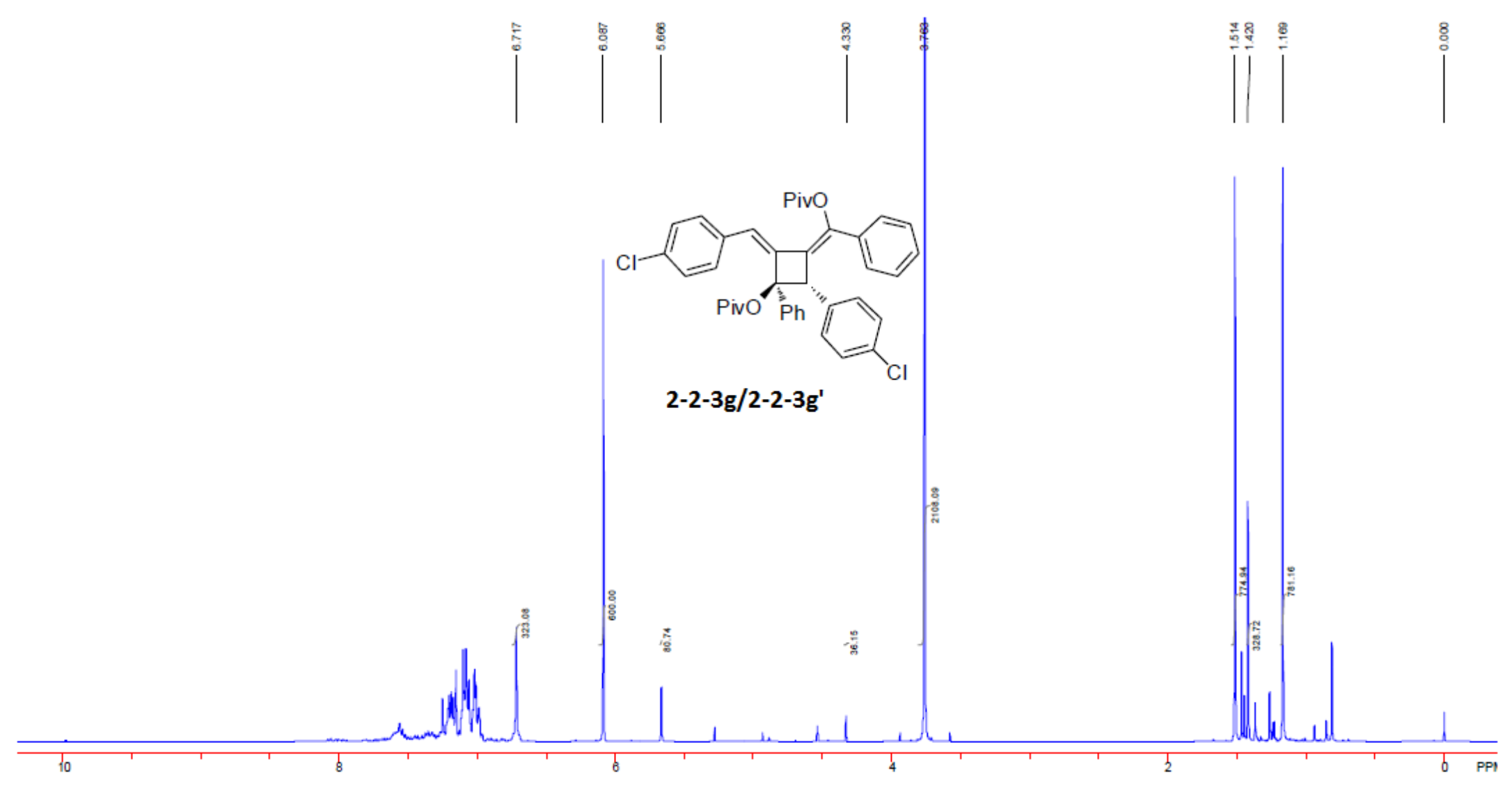




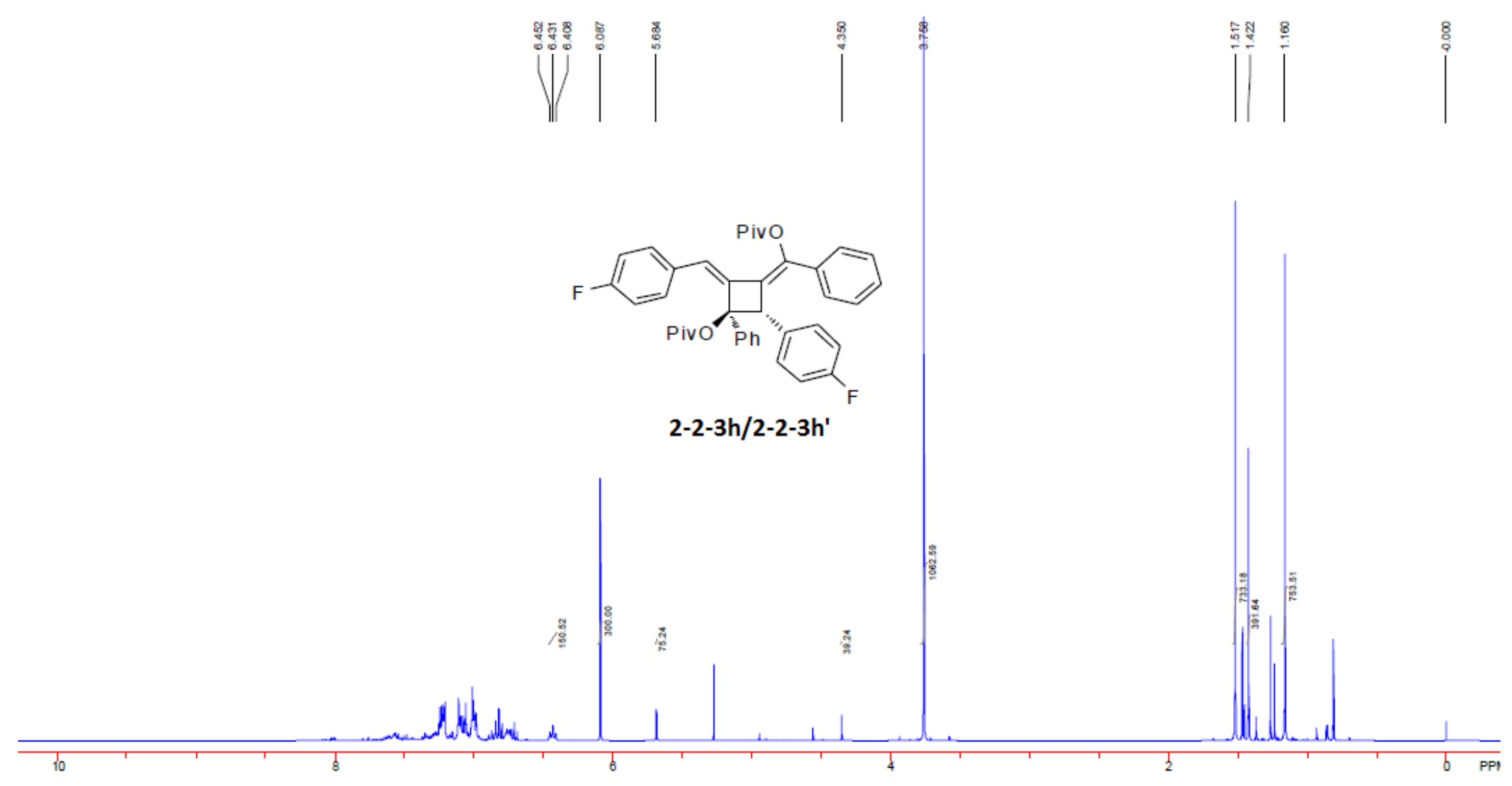




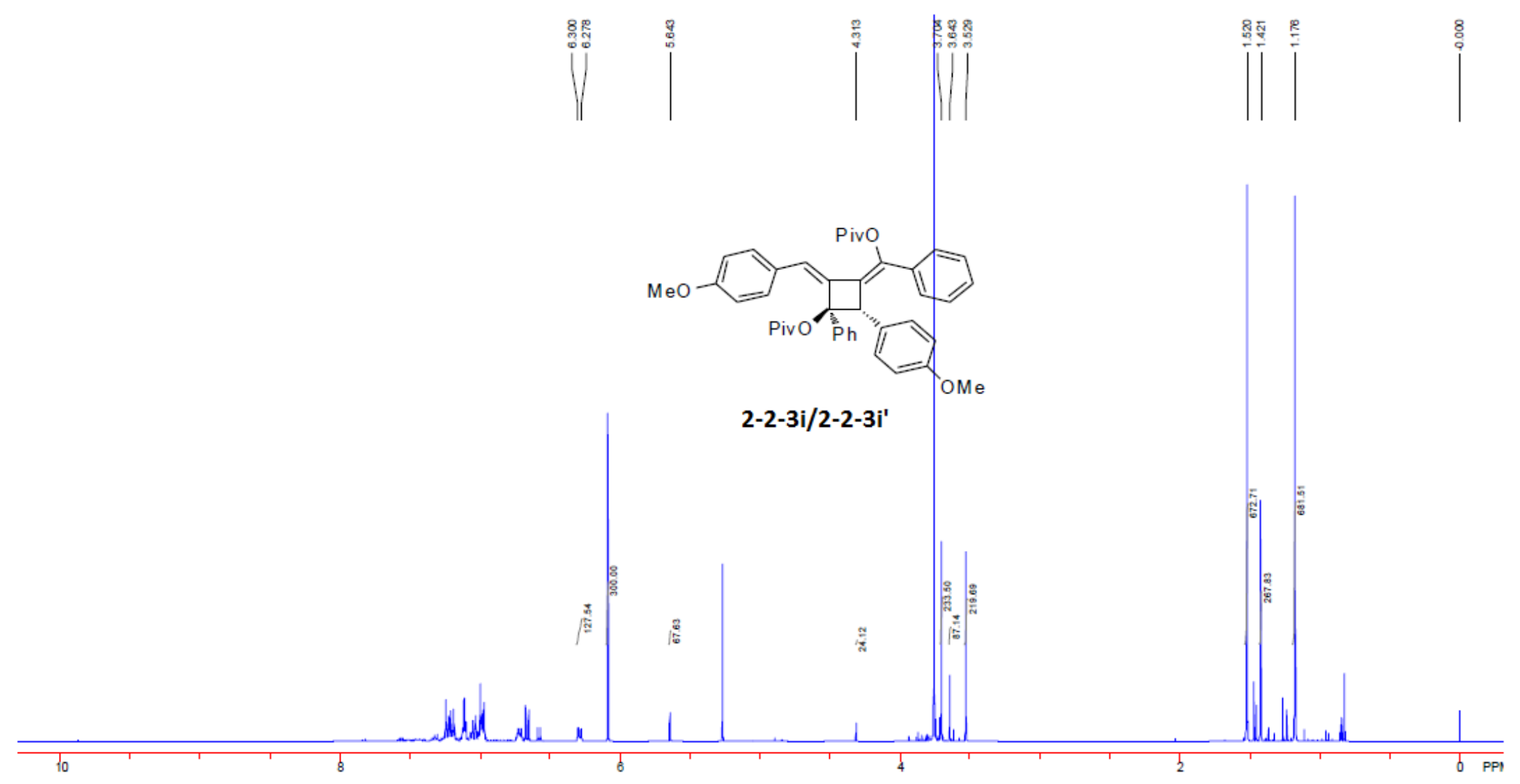




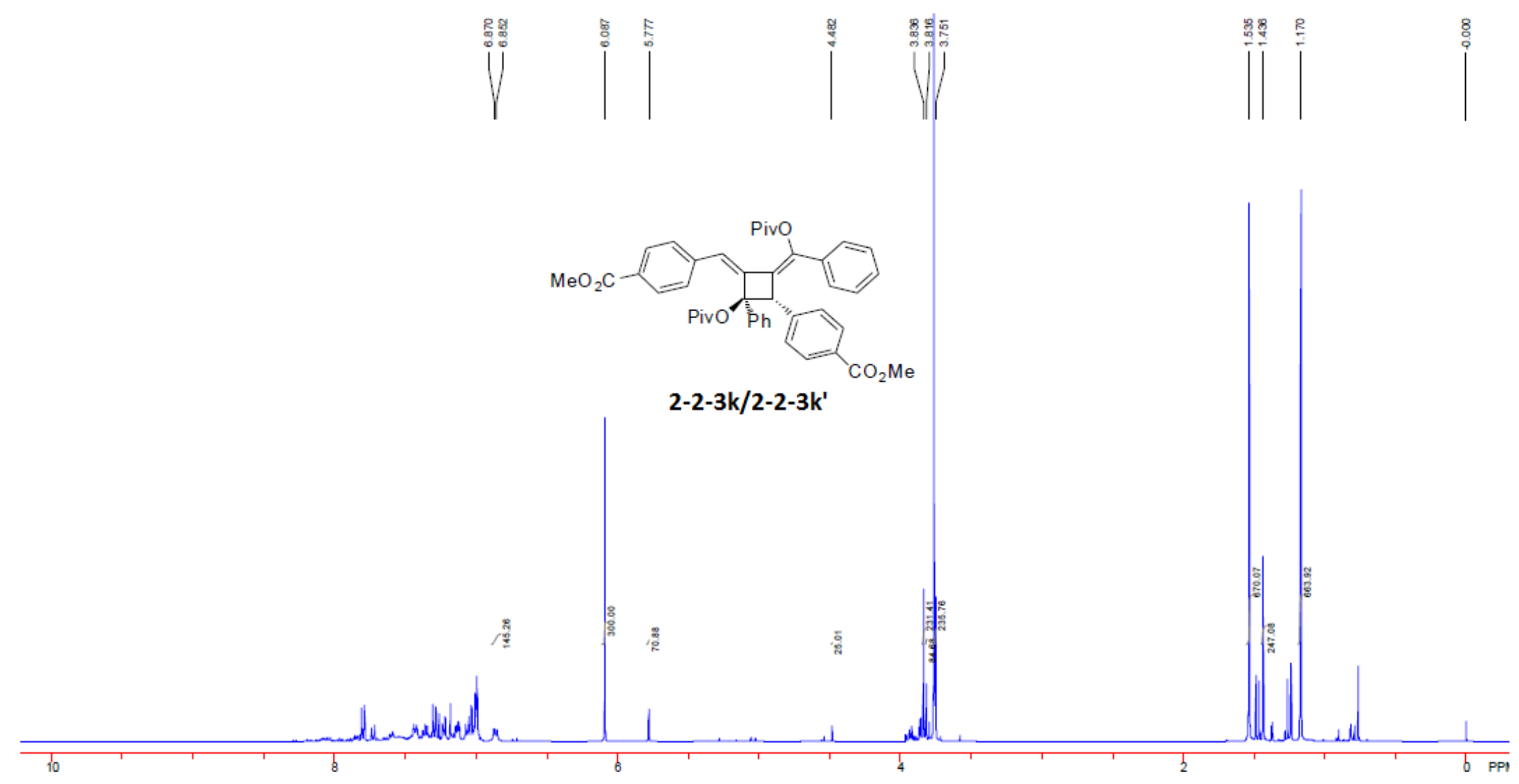




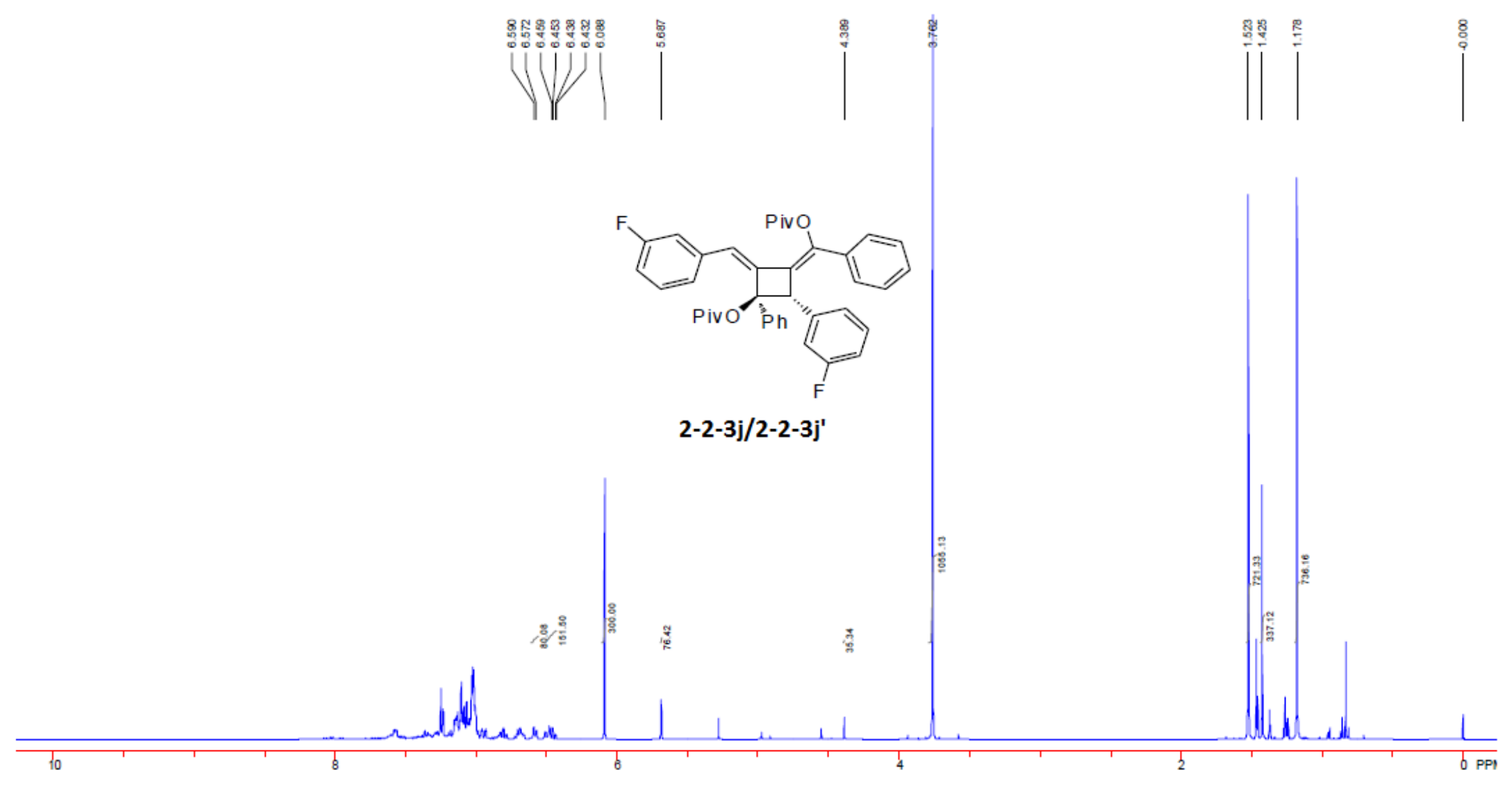




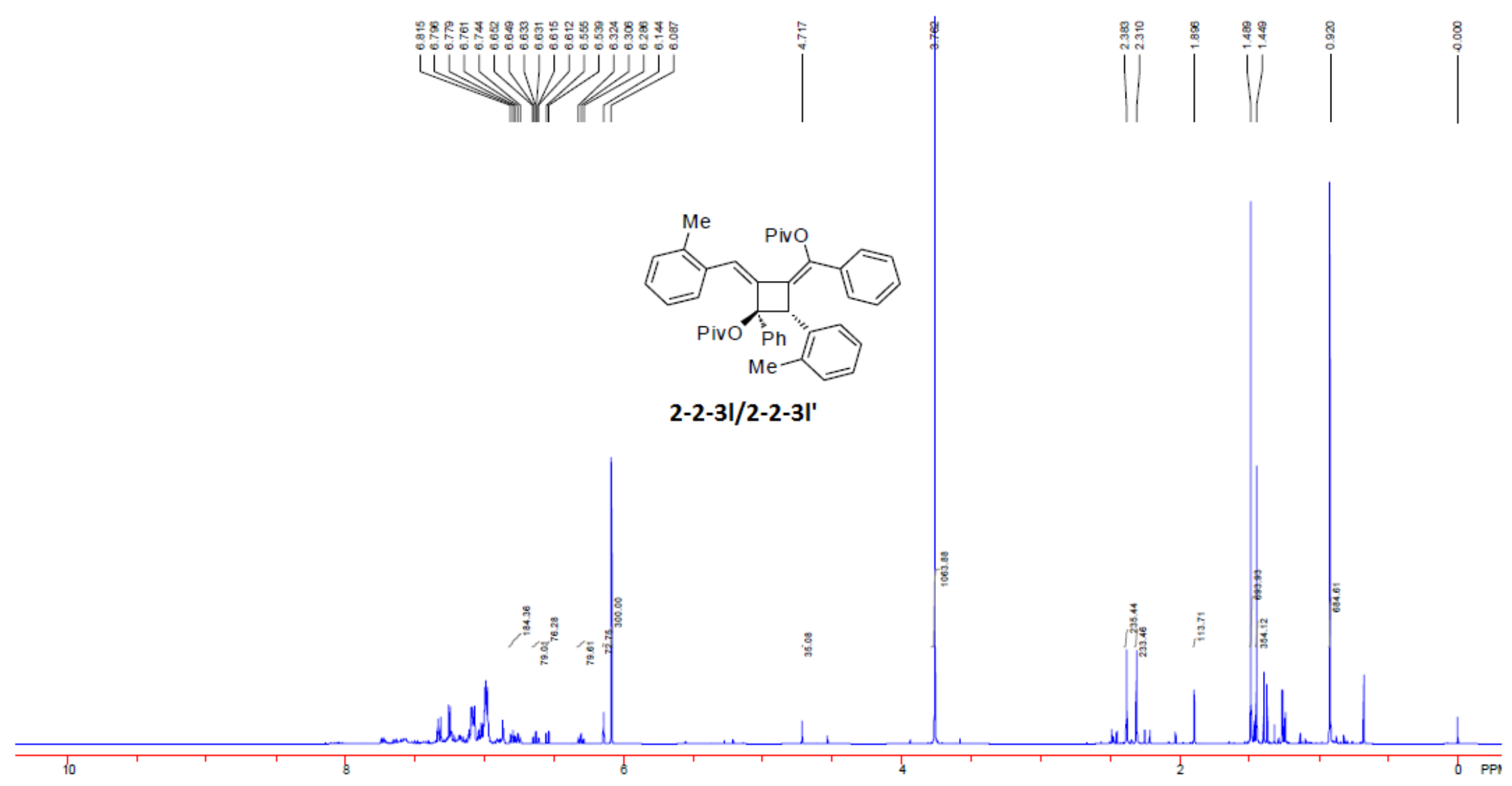




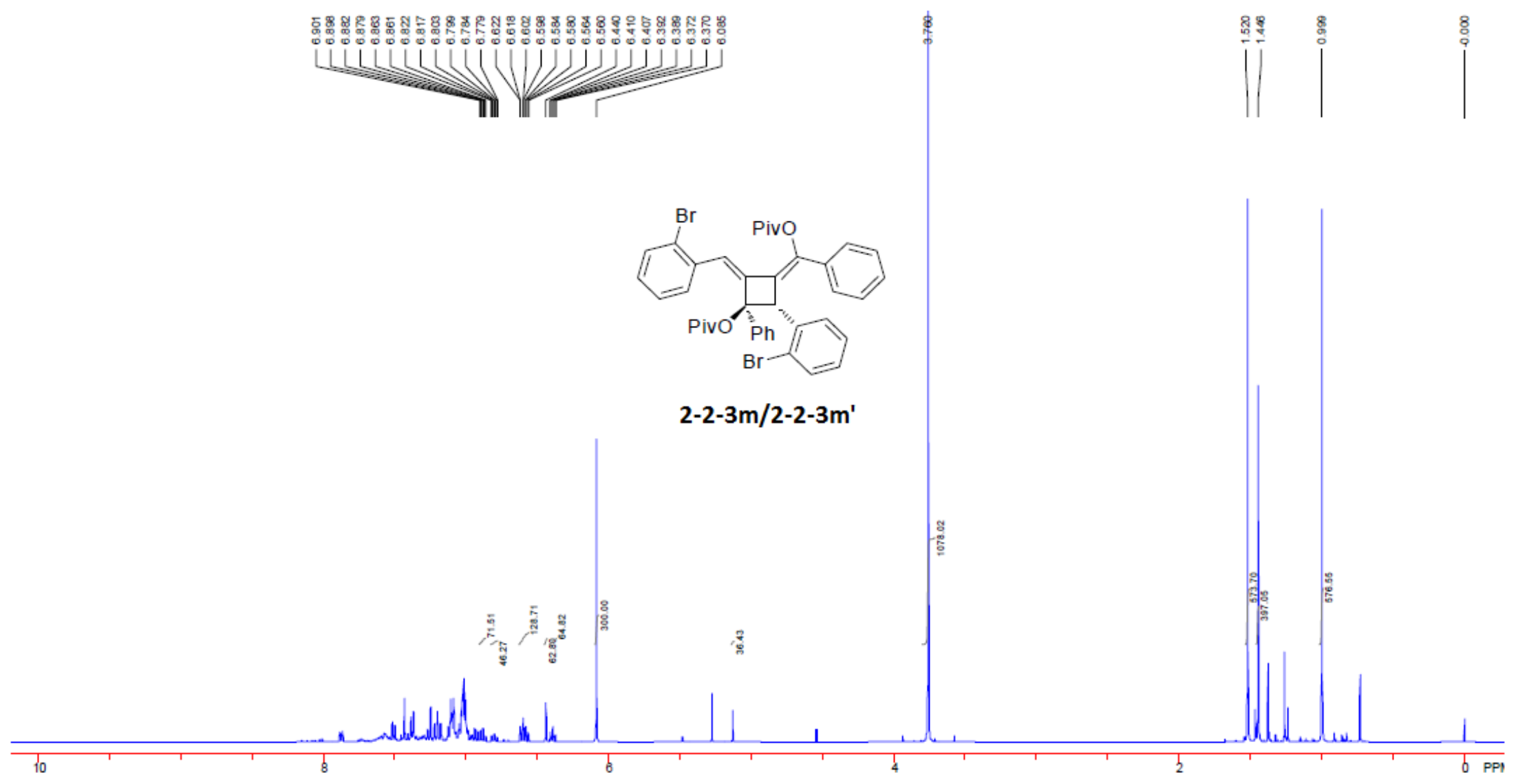




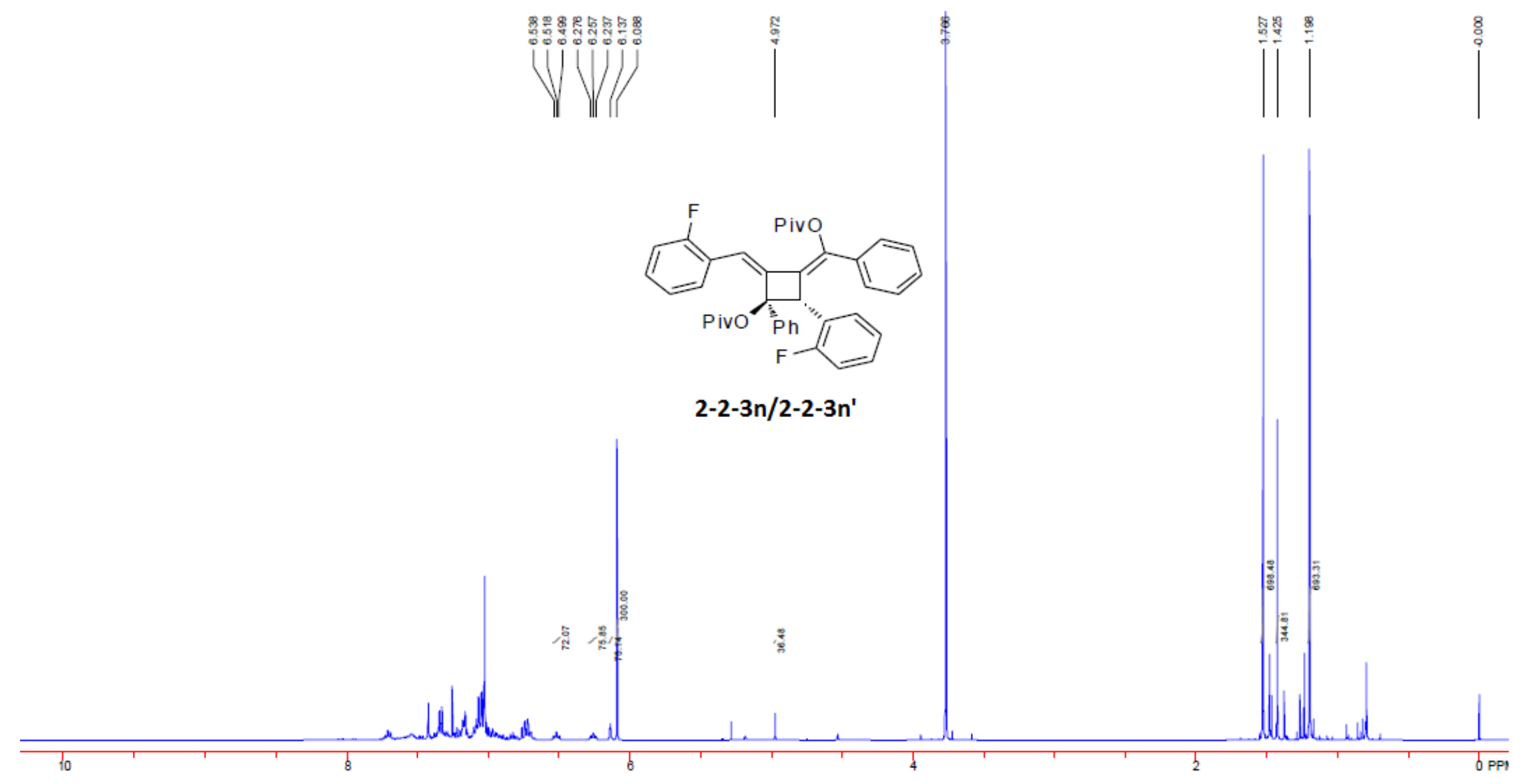




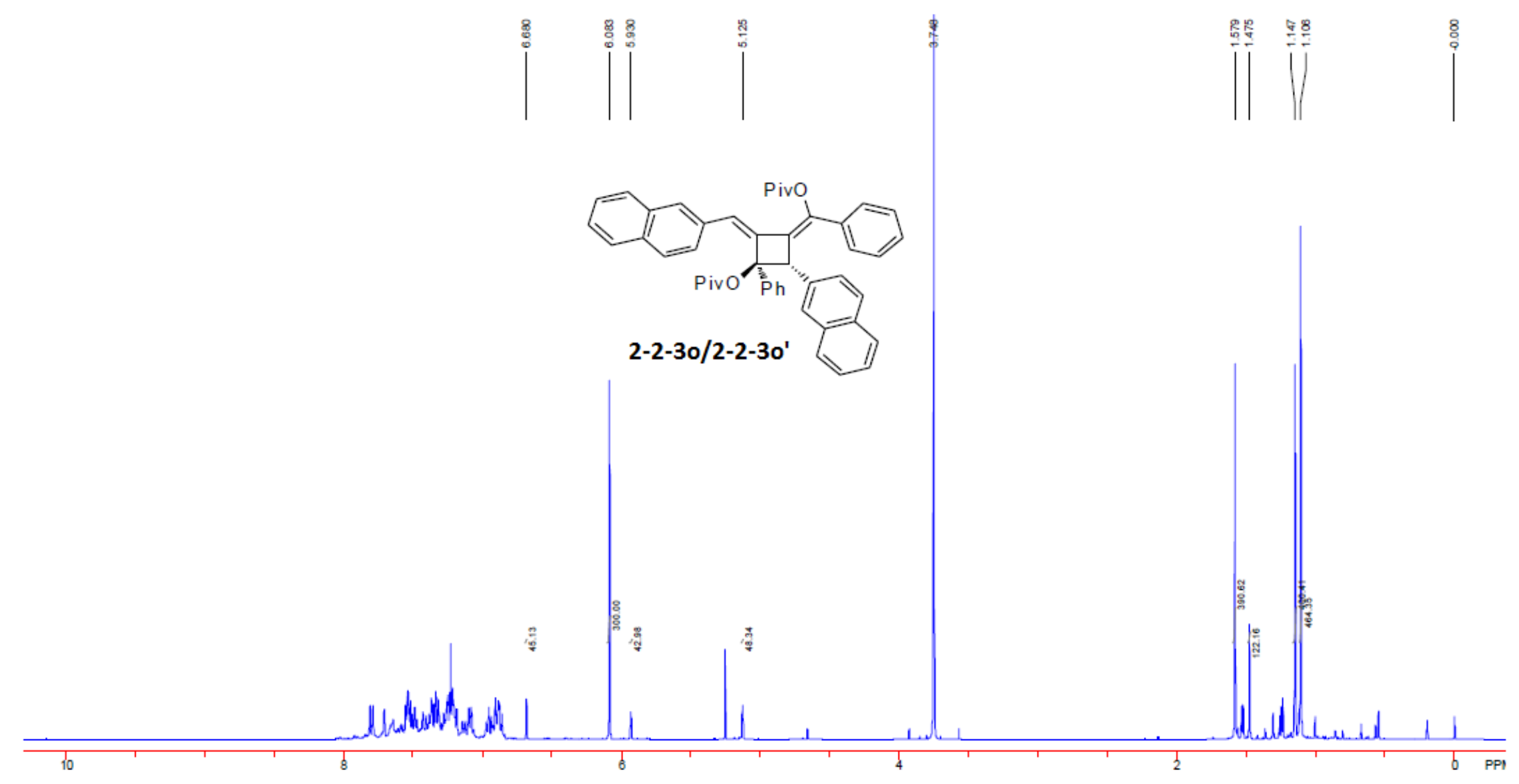




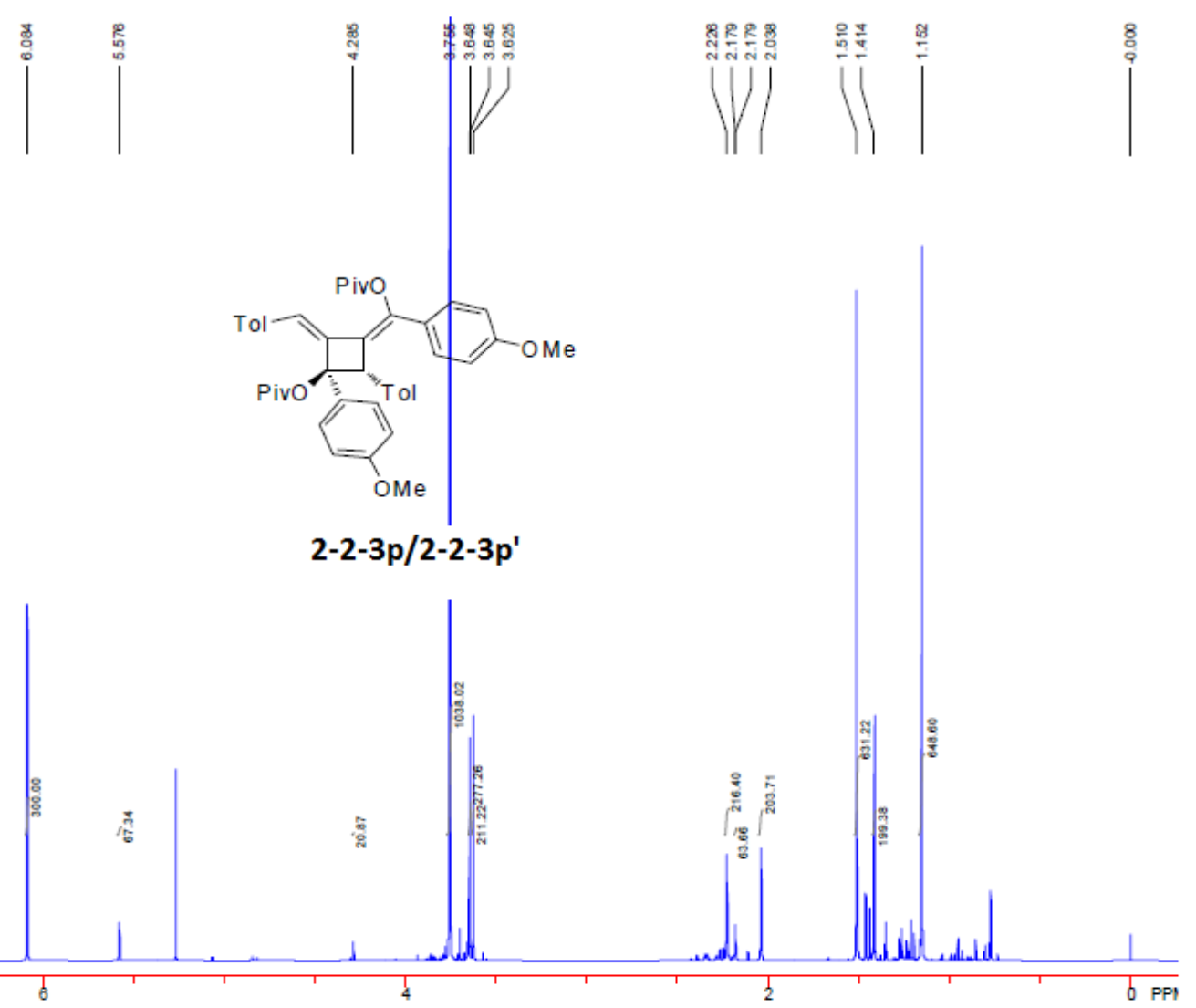



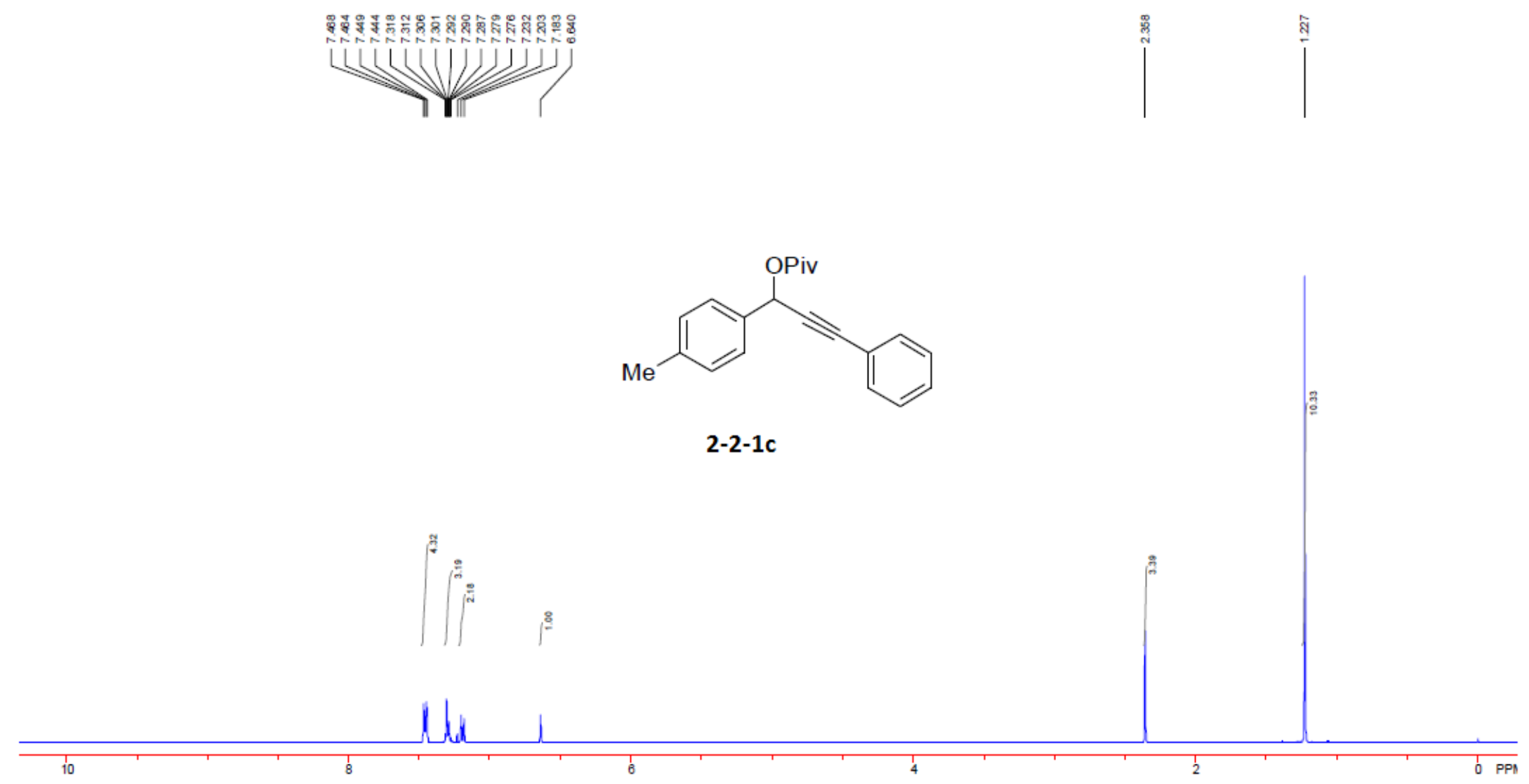

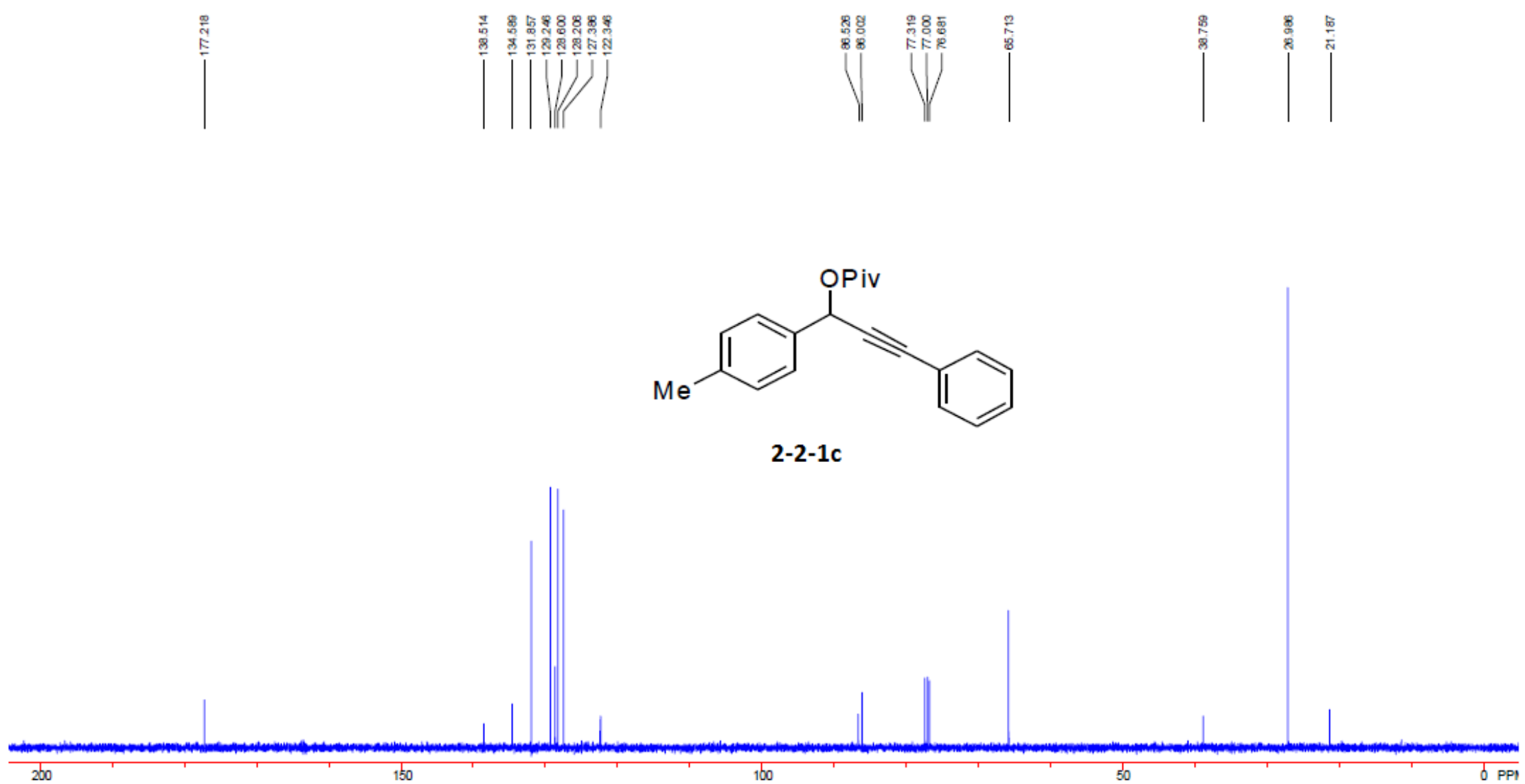


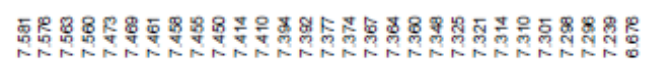

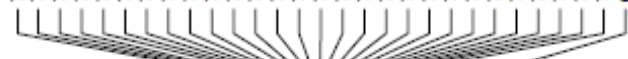

71

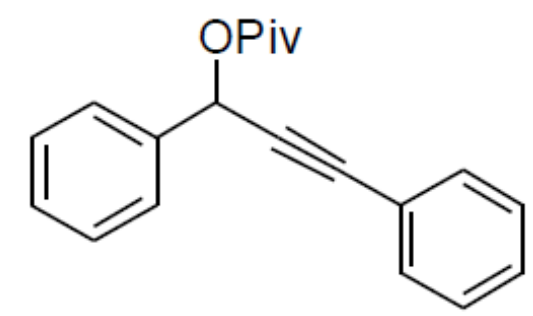

2-2-1d

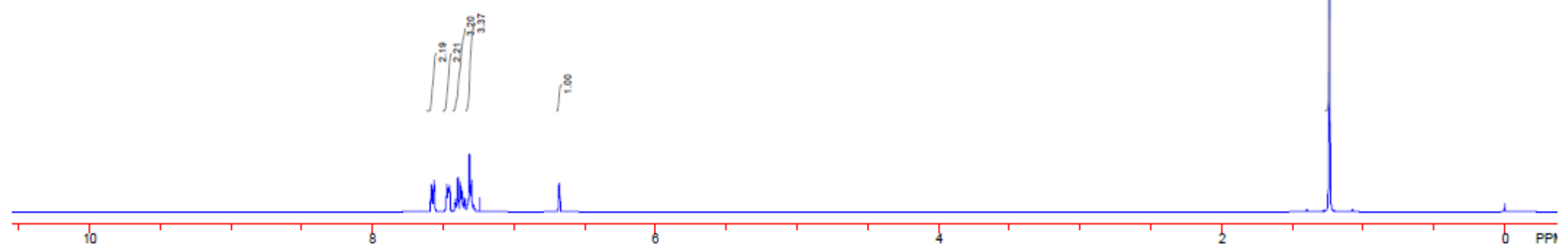



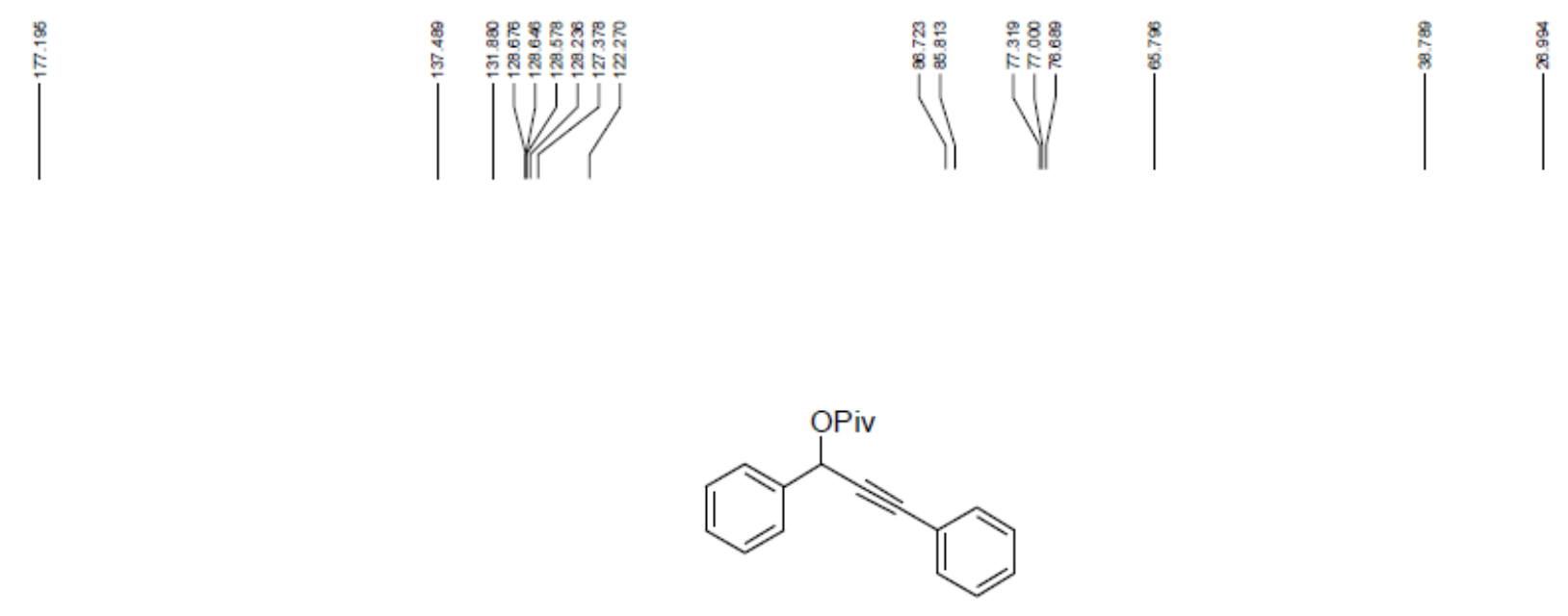

2-2-1d

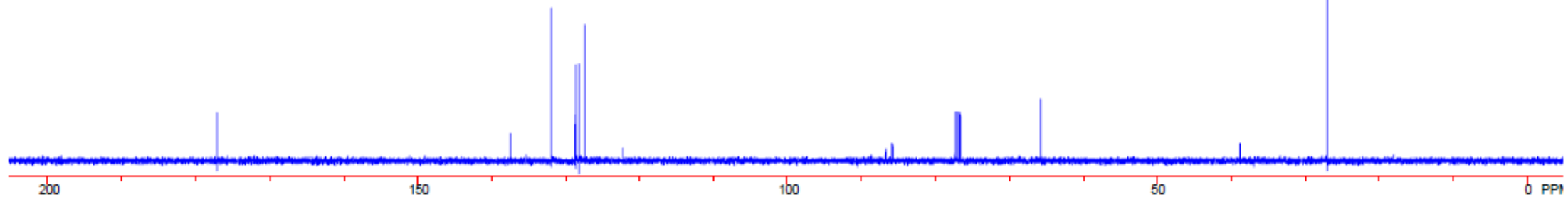




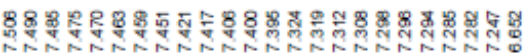

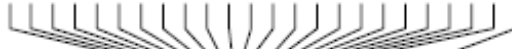 \\ 4}
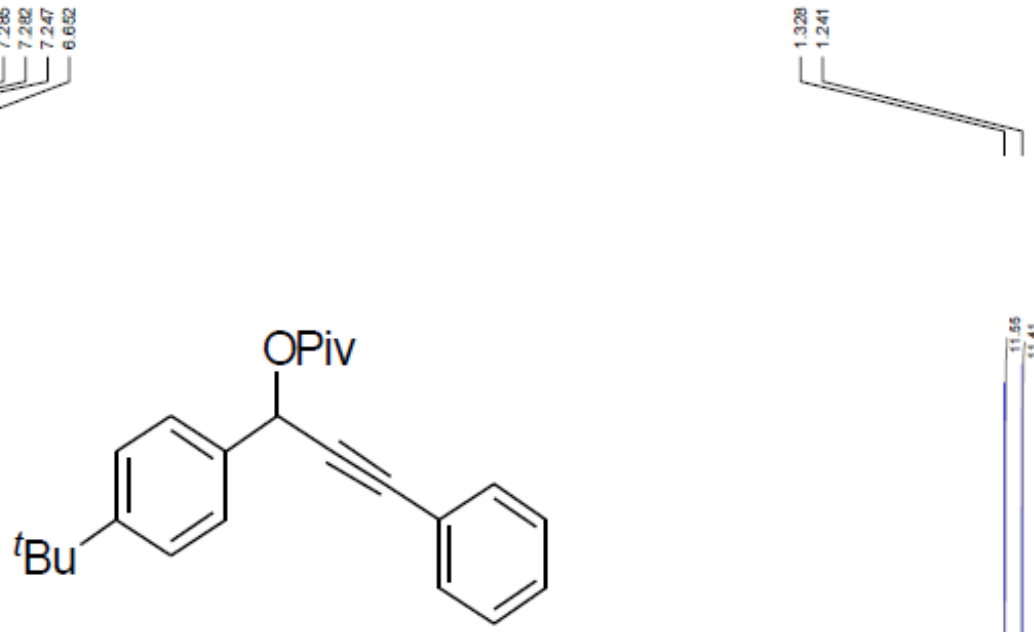

2-2-1e

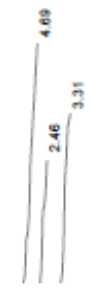

情.

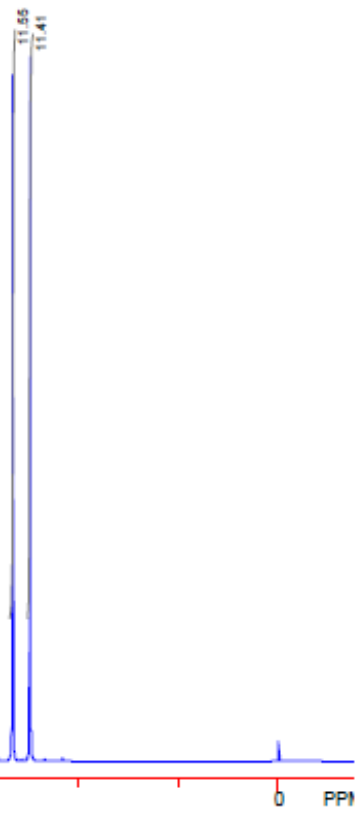




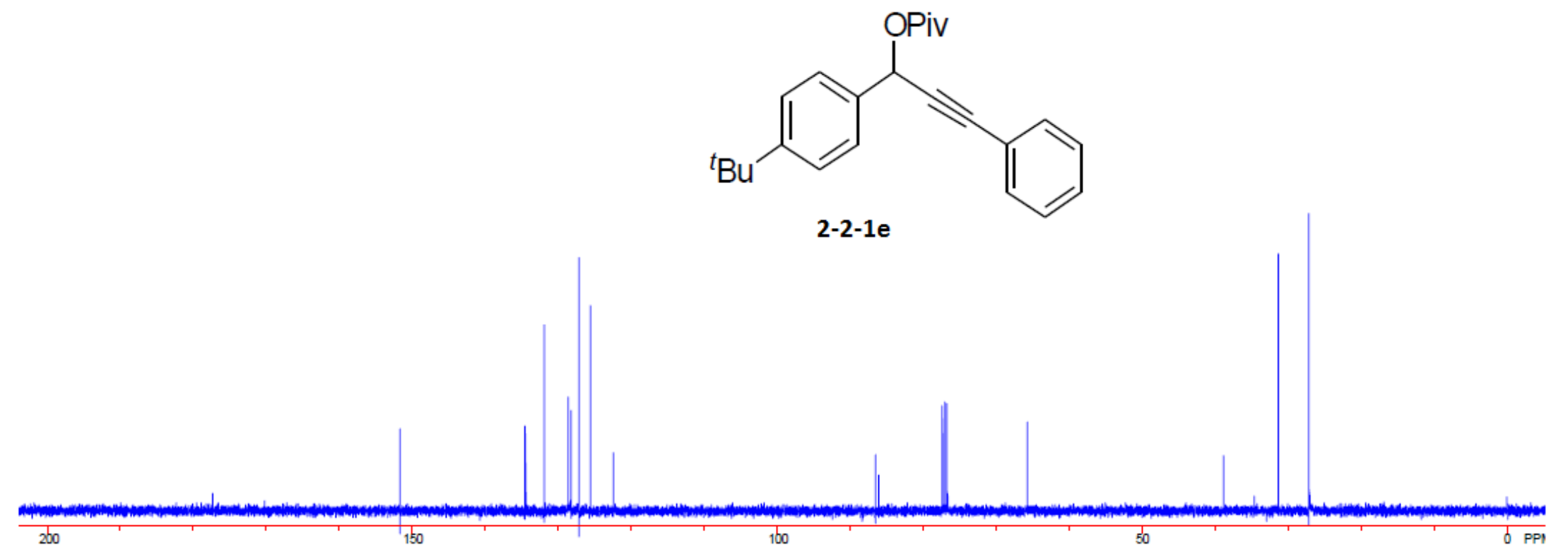




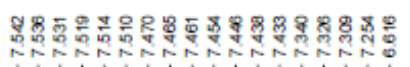

UuजujJjjJj

thi
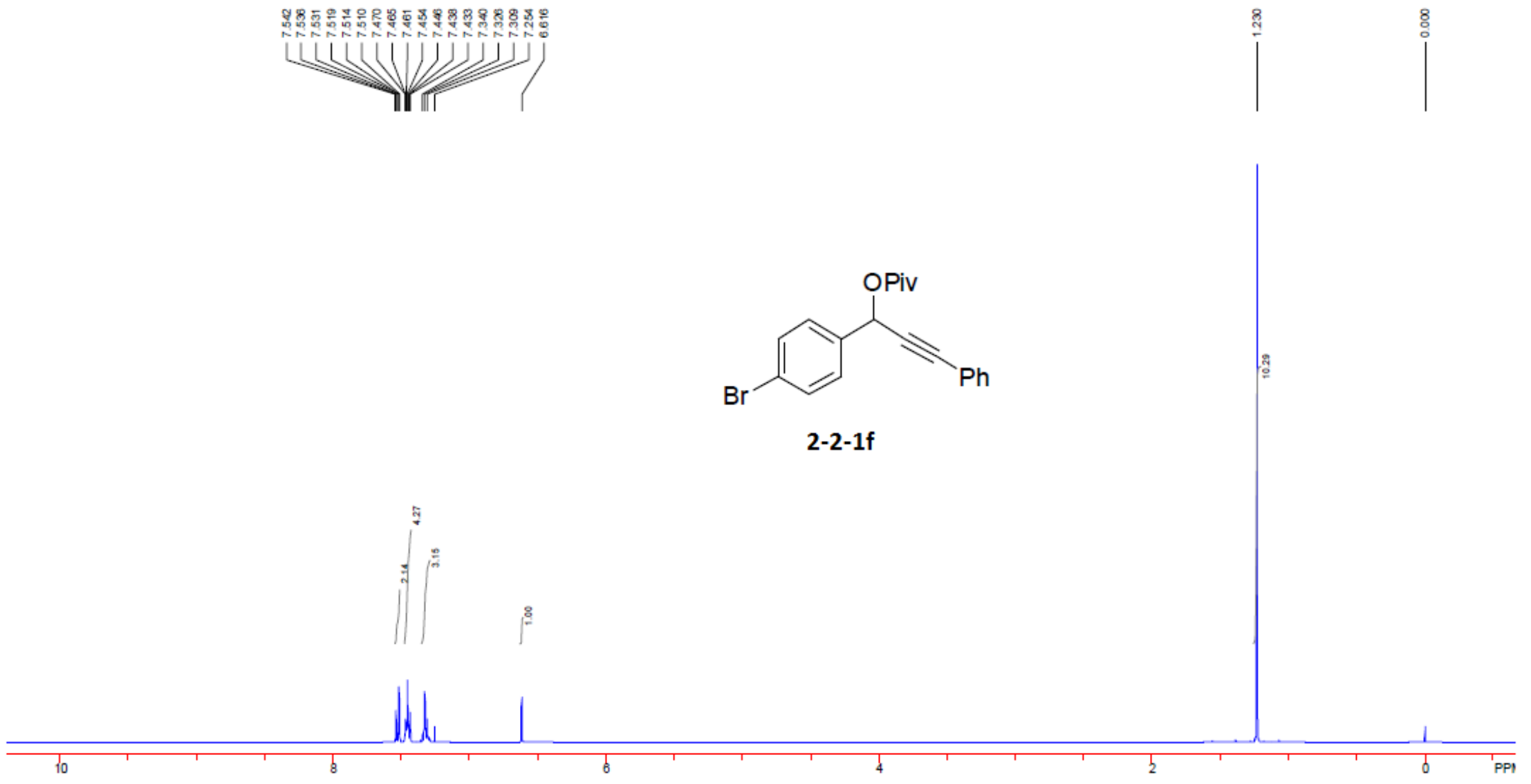

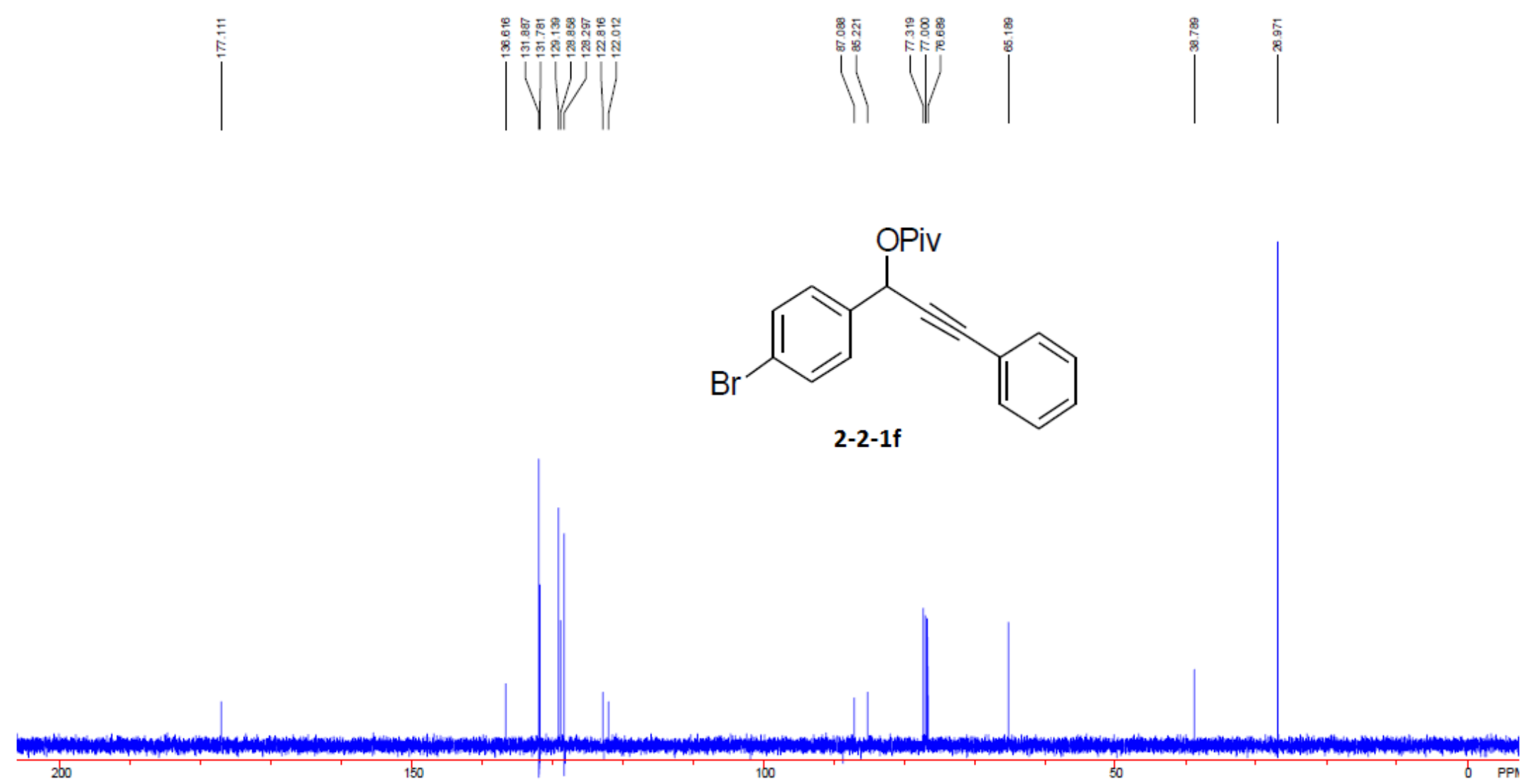


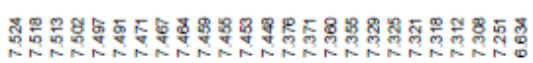

LLLuUU. UJJJdd

III II

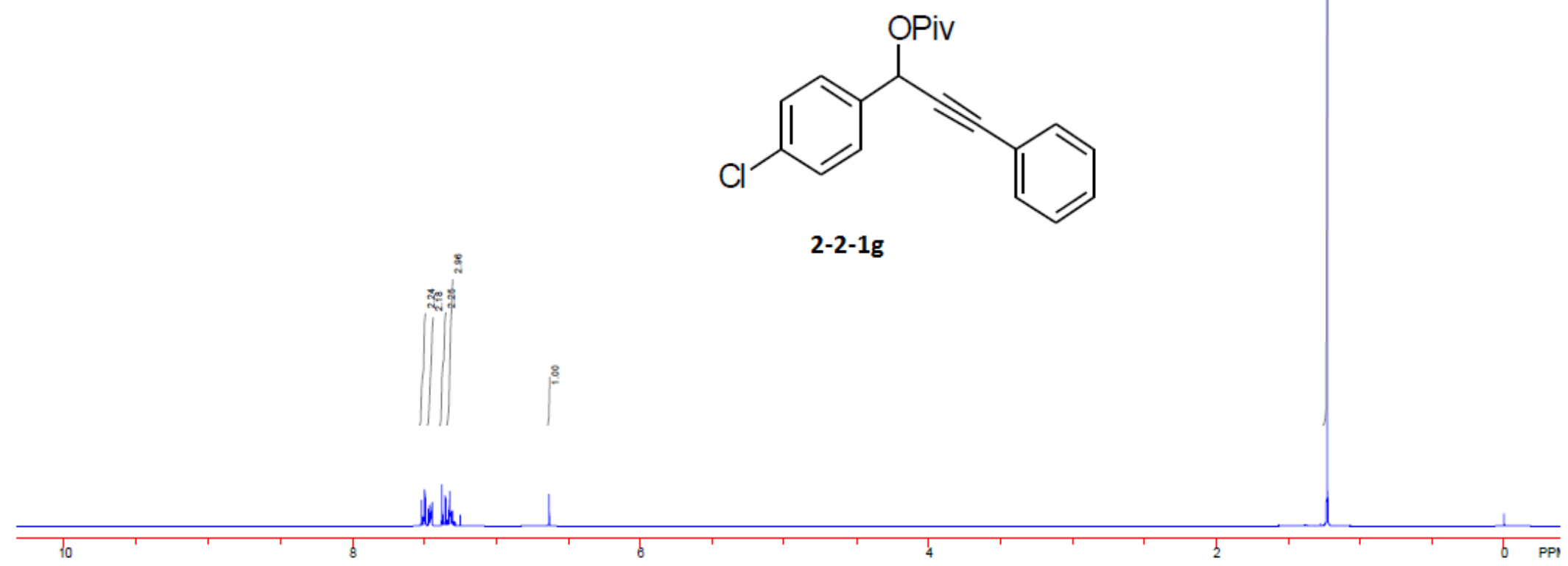




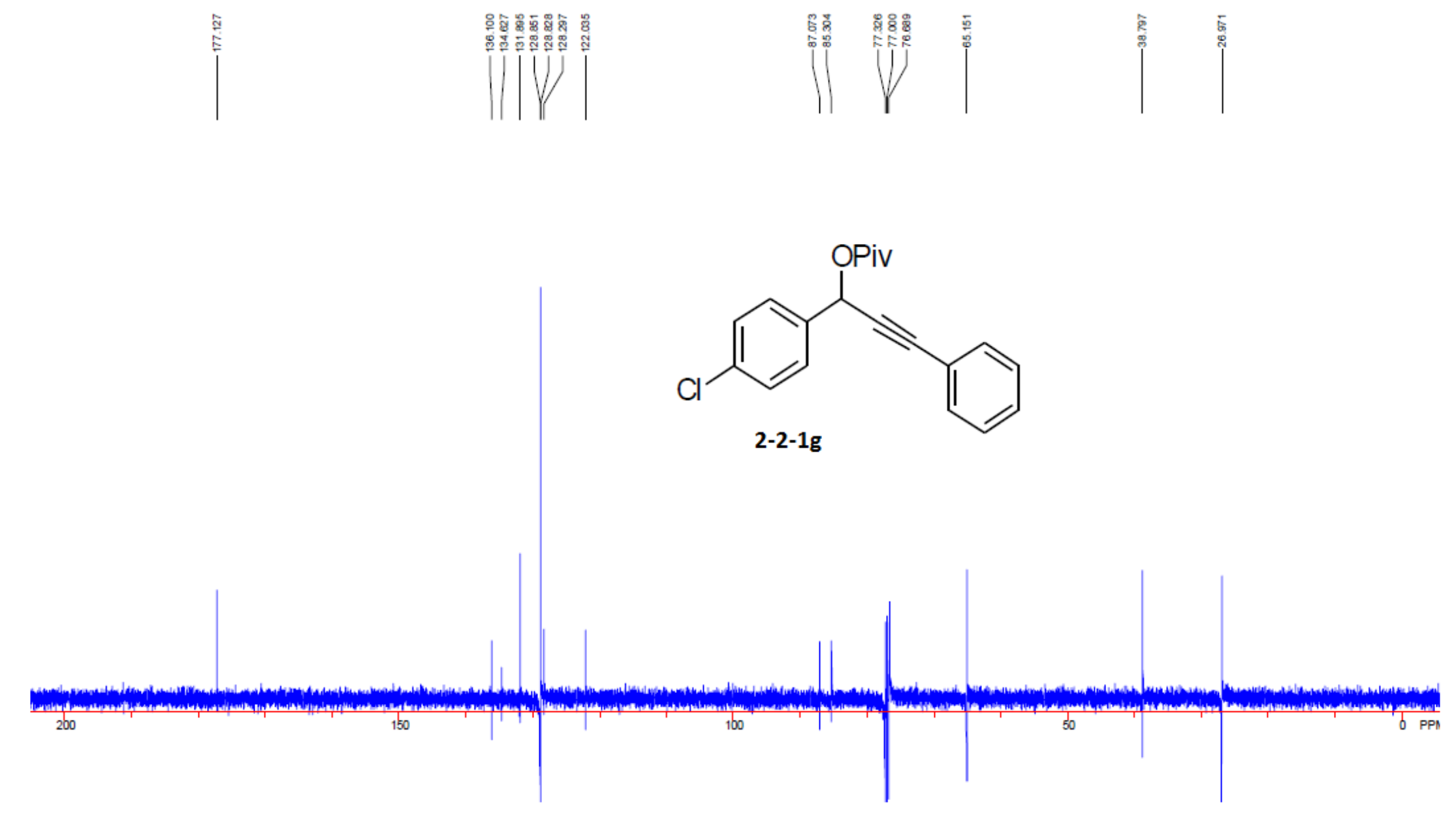




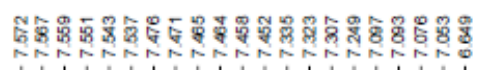

ULMUUUUJJJJ)

IIII !
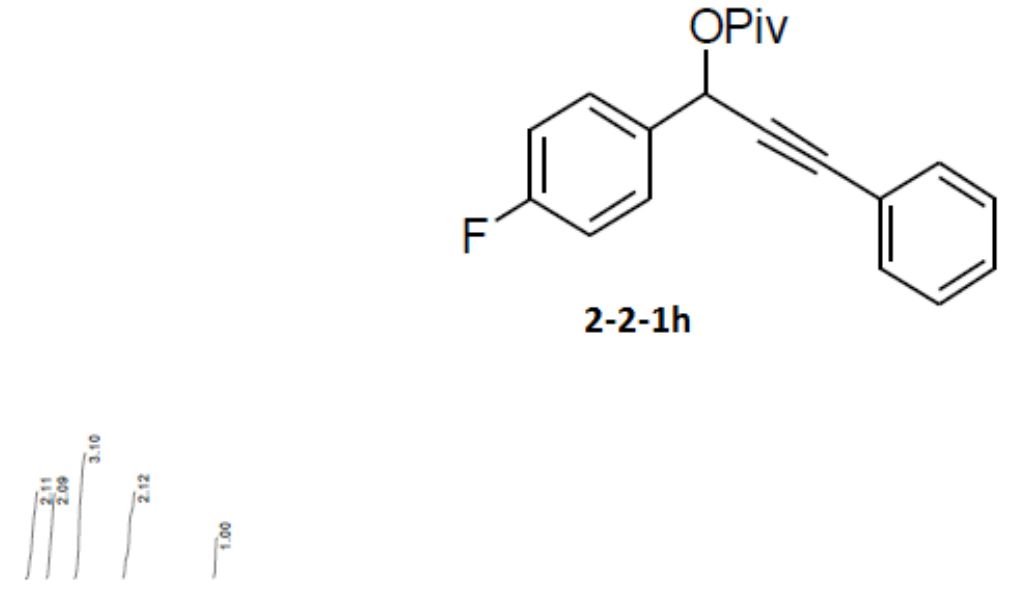

ald 

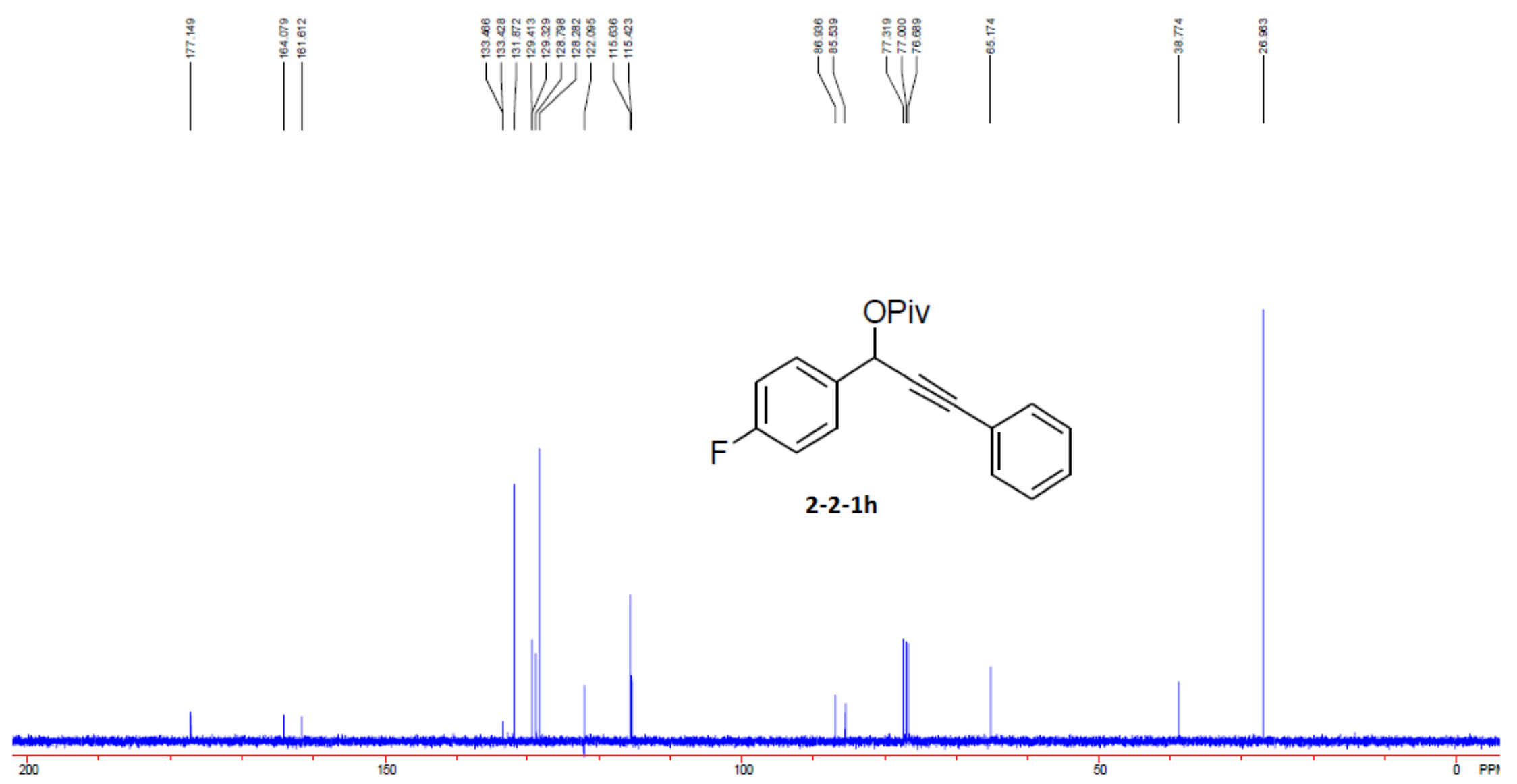


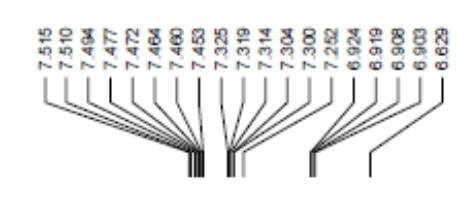

$$
1
$$
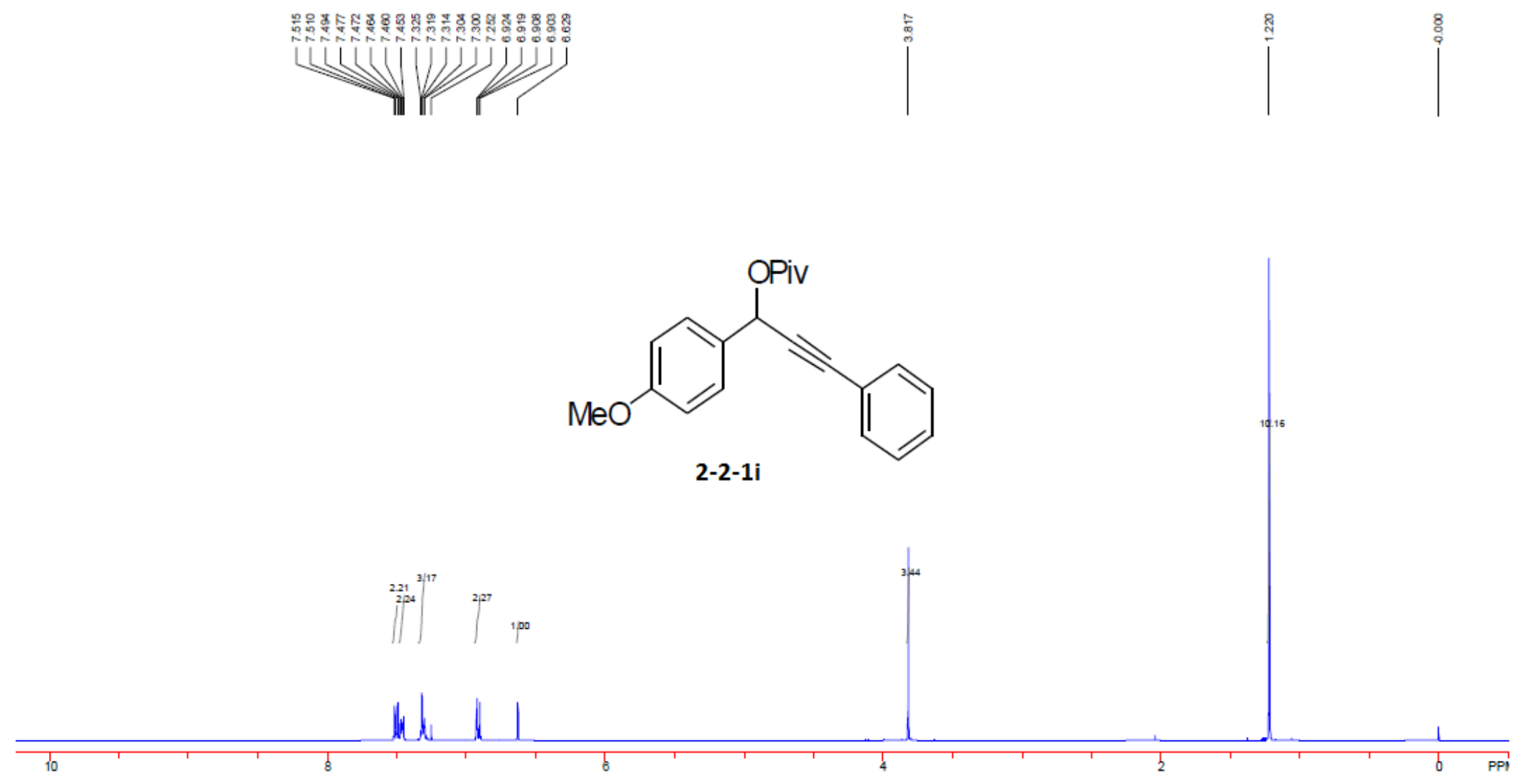


$\mid$

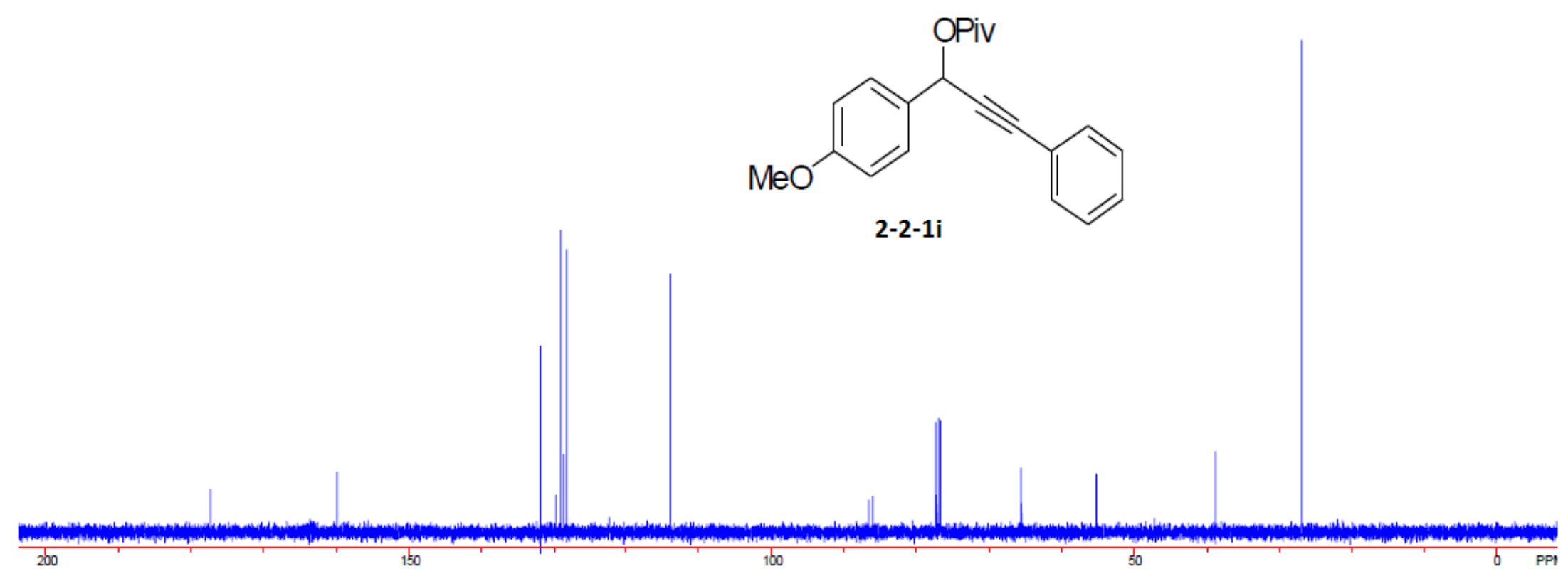



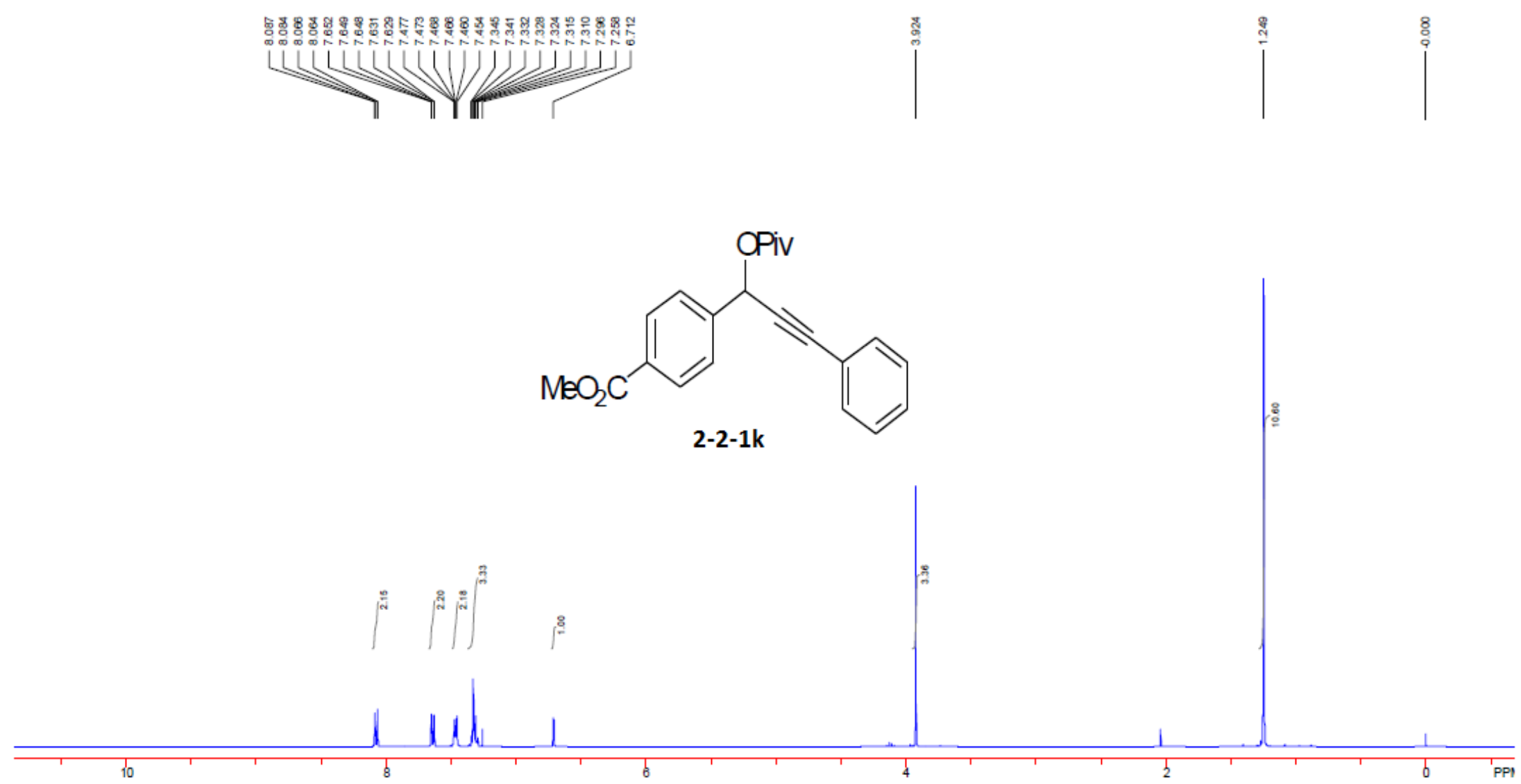


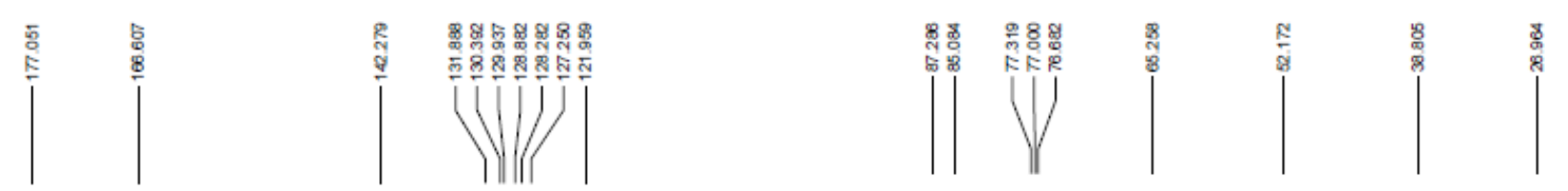

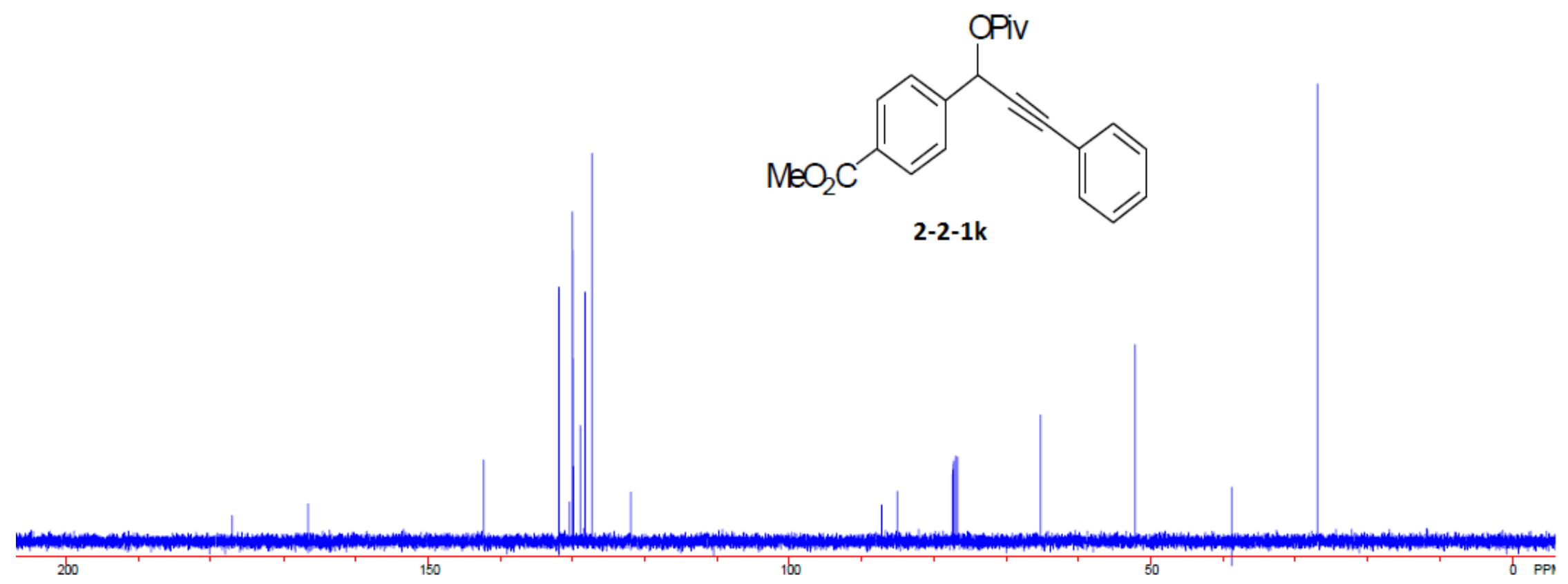




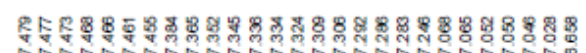

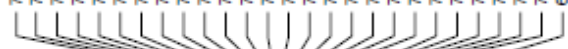

רill

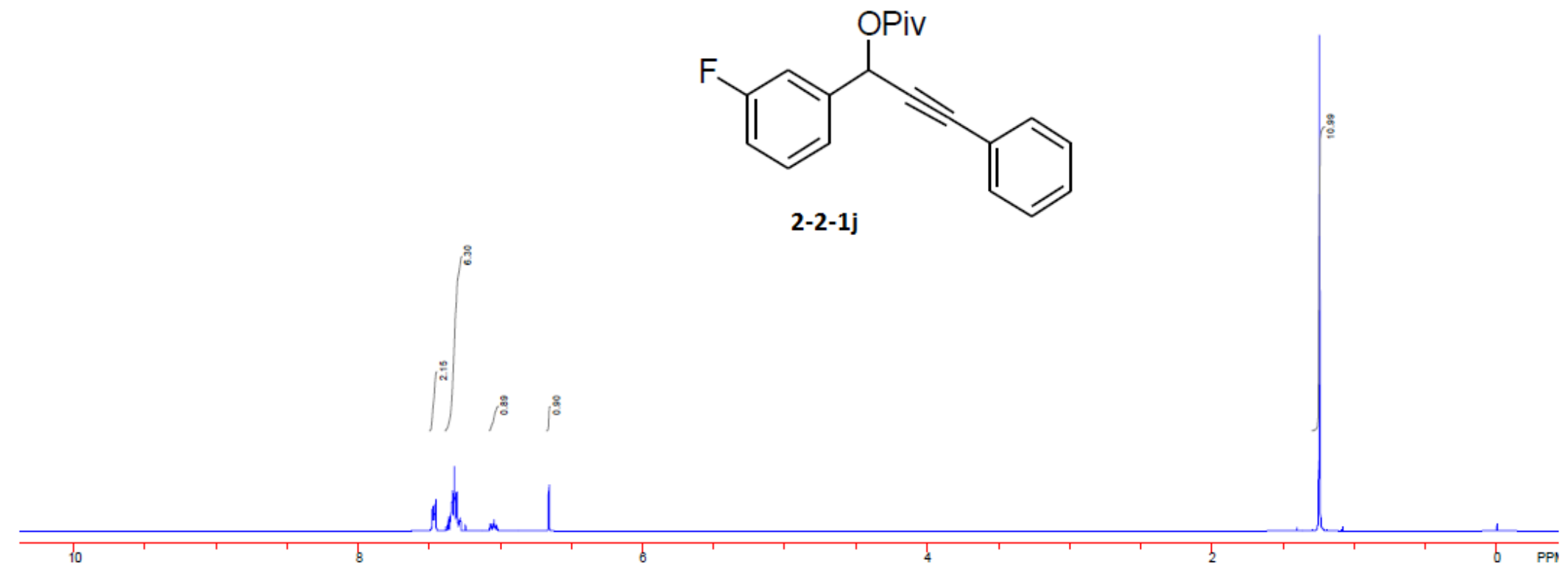



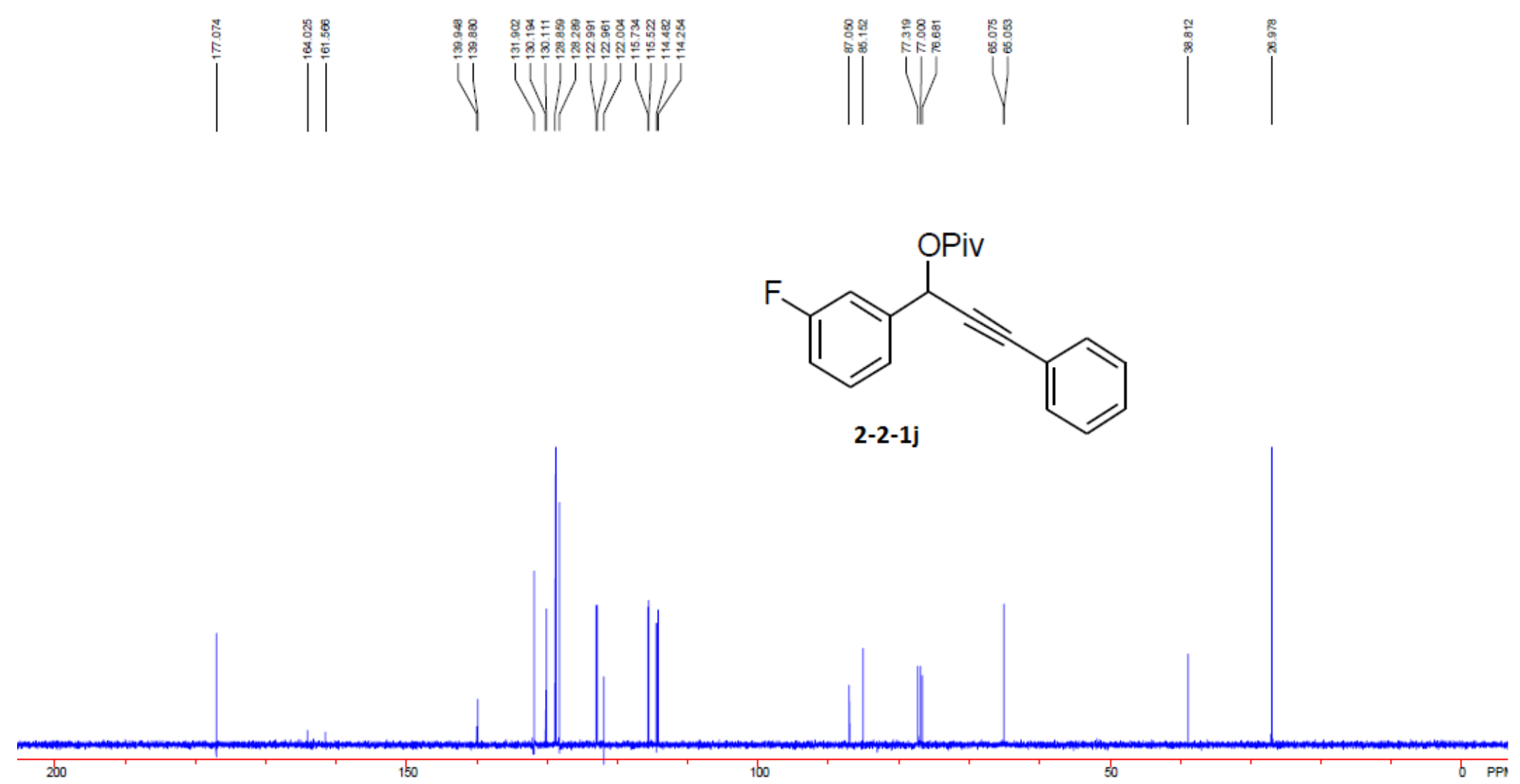


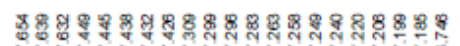

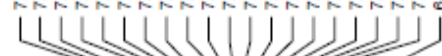

$\rightarrow 7$
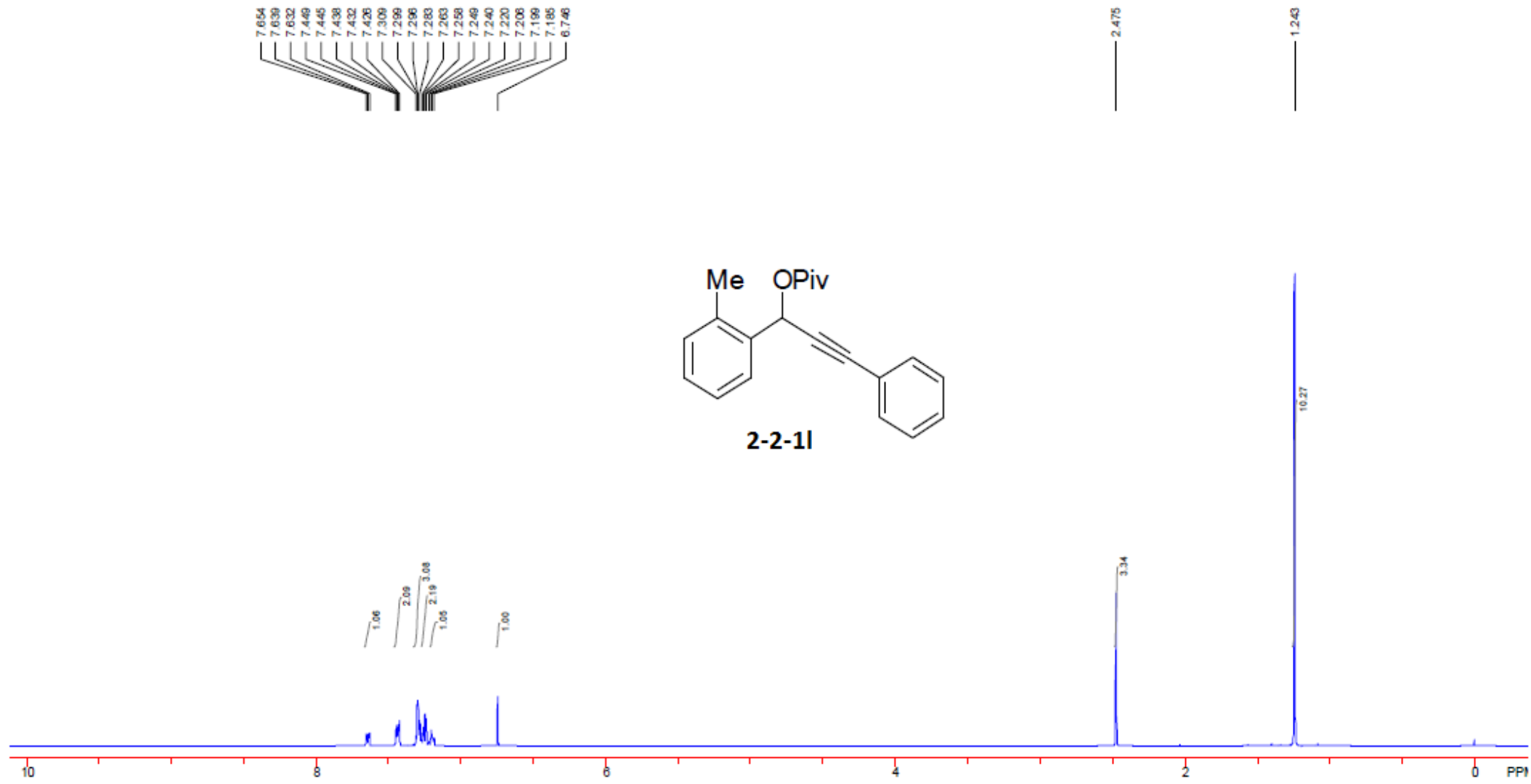

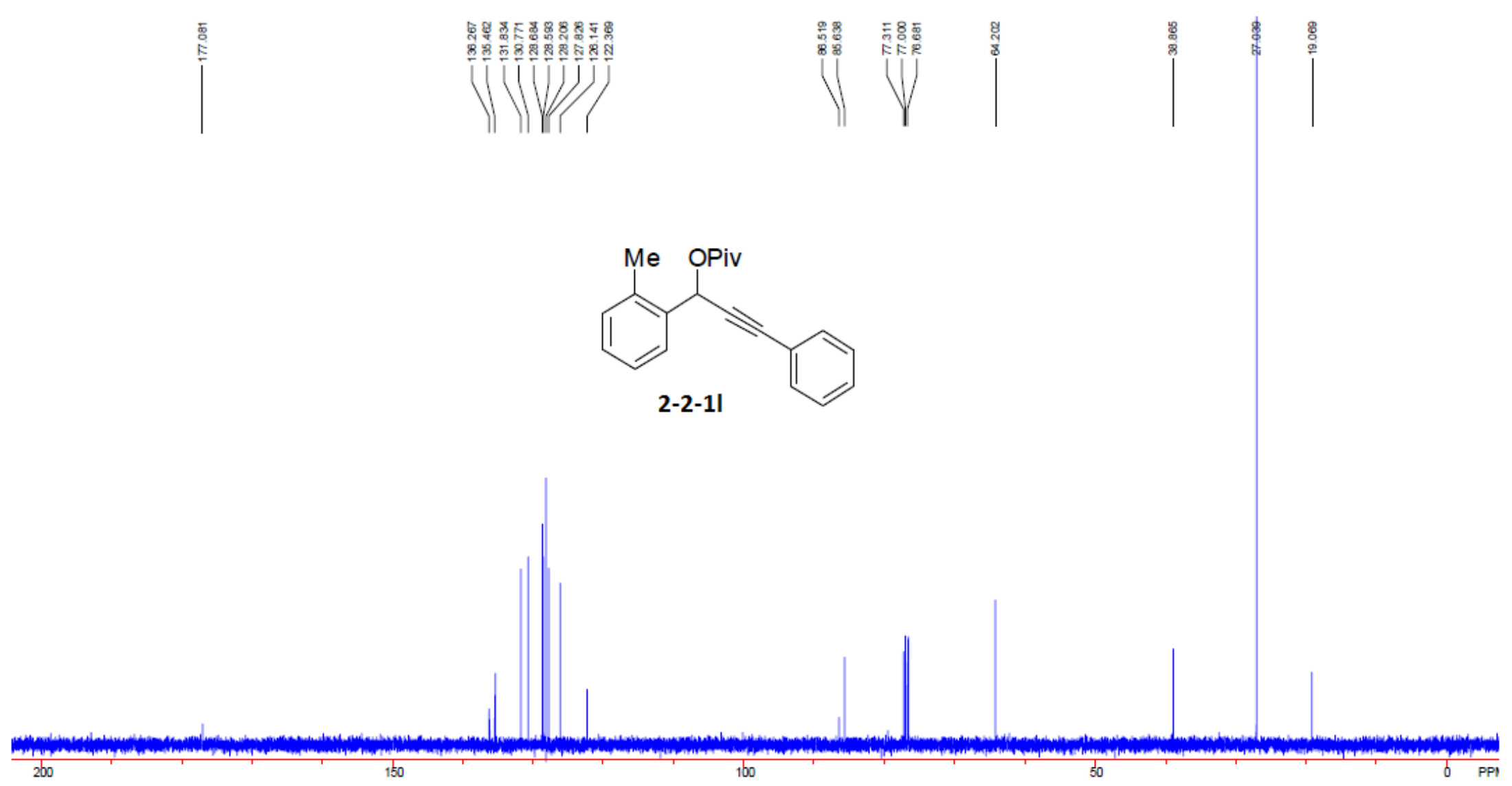


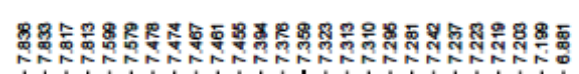

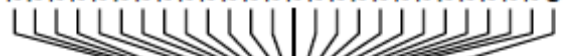

( )
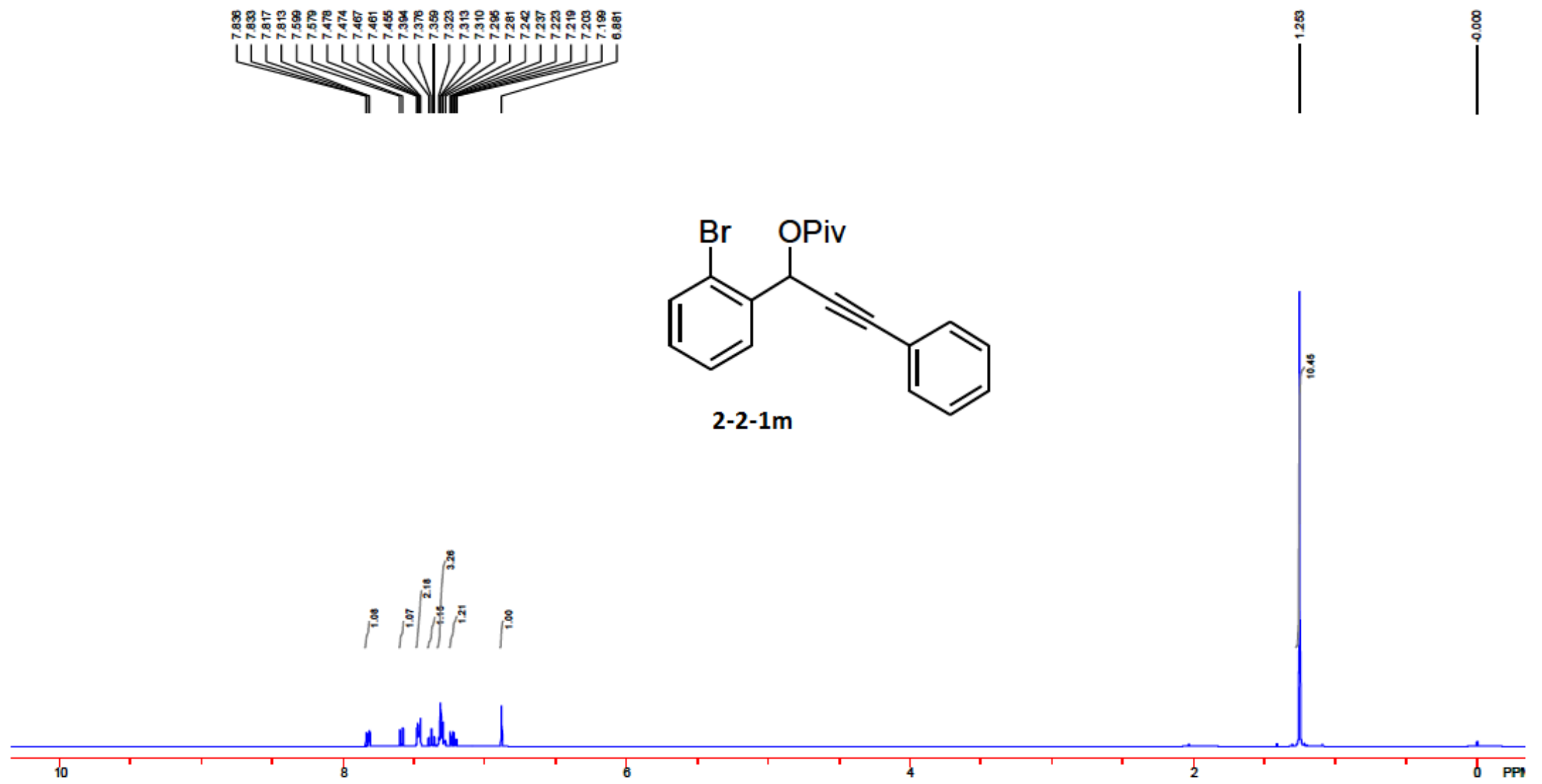

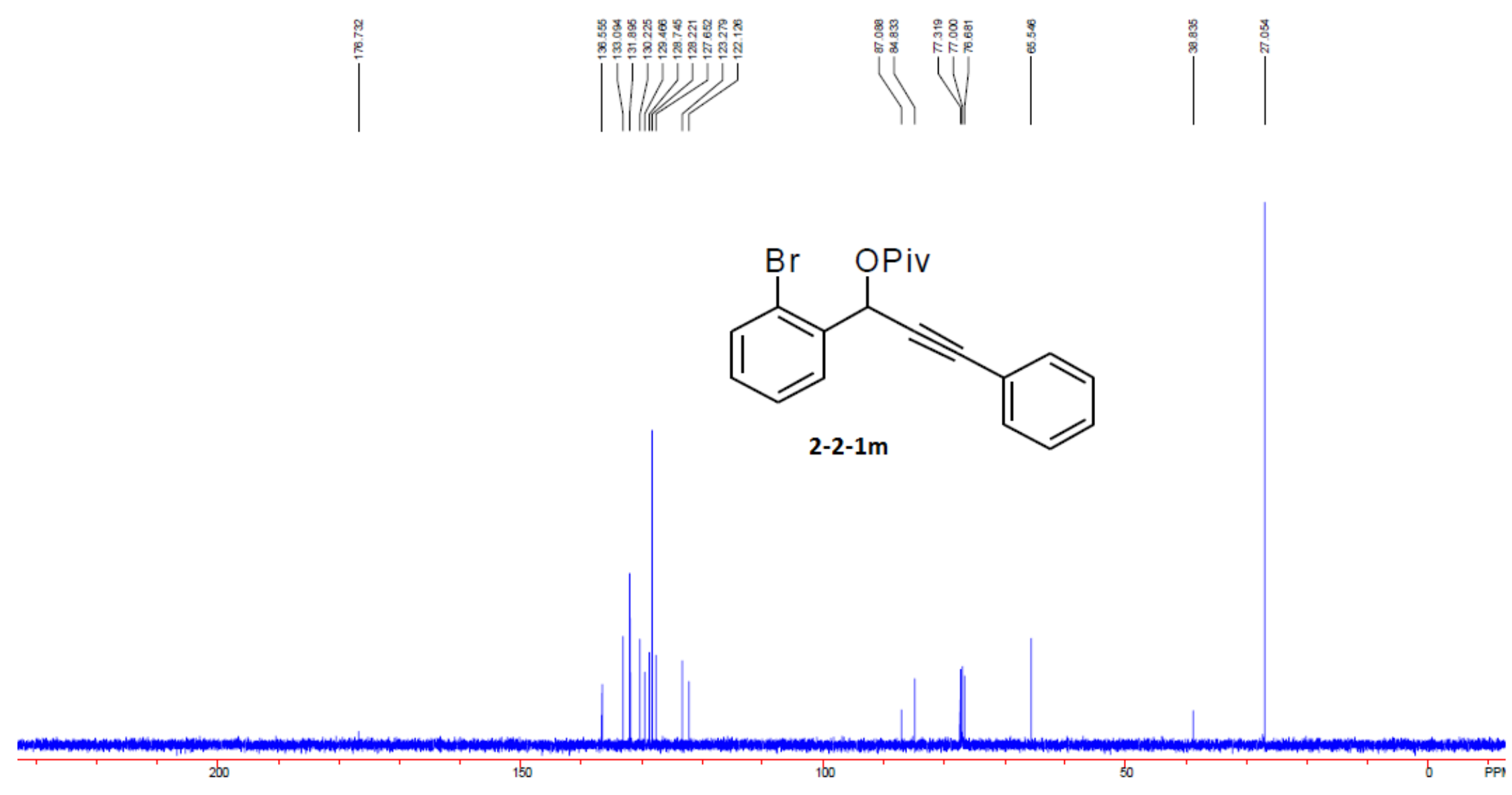


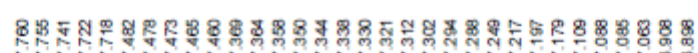

LLLULULUUUU|UJJJJJJ」JJ

- 1 1
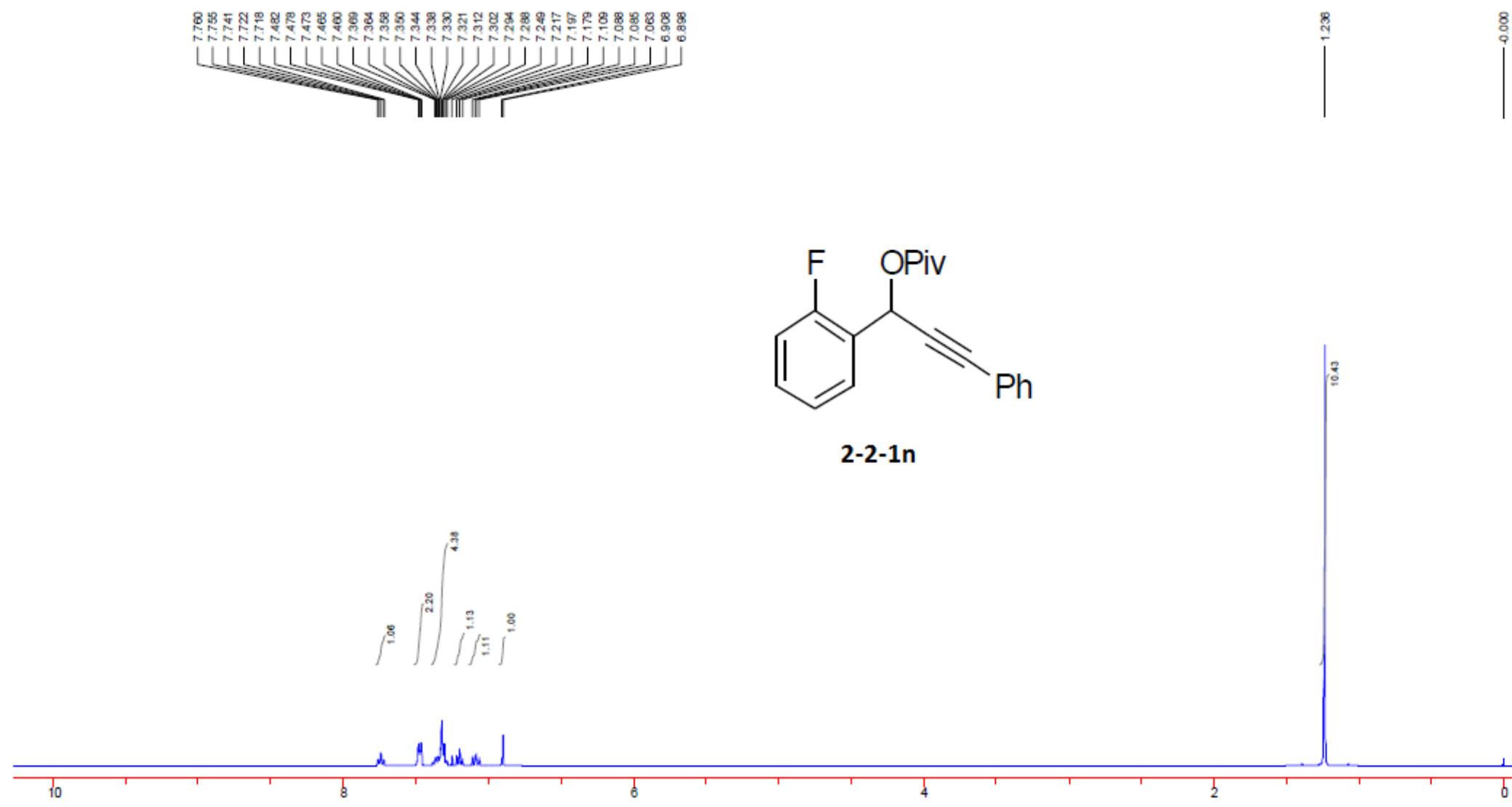

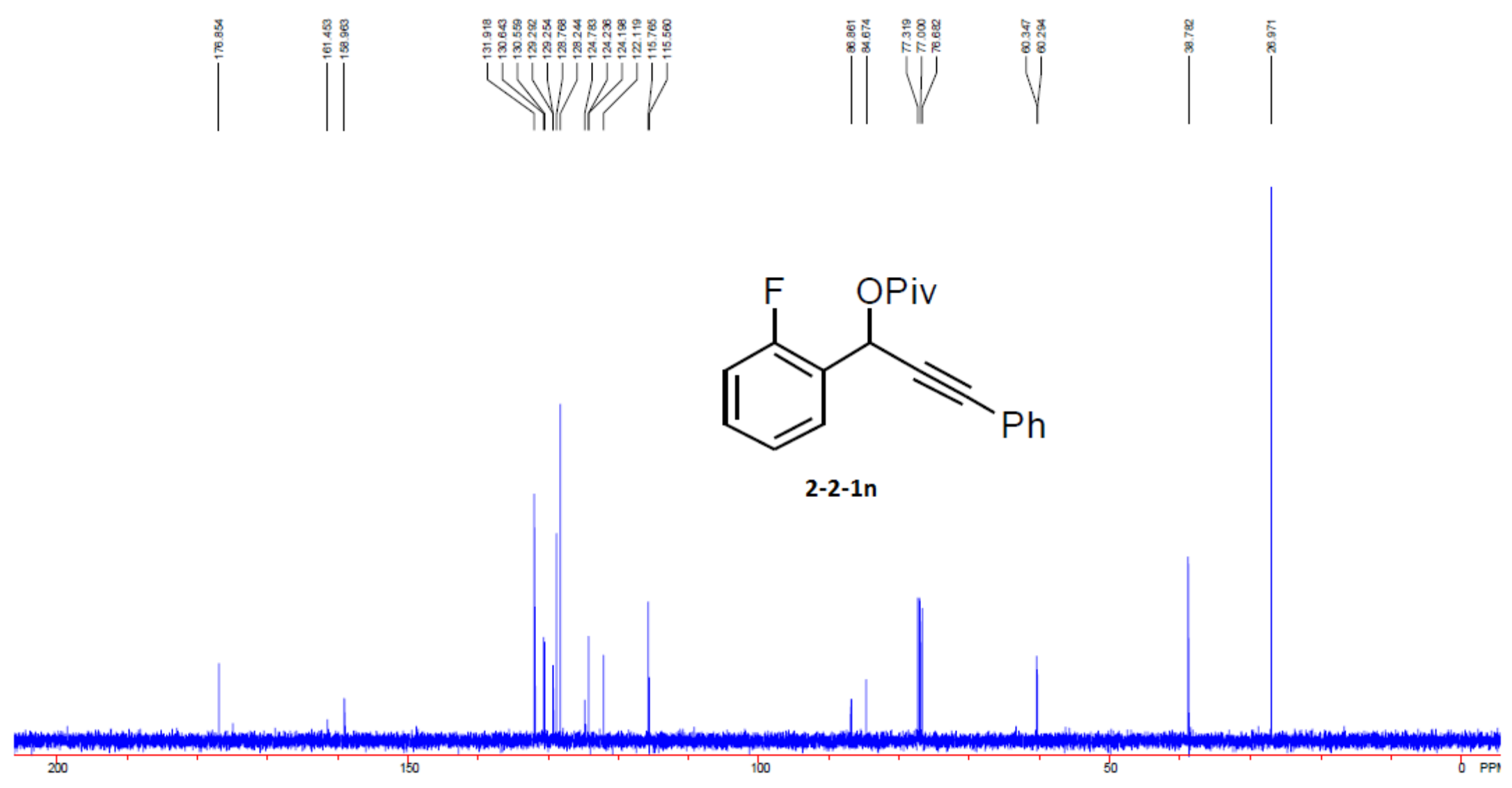


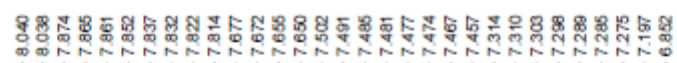

LLLLMUUUUJjJjJjJjJj

(1)

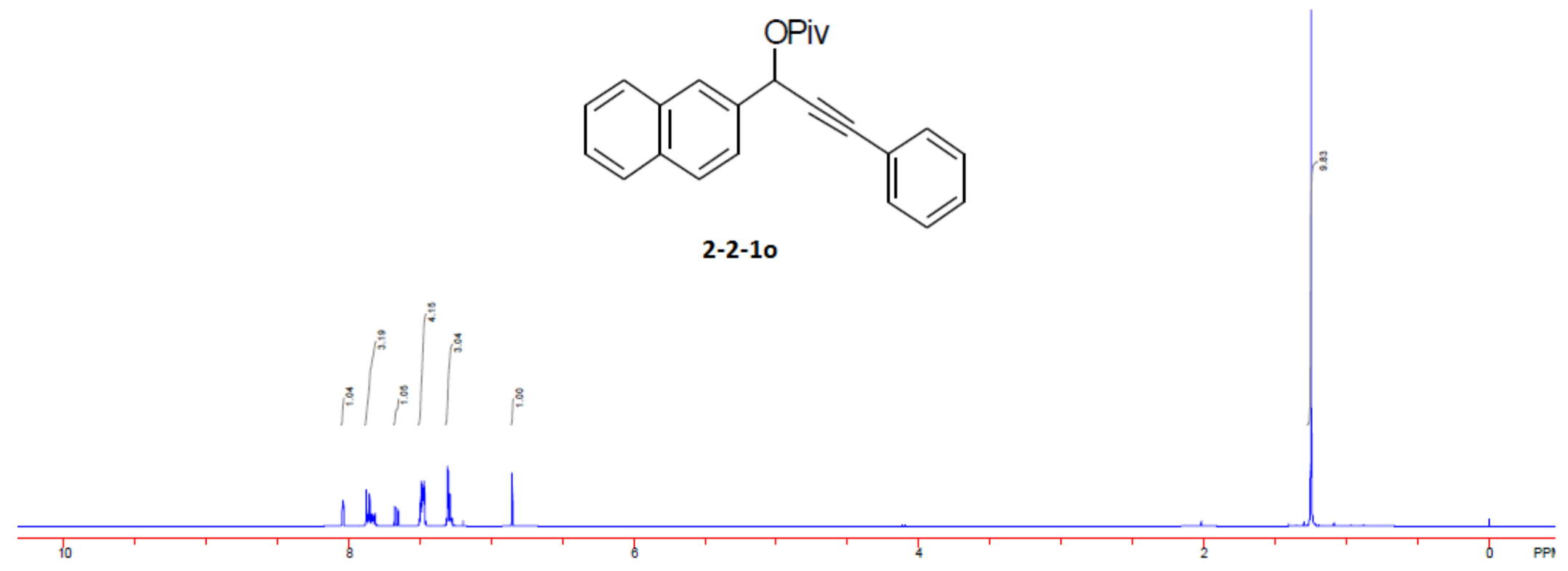



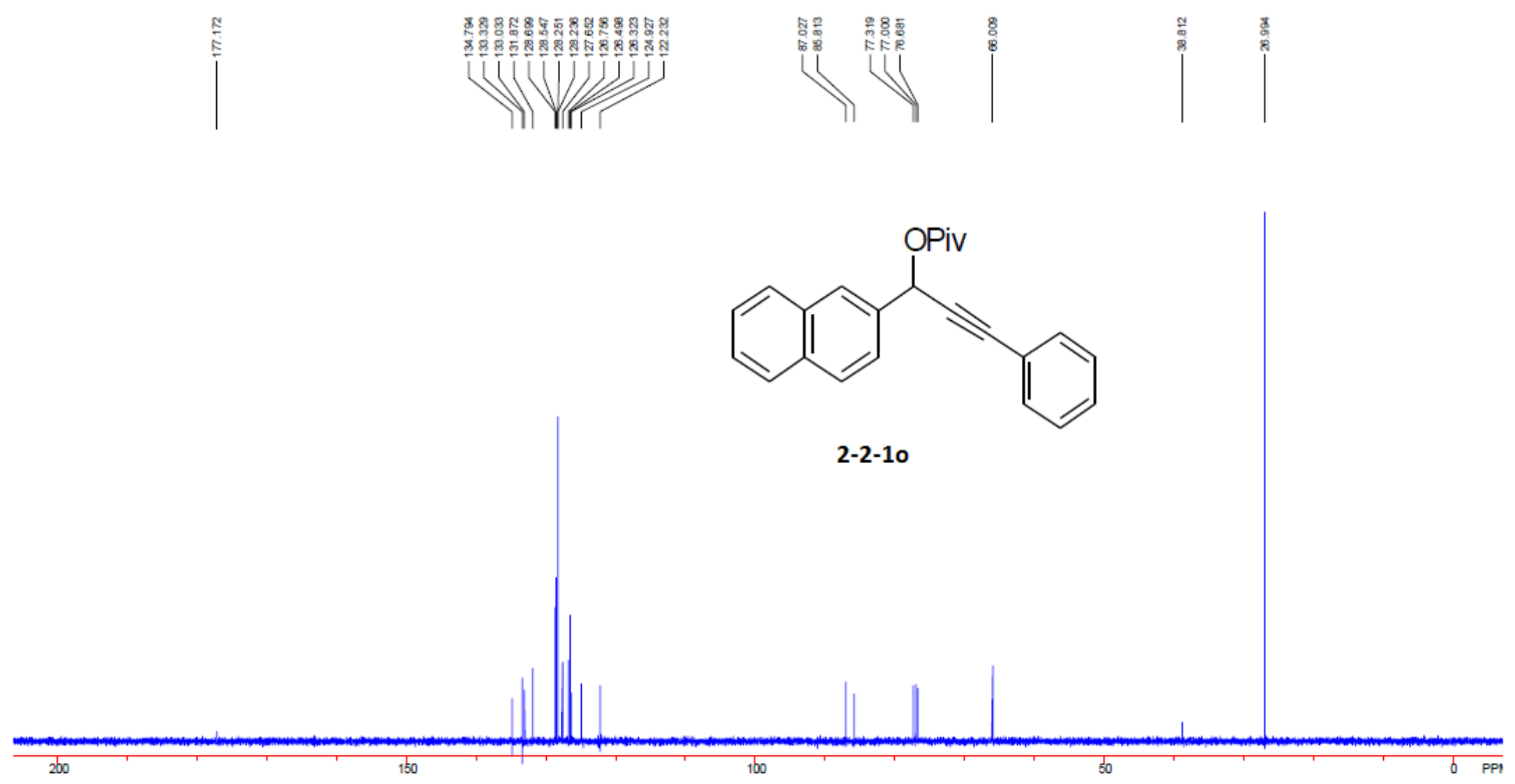


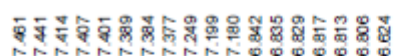

U.U.

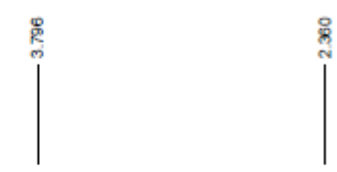

$\left.\right|^{\text {สิ }}$

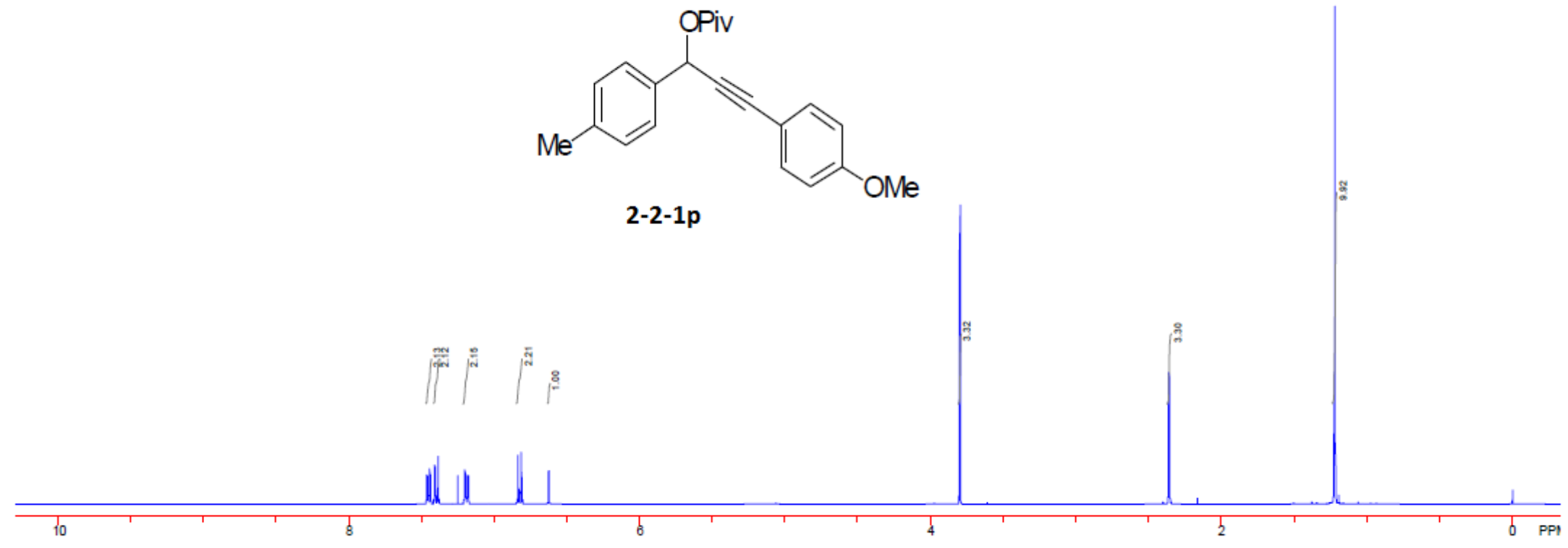




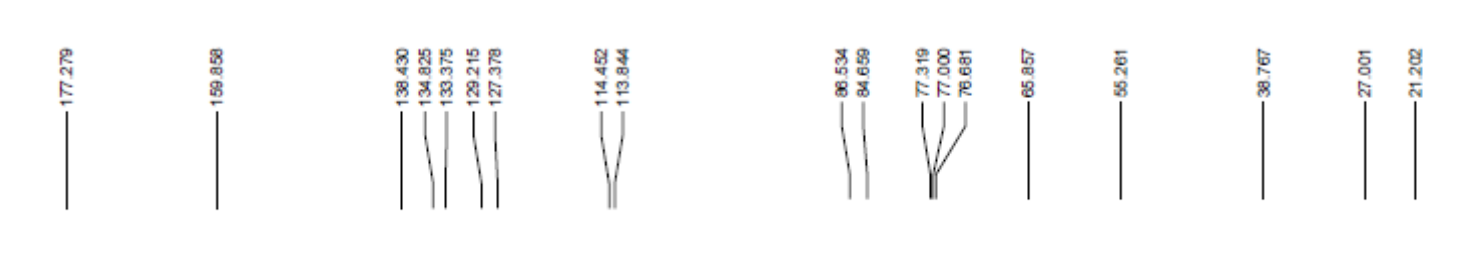

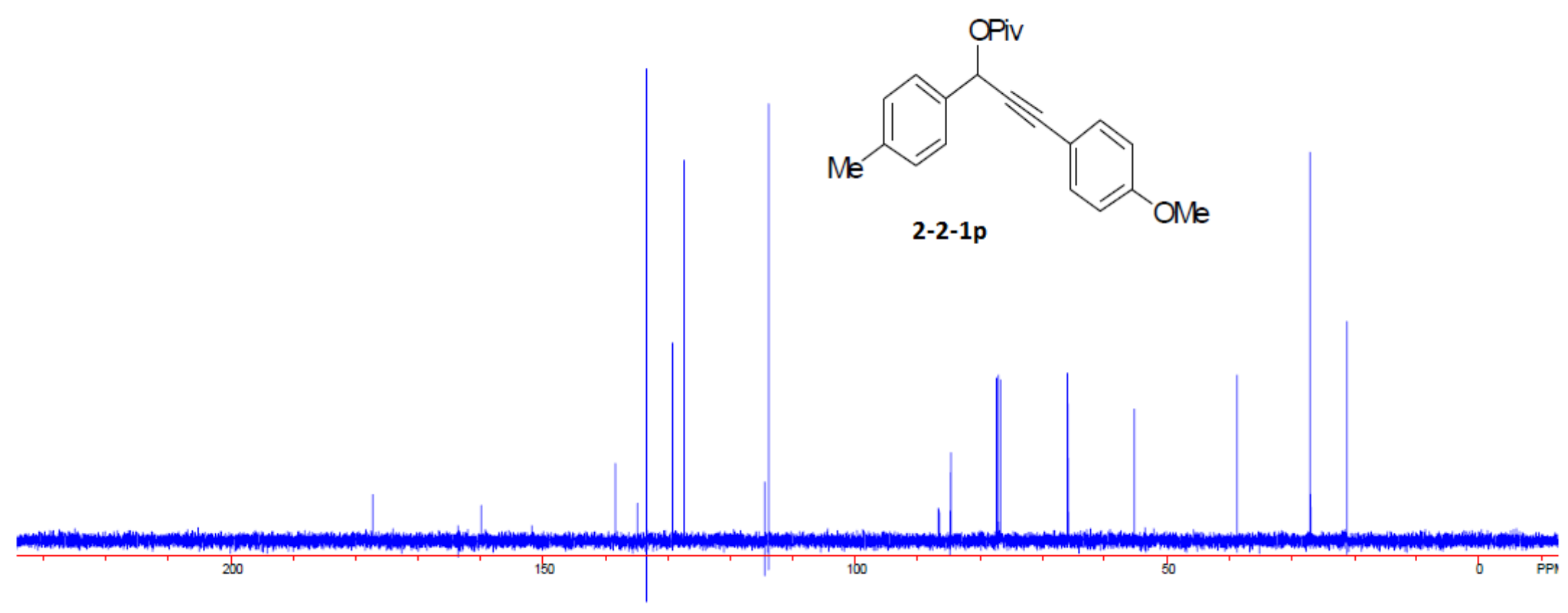



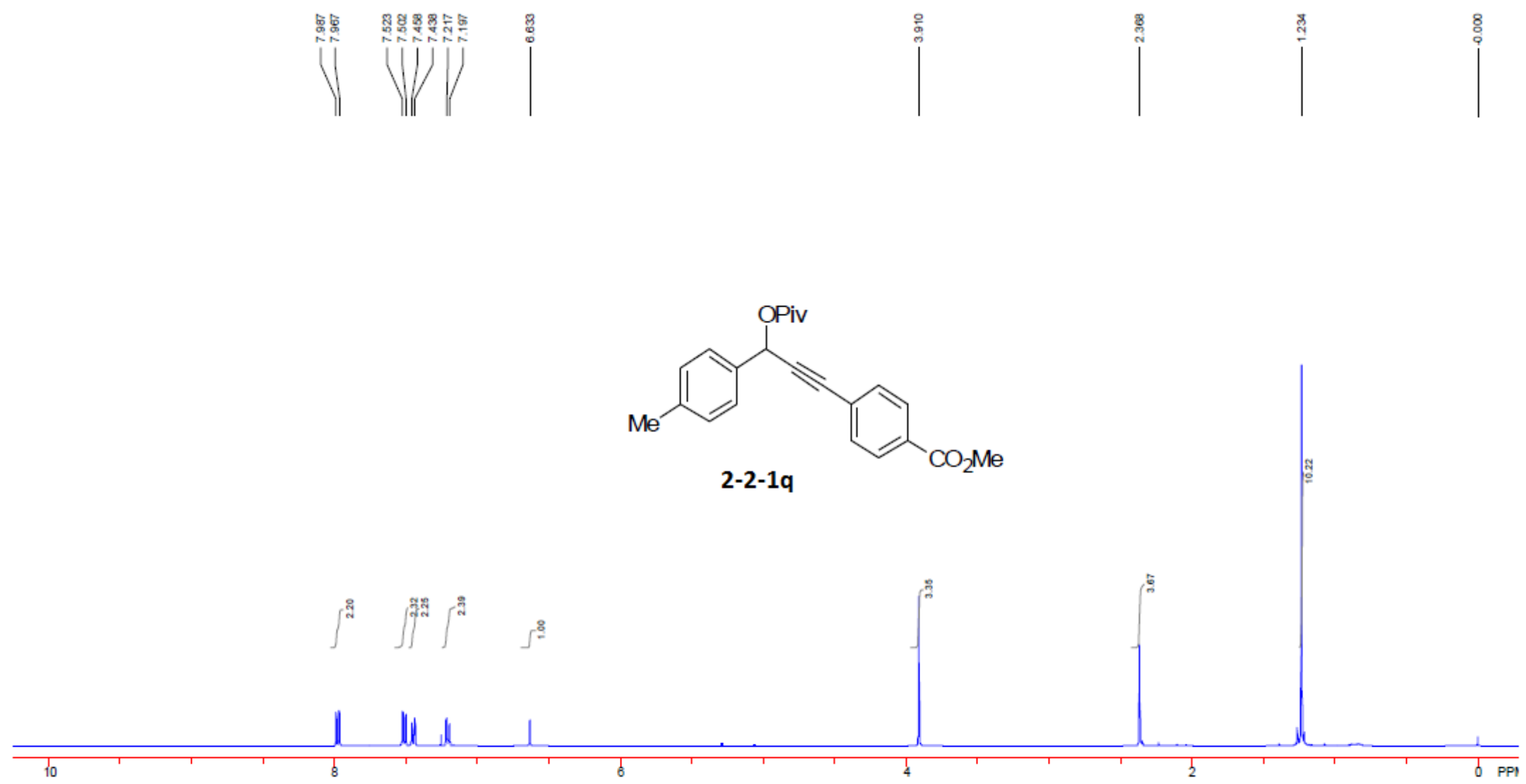

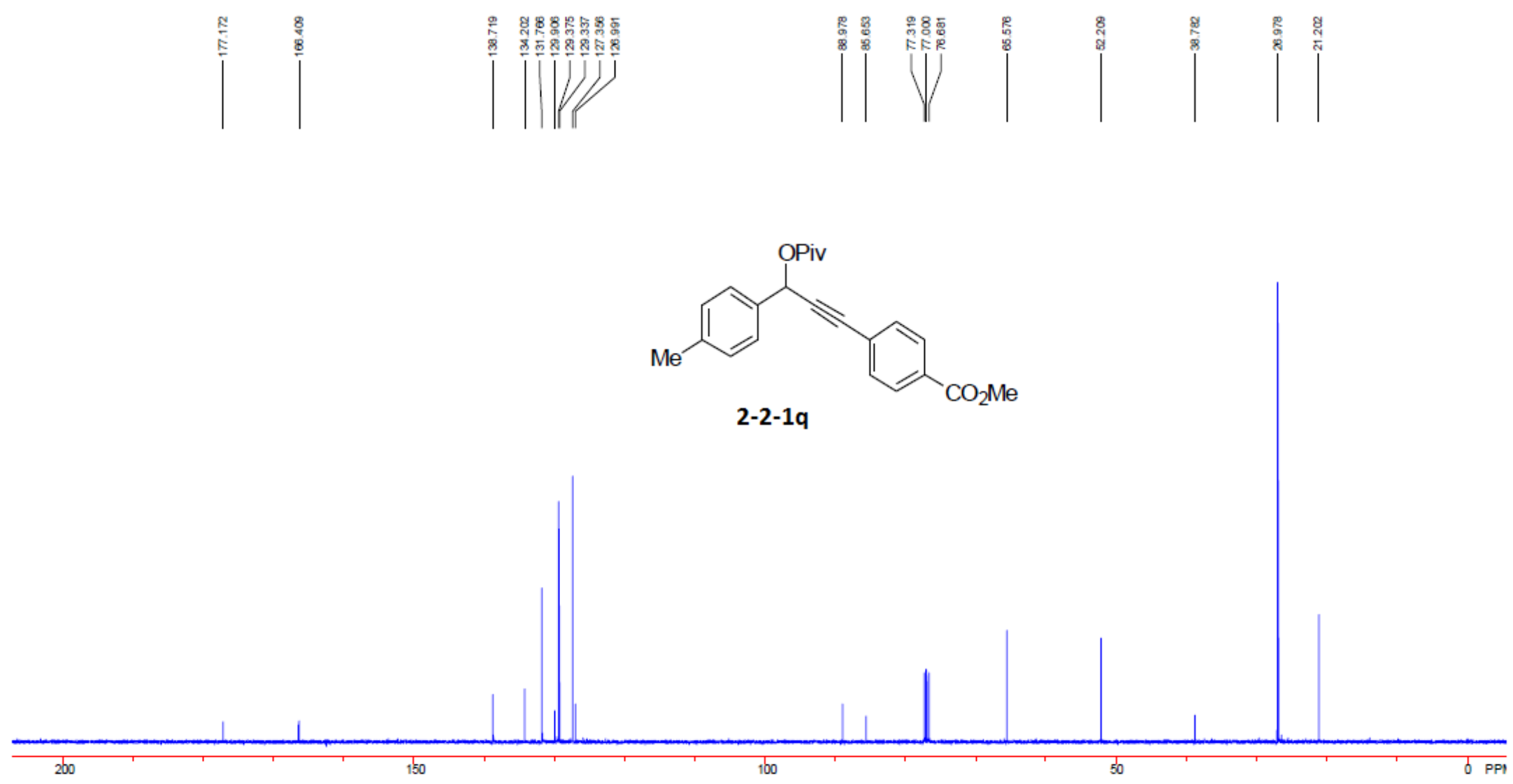


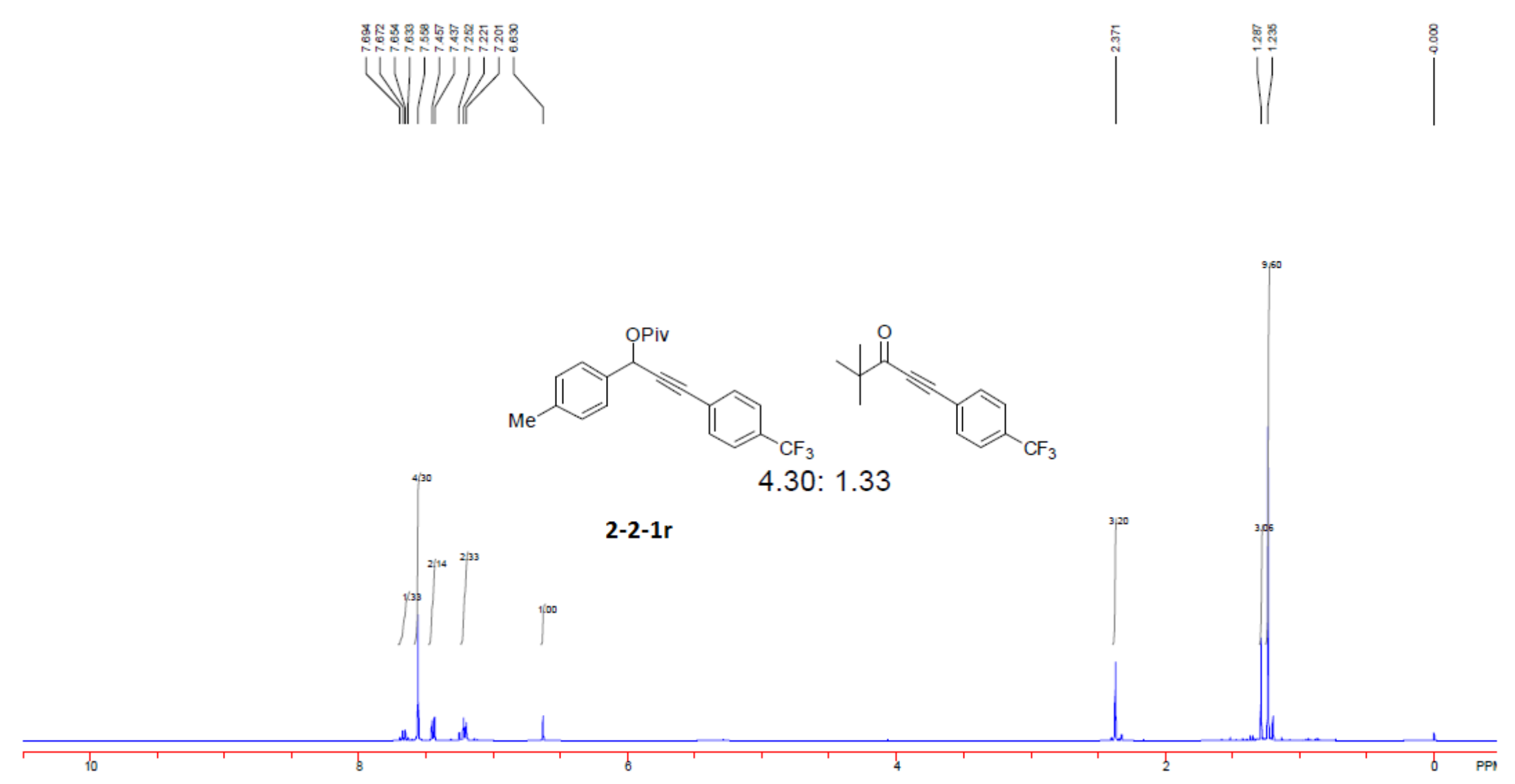


$\mathrm{rz}-1-111 \mathrm{C}-1 \mathrm{H}$

Archive directory: /export/hone/vnnr 1/vnarsys/data pulse Sequence: szpul

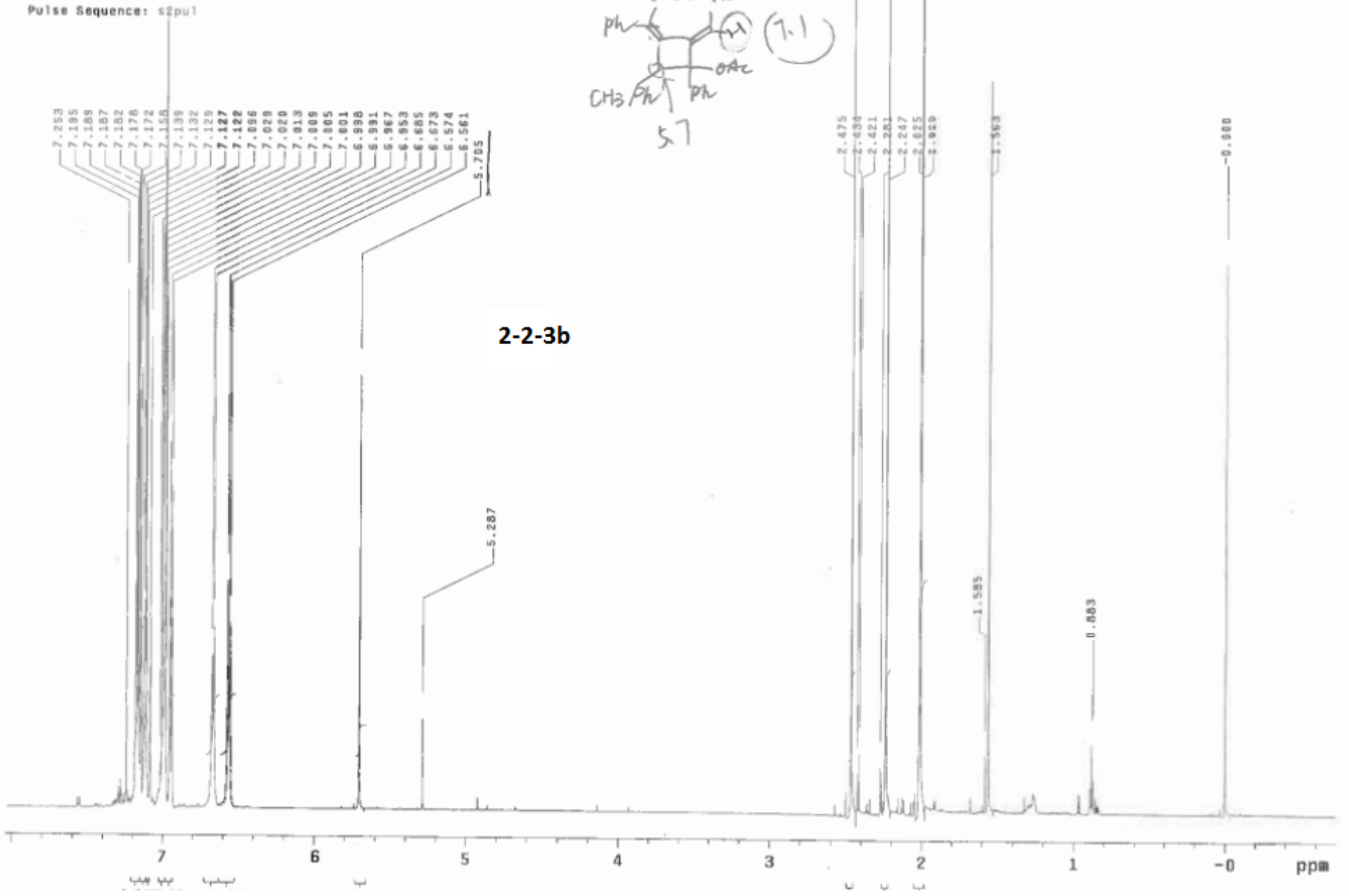


Y2-1-111c-13C

Pulse Sequence: s2pul

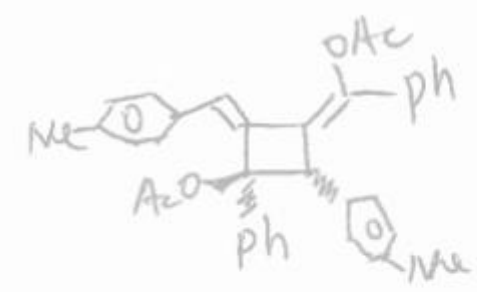

2-2-3b

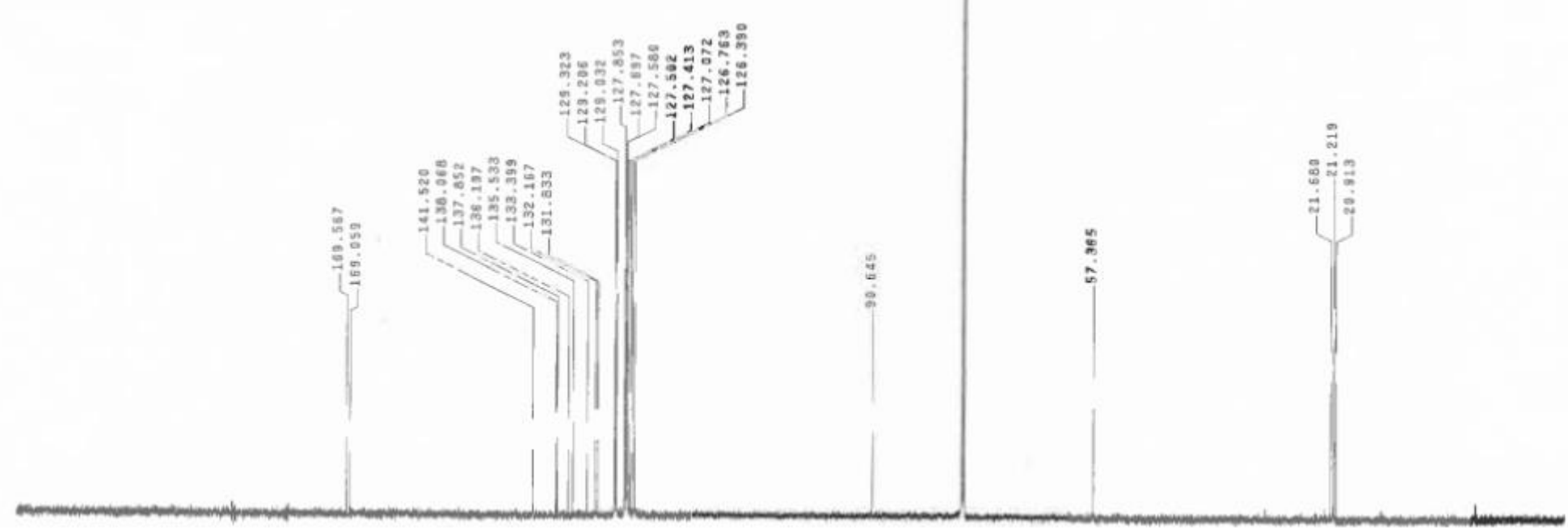


yvz-1-80-H

Archive dir ectory: /export/hone/vine 1/vnar sys/data

Sanple directory

Pulse Sequence: s2pul

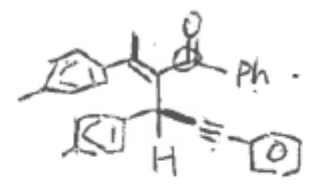

2-2-2b

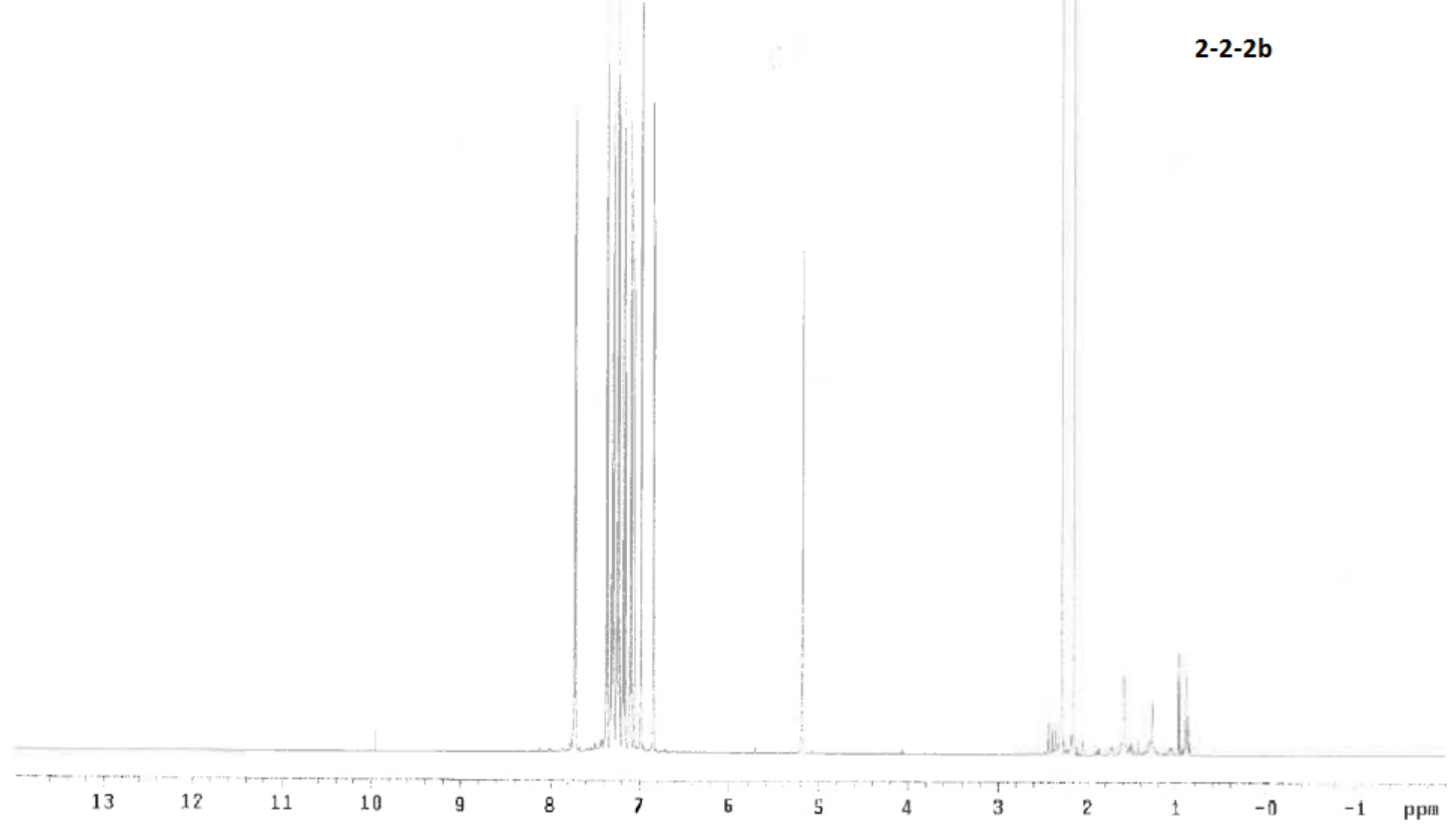


ywz-1-8n-c

Pulse Sequence: s2pul

gis

$\stackrel{\text { g. }}{g}$

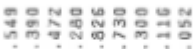

تี่

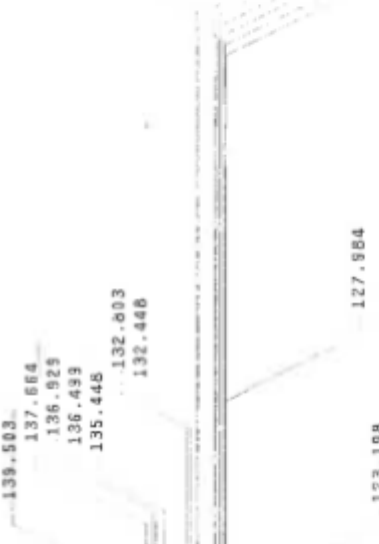

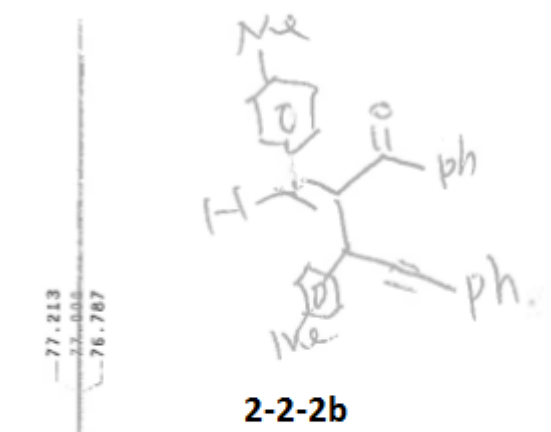

2-2-2b

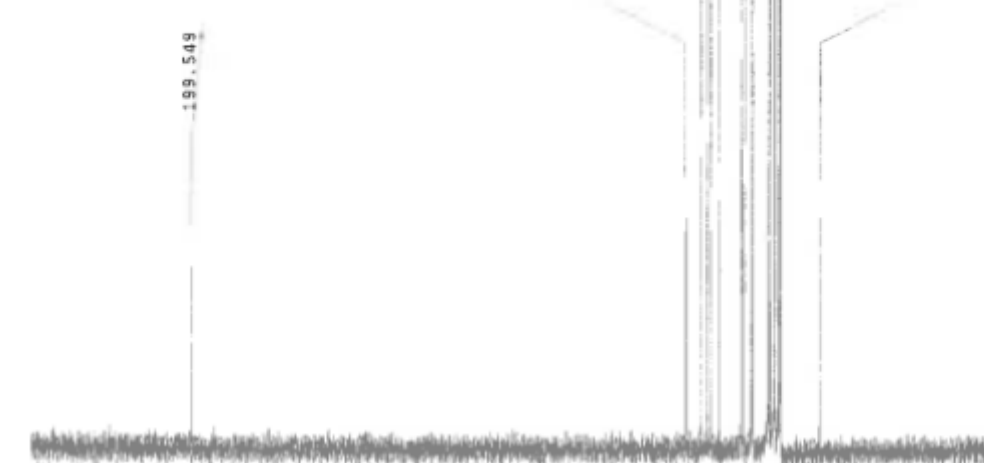

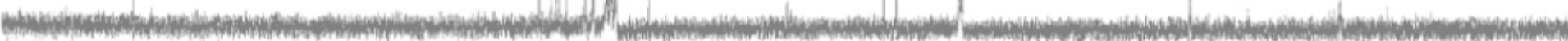




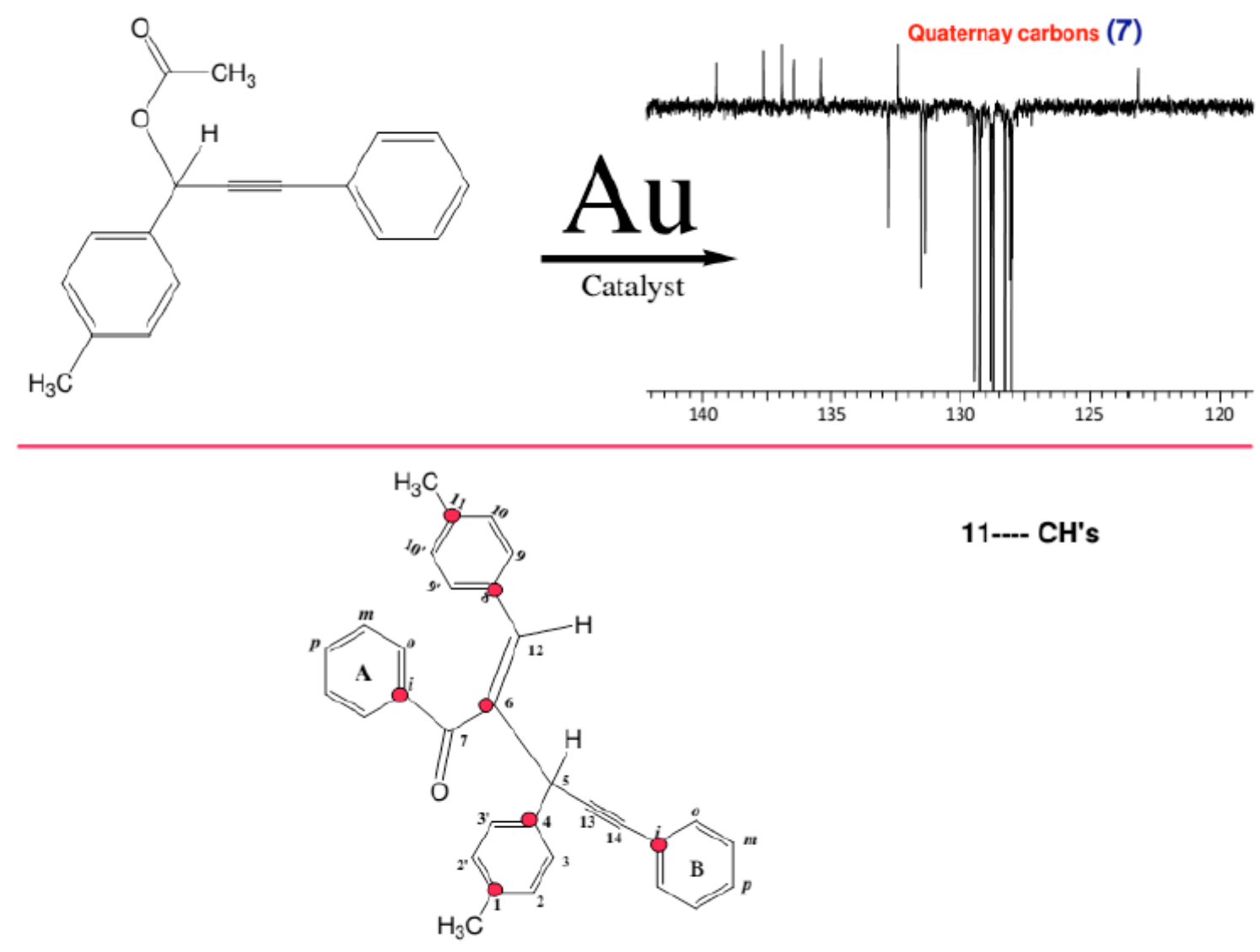




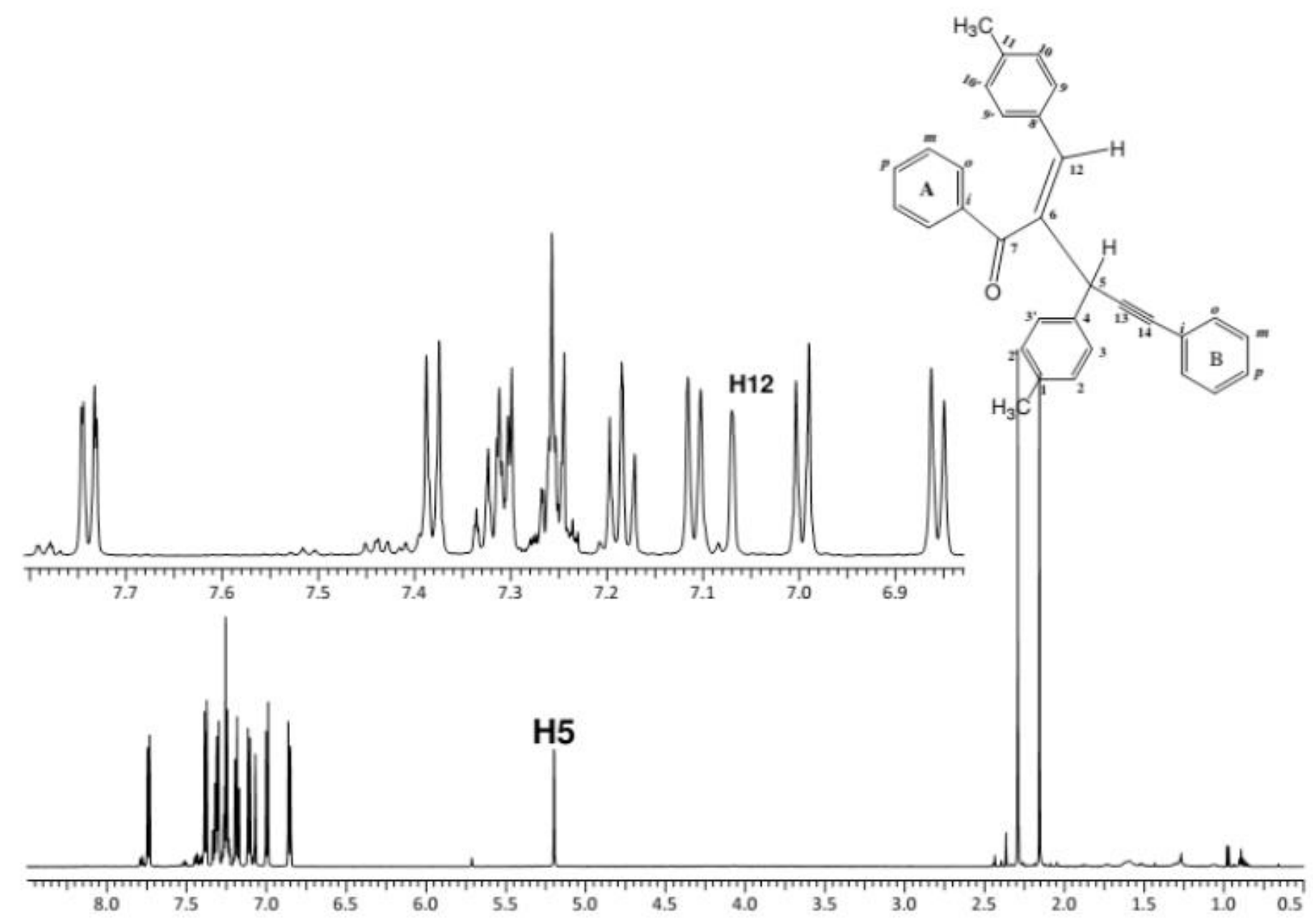




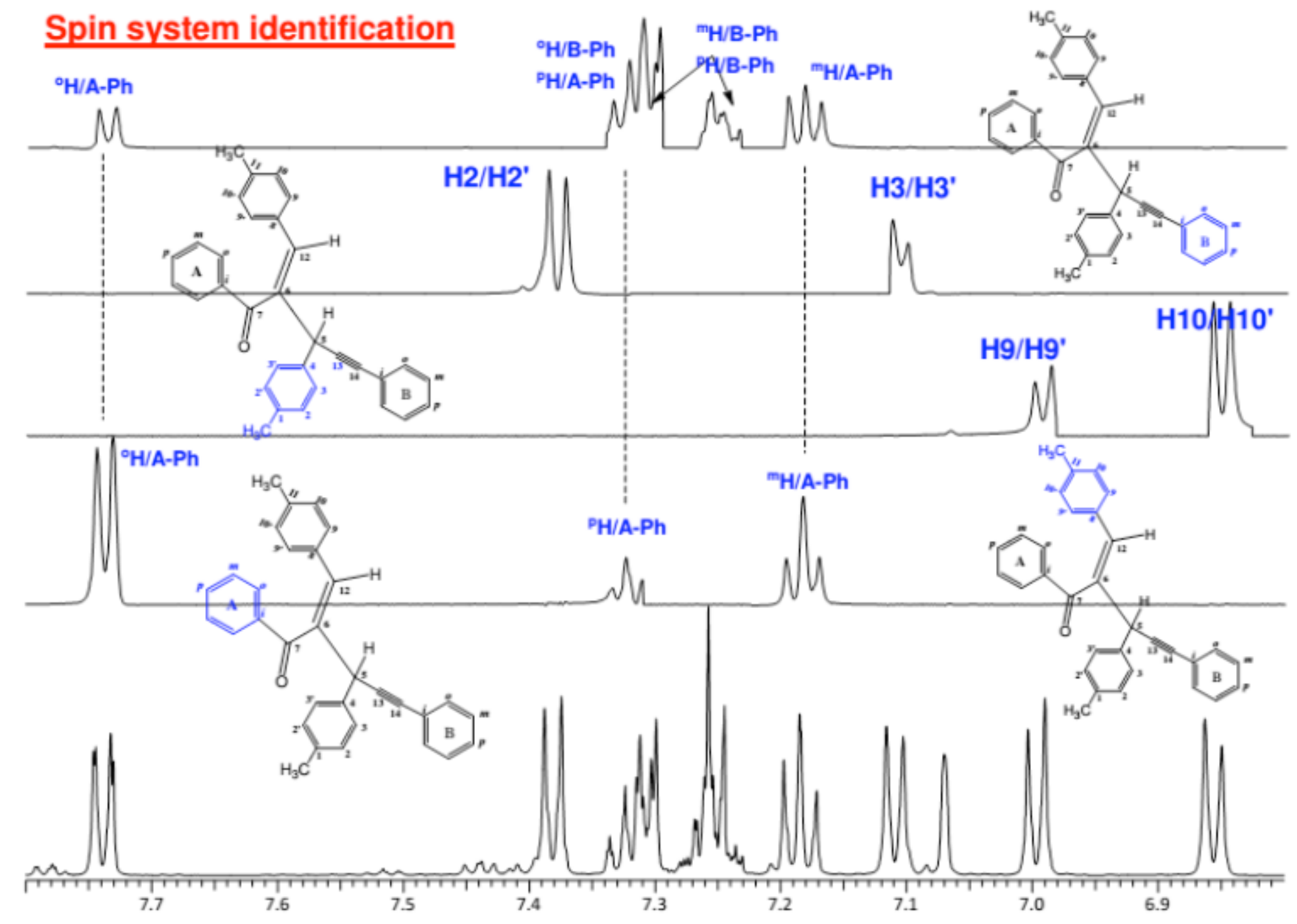




\section{DPFGSENOE}

spectra

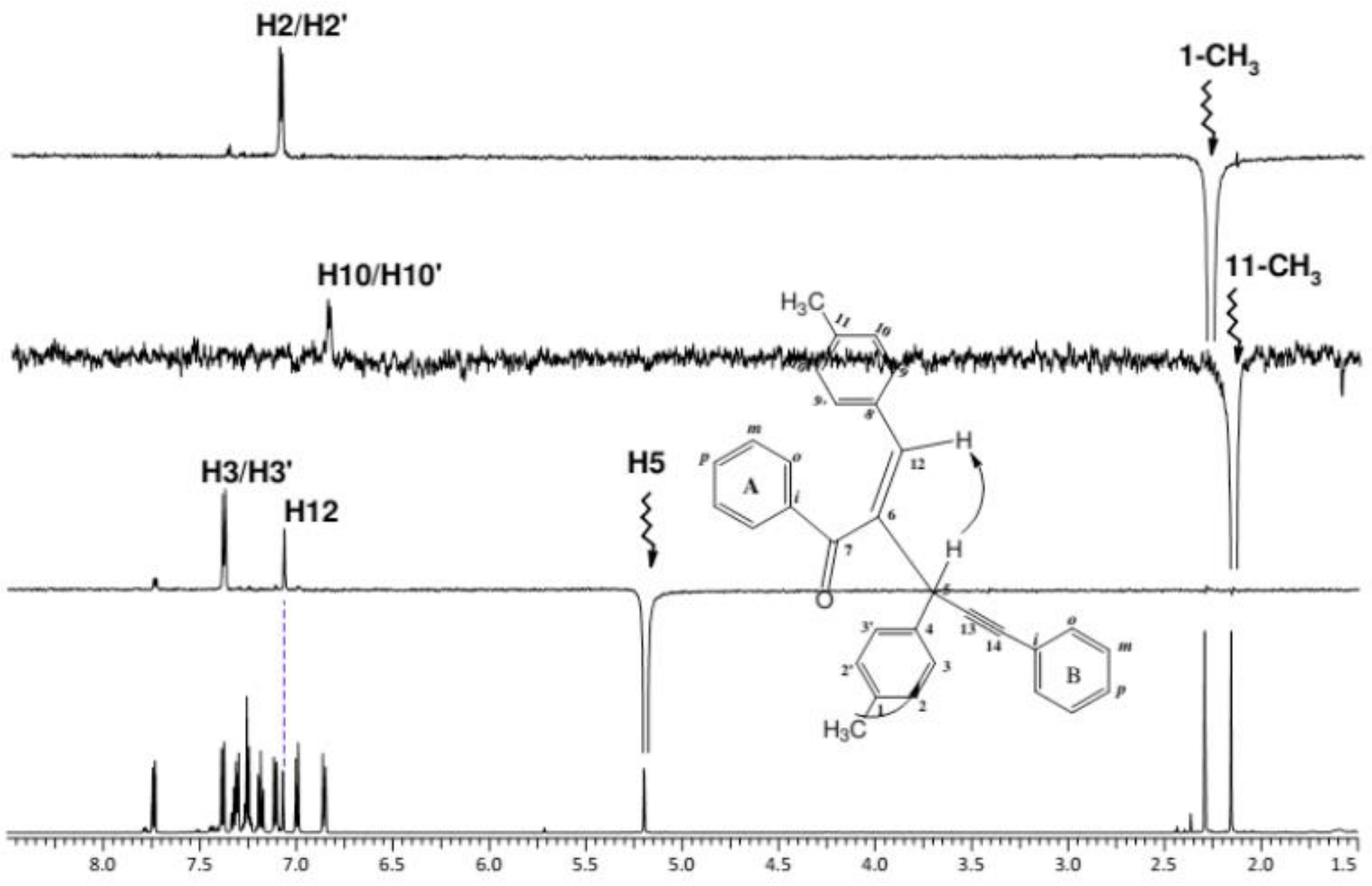


Expansion of the HMBC spectrum

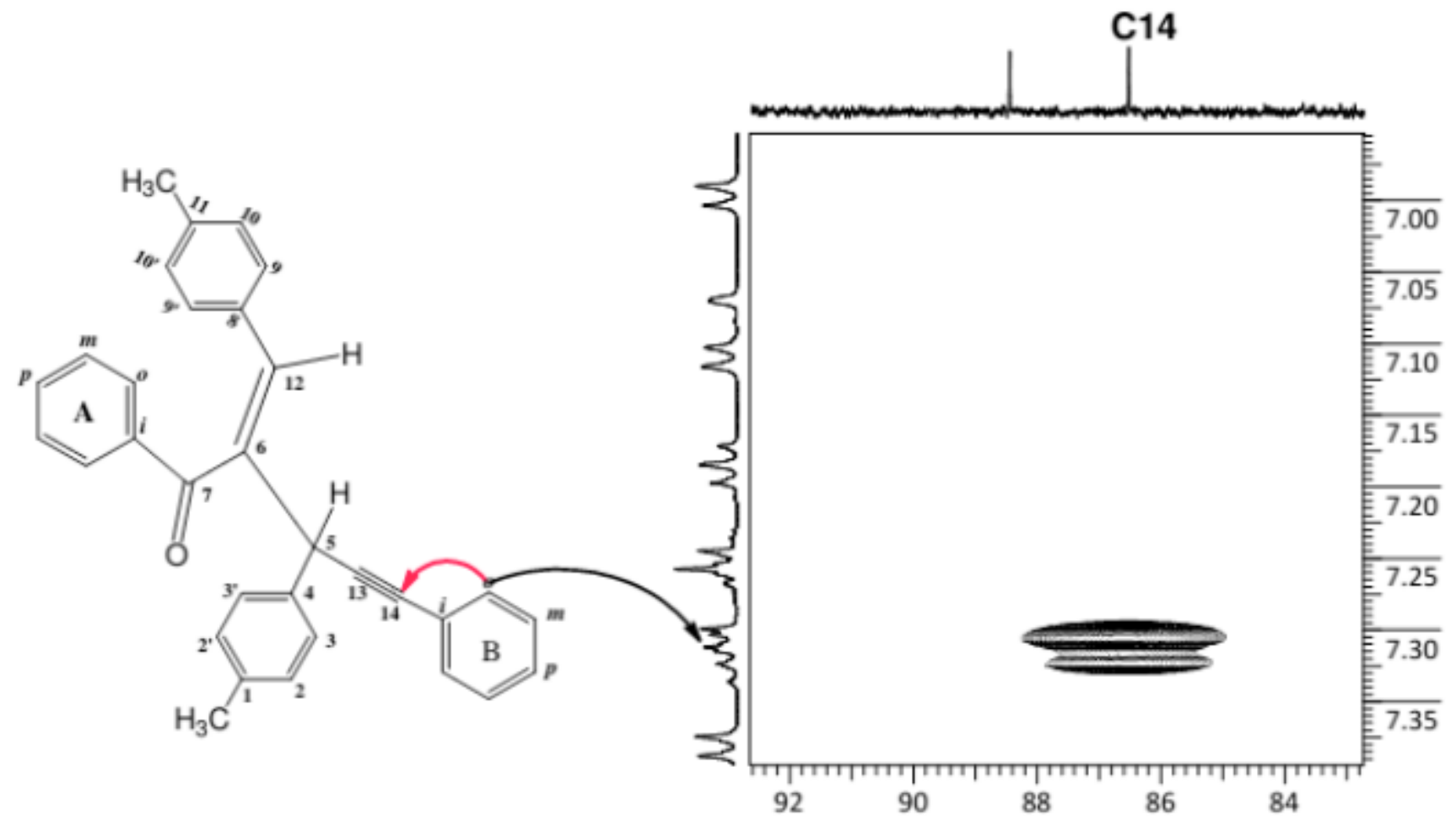




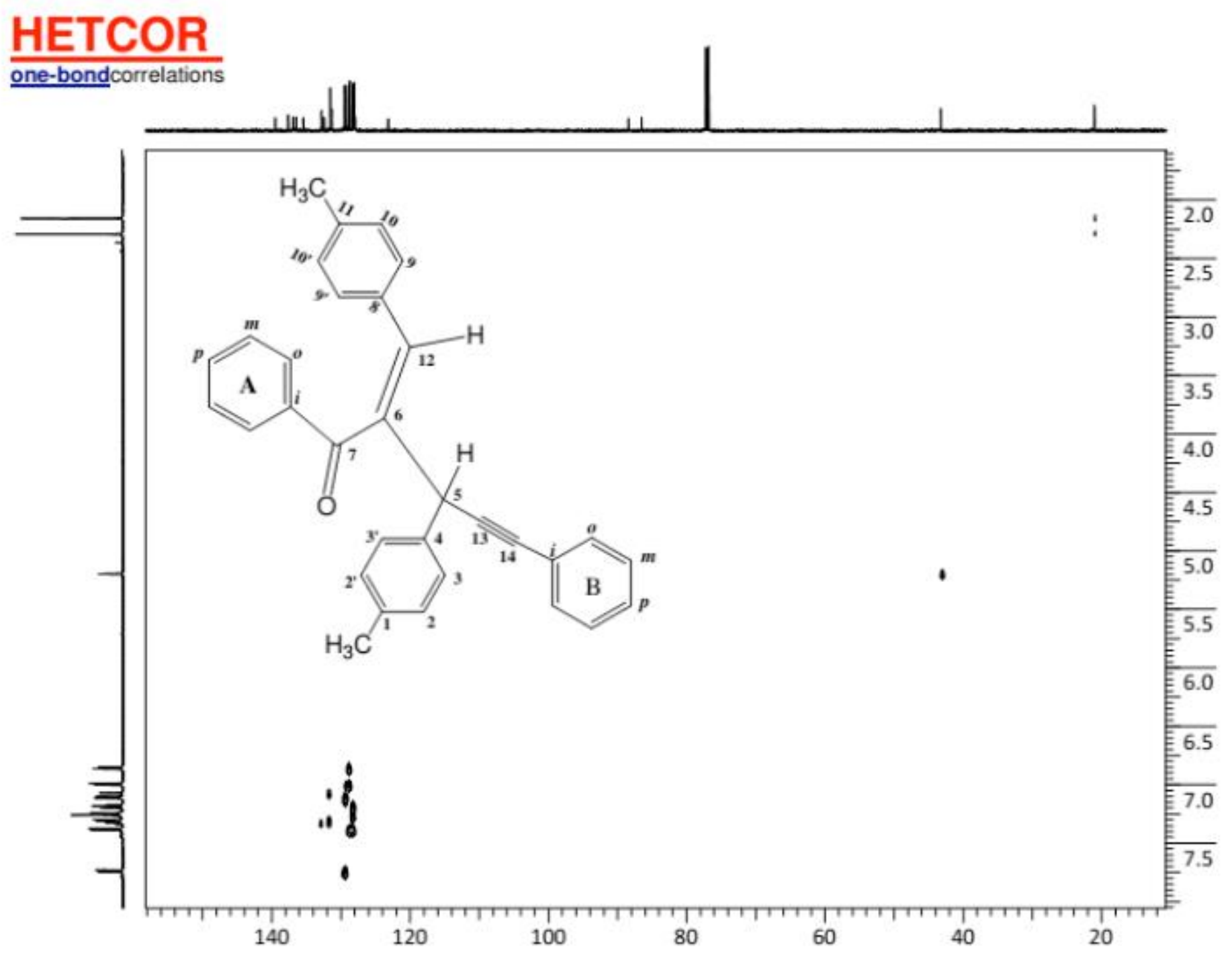




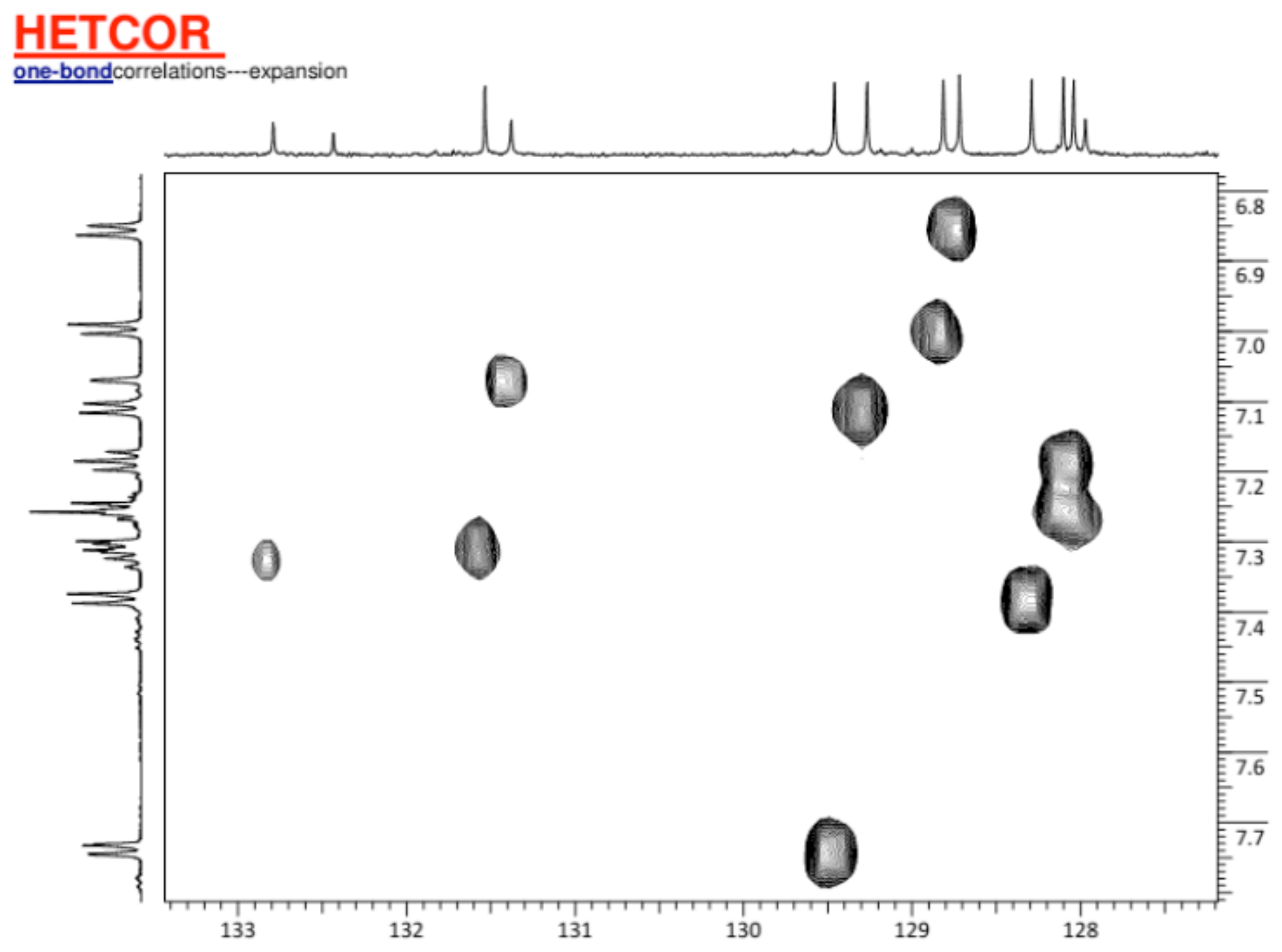




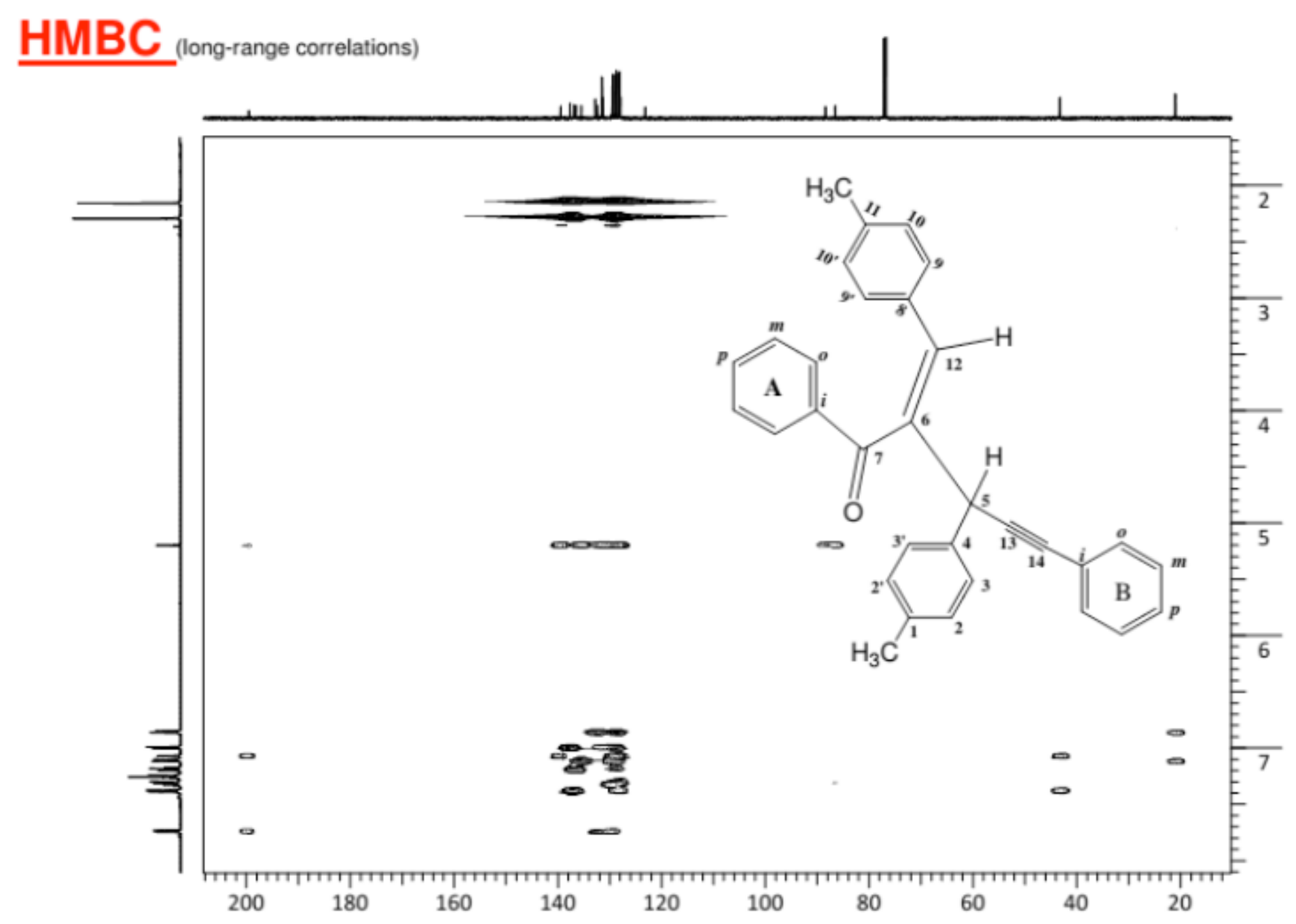




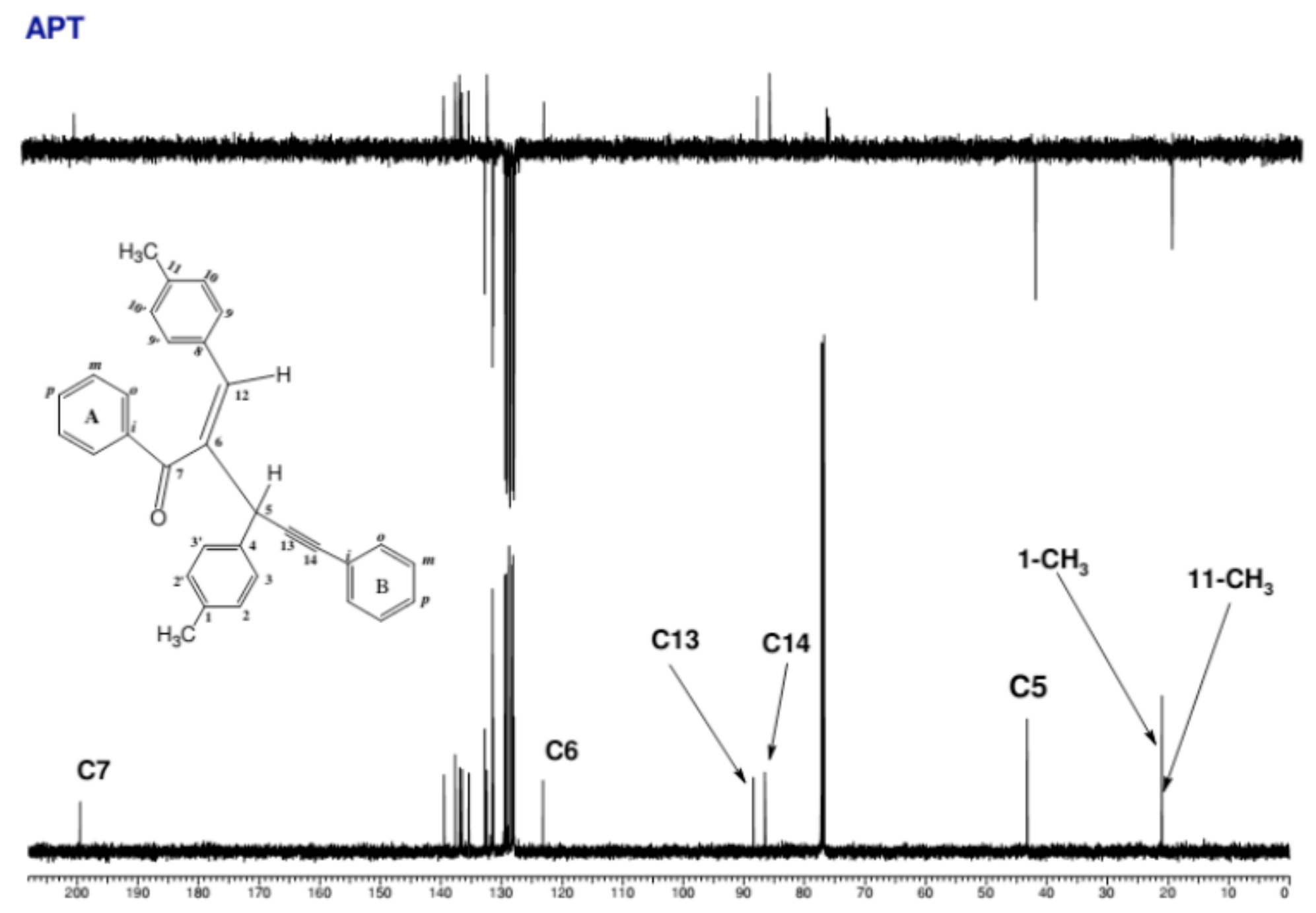



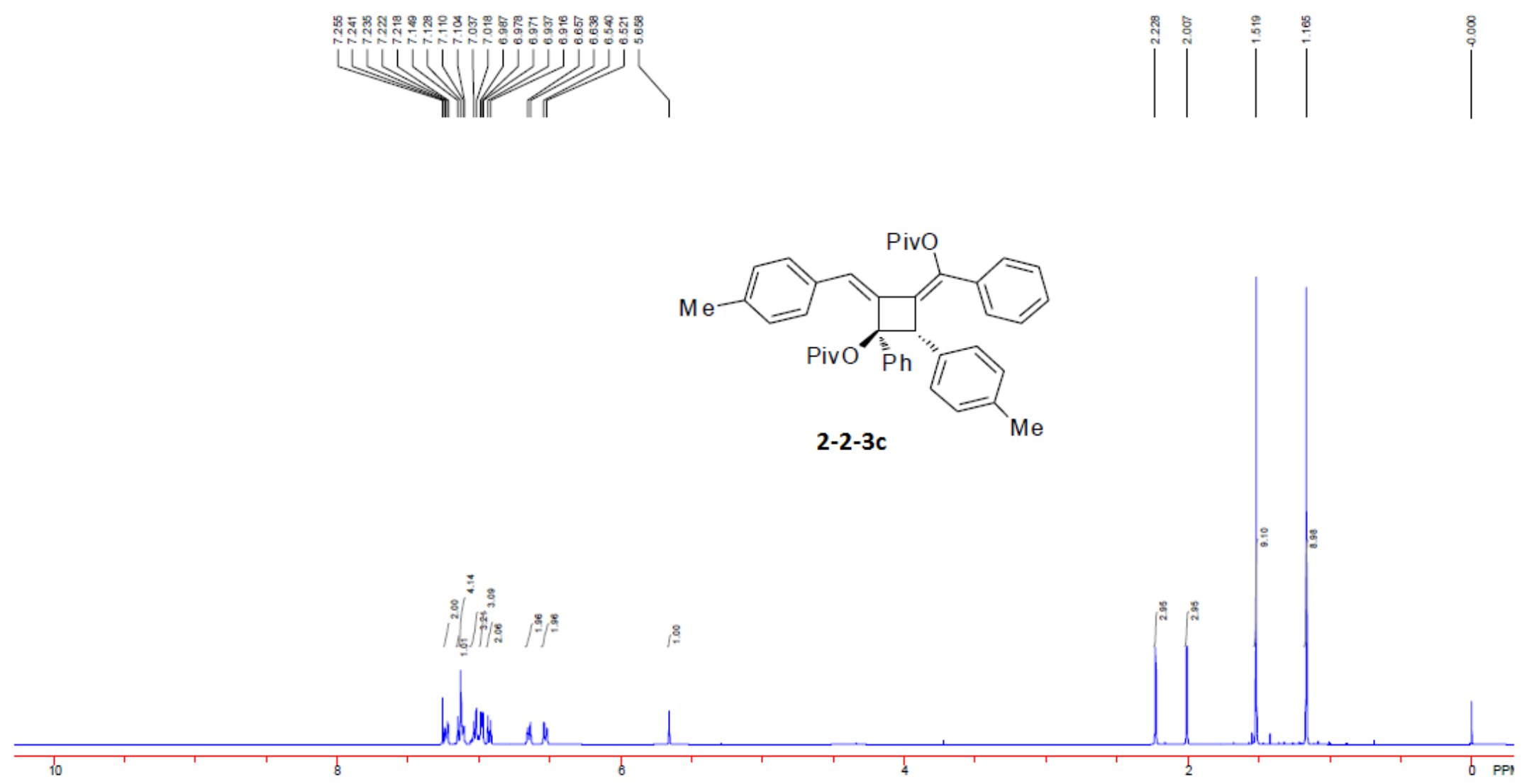

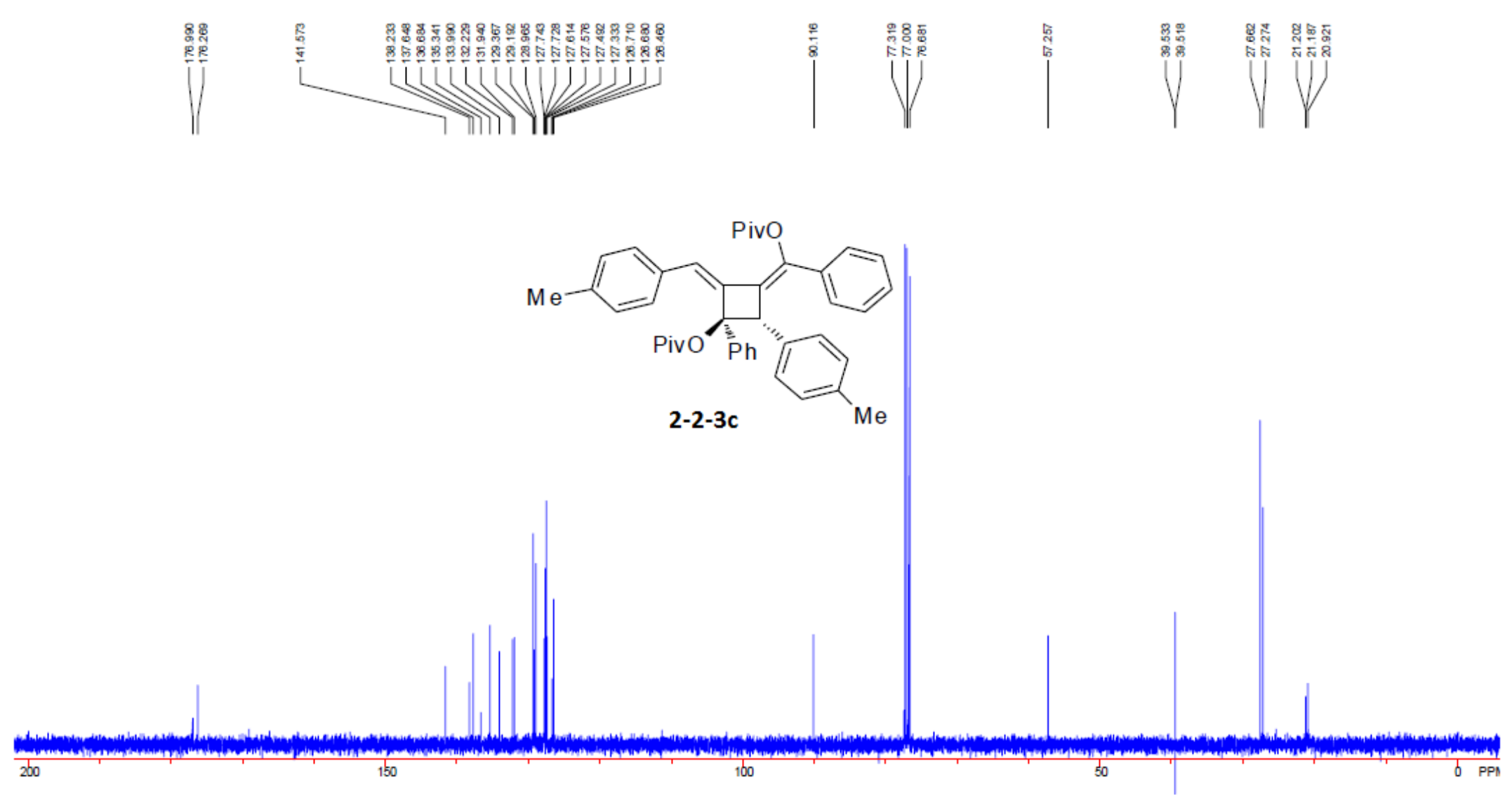


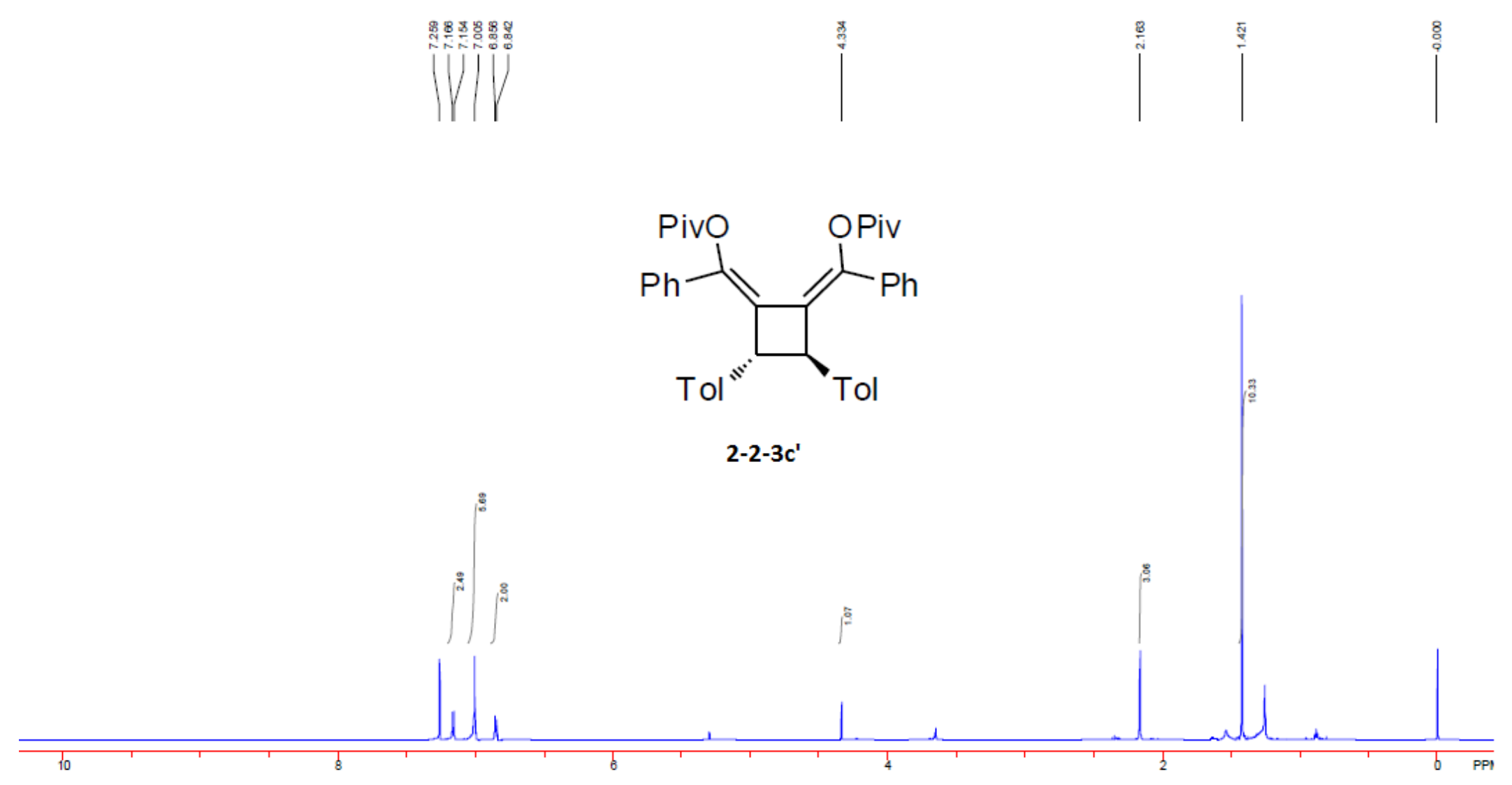




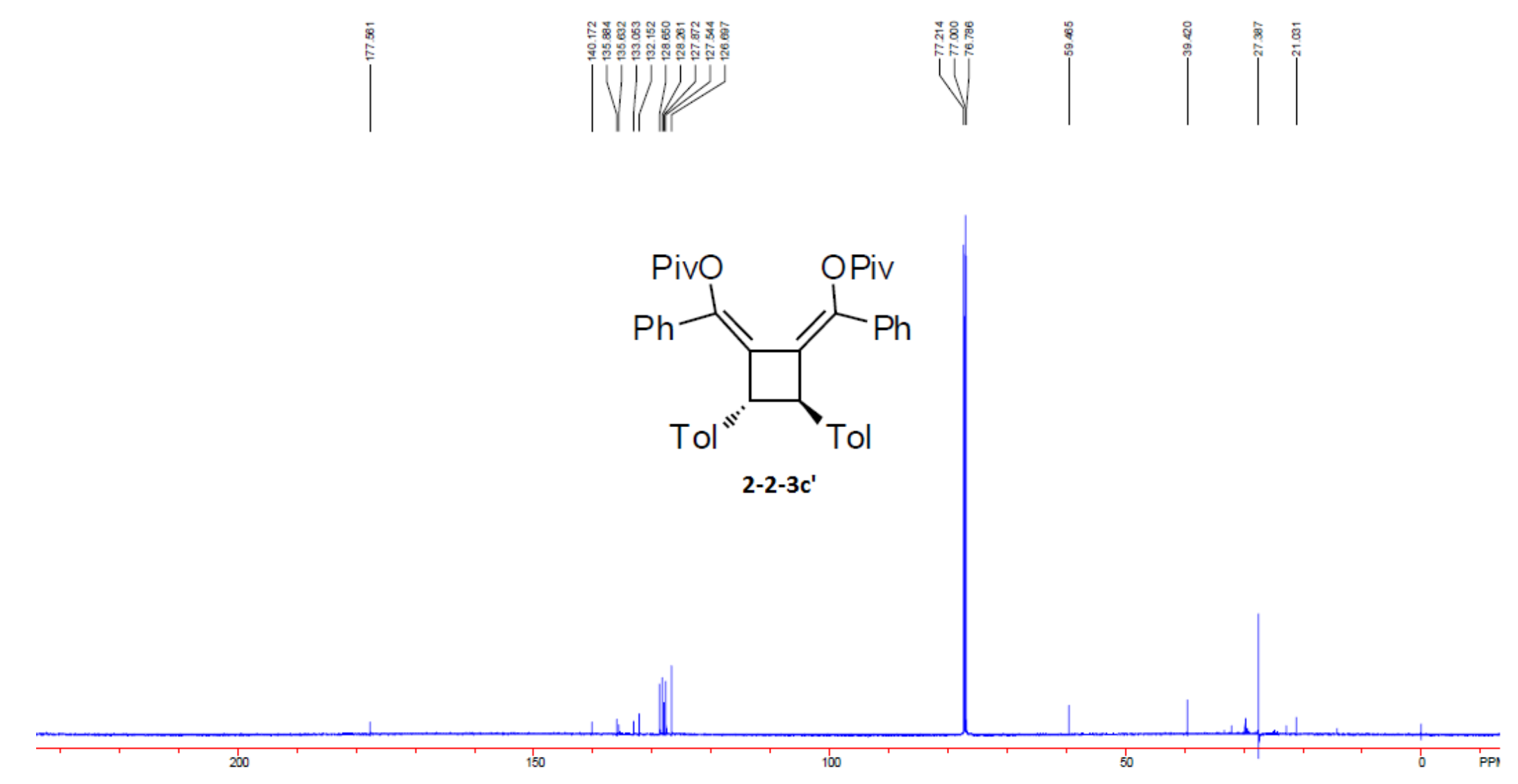



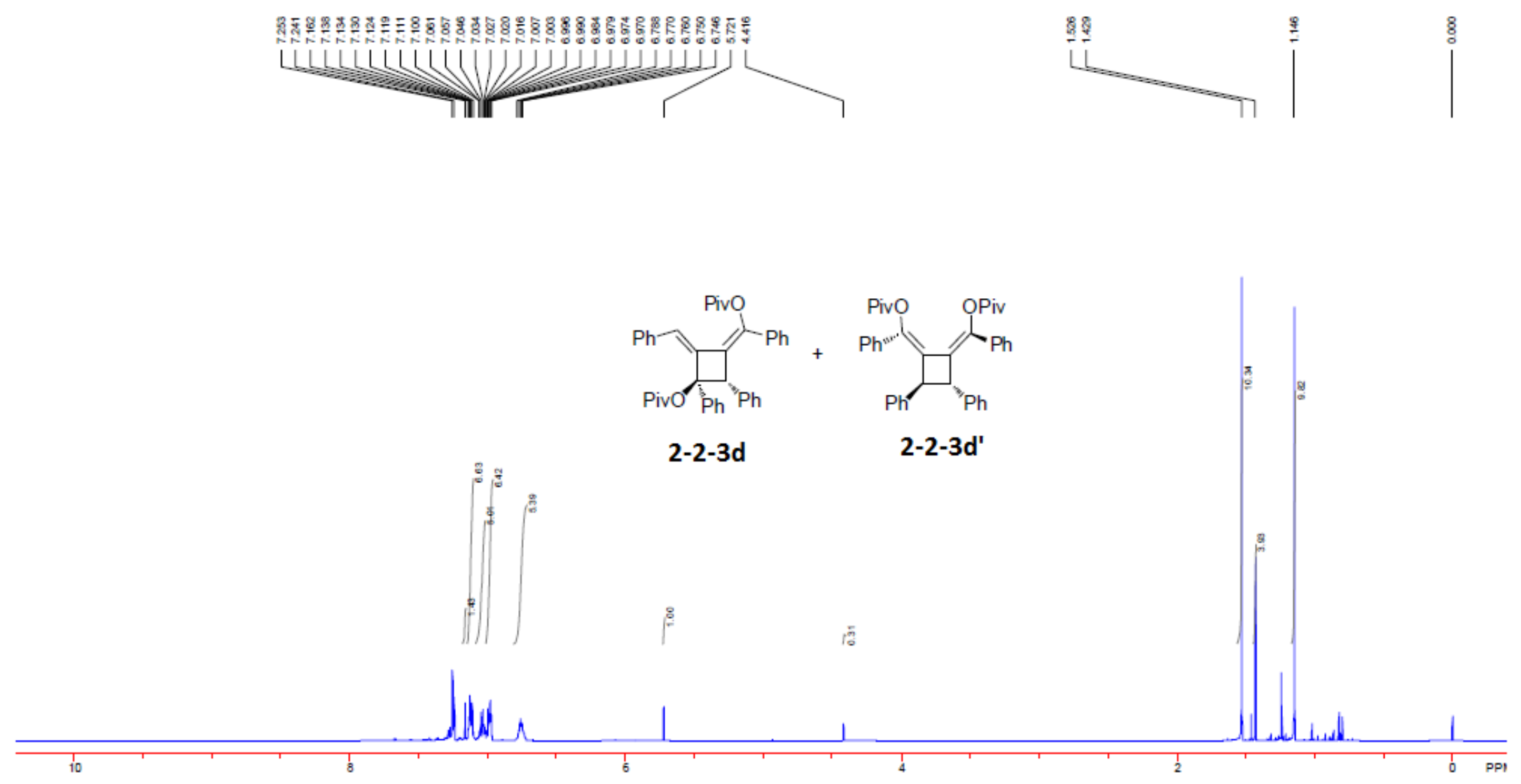


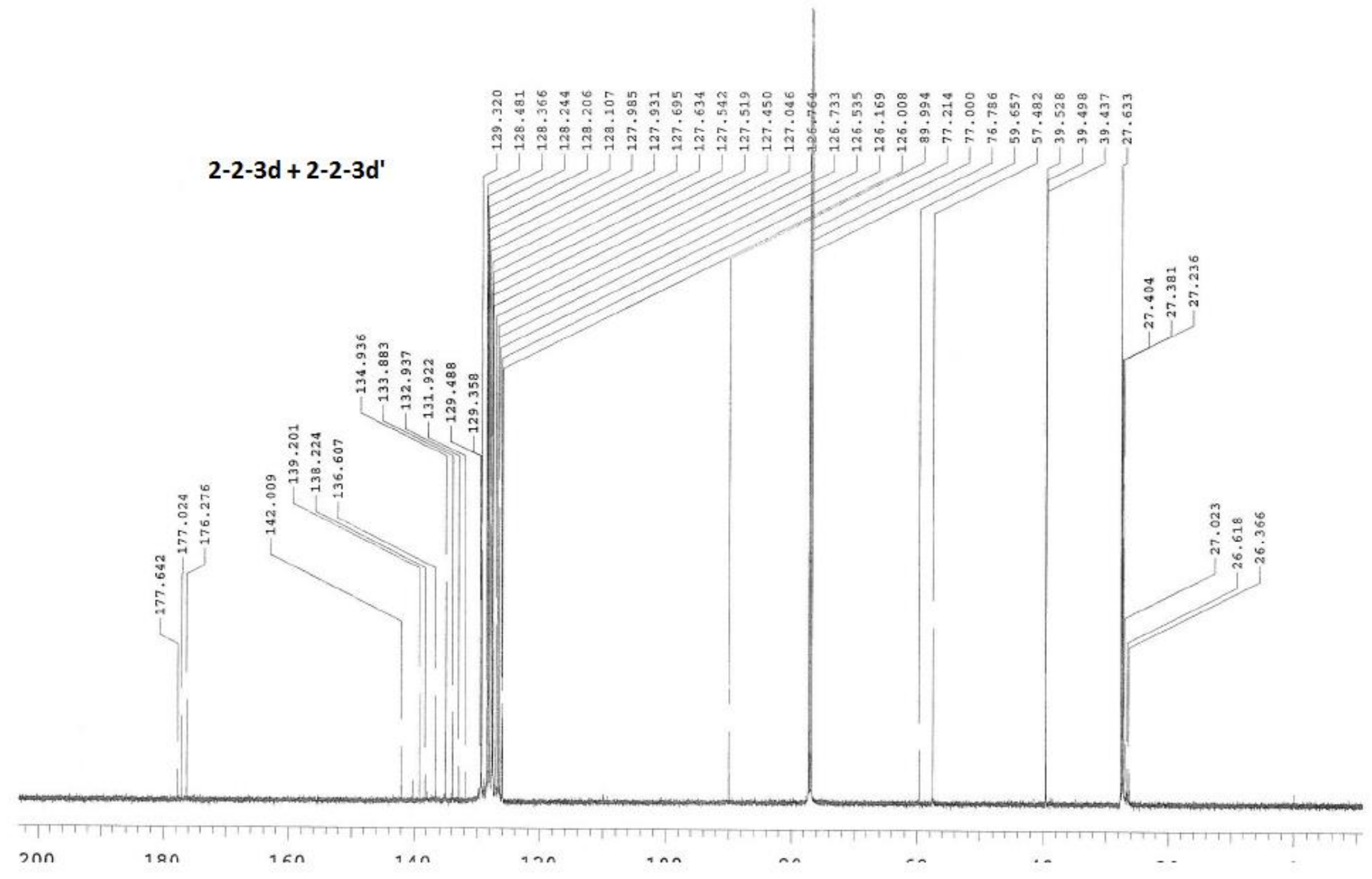




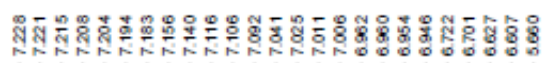

ULMULU|MJJjJjJj

|| $\mid$

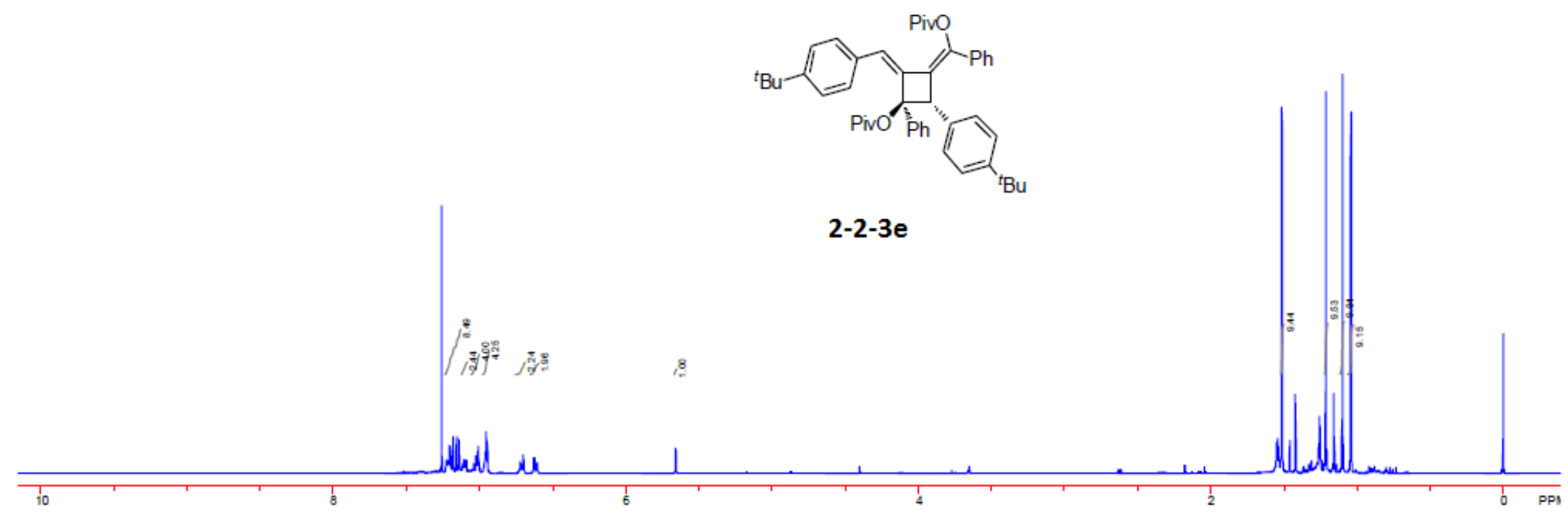




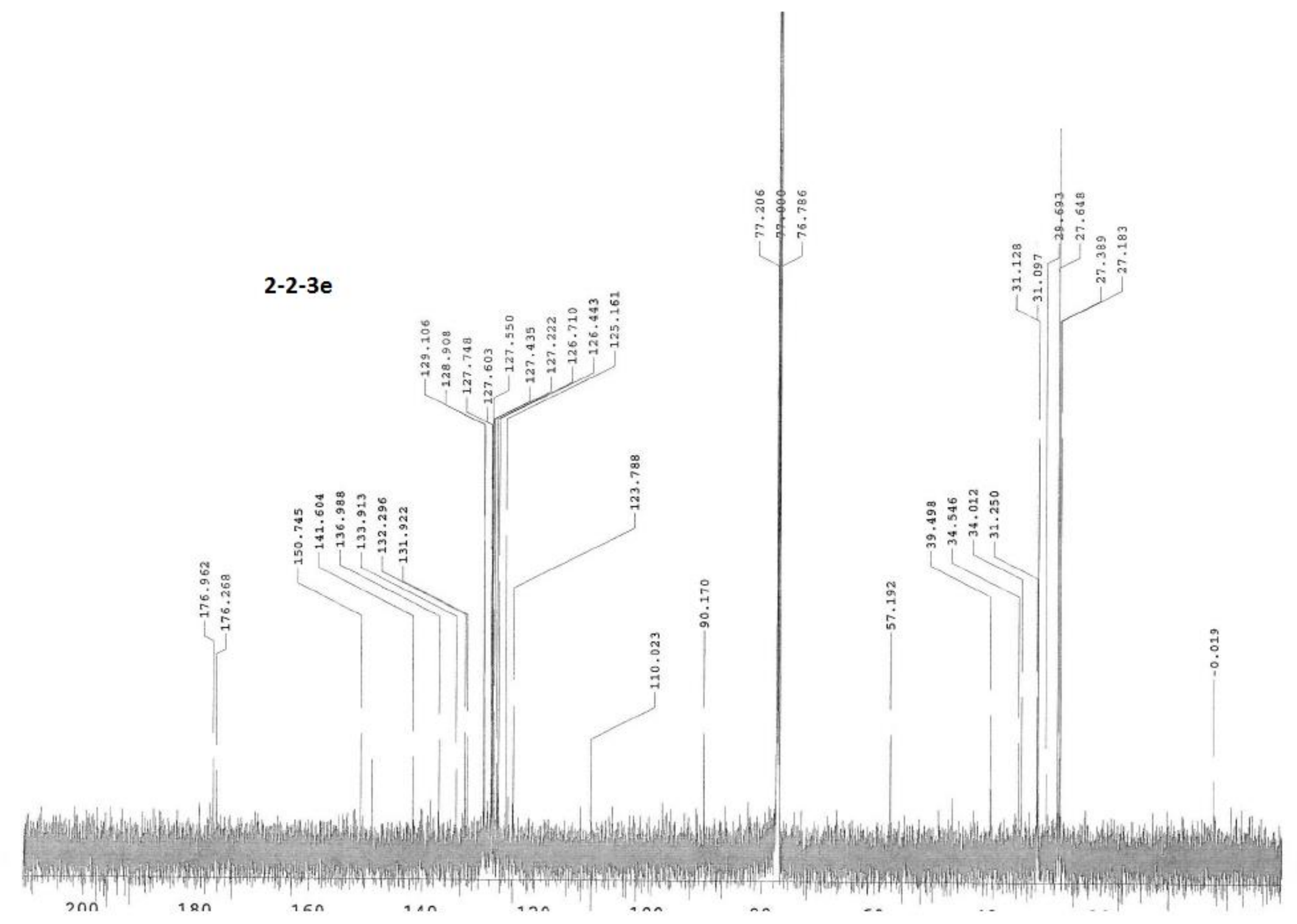


V||ij

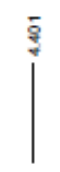

$\left.\right|^{\approx} \frac{\mathscr{2}}{2}$

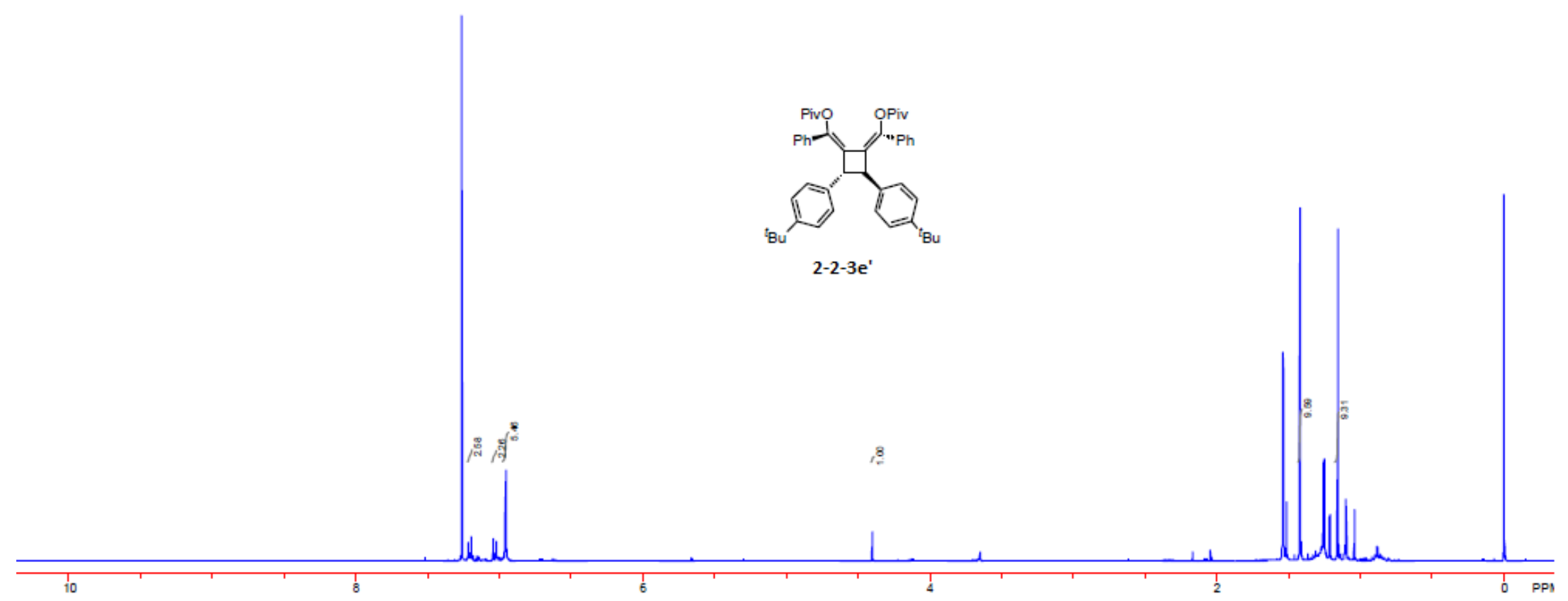




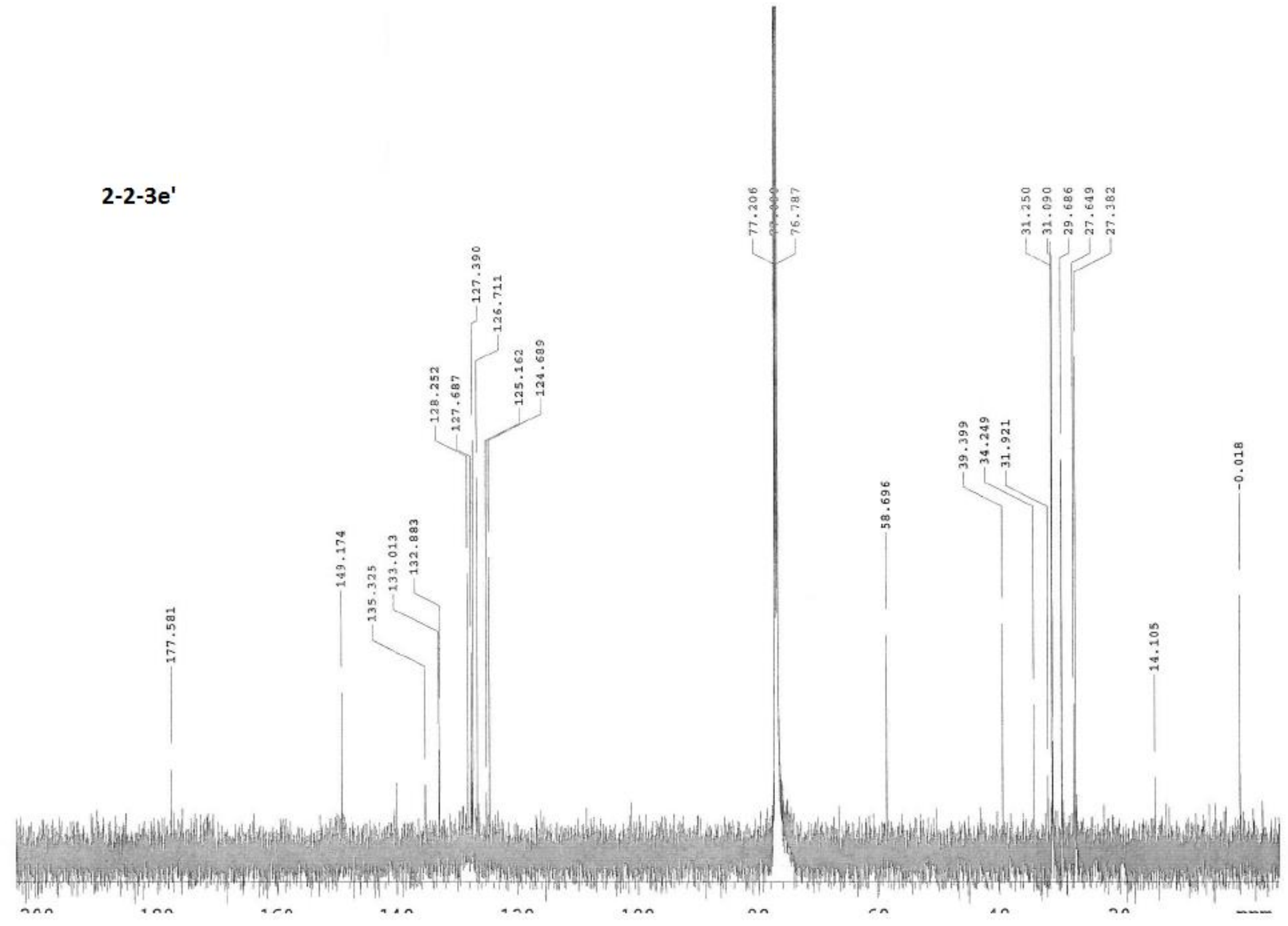




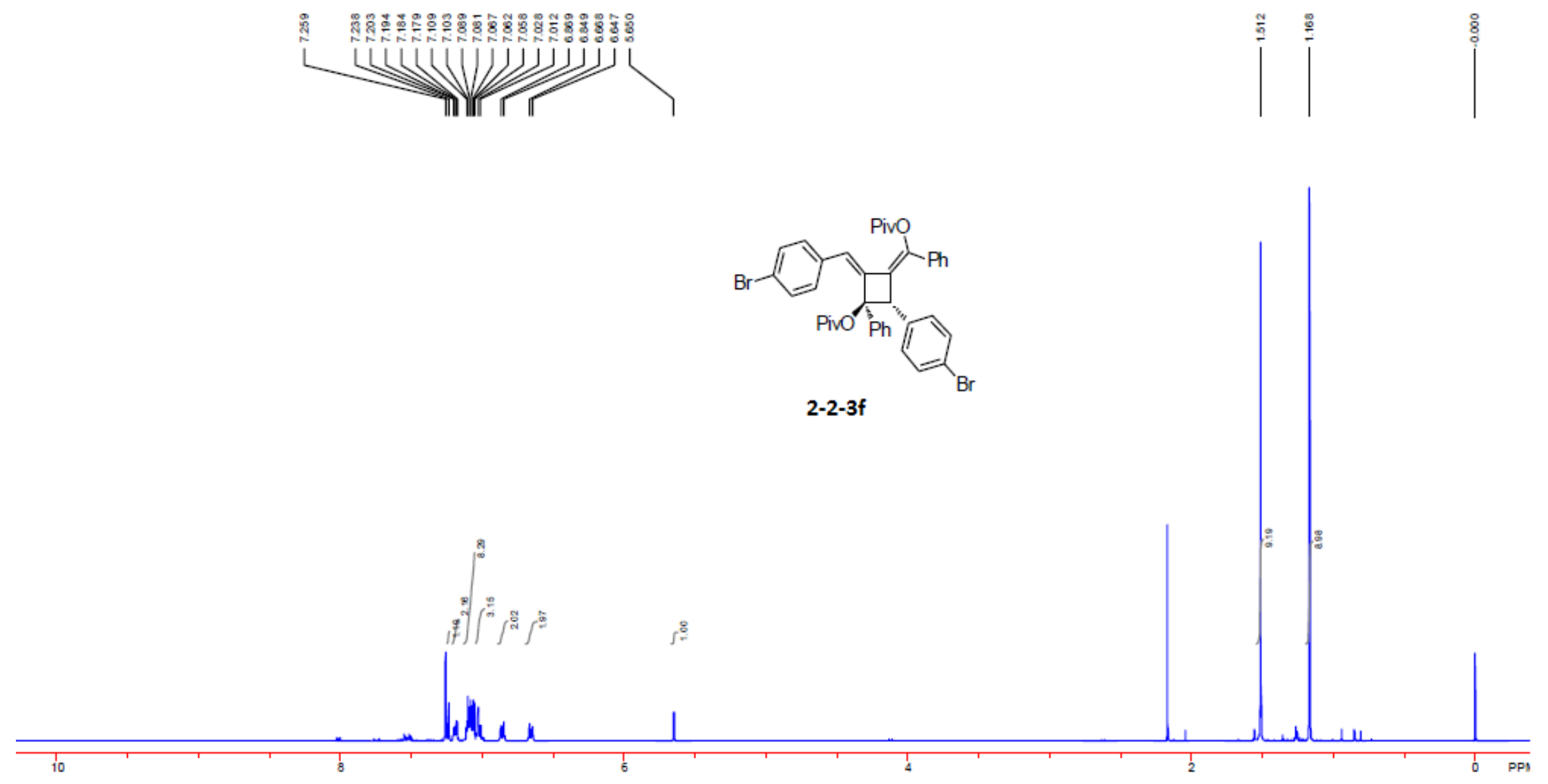




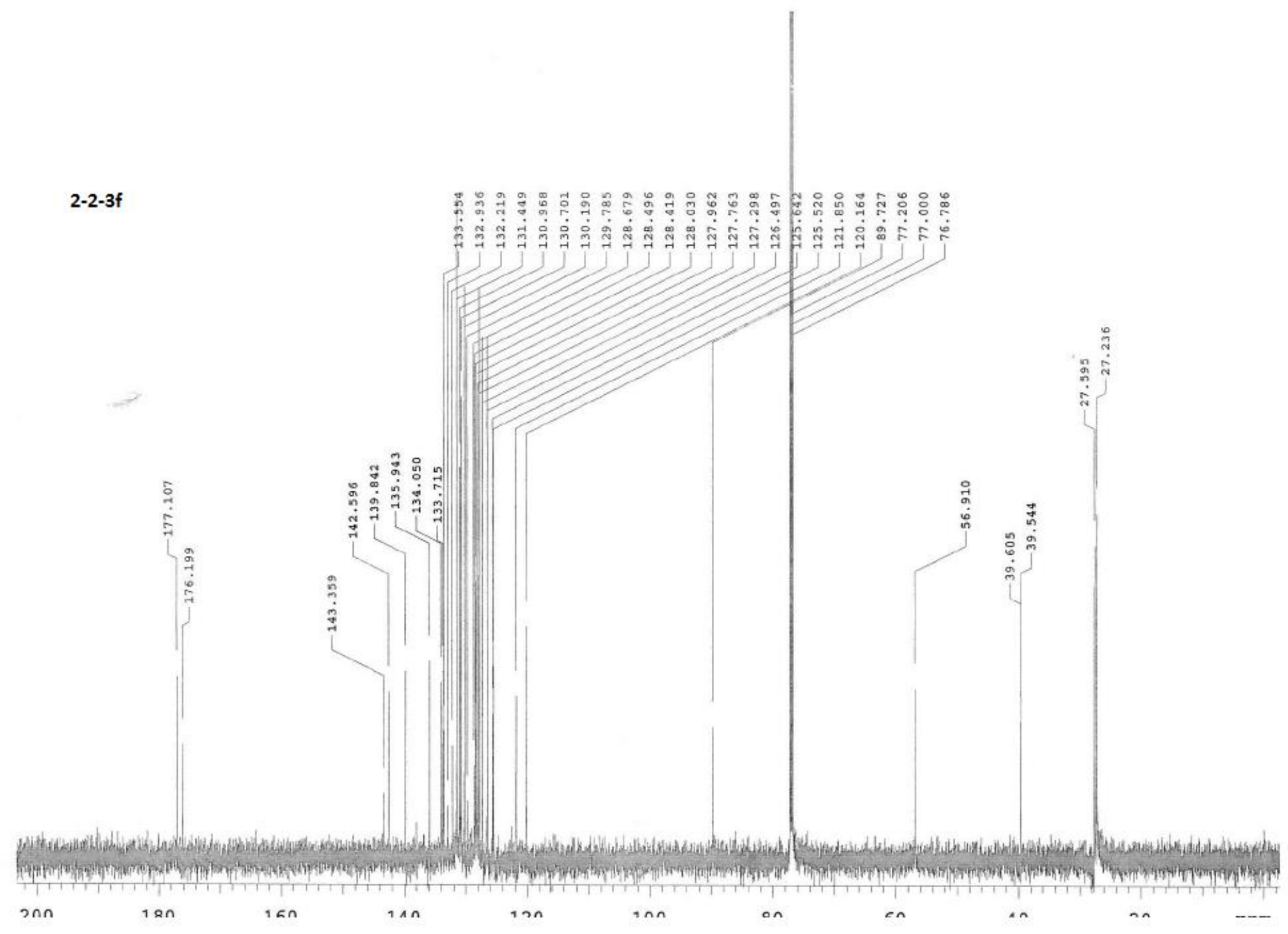




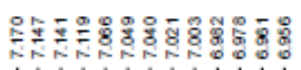

(1)
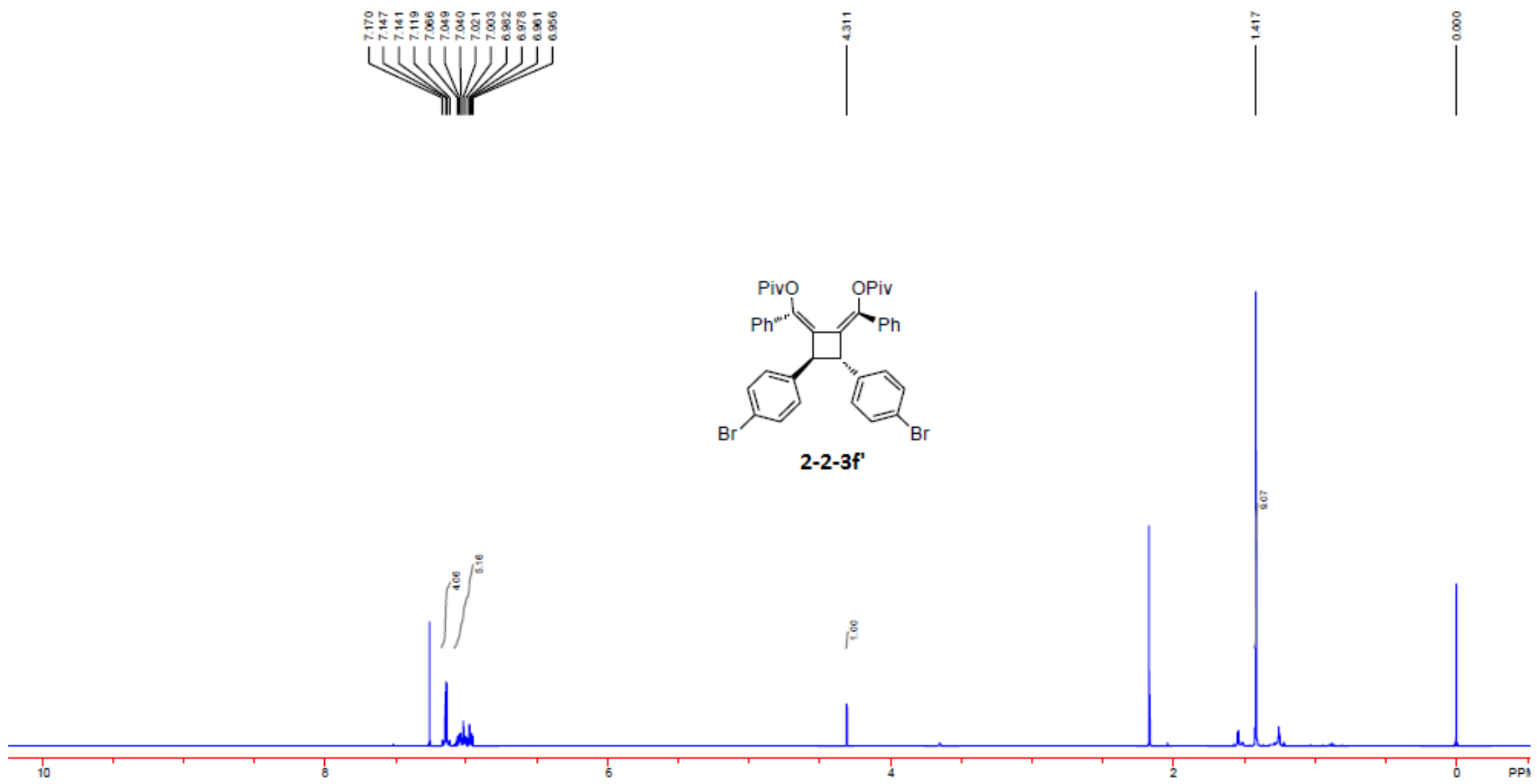


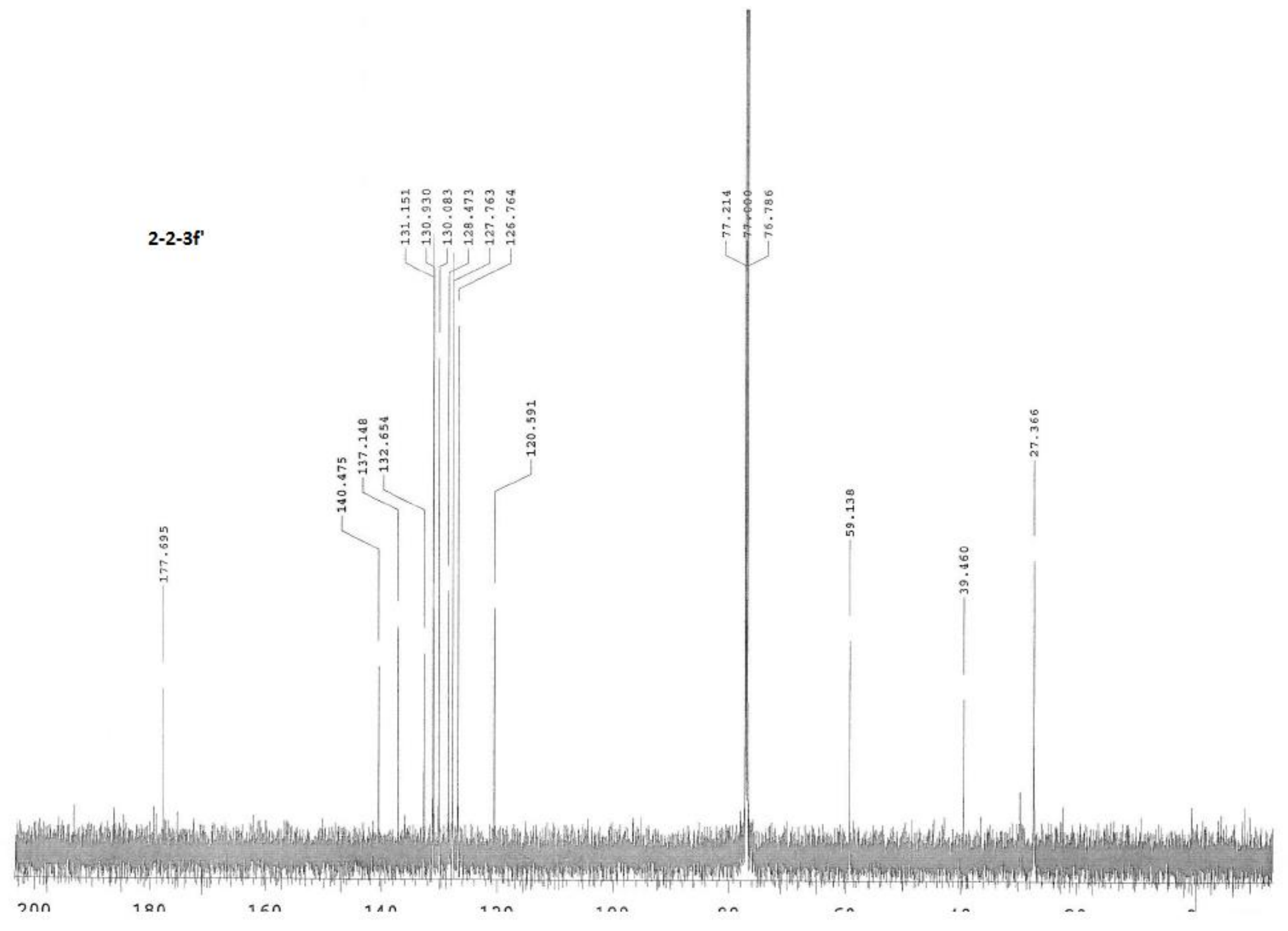




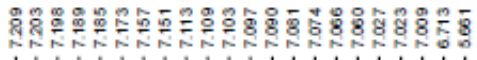

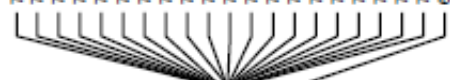

$\left.\right|^{\frac{1}{2}}$

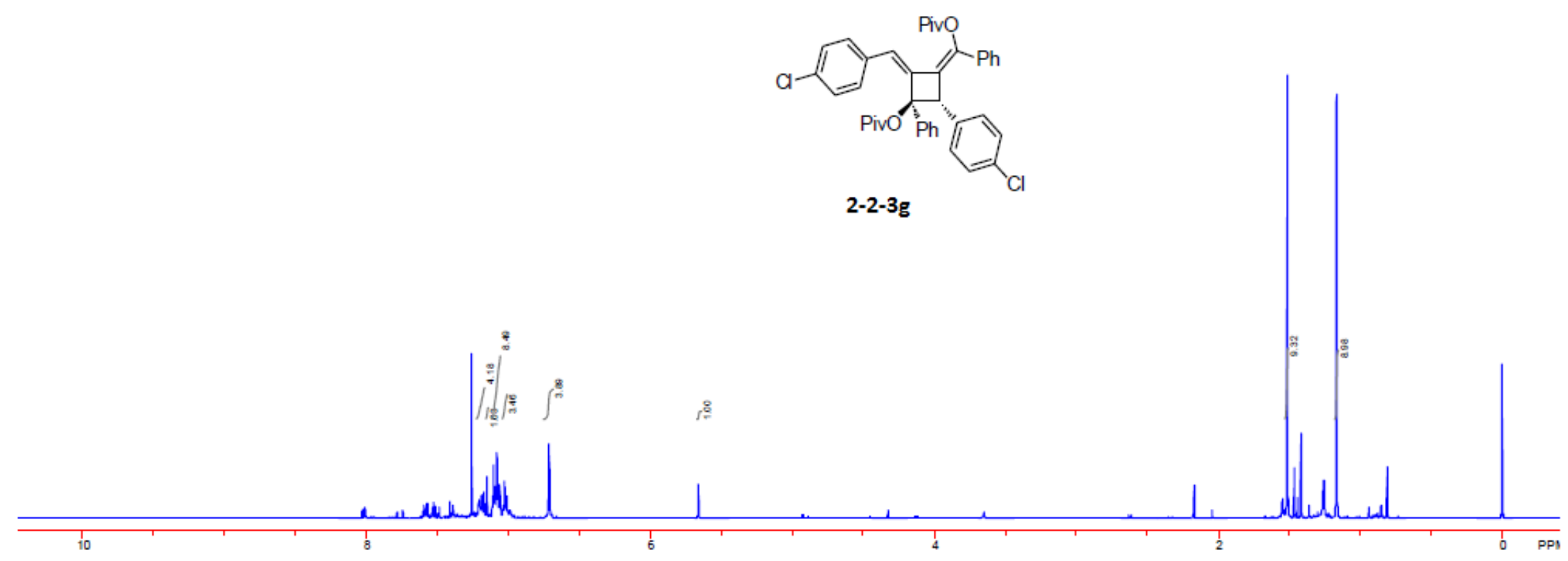




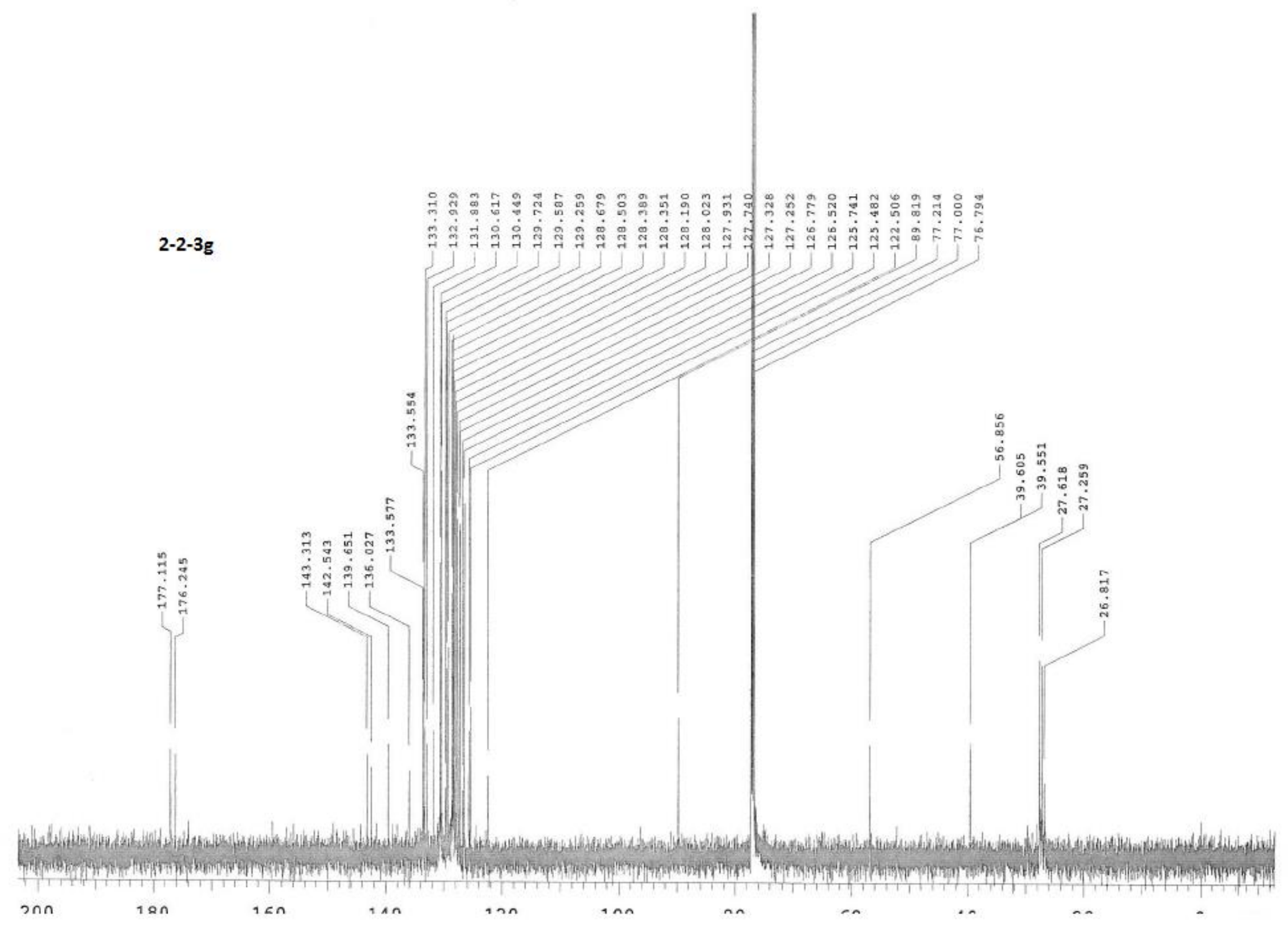




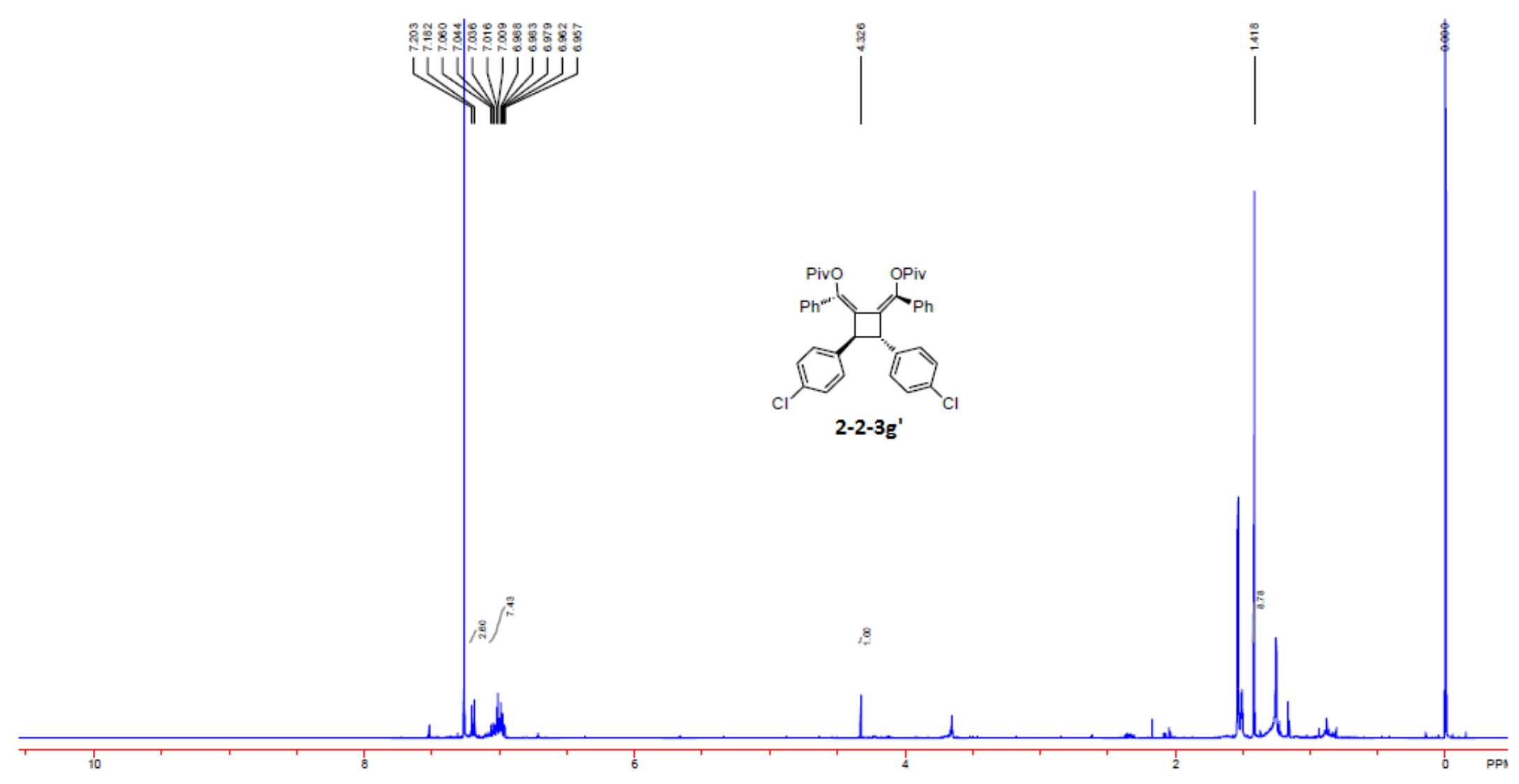




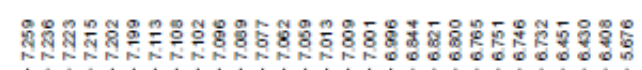

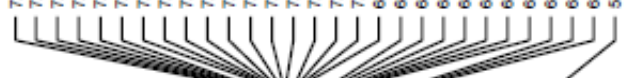

$\left.\right|^{\frac{5}{3}} \stackrel{5}{\frac{5}{8}}$

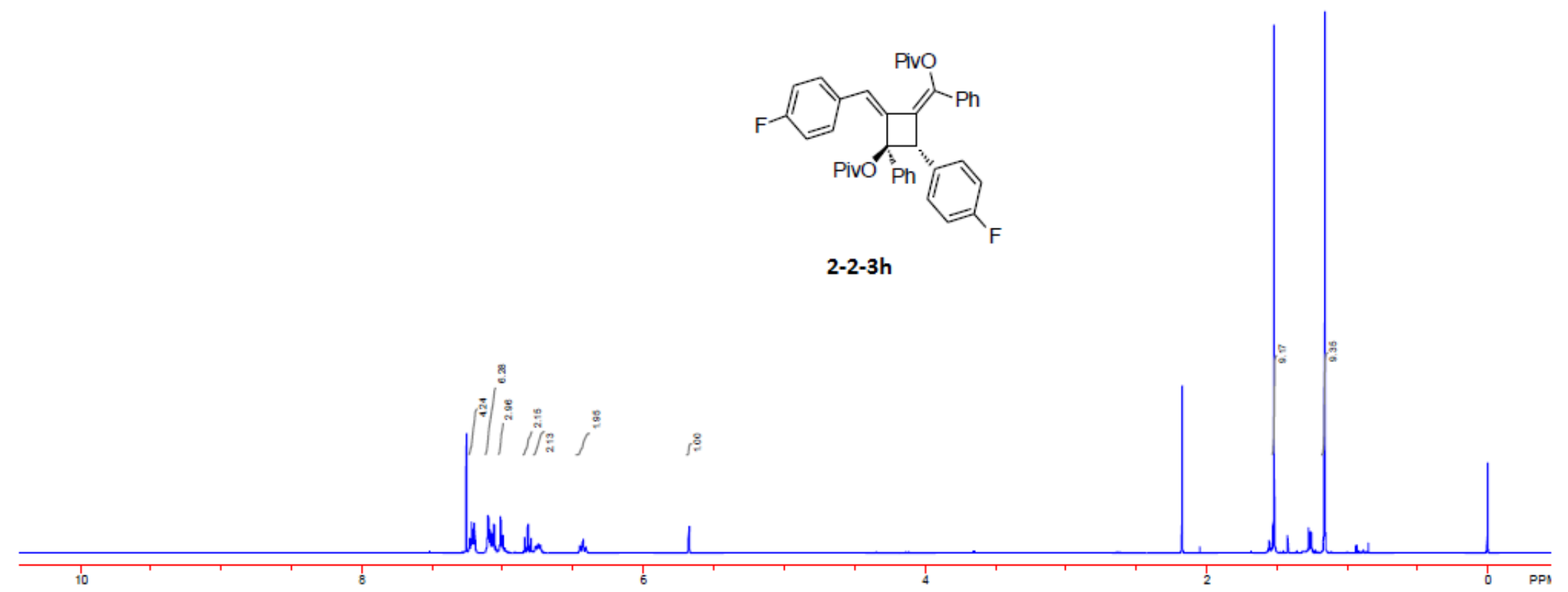




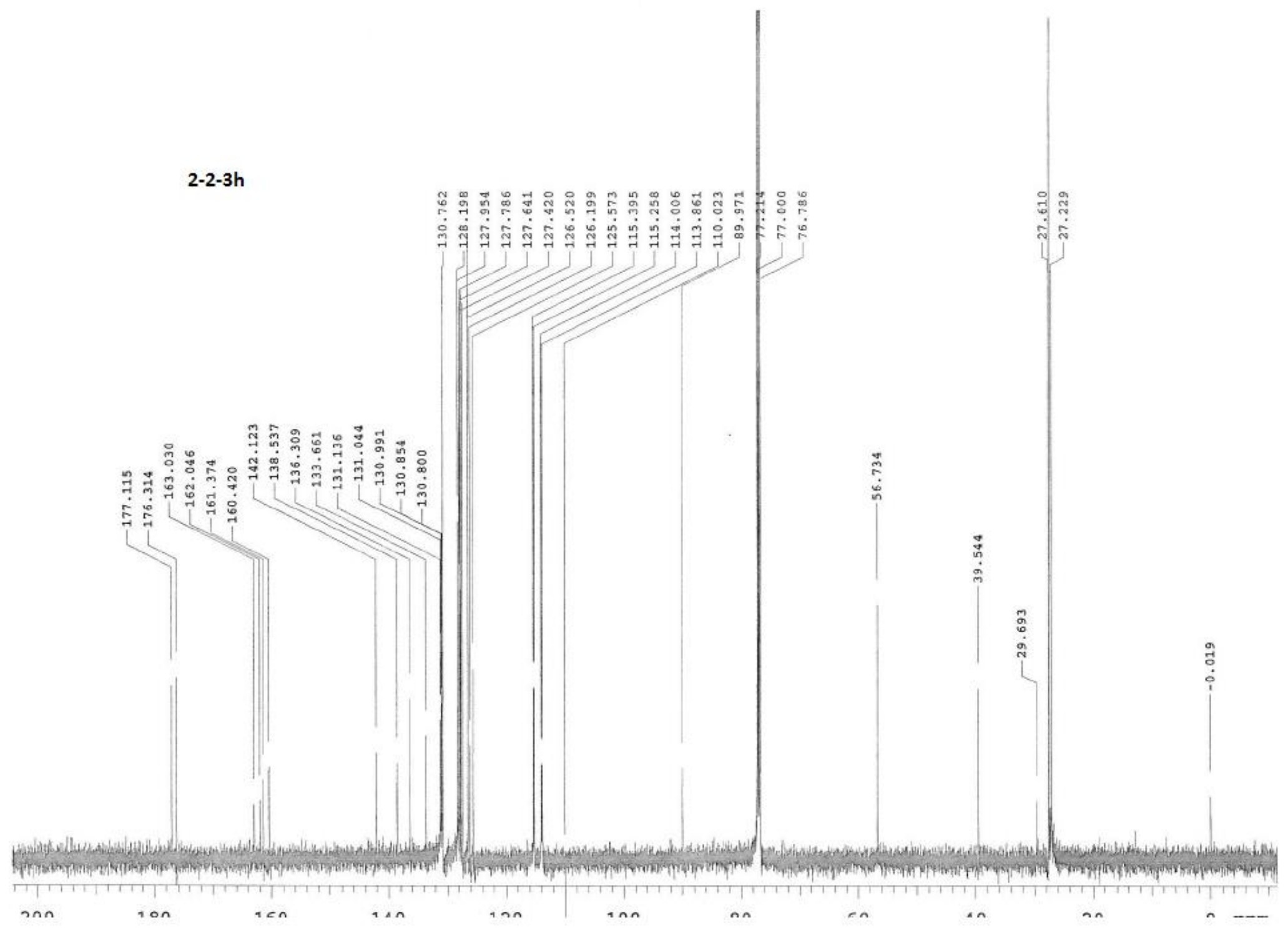




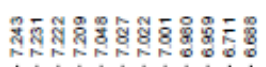

UWW
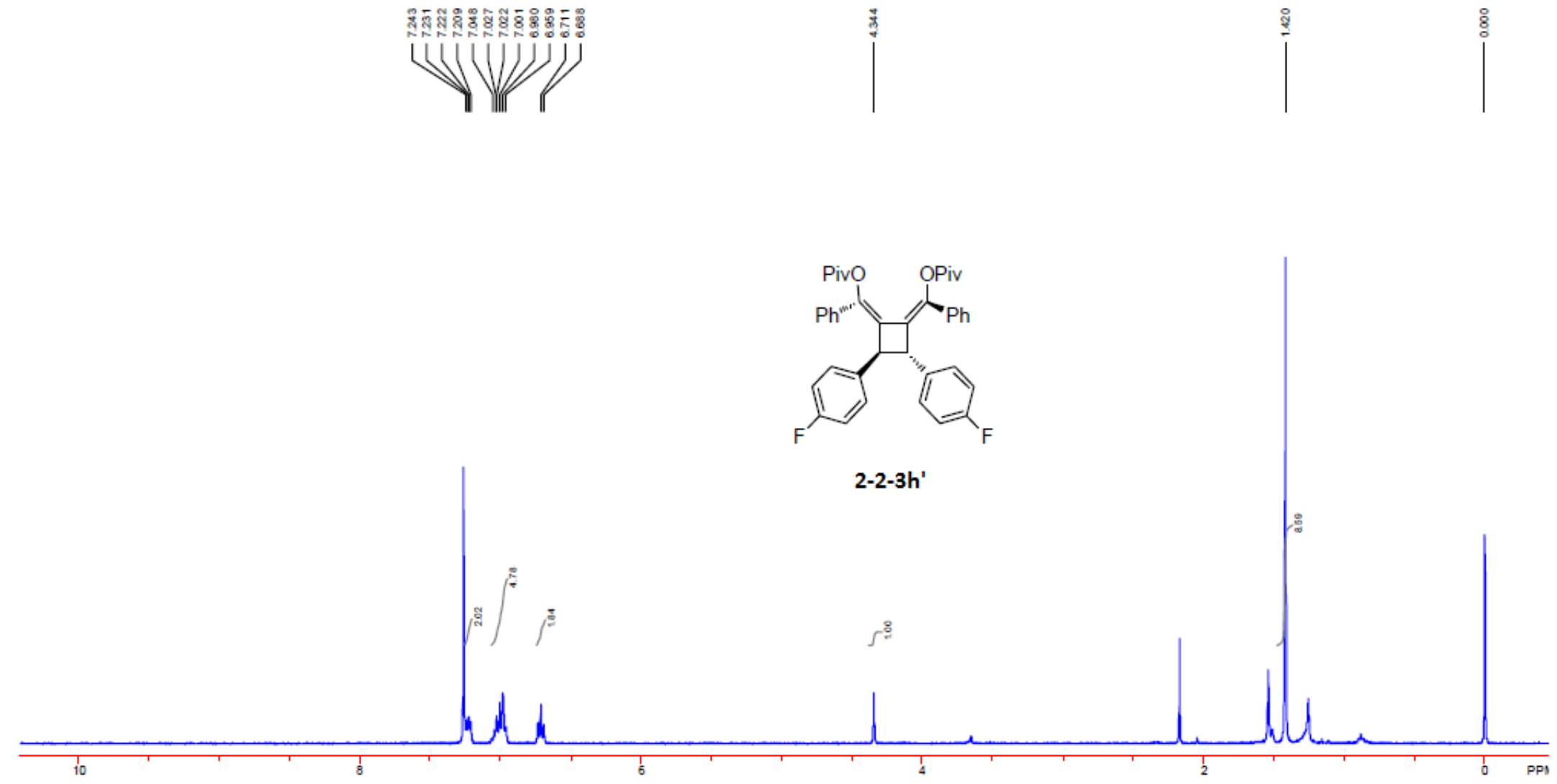


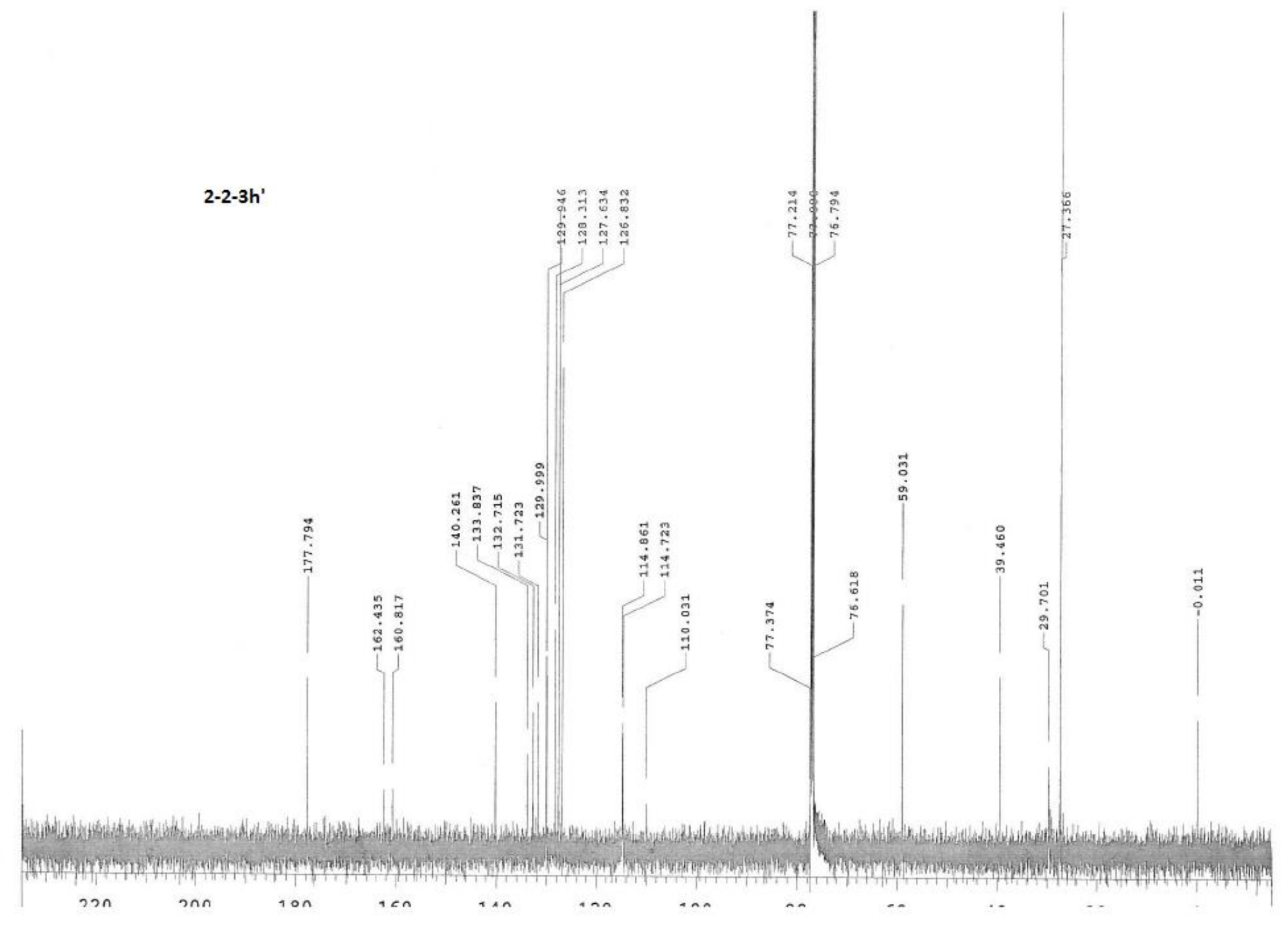



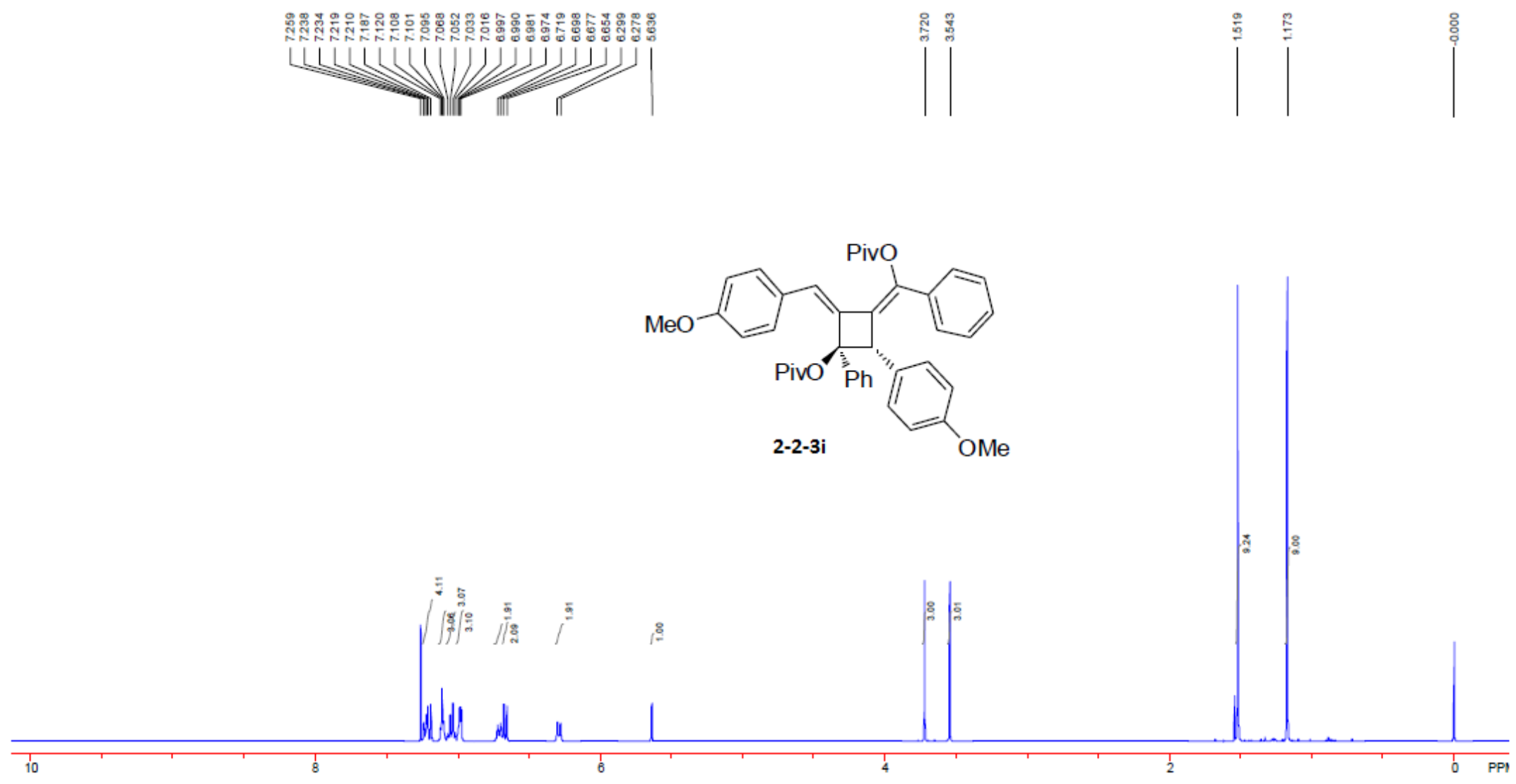

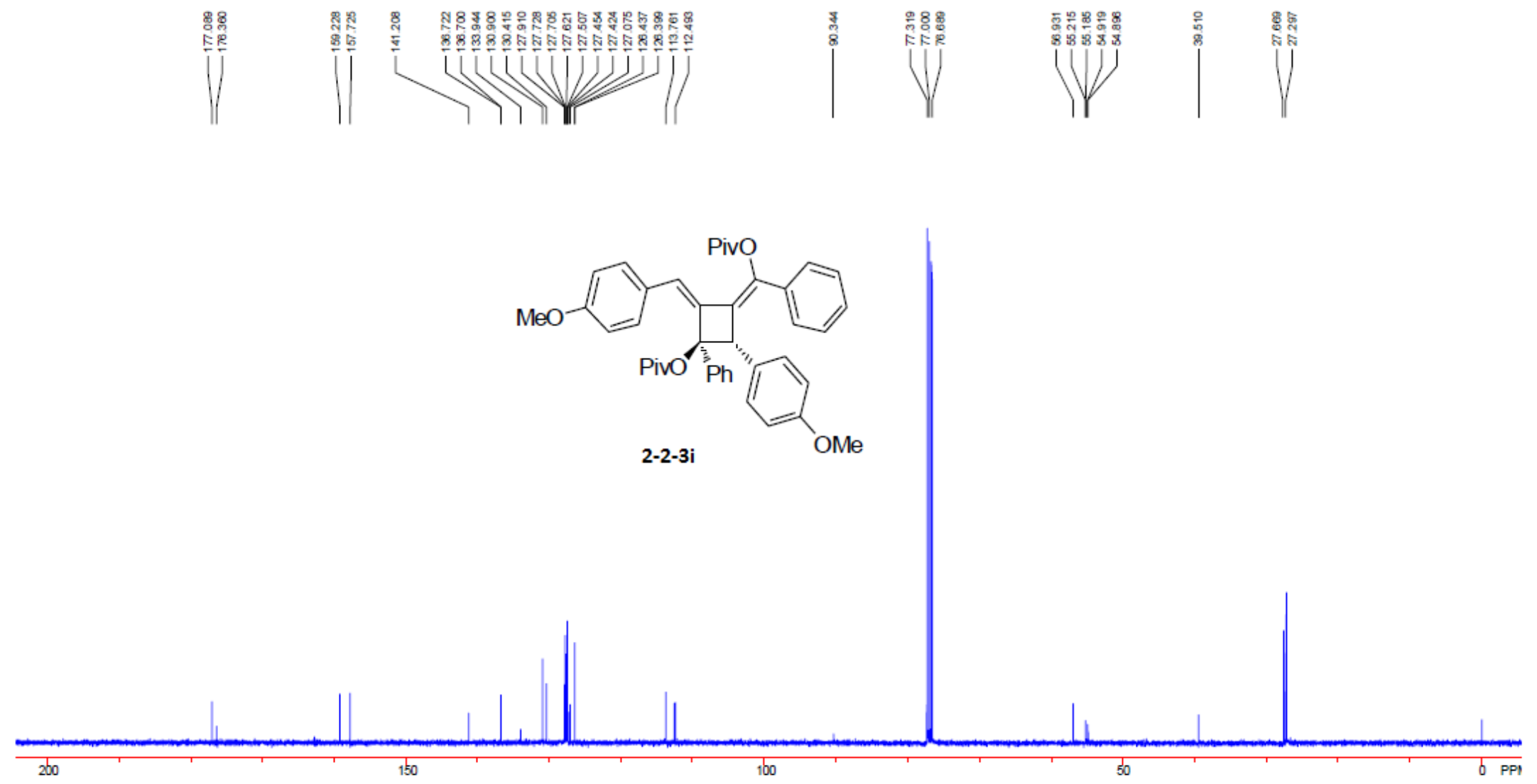


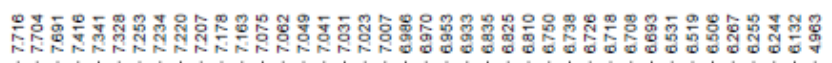

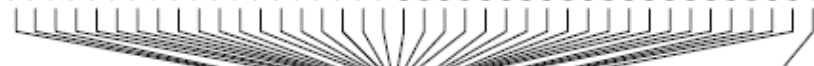
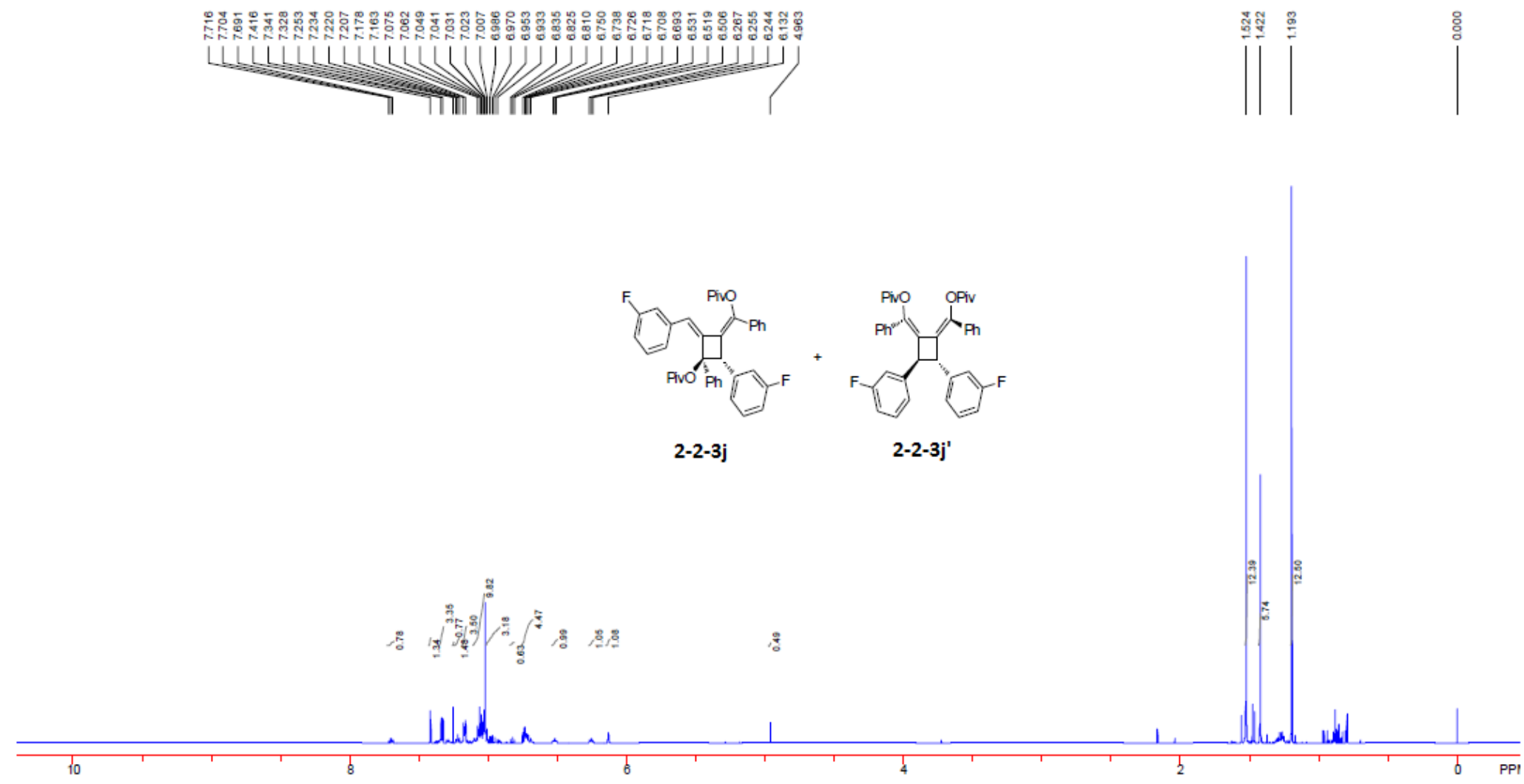


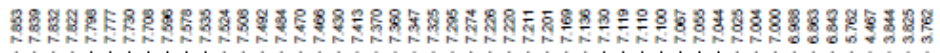
LLULCaL - 11 Tा
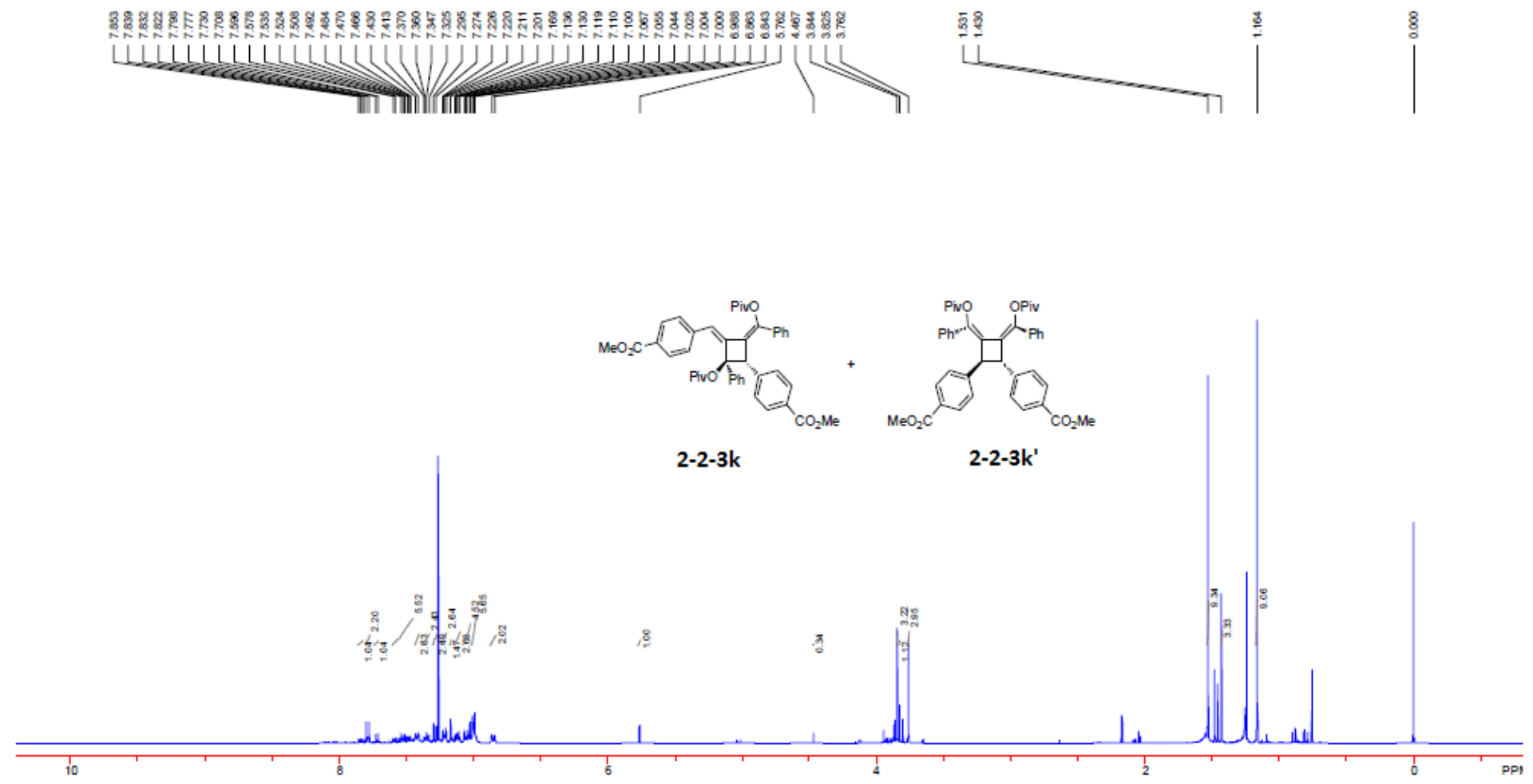


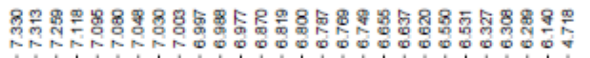

UMULUU|UJjJjJjJjJj

( $)$
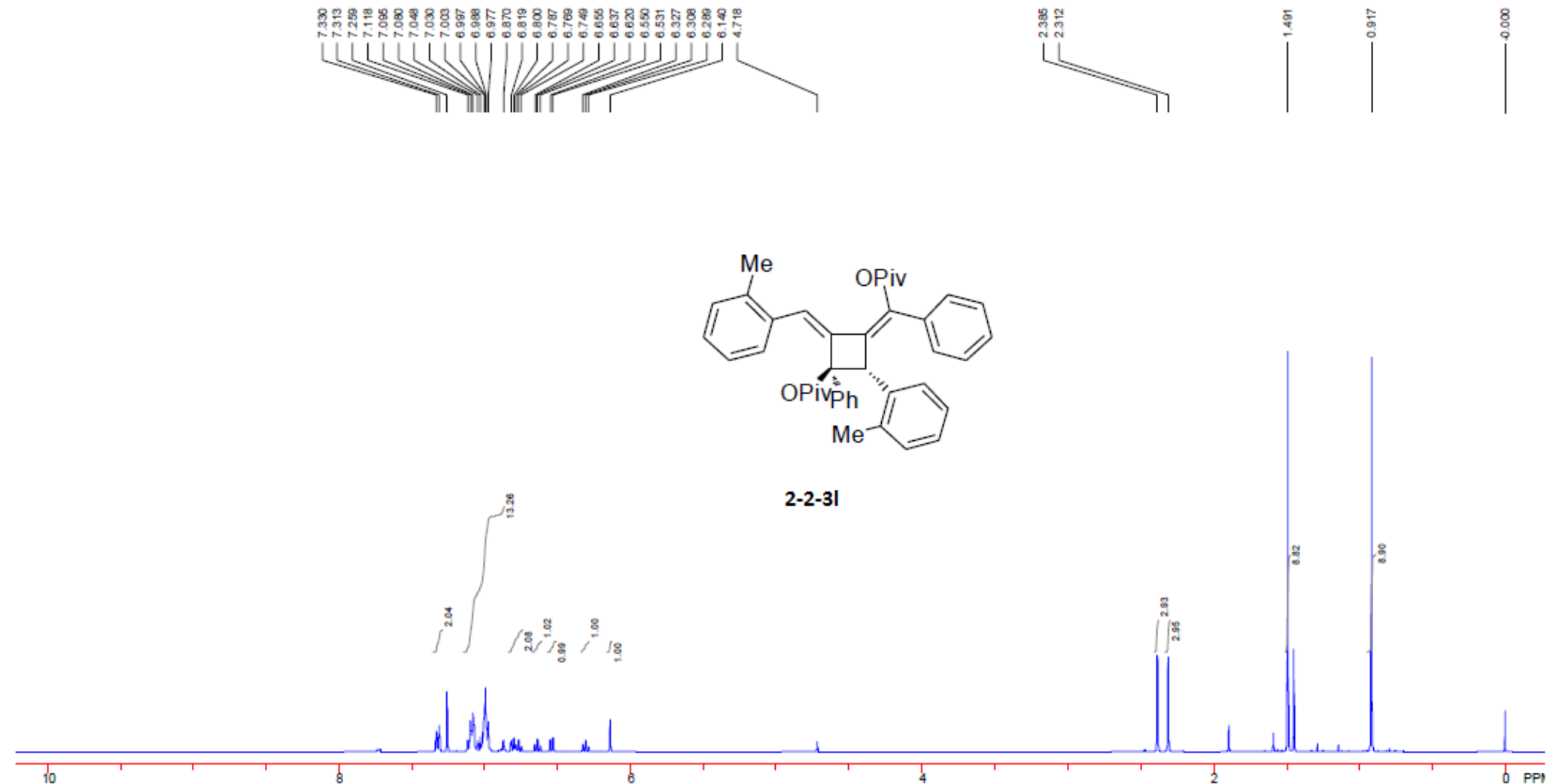

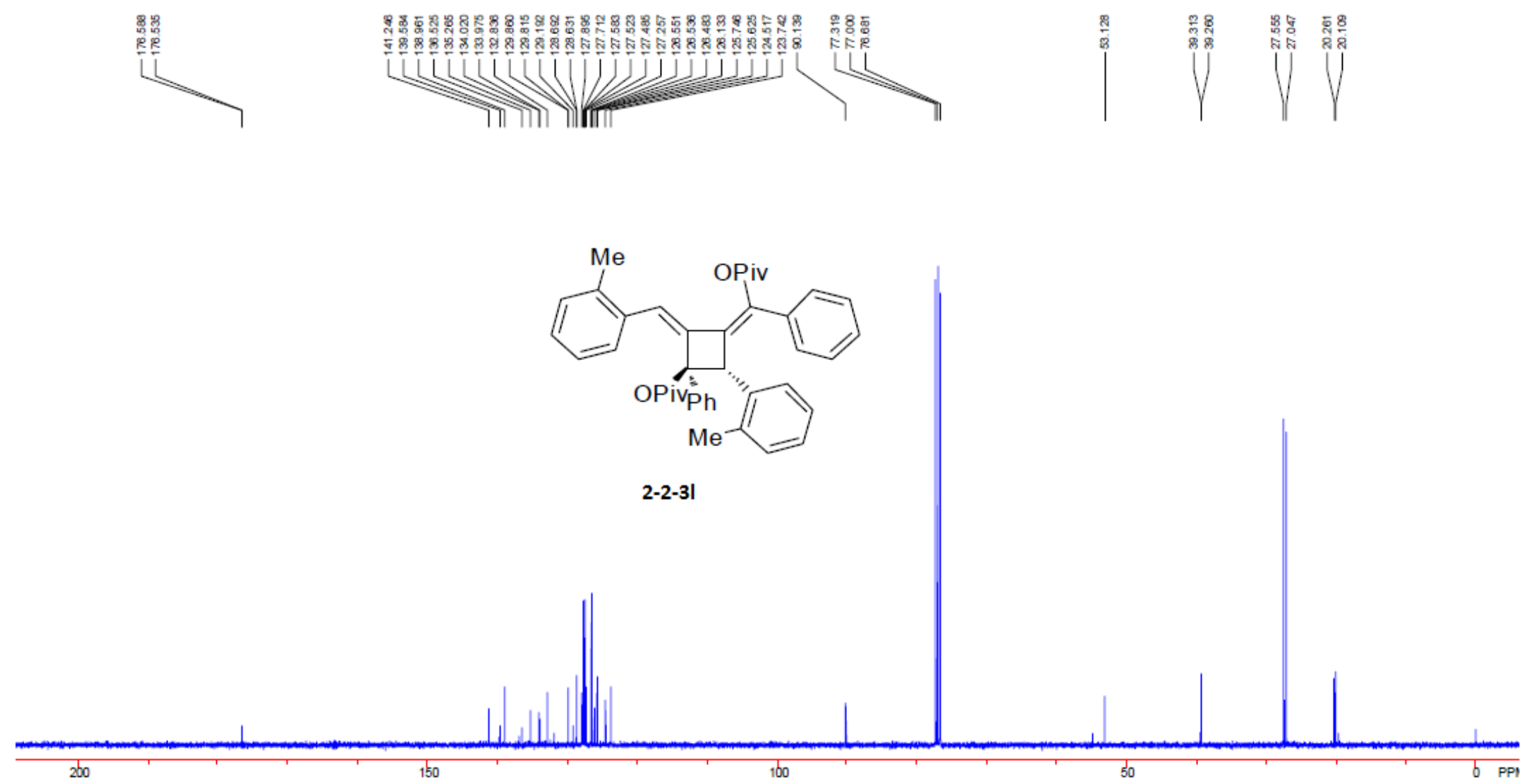


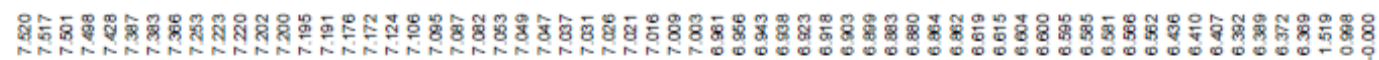

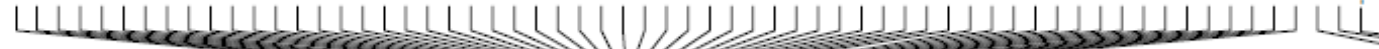

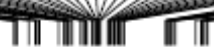

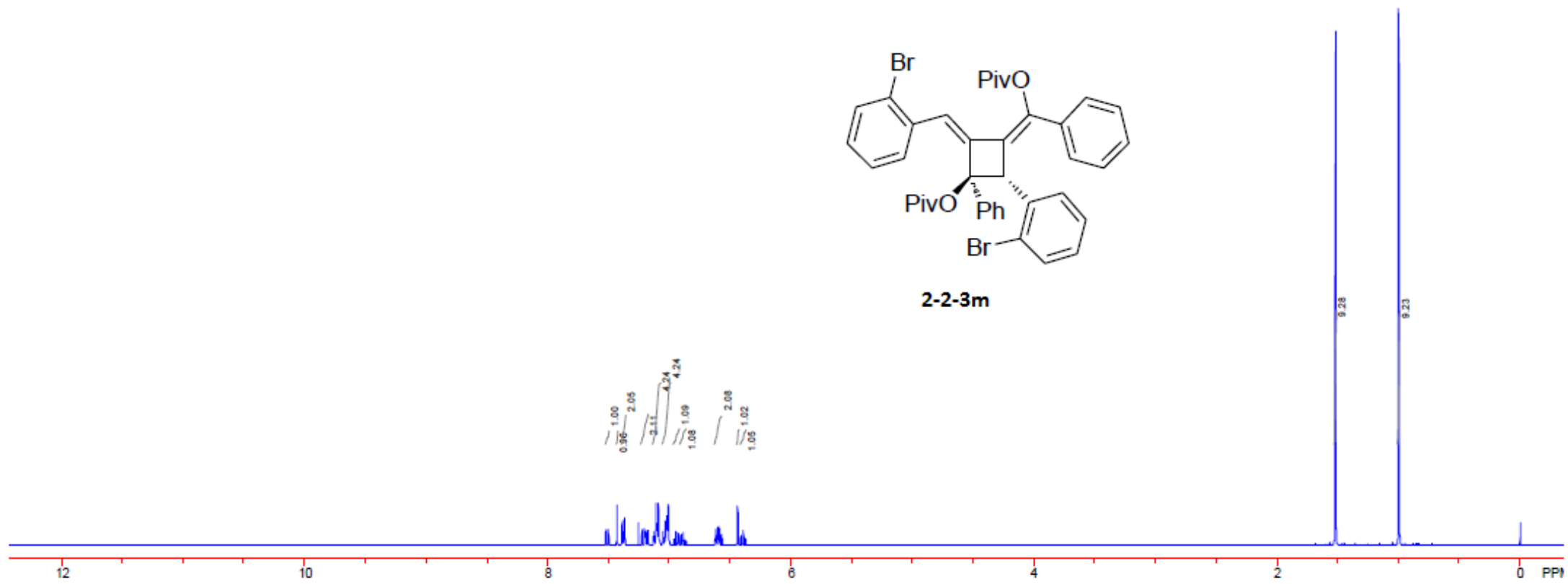



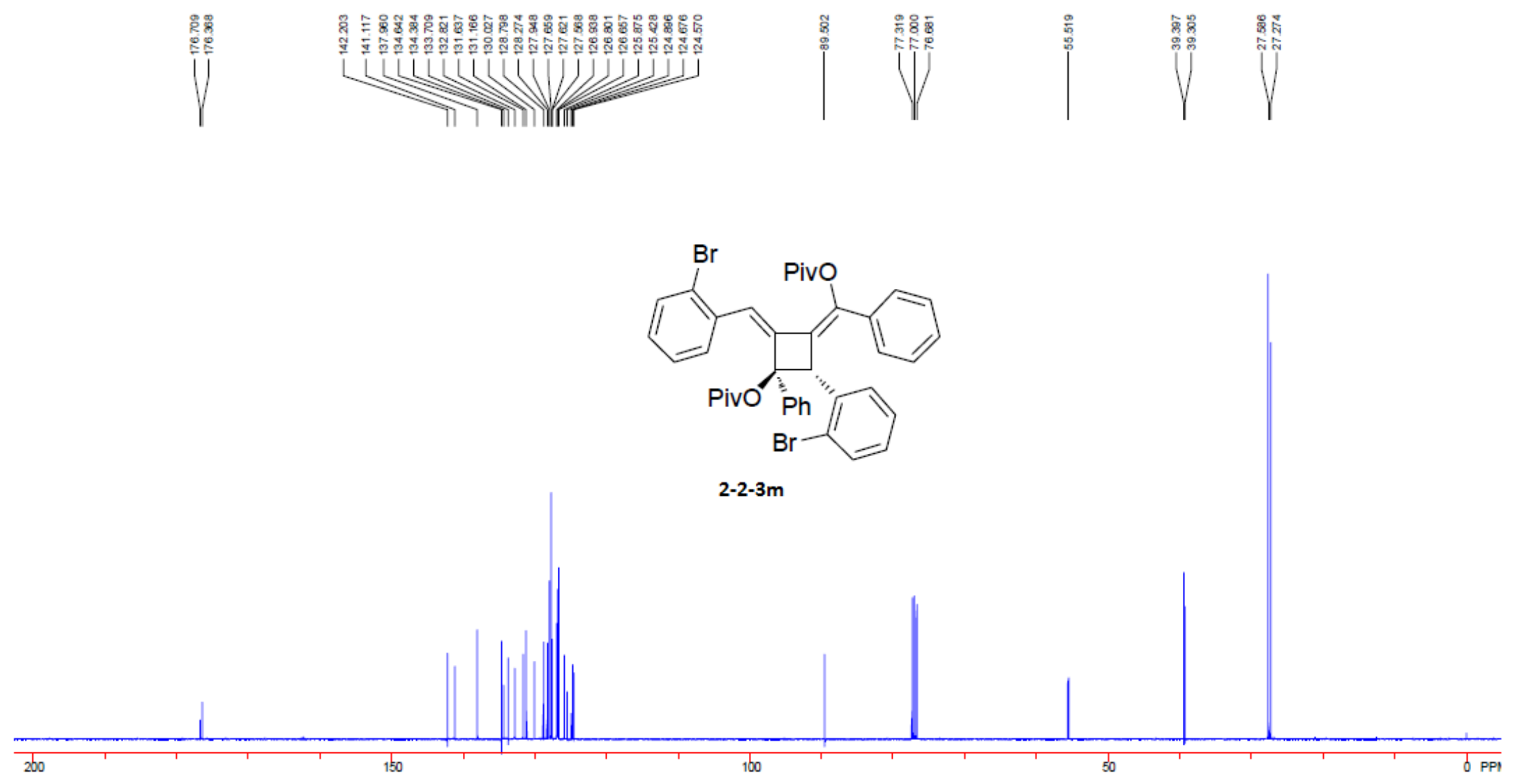


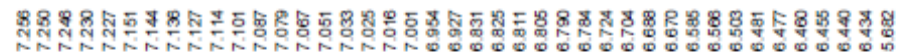

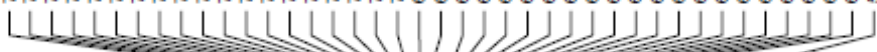
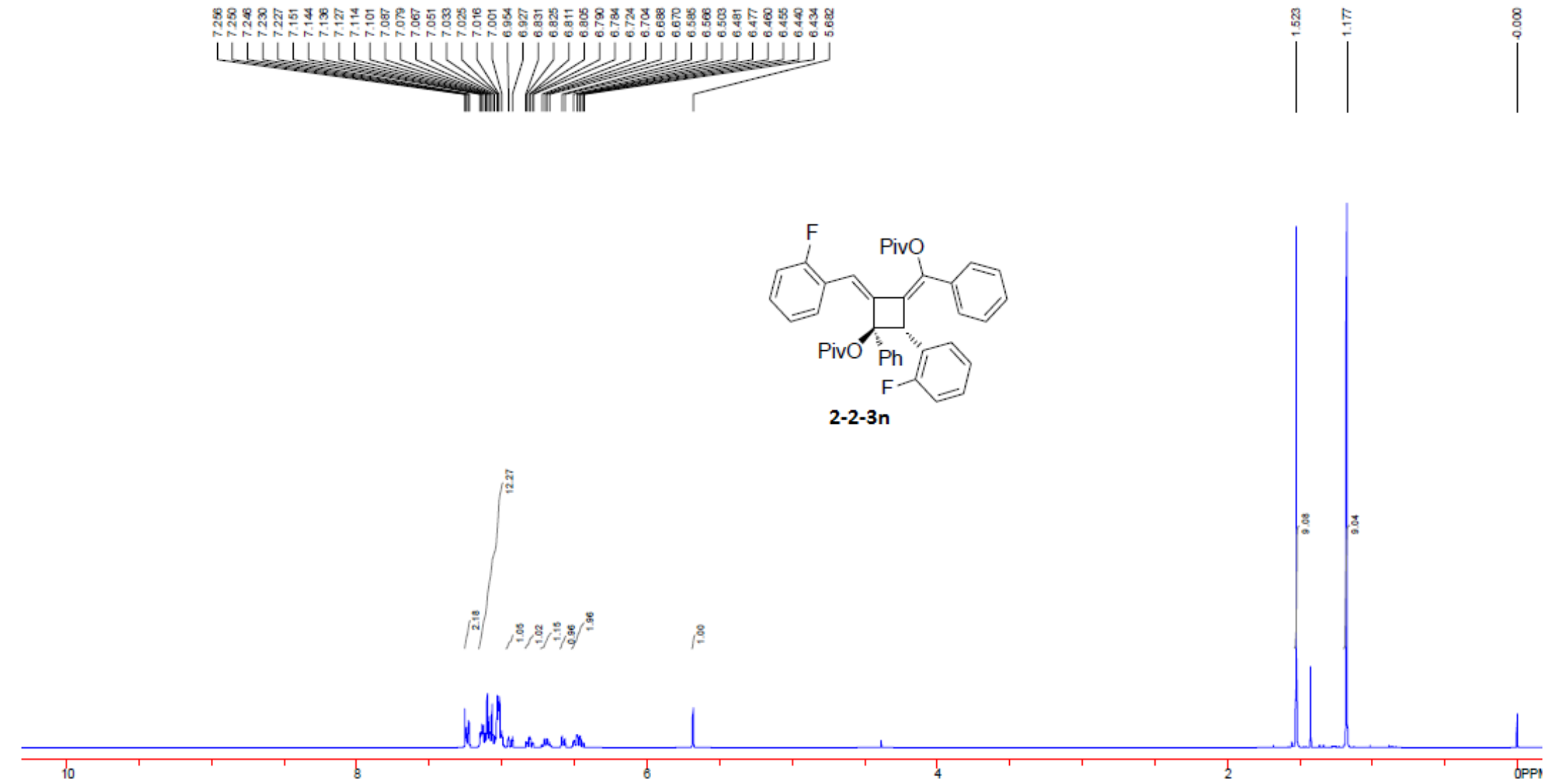

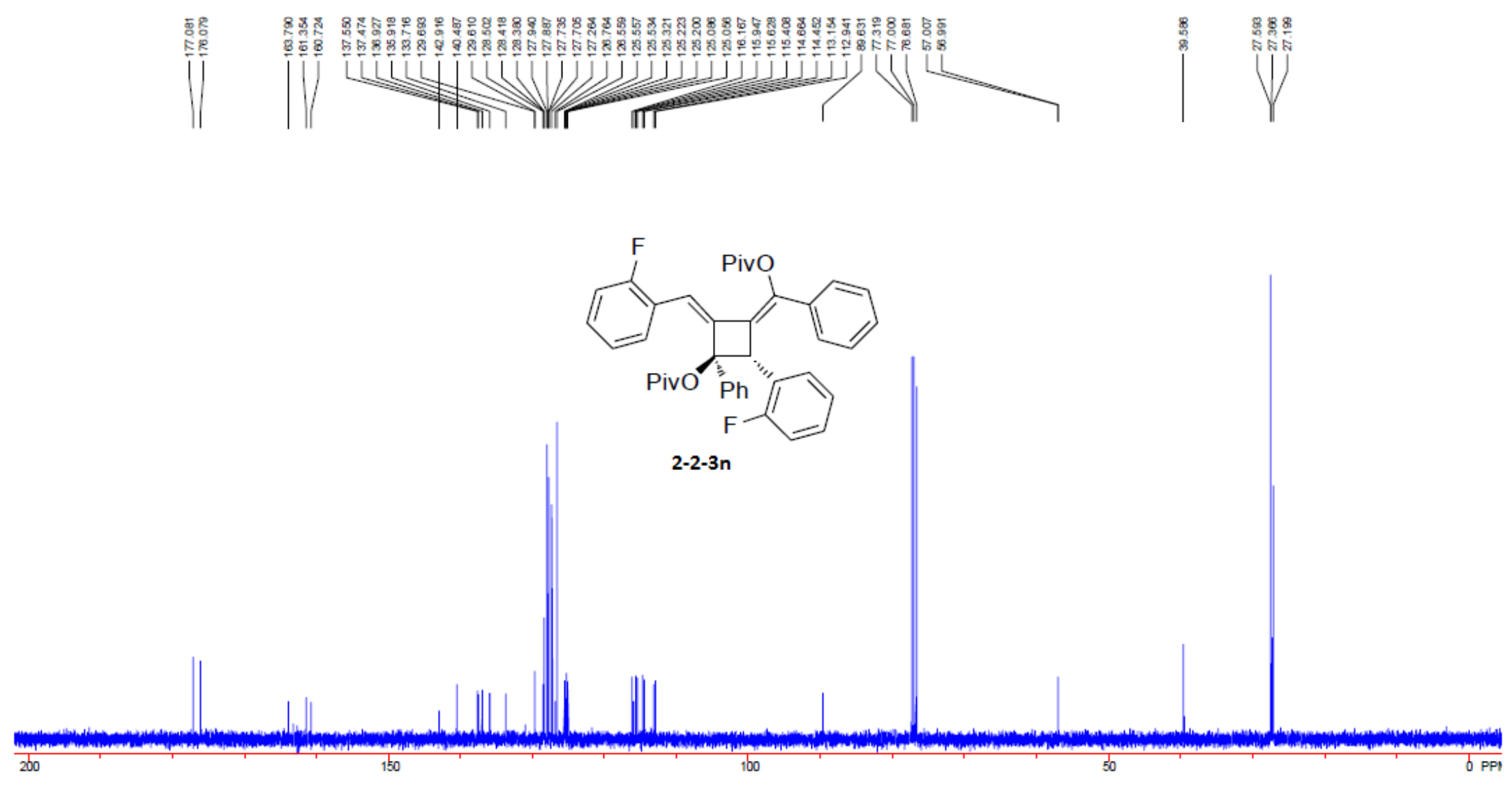


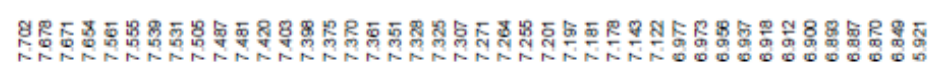

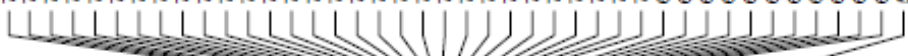

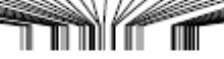
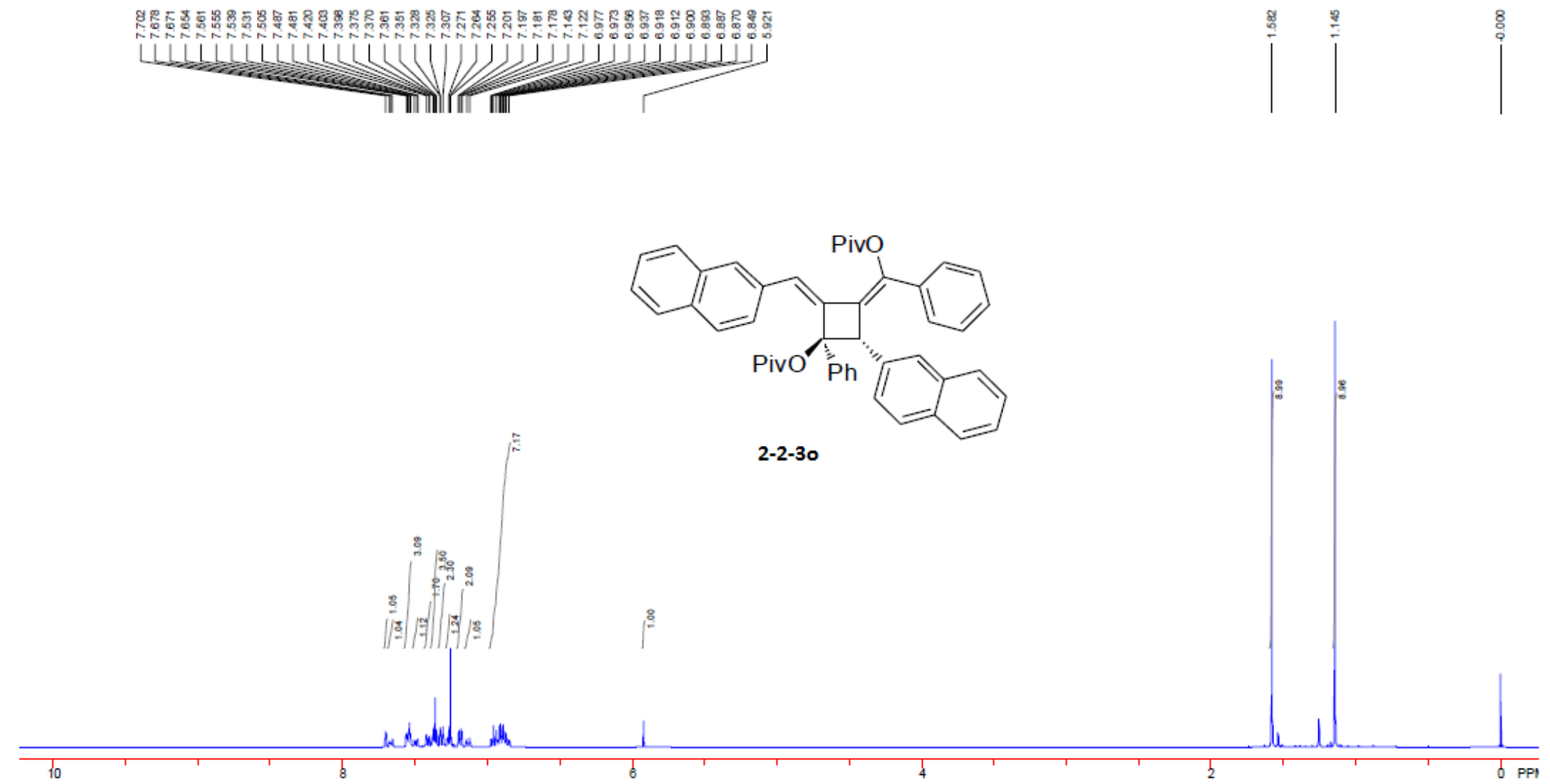

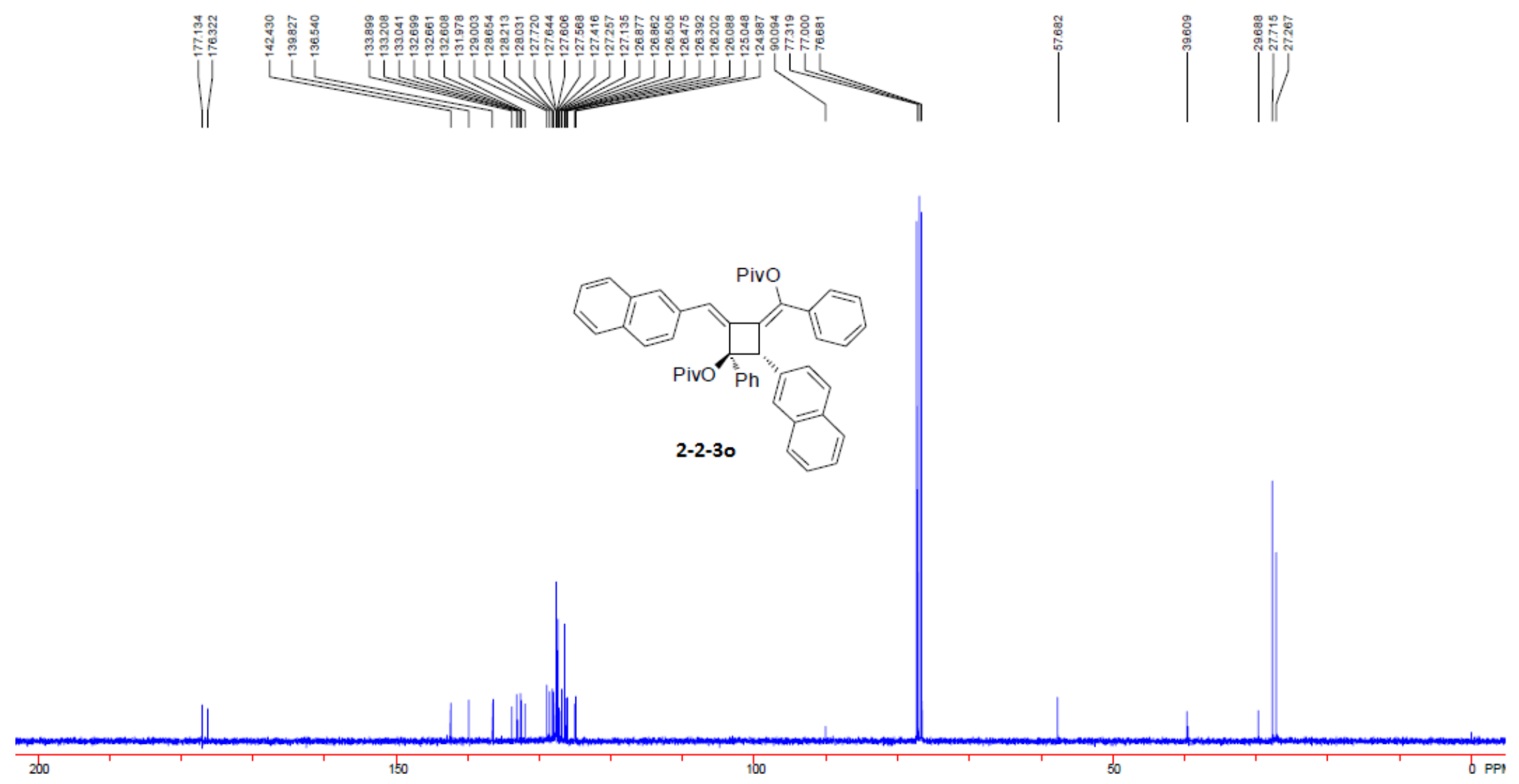

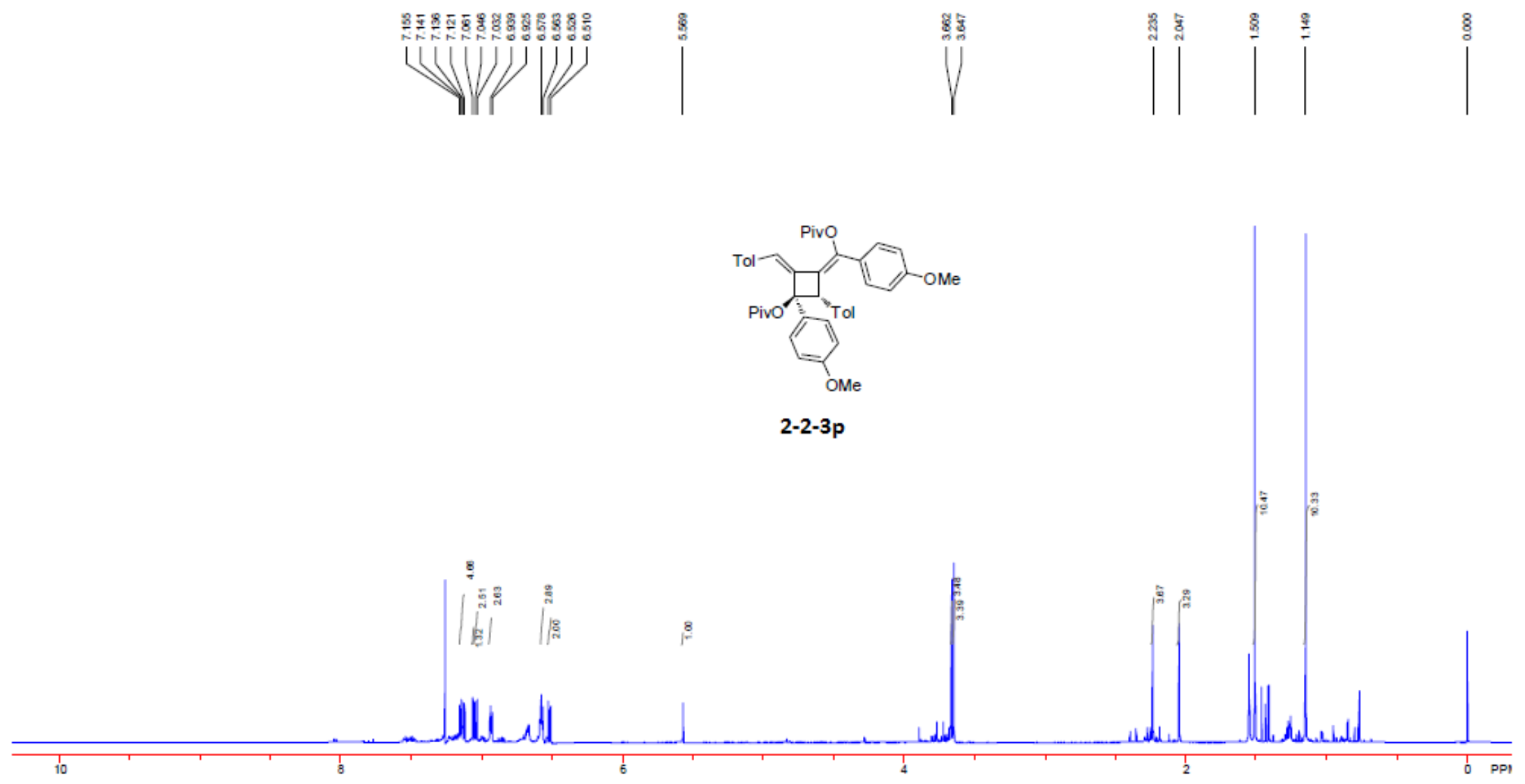


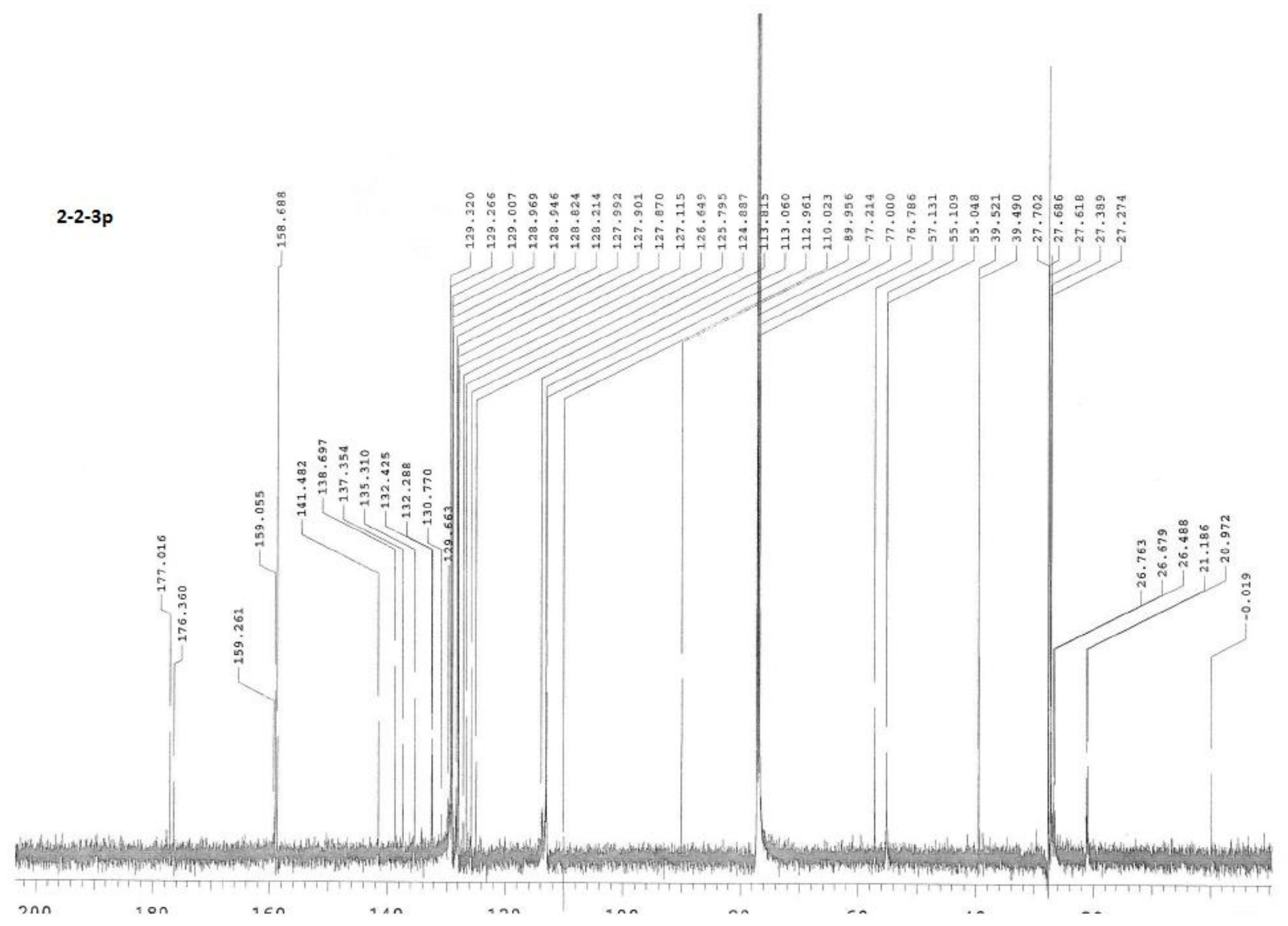


Chapter Three: Synthesis and characterization of bis-N-2-aryl triazole as efficient

fluorescence probe

\section{General methods and materials and compounds characterization:}

All of the reactions dealing with air and/or moisture-sensitive reactions were carried out under an atmosphere of nitrogen using oven dried glassware and standard syringe/septa techniques. Unless otherwise noted, all commercial reagents and solvents were obtained from the commercial provider and used without further purification. Chemical shifts were reported relative to internal tetramethylsilane $(\delta 0.00$ ppm) or $\mathrm{CDCl}_{3}(\delta 7.26 \mathrm{ppm})$ for ${ }^{1} \mathrm{H}$ NMR and $\mathrm{CDCl}_{3}(\delta 77.0 \mathrm{ppm})$ or $d 6-\mathrm{DMSO}(\delta 39.5$ ppm) for ${ }^{13} \mathrm{C}$ NMR.

Representative procedure for the preparation of 2-(anthracen-9-yl)-4-phenyl2H-1,2,3-triazole (3-1e) (Condition A) To a solution of 9-bromoanthracene (514 mg, $2.0 \mathrm{mmol}, 1.0$ eq.) in dry DMSO $(4 \mathrm{ml}, 0.5 \mathrm{M})$, were added successively 4-Phenyl-1,2,3$\mathrm{NH}$-triazole (725 mg, $5.0 \mathrm{mmol}, 2.5 \mathrm{eq}$.) and Cul (76 mg, 20\%), L-Proline (92 mg, 40\%), and $\mathrm{K}_{2} \mathrm{CO}_{3}\left(1.1 \mathrm{~g}, 8.0 \mathrm{mmol}, 4.0\right.$ eq.) under $\mathrm{N}_{2}$ atmosphere. The mixture was stirred at $120^{\circ} \mathrm{C}$ and monitored by TLC. After the reaction is completed, the reaction was quenched with brine and extracted with ethyl acetate for three times. Organic phases were combined and the solvent was removed under vacuum. The residue was purified by flash silica gel chromatography (Hexane - EtOAc v/v 20:1), giving desired product as yellow solid (yield: $340 \mathrm{mg}, 53 \%) .{ }^{1} \mathrm{H}$ NMR $\left(400 \mathrm{MHz} ; \mathrm{CDCl}_{3}\right)$ : $\delta 8.66(\mathrm{~s}, 1 \mathrm{H}), 8.37$ (s, $1 \mathrm{H}$ ), 8.32 (dd, $J=5.8,3.3 \mathrm{~Hz}, 1 \mathrm{H}$ ), 8.09 (dd, $J=7.1,1.9 \mathrm{~Hz}, 2 \mathrm{H}), 8.00-7.98(\mathrm{~m}, 2 \mathrm{H})$, $7.79(\mathrm{dd}, J=5.8,3.3 \mathrm{~Hz}, 1 \mathrm{H}), 7.51-7.44(\mathrm{~m}, 7 \mathrm{H}) ;{ }^{13} \mathrm{C}$ NMR $\left(100 \mathrm{MHz} ; \mathrm{CDCl}_{3}\right): \delta$ 148.94, $134.1,132.5,131.3,129.5,129.00,128.85,128.70,128.2,127.6,127.2,126.2,125.7$, 122.6; HRMS Calculated for $\mathrm{C}_{22} \mathrm{H}_{15} \mathrm{~N}_{3}[\mathrm{M}+\mathrm{H}]^{+}: 322.1338$, Found: 322.1342 .

Representative procedure for the preparation of 1-(anthracen-9-yl)-4-phenyl1H-1,2,3-triazole (3-1f) (Condition A) To a solution of 9-bromoanthracene (514 mg, 2.0 $\mathrm{mmol}, 1.0$ eq.) in dry DMSO (4 ml, $0.5 \mathrm{M})$, were added successively 4-Phenyl-1,2,3-NHtriazole (725 mg, $5.0 \mathrm{mmol}, 2.5$ eq.) and Cul (76 mg, 20\%), L-Proline (92 mg, 40\%), and $\mathrm{K}_{2} \mathrm{CO}_{3}\left(1.1 \mathrm{~g}, 8.0 \mathrm{mmol}, 4.0\right.$ eq.) under $\mathrm{N}_{2}$ atmosphere. The mixture was stirred at 120 ${ }^{\circ} \mathrm{C}$ and monitored by TLC. After the reaction is completed, the reaction was quenched with brine and extracted with ethyl acetate for three times. Organic phases were combined and the solvent was removed under vacuum. The residue was purified by flash silica gel chromatography (Hexane - EtOAc v/v 15:1), giving desired product as light yellow solid (yield: $237 \mathrm{mg}, 37 \%) .{ }^{1} \mathrm{H}$ NMR $\left(400 \mathrm{MHz} ; \mathrm{CDCl}_{3}\right): \delta 8.69(\mathrm{~s}, 1 \mathrm{H}), 8.20$ (s, $1 \mathrm{H}), 8.11(\mathrm{~d}, J=7.6 \mathrm{~Hz}, 2 \mathrm{H}), 8.03(\mathrm{~d}, J=8.4 \mathrm{~Hz}, 2 \mathrm{H}), 7.55-7.51(\mathrm{~m}, 5 \mathrm{H}), 7.43-7.40$ $(\mathrm{m}, 2 \mathrm{H}) ;{ }^{13} \mathrm{C}$ NMR $\left(100 \mathrm{MHz} ; \mathrm{CDCl}_{3}\right): \delta 147.8,131.2,130.3,129.8,129.0,128.46$, 
128.35, 128.0, 127.4, 126.7, 125.97, 125.89, 124.0, 122.1; HRMS Calculated for $\mathrm{C}_{22} \mathrm{H}_{15} \mathrm{~N}_{3}[\mathrm{M}+\mathrm{H}]^{+}:$322.1338, Found: 322.1342 .

Representative procedure for the preparation of 1,8-bis(4-phenyl-2H-1,2,3triazol-2-yl)naphthalene (3-3c) (Condition A) To a solution of 1,8-diiodonaphthalene (760 mg, $2.0 \mathrm{mmol}, 1.0$ eq.) in dry DMSO $(4 \mathrm{ml}, 0.5 \mathrm{M})$, were added successively 4Phenyl-1,2,3-NH-triazole (725 mg, $5.0 \mathrm{mmol}, 2.5 \mathrm{eq}$.) and Cul (76 mg, 20\%), L-Proline (92 $\mathrm{mg}, 40 \%$ ), and $\mathrm{K}_{2} \mathrm{CO}_{3}\left(1.1 \mathrm{~g}, 8.0 \mathrm{mmol}, 4.0\right.$ eq.) under $\mathrm{N}_{2}$ atmosphere. The mixture was stirred at $120^{\circ} \mathrm{C}$ and monitored by TLC. After the reaction is completed, the reaction was quenched with brine and extracted with ethyl acetate for three times. Organic phases were combined and the solvent was removed under vacuum. The residue was purified by flash silica gel chromatography (Hexane - EtOAc v/v 5:1), giving desired product as light yellow solid (yield: $472 \mathrm{mg}, 57 \%)$. ${ }^{1} \mathrm{H} \mathrm{NMR}\left(400 \mathrm{MHz} ; \mathrm{CDCl}_{3}\right)$ : $\delta$ 8.12 (dd, $J=8.4,1.2 \mathrm{~Hz}, 2 \mathrm{H}$ ), 7.96 (dd, $J=7.4,1.2 \mathrm{~Hz}, 2 \mathrm{H}), 7.71$ (dd, $J=8.2,7.4 \mathrm{~Hz}$, 2H), 7.48-7.51 (m, 4H), 7.28-7.22 (m, 6H); $\left.{ }^{13} \mathrm{C} \mathrm{NMR} \mathrm{(100} \mathrm{MHz;} \mathrm{CDCl}_{3}\right): \delta$ 148.3, 136.1, 135.6, 131.7, 130.2, 129.4, 128.5, 128.3, 127.0, 125.9, 121.1; HRMS Calculated for $\mathrm{C}_{26} \mathrm{H}_{18} \mathrm{~N}_{6}[\mathrm{M}+\mathrm{H}]^{+}:$415.1666, Found: 415,1672.

Representative procedure for the preparation of 2-(8-iodonaphthalen-1-yl)-4phenyl-2H-1,2,3-triazole (3-4a) (Condition $\mathbf{B}$ ) To a solution of 1,8-diiodonaphthalene (760 mg, $2.0 \mathrm{mmol}, 1.0$ eq.) in dry DMSO $(4 \mathrm{ml}, 0.5 \mathrm{M})$, were added successively 4Phenyl-1,2,3-NH-triazole (290 mg, $2.0 \mathrm{mmol}, 1.0$ eq.) and Cul (38 mg, 10\%), L-Proline (46 mg, 20\%), $\mathrm{K}_{2} \mathrm{CO}_{3}$ (552 mg, $4.0 \mathrm{mmol}, 2.0$ eq.) under $\mathrm{N}_{2}$ atmosphere. The mixture was stirred at $80{ }^{\circ} \mathrm{C}$ and monitored by TLC. After the reaction is completed, the reaction was quenched with brine and extracted with ethyl acetate for three times. Organic phases were combined and the solvent was removed under vacuum. The residue was purified by flash silica gel chromatography (Hexane - EtOAc v/v 10:1), giving desired product as light yellow solid (yield: $401 \mathrm{mg}, 51 \%)$. ${ }^{1} \mathrm{H}$ NMR $\left(400 \mathrm{MHz} ; \mathrm{CDCl}_{3}\right): \delta 8.29$ (dd, $J=7.4,1.2 \mathrm{~Hz}, 1 \mathrm{H}$ ), $8.21(\mathrm{~s}, 1 \mathrm{H}), 8.04(\mathrm{dd}, J=8.3,1.3 \mathrm{~Hz}, 1 \mathrm{H}), 7.97$ (dd, $J=8.3$, $1.1 \mathrm{~Hz}, 1 \mathrm{H}), 7.94-7.91(\mathrm{~m}, 2 \mathrm{H}), 7.68(\mathrm{dd}, J=7.2,1.6 \mathrm{~Hz}, 1 \mathrm{H}), 7.59(\mathrm{dd}, J=8.1,7.3 \mathrm{~Hz}$, $1 \mathrm{H}), 7.49-7.45(\mathrm{~m}, 2 \mathrm{H}), 7.42-7.38(\mathrm{~m}, 1 \mathrm{H}), 7.19(\mathrm{dd}, J=8.1,7.4 \mathrm{~Hz}, 1 \mathrm{H}) ;{ }^{13} \mathrm{C}$ NMR $(100$ $\left.\mathrm{MHz} ; \mathrm{CDCl}_{3}\right): \delta 149.1,143.0,137.2,135.8,132.6,132.0,130.1,129.5,129.1,128.92$, 128.75, 128.73, 127.4, 126.2, 125.2, 86.5; HRMS Calculated for $\mathrm{C}_{18} \mathrm{H}_{22} \mathrm{~N}_{3} \mathrm{l}[\mathrm{M}+\mathrm{H}]^{+}$: 398.0149, Found: 398.0155.

Representative procedure for the preparation of 1,8-bis(4-phenyl-1H-1,2,3triazol-1-yl)naphthalene (3-3a) To a solution of 1,8-diazidonaphthalene (420 mg, 2.0 $\mathrm{mmol}, 1.0$ eq.) in $1: 1 \quad t-\mathrm{BuOH} / \mathrm{H}_{2} \mathrm{O}(5 \mathrm{ml}, 0.4 \mathrm{M})$, were added successively phenylacetylene (1.02 g, $10.0 \mathrm{mmol}, 5.0$ eq.) and $\mathrm{CuSO}_{4}(128 \mathrm{mg}, 40 \%)$, and LAscorbic acid sodium salt (237.6 mg, 60\%) under $\mathrm{N}_{2}$ atmosphere. The mixture was stirred at $80^{\circ} \mathrm{C}$ and monitored by TLC. After the reaction is completed, the reaction was quenched with brine and extracted with ethyl acetate for three times. Organic phases 
were combined and the solvent was removed under vacuum. The residue was purified by flash silica gel chromatography (Hexane - EtOAc v/v 5:1), giving desired product as light yellow solid (yield: $712 \mathrm{mg}, 86 \%$ ). ${ }^{1} \mathrm{H}$ NMR $\left(400 \mathrm{MHz} ; \mathrm{CDCl}_{3}\right)$ : $\delta 8.25$ (dd, $J=8.3$, $1.2 \mathrm{~Hz}, 1 \mathrm{H}), 7.75(\mathrm{t}, J=7.8 \mathrm{~Hz}, 1 \mathrm{H}), 7.66(\mathrm{dd}, J=7.6,1.2 \mathrm{~Hz}, 1 \mathrm{H}), 7.56(\mathrm{~s}, 1 \mathrm{H}), 7.47-$ $7.43(\mathrm{~m}, 2 \mathrm{H}), 7.25-7.21(\mathrm{~m}, 3 \mathrm{H}) ;{ }^{13} \mathrm{C}$ NMR (100 MHz; d6-DMSO): $\delta 146.4,135.7,132.1$, 131.7, 130.5, 129.4, 128.7, 128.0, 127.0, 125.8, 124.4; HRMS Calculated for $\mathrm{C}_{26} \mathrm{H}_{18} \mathrm{~N}_{6}$ $[\mathrm{M}+\mathrm{H}]^{+}:$415.1665, Found: 415.1677.

Representative procedure for the preparation of 2,3'-(naphthalene-1,8diyl)bis(5-phenyl-2H-1,2,3-triazole) (3-3b) 2-(8-azidonaphthalen-1-yl)-4-phenyl-2 $\mathrm{H}$ $1,2,3$-triazole is prepared from 1 -azido-8-iodonaphthalene under condition $B$. Then to a solution of 2-(8-azidonaphthalen-1-yl)-4-phenyl-2H-1,2,3-triazole $(624 \mathrm{mg}, 2.0 \mathrm{mmol}$, $1.0 \mathrm{eq})$ in $1: 1 \mathrm{t}-\mathrm{BuOH} / \mathrm{H}_{2} \mathrm{O}(5 \mathrm{ml}, 0.4 \mathrm{M})$, were added successively phenylacetylene (510 $\mathrm{mg}, 5.0 \mathrm{mmol}, 2.5$ eq.) and $\mathrm{CuSO}_{4}(64 \mathrm{mg}, 20 \%)$, and L-Ascorbic acid sodium salt (118.8 mg, 30\%) under $\mathrm{N}_{2}$ atmosphere. The mixture was stirred at $120{ }^{\circ} \mathrm{C}$ and monitored by TLC. After the reaction is completed, the reaction was quenched with brine and extracted with ethyl acetate for three times. Organic phases were combined and the solvent was removed under vacuum. The residue was purified by flash silica gel chromatography (Hexane - EtOAc v/v 3:1), giving desired product as light yellow solid (yield: $605 \mathrm{mg}, 73 \%)$. ${ }^{1} \mathrm{H}$ NMR $\left(400 \mathrm{MHz} ; \mathrm{CDCl}_{3}\right.$ ): $\delta 8.17$ (dd, $\left.J=7.5,5.2 \mathrm{~Hz}, 2 \mathrm{H}\right), 7.84$ (d, $J=7.2 \mathrm{~Hz}, 1 \mathrm{H}), 7.79(\mathrm{~d}, J=7.1 \mathrm{~Hz}, 1 \mathrm{H}), 7.72(\mathrm{t}, J=7.8 \mathrm{~Hz}, 2 \mathrm{H}), 7.63(\mathrm{~s}, 1 \mathrm{H}), 7.52$ (s, 1H), 7.45 (ddd, $J=12.2,6.4,2.7 \mathrm{~Hz}, 4 \mathrm{H}$ ), 7.26-7.24 (t, $J=3.0 \mathrm{~Hz} 3 \mathrm{H}$ ), 7.18 (t, $J=2.8$ $\mathrm{Hz}, 3 \mathrm{H}) ;{ }^{13} \mathrm{C}$ NMR $\left(100 \mathrm{MHz} ; \mathrm{CDCl}_{3}\right): \delta 149.0,146.9,135.8,135.0,132.4,132.0,131.1$, $130.8,129.7,129.1,128.52,128.48,128.38,128.25,128.08,127.7,126.16,126.12$, 126.04, 125.5, 122.3, 121.6, 116.0; HRMS Calculated for $\mathrm{C}_{26} \mathrm{H}_{18} \mathrm{~N}_{6}[\mathrm{M}+\mathrm{H}]^{+}:$415.1665, Found: 415.1672.

Representative procedure for the preparation of 1,8-bis(4-(4-chlorophenyl)-2H1,2,3-triazol-2-yl)naphthalene (3-5a) (Condition A) To a solution of 1,8diiodonaphthalene (760 mg, $2.0 \mathrm{mmol}, 1.0$ eq.) in dry DMSO $(4 \mathrm{ml}, 0.5 \mathrm{M})$, were added successively 4-(4-chlorophenyl)-1,2,3-NH-triazole (898 mg, $5.0 \mathrm{mmol}, 2.5 \mathrm{eq}$.) and Cul (76 mg, 20\%), L-Proline (92 mg, 40\%), and $\mathrm{K}_{2} \mathrm{CO}_{3}\left(1.1 \mathrm{~g}, 8.0 \mathrm{mmol}, 4.0\right.$ eq.) under $\mathrm{N}_{2}$ atmosphere. The mixture was stirred at $120{ }^{\circ} \mathrm{C}$ and monitored by TLC. After the reaction is completed, the reaction was quenched with brine and extracted with ethyl acetate for three times. Organic phases were combined and the solvent was removed under vacuum. The residue was purified by flash silica gel chromatography (Hexane - EtOAc $\mathrm{v} / \mathrm{v} 5: 1$ ), giving desired product as light yellow solid (yield: $580 \mathrm{mg}, 60 \%)$. ${ }^{1} \mathrm{H}$ NMR (400 $\mathrm{MHz} ; \mathrm{CDCl}^{3}$ ): $\delta 8.14(\mathrm{dd}, J=8.4,1.1 \mathrm{~Hz}, 2 \mathrm{H}), 7.95(\mathrm{dd}, J=7.4,1.2 \mathrm{~Hz}, 2 \mathrm{H}), 7.72(\mathrm{dd}, J$ $=8.1,7.6 \mathrm{~Hz}, 2 \mathrm{H}), 7.56(\mathrm{~s}, 2 \mathrm{H}), 7.42-7.39(\mathrm{~m}, 4 \mathrm{H}), 7.24-7.22(\mathrm{~m}, 4 \mathrm{H}) ;{ }^{13} \mathrm{C}$ NMR $(100$ $\left.\mathrm{MHz} ; \mathrm{CDCl}_{3}\right): \delta 147.1,136.0,135.3,134.3,131.44,131.41,130.4,128.7,127.8,127.07$, 127.00, 126.0, 121.0; HRMS Calculated for $\mathrm{C}_{26} \mathrm{H}_{16} \mathrm{~N}_{6} \mathrm{Cl}_{2}[\mathrm{M}+\mathrm{H}]^{+}:$483.0887, Found: 483.0897. 
Representative procedure for the preparation of 1,8-bis(4-(4-methoxyphenyl)2H-1,2,3-triazol-2-yl)naphthalene (3-5b) (Condition $A$ ) To a solution of 1,8diiodonaphthalene (760 mg, $2.0 \mathrm{mmol}, 1.0$ eq.) in dry DMSO (4 ml, $0.5 \mathrm{M})$, were added successively 4-(4-methoxyphenyl)-1,2,3- $\mathrm{NH}$-triazole $(875 \mathrm{mg}, 5.0 \mathrm{mmol}, 2.5 \mathrm{eq}$.) and Cul (76 mg, 20\%), L-Proline (92 mg, 40\%), and $\mathrm{K}_{2} \mathrm{CO}_{3}(1.1 \mathrm{~g}, 8.0 \mathrm{mmol}, 4.0$ eq.) under $\mathrm{N}_{2}$ atmosphere. The mixture was stirred at $120{ }^{\circ} \mathrm{C}$ and monitored by TLC. After the reaction is completed, the reaction was quenched with brine and extracted with ethyl acetate for three times. Organic phases were combined and the solvent was removed under vacuum. The residue was purified by flash silica gel chromatography (Hexane EtOAc v/v 5:1), giving desired product as light yellow solid (yield: $607 \mathrm{mg}, 64 \%$ ). ${ }^{1} \mathrm{H}$ NMR (400 MHz; $\left.\mathrm{CDCl}_{3}\right): \delta 8.10$ (dd, $\left.J=8.4,1.2 \mathrm{~Hz}, 2 \mathrm{H}\right), 7.94(\mathrm{dd}, J=7.4,1.2 \mathrm{~Hz}, 2 \mathrm{H})$, 7.69 (dd, $J=8.2,7.4 \mathrm{~Hz}, 2 \mathrm{H}), 7.50(\mathrm{~s}, 2 \mathrm{H}), 7.44-7.40(\mathrm{~m}, 4 \mathrm{H}), 6.80-6.76(\mathrm{~m}, 4 \mathrm{H}), 3.80$ (s, 6H); ${ }^{13} \mathrm{C}$ NMR $\left(100 \mathrm{MHz} ; \mathrm{CDCl}_{3}\right): \delta 159.6,148.0,136.0,135.6,131.1,130.0,127.2$, $126.9,125.9,122.2,121.2,113.8,55.1$; HRMS Calculated for $\mathrm{C}_{28} \mathrm{H}_{22} \mathrm{~N}_{6} \mathrm{O}_{2}[\mathrm{M}+\mathrm{H}]^{+}$: 475.1877, Found: 475.1883.

Representative procedure for the preparation of dimethyl $4,44^{\prime}-\left(2,2^{\prime}-\right.$ (naphthalene-1,8-diyl)bis(2H-1,2,3-triazole-4,2-diyl))dibenzoate (3-5c) (Condition A) To a solution of 1,8-diiodonaphthalene $(760 \mathrm{mg}, 2.0 \mathrm{mmol}, 1.0$ eq.) in dry DMSO (4 ml, $0.5 \mathrm{M})$, were added successively 4-(1H-1,2,3-triazole-4-yl)-benzoic acid methyl ester (1.015 g, $5.0 \mathrm{mmol}, 2.5 \mathrm{eq}$.) and Cul (76 mg, 20\%), L-Proline (92 mg, 40\%), and $\mathrm{K}_{2} \mathrm{CO}_{3}$ $\left(1.1 \mathrm{~g}, 8.0 \mathrm{mmol}, 4.0 \mathrm{eq}\right.$.) under $\mathrm{N}_{2}$ atmosphere. The mixture was stirred at $120^{\circ} \mathrm{C}$ and monitored by TLC. After the reaction is completed, the reaction was quenched with brine and extracted with ethyl acetate for three times. Organic phases were combined and the solvent was removed under vacuum. The residue was purified by flash silica gel chromatography (Hexane - EtOAc v/v 5:1), giving desired product as light yellow solid (yield: $456 \mathrm{mg}, 43 \%)$. ${ }^{1} \mathrm{H} \mathrm{NMR}\left(400 \mathrm{MHz} ; \mathrm{CDCl}_{3}\right): \delta 8.15$ (d, $\left.J=8.2 \mathrm{~Hz}, 2 \mathrm{H}\right), 7.96(\mathrm{~d}, J=$ $7.4 \mathrm{~Hz}, 2 \mathrm{H}), 7.86(\mathrm{~d}, J=8.2 \mathrm{~Hz}, 4 \mathrm{H}), 7.73(\mathrm{t}, J=7.8 \mathrm{~Hz}, 2 \mathrm{H}), 7.62(\mathrm{~s}, 2 \mathrm{H}), 7.51(\mathrm{~d}, J=$ $8.3 \mathrm{~Hz}, 4 \mathrm{H}), 3.91(\mathrm{~s}, 6 \mathrm{H}) ;{ }^{13} \mathrm{C}$ NMR $\left(100 \mathrm{MHz} ; \mathrm{CDCl}_{3}\right): \delta 166.5,147.2,136.0,135.2$, 133.5, 132.01, 131.96, 130.5, 129.82, 129.69, 127.2, 126.0, 125.5, 121.0, 52.1; HRMS Calculated for $\mathrm{C}_{30} \mathrm{H}_{22} \mathrm{~N}_{6} \mathrm{O}_{4}[\mathrm{M}+\mathrm{Na}]^{+}:$553.1595, Found: 553.1600.

Representative procedure for the preparation of $4,4^{\prime}-\left(2,2^{\prime}-(\right.$ naphthalene-1,8diyl)bis(2H-1,2,3-triazole-4,2-diyl))dibenzonitrile (3-5d) (Condition A) To a solution of 1,8-diiodonaphthalene (760 mg, $2.0 \mathrm{mmol}, 1.0$ eq.) in dry DMSO (4 ml, $0.5 \mathrm{M})$, were added successively 4-(2H-1,2,3-triazol-4-yl)-benzonitrile $(850 \mathrm{mg}, 5.0 \mathrm{mmol}, 2.5 \mathrm{eq}$.) and Cul (76 mg, 20\%), L-Proline (92 mg, 40\%), and $\mathrm{K}_{2} \mathrm{CO}_{3}(1.1 \mathrm{~g}, 8.0 \mathrm{mmol}, 4.0$ eq.) under $\mathrm{N}_{2}$ atmosphere. The mixture was stirred at $120{ }^{\circ} \mathrm{C}$ and monitored by TLC. After the reaction is completed, the reaction was quenched with brine and extracted with ethyl acetate for three times. Organic phases were combined and the solvent was removed under vacuum. The residue was purified by flash silica gel chromatography (Hexane EtOAc v/v 5:1), giving desired product as light yellow solid (yield: $389 \mathrm{mg}, 42 \%$ ). ${ }^{1} \mathrm{H}$ NMR $\left(400 \mathrm{MHz} ; \mathrm{CDCl}_{3}\right): \delta 8.18(\mathrm{~d}, J=8.2 \mathrm{~Hz}, 2 \mathrm{H}), 7.97(\mathrm{~d}, J=7.4 \mathrm{~Hz}, 2 \mathrm{H}), 7.76(\mathrm{dd}, J$ $=9.7,6.0 \mathrm{~Hz}, 2 \mathrm{H}), 7.63(\mathrm{~s}, 2 \mathrm{H}), 7.63-7.53(\mathrm{~m}, 8 \mathrm{H}) ;{ }^{13} \mathrm{C} \mathrm{NMR}\left(100 \mathrm{MHz} ; \mathrm{CDCl}_{3}\right): \delta 146.3$, 
136.0, 135.0, 133.5, 132.4, 131.9, 130.7, 128.4, 127.1, 126.1, 120.7, 118.3, 112.0; HRMS Calculated for $\mathrm{C}_{28} \mathrm{H}_{16} \mathrm{~N}_{8}[\mathrm{M}+\mathrm{Na}]^{+}:$487.1390, Found: 487.1396.

Representative procedure for the preparation of 3-5e (Condition $B$ and Condition A) To a solution of 1,8-diiodonaphthalene (760 mg, $2.0 \mathrm{mmol}, 1.0$ eq.) in dry DMSO (4 ml, $0.5 \mathrm{M}$ ), were added successively 4-(4-methoxyphenyl)-1,2,3-NH-triazole (350 mg, $2.0 \mathrm{mmol}, 1.0$ eq.) and Cul (38 mg, 10\%), L-Proline (46 mg, 20\%), $\mathrm{K}_{2} \mathrm{CO}_{3}(552$ $\mathrm{mg}, 4.0 \mathrm{mmol}, 2.0$ eq.) under $\mathrm{N}_{2}$ atmosphere. The mixture was stirred at $80{ }^{\circ} \mathrm{C}$ and monitored by TLC. After the reaction is completed, the reaction was quenched with brine and extracted with ethyl acetate for three times. Organic phases were combined and the solvent was removed under vacuum. The residue was purified by flash silica gel chromatography (Hexane - EtOAc v/v 10:1), giving desired intermediate 2-(8iodonaphthalen-1-yl)-4-(4-methoxyphenyl)-2H-1,2,3-triazole as light yellow solid (yield: $563 \mathrm{mg}, 66 \%$ ). To a solution of 2-(8-iodonaphthalen-1-yl)-4-(4-methoxyphenyl)-2H1,2,3-triazole (854 mg, $2.0 \mathrm{mmol}, 1.0$ eq.) in dry DMSO $(4 \mathrm{ml}, 0.5 \mathrm{M})$, were added successively 4-(2H-1,2,3-triazol-4-yl)-benzonitrile $(850 \mathrm{mg}, 5.0 \mathrm{mmol}, 2.5 \mathrm{eq}$.) and Cul (76 mg, 20\%), L-Proline (92 mg, 40\%), and $\mathrm{K}_{2} \mathrm{CO}_{3}\left(1.1 \mathrm{~g}, 8.0 \mathrm{mmol}, 4.0\right.$ eq.) under $\mathrm{N}_{2}$ atmosphere. The mixture was stirred at $120^{\circ} \mathrm{C}$ and monitored by TLC. After the reaction is completed, the reaction was quenched with brine and extracted with ethyl acetate for three times. Organic phases were combined and the solvent was removed under vacuum. The residue was purified by flash silica gel chromatography (Hexane - EtOAc $\mathrm{v} / \mathrm{v} 5: 1$ ), giving desired product as light yellow solid (yield: $498 \mathrm{mg}, 53 \%) .{ }^{1} \mathrm{H}$ NMR (400 $\left.\mathrm{MHz} ; \mathrm{CDCl}_{3}\right): \delta 8.16-8.12(\mathrm{~m}, 2 \mathrm{H}), 7.96-7.94(\mathrm{~m}, 2 \mathrm{H}), 7.73$ (ddd, $J=8.3,7.4,1.0 \mathrm{~Hz}$, $2 \mathrm{H}), 7.65(\mathrm{~s}, 1 \mathrm{H})$, 7.59-7.57 (m, 2H), 7.52-7.49 (m, 3H), 7.39-7.37 (m, 2H), 6.77-6.75 (m, 2H), $3.82(\mathrm{~s}, 3 \mathrm{H}) ;{ }^{13} \mathrm{C} \mathrm{NMR}\left(100 \mathrm{MHz} ; \mathrm{CDCl}_{3}\right): \delta 159.8,148.1,146.3,136.0,135.39$, $135.24,133.9,132.3,132.05,132.01,131.05,131.01,130.6,130.2,127.13,127.05$, 126.27, 126.11, 125.9, 121.8, 121.0, 118.6, 113.9, 111.5, 55.28; HRMS Calculated for $\mathrm{C}_{28} \mathrm{H}_{19} \mathrm{~N}_{7} \mathrm{O}[\mathrm{M}+\mathrm{Na}]^{+}:$492.1543, Found: 492.1550 .

UV absorption spectra The UV-Vis spectra were measured in a $10.00 \mathrm{~mm}$ quartz cell. All samples were measured as $10^{-6} \mathrm{~mol} / \mathrm{L}$ solution of bis- $\mathrm{N}-2$-aryl triazole in $\mathrm{CH}_{2} \mathrm{Cl}_{2}$. The wavelength range is between $200-600 \mathrm{~nm}$.

Fluorescence excitation and emission spectra Fluorescence emission and excitation spectra were measured in a $10.00 \mathrm{~mm}$ quartz cell. All samples were measured as a $10^{-6} \mathrm{~mol} / \mathrm{L}$ solution of bis- $\mathrm{N}-2$-aryl triazole in $\mathrm{CH}_{2} \mathrm{Cl}_{2}$. The emission spectra are obtained with an excitation wavelength around 300 to $310 \mathrm{~nm}$, and the excitation spectra are obtained with the emission $\lambda_{\max }$ according to different compounds.

Quantum yield Quantum yield were calculated by using the standard 9,10diphenylanthracene which excited at $340 \mathrm{~nm}(\Phi=0.9)$ in cyclohexane. Quantum yields were calculated by using the following equation, where $\Phi$ is the quantum yield, Int is the 
area of emission peak, $A$ represents absorbance at the excitation wavelength and $n$ is reflective index of the solvent. The subscript reference is the respective values of the standard 9,10-diphenylanthracene. The absorption of bis-N-2-aryl triazole and 9,10diphenylanthracene were less than 0.05 (Conc. $\left.=10^{-6} \mathrm{~mol} / \mathrm{L}\right)$.

$$
\Phi=\Phi_{\text {reference }} \times \frac{\operatorname{Int} \times A_{\text {reference }} \times n^{2}}{I n t_{\text {reference }} \times \mathrm{A} \times n_{\text {reference }}{ }^{2}}
$$




\section{ORTEP drawing of the crystal structures}

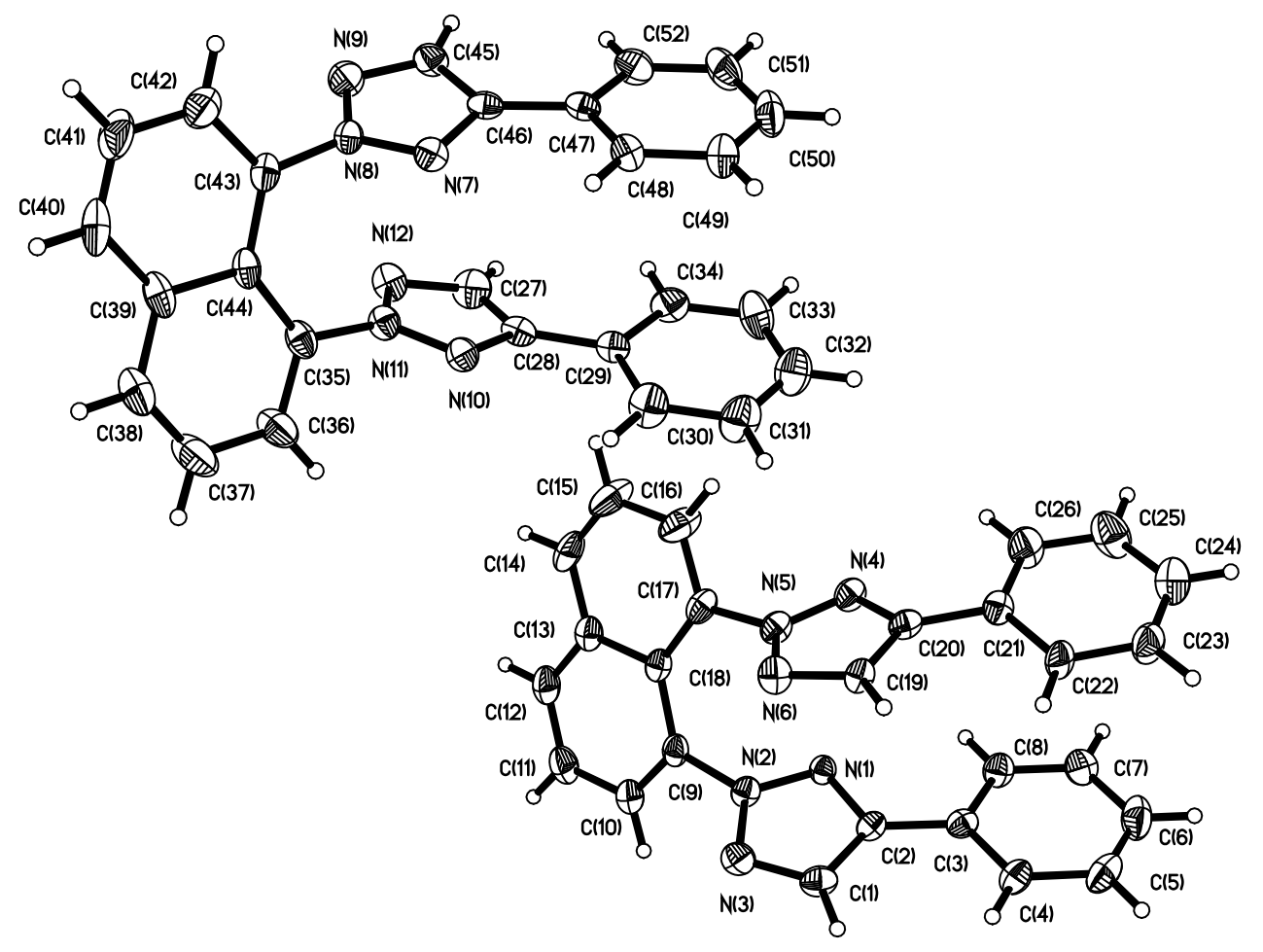

Figure 1. Perspective view of the molecular structures of the two independent molecules of $3 \mathbf{c}\left(\mathrm{C}_{26} \mathrm{H}_{18} \mathrm{~N}_{6}\right)$ with the atom labeling scheme for the nonhydrogen atoms. The thermal ellipsoids are scaled to $30 \%$ probability. CCDC number: 1037989 


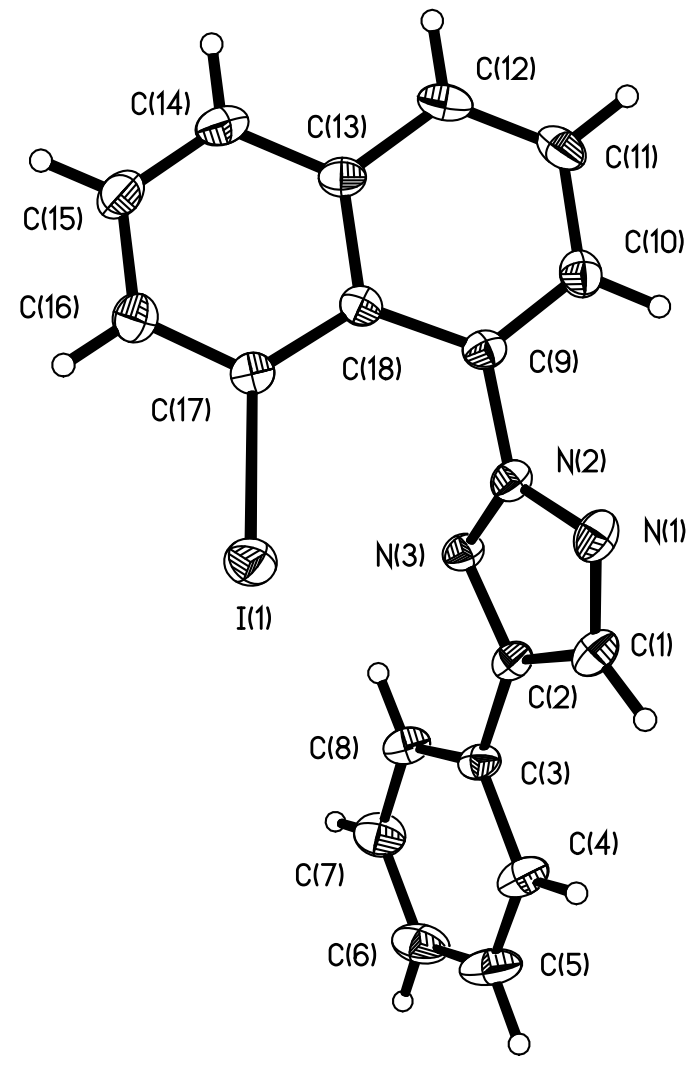

Figure 2. Perspective view of the molecular structure of $4 a\left(\mathrm{C}_{18} \mathrm{H}_{12} \mathrm{~N}_{3}\right)$ with the atom labeling scheme for the non-hydrogen atoms. The thermal ellipsoids are scaled to enclose $30 \%$ probability. CCDC number: 1037988. 


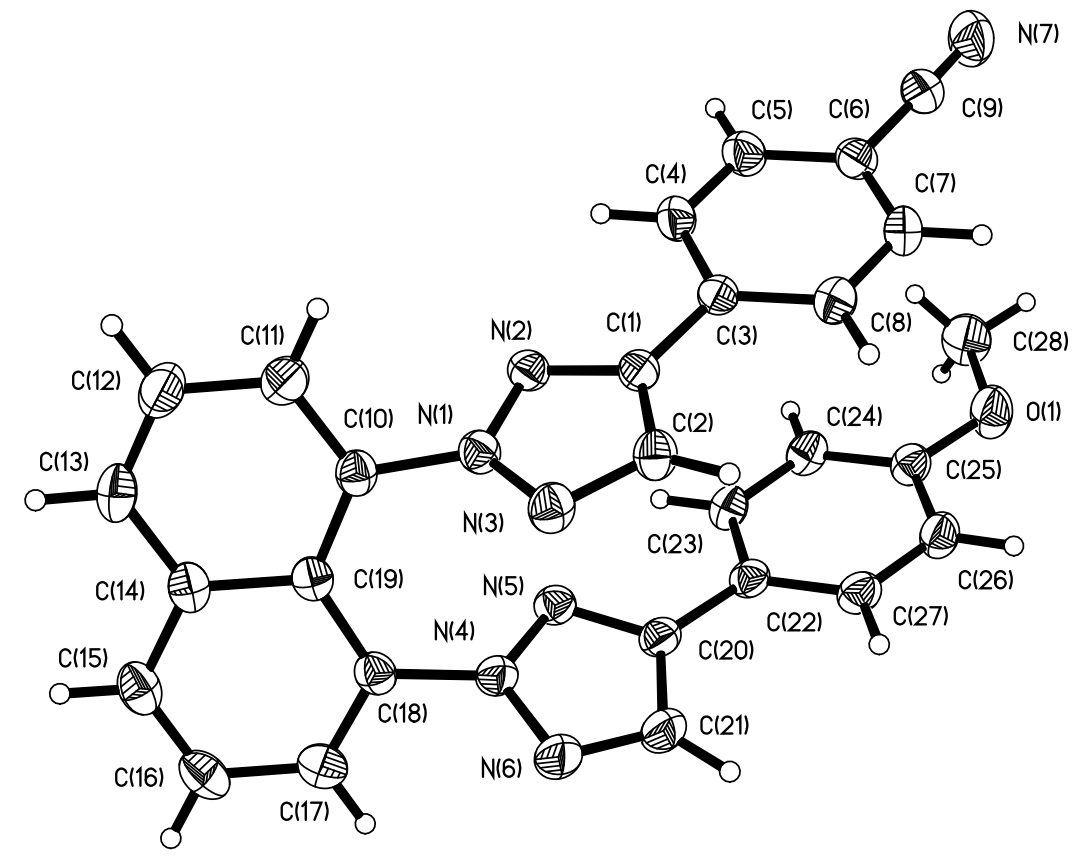

Figure 3. Perspective view of the molecular structure of $5 e\left(\mathrm{C}_{28} \mathrm{H}_{19} \mathrm{~N}_{7} \mathrm{O}\right)$ with the atom labeling scheme for the non-hydrogen atoms. The thermal ellipsoids are scaled to enclose $30 \%$ probability. CCDC number: 1038048 . 


\section{The data of fluorophores with emission spectra}

Sample preparation: To a $100 \mathrm{ml}$ volumetric flask was added the NBT $(0.01 \mathrm{mmol})$ in $100 \mathrm{ml}$ Dichloromethane. After the NBT was absolutely dissolved, the $100 \mu \mathrm{l}$ triazole solution has been transferred to another $10 \mathrm{ml}$ volumetric flask by using single-channel pipetter (20-200 $\mu \mathrm{l})$, and was then diluted with additional $9.9 \mathrm{ml}$ Dichloromethane.

Integrated emission area: All the areas were integrated from the original spectra by FL Solution 2.0 software at the wavelength range that was $300 \mathrm{~nm}$ to $600 \mathrm{~nm}$ with an excitation wavelength around 300 to $310 \mathrm{~nm}$.

Quantum yield determination: All the quantum yields of samples were determined based on conc. $=10^{-6} \mathrm{~mol} / \mathrm{L}$ 9,10-diphenylanthracene in cyclohexane $(\Phi=0.9)$. 


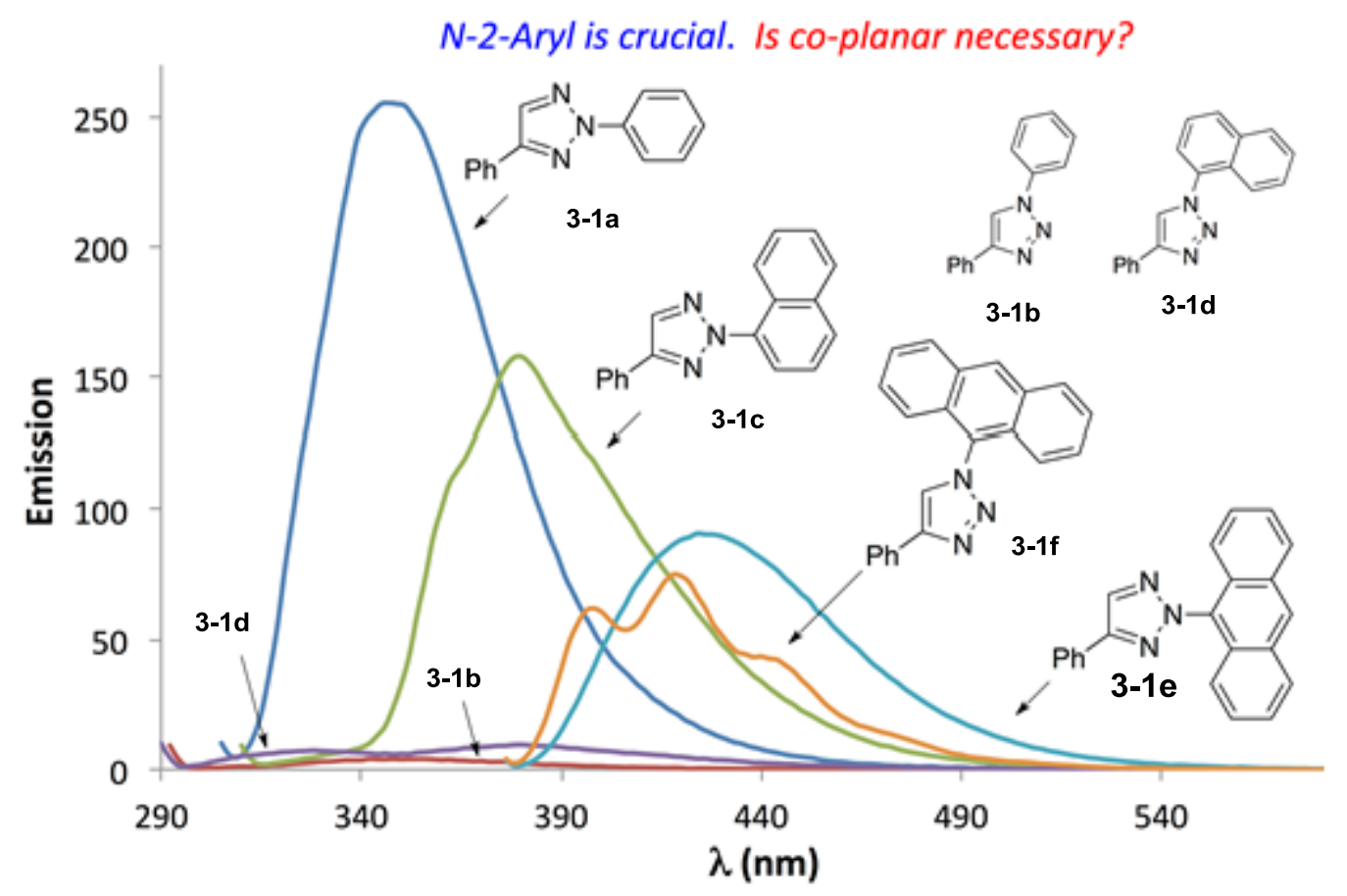

Figure 4. Fluorescence emission of NAT with different aryl groups: sample preparation: $10^{-6} \mathrm{~mol} / \mathrm{L}$ in DCM.

Table 1. Comparison of optical properties of NATs.

\begin{tabular}{lccccc}
\hline & $\begin{array}{c}\text { Absorption } \\
(\mathbf{n m})\end{array}$ & $\begin{array}{c}\text { Excitation } \\
\left(\boldsymbol{\lambda}_{\max }\right)\end{array}$ & $\begin{array}{c}\text { Emission } \\
\left(\boldsymbol{\lambda}_{\max }\right)\end{array}$ & $\begin{array}{c}\text { Stokes } \\
\text { Shift (nm) }\end{array}$ & $\boldsymbol{\Phi}$ \\
\hline 3-1a & $295(0.027)$ & 298 & 347 & 49 & 0.34 \\
3-1b & $292(0.009)$ & - & - & - & $<0.1$ \\
3-1c & $296(0.021)$ & 293 & 379 & 86 & 0.32 \\
3-1d & $286(0.008)$ & - & - & - & $<0.1$ \\
3-1e & $365(0.029)$ & 368 & 420 & 52 & 0.43 \\
3-1f & $366(0.022)$ & 367 & $418^{\mathrm{a}}$ & 51 & 0.27 \\
\hline
\end{tabular}

a Three different emission bands were observed in 3-1f fluorescence spectra. Peak $\lambda=418$ is the highest one. The other two peaks $\lambda=392$ and 436 . 


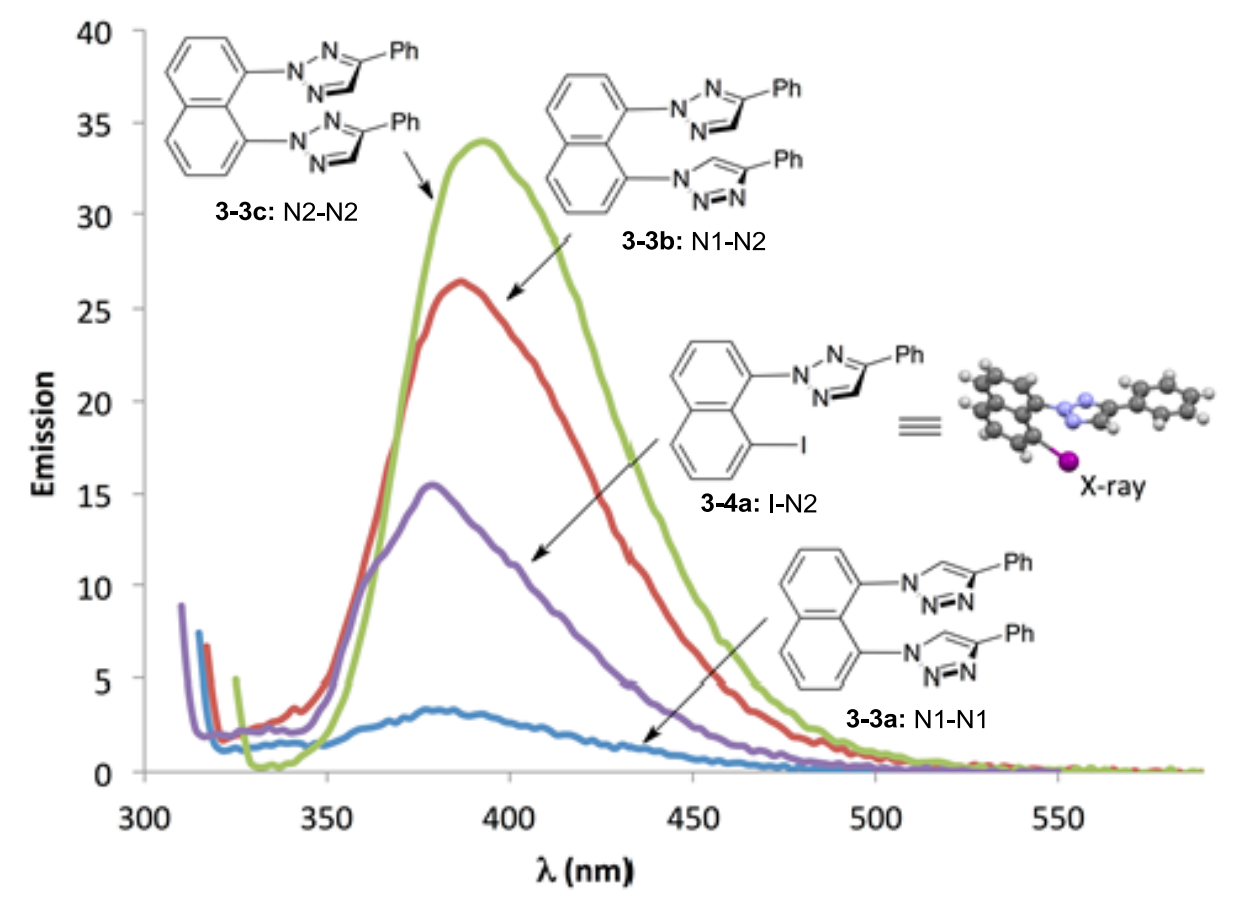

Figure 5. Fluorescence emission of NBT 3-3 and triazole iodide 3-4a : sample preparation: $10^{-6} \mathrm{~mol} / \mathrm{L}$ in $\mathrm{DCM}$.

Table 2. Comparison of optical properties of NBT 3-3 and 3-4a

\begin{tabular}{cccccc}
\hline & $\begin{array}{c}\text { Absorption } \\
(\mathrm{nm})\end{array}$ & $\begin{array}{c}\text { Excitation } \\
\left(\lambda_{\max }\right)\end{array}$ & $\begin{array}{c}\text { Emission } \\
\left(\lambda_{\max }\right)\end{array}$ & $\begin{array}{c}\text { Stokes } \\
\text { Shift }(\mathrm{nm})\end{array}$ & $\Phi$ \\
\hline 3-3a & $282(0.079)$ & - & - & - & $<0.01$ \\
3-3b & $307(0.073)$ & 307 & 384 & 77 & 0.13 \\
3-3c & $310(0.063)$ & 315 & 393 & 78 & 0.24 \\
3-4a & $297(0.064)$ & 300 & 378 & 78 & 0.20 \\
\hline
\end{tabular}




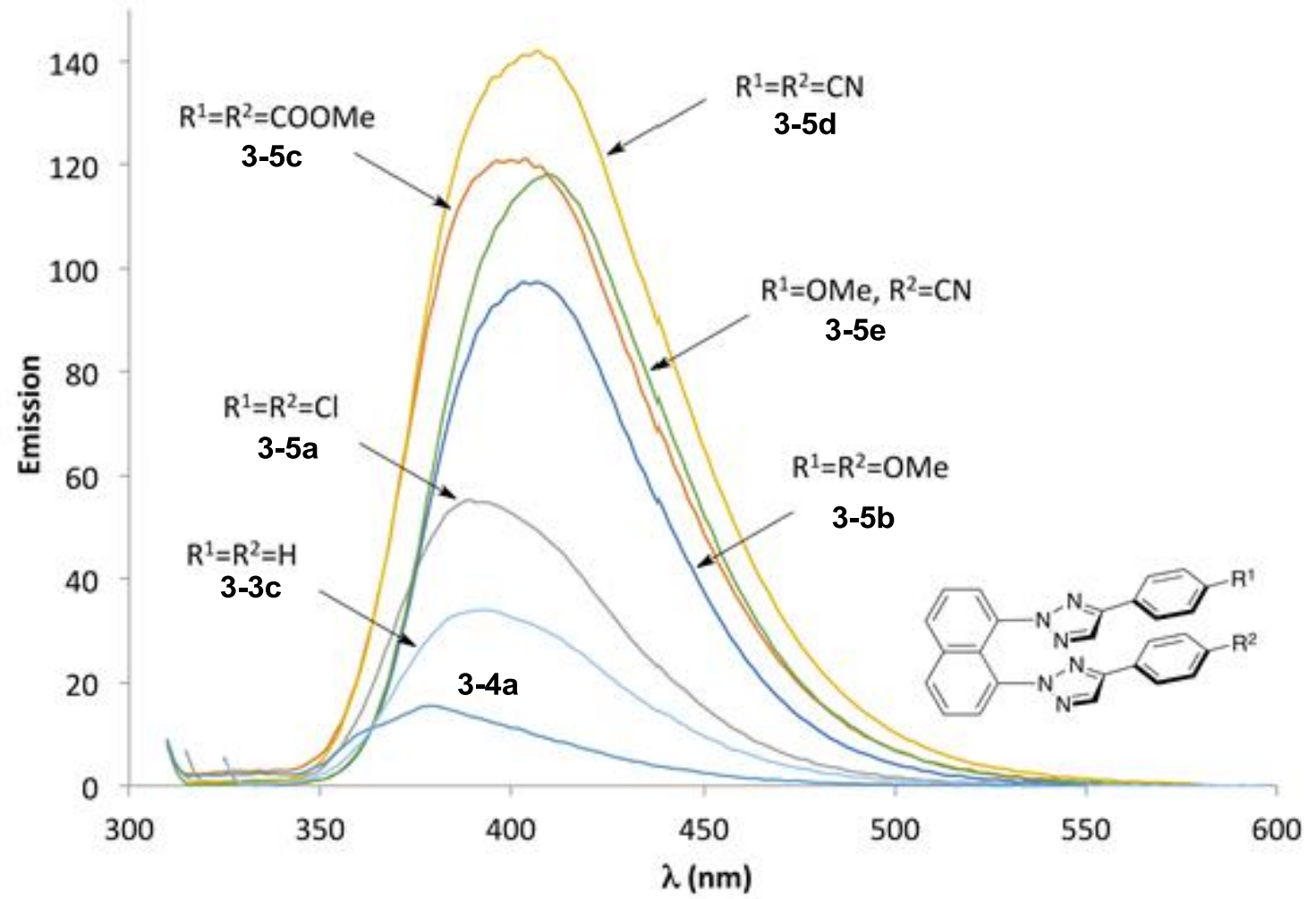

Figure 6. Fluorescence emission of NBT 3-5 and triazole iodide 3-4a: sample preparation: $10^{-6} \mathrm{~mol} / \mathrm{L}$ in DCM.

Table 3. Comparison of optical properties of NBT 3-5 and 3-4a

\begin{tabular}{cccccc}
\hline & $\begin{array}{c}\text { Absorption } \\
(\mathbf{n m})\end{array}$ & $\begin{array}{c}\text { Excitation } \\
\left(\boldsymbol{\lambda}_{\max }\right)\end{array}$ & $\begin{array}{c}\text { Emission } \\
\left(\boldsymbol{\lambda}_{\max }\right)\end{array}$ & $\begin{array}{c}\text { Stokes } \\
\text { Shift }(\mathbf{n m})\end{array}$ & $\boldsymbol{\Phi}$ \\
\hline 3-4a & $297(0.064)$ & 300 & 378 & 78 & 0.20 \\
3-5a & $306(0.061)$ & 305 & 393 & 88 & 0.26 \\
3-5b & $313(0.061)$ & 315 & 403 & 88 & 0.27 \\
3-5c & $300(0.080)$ & 300 & 396 & 96 & 0.41 \\
3-5d & $303(0.068)$ & 302 & 403 & 101 & 0.47 \\
3-5e & $300(0.067)$ & 300 & 408 & 108 & 0.39 \\
\hline
\end{tabular}




\section{Excited state lifetime}

All the sample are tested under same conditions as described above (section II). All the complexes were fitted with one exponential using DAS6.

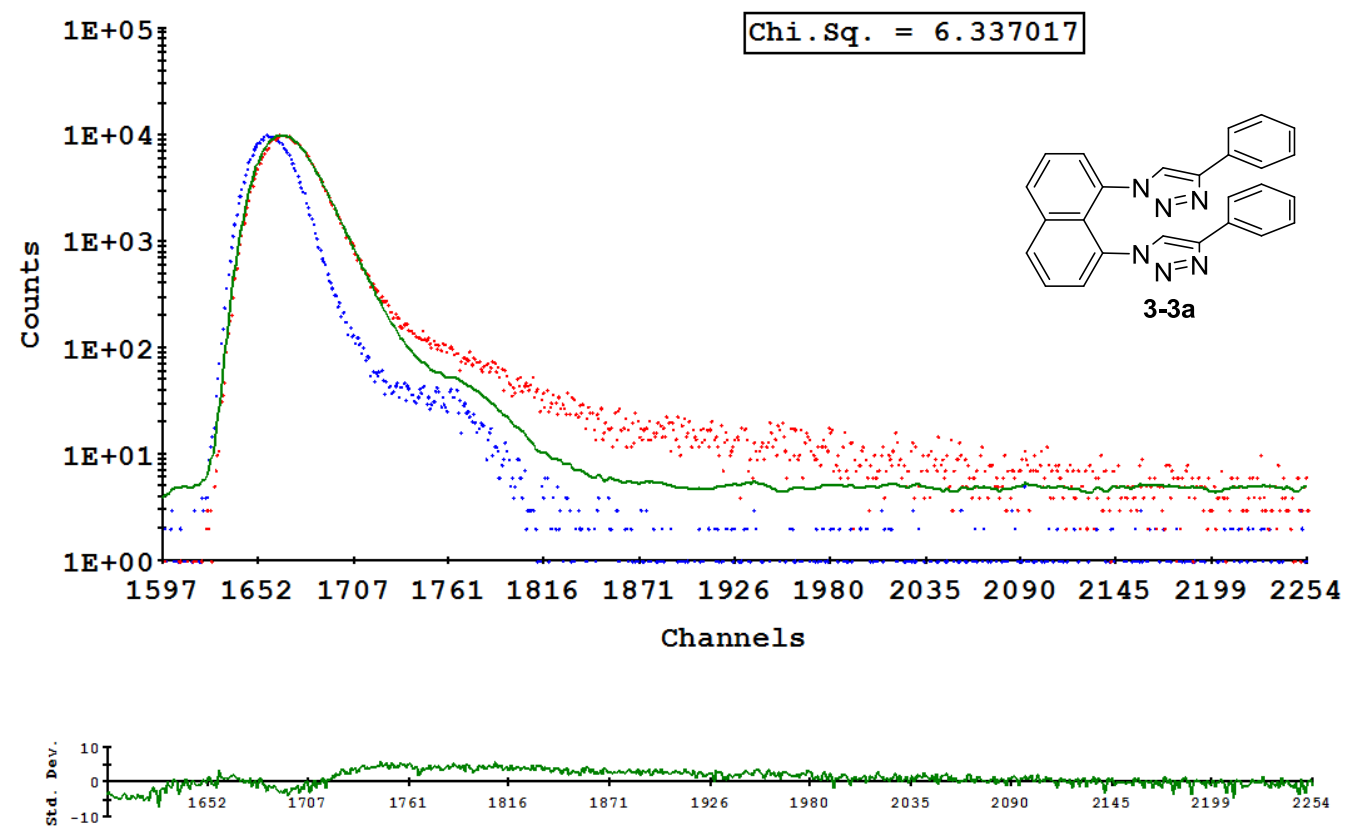

Calculated using 1 exponential

The initial paramters are:

\begin{tabular}{|c|c|}
\hline $\begin{array}{ll}\text { Shift Value }=0 & \text { ch; } \\
\text { Shift Limit }=40 & \text { ch; }\end{array}$ & $\begin{array}{lr}0 & \text { sec } \\
2.194787 E-09\end{array}$ \\
\hline $\begin{array}{l}\text { T1 Estimate = } 12.91663 \mathrm{ch} \text {; } \\
\text { A Free } \\
\text { B1 Free }\end{array}$ & 7.087312E-10 \\
\hline $\begin{array}{l}\text { Prompt and decay LO = } 1597 \mathrm{ch} \text {; } \\
\text { Prompt and decay } \mathrm{HI}=2294 \mathrm{ch}\end{array}$ & $\begin{array}{l}8.762689 \mathrm{E}-08 \\
1.258711 \mathrm{E}-07\end{array}$ \\
\hline
\end{tabular}

Background on prompt $=0$ (manual)

Time calibration $=5.486969 \mathrm{E}-11 \mathrm{sec} / \mathrm{ch}$

The fitted parameters are:

Hi reduced to: $2254 \mathrm{ch}$

SHIFT $=0.552488 \quad$ ch; $3.031484 \mathrm{E}-11$ secS.Dev $=3.574068 \mathrm{E}-12 \mathrm{sec}$ $\mathrm{T} 1=10.33031 \quad \mathrm{ch} ; \quad 5.668208 \mathrm{E}-10 \mathrm{sec}$. Dev $=6.771148 \mathrm{E}-12 \mathrm{sec}$

$A=3.857545 \quad S . D e v=0.1000181$

B1 $=0.1259739 \quad[100.00$ Rel.Ampl][ 1.00 Alpha] S.Dev $=2.429185 \mathrm{E}-04$

Average Life Time $=5.668208 \mathrm{E}-10 \mathrm{sec}$

$\mathrm{CHISQ}=6.337017 \quad$ [ 654 degrees of freedom ] 

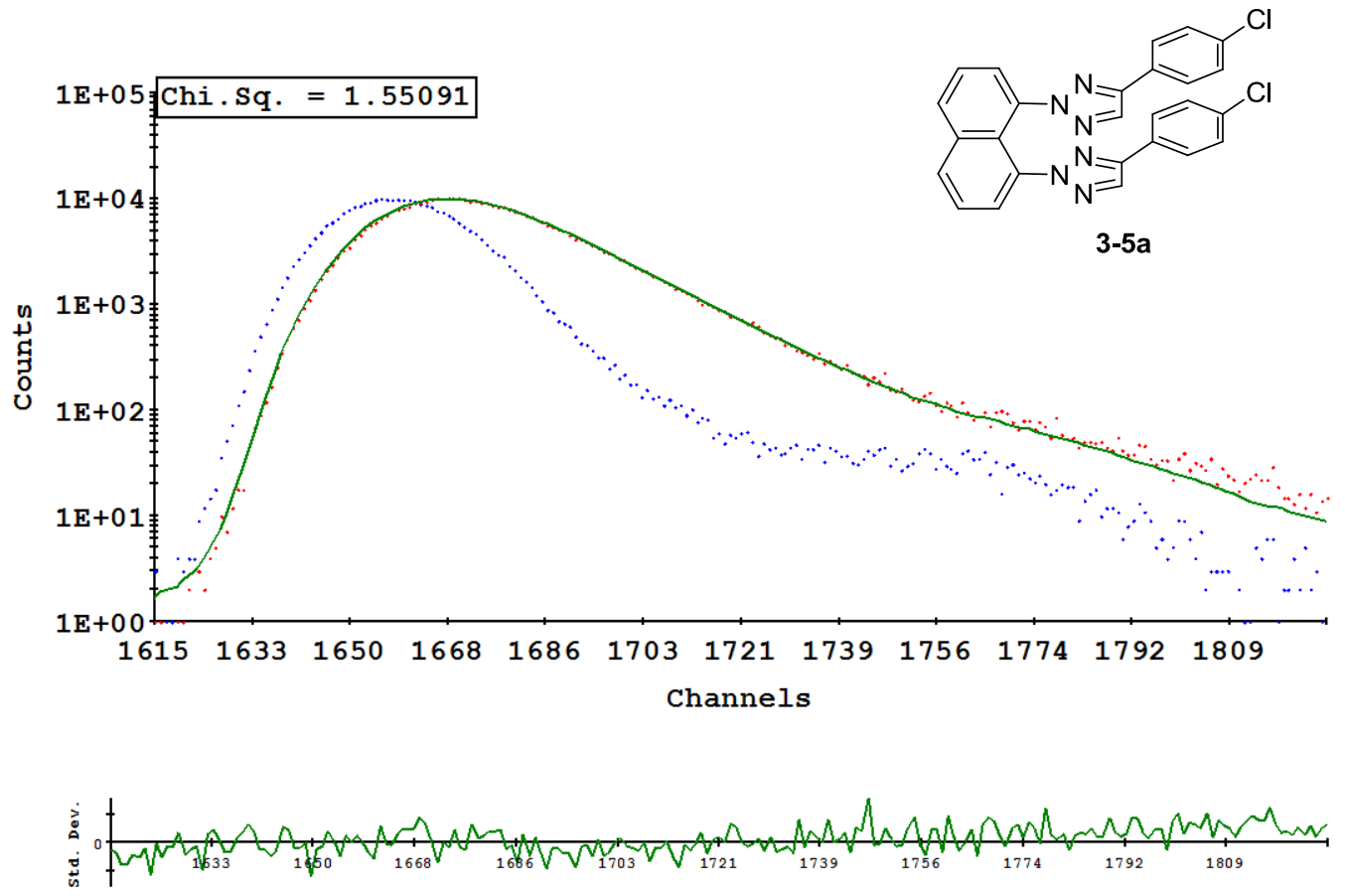

Calculated using 1 exponential

The initial paramters are:

$\begin{array}{llll}\text { Shift Value }=0 & \text { ch; } & 0 & \mathrm{sec} \\ \text { Shift Limit }=40 & \text { ch; } & 2.194787 \mathrm{E}-09 \mathrm{sec}\end{array}$

T1 Estimate = $15.02722 \mathrm{ch} ; \quad 8.245389 \mathrm{E}-10 \mathrm{sec}$

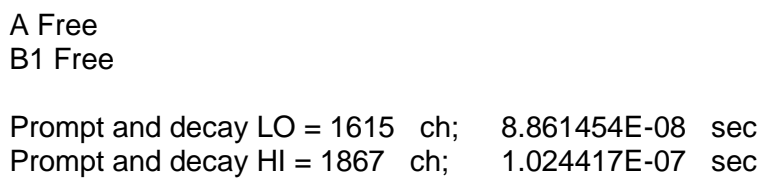

The fitted parameters are:

Hi reduced to: $1827 \mathrm{ch}$

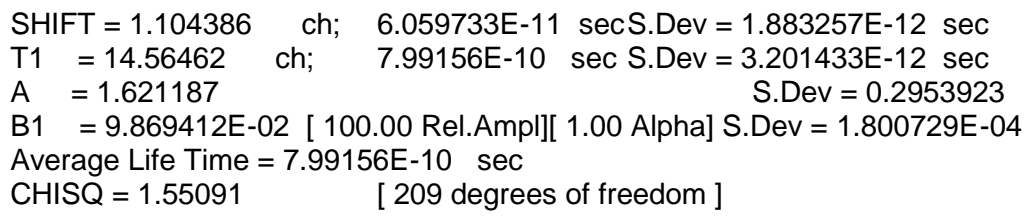




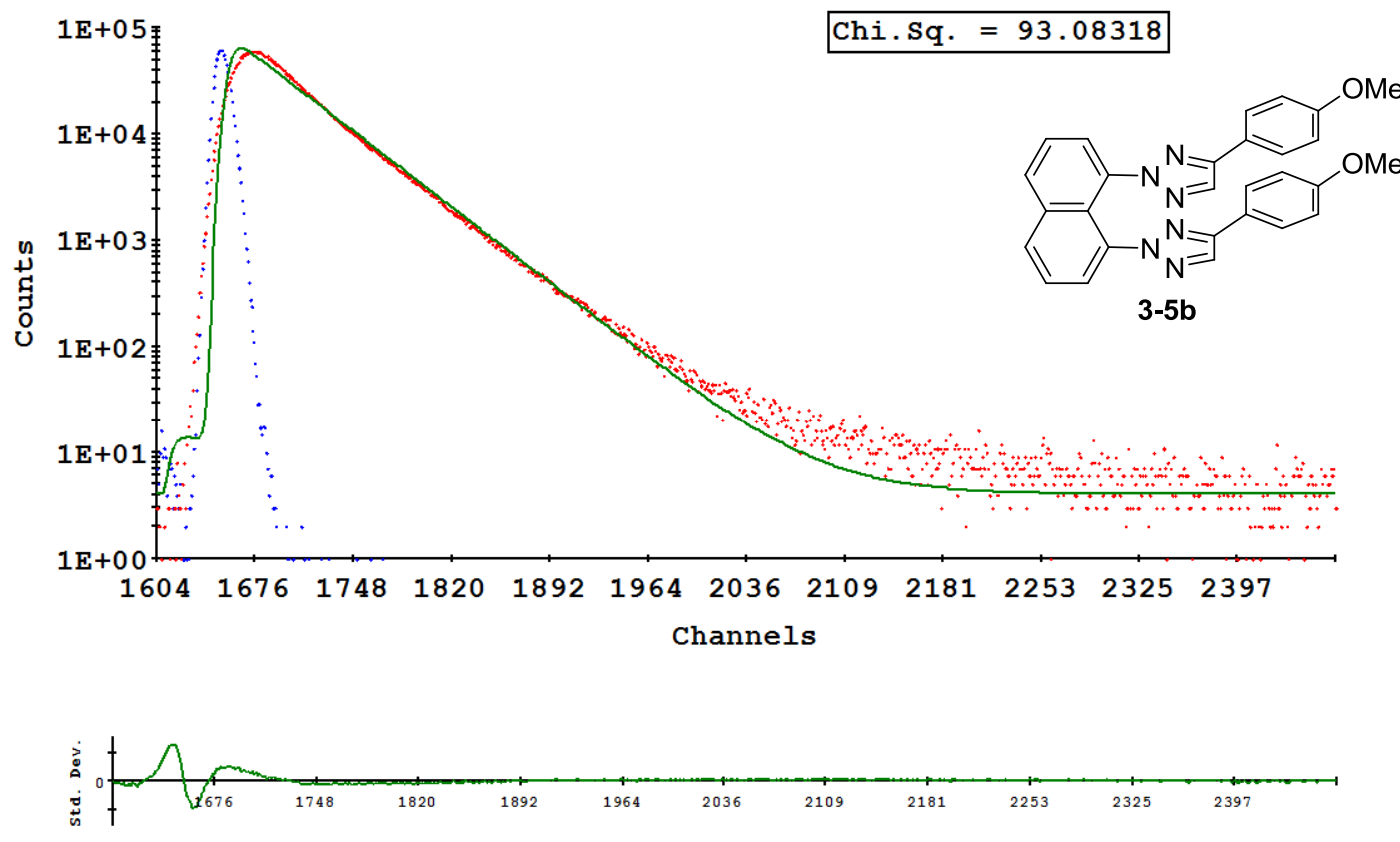

Calculated using 1 exponential

The initial paramters are:

Shift Value $=0$

ch;

$0 \quad \mathrm{sec}$

Shift Limit $=40 \quad$ ch;

2.194787E-09 sec

T1 Estimate $=48.82361 \mathrm{ch}$;

2.678936E-09 sec

\section{A Free}

B1 Free

Prompt and decay LO = $1604 \mathrm{ch} ; \quad 8.801098 \mathrm{E}-08 \mathrm{sec}$

Prompt and decay $\mathrm{HI}=2509 \mathrm{ch} ; \quad 1.37668 \mathrm{E}-07 \mathrm{sec}$

Background on prompt $=0$ (manual)

Time calibration $=5.486969 \mathrm{E}-11 \mathrm{sec} / \mathrm{ch}$

The fitted parameters are:

Hi reduced to: $2469 \mathrm{ch}$

SHIFT $=6.276135 \quad \mathrm{ch} ; \quad 3.443696 \mathrm{E}-10 \mathrm{sec}$. $\mathrm{Dev}=6.684059 \mathrm{E}-12 \mathrm{sec}$

$\mathrm{T} 1=43.90302 \quad \mathrm{ch} ; \quad 2.408945 \mathrm{E}-09 \mathrm{secS} \cdot \mathrm{Dev}=1.631257 \mathrm{E}-11 \mathrm{sec}$

$A=4.041021 \quad S$. Dev $=0.1016247$

B1 $=0.1070184 \quad[100.00$ Rel.Ampl][ 1.00 Alpha] S.Dev $=7.564617 \mathrm{E}-05$

Average Life Time $=2.408945 \mathrm{E}-09 \mathrm{sec}$

$\mathrm{CHISQ}=93.08318 \quad$ [ 862 degrees of freedom ] 

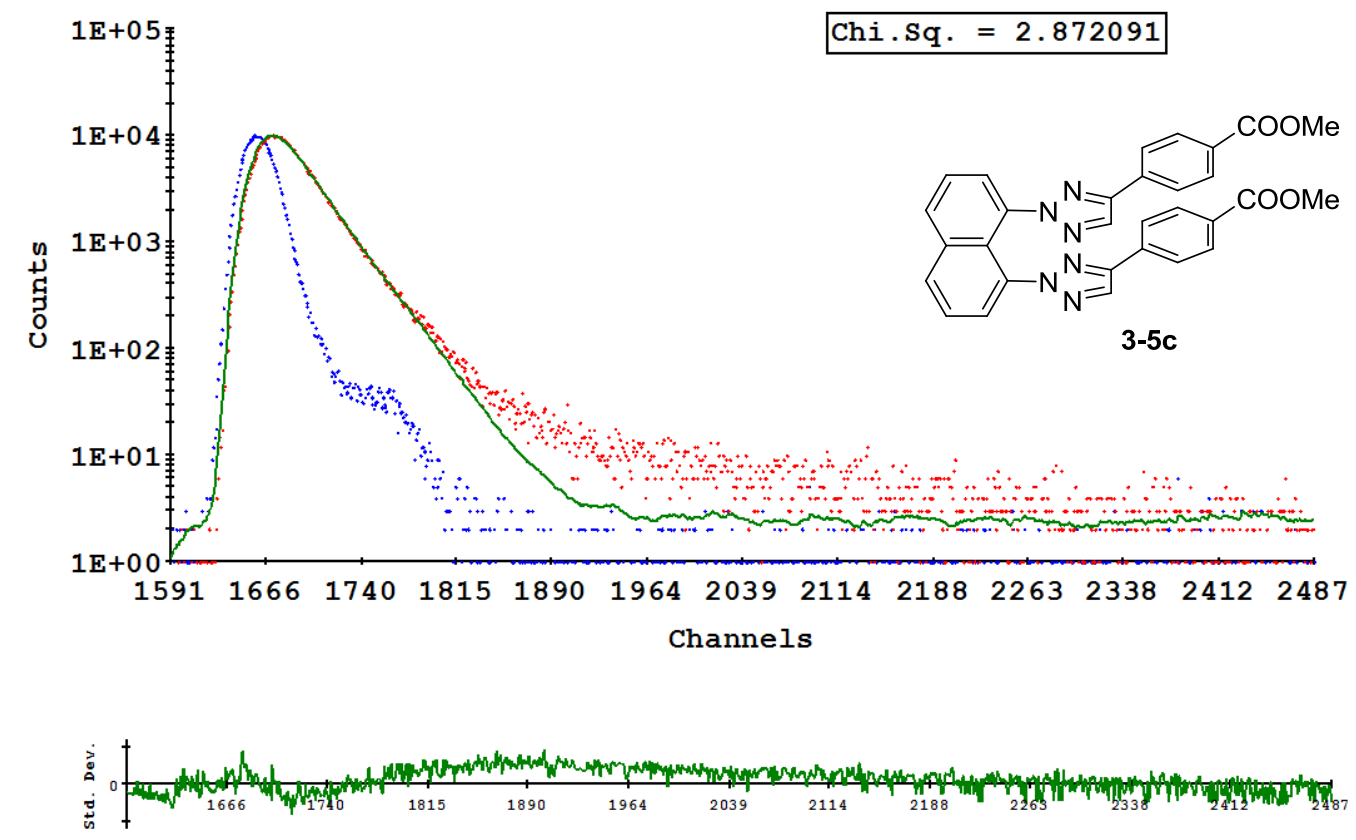

Calculated using 1 exponential

The initial paramters are:

Shift Value $=0$

ch;

$0 \quad$ sec

Shift Limit $=40$

ch;

2.194787E-09 sec

T1 Estimate = $26.07678 \mathrm{ch}$;

1.430825E-09 sec

A Free

B1 Free

Prompt and decay LO = $1591 \mathrm{ch} ; \quad 8.729767 \mathrm{E}-08 \mathrm{sec}$

Prompt and decay $\mathrm{HI}=2527 \mathrm{ch} ; 1.386557 \mathrm{E}-07 \mathrm{sec}$

Background on prompt $=0$ (manual)

Time calibration $=5.486969 \mathrm{E}-11 \mathrm{sec} / \mathrm{ch}$

The fitted parameters are:

Hi reduced to: $2487 \mathrm{ch}$

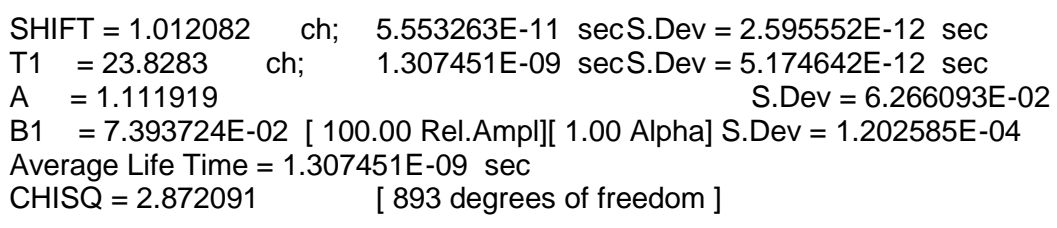



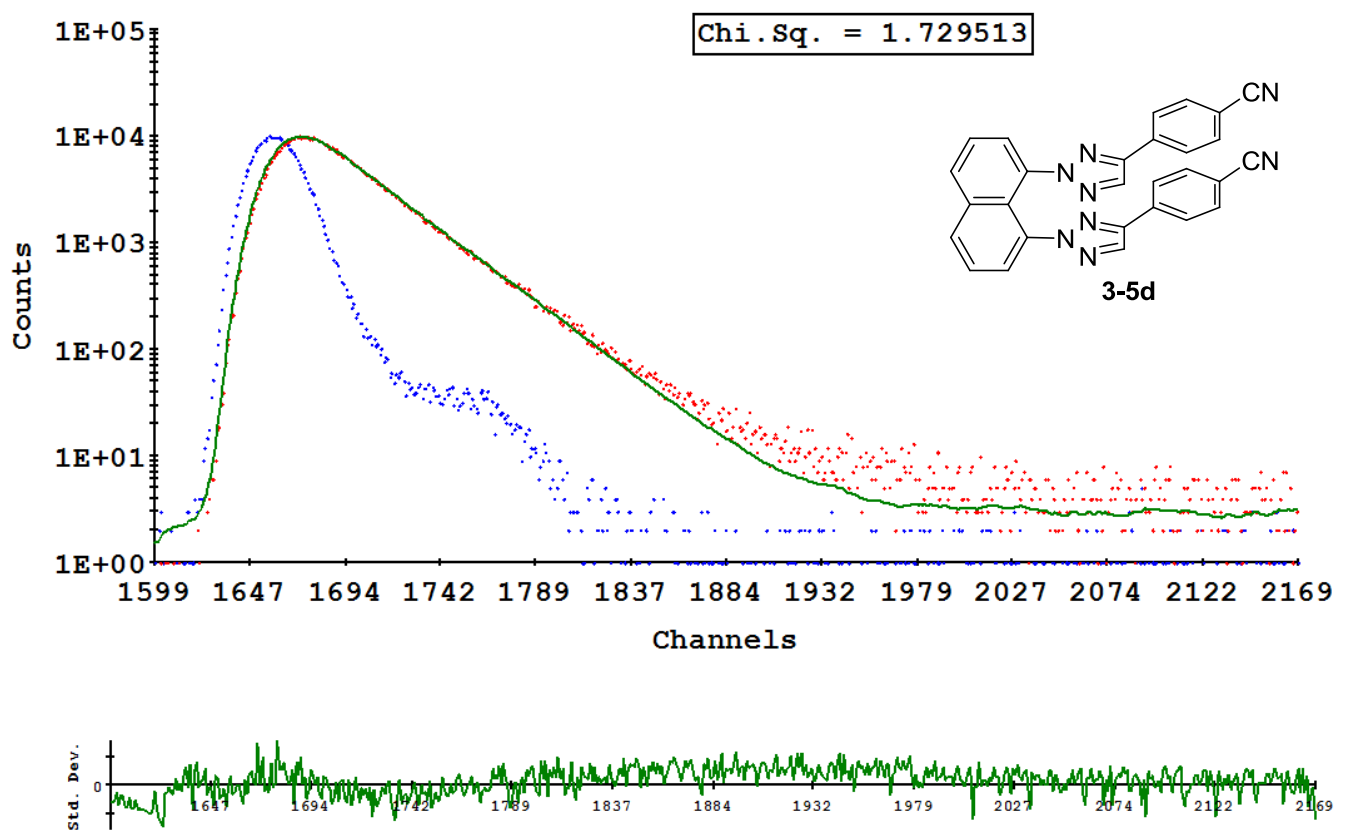

Calculated using 1 exponential

The initial paramters are:

$\begin{array}{llll}\text { Shift Value }=0 & \text { ch; } & 0 & \text { sec } \\ \text { Shift Limit }=40 & \text { ch; } & 2.194787 \mathrm{E}-09 \mathrm{sec}\end{array}$

T1 Estimate $=29.85876 \mathrm{ch} ; \quad 1.638341 \mathrm{E}-09 \mathrm{sec}$

A Free

B1 Free

Prompt and decay LO = $1599 \mathrm{ch} ; \quad 8.773662 \mathrm{E}-08 \mathrm{sec}$ Prompt and decay $\mathrm{HI}=2209 \mathrm{ch} ; \quad 1.212071 \mathrm{E}-07 \mathrm{sec}$

Background on prompt $=0$ (manual)

Time calibration $=5.486969 \mathrm{E}-11 \mathrm{sec} / \mathrm{ch}$

The fitted parameters are:

Hi reduced to: $2169 \mathrm{ch}$

SHIFT $=1.210837 \quad$ ch; $6.643825 \mathrm{E}-11$ secS.Dev $=2.213482 \mathrm{E}-12 \mathrm{sec}$ $\mathrm{T} 1=28.58036$ ch; $1.568195 \mathrm{E}-09 \mathrm{secS} . \mathrm{Dev}=4.21055 \mathrm{E}-12 \mathrm{sec}$ $A=1.481617 \quad$ S.Dev $=0.1002949$ B1 = 6.720192E-02 [ 100.00 Rel.Ampl][ 1.00 Alpha] S.Dev $=1.043928 \mathrm{E}-04$ Average Life Time $=1.568195 \mathrm{E}-09 \mathrm{sec}$ $\mathrm{CHISQ}=1.729513 \quad$ [ 567 degrees of freedom ] 

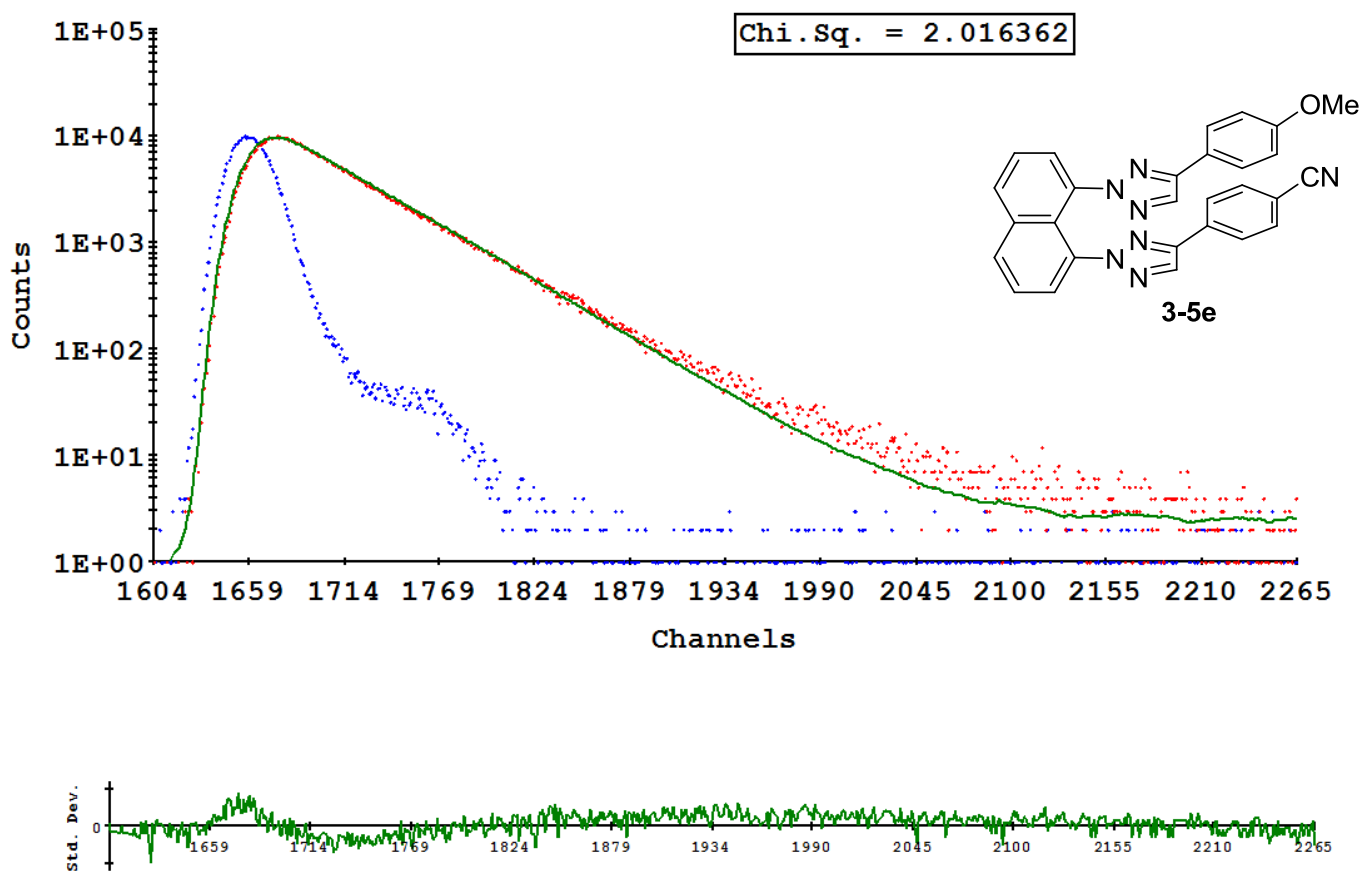

Calculated using 1 exponential

The initial paramters are:

\begin{tabular}{|c|c|}
\hline Shift Value $=0$ & $0 \quad$ sec \\
\hline Shift Limit = 40 & 2.194787E-09 \\
\hline T1 Estimate = $45.05786 \mathrm{ch}$; & 2.472311E-09 \\
\hline $\begin{array}{l}\text { A Free } \\
\text { B1 Free }\end{array}$ & \\
\hline $\begin{array}{l}\text { Prompt and decay LO = } 1604 \mathrm{ch} \text {; } \\
\text { Prompt and decay } \mathrm{HI}=2305 \mathrm{ch}\end{array}$ & $\begin{array}{l}8.801098 \mathrm{E}-08 \\
1.264746 \mathrm{E}-07\end{array}$ \\
\hline
\end{tabular}

Background on prompt $=0$ (manual)

Time calibration $=5.486969 \mathrm{E}-11 \mathrm{sec} / \mathrm{ch}$

The fitted parameters are:

Hi reduced to: $2265 \mathrm{ch}$

SHIFT $=0.8243643$ ch; $4.523261 \mathrm{E}-11$ secS.Dev $=2.415798 \mathrm{E}-12 \mathrm{sec}$

$\mathrm{T} 1=44.52381 \quad \mathrm{ch} ; \quad 2.443007 \mathrm{E}-09 \mathrm{secS} . \mathrm{Dev}=5.735076 \mathrm{E}-12 \mathrm{sec}$

$A=0.6034257 \quad$ S.Dev $=9.464832 \mathrm{E}-02$

$\mathrm{B} 1=5.459966 \mathrm{E}-02$ [ 100.00 Rel.Ampl][ 1.00 Alpha] S.Dev $=7.483848 \mathrm{E}-05$

Average Life Time $=2.443007 \mathrm{E}-09 \mathrm{sec}$

$\mathrm{CHISQ}=2.016362 \quad$ [ 658 degrees of freedom ] 
V NMR spectra 

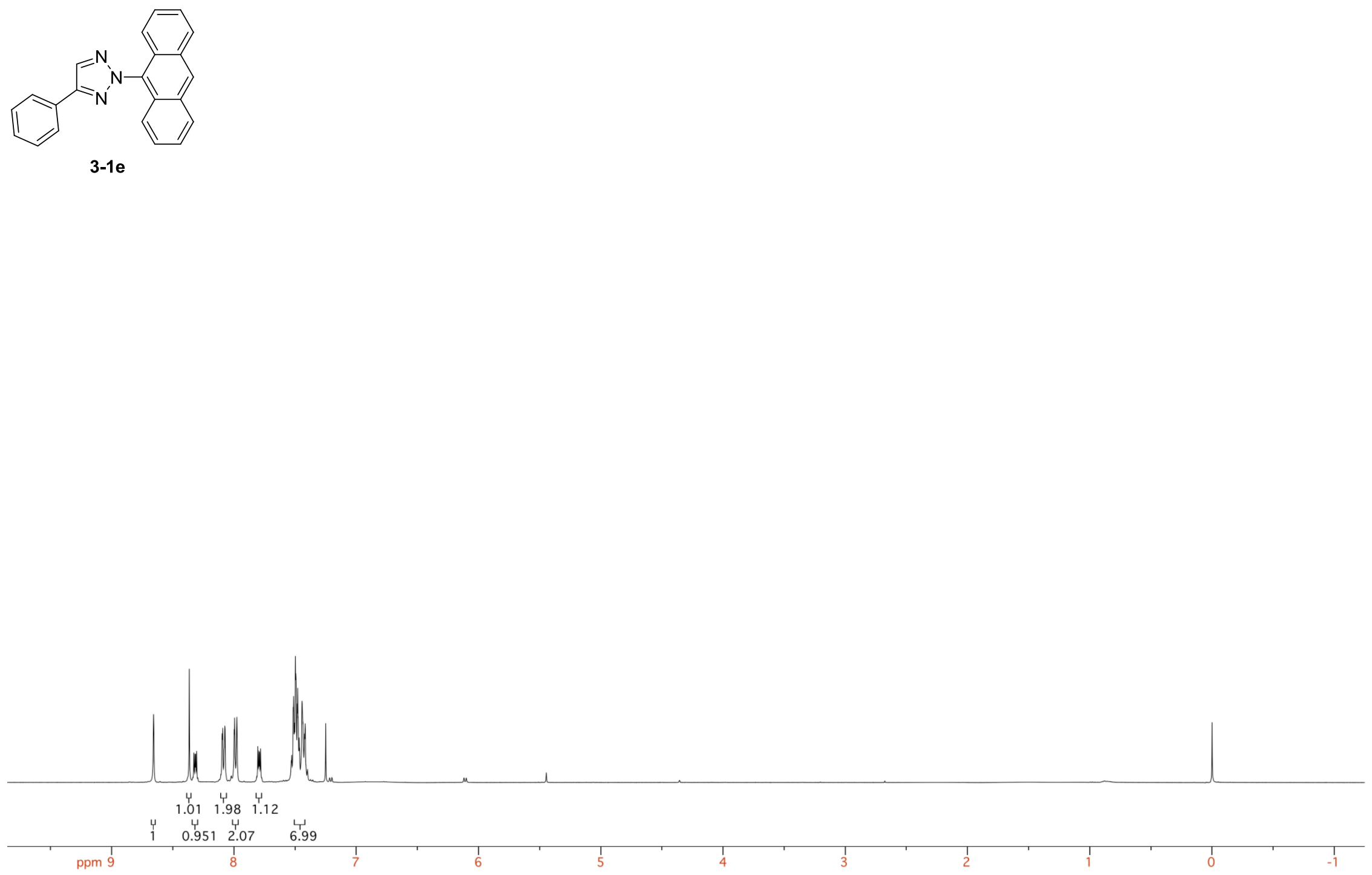

297 


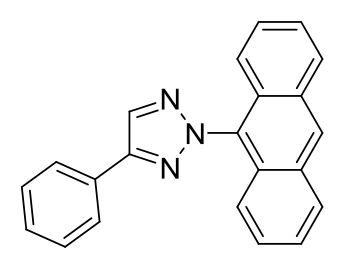

3-1e
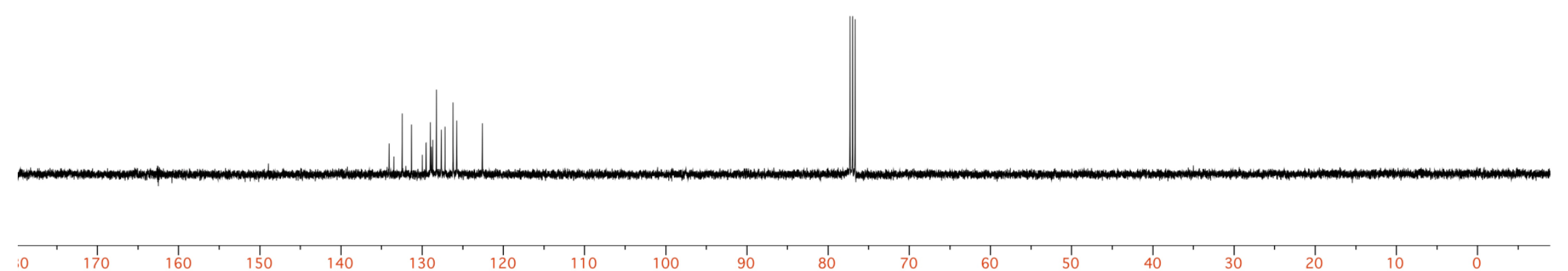

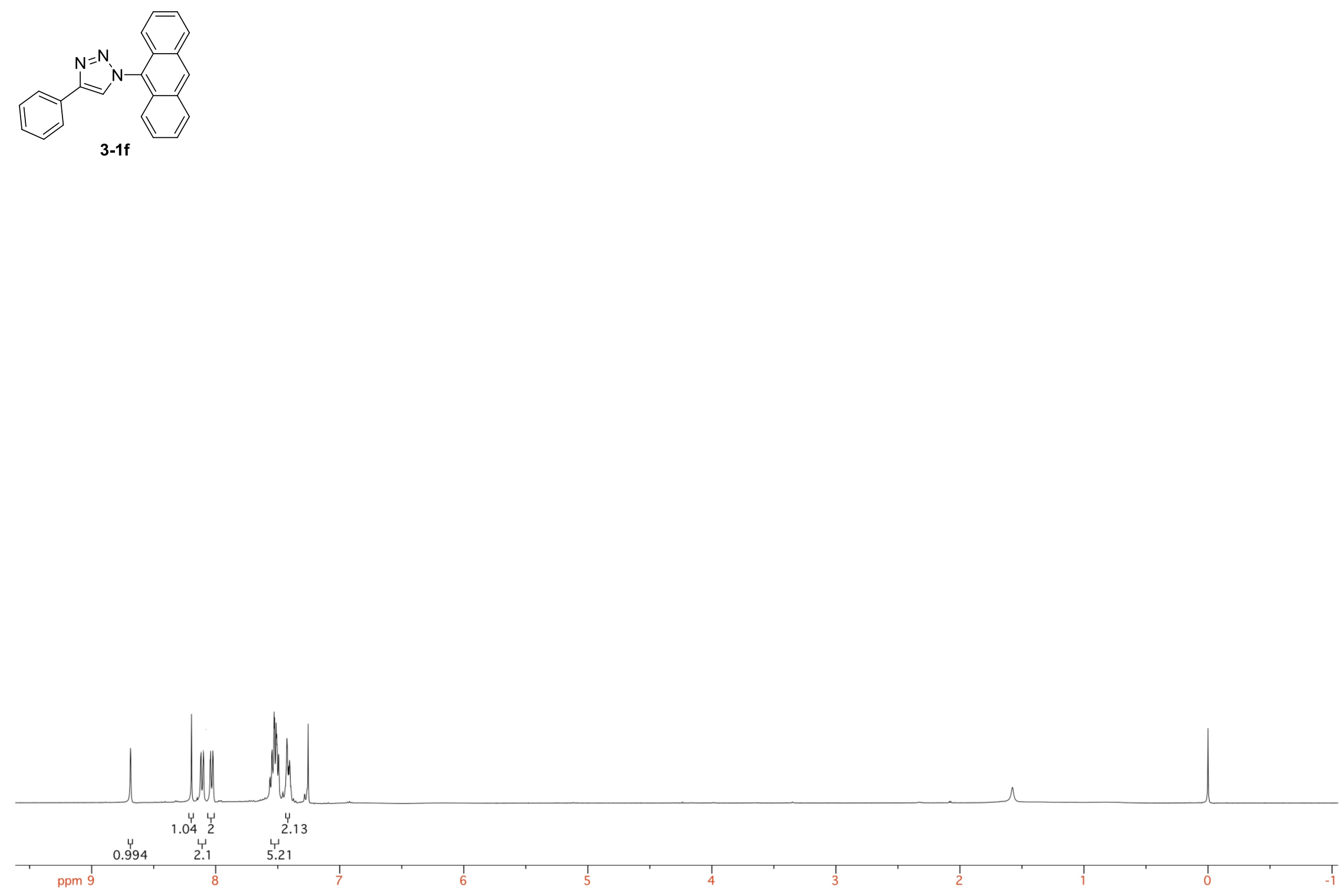


$$
\text { 3-16 }
$$

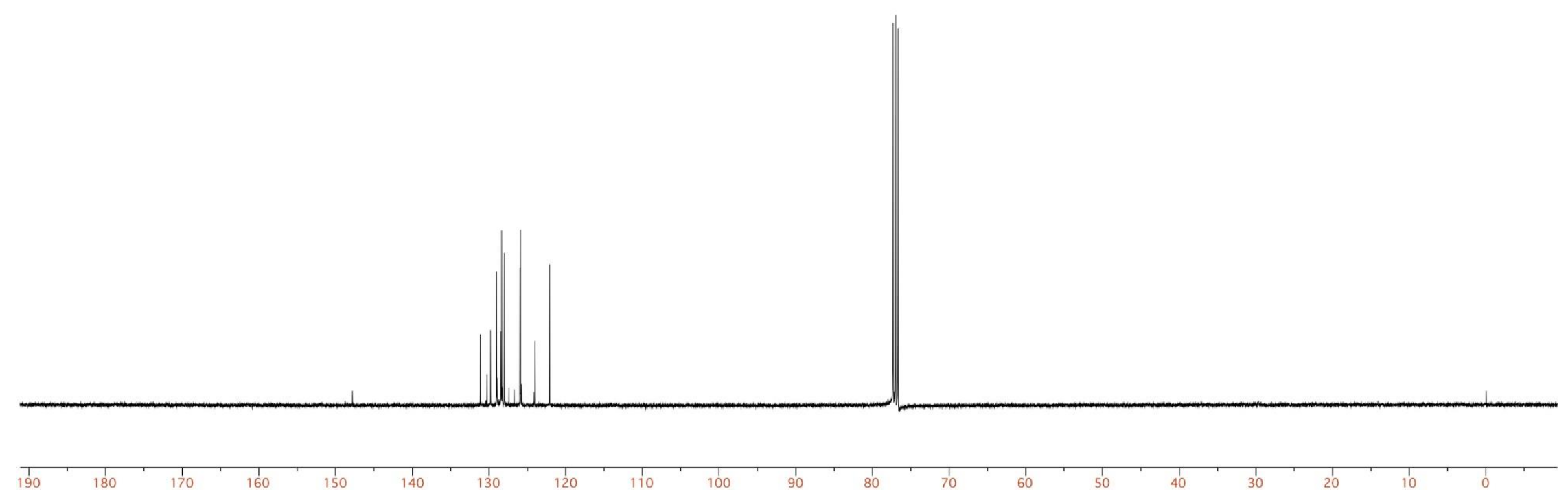



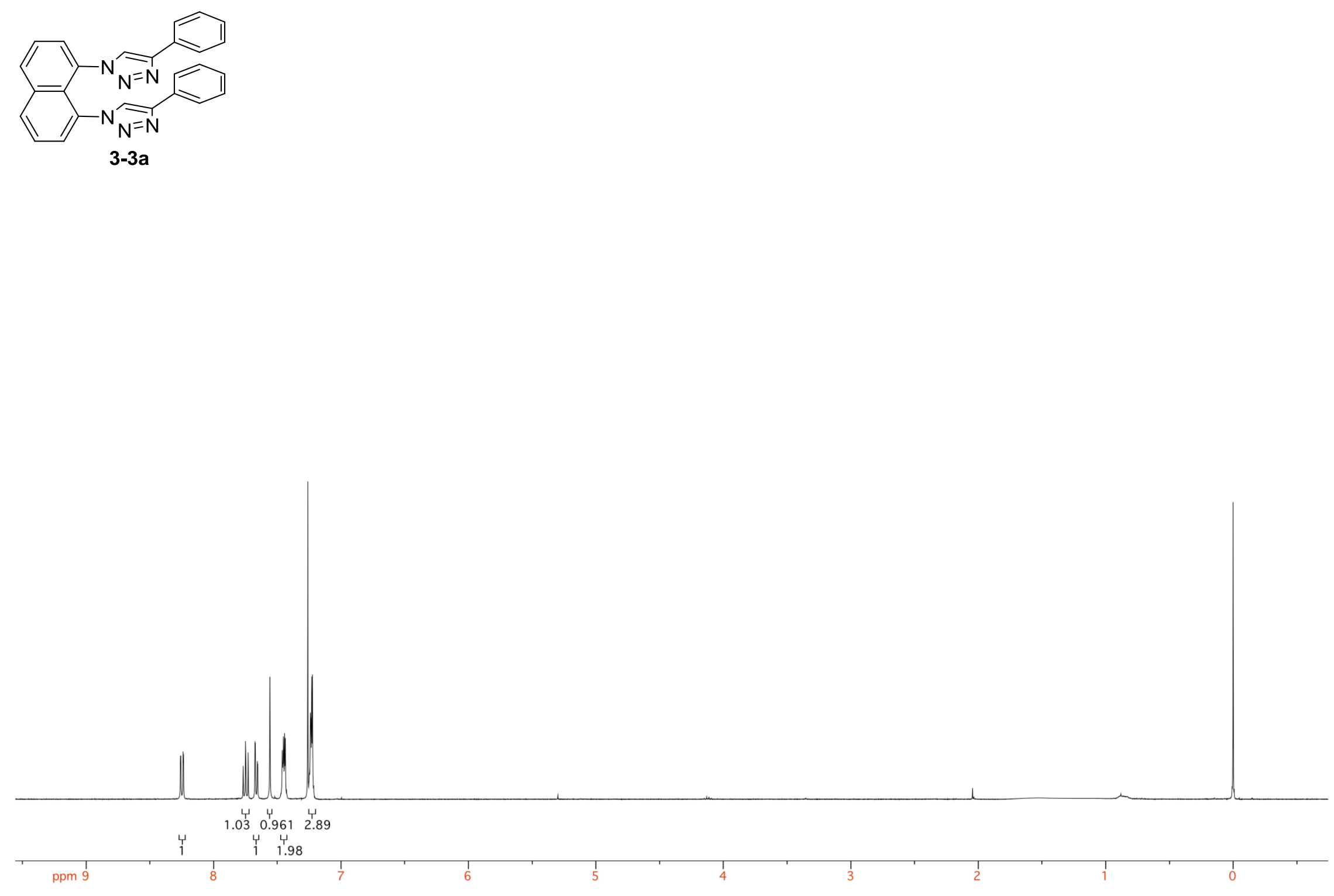


$$
\sum_{\substack{3-3 a \\ N=N}}^{2}
$$
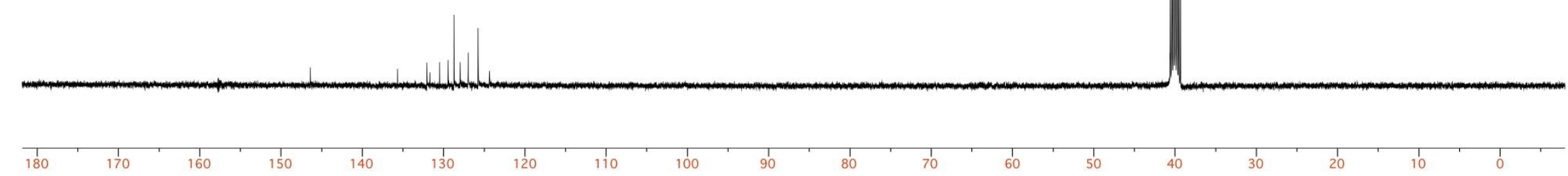


$$
8
$$

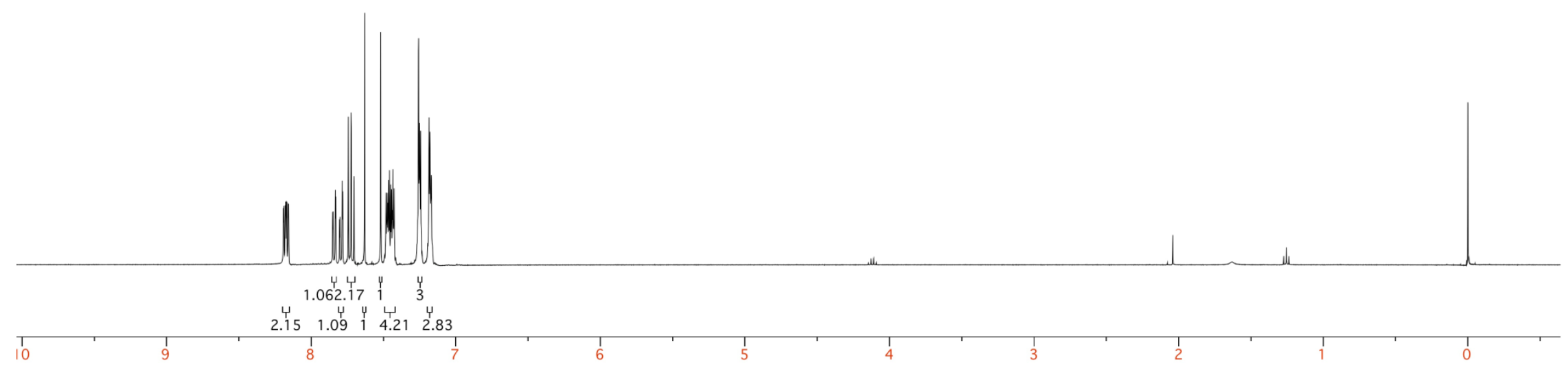




$$
\sum_{\substack{N=N \\ 3-3 b}}^{N}
$$
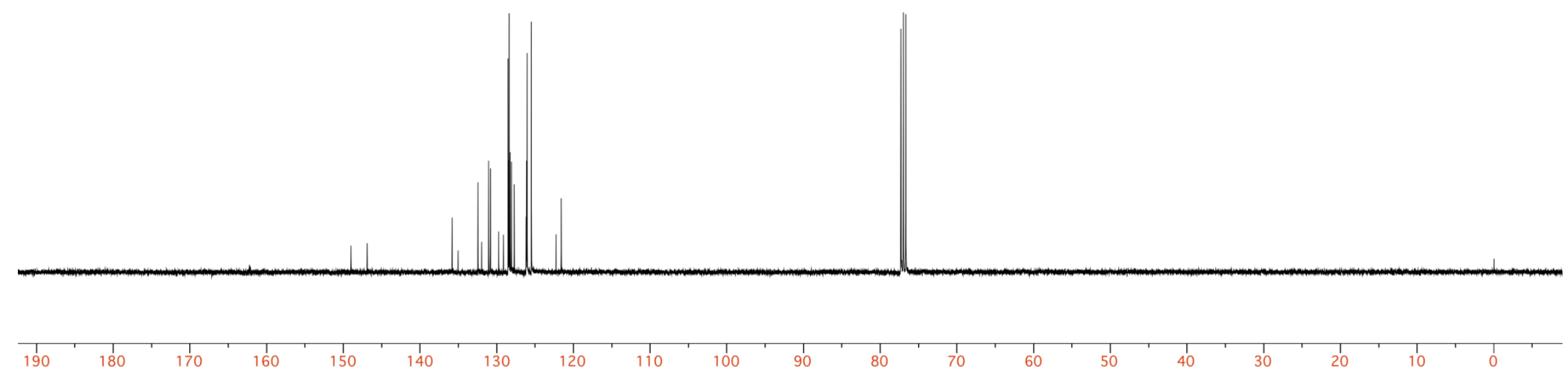

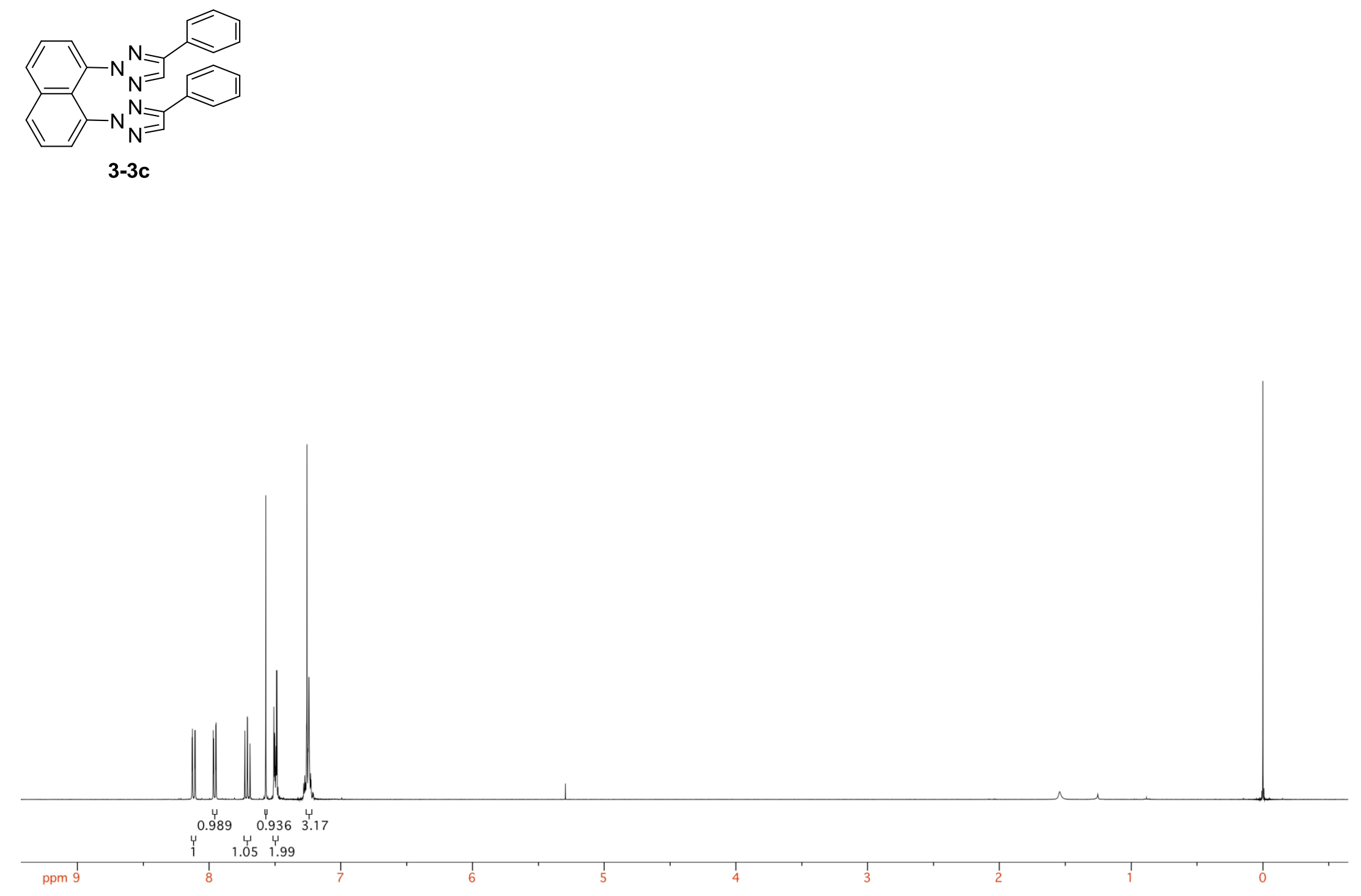


$$
\sum_{3-3 c}^{N}
$$

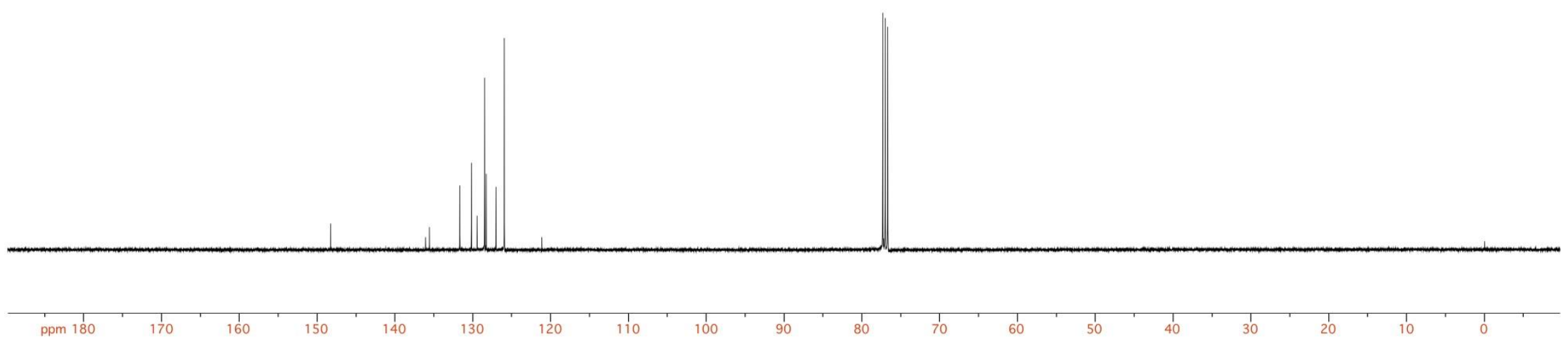



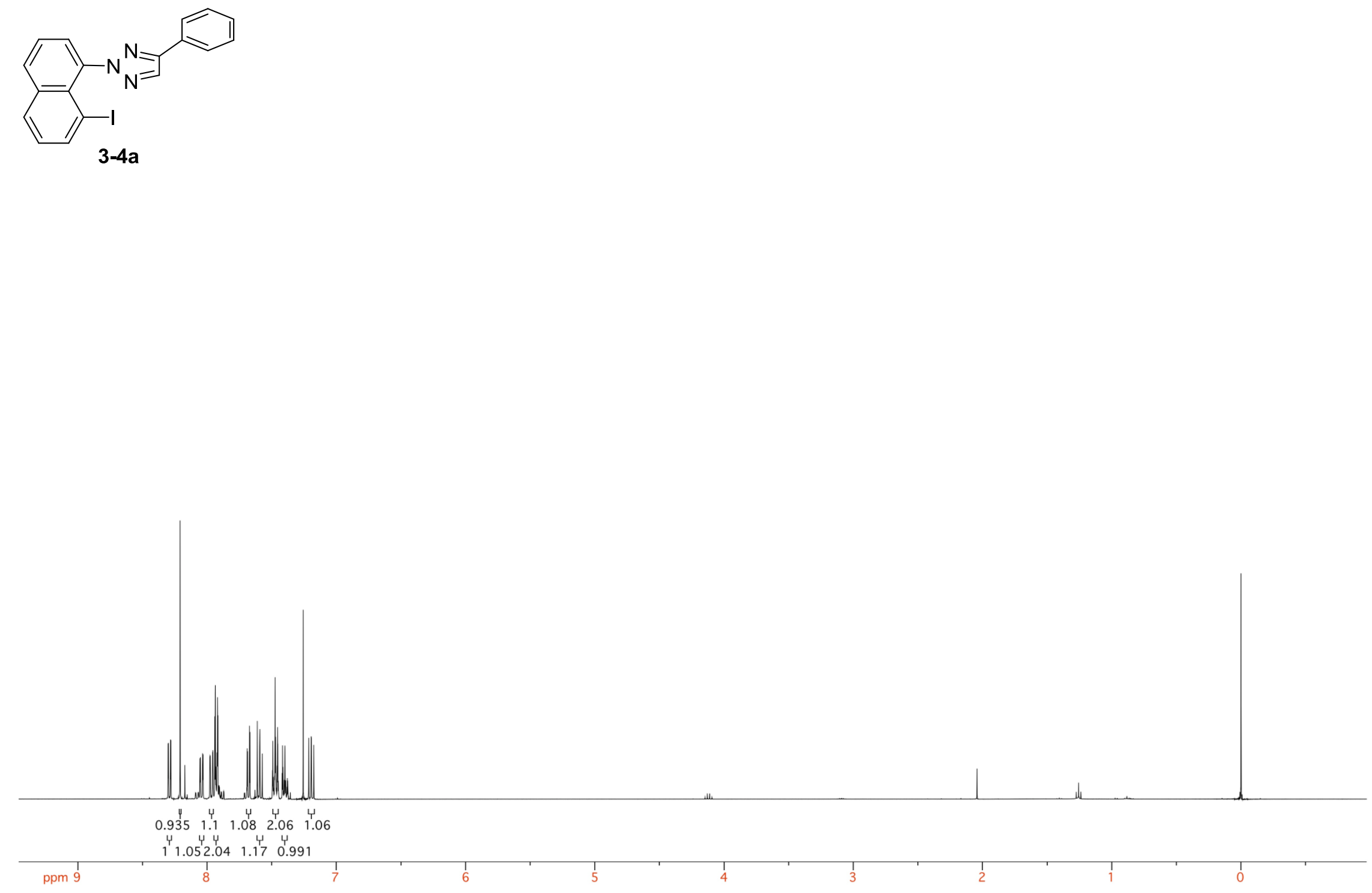


$$
\sum_{3-4 a}^{N}
$$
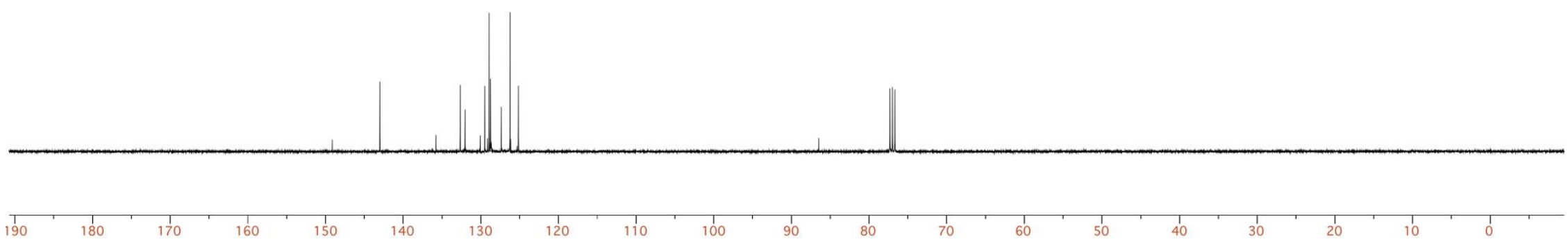

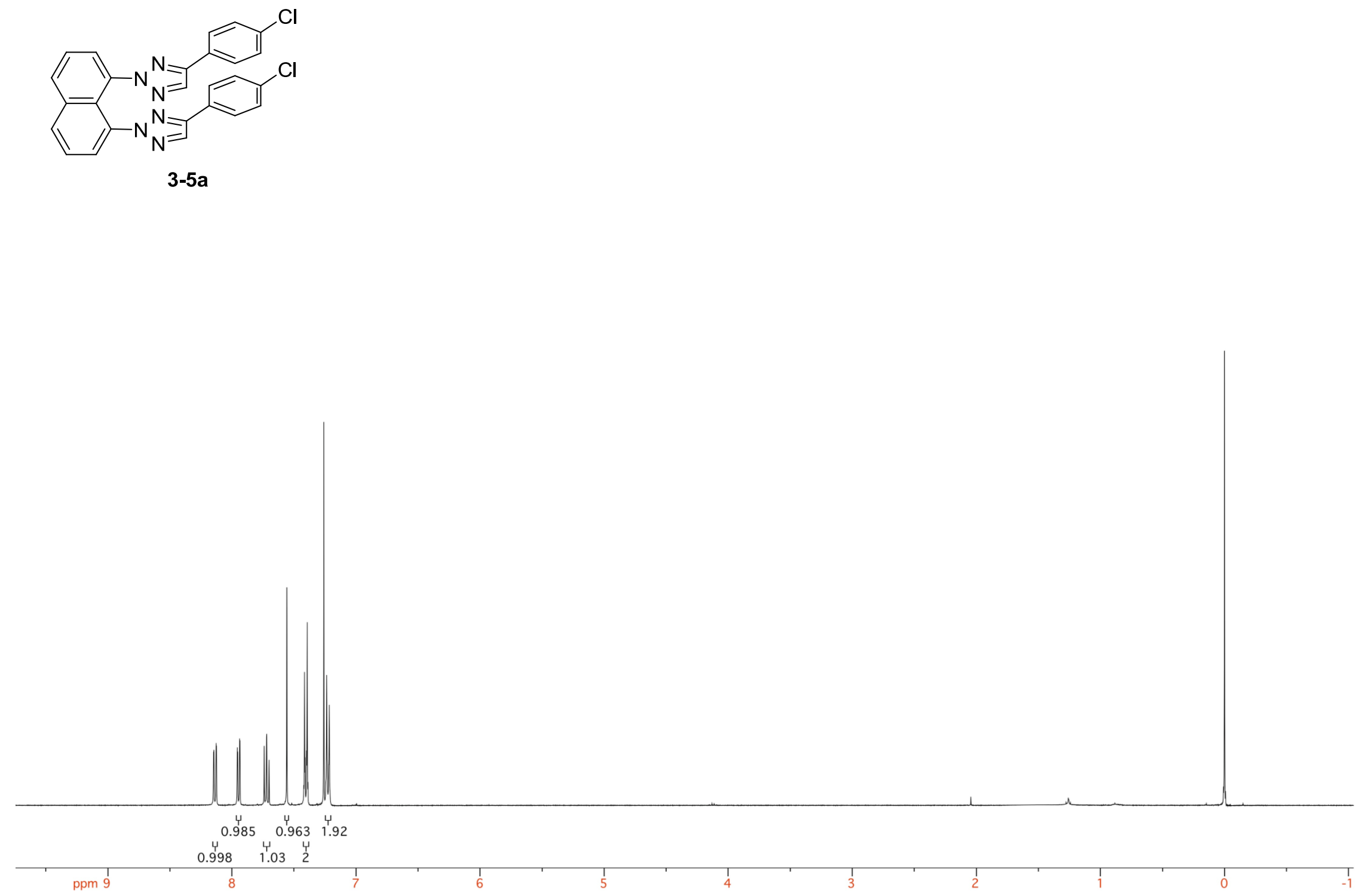

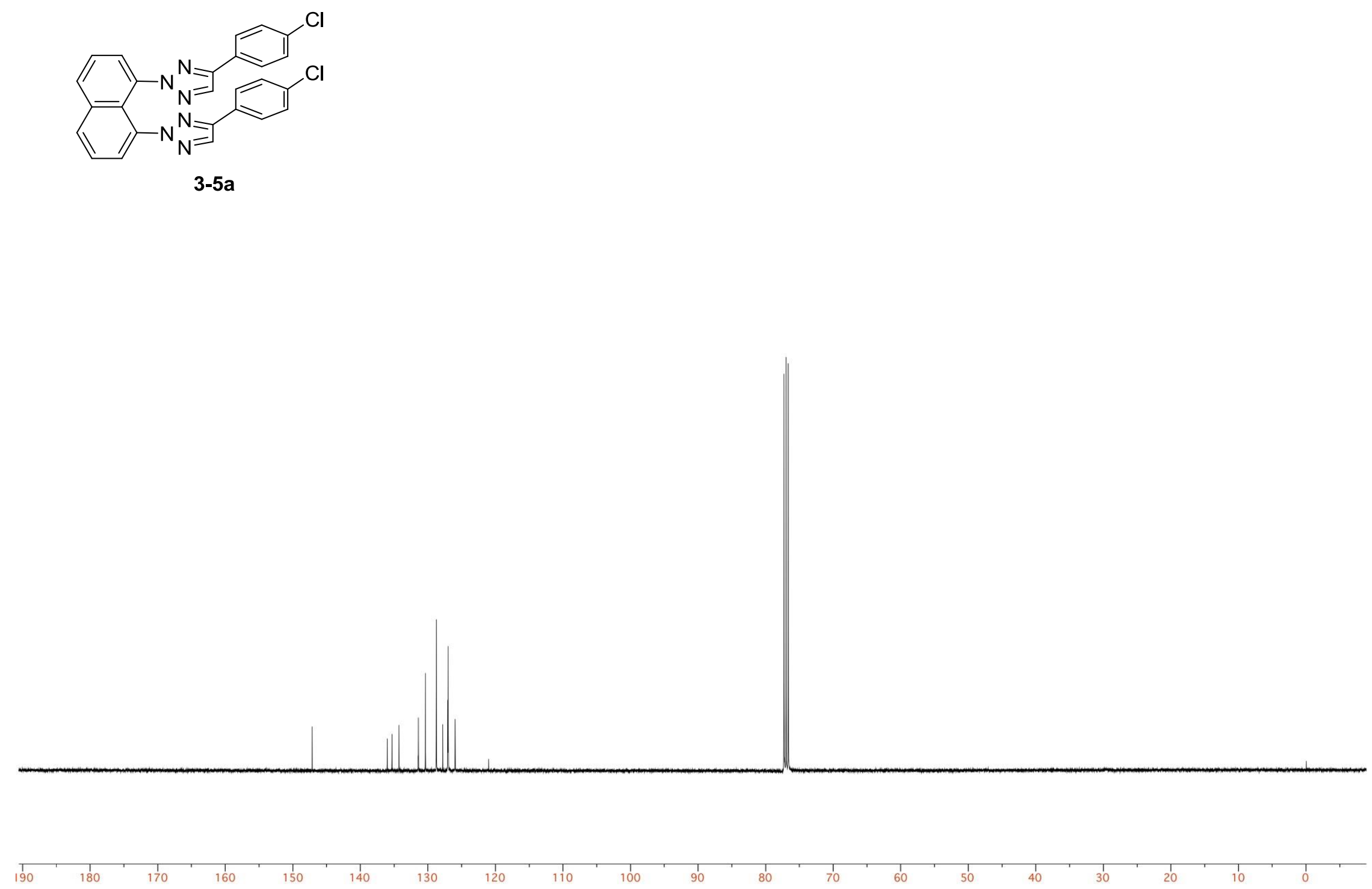

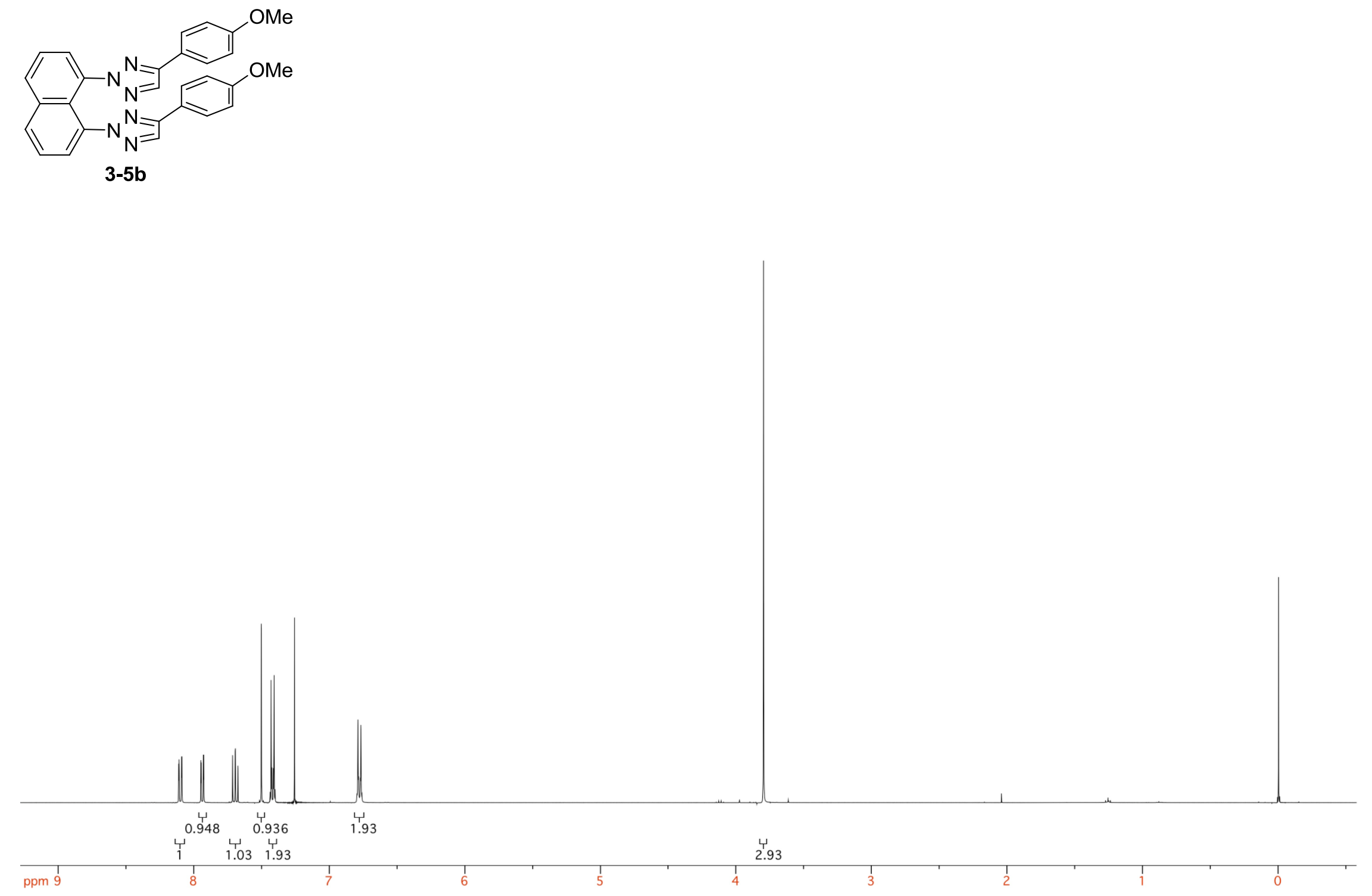


$$
\text { (OMe }
$$

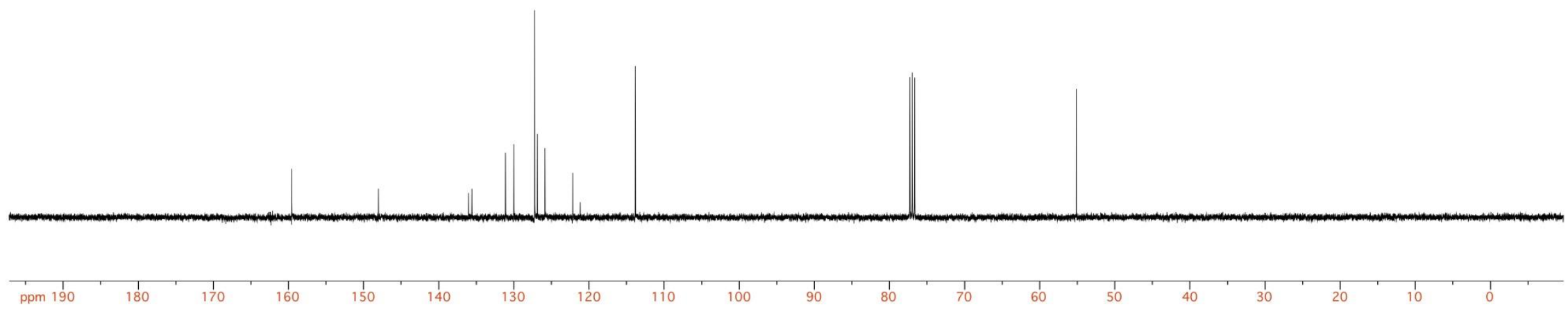



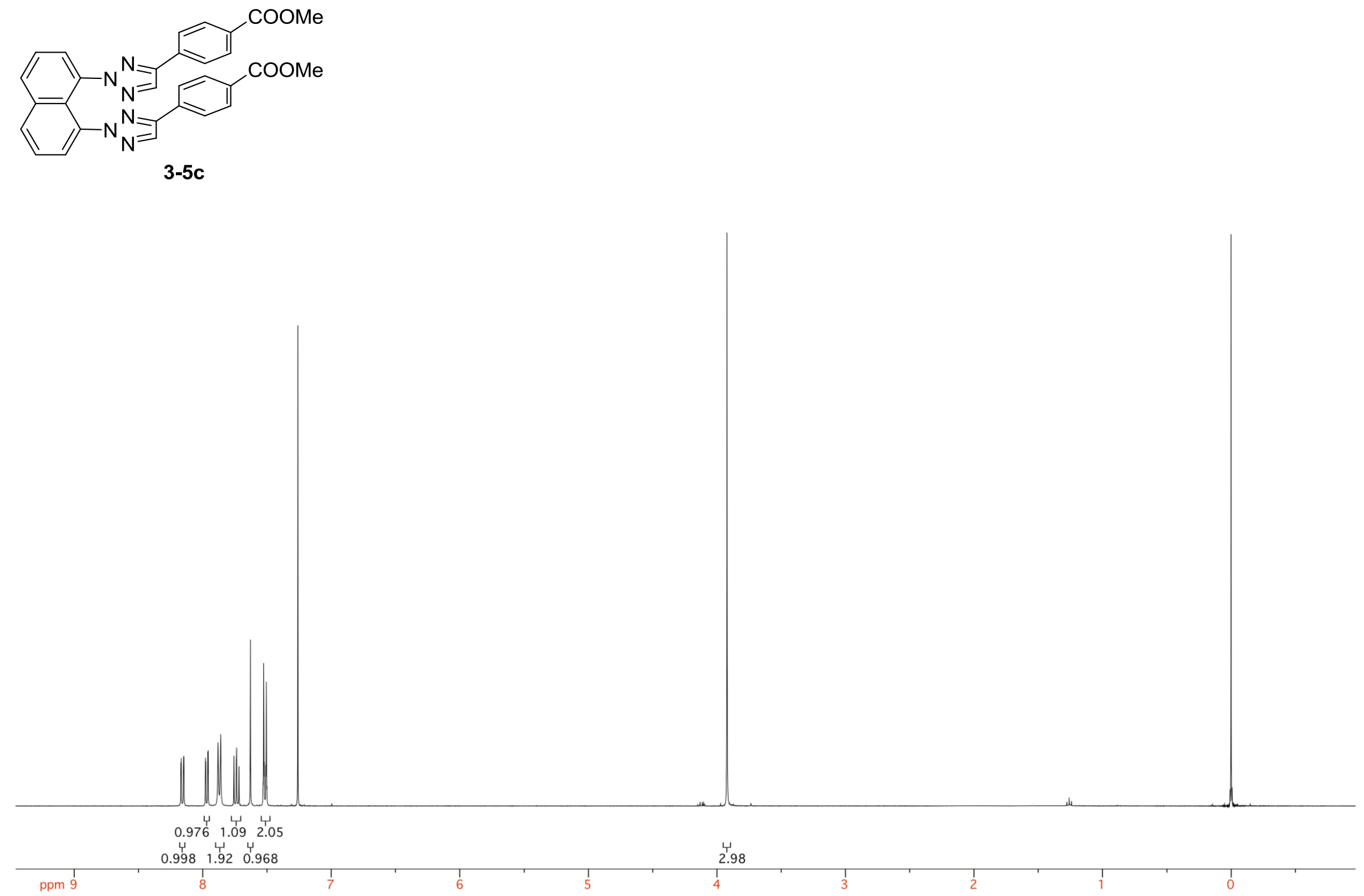

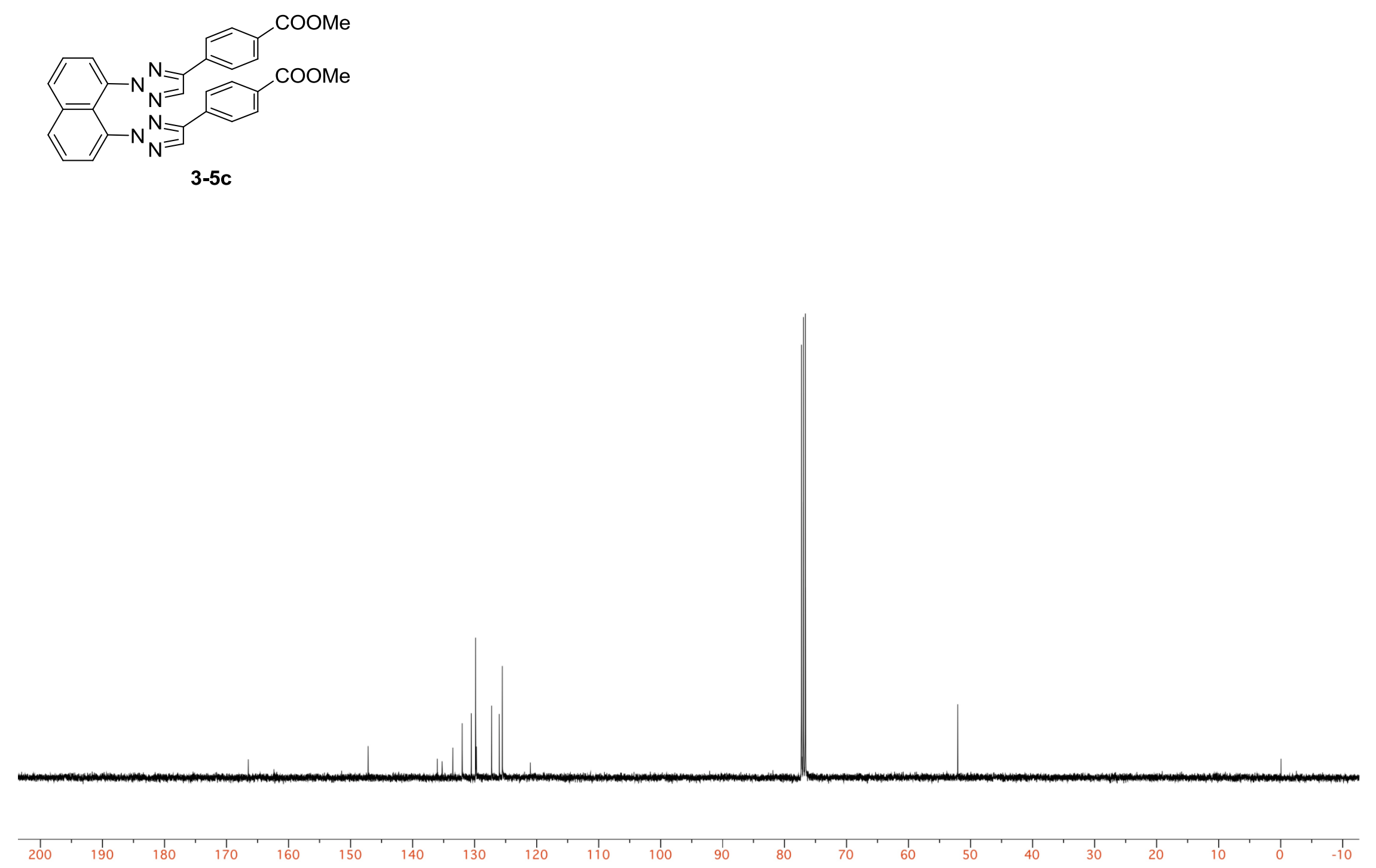

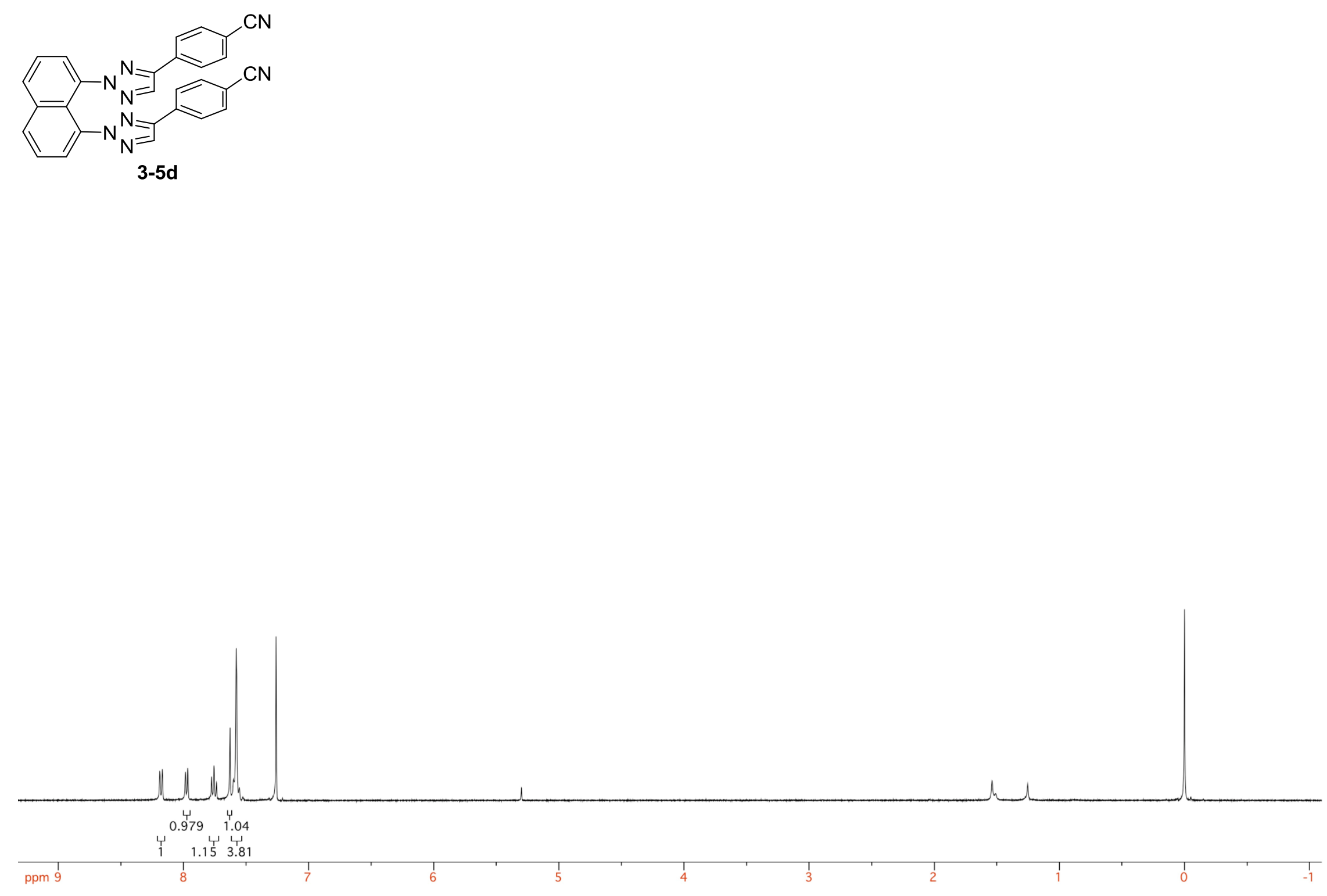


$$
\sum_{3-5 d}^{C N}
$$

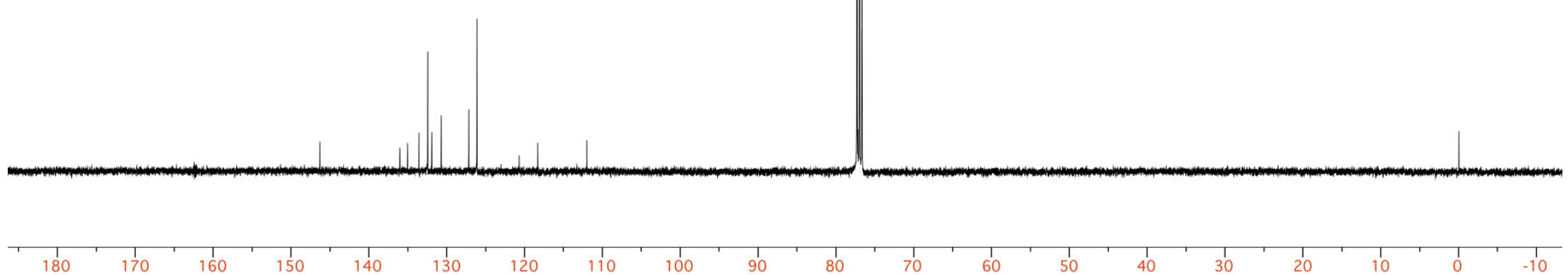




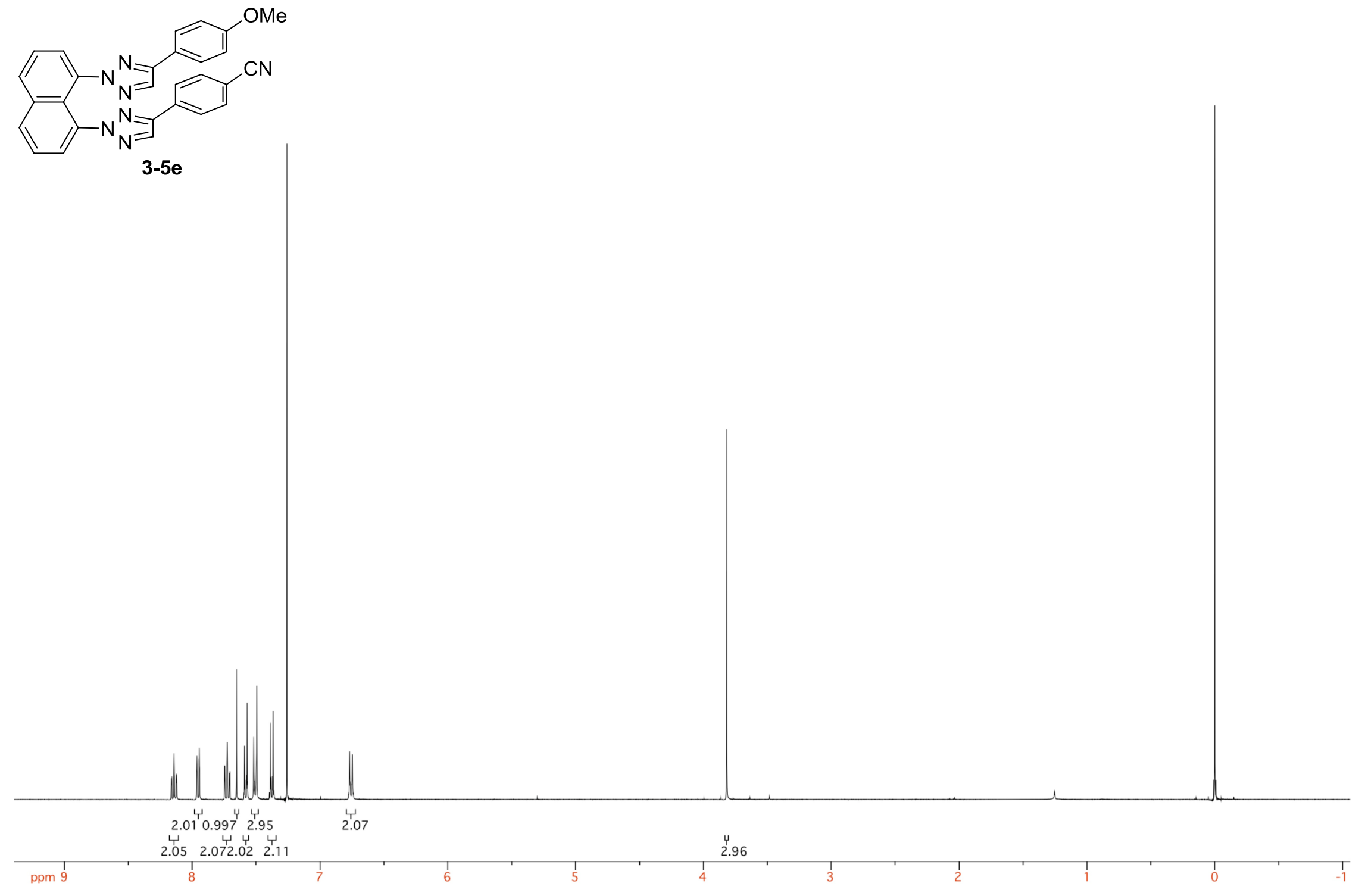




$$
\sum_{3-5 e}^{O M}
$$

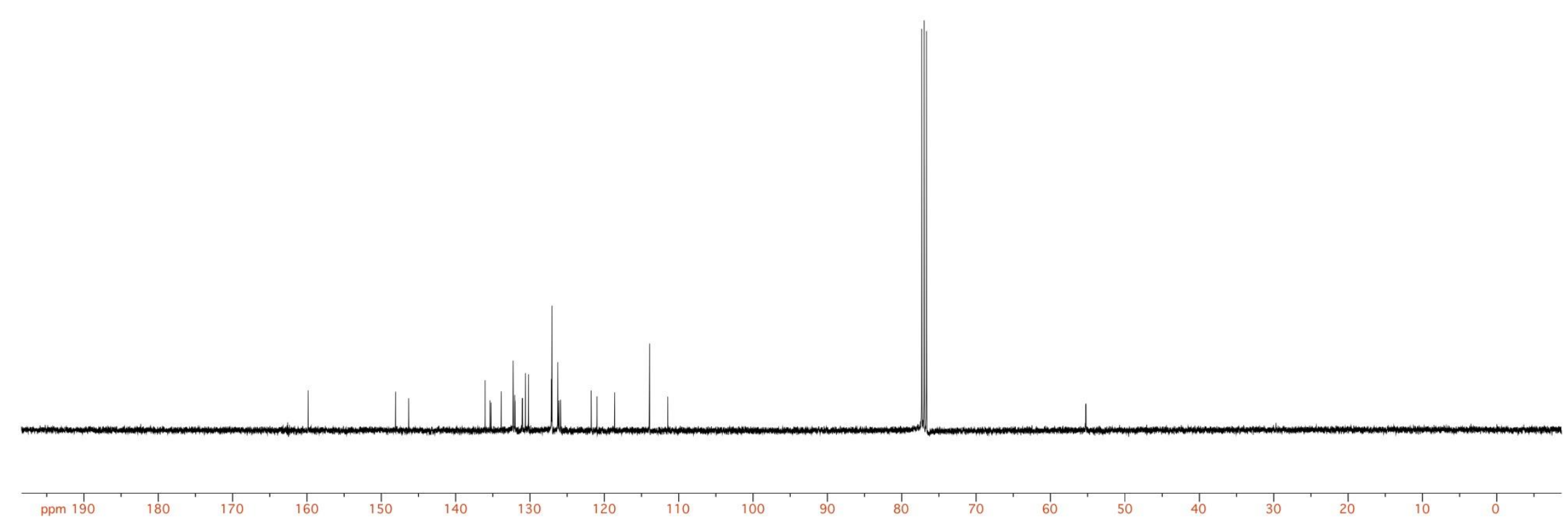

